COVID-19 desafios para a organização e repercussões nos sistemas e serviços de saúde

Margareth Crisóstomo Portela Lenice Gnocchi da Costa Reis Shevla Maria Lemos Lima organizadoras

\title{
SÉRIE
}


Série Informação para ação na Covid-19
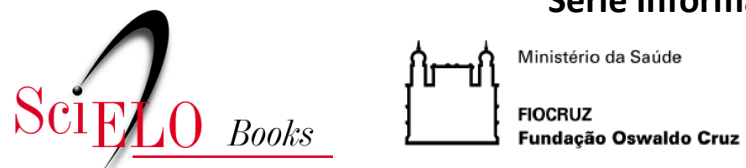

OBSERVATÓRIO COVID-19

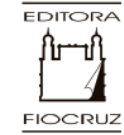

COVID-19: desafios para a organização e repercussões nos sistemas e serviços de saúde

\author{
Margareth Crisóstomo Portela \\ Lenice Gnocchi da Costa Reis \\ Sheyla Maria Lemos Lima \\ (orgs.)
}

\title{
SciELO Books / SciELO Livros / SciELO Libros
}

PORTELA, M. C., REIS, L. G. C., and LIMA, S. M. L., eds. Covid-19: desafios para a organização e repercussões nos sistemas e serviços de saúde [online]. Rio de Janeiro: Observatório Covid-19 Fiocruz, Editora Fiocruz, 2022, 472 p. Informação para ação na Covid-19 series. ISBN: 978-65-5708-123-5. https://doi.org/10.7476/9786557081587.

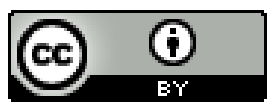

All the contents of this work, except where otherwise noted, is licensed under a Creative Commons Attribution 4.0 International license.

Todo o conteúdo deste trabalho, exceto quando houver ressalva, é publicado sob a licença Creative Commons Atribição 4.0.

Todo el contenido de esta obra, excepto donde se indique lo contrario, está bajo licencia de la licencia Creative Commons Reconocimento 4.0. 

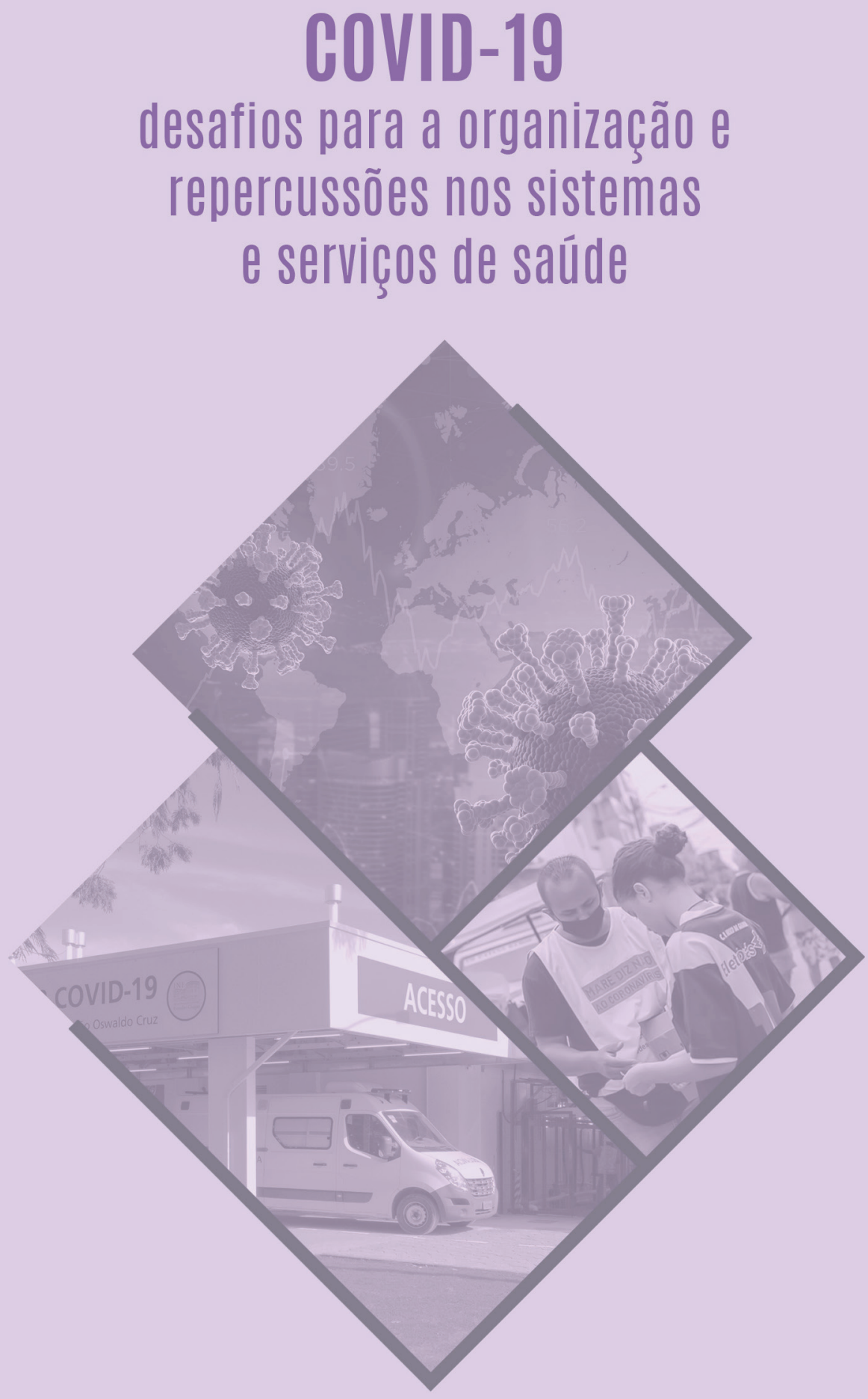


\section{FUNDAÇÃO OSWALDO CRUZ}

Presidente

Nísia Trindade Lima

Vice-Presidente de Educação, Informação e Comunicação

Cristiani Vieira Machado

\section{EDITORA FIOCRUZ}

Diretora

Cristiani Vieira Machado

Editor Executivo

João Carlos Canossa Mendes

Editores Científicos

Carlos Machado de Freitas

Gilberto Hochman

Conselho Editorial

Bernadete Perez Coêlho

Denise Valle

José Roberto Lapa e Silva

Kenneth Rochel de Camargo Jr.

Luciana Dias de Lima

Margareth Maria Pretti Dalcolmo

Maria Cecilia de Souza Minayo

Moisés Goldbaum

Rafael Linden

Ricardo Ventura Santos

\section{OBSERVATÓRIO COVID- I 9}

Comitê Editorial

Carlos Machado de Freitas (coordenador)

Christovam Barcellos

Daniel Antunes Maciel Villela

Gustavo Corrêa Matta

Lenice Gnocchi da Costa Reis

Margareth Crisóstomo Portela 
Margareth Crisóstomo Portela Lenice Gnocchi da Costa Reis

Sheyla Maria Lemos Lima

organizadoras

\section{COVID-19}

\section{desafios para a organização e repercussões nos sistemas e serviços de saúde}

Série Informação para Ação na Covid-19

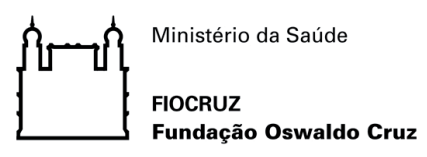

OBSERVATÓRIO COVID-19

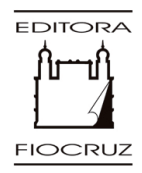


Copyright (C) 2022 dos autores

Todos os direitos desta edição reservados à

FUNDAÇÃO OSWALDO CRUZ / EDITORA

Revisão: Irene Ernest Dias

Normalização de referências: Clarissa Bravo

Capa, projeto gráfico e editoração: Adriana Carvalho e Carlos Fernando Reis

Supervisão editorial: Phelipe Gasiglia

Imagens da capa

Vírus

Depositphotos, ID 391488244 - @ apid

Articulador da Redes da Maré e SAS Brasil em ação na favela Conjunto Esperança, no Conjunto de Favelas da Maré

Foto Douglas Lopes

Centro Hospitalar para a Pandemia de Covid-19 - Instituto Nacional de Infectologia Evandro Chagas (INI/Fiocruz), localizado no campus Manguinhos. Unidade hospitalar destinada a pacientes graves contaminados pela doença criada em maio de 2020.

Foto Raquel Portugal. Acervo Fiocruz Imagens

Catalogação na fonte

Fundação Oswaldo Cruz

Instituto de Comunicação e Informação Científica e Tecnológica em Saúde

Biblioteca de Saúde Pública

C873c Covid-19: desafios para a organização e repercussões nos sistemas e serviços de saúde / organizado por Margareth Crisóstomo Portela, Lenice Gnocchi da Costa Reis e Sheyla Maria Lemos Lima. - Rio de Janeiro : Observatório Covid- I 9 Fiocruz, Editora Fiocruz, 2022.

472 p. : il. color. ; graf. ; tab. (Série Informação para Ação na Covid- 19)

ISBN: 978-65-5708-I23-5

Inclui Bibliografia.

Site: http://books.scielo.org

I. COVID- 19 - epidemiologia. 2. Infecções por Coronavírus. 3. Setor de Assistência à Saúde - organização E administração. 4. Estratégias de Saúde Globais. 5. Acesso aos Serviços de Saúde. 6. Cuidados Críticos. 7. Segurança do Paciente. 8. Hospitais de Emergência. 9. Atenção Primária à Saúde. 10. Sistema Único de Saúde. I I. Condições de Trabalho. 12. Agentes Comunitários de Saúde. 13. Áreas de Pobreza. 14. Brasil. 15. Riscos Ocupacionais. 16. Saúde Mental. 17. Violência Doméstica. 18. Defensoria Pública. I. Portela, Margareth Crisóstomo (Org). II. Reis, Lenice Gnocchi da Costa (Org.). III. Lima, Sheyla Maria Lemos (Org.). IV. Título.

CDD - 23.ed. -616.2

Glauce de Oliveira Pereira - Bibliotecária CRB 7/5642

2022

EDITORA FIOCRUZ

Av. Brasil, 4036, térreo, sala II 2 - Manguinhos

2 I 040-36 I - Rio de Janeiro, RJ

Tels: (2 I) 3882-9039 e 3882-904 I

Telefax: (2I) 3882-9006

e-mail: editora@fiocruz.br

www.fiocruz.br/editora

Editora filiada

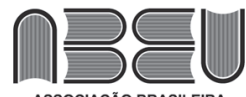

ASSOCIACÃO BRASILEIRA DAS EDITORAS UNIVERSITÁRIAS 


\section{Organizadoras}

\section{Margareth Crisóstomo Portela}

Engenheira eletricista, mestra em engenharia biomédica, Ph.D. em health policy and administration, com pós-doutorado na Medical University of South Carolina, EUA. Pesquisadora da Escola Nacional de Saúde Pública Sergio Arouca/Fiocruz, onde é docente permanente do Programa de Pós-Graduação em Saúde Pública.

\section{Lenice Gnocchi da Costa Reis}

Médica, doutora em saúde pública. Pesquisadora titular em saúde pública da Escola Nacional de Saúde Pública Sergio Arouca/Fiocruz.

\section{Sheyla Maria Lemos Lima}

Médica, mestra em administração pública, doutora em saúde pública. Tecnologista em saúde pública da Escola Nacional de Saúde Pública Sergio Arouca/Fiocruz.

\section{Autores}

\section{Adelyne Maria Mendes Pereira}

Enfermeira, mestra em saúde pública com concentração em planejamento e gestão, doutora em saúde pública, com pós-doutorado em saúde global na Universitat de les Illes Baleares, Espanha. Professora e pesquisadora no Departamento de Administração e Planejamento em Saúde da Escola Nacional de Saúde Pública Sergio Arouca/Fiocruz.

\section{Adriana Leiras}

Engenheira de produção, mestra e doutora em engenharia de produção, com pós-doutorado em engenharia de sistemas logísticos pela Universidade de São Paulo. Professora do Departamento de Engenharia Industrial da PUC-Rio e fundadora e coordenadora do Lab HANDs - Humanitarian Assistance and Needs for Disasters.

\section{Alessandro Jatobá}

Doutor em engenharia de produção. Pesquisador no Centro de Estudos Estratégicos da Fiocruz.

\section{Alexandre Pessoa Dias}

Engenheiro civil, especialista em saneamento e controle ambiental e em engenharia sanitária e ambiental, mestre em engenharia ambiental, doutor em medicina tropical. Professor pesquisador do Laboratório de Educação Profissional em Vigilância em Saúde da Escola Politécnica de Saúde Joaquim Venâncio/Fiocruz.

\section{Aline Silva-Costa}

Bióloga, doutora em epidemiologia em saúde pública. Professora do Departamento de Saúde Coletiva da Universidade Federal do Triângulo Mineiro. 


\section{Ana Cristina Magalhães Fernandes Báfica}

Graduada em enfermagem com residência em saúde da família, especialista em políticas públicas em saúde informadas por evidência. Chefe de Departamento da Atenção Primária da Secretaria Municipal de Saúde de Florianópolis.

\section{Ana Cristina Simões Rosa}

Química, mestra em saúde pública, doutora em saúde pública e meio ambiente. Tecnologista em saúde pública do Centro de Estudos da Saúde do Trabalhador e Ecologia Humana da Escola Nacional de Saúde Pública Sergio Arouca/Fiocruz.

\section{Ana Luiza Braz Pavão}

Médica, especialista em medicina preventiva e social, doutora em saúde coletiva (epidemiologia). Tecnologista em saúde pública do Instituto de Comunicação e Informação Científica e Tecnológica em Saúde (Icict/Fiocruz), onde é coordenadora adjunta do Centro Colaborador para a Qualidade do Cuidado e a Segurança do Paciente (Proqualis).

\section{Ana Paula das Neves Silva}

Farmacêutica, especialista em química e toxicologia forense, especialista em hematologia e imunohematologia, e em toxicologia geral.

\section{Anselmo Rocha Romão}

Geógrafo, especialista em engenharia sanitária e ambiental e em filosofia, mestre em saúde pública. Tecnologista em saúde pública do Laboratório de Informação em Saúde do Instituto de Comunicação e Informação Científica e Tecnológica em Saúde/Fiocruz.

\section{Antônio Carlos dos Santos Cardoso}

Médico do trabalho e sanitarista. Tecnologista sênior do Centro de Estudos de Saúde do Trabalhador e Ecologia Humana da Escola Nacional de Saúde Pública Sergio Arouca/Fiocruz.

\section{Antônio Vieira Machado}

Médico, mestre em obstetrícia e ginecologia. Professor da Faculdade de Ciências Médicas de Minas Gerais. Integrante da equipe da Pesquisa Condições de Trabalho dos Profissionais de Saúde no Contexto da Covid- 9 no Brasil.

\section{Ariane Leites Larentis}

Engenheira química, mestra e doutora em engenharia química. Pesquisadora do Centro de Estudos da Saúde do Trabalhador e Ecologia Humana e orientadora do Programa de Pós-Graduação em Saúde Pública e Meio Ambiente, ambos da Escola Nacional de Saúde Pública Sergio Arouca/Fiocruz.

\section{Aylene Bousquat}

Médica, doutora em medicina preventiva, professora da Faculdade de Saúde Pública da Universidade de São Paulo.

\section{Bárbara do Nascimento Caldas}

Médica, doutora em saúde pública. Médica da área da qualidade e segurança do Instituto Nacional de Cardiologia e pesquisadora colaboradora da Escola Nacional de Saúde Pública Sergio Arouca/Fiocruz. 


\section{Beatriz de Castro Fialho}

Economista, especialista em inovação tecnológica e desenvolvimento econômico, mestra e doutora em engenharia de produção. Assessora executiva da Diretoria de Bio-Manguinhos/Fiocruz.

\section{Beatriz Schmidt}

Psicóloga, doutora em psicologia. Professora em psicologia da Universidade Federal do Rio Grande.

\section{Bernardo Dolabella Melo}

Psicólogo, mestre em psicologia. Conselheiro estadual da Cruz Vermelha Brasileira - Filial Minas Gerais e, na Fiocruz, pesquisador colaborador do Centro de Estudos e Pesquisas em Emergências e Desastres em Saúde e do Observatório Mineração, Desastres \& Saúde.

\section{Bianca Caroline Pickler}

Psicóloga. Assistente de pesquisa no Departamento de Estudos sobre Violência e Saúde Jorge Careli da Escola Nacional de Saúde Pública Sergio Arouca/Fiocruz.

\section{Caio de Paula Peixoto}

Físico, especialista em ciência de dados. Bolsista de pesquisa do Projeto de Avaliação do Desempenho do Sistema de Saúde, no Laboratório de Informação em Saúde/Instituto de Comunicação e Informação Científica e Tecnológica em Saúde/Fiocruz.

\section{Camilla Maia Franco}

Psicóloga e sanitarista, mestra em saúde coletiva, especialista em saúde da família e em apoio institucional a serviços de saúde. Atua como subsecretária de Saúde do Município de Niterói.

\section{Carla Gouvêa}

Médica, doutora em saúde pública. Pesquisadora associada e professora no Instituto de Medicina Social da Universidade do Estado do Rio de Janeiro e assessora técnico-científica do Centro Colaborador para a Qualidade do Cuidado e a Segurança do Paciente (Proqualis).

\section{Carla Lourenço Tavares de Andrade}

Estatística, doutora em saúde pública. Tecnologista em saúde pública da Escola Nacional de Saúde Pública Sergio Arouca/Fiocruz.

\section{Carlos Machado de Freitas}

Historiador, doutor em saúde pública. Coordenador do Centro de Estudos e Pesquisas em Emergências e Desastres em Saúde/Fiocruz.

\section{Carolina de Campos Carvalho}

Cientista social, especialista em políticas públicas, mestra em saúde pública. Analista técnica de políticas sociais no Laboratório de Informação em Saúde do Instituto de Comunicação e Informação Científica e Tecnológica em Saúde/Fiocruz, onde atua no Projeto de Avaliação do Desempenho do Sistema de Saúde. 


\section{Carolyne Cesar Lima}

Psiquiatra geral e psiquiatra da infância e da adolescência, mestra em saúde global pela Chent University. Pesquisadora colaboradora do Centro de Estudos e Pesquisas em Emergências e Desastres em Saúde/Fiocruz.

\section{Celia Almeida}

Médica, doutora em saúde pública. Pesquisadora titular da Escola Nacional de Saúde Pública Sergio Arouca da Escola Nacional de Saúde Pública Sergio Arouca/Fiocruz.

\section{Ciane dos Santos Rodrigues}

Enfermeira com residência de enfermagem em saúde coletiva, mestra em saúde coletiva. Assessora de planejamento da Secretaria Municipal de Saúde de Niterói.

\section{Claudia Cristina de Aguiar Pereira}

Economista, mestra em demografia, doutora em saúde populacional. Pesquisadora em saúde pública da Escola Nacional de Saúde Pública Sergio Arouca/Fiocruz.

\section{Claudia Garcia Serpa Osorio-de-Castro}

Farmacêutica industrial, doutora em saúde da criança e da mulher. Pesquisadora titular do Departamento de Política de Medicamentos e Assistência Farmacêutica da Escola Nacional de Saúde Pública Sergio Arouca/Fiocruz.

\section{Claudia Travassos}

Médica, mestra em saúde coletiva e em medicina comunitária, doutora em administração pública. Pesquisadora titular aposentada do Instituto de Comunicação e Informação Científica e Tecnológica em Saúde/Fiocruz.

\section{Cristine Vieira}

Doutora em saúde pública. Servidora da Fiocruz, onde atua na Escola Nacional de Saúde Pública Sergio Arouca.

\section{Cynthia Magluta}

Médica, doutora em saúde da criança e da mulher. Pesquisadora e docente do Mestrado Profissional em Saúde da Criança e da Mulher e coordenadora adjunta da Coordenação de Ações Nacionais e de Cooperação do Instituto Nacional de Saúde da Mulher, da Criança e do Adolescente Fernandes Figueira/Fiocruz.

\section{Daniel Granada}

Cientista Social, doutor em etnologia e história. Professor da Universidade Federal de Santa Catarina - Campus de Curitibanos.

\section{Daphne Rodrigues Pereira}

Psicóloga, mestra em teoria psicanalítica. Pesquisadora colaboradora do Centro de Estudos e Pesquisas em Emergências e Desastres em Saúde/Fiocruz. 


\section{Davi da Silveira Barroso Alves}

Enfermeiro, doutor em ciências. Professor do Departamento de Métodos Quantitativos da Universidade Federal do Estado do Rio de Janeiro.

\section{Débora da Silva Noal}

Psicóloga, doutora em processos do desenvolvimento humano e saúde, com pós-doutorado em saúde pública. Pesquisadora da Fiocruz Brasília.

\section{Deborah Uhr}

Doutora em psicologia. Professora da Universidade Federal Rural do Rio de Janeiro, no Departamento de Psicologia.

\section{Denise Cotrim da Cunha}

Médica, mestra em doenças infecciosas e parasitárias. Tecnologista em saúde pública do Centro de Saúde Escola Germano Sinval Faria da Escola Nacional de Saúde Pública Sergio Arouca/Fiocruz.

\section{Denize Nogueira}

Psicóloga, mestra em ciências. Psicóloga da Coordenação de Saúde do Trabalhador da Fiocruz.

\section{Dominique Marçal Mattos}

Psicóloga, especialista em psicologia hospitalar. Colaboradora no projeto de pesquisa Estudo do Impacto à Saúde de Agentes de Combate às Endemias/Guardas de Endemias pela Exposição a Agrotóxicos no Estado do Rio de Janeiro, coordenado pelo Centro de Estudos da Saúde do Trabalhador e Ecologia Humana da Escola Nacional de Saúde Pública Sergio Arouca/Fiocruz.

\section{Edilene de Menezes Pereira}

Geógrafa, mestra em práticas em desenvolvimento sustentável, especialista em análise ambiental e gestão do território. Professora pesquisadora do Laboratório de Educação Profissional em Vigilância em Saúde da Escola Politécnica de Saúde Joaquim Venâncio/Fiocruz.

\section{Eduardo Alves Melo}

Médico sanitarista, mestre e doutor em saúde pública. Pesquisador do Departamento de Administração e Planejamento em Saúde da Escola Nacional de Saúde Pública Sergio Arouca/Fiocruz e professor do Instituto de Saúde Coletiva da Universidade Federal Fluminense.

\section{Eduardo Kaplan Barbosa}

Economista, mestre em políticas públicas.

\section{Eliana Elisabeth Diehl}

Farmacêutica, doutora em saúde pública. Professora titular aposentada da Universidade Federal de Santa Catarina.

\section{Eliane Chaves Vianna}

Psicóloga, doutora em saúde pública. Professora associada e pesquisadora em saúde pública do Centro Escola Germano Sinval Faria, Escola Nacional de Saúde Pública Sergio Arouca da Escola Nacional de Saúde Pública Sergio Arouca/Fiocruz. 


\section{Eline Simões Gonçalves}

Bióloga, mestra e doutora em geoquímica ambiental com pós-doutorado em saúde pública e meio ambiente, especialista em análises clínicas e toxicológicas e em ensino de ciências e biologia. Pesquisadora colaboradora no projeto de pesquisa Estudo do Impacto à Saúde de Agentes de Combate às Endemias/Guardas de Endemias pela Exposição a Agrotóxicos no Estado do Rio de Janeiro, coordenado pelo Centro de Estudos da Saúde do Trabalhador e Ecologia Humana da Escola Nacional de Saúde Pública Sergio Arouca/Fiocruz.

\section{Elizimara Ferreira Siqueira}

Graduada em enfermagem, especialista em saúde da família e mestra em enfermagem. Gerente de Enfermagem na Secretaria Municipal de Saúde de Florianópolis.

\section{Elyne Montenegro Engstrom}

Médica sanitarista, mestra em saúde da criança, mulher e adolescente, doutora em saúde pública, coordenadora do Programa de Pós-Graduação em Saúde Pública - Mestrado Profissional e pesquisadora do Departamento de Ciências Sociais da Escola Nacional de Saúde Pública Sergio Arouca/Fiocruz.

\section{Everson Justino Pereira}

Analista de sistemas. Pesquisador do Núcleo de Estudos e Pesquisa de Recursos Humanos em Saúde da Escola Nacional de Saúde Pública Sergio Arouca/Fiocruz, integrante da equipe da Pesquisa Condições de Trabalho dos Profissionais de Saúde no Contexto da Covid- I 9 no Brasil.

\section{Fernanda K. Melchior Silva Pinto}

Médica com residência em medicina de família e comunidade, especialista em preceptoria em medicina de família. Integrante do Departamento Gestão da Clínica/Gerência de Integração Assistencial da Secretaria Municipal de Saúde de Florianópolis.

\section{Fernanda Lazzari Freitas}

Médica com residência em medicina de família e comunidade, mestra em saúde coletiva. Supervisora do Programa de Residência em Medicina de Família e Comunidade da Secretaria Municipal de Saúde de Florianópolis.

\section{Fernanda Mendes Lages Ribeiro}

Psicóloga, doutora em saúde pública. Pesquisadora do Departamento de Estudos sobre Violência e Saúde Jorge Careli da Escola Nacional de Saúde Pública Sergio Arouca/Fiocruz e professora do Instituto Brasileiro de Medicina de Reabilitação.

\section{Fernanda Paese}

Graduada em enfermagem, mestra e doutora em enfermagem, especializada em políticas públicas em saúde informadas por evidência. Gerente do Distrito Sanitário Centro da Secretaria Municipal de Saúde de Florianópolis.

\section{Fernanda Serpeloni}

Psicóloga, doutora em psicologia clínica e neurociências. Pesquisadora do Departamento de Estudos sobre Violência e Saúde Jorge Careli da Escola Nacional de Saúde Pública Sergio Arouca/Fiocruz. Bolsista de pós-doutorado Faperj Nota-10. 


\section{Fernando A. Bozza}

Médico, doutor em medicina. Pesquisador da Fundação Oswaldo Cruz, membro do Comitê Gestor do Conexão Saúde, idealizador da iniciativa Dados do Bem.

\section{Fernando Ramalho Gameleira Soares}

Geógrafo, mestre em estudos populacionais e pesquisa social. Tecnologista em informações geográficas e estatísticas do Instituto Brasileiro de Geografia e Estatística.

\section{Filipe de Barros Perini}

Medicina com residência médica em infectologia, especialista em gestão de redes de atenção à saúde. Gerente de Integração Assistencial da Secretaria Municipal de Saúde de Florianópolis.

\section{Filipe Leonel Vargas}

Jornalista, especialista em comunicação e saúde. Atua na Coordenação de Comunicação Institucional da Escola Nacional de Saúde Pública Sergio Arouca/Fiocruz, onde integra a equipe da Pesquisa Condições de Trabalho dos Profissionais de Saúde no Contexto da Covid-I 9 no Brasil.

\section{Francisco Viacava}

Médico, mestre em medicina preventiva e em nutrição humana. Pesquisador visitante do Laboratório de Informação em Saúde do Instituto de Comunicação e Informação Científica e Tecnológica em Saúde/Fiocruz.

\section{Fúlvio Borges Nedel}

Médico, doutor em epidemiologia. Professor do Departamento de Saúde Pública da Universidade Federal de Santa Catarina.

\section{Gisele O’Dwyer}

Médica, doutora em saúde pública. Pesquisadora da Escola Nacional de Saúde Pública Sergio Arouca/ Fiocruz, onde é coordenadora do plano Territórios Integrados de Atenção à Saúde (Teias).

\section{Gladys Miyashiro Miyashiro}

Médica, mestra em saúde pública, especialista em educação profissional e em estudos em população. Professora pesquisadora do Laboratório de Educação Profissional em Vigilância em Saúde da Escola Politécnica de Saúde Joaquim/Fiocruz.

\section{Gracia Maria de Miranda Gondim}

Arquiteta, mestra e doutora em saúde pública, especialista em saúde pública, em engenharia de saúde pública e em arquitetura do sistema de saúde. Professora pesquisadora do Laboratório de Educação Profissional em Vigilância em Saúde da Escola Politécnica de Saúde Joaquim Venâncio/Fiocruz e professora da Universidade Federal do Rio Grande do Norte.

\section{Híngred Ferraz Pereira Resende}

Engenheira de produção e mestra em engenharia de produção. Pesquisadora do Laboratório HANDs (Humanitarian Assistance and Needs for Disasters) do Departamento de Engenharia Industrial da PUC-Rio. 


\section{Hugo Bellas}

Doutor em engenharia de produção. Pesquisador no Centro de Estudos Estratégicos/Fiocruz.

\section{Ionara Vieira Moura Rabelo}

Psicóloga, doutora em psicologia. Atua na área de vigilância às violências na Secretaria Municipal de Saúde de Goiânia e é professora adjunta na Universidade Federal de Goiás e colaboradora do Centro de Estudos e Pesquisas em Emergências e Desastres em Saúde/Fiocruz.

\section{Isabele Campos Costa-Amaral}

Farmacêutica, mestra em saúde pública e doutora com pós-doutorado em saúde pública e meio ambiente. Pesquisadora colaboradora no projeto de pesquisa Estudo do Impacto à Saúde de Agentes de Combate às Endemias/Guardas de Endemias pela Exposição a Agrotóxicos no Estado do Rio de Janeiro, coordenado pelo Centro de Estudos da Saúde do Trabalhador e Ecologia Humana da Escola Nacional de Saúde Pública Sergio Arouca/Fiocruz.

\section{Jaqueline Toledo de Oliveira Figueira}

Licenciada em letras, especialista em gestão de negócios. Analista de gestão em Bio-Manguinhos/Fiocruz.

\section{João Paulo Mello da Silveira}

Médico com residência médica em medicina de família e comunidade, especialista em processos educacionais na saúde com ênfase em avaliação de competência. Gerente de Atenção Primária na Secretaria Municipal de Saúde de Florianópolis.

\section{Jorge Mesquita Huet Machado}

Médico do trabalho e sanitarista, com pós-doutorado em saúde coletiva. Coordenador do Programa de Promoção da Saúde, Ambiente e Trabalho da Fiocruz Brasília e pesquisador associado no Instituto de Saúde Coletiva da Universidade Federal de Mato Grosso.

\section{Joseane Pessanha Ferreira}

Psicóloga, doutora em saúde pública. Bolsista de pós-doutorado em saúde coletiva no Programa Inova Fiocruz.

\section{Josy Maria de Pinho da Silva}

Fisioterapeuta, especialista em saúde coletiva, mestra e doutora em saúde coletiva. Assessora de planejamento da Secretaria Municipal de Saúde de Niterói.

\section{Júlia Fortes Guimarães de Moura}

Psicóloga. Bolsista de iniciação científica Pibic CNPq no Departamento de Estudos sobre Violência e Saúde Jorge Careli da Escola Nacional de Saúde Pública Sergio Arouca/Fiocruz.

\section{Júlia Maria Souza}

Graduada em enfermagem, especialista em saúde da família e em gestão da clínica. Integrante da Gerência de Atenção Primária da Secretaria Municipal de Saúde de Florianópolis. 


\section{Juliana Fernandes Kabad}

Bacharel em ciências sociais, doutora em saúde pública.

\section{Juliana Gagno Lima}

Nutricionista, doutora em saúde pública. Professora do Instituto de Saúde Coletiva da Universidade Federal do Oeste do Pará.

\section{Juliana Valentim Chaiblich}

Geógrafa, mestra em saúde coletiva. Professora pesquisadora do Laboratório de Educação Profissional em Vigilância em Saúde da Escola Politécnica de Saúde Joaquim Venâncio/Fiocruz.

\section{Leandro Vargas Barreto de Carvalho}

Farmacêutico, mestre em saúde pública e meio ambiente, especialista em saúde do trabalhador. Técnico em saúde pública do Centro de Estudos da Saúde do Trabalhador e Ecologia Humana da Escola Nacional de Saúde Pública Sergio Arouca/Fiocruz.

\section{Leticia Janotti}

Médica infectologista, mestra em saúde pública, especialista em controle de infecção, qualidade em saúde e segurança do paciente. Coordenadora da Câmara Técnica de Segurança do Paciente do Conselho Regional de Medicina do Estado do Rio de Janeiro.

\section{Letícia Kegele Lignani}

Farmacêutica, mestra em química analítica. Analista de farmacovigilância de Bio-Manguinhos/Fiocruz.

\section{Lidianne Albernaz}

Administradora. Gerente de Projetos da Coordenação de Ações Nacionais e de Cooperação do Instituto Nacional de Saúde da Mulher, da Criança e do Adolescente Fernandes Figueira/Fiocruz.

\section{Ligia Giovanella}

Médica sanitarista, doutora em saúde pública. Pesquisadora sênior da Escola Nacional de Saúde Pública Sergio Arouca/Fiocruz.

\section{Liliane Reis Teixeira}

Bióloga, mestra e doutora com pós-doutorado em saúde ambiental, na área de saúde do trabalhador. Pesquisadora do Centro de Estudos da Saúde do Trabalhador e Ecologia Humana da Escola Nacional de Saúde Pública Sergio Arouca/Fiocruz.

\section{Lívia Almeida de Menezes}

Pediatra e infectologista pediátrica. Coordenadora de Atenção à Saúde do Instituto Nacional de Saúde da Mulher, da Criança e do Adolescente Fernandes Figueira/Fiocruz.

\section{Lúcia Rotenberg}

Bióloga, doutora em psicologia. Pesquisadora em saúde pública do Laboratório de Educação em Ambiente e Saúde do Instituto Oswaldo Cruz/Fiocruz. 


\section{Luciana Bicalho Cavanellas}

Psicóloga, mestra em filosofia, doutora em saúde pública. Assessora da Coordenação de Saúde do Trabalhador da Fiocruz, com atuação na área de saúde mental e trabalho.

\section{Luciana Gomes}

Psicóloga, mestra e doutora com pós-doutorado em saúde pública, especialista em saúde do trabalhador. Pesquisadora em saúde pública do Centro de Estudos da Saúde do Trabalhador e Ecologia Humana da Escola Nacional de Saúde Pública Sergio Arouca/Fiocruz.

\section{Luisa Arueira Chaves}

Farmacêutica, doutora em saúde pública. Professora adjunta da Universidade Federal do Rio de Janeiro - Campus Macaé.

\section{Luiz Augusto Facchini}

Médico, doutor em ciências médicas. Professor do Departamento de Medicina Social da Universidade Federal de Pelotas.

\section{Luiz Claudio Meirelles}

Agrônomo, mestre em engenharia da produção, especialista em saúde do trabalhador e especialista em engenharia sanitária e ambiental. Pesquisador do Centro de Estudos da Saúde do Trabalhador e Ecologia Humana da Escola Nacional de Saúde Pública Sergio Arouca/Fiocruz.

\section{Luiza Beatriz Acioli}

Psicóloga sanitarista, mestra em saúde da criança e da mulher. Assessora técnica da Coordenação de Ações Nacionais e de Cooperação do Instituto Nacional de Saúde da Mulher, da Criança e do Adolescente Fernandes Figueira/Fiocruz.

\section{Luna Escorel Arouca}

Assistente social, mestra em ciência política. Coordenadora do Conexão Saúde e do Espaço Normal na Redes da Maré.

\section{Manuella Pessanha}

Assistente social, especialista em saúde da família e comunidade nos moldes de residência multiprofissional.

\section{Marcela de Souza Caldas}

Enfermeira, mestra em saúde coletiva. Secretária executiva do Conselho de Secretarias Municipais de Saúde do Estado do Rio de Janeiro.

\section{Marcello Rezende}

Psicólogo, mestre em saúde pública, doutor em psicologia social. Psicólogo da Coordenação de Saúde do Trabalhador da Fiocruz.

\section{Marcia Grisotti}

Socióloga, doutora em sociologia. Professora titular do Departamento de Sociologia e Ciência Política da Universidade Federal de Santa Catarina. 


\section{Márcia Vieira Leite}

Médica, especialista em saúde pública, epidemiologia e administração de serviços de saúde. Integrante do quadro de auditores do Departamento Nacional de Auditoria do SuS/Ministério da Saúde.

\section{Marcio Fernandes Nehab}

Pediatra e infectologista pediátrico, mestre em saúde da criança e da mulher. Supervisor do Programa de Residência em Pediatria do Instituto Nacional de Saúde da Mulher, da Criança e do Adolescente Fernandes Figueira/Fiocruz.

\section{Marcus Vinícius Corrêa dos Santos}

Bacharel em ciências biológicas, mestre em saúde pública e meio ambiente, especialista em farmacologia e toxicologia.

\section{Maria Auxiliadora de Souza Mendes Gomes}

Médica, doutora em saúde da criança e da mulher. Pesquisadora e docente da Pós-Graduação em Saúde da Criança e da Mulher e Coordenadora de Ações Nacionais e de Cooperação no Instituto Nacional de Saúde da Mulher, da Criança e do Adolescente Fernandes Figueira/Fiocruz.

\section{Maria Blandina Marques dos Santos}

Assistente social, mestra em saúde pública e meio ambiente, especialista em saúde do trabalhador. Tecnologista em saúde pública do Centro de Estudos da Saúde do Trabalhador e Ecologia Humana da Escola Nacional de Saúde Pública Sergio Arouca/Fiocruz.

\section{Maria Conceição de Oliveira}

Médica, doutora em ciências humanas. Professora da Universidade Federal de Santa Catarina - Campus Curitibanos.

\section{Maria Cristina Strausz}

Enfermeira, doutora em saúde pública. Tecnologista em saúde pública do Centro de Estudos de Saúde do Trabalhador e Ecologia Humana da Escola Nacional de Saúde Pública Sergio Arouca/Fiocruz.

\section{Maria da Conceição de Souza Rocha}

Enfermeira, mestra em saúde coletiva. Secretária municipal de Saúde de Volta Redonda, RJ, e representante do Conselho de Secretarias Municipais de Saúde do Estado do Rio de Janeiro no Conselho Nacional de Representantes Estaduais.

\section{Maria de Fátima Ramos Moreira}

Engenheira química, mestra em química, doutora em saúde pública. Tecnologista em saúde pública do Centro de Estudos da Saúde do Trabalhador e Ecologia Humana da Escola Nacional de Saúde Pública Sergio Arouca/Fiocruz.

\section{Maria de Jesus Fonseca}

Estatística, mestra em ciência, doutora em saúde coletiva. Pesquisadora em saúde pública no Departamento de Epidemiologia e Métodos Quantitativos da Escola Nacional de Saúde Pública Sergio Arouca/Fiocruz. 


\section{Maria de Lourdes de Sousa Maia}

Médica, mestra em pesquisa clínica, especialista em saúde pública e medicina tropical. Coordenadora da Assessoria Clínica de Bio-Manguinhos/Fiocruz.

\section{Maria de Lourdes Moura}

Médica, mestra em saúde pública. Coordenadora da Coordenação de Desenvolvimento Institucional e Apoio à Descentralização da Superintendência de Vigilância Sanitária da Secretaria de Estado de Saúde do Rio de Janeiro (SES-RJ), coordenadora adjunta do Comitê Estadual de Segurança do Paciente da SES-RJ e assessora técnico-científica do Centro Colaborador para a Qualidade do Cuidado e a Segurança do Paciente (Proqualis).

\section{Maria Fabiana Damásio Passos}

Psicóloga, doutora em psicologia. Diretora da Fiocruz Brasília e secretária executiva do Sistema Universidade Aberta do SuS.

\section{Maria Guadalupe Medina}

Médica, doutora em saúde coletiva. Pesquisadora do Instituto de Saúde Coletiva da Universidade Federal da Bahia.

\section{Maria Helena Machado}

Socióloga, doutora em sociologia. Pesquisadora titular da Escola Nacional de Saúde Pública Sergio Arouca/Fiocruz, onde é coordenadora do Núcleo de Estudos e Pesquisa de Recursos Humanos em Saúde e coordenadora geral da Pesquisa Condições de Trabalho dos Profissionais de Saúde no Contexto da Covid- I 9 no Brasil.

\section{Maria Helena Magalhães de Mendonça}

Socióloga, doutora em saúde coletiva. Pesquisadora titular da Escola Nacional de Saúde Pública Sergio Arouca/Fiocruz.

\section{Marina Noronha}

Enfermeira, doutora em saúde pública. Pesquisadora em saúde pública da Escola Nacional de Saúde Pública/Fiocruz e assessora técnico-científica do Centro Colaborador para a Qualidade do Cuidado e a Segurança do Paciente (Proqualis).

\section{Marisa Augusta de Oliveira}

Enfermeira, mestra em saúde pública. Coordenadora do Núcleo de Saúde do Trabalhador do Instituto Nacional de Infectologia Evandro Chagas/Fiocruz.

\section{Marta Gama de Magalhães}

Psicóloga, mestra em saúde pública. Analista de gestão em saúde no Programa IdeiaSuS/Fiocruz e colaboradora do Conselho de Secretarias Municipais de Saúde do Estado do Rio de Janeiro no Projeto Rede Colaborativa para Fortalecimento da Gestão Municipal do SuS. 


\section{Maurício Monken}

Geógrafo, especialista em impactos ambientais, mestre em planejamento urbano e regional, especialista em desenvolvimento regional e planejamento territorial, doutor em saúde pública. Professor pesquisador do Laboratório de Educação Profissional em Vigilância em Saúde da Escola Politécnica de Saúde Joaquim Venâncio/Fiocruz.

\section{Mellina Marques Vieira Izecksohn}

Médica, mestra em saúde pública. Coordenadora da Residência Médica da Escola Nacional de Saúde Pública Sergio Arouca/Fiocruz e docente da Universidade Federal do Rio de Janeiro.

\section{Michele Costa Caetano}

Farmacêutica, mestra em saúde pública. Farmacêutica do Instituto de Puericultura e Pediatria Martagão Gesteira da Universidade Federal do Rio de Janeiro.

\section{Michele Rocha El Kadri}

Psicóloga, mestra em saúde e sociedade na Amazônia. Pesquisadora do Laboratório de História, Políticas Públicas e Saúde na Amazônia do Instituto Leônidas e Maria Deane - Fiocruz Amazônia.

\section{Michele Souza e Souza}

Cientista social, mestra, doutora com pós-doutorado em saúde pública pela Escola Nacional de Saúde Pública Sergio Arouca/Fiocruz, com estudos voltados para a proteção social, sobretudo da população idosa. Pesquisadora colaboradora do Centro de Estudos e Pesquisas em Emergências e Desastres em Saúde/Fiocruz e assistente de pesquisa no Laboratório de Avaliação de Situações Endêmicas Regionais da Escola Nacional de Saúde Pública Sergio Arouca/Fiocruz.

\section{Mírian Ribeiro Conceição}

Terapeuta ocupacional, mestra em psicologia do aprendizado e desenvolvimento humano, especialista em docência na saúde. Gerente de Atenção Psicossocial da Fundação Estatal de Saúde de Niterói.

\section{Mônica Martins}

Nutricionista, sanitarista, mestra em saúde pública, Ph.D. em santé publique (option organisation des soins, Université de Montreal, Canadá). Pesquisadora titular da Escola Nacional de Saúde Pública Sergio Arouca/Fiocruz.

\section{Monica Regina Martins}

Assistente social, mestra em saúde pública, especialista em violência doméstica contra criança e adolescente, especialista em políticas sociais. Tecnologista em saúde pública do Centro de Estudos em Saúde do Trabalhador e Ecologia Humana da Escola Nacional de Saúde Pública Sergio Arouca/Fiocruz.

\section{Mônica Wermelinger}

Bióloga, doutora em saúde pública. Pesquisadora sênior do Núcleo de Estudos e Pesquisa de Recursos Humanos em Saúde da Escola Nacional de Saúde Pública Sergio Arouca/Fiocruz, integrante da equipe da Pesquisa Condições de Trabalho dos Profissionais de Saúde no Contexto da Covid- I 9 no Brasil. 


\section{Nicolly Papacidero Magrin}

Psicóloga, residente em saúde da família. Pesquisadora colaboradora do Centro de Estudos e Pesquisas em Emergências e Desastres em Saúde/Fiocruz.

\section{Nilson do Rosário Costa}

Doutor em planejamento urbano. Pesquisador em saúde pública no Departamento de Ciências Sociais da Fiocruz da Escola Nacional de Saúde Pública Sergio Arouca/Fiocruz.

\section{Patrícia Mouta Nunes de Oliveira}

Médica, especialista em segurança do paciente. Médica da Farmacovigilância na Assessoria Clínica de Bio-Manguinhos/Fiocruz.

\section{Paulo Henrique dos Santos Mota}

Fisioterapeuta, doutor em saúde pública em estágio de pós-doutorado na Faculdade de Saúde Pública da Universidade de São Paulo.

\section{Paulo Roberto Fagundes da Silva}

Pesquisador do Departamento de Ciências Sociais da Escola Nacional de Saúde Pública Sergio Arouca/Fiocruz.

\section{Paulo Victor Rodrigues de Carvalho}

Doutor em engenharia de produção. Pesquisador do Instituto de Engenharia Nuclear e professor do Programa de Pós-Graduação em Informática da Universidade Federal do Rio de Janeiro.

\section{Pedro Ribeiro Barbosa}

Médico, mestre e doutor em saúde pública. Diretor-presidente do Instituto de Biologia Molecular do Paraná, vinculado à Fiocruz e ao Instituto de Tecnologia do Paraná.

\section{Priscila Almeida Faria}

Pedagoga, mestra em ciências aeroespaciais, especialista em planejamento, implementação e gestão de educação a distância, especialista em supervisão escolar. Professora pesquisadora do Laboratório de Educação Profissional em Vigilância em Saúde da Escola Politécnica de Saúde Joaquim Venâncio/Fiocruz.

\section{Priscila Jeronimo da Silva Rodrigues Vidal}

Psicóloga, mestra em saúde pública e meio ambiente, especialista em promoção da saúde e desenvolvimento social e especialista em direito e saúde.

\section{Priscila Pavan Detoni}

Psicóloga, doutora em psicologia social e institucional. Professora da Universidade Federal da Fronteira Sul - Campus Passo Fundo.

\section{Rafael Almeida da Silva}

Médico veterinário, mestre em saúde pública. 


\section{Raíla de Souza Santos}

Enfermeira, doutora em ciências. Técnica universitária superior enfermeira na Universidade do Estado do Rio de Janeiro.

\section{Regina Paiva Daumas}

Médica, doutora em ciências. Pesquisadora da Escola Nacional de Saúde Pública Sergio Arouca/Fiocruz.

\section{Renato Tasca}

Médico sanitarista, mestre em saúde pública. Pesquisador da Fundação Getulio Vargas São Paulo.

\section{Ricardo Antunes Dantas de Oliveira}

Geógrafo, doutor em demografia. Pesquisador em saúde pública do Laboratório de Informação em Saúde do Instituto de Comunicação e Informação Científica e Tecnológica em Saúde/Fiocruz, coordena o Projeto de Avaliação do Desempenho do Sistema de Saúde e colabora com a iniciativa Brasil Saúde Amanhã.

\section{Rodrigo Alves Torres Oliveira}

Médico sanitarista. Secretário Municipal de Saúde de Niterói e presidente do Conselho de Secretarias Municipais de Saúde do Estado do Rio de Janeiro.

\section{Ronaldo Zonta}

Médico com residência médica em medicina de família e comunidade. Líder de guideline e treinamento no Programa PACK Brasil e chefe do Departamento de Gestão da Clínica da Gerência de Integração Assistencial da Secretaria Municipal de Saúde de Florianópolis.

\section{Rosana Aquino}

Médica, doutora em saúde coletiva. Pesquisadora do Instituto de Saúde Coletiva da Universidade Federal da Bahia.

\section{Rosane Härter Griep}

Enfermeira, doutora em ciências. Pesquisadora em saúde pública do Laboratório de Educação em Ambiente e Saúde do Instituto Oswaldo Cruz/Fiocruz.

\section{Sabrina Duarte}

Enfermeira, doutora em enfermagem. Professora adjunta da Escola de Enfermagem Anna Nery/Universidade Federal do Rio de Janeiro e assessora técnico-científica do Centro Colaborador para a Qualidade do Cuidado e a Segurança do Paciente (Proqualis).

\section{Sara da Silva Meneses}

Psicóloga, especialista em saúde da família e comunidade. Pesquisadora voluntária no Grupo de Pesquisa em Saúde Mental e Atenção Psicossocial na Covid- 19 da Fiocruz Brasília e coordenadora da Comissão Especial de Psicologia na Saúde do Conselho Regional de Psicologia do Distrito Federal. 


\section{Simone Gonçalves de Assis}

Médica, doutora em saúde pública. Pesquisadora titular do Departamento de Estudos sobre Violência e Saúde Jorge Careli da Escola Nacional de Saúde Pública Sergio Arouca/Fiocruz e professora visitante na Pós-Graduação em Neurologia do Hospital Universitário Gaffrée e Guinle/Universidade Federal do Estado do Rio de Janeiro.

\section{Simone Santos Oliveira}

Cientista social, doutora em saúde pública. Pesquisadora em saúde pública no Centro de Estudos de Saúde do Trabalhador e Ecologia Humana da Escola Nacional de Saúde Pública Sérgio Arouca/Fiocruz.

\section{Sônia Gertner}

Psicóloga, mestra em saúde pública. Coordenadora da Saúde do Trabalhador/Fiocruz.

\section{Tatiana Nascimento Docile}

Bióloga, mestra e doutora em ecologia. Professora pesquisadora do Laboratório de Educação Profissional em Vigilância em Saúde da Escola Politécnica de Saúde Joaquim Venâncio/Fiocruz e professora de biologia do Colégio de Aplicação da Universidade do Estado do Rio de Janeiro.

\section{Thaísa Guerreiro Souza}

Sanitarista, mestra em saúde coletiva. Defensora pública, coordenadora de Saúde e Tutela Coletiva da Defensoria Pública do Estado do Rio de Janeiro.

\section{Tharcisio Cotta Fontainha}

Engenheiro de produção, mestre e doutor em engenharia de produção, com pós-doutorado em engenharia de produção pela PUC-Rio. Professor adjunto no Programa de Engenharia de Produção do Instituto Alberto Luiz Coimbra de Pós-Graduação e Pesquisa de Engenharia da Universidade Federal do Rio de Janeiro e coordenador de projetos no Laboratório HANDs (Humanitarian Assistance and Needs for Disasters).

\section{Vera Lúcia Luiza}

Farmacêutica, doutora em saúde pública. Pesquisadora voluntária em saúde pública na Escola Nacional de Saúde Pública Sergio Arouca/Fiocruz.

\section{Victor Grabois}

Médico, doutor em saúde pública. Docente na Escola Nacional de Saúde Pública Sergio Arouca/ Fiocruz, presidente da Sociedade Brasileira para a Qualidade do Cuidado e Segurança do Paciente e coordenador executivo do Centro Colaborador para a Qualidade do Cuidado e a Segurança do Paciente (Proqualis).

\section{Victor Oliva Figueiredo}

Farmacêutico, mestre em saúde pública e meio ambiente, especialista em farmácia clínica e hospitalar.

\section{Wilson Aguiar Filho}

Enfermeiro, mestre em saúde pública. Pesquisador do Núcleo de Estudos e Pesquisa de Recursos Humanos em Saúde da Escola Nacional de Saúde Pública Sergio Arouca/Fiocruz e integrante da equipe da Pesquisa Condições de Trabalho dos Profissionais de Saúde no Contexto da Covid- 99 no Brasil. 


\section{Sumário}

Apresentação

Margareth Crisóstomo Portela, Lenice Gnocchi da Costa Reis e Sheyla Maria Lemos Lima

\section{PARTE I - ENFRENTAMENTO DA COVID- I 9 NO ÂMBITO NACIONAL E INTERNACIONAL}

1. Pandemia de Covid- 19: por que devemos olhar para o contexto internacional? Reflexões sobre a governança do setor Saúde Celia Almeida

2. Governança, Coordenação e Estratégias de Enfrentamento da Crise Gerada pela Covid- 19: lições aprendidas dos casos chinês, alemão e espanhol Adelyne Maria Mendes Pereira

3. Covid- 19: por uma aposta radical na saúde, para o bem da sociedade Pedro Ribeiro Barbosa e Eduardo Kaplan Barbosa

\section{PARTE II - ORGANIZAÇÃO DO CUIDADO NA PANDEMIA DE COVID- 19}

4. Logística para o Enfrentamento de Desastres e Aplicações ao Contexto da Pandemia de Covid- 19 Híngred Ferraz Pereira Resende, Tharcisio Cotta Fontainha e Adriana Leiras

5. Desabastecimento, uma Questão de Saúde Pública Global: sobram problemas, faltam medicamentos

Luisa Arueira Chaves, Claudia Garcia Serpa Osorio-de-Castro, Michele Costa Caetano, Rafael Almeida da Silva e Vera Lúcia Luiza

6. Qualidade do Cuidado e Segurança do Paciente: desafios e contribuições diante da pandemia de Covid- 19

Bárbara do Nascimento Caldas e Lenice Gnocchi da Costa Reis

7. Evolução da Disponibilidade dos Leitos de Terapia Intensiva na Rede Hospitalar do Brasil para o Enfrentamento da Emergência Sanitária

Carla Lourenço Tavares de Andrade, Sheyla Maria Lemos Lima, Claudia Cristina de

Aguiar Pereira, Mônica Martins, Fernando Ramalho Gameleira Soares e Margareth

Crisóstomo Portela

8. Cenários de Regionalização para Atenção Hospitalar à Covid- 19 no Estado do Rio de Janeiro

Ricardo Antunes Dantas de Oliveira, Francisco Viacava, Anselmo Rocha Romão, Mônica Martins, Carolina de Campos Carvalho e Caio de Paula Peixoto 
9. Proposta de Matriz de Linha de Cuidado Covid-1 9 na Rede de Atenção à Saúde

Margareth Crisóstomo Portela, Victor Grabois e Claudia Trauassos

10. Organização da Atenção Primária à Saúde no SUS no Enfrentamento da Covid- 19

Elyne Montenegro Engstrom, Eduardo Alves Melo, Ligia Giovanella, Adelyne Maria

Mendes Pereira, Victor Grabois e Maria Helena Magalhães de Mendonça

I I. Desafios da Atenção Básica no Enfrentamento da Pandemia de Covid- 19 no SUS

Ligia Giovanella, Aylene Bousquat, Maria Guadalupe Medina, Maria Helena Magalhães de Mendonça, Luiz Augusto Facchini, Renato Tasca, Fúlvio Borges Nedel, Juliana Gagno Lima, Paulo Henrique dos Santos Mota e Rosana Aquino

12. A Assistência Hospitalar de Nível de Complexidade Intermediário na Linha de Cuidado Covid- 19

Leticia Janotti

13. Maternidades e Covid- 19: atenção às gestantes e recém-nascidos no contexto da pandemia

Maria Auxiliadora de Souza Mendes Gomes, Cynthia Magluta, Luiza Beatriz Acioli e Lidianne Albernaz

14. Impacto da Covid- 9 na Saúde da Criança e do Adolescente Marcio Fernandes Nehab e Lívia Almeida de Menezes

15. Produção, Disseminação e Pronta Resposta de Amplo Acesso para Equipes de Saúde Mental e Atenção Psicossocial na Pandemia de Covid- 19

Débora da Silva Noal, Maria Fabiana Damásio Passos, Bernardo Dolabella Melo,

Carlos Machado de Freitas, Juliana Fernandes Kabad, Nicolly Papacidero Magrin,

Michele Souza e Souza, Michele Rocha El Kadri, Carolyne Cesar Lima, Fernanda Serpeloni,

Daphne Rodrigues Pereira, Sara da Silva Meneses e Beatriz Schmidt

16. Covid- 19: revendo processos para uma campanha de vacinação

Maria de Lourdes de Sousa Maia, Márcia Vieira Leite, Jaqueline Toledo de Oliveira Figueira.

Patrícia Mouta Nunes de Oliveira, Letícia Kegele Lignani e Beatriz de Castro Fialho

\section{PARTE III - OS PROFISSIONAIS DA SAÚDE E A PANDEMIA DE COVID- I 9}

17. Perfil e Condições de Trabalho dos Profissionais da Saúde em Tempos de Covid- 19: a realidade brasileira

Maria Helena Machado, Mônica Wermelinger, Antônio Vieira Machado,

Filipe Leonel Vargas, Everson Justino Pereira e Wilson Aguiar Filho

18. Insegurança e Medo na Atenção Primária: os agentes comunitários de saúde e a pandemia da Covid- 19 nas favelas do Brasil 
19. A Morte Contaminada: a experiência da morte por Covid- I 9 na perspectiva de profissionais da saúde

Marcia Grisotti, Daniel Granada, Priscila Pavan Detoni, Maria Conceição de Oliveira e Eliana Elisabeth Diehl

20. Agentes de Combate às Endemias: uma população em risco no enfrentamento da Covid- 19

Luiz Claudio Meirelles, Leandro Vargas Barreto de Carvalho, Marcus Vinícius Corrêa dos Santos, Ana Cristina Simões Rosa, Victor Oliva Figueiredo, Priscila Jeronimo da Silva Rodrigues Vidal, Ana Paula das Neves Silva, Dominique Marçal Mattos, Antônio Carlos dos Santos Cardoso, Monica Regina Martins, Maria de Fátima Ramos Moreira, Eline Simões Gonçalves, Isabele Campos Costa-Amaral, Luciana Gomes, Liliane Reis Teixeira, Maria Blandina Marques dos Santos, Alexandre Pessoa Dias, Edilene de Menezes Pereira, Gladys Miyashiro Miyashiro, Gracia Maria de Miranda Gondim, Juliana Valentim Chaiblich, Maurício Monken, Priscila Almeida Faria, Tatiana Nascimento Docile e Ariane Leites Larentis

21. Sofrimento Mental e Trabalho na Pandemia de Covid- 19: com a palavra, profissionais da saúde de UTIs e emergências no Rio de Janeiro Lúcia Rotenberg, Simone Santos Oliveira, Joseane Pessanha Ferreira, Raíla de Souza Santos, Davi da Silveira Barroso Alves, Aline Silva-Costa e Rosane Härter Griep

22. A Saúde dos Trabalhadores da Saúde: a experiência do Centro Hospitalar do Instituto Nacional de Infectologia

Simone Santos Oliveira, Lúcia Rotenberg, Denize Nogueira, Eliane Chaves Vianna, Jorge Mesquita Huet Machado, Joseane Pessanha Ferreira, Luciana Bicalho Cavanellas, Manuella Pessanha, Marcello Rezende, Maria Cristina Strausz, Maria de Jesus Fonseca, Marisa Augusta de Oliveira, Rosane Härter Griep e Sônia Gertner

23. Violência Doméstica e Familiar na Covid-19: capacitação emergencial on-line durante a pandemia

Fernanda Serpeloni, Fernanda Mendes Lages Ribeiro, Débora da Silva Noal,

Bernardo Dolabella Melo, Júlia Fortes Guimarães de Moura, Bianca Caroline Pickler,

Michele Souza e Souza, Ionara Vieira Moura Rabelo e Simone Gonçalves de Assis

\section{PARTE IV - EXPERIÊNCIAS BRASILEIRAS NA PANDEMIA DE COVID- I 9}

24. Atuação da Defensoria Pública na Pandemia: a luta por melhor organização e priorização da assistência à saúde

Thaísa Guerreiro Souza

25. A Experiência do Proqualis na Produção e Divulgação de Informações para o Enfrentamento da Pandemia de Covid- 19

Ana Luiza Braz Pavão, Victor Grabois, Carla Gouvêa, Maria de Lourdes Moura,

Marina Noronha e Sabrina Duarte

26. Enfrentamento da Pandemia de Covid- I 9 no Estado do Rio de Janeiro: a experiência do Cosems RJ

Maria da Conceição de Souza Rocha, Marcela de Souza Caldas e Marta Gama de Magalhães 
27. Pandemia de Covid- 19: a experiência da organização da rede de serviços de saúde em Florianópolis

João Paulo Mello da Silveira, Ronaldo Zonta, Fernanda Paese, Fernanda K. Melchior Silva Pinto, Filipe de Barros Perini, Ana Cristina Magalhães Fernandes Báfica, Elizimara Ferreira Siqueira, Júlia Maria Souza e Fernanda Lazzari Freitas

28. Desafios e Repercussões na Organização da Atenção Primária à Saúde no Contexto da Covid- 19: o caso do CSEGSF/Teias Manguinhos

Gisele O'Dwyer, Regina Paiva Daumas, Denise Cotrim da Cunha e Mellina Marques Vieira Izecksohn

29. Papel do SUS no Retorno às Atividades Escolares Presenciais na Pandemia de Covid- 19: a experiência do município de Niterói, RJ

Mírian Ribeiro Conceição, Josy Maria de Pinho da Silva. Ciane dos Santos Rodrigues,

Camilla Maia Franco e Rodrigo Alves Torres Oliveira

30. Integrando Vigilância e Atenção em Saúde Durante a Pandemia de Covid- I 9 : a experiência do Conexão Saúde na favela da Maré Luna Escorel Arouca e Fernando A. Bozza 


\section{Apresentação}

Margareth Crisóstomo Portela, Lenice Gnocchi da Costa Reis e

Sheyla Maria Lemos Lima

\footnotetext{
O
} enfrentamento da pandemia de Covid-19 impôs e continua impondo inúmeros desafios para os sistemas de saúde do mundo, que têm sido mais ou menos bemsucedidos nas ações voltadas para o seu controle e para a oferta de cuidados de saúde para a população afetada.

A Covid-19, doença ocasionada pelo coronavírus Sars-CoV-2, teve rápido espaIhamento no mundo e, apesar do conhecimento já acumulado, ainda permanece desconhecida em diversos aspectos, gerando assim incertezas. Desde dezembro de 2019, quando o primeiro caso foi diagnosticado em Wuhan, na China, a pandemia vem se propagando com o surgimento de novos casos e novas cepas do vírus, apesar de medidas de contenção, mitigação ou supressão implementadas por diferentes países, em momentos e abrangências distintos, e do início da vacinação, a partir de dezembro de 2020 (United Kingdom, 2020).

A Covid- 9 pode cursar nos indivíduos de forma assintomática, mas também pode se expressar com um conjunto de sinais e sintomas que demandam manejo clínico diferenciado, no âmbito ambulatorial e hospitalar, em internação clínica e de cuidados intensivos (Opas, 202I).

O ambiente global de espraiamento da pandemia se mostrou bastante complexo, testando a capacidade dos países de se organizarem e colaborarem entre si. Se por um lado o compartilhamento do conhecimento que foi sendo produzido se deu de forma rápida, por outro houve, em alguns momentos, competição por equipamentos e insumos médicos indisponíveis na escala demandada. Diante desse quadro, o papel desempenhado pela Organização Mundial da Saúde (OMS) na coordenação de ações globais demons- 
tra a relevância da cooperação multilateral para a produção e aceleração de respostas que beneficiem um contingente expressivo da população mundial.

A Covid-I 9 tem afetado a economia, a possibilidade de circulação das pessoas, as formas de trabalho, o convívio social e as rotinas individuais, como nunca experimentado no mundo globalizado. As curvas epidêmicas e a letalidade, em diferentes lugares e momentos, têm refletido a capacidade de coordenação dos países para o enfrentamento da pandemia, a capacidade de organização dos sistemas de saúde, valores culturais, condições de vida, perfil demográfico e desigualdades sociais. Ainda assim, com as suas peculiaridades, tensionam a necessidade de produção de conhecimento e busca de respostas, cujos efeitos certamente transcendem níveis nacionais. Pesquisadores e profissionais de diferentes áreas do conhecimento têm demonstrado destacada capacidade de análise e de formulação de propostas de intervenção para contribuir com o enfrentamento da pandemia (Ventura et al., 2020).

Responder rapidamente às novas e crescentes demandas por atendimento em nível ambulatorial e hospitalar tornou-se tarefa inescusável para os sistemas de saúde. Diante de um percentual estimado em torno de $5 \%$ de pacientes com formas muito graves da Covid-19, logo se colocou a necessidade de ampliação do número de leitos de unidades de terapia intensiva (UTIs), incluindo equipamentos e profissionais especializados. A taxa de ocupação de leitos de UTI para o atendimento à Covid-I 9 tornou-se um dos indicadores preconizados pela OMS para a sinalização do nível de alerta sobre a pandemia em uma área geográfica (WHO, 2020). Além de cuidados complexos no quadro agudo grave da doença, a Covid-I9 impõe a organização da rede de serviços de saúde, segundo uma linha de cuidados relacionados à doença, para lidar com as suas diferentes manifestações, níveis de gravidade e sequelas, nos diferentes pontos de atenção componentes dessa rede. As experiências de diferentes países confirmam que o papel da Atenção Primária à Saúde (APS) é central e deve ser fortalecido de modo a permitir o monitoramento adequado e a resolutividade de casos passíveis de acompanhamento domiciliar e em unidades básicas de saúde. O cuidado efetivo nesse nível de atenção modifica o risco de agravamento do paciente. Idealmente, a APS deve incorporar ações de vigilância em saúde, com testagem e rastreamento de contatos, além de apoiar medidas de isolamento e orientar sobre as medidas de proteção. Decerto, outros pontos de atenção se fazem necessários e precisam estar interligados para garantir o cuidado oportuno a pacientes que requerem hospitalização ou cuidados especializados e de reabilitação após a doença, pois suas repercussões podem persistir após a sua fase aguda em parte da população afetada (Raveendran, Jayadevan E Sashidharan, 202 I). 
No enfrentamento da Covid-19, outro problema que se impôs foi o adoecimento e perda de profissionais na linha de frente do cuidado em saúde por conta da própria doença e da imensa sobrecarga física e emocional. Contribuíram, especialmente no início da pandemia, o desconhecimento sobre a doença, a escassez de materiais de proteção individual e a necessidade de atuar em ambientes e estruturas, por vezes, inadequados. No decorrer do tempo, somaram-se o cansaço diante da rotina desgastante tão estendida, assim como a persistência de condições inadequadas para a provisão de cuidado, em contextos, frequentemente, de colapso do sistema de saúde, diante de elevada demanda (Teixeira et al., 2020).

A pandemia também impôs imensa necessidade de adaptação e aprimoramento dos serviços de saúde no que concerne ao objetivo de prover um cuidado seguro para o paciente. A produção e a disseminação de protocolos, diretrizes, fluxos para manejo de pacientes e orientações para a organização dos processos de trabalho exigiram empenho tenaz de pesquisadores e profissionais da saúde na busca pelas melhores evidências científicas disponíveis para seu embasamento. Novas questões emergiram para a segurança do paciente, que parece se imbricar mais à própria segurança dos trabalhadores da saúde, ampliando o escopo de sua atenção.

Muito conhecimento se produziu, mas a sua incorporação na organização dos serviços de saúde ainda é desigual e frequentemente incipiente. A Covid- 19 desafia não somente porque exige respostas dos sistemas de saúde, mas também porque tem desorganizado a provisão de cuidados necessários a outras condições de saúde. No Brasil, houve muitos óbitos por Covid- 19 nas unidades de saúde e fora delas, e o agravamento ou ocorrência de óbitos por outras condições parecem, de alguma forma, também estar atrelados ao curso da pandemia (Ranzani et al., 202I).

Esforços para construir um sistema de saúde resiliente exigem coordenação e articulação com todos os atores. É fundamental que juntos definam estratégias de financiamento, investimento na força de trabalho e tecnologias, com forte componente de comunicação e orientação à população. A população precisa ter noção clara da situação da pandemia e de seu papel nesse contexto, e o Estado deve ser responsável por fornecer informações fidedignas de forma sistemática e permanente. Além disso, o Estado deve estabelecer e coordenar as ações de enfrentamento da pandemia, com base no conhecimento científico vigente, sedimentando uma relação de confiança que favoreça a adesão da população às orientações e às medidas de controle preconizadas. Também é importante o seu papel na mitigação de desigualdades sociais e no acesso aos serviços de saúde. 
Neste livro são sistematizadas análises, reflexões e experiências vinculadas especialmente a dois eixos do Observatório Covid- 19 Fiocruz: Medidas de Controle e Organização dos Serviços e Sistemas de Saúde; e Qualidade do Cuidado, Segurança do Paciente e Saúde do Trabalhador. A maior parte dos textos apresentados foi produzida do início da pandemia no Brasil até meados de abril de 2021. Pretende-se contribuir para o registro histórico da pandemia, mas ao mesmo tempo são trazidos elementos que apontam perspectivas para o enfrentamento, no futuro, de situações semelhantes, de modo que possam ser mais bem gerenciados com base em lições aprendidas.

Os capítulos estão organizados em torno de quatro eixos, correspondentes às quatro partes do volume: Apontamentos sobre o Enfrentamento da Covid-19 no Âmbito Nacional e Internacional; Organização do Cuidado na Pandemia de Covid-I9; Os Profissionais da Saúde e a Pandemia de Covid-19; e Relatos de Experiências Brasileiras na Pandemia de Covid- 19.

Na primeira parte estão reunidos três capítulos que convidam a olhar o contexto internacional e a refletir sobre o papel de outras dimensões da vida - sociais, econômicas e ambientais. No primeiro deles, a pandemia de Covid-19 é mote para discutir o multilateralismo em um mundo de incertezas e crises, com reflexões acerca do papel de organizações multilaterais para garantir maior solidariedade, cooperação e coordenação, das mudanças nas relações de poder e da institucionalização de novos arranjos no setor Saúde, apresentando elementos relevantes na governança da pandemia em nível nacional (cap. I, Almeida). No capítulo seguinte, é apresentada a análise, em perspectiva comparada, de estratégias e ações políticas em resposta à Covid- 19 de três países que possuem diferentes sistemas de saúde e de vigilância: China, Alemanha e Espanha. Ainda que em contextos distintos, o papel da coordenação nacional da resposta a situações dessa natureza é apontado como imprescindível para que as desigualdades não sejam aprofundadas (cap. 2, Pereira). O eixo se completa com o capítulo no qual se propõe articular a saúde com diversas outras dimensões do desenvolvimento, destacando a importância de preservar a renda das famílias, promover o dinamismo econômico, tanto para gerar empregos qualificados como para suprir as carências tecnológicas do setor Saúde (cap. 3, Barbosa \& Barbosa).

A segunda parte, centrada na organização do cuidado na pandemia de Covid-19, engloba 16 capítulos que abordam diferentes aspectos associados ao cuidado em saúde e aos níveis de atenção da rede de serviços de saúde, para dar conta de uma doença desconhecida e continuar respondendo às suas demandas de rotina.

Os primeiros aspectos abordados nessa parte são a capacidade hospitalar do sistema de saúde e sua adaptação, a logística necessária para garantir suprimentos e 
continuidade da prestação do cuidado necessário, inclusive no que tange à imunização, e um conjunto de recomendações que podem orientar gestores no enfrentamento da pandemia de Covid- 9 (cap. 4, Resende, Fontainha E Leiras). O capítulo seguinte traz reflexões sobre a dinâmica do mercado farmacêutico, as fragilidades da cadeia de suprimento farmacêutico e a dependência do país das cadeias de produção global de medicamentos que, em situações como a da atual pandemia, leva ao risco de desabastecimento (cap. 5, Chaves e colaboradores).

Diante do aumento da demanda por cuidado ao longo da pandemia, outra questão que preocupa e foi objeto de reflexão no capítulo seguinte é a manutenção da qualidade do cuidado e da segurança do paciente, também incluindo a apresentação de ações e estratégias para o gerenciamento de risco (cap. 6, Caldas E Reis). Em seguida, é apresentada a capacidade instalada de leitos de terapia intensiva no país no início e no decorrer da pandemia, evidenciando a concentração de leitos em algumas áreas, em contraposição a grandes vazios assistenciais, especialmente no Norte e no Nordeste. O estudo remete à relevância de sistemas nacionais de informação em saúde para a tomada de decisões por gestores (cap. 7, Andrade e colaboradores). A importância da informação é retomada no capítulo 8, de Oliveira e colaboradores, em que são apresentados possíveis cenários para a reconfiguração da regionalização da rede de serviços de saúde, para garantir a atenção a casos graves, no estado do Rio de Janeiro.

Portela, Grabois e Travassos (cap. 9) propõem um arcabouço matricial que, com o objetivo de orientar a organização do cuidado dos pacientes de Covid-19, abrange a clínica, aspectos da vigilância, gestão do processo de cuidado, articulando todos os elementos do sistema de saúde.

Os dois capítulos seguintes tratam da APS. No primeiro deles são apresentadas recomendações para a organização dos serviços da APS, que precisa ser fortalecida para dar conta da demanda de rotina e daquelas trazidas pela pandemia causada pelo vírus Sars-CoV-2 (cap. 10, Engstrom e colaboradores). No seguinte, são apresentados alguns resultados da Pesquisa Desafios da Atenção Básica no Enfrentamento da Pandemia da Covid- 19 no SUS, conduzida pela Rede de Pesquisa em Atenção Primária da Associação Brasileira de Saúde Coletiva, e recomendadas ações urgentes para apoiar e qualificar as equipes da saúde da família (cap. I I, Giovanella e colaboradores).

O papel dos hospitais intermediários e sua importância tanto no cuidado do quadro agudo de pacientes sem necessidade de internação em UTI quanto na atenção àqueles com sequelas provocadas pela doença, também chamada de Covid longa ou síndrome pós-Covid, é abordado no cap. 12, de Janotti. 
As dificuldades enfrentadas e proposições feitas diante da pandemia Covid- 19 sobre a saúde materna e neonatal e sobre a saúde das crianças e adolescentes foram tratadas em dois capítulos. No capítulo 13, Gomes e colaboradoras tratam da importância da disseminação de conhecimento baseado em evidências como base para as decisões de reorganização da rede e do cuidado. No capítulo seguinte, a tônica está na necessidade de fortalecer a capacidade de atenção à saúde da criança e adolescente no âmbito do Sistema Único de Saúde (SUS) diante da dificuldade de acesso ao cuidado e do aumento da vulnerabilidade social (cap. 14, Nehab \& Menezes).

Noal e colaboradores (cap. 15) trazem relato e reflexões acerca da construção e realização do Curso Nacional de Saúde Mental e Atenção Psicossocial e de outras estratégias para disseminação do conhecimento sobre saúde mental e emergências sanitárias.

Esse eixo se completa com o tema da imunização contra a Covid- 19 e a apresentação da trajetória, da importância e dos desafios de implementar um programa de caráter nacional em um país de extensão territorial continental (cap. 16, Maia e colaboradores).

A terceira parte traz diversos aspectos relacionados aos profissionais da saúde em atuação na pandemia de Covid-19. No capítulo 17 é apresentada a grave realidade dos profissionais da saúde na linha de frente da Covid-19, com base em dados da Pesquisa Perfil e Condições de Trabalho dos Profissionais da Saúde no Contexto da Covid- 9 no Brasil (cap. 17, Machado e colaboradores).

Com base na percepção dos agentes comunitários de saúde (ACS) acerca da pandemia, foram discutidas evidências que podem ajudar na sua compreensão da dinâmica social e na elaboração de recomendações para a atuação segura e efetiva desses agentes (cap. 18. Costa e colaboradores). O capítulo seguinte traz a perspectiva de profissionais da saúde que prestam assistência a pacientes com Covid- 19 em UTIs sobre a circunstância de se ver diante da morte e sobre as mudanças no processo de cuidar dos pacientes, destacando a importância de que haja suporte psicossocial efetivo para os que atuam na linha de frente (cap. 19, Grisotti e colaboradoras). As condições e o processo de trabalho dos agentes de combate a endemias foram objeto de reflexões que se desdobraram em algumas recomendações para redução de riscos e proteção dos agentes e da população (cap. 20, Meirelles e colaboradores). Os dois capítulos que se seguem são dedicados a apresentar o tema da saúde mental dos profissionais da saúde. No primeiro deles, são discutidos os fatores que afetam a saúde mental dos profissionais da saúde durante a pandemia de Covid-19, mostrando a necessidade de ações que atenuem o seu sofrimento mental e físico (cap. 21, Rotenberg e colaboradores). No seguinte, são analisadas as condições e os aspectos psicossociais e de saúde mental relacionados ao trabalho dos profissionais em um hospital de alta complexidade de referência durante a pandemia de 
Covid- 19 (cap. 22, Oliveira e colaboradores). Por fim, é tratado o tema da capacitação dos profissionais e da rede de serviços de saúde para a proteção da população vulnerável contra a violência doméstica e familiar na pandemia (cap. 23, Serpeloni e colaboradores).

A quarta e última parte reúne sete relatos de experiências desenvolvidas no enfrentamento da pandemia no país. O primeiro apresenta uma síntese da atuação da Defensoria Pública do Estado do Rio de Janeiro durante a pandemia na busca de garantir assistência a todos, sublinhando a importância da atuação conjunta entre as instituições e a troca de informações (cap. 24, Guerreiro Souza).

A atuação das instituições científicas na produção e divulgação do conhecimento em momentos de crise sanitária foi apresentada tomando-se a experiência do Centro Colaborador para a Qualidade do Cuidado e Segurança do Paciente (Proqualis) da Fundação Oswaldo Cruz (cap. 25, Pavão e colaboradores). Nos dois capítulos subsequentes aborda-se a experiência de municípios. No primeiro deles o Conselho de Secretarias Municipais de Saúde do Rio de Janeiro (Cosems RJ) faz um apanhado de sua atuação ao longo do primeiro ano da pandemia, propiciando o diálogo com a Secretaria de Estado de Saúde do Rio de Janeiro e com outros atores e o acompanhamento dos movimentos de enfrentamento da pandemia do novo coronavírus no território fluminense (cap. 26, Rocha, Caldas E Magalhães). Em seguida é apresentada a experiência da organização da rede de serviços de saúde do município de Florianópolis para dar conta da atenção à saúde da população e das ações de vigilância em saúde, inclusive com a incorporação de novas tecnologias (cap. 27, Silveira e colaboradores). O capítulo 28 (O’Dwyer e colaboradoras) traz a experiência do Centro de Saúde Escola Germano Sinval Faria, da Escola Nacional de Saúde Pública Sergio Arouca/Fundação Oswaldo Cruz, na reorganização dos processos de atenção com vistas ao enfrentamento dos entraves colocados pela pandemia, apresentando aportes para outras unidades de APS. Em seguida, apresenta-se a experiência do município de Niterói, no Rio de Janeiro, no trabalho intersetorial envolvendo a saúde e a educação, para a adaptação de ambientes e atividades presenciais escolares, contemplando ações de vigilância e monitoramento do risco em diferentes espaços escolares e a elaboração de plano de retorno (cap. 29, Conceição e colaboradores). O último capítulo traz a experiência Conexão Saúde - De Olho na Covid, que envolve um conjunto de instituições e organizações comunitárias, com ações de comunicação, vigilância, atenção e gestão na Favela da Maré (cap. 30, Arouca e Bozza).

Em termos gerais, a pandemia de Covid- 19 reforçou a importância da coordenação e da articulação de ações e recursos no nível internacional para o adequado controle da sua propagação e a mitigação das desigualdades existentes. Também expôs as fragilidades do 
multilateralismo para fazer frente à perspectiva de muitas nações que optam por resolver exclusivamente os seus problemas, sem a compreensão de que sua solução transpõe barreiras territoriais. Outro aspecto que também emerge é a importância dos sistemas universais de saúde na articulação de ações nos níveis da vigilância e da prevenção, com destaque para a vacinação, e da assistência, incluindo reabilitação. No Brasil, ficou clara a necessidade de fortalecimento do SUS, que contemple aspectos estruturais e sua capacidade de planejamento e gestão. As desigualdades na distribuição de recursos e o passivo resultante do sucateamento do sistema no decorrer de anos repercutiram na capacidade de resposta do país à pandemia, expressa em problemas de qualidade na atenção e no elevado índice de mortalidade. O papel da rede de serviços de saúde, com pontos de cuidado com atribuições claras e mecanismos de referência e contrarreferência ativos, também deve ser sublinhado. Ainda que inicialmente se tenha conferido muita ênfase à necessidade de recursos assistenciais complexos, a experiência mostrou a relevância de uma APS resolutiva para a redução do risco da evolução indesejável da doença e, consequentemente, da necessidade de hospitalizações e do uso de terapia intensiva. Por fim, ficaram evidentes as vulnerabilidades dos trabalhadores da saúde, fortemente expostos na pandemia, que indicam a necessidade de capacitação, proteção, reposição e valorização profissional. O cuidado em saúde requer competências e habilidades que se constroem a longo prazo, não havendo condições, em um momento de crise, de compensar déficits, por exemplo, na formação profissional e na capacidade de trabalho em equipe.

Certamente, nem todos os aspectos relevantes e pertinentes à organização dos sistemas e serviços de saúde na pandemia de Covid- 19 estão contemplados neste livro. Acreditamos, entretanto, que ele traz um painel de desafios enfrentados e soluções encontradas durante a pandemia que não somente documenta reflexões, proposições e experiências, mas também propicia lições para situações futuras.

Após quase dois anos do início da pandemia de Covid-19, os números de casos e de mortes evidenciam a magnitude de seu impacto no mundo e no Brasil. Ao final de outubro de 202 I, havia registro de 245,0 milhões de casos e 4,5 milhões de mortes no mundo. No Brasil, alcançávamos 21,8 milhões de casos e a assombrosa cifra de 606,7 mil mortes. Em valores absolutos, o país é o $2^{\circ}$ em número de óbitos, o $3^{\circ} \mathrm{com}$ mais casos confirmados. Relativamente à população, o país é o $8^{\circ}$ em óbitos e o $16^{\circ} \mathrm{em}$ casos (Our World in Data, 2021).

O quadro brasileiro se deve, pelo menos em parte, ao fato de o governo federal não ter reconhecido a importância da adoção de medidas não farmacológicas, como distanciamento físico e social, uso de máscaras e campanhas de orientação à população. 
Além disso, a atuação errática do Ministério da Saúde, que durante a pandemia sofreu três sucessivas trocas de ministro, levou à desarticulação entre os gestores das três esferas do SUS e tornou evidente sua descoordenação. A falta de equipamentos, medicamentos e outros insumos no decorrer da pandemia foi fruto dessa incapacidade e descontinuidade de gestão. Pelos mesmos motivos, a decisão e atuação tardias para a aquisição das vacinas de modo a assegurar imunização a todos os cidadãos elegíveis no momento oportuno contribuíram para esse quadro.

Apesar disso, até o final de outubro de 202I foram administradas mais de 275 miIhões de doses de vacinas, o que corresponde a $72 \%$ da população com a primeira dose e 53\% com o esquema de vacinação completo (Fiocruz, 202 I). Esses dados colocam o Brasil como o $3^{\circ}$ país com mais doses administradas e como o $14^{\circ}$ país com população parcial ou completamente vacinada (Our World in Data, 202 I). Certamente essa situação se deve à histórica capacidade de atuação do Programa Nacional de Imunizações, embora hoje esteja em franco processo de deterioração. Outros fatores contribuem para esse quadro positivo, como a agilidade na distribuição e na aplicação das vacinas, responsabilidade de gestores estaduais e municipais, a pressão popular, pois o país está acostumado a fazer uso de imunizantes fornecidos pelo SUS, e a instalação da Comissão Parlamentar de Inquérito (CPI) da Pandemia, no Senado Federal.

Fazemos os últimos ajustes editoriais neste e-book, coincidentemente, na mesma semana em que o relatório final da CPI foi aprovado, com evidências incontestáveis de ações e omissões do governo federal que contribuíram para o agravamento da crise sanitária e humanitária que se instalou no país.

A pandemia parece começar a ser controlada com a vacinação iniciada em janeiro de 2021. Em agosto, ampliou-se a cobertura para faixas etárias mais jovens, após a imunização de segmentos da população mais vulneráveis e expostos e de adultos. Ao final de setembro, foi iniciada a aplicação de dose de reforço, adicional ao esquema vacinal inicial, de grupos de idosos e imunossuprimidos.

A incidência de Covid- 19 e a mortalidade por esta doença ainda se encontram em patamares muito elevados, mas apresentam diminuição consistente. Apesar da possibilidade de que surjam novas variantes não sensíveis às vacinas disponíveis, pode-se vislumbrar um novo cenário em que a doença se configure como endêmica, requerendo respostas específicas dos serviços de saúde na sua convivência com outras demandas rotineiras que eventualmente se coloquem.

Ainda são necessários esforços para assegurar a elevada cobertura vacinal da população e, possivelmente, a revacinação regular nos moldes da vacina de influenza. 
Também é preciso incrementar o monitoramento das mudanças genômicas do vírus, dos indicadores epidemiológicos e da capacidade de oferta e organização dos serviços de saúde para atender os novos casos que ainda venham a surgir e as consequências da Covid longa. Por fim, e não menos importante, faz-se necessário o fortalecimento de estruturas do SUS para dar conta do passivo de atendimentos não realizados durante a pandemia, adicionado a filas de espera tradicionalmente longas e às novas demandas, oriundas da Covid longa, com variada gama de sequelas e danos em parte da população acometida.

\section{REFERENCIAS}

FUNDAÇÃO OSWALDO CRUZ (FIOCRUZ). Instituto de Comunicação e Informação Científica e Tecnológica em Saúde (Icict). MonitoraCovid- 19. Rio de Janeiro, 202I. Disponível em: < https://bigdatacovid I 9.icict.fiocruz.br/>. Acesso em: 28 out. 2021.

ORGANIZAÇÃO PAN-AMERICANA DA SAÚDE (OPAS). Covid-19 Manejo Clínico: orientação dinâmica, 25 de janeiro de 2021. Brasília: Opas, 2021. Disponível em: <https://iris.paho.org/ handle/10665.2/53296>. Acesso em: 26 out. 2021.

OUR WORLD IN DATA. Disponível em: < https://ourworldindata.org/coronavirus>. Acesso em: 28 out. 2021 .

RANZANI, O. T. et al. Characterisation of the first 250,000 hospital admissions for Covid- 9 in Brazil: a retrospective analysis of nationwide data. The Lancet Respiratory Medicine, 9(4): 407-418, 2021. Disponível em: <www.thelancet.com/journals/lanres/article/PIIS22 I 3-2600(20)30560-9/fulltext>. Acesso em: 26 out. 2021.

RAVEendRAN, A. V.; JAYADEVAN, R. \& SASHIDHARAN, S. Long Covid: an overview. Diabetes and Metabolic Syndrome, 15(3): 869-875, 2021. Disponível em: <https://pubmed.ncbi.nlm.nih. gov/33892403/>. Acesso em: 26 out. 2021 .

TEIXEIRA, C. F. S. et al. A saúde dos profissionais de saúde no enfrentamento da pandemia de Covid- 19. Ciência E Saúde Coletiva, 25(9): 3.465-3.474, 2020. Disponível em: < https://scielosp.org/article/ csc/2020.v25n9/3465-3474/>. Acesso em: 26 out. 2021.

UNITED KINGDOM. Department of Health and Social Care. More than 137,000 people in UK receive first dose of Covid vaccine in one week, 2020. Disponível em: <www.gov.uk/government/news/more-than137000-people-in-uk-receive-first-dose-of-covid-vaccine-in-one-week>. Acesso em: 26 out. 2021 .

VENTURA, D. F. L. et al. Desafios da pandemia de Covid-19: por uma agenda brasileira de pesquisa em saúde global e sustentabilidade. Cadernos de Saúde Pública, 36(4): e00040620, 2020. Disponível em: <www.scielosp.org/pdf/csp/2020.v36n4/e00040620/pt>. Acesso em: 26 out. 2021.

WORLD HEALTH ORGANIZATION (WHO). Regional Office for the Western Pacific. Indicators to Monitor Health-Care Capacity and Utilization for Decision-Making on Covid-19. Manila: WHO Regional Office for the Western Pacific, 2020. Disponível em: <https://iris.wpro.who.int/handle/I 0665. I/I 4568>. Acesso em: 26 out. 2021 . 
PARTE I

ENFRENTAMENTO DA COVID-19 NO ÂMBITO NACIONAL E INTERNACIONAL 



\section{Pandemia de Covid-19}

\section{por que devemos olhar para o contexto internacional? Reflexões sobre a governança do setor Saúde ${ }^{1}$}

Celia Almeida

esde o início de 2020 vivemos uma situação inusitada com a pandemia de Covid- I 9 e seu impacto em todos os âmbitos da vida cotidiana, em todos os níveis - mundial, nacional, grupal e individual - onde a incerteza e a insegurança parecem permanentes.

Mais do que nunca, precisamos estar atentos às várias dimensões interconectadas desse processo. Muitas dinâmicas complexas que já estavam em curso se exacerbaram e ficaram mais visíveis com esta catástrofe humanitária, que não foi produzida só pelo vírus até então desconhecido, mas por todo contexto global, multifacetado e agressivo do qual ele emana.

Hoje sabemos mais sobre o vírus, graças a um historicamente inédito e rápido desenvolvimento científico e tecnológico. Sabemos, teoricamente, o que se deve (ou deveria) fazer e o que pode (ou poderia) ainda ser feito. Proliferam recomendações, sugestões de procedimentos/alianças que poderiam ser adotadas, com melhores possivelmente resultados. Por que não se cumprem, ou não são alcançados os benefícios que apregoam?

Para além das fronteiras nacionais, e sem diminuir em nada a inadmissível irresponsabilidade de alguns governantes, parece-nos importante olhar um pouco mais além. Existem conexões entre os contextos internacional e nacional que merecem nossa atenção.

Constata-se a simultaneidade de mudanças que vinham ocorrendo no mundo desde os anos 1990, e discussões sobre a área social, incluída a saúde, pari passu com o surgimento dos novos termos - saúde global, diplomacia da ou em saúde global, governança da saúde global. Aquelas mudanças alteravam a dinâmica do sistema mundial, composto pelos Estados-nação em um mundo caracterizado por grandes assimetrias de poder (centro, periferia e semiperiferia) e do sistema internacional, formado pelo

\footnotetext{
I Síntese atualizada de trabalhos publicados pela autora em 2020 e 2021.
} 
conjunto de instituições e organizações multilaterais - a Organização das Nações Unidas (ONU), as instituições resultantes dos acordos de Bretton Woods (Fundo Monetário Internacional, Banco Mundial, Banco Interamericano de Desenvolvimento etc.) e outros grupos multiestatais -, assim como as relações entre diferentes atores (antigos e novos) nas arenas internacionais, repercutindo de forma relevante nas políticas nacionais em todos os setores.

Algumas perguntas se sobrepõem: por que as respostas nacionais e regionais são tão diferentes, para além dos respectivos contextos e conjunturas específicas e dos regimes políticos em cada país? Por que as organizações multilaterais têm sido tão criticadas há décadas, especialmente a Organização Mundial da Saúde (OMS)? Por que as disputas globais por insumos essenciais aos cuidados em saúde são tão acirradas (p. ex., a "corrida” por equipamentos de proteção individual (EPIs), por respiradores e pelas vacinas, atualmente a ponta mais visível desse iceberg)?

Não temos respostas fáceis ou completas para essas perguntas complexas, pois são muitas as variáveis envolvidas e tampouco existe uma única resposta para qualquer pergunta. A forma como olhamos para determinada questão varia segundo os diferentes pontos de vista que adotamos para a nossa reflexão, que podem ser complementares ou até antagônicos. Portanto, nossas "respostas" serão seletivas e necessariamente parciais.

A proposta neste texto é explorar elementos que nos ajudem a refletir sobre algumas dessas perguntas. Adotamos as perspectivas da economia política internacional e da formulação/implementação de políticas, com foco na dinâmica global. As reflexões apresentadas se baseiam em revisão bibliográfica e análise documental.

\section{ORDEM INTERNACIONAL INCERTA E CRISE DO MULTILATERALISMO}

A ordem mundial pode ser definida com base nas características institucionais e normativas que condicionam os mecanismos de cooperação, concorrência e conflito no sistema interestatal. Foi reestruturada em diferentes momentos históricos, consolidando a acumulação capitalista.

Multilateralismo e ordem mundial são inter-relacionados: o primeiro é uma força ativa e não pode ser desvinculado do contexto histórico em que ocorre, isto é, do contexto que molda a estrutura da ordem mundial. O "termo multilateral incorpora pelo menos dois significados - um relacionado às relações interestatais e outro às relações entre variados atores - públicos, privados e da sociedade civil", [portanto] "é necessário analisá-lo na perspectiva das relações de poder que movem o sistema mundial” (Almeida E Campos, 2020: 15). 
O contexto específico do surgimento do multilateralismo contemporâneo remonta ao pós-guerra e, nele, duas dimensões são relevantes: a econômica e a política. As inflexões e mudanças de rota na dinâmica da ordem mundial, e consequentemente do multilateralismo, foram profundas e significativas desde então. Em termos muito sintéticos, na dimensão econômica o consenso provisório da ordem mundial liberal lançou as bases para a expansão do capitalismo, e na dimensão política institucionalizou os arranjos necessários, materializados no sistema internacional (Almeida $\mathcal{E}$ Campos, 2020).

As atribulações econômicas dos anos 1970 e o fim da bipolaridade alteraram a ordem mundial liberal no pós-guerra fria (1 990 em diante) e evidenciaram as estratégias unilaterais do hegemon (EUA), extremamente bélicas e intervencionistas, ampliando de forma importante o "poder imperial” norte-americano (Fiori, 2020).

Concomitantemente, o ideário econômico e político-ideológico neoliberal, descartado no imediato pós-guerra, retomou protagonismo em nível global, sob a liderança do Fundo Monetário Internacional e do Banco Mundial, materializado nos ajustes macroeconômicos, que promoveram também o desmonte das políticas sociais, incluídas as de saúde (Almeida E Campos, 2020). Uma agenda de reorganização dos serviços de saúde se difundiu mundo afora, estimulando as controvérsias e as reformas "pós-welfare". O rastro global de destruição desse processo é bem conhecido: aumento exponencial das desigualdades e iniquidades (entre países e dentro de um mesmo país), da extrema pobreza e das migrações (sul-norte, norte-norte e sul-sul). Registra-se também a concentração, cada vez maior, da produção de insumos (variados e necessários para o cuidado em saúde) em empresas nacionais/multinacionais, em um primeiro momento, e transnacionais e desterritorializadas, logo em seguida.

Em resumo, com o desaparecimento do regime geopolítico bipolar, alteraramse também os princípios éticos e político-ideológicos que sustentavam as relações no sistema interestatal, como a cooperação entre as grandes potências capitalistas, anunciando que estávamos entrando em um período de transição para uma "ordem mundial incerta”, encoberta pelo entusiasmo que despertou a ideologia da globalização neoliberal (Fiori, 2020). Paulatinamente, os Estados Unidos da América do Norte (EUA) consolidaram seu poder imperial, promovendo inúmeras guerras e intervenções alémmar, sob diferentes governos, em nome de princípios "solidários" e "democráticos". Após o ataque de 11 de setembro de 200I, suas intervenções "humanitárias" e de “ajuda internacional” foram instrumentalizadas para fins geopolíticos (Almeida, 20 I I).

Uma sucessão de crises econômicas localizadas e inúmeros conflitos adentraram o século XXI, desembocando na grande crise financeira de 2008 que se espalhou pelo 
mundo desregulado e globalizado. As políticas de austeridade conduzidas a partir de então exacerbaram as restrições/imposições à formulação e implementação das políticas nacionais, estimularam a ascensão de governos de ultradireita, ${ }^{2}$ alguns explicitamente antidemocráticos e autoritários, e subverteram os preceitos fundacionais e procedurais do multilateralismo, exponenciando a sua crise. Vivenciamos desde então crescente piora das condições de vida de expressivo contingente populacional em todo o mundo: desemprego, informalidade do trabalho, crescente concentração de renda e riqueza, exacerbação do consumismo, exploração intensa e desordenada de recursos naturais, de espaços rurais e urbanos, poluição e proliferação de riscos catastróficos que ameaçam a sobrevivência no planeta.

Durante a segunda década do século XXI, os EUA, agora um poder imperial explícito e claramente unilateral, se desvincularam completamente de qualquer compromisso com a coesão do sistema interestatal e a promoção do desenvolvimento no mundo, desconsiderando, e tentando destruir, o sistema multilateral e qualquer ordem que não fosse em defesa de seus próprios interesses nacionais (Fiori, 2019). Como consequência, exacerbaram-se as disputas no sistema interestatal, com resistências cada vez mais frequentes (Obsal \& Tricontinental, 2020) e revides de outros Estados, que utilizam inclusive os mesmos mecanismos intervencionistas da política externa norte-americana. A disputa geopolítica explícita entre EUA e China é escancarada com a pandemia de Covid- 19.

\section{GOVERNANÇA GLOBAL E DO SETOR SAÚDE}

No concernente à governança do setor Saúde, termo que preferimos, constatamos nessa dinâmica a restruturação da governança global no mesmo período.

O termo governança incorpora questões relativas aos padrões de articulação e cooperação entre diferentes atores, a partir de arranjos institucionais e mecanismos, formais e informais, que os coordenam e regulam, segundo determinados princípios e diretrizes. O sistema internacional e suas agências é parte relevante desse processo formal de condução global, no qual os Estados nacionais ocupam posição de destaque, apesar das grandes assimetrias de poder entre eles, da dominância das grandes potências e das disputas por esse lugar. O conjunto de forças composto por distintos atores - públicos, privados, da sociedade civil, transnacionais - cada vez mais numerosos, mais ou menos institucionalizado e que extrapola o poder estatal ainda que

\footnotetext{
2 Ultradireita é entendida aqui como resultante da fusão do neoliberalismo econômico com o neoconservadorismo político, social e cultural, que expressa um feroz ataque à democracia, às políticas sociais de cunho solidário $e$ à diversidade.
} 
articulado com ele, cresceu muito a partir dos anos 1990 e constitui outra dimensão da governança. Essa pletora de atores configura uma intrincada teia de relações, um sistema cada vez mais denso de instituições públicas e privadas entrelaçadas, em escala nacional, internacional e transnacional.

As mudanças nas relações de poder decorrentes afetaram a articulação entre os processos de decisão em nível global e sua implementação regional, nacional ou local, e vice-versa. Aumentaram as coalizões intergovernamentais de grupos de países (os grupos G), em âmbito regional e geopolítico (p. ex., Mercosul, Ibas, Unasul, Brics, União Africana), além de outros atores não governamentais.

Essa dinâmica, associada aos valores neoliberais, conferiu predominância ao setor privado lucrativo, a doadores de programas verticais, organizações filantrópicas e organizações não governamentais (ONGs), interferindo nos processos de decisão em todos os níveis e, portanto, na governança global (Almeida, 202I). Esse panorama impulsiona a institucionalização de novos arranjos: parcerias público-privadas (PPPs) a partir de diferentes iniciativas globais, redes transgovernamentais e transnacionais que atuam junto com os órgãos multilaterais, ou paralelamente a estes, com proeminência crescente. E tem resultado em inflexões substantivas, não apenas no financiamento e organização dos cuidados de saúde prestados às populações, mas também na produção e distribuição de insumos essenciais para suprir as necessidades dos indivíduos e coletividades, em territórios e contextos específicos, ou seja, interfere significativamente na governança do setor Saúde.

Assim, governança refere-se a um processo dinâmico, cuja análise requer identificar a configuração de atores e levar em consideração as relações de poder (econômico e político-ideológico) entre eles e os valores éticos e morais presentes nas negociações em diferentes níveis políticos (nacional, global, regional), as quais são parcialmente determinadas pelo contexto e pela questão específica.

O reconhecimento de que saúde é uma questão multissetorial requer uma governança correspondente, pois está submetida a (e modelada por) regulamentações, tendências e desenvolvimentos estabelecidos em outras áreas de políticas. Portanto, a governança do setor Saúde deve ser entendida como um espaço político amplo, complexo e imanente aos processos contemporâneos de globalização, marcado por inflexões históricas, agudas divisões políticas, ideacionais e motivações conflitantes. Nesse espaço se constroem discursos sobre a saúde global que competem entre si e se materializam em políticas internacionais promovidas e defendidas por diferentes organizações, instituições, agências e coalizões, permeadas por interesses diversificados e poderosos (Almeida, 202I). 
Esse é o cenário em que a pandemia de Covid- 19 se espalha pelo mundo, exacerbando os resultados desastrosos das últimas décadas e descortinando as dificuldades inerentes a essas configurações.

\section{A ONU E A LIDERANÇA DA OMS NA SAÚDE}

A resposta multilateral das Organização das Nações Unidas (ONU) como um todo na pandemia de Covid-19 deixou a desejar, apesar dos esforços do secretário-geral, António Manuel de Oliveira Guterres (Quadro I).

Quadro I - Ações de organizações da ONU e outras intergovernamentais voltadas para a pandemia (exceto OMS)

\begin{tabular}{|c|c|}
\hline Organização & Ação / Crítica \\
\hline \multicolumn{2}{|r|}{ Âmbito global } \\
\hline $\begin{array}{l}\text { Secretário-geral, } \\
\text { António Guterres }\end{array}$ & $\begin{array}{l}\text { Grande protagonismo, em 4/02/2020 acionou a Política de Gestão de Crises } \\
\text { da ONU, o maior nível possível de alerta no sistema, pela primeira vez em } \\
\text { uma emergência em saúde }\end{array}$ \\
\hline $\begin{array}{l}\text { Conselho de } \\
\text { Segurança }\end{array}$ & $\begin{array}{l}\text { Apresentou certa paralisia diante da disputa entre EUA e China, não aprovou } \\
\text { declaração definindo a pandemia de Sars-Covid-2 como uma ameaça à } \\
\text { segurança e à paz mundial (como anteriormente com a HIV/Aids) } \\
\text { Debilitou a proposta de cessar-fogo planetário } \\
\text { Mantém manifestações tímidas e sem resultados práticos concretos }\end{array}$ \\
\hline $\begin{array}{l}\text { Respostas } \\
\text { conjuntas } \\
\text { dos órgãos } \\
\text { especializados }\end{array}$ & $\begin{array}{l}\text { Formulação do Plano Humanitário Global e dinamização do Fundo Central de } \\
\text { Resposta à Emergência da Coordenação de Assuntos Humanitários. } \\
\text { Organização das Nações Unidas para a Alimentação e a Agricultura (FAO), } \\
\text { Conselho Econômico e Social das Nações Unidas (Ecosoc) e Programa das } \\
\text { Nações Unidas para o Desenvolvimento (Pnud) também se manifestaram na } \\
\text { Assembleia Geral da ONU, ainda que de forma vaga e com recomendações } \\
\text { mais retóricas do que propositivas, reiterando a função da OMS na } \\
\text { governança da pandemia }\end{array}$ \\
\hline \multicolumn{2}{|r|}{ Âmbito regional } \\
\hline $\begin{array}{l}\text { Comissão } \\
\text { Econômica para a } \\
\text { América Latina e } \\
\text { o Caribe (Cepal) }\end{array}$ & $\begin{array}{l}\text { Acompanhamento da pandemia na região } \\
\text { Elaboração constante de documentos e estudos sobre os desdobramentos } \\
\text { do processo pandêmico e cenários para um futuro (próximo e possível) } \\
\text { pós-pandemia }\end{array}$ \\
\hline $\begin{array}{l}\text { Organização Pan- } \\
\text { Americana da } \\
\text { Saúde (Opas) }\end{array}$ & $\begin{array}{l}\text { Papel relevante de referência regional, tanto na retransmissão das estratégias } \\
\text { formuladas em Genebra quanto no acompanhamento da dinâmica regional da } \\
\text { pandemia }\end{array}$ \\
\hline
\end{tabular}


Quadro I - Ações de organizações da ONU e outras intergovernamentais voltadas para a pandemia (exceto OMS) (continuação)

\begin{tabular}{|c|c|}
\hline Organização & Ação / Crítica \\
\hline \multicolumn{2}{|r|}{ Âmbito global } \\
\hline \multirow{5}{*}{$\begin{array}{l}\text { Arranjos ou } \\
\text { coalizões } \\
\text { regionais do Sul } \\
\text { geopolítico }\end{array}$} & $\begin{array}{l}\text { O Mercado Comum do Sul (Mercosul) não conseguiu se organizar para } \\
\text { nenhuma ação conjunta }\end{array}$ \\
\hline & $\begin{array}{l}\text { A União de Nações Sul-Americanas (Unasul) havia sido desmontada, por } \\
\text { problemas político-ideológicos desencadeados pelo Brasil e outros governos } \\
\text { de extrema direita na região. Esses mesmos governantes criaram uma nova } \\
\text { organização, o Foro para el Progreso de America del Sur (Prosur), que não } \\
\text { decolou e desapareceu na pandemia. Como resultado, não foi desenvolvida } \\
\text { nenhuma coordenação ou cooperação efetiva de ações para enfrentamento da } \\
\text { pandemia na América do Sul }\end{array}$ \\
\hline & $\begin{array}{l}\text { Observa-se a exceção na América Central e Caribe, onde foi possível } \\
\text { enfrentar discordâncias e se conseguiu alguma cooperação sub-regional com } \\
\text { financiamento externo }\end{array}$ \\
\hline & $\begin{array}{l}\text { A coalizão Brics (Brasil, Rússia, Índia, China e África do Sul), que teria } \\
\text { potencial para uma atuação mais efetiva em prol dos países do Sul global, } \\
\text { não conseguiu atuar conjuntamente de forma efetiva }\end{array}$ \\
\hline & $\begin{array}{l}\text { A União Africana (UA) firmou parceria entre a African Union Comission, } \\
\text { o CDC Africa e a Coalition for Epidemic Preparedness Innovations (Cepi) e } \\
\text { criou o African Vaccine Acquisition Trust (Avat), para fortalecer a resposta } \\
\text { regional à Covid- 19, incluindo apoio aos sistemas de saúde e à produção de } \\
\text { vacinas para a região. Para tanto, realizaram a African Vaccine Manufacturing } \\
\text { Virtual Conference em meados de abril de } 202 \text { I. A UA continua lutando para } \\
\text { conseguir vacinas e lidando com inúmeros problemas da região }\end{array}$ \\
\hline \multicolumn{2}{|r|}{ Grandes financiadores } \\
\hline $\begin{array}{l}\text { Grupo Banco } \\
\text { Mundial }\end{array}$ & $\begin{array}{l}\text { O Banco Interamericano de Desenvolvimento (BID) e o BCIE destinaram } \\
\text { créditos emergenciais para a região das Américas do Sul e Central }\end{array}$ \\
\hline $\begin{array}{l}\text { Banco Centro- } \\
\text { Americano } \\
\text { de Integração } \\
\text { Econômica (BCIE) }\end{array}$ & $\begin{array}{l}\text { O grupo Banco Mundial e outros bancos regionais, como o BID, destinaram } \\
\text { bilhões de dólares para os programas de vacinação nos países de rendas } \\
\text { média e baixa, que podem ser utilizados tanto para compra de vacinas } \\
\text { quanto para a logística da vacinação }\end{array}$ \\
\hline $\begin{array}{l}\text { Afreximbanke } \\
\text { Africa Finance } \\
\text { Corporation }\end{array}$ & $\begin{array}{l}\text { Firmaram compromisso com a União Africana para apoiar a região no } \\
\text { enfrentamento da pandemia }\end{array}$ \\
\hline
\end{tabular}

Fonte: vários autores apud Almeida, 2021.

A OMS, por sua vez, tem se esforçado para cumprir seu papel a contento, apesar das inúmeras críticas ao multilateralismo, dos ataques de diferentes governos, da deslegitimação de seu papel, da perda de poder e dos revezes das últimas décadas 
no aprendizado de como lidar com pandemias potencialmente danosas (Almeida $\varepsilon$ Campos, 2020) (Figura I).

Figura I - Atuação criticada da OMS em algumas pandemias recentes - 1990 a 2004

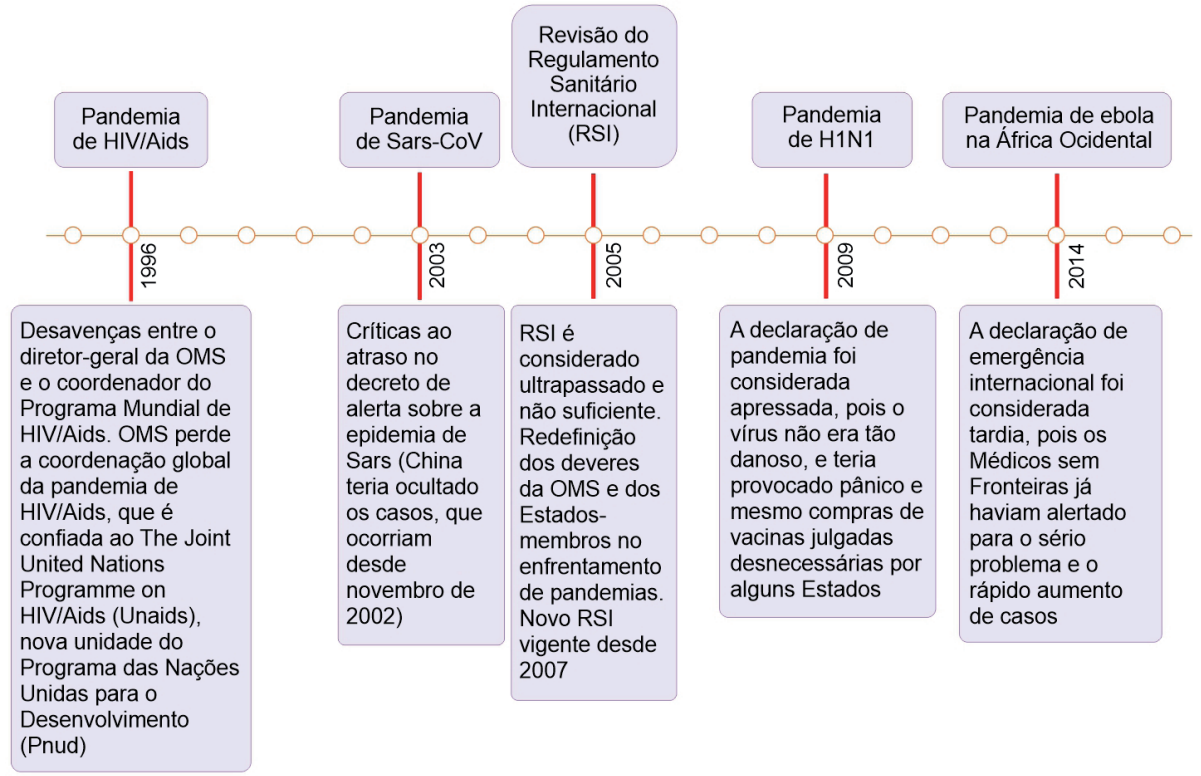

Fonte: elaboração própria com base em Almeida E Campos, 2020, Quadro I.

A liderança oficial da OMS configura-se como um espaço social e político de embates, negociações e enfrentamentos que refletem a dinâmica mais ampla do multilateralismo e da ordem mundial, assim como do setor Saúde como um todo (Almeida E Campos, 2020). Como qualquer organização multilateral, é uma "arena em que os atores orientam suas ações em relação a outros atores" (Almeida, 2021 : 28). Há muitos anos, portanto, os debates e ações da OMS refletem as contradições geopolíticas e de sua estruturação histórica (Lima E Albuquerque, 202I), sobretudo aquelas entre o Norte e o Sul globais.

Especificamente em relação à Covid-19, a direção-geral da OMS foi cautelosa, na tentativa de não repetir os erros anteriores; mesmo assim não conseguiu evitar as críticas, e as dificuldades na coordenação global do enfrentamento da pandemia se sucedem (Figura 2). 
Figura 2 - Atuação da OMS no início da pandemia de Covid-19 - dez. 2019 a fev. 2020

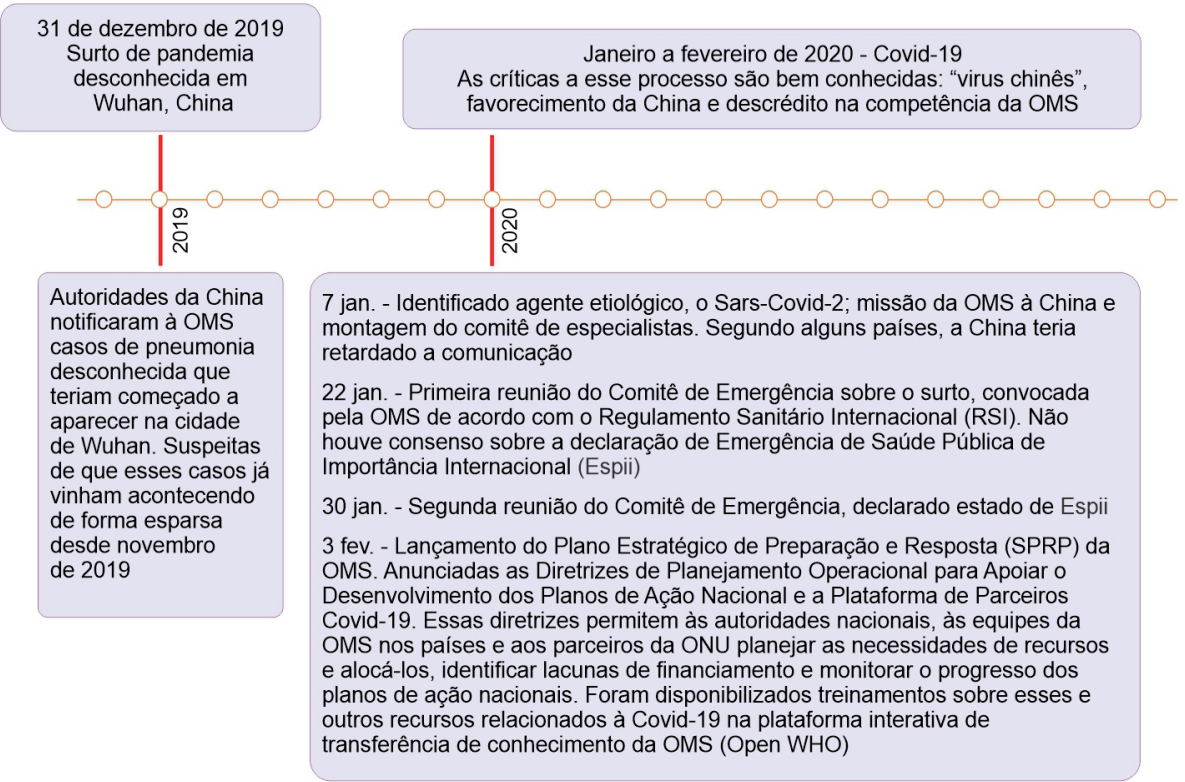

Fonte: elaboração própria com base em Almeida, 202 I, Quadro I.

A atitude dos EUA (na administração Trump) de desqualificar e marginalizar a OMS, assim como de boicotar acordos multilaterais ou regionais, coalizões ou instituições que representassem o multilateralismo ou nele se apoiassem, aprofundou a crise de legitimidade e de eficácia não apenas da OMS, mas de praticamente todas as organizações multilaterais da ONU (Almeida, 2021; Lima \& Albuquerque, 202 I). As críticas e reivindicações por "reforma" se repetem há décadas, muitas vezes encobrindo as tentativas de captura da organização por diversificados (e poderosos) atores interessados no setor (Almeida, 202I).

Os problemas que a OMS enfrenta são antigos e decorrem de escolhas que têm raízes internas e externas à organização, e as controvérsias são permanentes, especialmente visíveis na crise multidimensional desvelada pela Covid-19. Há décadas há consenso sobre a necessidade, diante dos "novos tempos", de mudanças, as quais, entretanto, não são fáceis nem se restringem à "pesada burocracia" ou à ausência de poder coercitivo, como argumentam alguns.

O crescente interesse na saúde como uma questão de política externa, de diplomacia e de governança, sobretudo a partir dos anos 2000, se traduziu em aumento de recursos financeiros para a denominada saúde global, mas não foi acompanhado de 
aprofundamento da reflexão sobre o real significado dessa relação. Paralelamente, a chamada diplomacia em saúde (ou diplomacia da saúde global) tem sido difundida de forma funcionalista, como argumentam alguns autores, "sem considerar as diferenças, e articulações, entre a formulação de uma política externa em nível nacional, a condução diplomática entre Estados e o funcionamento dos mecanismos de governança como instrumentos de uma ação coletiva coordenada" (Almeida, 2021 : 29).

Os descalabros que observamos no enfrentamento da Covid-19 evidenciam elementos cruciais e problemas conhecidos da governança setorial, agravados pela pandemia. Pelo menos duas dimensões dessa dinâmica contêm elementos de governança (ou denunciam a falta dela) e merecem ser analisadas: a extraordinária variação nas respostas nacionais e os enfrentamentos em relação ao desenvolvimento e aquisição de insumos, bem exemplificado pela questão das vacinas.

\section{As respostas nacionais à pandemia}

Apesar de os alertas da OMS e da progressão da pandemia terem ocorrido em um processo rápido, mas gradativo (da China para a Ásia, Europa, EUA, América do Sul e África), o que permitiria algum aprendizado entre os países, não foi isso que aconteceu. As respostas nacionais variaram muito em todas as regiões.

Em um primeiro momento, a prepotência ocidental se fez sentir nos diferentes países que subestimaram o perigo da nova pandemia, pois muitos não acreditavam que esta, vinda da Ásia, chegaria, por exemplo, à União Europeia (UE), quanto mais ao resto do planeta. Essa atitude de certo descaso se respaldou na experiência com as outras pandemias do século XXI ${ }^{3}$ (Roberts, 2020; Louis, 2020; Almeida \& Campos, 2020).

Essa certeza durou pouco, e o vírus alcançou os países europeus bastante desprevenidos. O mesmo não se pode dizer sobre os países continentais nas Américas, como Brasil e EUA, que, teoricamente, tiveram tempo de se preparar, mas a negação da pandemia e dos achados científicos, além do desdém pelas recomendações da OMS e o desrespeito à população por parte dos respectivos governantes, transformou o problema em uma enorme catástrofe humanitária, muito antes dessa caracterização se generalizar mundo afora.

\footnotetext{
${ }^{3}$ Entre tais experiência se incluem as duas epidemias de coronavírus (Sars-CoV), em 2002-2003, e a Middle East Respiratory Syndrome Coronavirus (Mers-CoV), em 20I2-20I3, ambas na Ásia com pouca difusão para outros países e rapidamente controladas; a do vírus HINI (2009), que não foi tão virulento e transmissível como inicialmente previsto; e a do vírus ebola na África, restrita a alguns países africanos (2014-2016, na Guiné, Libéria e Serra Leoa; e 2018, na República Democrática do Congo) (Almeida E Campos, 2020, quadro 4).
} 
Mesmo países com índices de preparação considerados bons para o enfrentamento de pandemias (como o Global Health Security Index) ${ }^{4}$ não tiveram bom desempenho, ao passo que outros, considerados não preparados, se saíram melhor, realçando a parcialidade deste e de outros índices globais e as vulnerabilidade dos sistemas de cuidados de saúde, mesmo nos países ricos (Lafortune, 2020; Baum, 2021; Cole E Dodds, 2021; Almeida, 2021).

A severidade da pandemia também tem mudado em um mesmo país ao longo do tempo, com picos subsequentes, produzidos pelo relaxamento das medidas preventivas (o trade-off saúde versus economia) ou pelas mutações do próprio patógeno. De qualquer forma, o mundo não se livrará completamente da Covid- I9, nem conseguirá controlá-la minimamente enquanto todos os países não puderem conter a disseminação do vírus em um nível considerado globalmente satisfatório. O mais provável é que a Covid- 19 se torne endêmica.

Resultados desses estudos apontam elementos relevantes na governança da pandemia em nível nacional que repercutiram na governança global do setor Saúde. Embora, historicamente, não sejam novos em situações pandêmicas, esses comportamentos adquiriram novos contornos na pandemia de Covid- 19 (Quadro 2).

Quadro 2 - Elementos relevantes nas respostas nacionais à pandemia

\begin{tabular}{|l|l|}
\hline \multicolumn{1}{|c|}{ Variável } & \multicolumn{1}{c|}{ Interferência no controle da pandemia } \\
\hline $\begin{array}{l}\text { Discordâncias } \\
\text { quanto a medidas de } \\
\text { prevenção e controle }\end{array}$ & $\begin{array}{l}\text { Foram intensas, sobretudo em relação a quando e como aplicar as medidas } \\
\text { de prevenção e contenção recomendadas, principalmente no tocante às } \\
\text { restriçães ao livre movimento dos cidadãos } \\
\text { Países que seguiram rigidamente as recomendaçães tiveram inicialmente } \\
\text { melhores resultados, que não se perpetuaram nos momentos seguintes } \\
\text { da pandemia, levando ao cansaço, à frustração e ao quase descrédito } \\
\text { da população, em muitos países, e até a movimentos de resistência } \\
\text { civil. Mesmo assim, muitos retomaram as medidas mais drásticas nos } \\
\text { momentos de recrudescimento do número de casos e de mortes, com } \\
\text { bons resultados }\end{array}$
\end{tabular}

${ }^{4}$ O GHS Index foi elaborado pelo Johns Hopkins Center for Health Security, a Nuclear Threat Initiative (NTI) e a Economist Intelligence Unit (EIU), para avaliar a capacidade de 195 países em relação à "segurança da saúde global” (Global Health Security Index, GHSI). Foi publicado pela primeira vez em 20I9, mas ganhou notoriedade em 2020 (GHSI, 2020). 
Quadro 2 - Elementos relevantes nas respostas nacionais à pandemia (continuação)

\begin{tabular}{|c|c|}
\hline Variável & Interferência no controle da pandemia \\
\hline Infodemia & $\begin{array}{l}\text { Teorias da conspiração, atitudes de negação da ciência e da própria } \\
\text { doença, difusão de tratamentos preventivos com medicamentos inefetivos, } \\
\text { fake news, relatos desencontrados, análises distorcidas etc. proliferaram } \\
\text { por toda parte (multiplicadas ad infinitum pelas redes sociais) } \\
\text { A tendência sensacionalista, em todo o mundo, das grandes mídias que, } \\
\text { além de não isentas ideológica e politicamente, privilegiam o "furo de } \\
\text { reportagem" e não a informação embasada e elucidativa sobre vários } \\
\text { problemas, confundiu e aterrorizou mais do que esclareceu }\end{array}$ \\
\hline $\begin{array}{l}\text { Tamanho da } \\
\text { população e } \\
\text { conexões internas } \\
\text { em um mesmo país }\end{array}$ & $\begin{array}{l}\text { Países mais ricos e com populações menores foram, em geral, mais ágeis } \\
\text { nas medidas de prevenção; os mais populosos tiveram mais dificuldades, } \\
\text { sobretudo se não foram tomadas as medidas de controle da disseminação } \\
\text { comunitária, nas grandes cidades e nas conexões internas do próprio } \\
\text { país, o que facilitou a rápida interiorização da pandemia, atingindo } \\
\text { inclusive áreas de difícil acesso e grupos vulneráveis que deveriam ser mais } \\
\text { protegidos (como as comunidades das periferias e indígenas) } \\
\text { O mesmo aconteceu regionalmente (em um mesmo país e entre países), } \\
\text { pois medidas de controle em um território delimitado não surtirão efeito } \\
\text { se os vizinhos não as implementarem também }\end{array}$ \\
\hline $\begin{array}{l}\text { Níveis de } \\
\text { desenvolvimento } \\
\text { econômico, graus } \\
\text { de desigualdade } \\
\text { e considerações } \\
\text { geopolíticas }\end{array}$ & $\begin{array}{l}\text { O desenvolvimento econômico teve menos impacto do que foi previsto; } \\
\text { porém, as imensas desigualdades entre países desenvolvidos ou em } \\
\text { desenvolvimento, e nas populações de um mesmo país (entre níveis de } \\
\text { renda, cor, raça e etnia) marcaram a diferença nos riscos e vulnerabilidades } \\
\text { no adoecimento e morte por Covid- } 9 \text { ou outras patologias } \\
\text { A desconsideração da crescente interconectividade mundial, da localização } \\
\text { geográfica e da organização regional, as disputas entre Estados e a } \\
\text { falta de padronização e regulação de políticas-chave de produção e } \\
\text { comercialização provocaram importante caos global, que resultou em } \\
\text { falta de insumos essenciais, corrupção e até aumento de ações criminosas } \\
\text { (desvios, pirataria, mercado paralelo, falsificações) }\end{array}$ \\
\hline $\begin{array}{l}\text { Diferenças na relação } \\
\text { com a sociedade }\end{array}$ & $\begin{array}{l}\text { A competência do Estado e de suas instituições, a transparência, a } \\
\text { confiança dos cidadãos nas suas lideranças, assim como na forma de } \\
\text { condução coordenada do enfrentamento da pandemia nacionalmente, } \\
\text { parecem ser elementos decisivos no trato com uma crise dessas } \\
\text { proporções. Em geral, países com sociedades mais uniformes, coesas e } \\
\text { atuantes, e com instituições estáveis e competentes tiveram melhores } \\
\text { resultados } \\
\text { Por sua vez, a capacidade das organizações da sociedade civil de atuar nas } \\
\text { comunidades de forma independente ou complementar às ações estatais, } \\
\text { a solidariedade e a empatia no contexto do desastre humanitário têm feito } \\
\text { toda a diferença }\end{array}$ \\
\hline
\end{tabular}


Quadro 2 - Elementos relevantes nas respostas nacionais à pandemia (continuação)

\begin{tabular}{|c|c|}
\hline Variável & Interferência no controle da pandemia \\
\hline $\begin{array}{l}\text { Fatores sistêmicos } \\
\text { isolados }\end{array}$ & $\begin{array}{l}\text { Características do sistema societário e do regime político, entre outros, } \\
\text { não podem ser responsabilizados, isoladamente, pelas diferenças } \\
\text { observadas nas respostas a essa crise multidimensional; no entanto, as } \\
\text { escolhas dos governantes e as circunstâncias políticas cotidianas parecem } \\
\text { muito importantes na modelagem das respostas de cada país }\end{array}$ \\
\hline $\begin{array}{l}\text { Capacidade de } \\
\text { resposta dos } \\
\text { sistemas de serviços } \\
\text { de saúde }\end{array}$ & $\begin{array}{l}\text { Em termos gerais, os sistemas de serviços de saúde financiados } \\
\text { majoritariamente com recursos públicos puderam oferecer melhores } \\
\text { condições de acesso e utilização pela população do que aqueles privados, } \\
\text { mistos ou bastante fragmentados } \\
\text { Contenção da transmissão comunitária, rastreamento e testes em massa } \\
\text { foram ações comprovadamente acertadas, assim como as medidas de } \\
\text { higiene, o uso de máscaras e o distanciamento físico } \\
\text { Entretanto, sistemas públicos cronicamente subfinanciados não tiveram } \\
\text { condições de atender às necessidades de suas populações; em vários } \\
\text { países, os cortes de recursos na área social, implementados pelas } \\
\text { políticas de austeridade, complicaram muito a situação e foram sérios } \\
\text { impedimentos para um desempenho mais efetivo. Além disso, todos os } \\
\text { problemas anteriores se refletem nos serviços de saúde, e muitos países } \\
\text { sofreram colapsos da atenção médica nos períodos mais críticos da } \\
\text { pandemia }\end{array}$ \\
\hline
\end{tabular}

Fonte: elaboração própria com base em vários autores (apud Almeida, 2021).

Ficou evidente, em muitos países, a enorme fragmentação dos sistemas de proteção social e de saúde, além do despreparo generalizado para o enfrentamento da pandemia, tanto pelas décadas de subfinanciamento e desmonte de todo o setor social com as políticas de ajuste e austeridade quanto pelas "reformas pós-welfare" implementadas em praticamente todos os países (Almeida, 2012, 2014; Casalí, Goldschmit \& Cetrángolo, 2021; Sojo, 2020; Godlee, 2021).

\section{As iniciativas da OMS e de países}

Para tentar minimizar as desigualdades entre os países no acesso aos insumos necessários para o controle da epidemia, a OMS implementou iniciativas específicas e mecanismos de financiamento e distribuição de insumos para os países de renda médiabaixa e baixa, apoiada por vários países e doadores (públicos e privados) (Almeida, 202 I, quadro I):

I. Fundo para arrecadar recursos financeiros, The Covid- I 9 Solidarity Response Fund for WHO, fruto de parceria entre a UN Foundation (com sede nos EUA) e a Swiss 
Philanthropy Foundation, SPF (com sede em Genebra). Os recursos arrecadados são encaminhados para a Covid-I 9 Strategic Preparedness e o Response Plan, para apoio aos países mais vulneráveis.

2. Access to Covid-19 Tools Accelerator (ACT-A ou Accelerator), mecanismo de financiamento que reúne países, doadores diversos, parceiros da indústria e da sociedade civil e várias PPPs, voltado para acelerar os desenvolvimentos, o aumento da produção e a distribuição equitativa de novos insumos necessários ao enfrentamento da Covid-19. Está apoiado em três pilares: métodos e reativos para diagnóstico, implementado pela Foundation for Innovative New Diagnostic (FIND) e pelo Global Forum; insumos terapêuticos, conduzido pela Unitaid e o Wellcome Trust; e o Covax Facility, o pilar das vacinas, liderado pela Gavi e a Cepi, ${ }^{5}$ junto com a OMS, apoiada pelo Fundo das Nações Unidas para a Infância (Unicef), para processos de aquisição de doses, frete, logística e armazenamento. Com a compra antecipada de vacinas pelos países ricos - com o Advanced Market Commitment (AMC) e doação para os países menos aquinhoados (para vacinar $20 \%$ de suas populações) -, o Covax pretendia promover a solidariedade e garantir vacinação de, pelo menos, 20\% da população mundial até 2021 .

3. Covid- 19 Technologic Access Pool (C-TAP), criado a partir da proposta da Costa Rica e da Solidarity Call for Action. Consiste em um pool de conhecimentos tecnológicos (open science), voluntariamente disponibilizado e aberto, arbitrado pelas vias multilaterais. Coordenado pela própria OMS juntamente com outras agências da ONU, aproveita mecanismos já existentes na organização, conectando diferentes plataformas. Não decolou e teve como principais opositores EUA, Reino Unido e Suíça.

Mais recentemente, as discussões (e acordos restritos) vêm acontecendo também em relação aos novos medicamentos para tratamento da Covid-19, que parecem efetivos na redução da gravidade da doença e do número de hospitalizações, mas são

\footnotetext{
${ }^{5}$ Gavi, Global Alliance for Vaccines, também uma PPP, foi criada em 2000 com a ajuda de vários parceiros - governos de países, a própria OMS, o Banco Mundial, a FBMG e outros doadores (ONGs, associações profissionais e comunitárias, organizações religiosas, universidades, fabricantes de vacina, institutos de pesquisa, entre outros) - para promover a distribuição de vacinas nos países em desenvolvimento. O IFFIm, International Finance Facility for Immunisation, instituição filantrópica inglesa fundada em 2006, angaria fundos para a PPP. E a Cepi, Coalition for Epidemic Preparedness Innovations, é uma PPP concebida em 2015 pelo governo da Noruega, à qual se juntaram outros países (Alemanha, Japão, União Europeia e Reino Unido, configurando um "consórcio de nações") e fundações filantrópicas (FBMG e Wellcome Trust). Foi formalizada em 2017, no Fórum Econômico Mundial de Davos, e trabalha junto da OMS. Dedica-se ao desenvolvimento de vacinas para o controle de epidemias ou pandemias.
} 
muito caros e sua produção está restrita a poucas farmacêuticas privadas. Um bom exemplo é o molnupiravir, um antiviral oral produzido pela Merck Sharp \& Dohme, que assinou acordo de licenciamento voluntário com o Medicine Patent Pool, possibilitando sublicenciamentos para outros 105 países de baixa renda. O problema é que nesse tipo de licença o detentor da patente é quem define quais países podem ser beneficiados (em qual região do mundo) e, portanto, exclui os países de renda média-alta e com capacidade produtiva (Bermudez \& Bermudez, $202 \mathrm{l} \mathrm{b).}$

Além dessas iniciativas, em outubro de 2020 a Índia e a África do Sul propuseram à Organização Mundial do Comércio (OMC) o Trips Waiver, fortemente apoiado pela OMS e por mais de cem países em desenvolvimento. Solicitaram aos membros da OMC a isenção temporária de quatro categorias de direitos de propriedade intelectual - copyright, desenho industrial, patentes e informações confidenciais (segredos comerciais) que estejam sob o Acordo Trips (Agreement of Trade-Related Intellectual Property Rights) para a produção de todos insumos (medicamentos, testes, vacinas) relacionados à Covid-19, até que a pandemia estivesse controlada e a maioria da população mundial estivesse segura. As farmacêuticas transnacionais e países ricos (Reino Unido, EUA, Canadá, Noruega, UE e Japão, entre outros) se opuseram veementemente. Com o governo Biden os EUA passaram a apoiar o waiver, declaração de peso e impacto político mundial, mas sem consequências práticas imediatas. Até o final de outubro de 2021 a questão continuava em discussão/negociação na OMC, com propostas alternativas e revisões, sem solução para o impasse, apesar das várias reuniões do Conselho do Trips. A $12^{\text {a }}$ Conferência Ministerial da OMC, prevista para novembro-dezembro de $202 \mathrm{I}$, não foi realizada.

Os debates têm sido acirrados e adquiriram contornos dramáticos com a insuficiência de vacinas, principalmente para os países não produtores e mais pobres. Diante da necessidade urgente de aumentar a sua produção em nível mundial/regional e do impasse na OMC, desde julho de 2021 a OMS vem implementando um novo mecanismo, o New Technology Transfer Hub (WHO, $202 \mathrm{I}$ a), para expandir a capacidade de produção e melhorar o processo de acesso às tecnologias nos países de renda baixa e média, priorizando inicialmente um tipo de vacina produzida com tecnologia de RNA mensageiro (mRNA), como a da Pfizer e a da Moderna. O primeiro hub começou a ser implantado na África do Sul e foi lançada convocatória internacional para outras regiões (MPP, 202 I). Em setembro de 202 I o Instituto de Tecnologia em Imunobiológicos (Bio-Manguinhos), da Fiocruz, foi selecionado como o centro para desenvolvimento e produção de vacinas na América Latina (Lang, 202 I).

O Accelerator divulgou no final de outubro de 2021 um novo plano estratégico para os próximos 12 meses (WHO, $202 \mathrm{lb}$ ), a partir de recomendações de uma revisão 
independente, publicada no início do mês (WHO E Dalberg, 202I). Redefiniu suas metas e os recursos necessários para cumpri-las (US 23,4 bilhões) (Tabela I). E, no final desse mesmo mês, em mais uma Cúpula do G20, o diretor-geral da OMS apelou aos países-membros que apoiem os esforços para o controle da pandemia (Alcazar $\&$ Buss, 202I). E a Cepi renovou seu Conselho, introduzindo novos membros. ${ }^{6}$

O C-TAP, por sua vez, não teve nenhuma tecnologia cedida, apesar de haver interesse de fabricantes de vacinas e outros insumos. E, em setembro de 2021, foi criado pela OMS o Grupo Técnico Consultivo (Technical Advisory Group, TAG) para tentar apoiar o seu desenvolvimento. ${ }^{7}$

\section{OS IMPASSES}

Várias dificuldades e impasses têm comprometido a efetividade desses mecanismos. A falta de acesso a insumos estratégicos, um drama para os países mais pobres, seja para a proteção individual, para testes diagnósticos ou cuidado hospitalar dos doentes, seja para medicamentos e vacinas (cruciais para salvar vidas, conter a disseminação e evitar o colapso dos serviços hospitalares), desnudou a feroz competição entre Estados nacionais, a falta de solidariedade, o peso mundial do setor privado e das disputas geopolíticas nesse processo.

O "nacionalismo das vacinas" (ou o "apartheid vacinal") exemplifica magistralmente essa situação global. Diante do desafio de vacinar cerca de 70\% da população mundial (em torno de I I bilhões de pessoas), assistimos a compras bilaterais antecipadas (entre país e empresas produtoras), por países ricos ou blocos de países desenvolvidos (onde habita cerca de um terço da população mundial), de quantidades de duas a quatro vezes maiores do que as necessárias, deixando desabastecido o restante do mundo. A falta de transparência desses contratos e a recusa a maior flexibilização dos direitos patentários é demonstração clara da "desordem" e do poder (sem limites) do setor privado neste mundo ultraliberal. As várias rodadas de negociações na OMC confirmam as dificuldades de aprovação de um acordo consensual. Alguns países reviram suas

\footnotetext{
${ }^{6}$ A presidente da Fiocruz, Nísia Trindade Lima, foi convidada como membro do Conselho da Cepi, que supervisiona o desempenho e a prestação de contas da PPP. O Conselho é composto por 12 membros, com direito a voto, e pretende garantir que a organização contribua para melhorar a preparação contra epidemias e pandemias no mundo. Nísia será membro de uma das quatro comissões desse conselho, a de Auditoria e Risco (Azevedo, 202I).

${ }^{7}$ Esse novo grupo técnico, composto por dez membros e com mandato de dois anos renováveis, tem entre seus integrantes Jorge Bermudez, pesquisador da Ensp/Fiocruz (Covid- 19: pesquisador..., 2021).
} 
posições, exceto a UE, que continua irredutível na oposição ao waiver, aceitando, no máximo, as "licenças compulsórias". 8

Esse debate ampliou a visibilidade da importância das transferências tecnológicas ${ }^{9}$ para aumentar rapidamente a produção de vacinas e atender à demanda global, algo difícil de se conseguir apenas com alguns poucos produtores. É um processo habitual entre as empresas privadas, assim como as intervenções governamentais para estimular essas "cooperações", que fortalece ainda mais a posição das grandes farmacêuticas, sobretudo em um cenário de emergência internacional e necessidade urgente de insumos (como as vacinas) em grande quantidade. O presidente Biden, dos EUA, utilizou o Defense Production Act para facilitar esse partilhamento entre empresas privadas norteamericanas e incrementar a produção de vacinas para abastecimento nacional. E, mais recentemente, tem se comprometido com a produção norte-americana de vacinas para doação aos países de baixa renda.

Reuniões de agências internacionais, ministros (de Economia, Finanças, Saúde, Comércio) e cúpulas de grupos de países (G7, G20), oficiais ou paralelas, assim como as assembleias da ONU e de suas agências, têm se sucedido com reiteração de práticas/ recomendações e nenhum avanço substantivo em direção à superação do impasse global (Alcazar E Buss, 202I).

Não há como aprofundar aqui esses temas, aliás muito debatidos por vários autores em artigos, lives e webinários, mas registramos alguns comentários.

Em primeiro lugar, parece-nos importante prestar atenção nos mecanismos que estão sendo implementados na OMS, como o C-TAP e o Accelerator. Em princípio, poderiam ser complementares, mas na realidade se contrapõem, pois traduzem diferentes opções políticas e evidenciam conflitos subjacentes: distintas formas de tentar resolver

\footnotetext{
${ }^{8}$ Licença compulsória não é o mesmo que waiver. Este é um dispositivo aplicável país a país e produto a produto, e depende da vontade/condição política e técnica do país. Um dos fatores a serem considerados nesses casos é a constante evolução geral do cenário patentário, o que impõe dificuldades extras na continuidade da produção (Chamas, 202I).

${ }^{9}$ Transferência tecnológica é o processo de repasse de conhecimento técnico, know-how, tecnologias complexas, de uma empresa/instituição para outra (p. ex., no Brasil, AstraZeneca e Fiocruz; Sinovac e Butantan). Consiste em acordos bilaterais arbitrados por contratos, que possuem cláusulas de confidencialidade. Pressupõe aprendizado e adaptações trabalhosas, com prazo de implementação de, usualmente, entre 5 e 7 meses, podendo ser bem maior. É uma forma de proteção dos direitos de propriedade intelectual do detentor e de seus ativos (financeiros e comerciais). Inclui também a produção dos insumos farmacêutico (IFAs) necessários à fabricação do produto objeto da transferência, que não raro requer outras negociações e está sujeita a restrições no mesmo contrato.
} 
problemas que envolvem bens públicos globais que, na realidade, são tratados como bens privados. Essa disputa não é nova, mas se exacerbou nesta pandemia.

Em segundo lugar, note-se que a maioria das principais vacinas disponíveis está sendo produzida em grandes empresas transnacionais localizadas no Norte geopolítico, coligadas com outras menores ou com universidades, ou com "parceiros" habituais no Sul (p. ex., Índia e Brasil), apoiados por processos de transferência tecnológica. Além disso, o desenvolvimento e produção em alta velocidade de produtos essenciais, como estamos observando, é especialmente beneficiado pela cumulatividade de conhecimentos e aprendizados específicos, que conferem vantagem comparativa àquelas empresas que trabalham com colaborações e apoio público em todas as etapas do processo de desenvolvimento de novos produtos (Chamas, 2020).

Considerando essas duas premissas e estudos de vários autores, constatamos que:

1. As pesquisas básicas que possibilitaram o desenvolvimento das vacinas para a Covid- 19 vêm sendo financiadas com recursos públicos (investimento de governos em universidades e institutos) há décadas; a colaboração global no compartilhamento de dados de sequenciamento genômico e de informações de saúde pública também foram essenciais, e não começaram agora. Ademais, os produtores privados de vacinas receberam recursos públicos adicionais para o processo de desenvolvimento e produção da nova vacina (p. ex., dos EUA e da UE). Mesmo assim, os países financiadores cederam o monopólio das patentes para as empresas privadas. Os EUA são pioneiros nessa prática desde os anos 1980, quando foi aprovado o Bayh-Doyle Act, ${ }^{10}$ que embora seja uma legislação nacional, tem enorme impacto no âmbito global, como estamos presenciando.

2. É bem conhecido que o sistema de inovação e pesquisa de produtos biomédicos e farmacêuticos é predominantemente orientado pelo mercado. Pesquisa $E$ Desenvolvimento (PED) de vacinas para pandemias/epidemias envolve ampla gama de atores e relativamente limitada prospecção de geração de renda; não por acaso várias doenças, como a HIV/Aids e malária, por exemplo, ainda não têm vacina, mas seu tratamento pode ser beneficiado por esses novos desenvolvimentos.

\footnotetext{
10 O Bayh-Doyle Act foi aprovado nos EUA em 1980 pelos dois partidos, Democrata e Republicano, e leva os nomes de dois ilustres congressistas, um de cada partido. O principal objetivo dessa lei foi permitir que empresas privadas obtivessem monopólio de patentes para a fabricação de produtos desenvolvidos com base em pesquisas financiadas com recursos públicos, sem qualquer contrapartida - controle de preços ou outro tipo de regulação. O principal resultado negativo foi o aumento exponencial dos preços dos medicamentos desde então (Baker, 202I).
} 
3. A Cepi e a Gavi, como PPPs, foram engendradas para enfrentar um antigo paradoxo do desenvolvimento de vacinas: é um bem essencial/crucial, mas seu desenvolvimento e sua distribuição são historicamente subvalorizados, devido tanto a questões de mercado quanto a certas particularidades biotecnológicas das próprias vacinas. Esse panorama mudou completamente com a Covid-19, no que se refere tanto ao mercado (previsão de bilhões de doses, provavelmente por bom tempo) quanto à acumulação tecnológica.

4. O Covax Facility teve que rever suas normas e fazer concessões a países abastados, para tentar assegurar os recursos financeiros ainda muito insuficientes (Usher, 202 I); e a Gavi continua tentando convencer os países a contribuírem, seja com recursos financeiros, seja com doações de doses de vacinas (Tabela I).

5. Vários autores e comentaristas têm mostrado os problemas desse mecanismo (Usher, 202I; Bermudez E Bermudez, 202 la), que não altera as questões estruturais subjacentes. A crença de que esse tipo de solidariedade forjada funcionaria no mundo do século XXI não se sustenta diante da realidade. A solução proposta, então, é assistencialista/beneficente: doação pelos países do centro de doses excedentes, como apregoa o G7," ou produzidas especialmente para serem doadas; ou de empresas privadas (p. ex., a Mastercard Foundation) (Adepoju, 2021). Mantém-se, assim, a submissão e dependência dos países mais pobres àqueles que têm dinheiro.

6. O modelo inovador das PPPs é atraente e materializa uma tendência que vem dos anos 1990: a institucionalização de parcerias transversais como solução para problemas estruturais da inovação em PED (assim como na provisão de serviços), com papel crucial na superação dos "incentivos imperfeitos da pesquisa biofarmacêutica", assim como para fazer frente a deficiências na arquitetura da governança global do setor Saúde. As PPPs foram pensadas como um novo lócus para funções de financiamento, coordenação e regulação que, historicamente, foram desempenhadas pelo Estado, pelo mercado ou ambos, articulados e regulados. Nessa perspectiva de "regulação de inovações" o mercado é considerado como o paradigma primordial para se alcançar "benefícios sociais" (bens públicos?) e tem sido um aspecto-chave nas visões da globalização nas últimas três décadas.

\footnotetext{
" Note-se que os sete países que compõem o G7 detêm " $60 \%$ da riqueza e 35\% do PIB mundial, com cerca de $10 \%$ da população global, sendo, porém, responsáveis por $50 \%$ das doses de vacina contra Covid- 19 contratadas até o momento [outubro de 202 I]" (Bermudez \& Bermudez, 202 Ia).
} 
7. Os ganhos financeiros no mercado de ações das empresas privadas produtoras foram (e continuam a ser) astronômicos, desde o primeiro anúncio de um possível grau elevado de eficácia das vacinas, permitindo a ampliação e adaptação subsidiada de suas plantas produtivas (AstraZeneca, BioNTech) e o apoio de outras empresas menores (p. ex., Pfizer/BioNTech e a francesa Sanofi, e, nos EUA, Merck e Johnson E Johnson).

8. O argumento em favor da manutenção do monopólio das detentoras dos direitos de propriedade intelectual é o de que não adiantaria "quebrar patentes", pois isto atrasaria a produção, uma vez que não se trata de aplicar uma receita e que poucos laboratórios na periferia disporiam de capacidade tecnológica para produzir, dada a complexidade dessas vacinas e de outros insumos. Essa postura desqualifica evidências em contrário e desconsidera a urgência global na busca de soluções (Bermudez \& Bermudez, 202 la).

9. A produção de vacinas, e de matéria-prima para tal, não é operação trivial, requer altos investimentos (públicos e privados) de longo prazo, capacidade instalada, recursos humanos treinados, agências reguladoras efetivas etc. A experiência de alguns países considerados em desenvolvimento atesta que é possível a produção fora do "centro", desde que haja vontade política e políticas públicas (nacionais e internacionais) que reconheçam o imperativo de superar a dependência tecnológica de poucos produtores (países e farmacêuticas transnacionais) e possibilitem o fortalecimento da capacidade produtiva e regulatória em diferentes regiões.

Em síntese, a exclusividade de direitos de propriedade intelectual fortalece a acumulação de capacidade inovadora pelas farmacêuticas privadas, é fundamental na concorrência e visa a alcançar lucros extraordinários (Chamas, 2020).

Alguns dados reforçam nossos argumentos. A concentração de insumos e da vacinação no mundo abastado é impactante (Tabela I). 
Tabela I - Iniquidades na vacinação mundial

Total de doses de vacinas administradas e de
testes utilizados na população mundial

Vacinas asseguradas

Canadá, Austrália, Nova Zelândia, Reino Unido, EUA (jan. 2021)

Covax (nov. 2021)

- Total previsto

- Asseguradas

- Recebidas por doação

- Compra potencial (meta)

Doação dos países do G7 para o Covax (9 nov. 2021)*

- Total anunciado

- Entregues

\begin{tabular}{l|c}
\multicolumn{1}{c|}{ Previsão de desperdício de doses acumuladas } & $\mathrm{N}$ \\
\hline $\begin{array}{l}\text { Até o final de } 2022 \text { (expiração da validade, caso não sejam utilizadas), } \\
\text { em posse de dez países, em grande maioria de alta renda }\end{array}$ & 3,8 bilhões \\
\hline \multicolumn{1}{c}{ Novas metas do Accelerator, plano estratégico até set. 2022} & $\mathrm{Ne} \%$ \\
\hline $\begin{array}{l}\text { Total recursos financeiros necessários } \\
\text { Covax }\end{array}$ & US $\$ 23,4$ bilhões \\
- Cobertura vacinal países do Advanced Market Commitment, AMC \\
(91\% de baixa renda). \\
- Taxa mínima de testagem em I44 países de baixa e média rendas \\
- Garantia de acesso aos tratamentos existentes, incluindo oxigênio, \\
nos países de renda média e baixa
\end{tabular}

Fonte: elaboração própria com base em Pai, 202 I; Our World in Data, 202 I e WHO, 202 la, 202 lb.

* Os 7 países anunciaram doação de doses de vacina e entregaram parte do anunciado, em quantidades variáveis. Os EUA foram o maior doador até 09/1 I/2021.

$\mathrm{Ne} \%$

7,34 bilhões

$4,2 \%$

$51,2 \%$

200-400\% da população

5.274 .400 bilhões (100\%)

2.534 .000 bilhões (25\%)

730.400 milhões (7\%)

2.010 bilhões (68\%)

Pouco mais de $10 \%$ do anunciado

1.611,35 bilhões

198,60 milhões

$\mathrm{N}$ (n) 
No final de fevereiro de 2021, as primeiras doses de vacinas começaram a chegar aos países em desenvolvimento a partir do Covax. A distribuição prosseguiu lentamente desde então, com grande difusão nas mídias, mas sempre lidando com a escassez e a dificuldade, muito menos divulgadas, de assegurar as entregas. Soma-se a isso a polêmica suscitada pelo "passaporte da vacina" e seus desdobramentos.

Por fim, a necessidade de uma terceira dose para grupos populacionais mais sujeitos a adoecer, mesmo depois de vacinados (idosos $>70$ anos e imunodeprimidos), ou possível reforço a todos já vacinados para fazer frente às mutações do vírus (p. ex., variante delta, inversamente correlacionada com a taxa de vacinação), e a vacinação de crianças e adolescentes recolocam o dilema da insuficiente produção mundial. Da mesma forma, as doações evidenciam o problema da validade das doses adquiridas: países pobres, sobretudo na África, têm referido dificuldades logísticas para usar as vacinas doadas com data próxima de expiração, arriscando ter que as destruir, além da falta de seringas adequadas à aplicação (Furneaux, Goldhill \& Davies, 202I).

\section{PARA CONCLUIR}

O panorama global de "desordem" ou de transição para uma nova ordem mundial e nacionalismos populistas de ultradireita nos confronta com um contexto complexo que nos atinge, como país da periferia capitalista, de forma deletéria e em várias dimensões. Não se trata de desconsiderar, ou minimizar, a conjuntura nacional, como já afirmamos, mas de ampliar o olhar, o que talvez nos ajude a entender melhor os enormes desafios que estamos enfrentando em escala global e se refletem em nossa região e em nosso país.

Não se desaprova a priori o enorme conjunto de iniciativas que envolvem amplo elenco de atores - públicos, privados, não governamentais -, primeiro porque já se consolidaram mecanismos relevantes nessas parcerias e, segundo, porque todos esforços são bem-vindos diante da catástrofe humanitária da Covid-19, além de outras pandemias que possivelmente virão. Porém, não é mais aceitável delegar atribuições eminentemente públicas a articulações que não enfrentam as bases das desigualdades globais. Existem mecanismos alternativos para apoiar inovações nas empresas privadas que não sejam a concessão de monopólio de direitos de propriedade. E mesmo que o monopólio seja legítimo, também pode ser administrado de diferentes formas, assim como o mercado pode ser estruturado e regulado de distintas maneiras. São escolhas políticas que definem esses parâmetros

Em certa medida, os desmandos locais se respaldam em vários outros atores, e a estes se aliam, nessa perversa dinâmica, submetida e reverente ao "sr. Mercado", a um setor privado que, em geral, trabalha para o aumento exponencial de seus lucros, to- 
talmente indiferente a qualquer solidariedade com os seres vivos, mesmo os humanos, considerados consumidores descartáveis quando não têm dinheiro. Além de entrópica e autodestrutiva, essa dinâmica atesta a falta de qualquer preocupação com o mundo ou as condições de vida na Terra.

Degradar nosso país até a posição de pária no sistema mundial, depois de ter alcançado, em passado recente, lugar de algum poder moral e de respeito internacional por ter sido protagonista em várias questões cruciais referidas à saúde que agora voltaram à agenda, com cores mais fortes, só é compreensível em uma perspectiva de destruição sem limites de certos governantes.

Os impasses estão em curso, as encruzilhadas são muitas e de difícil travessia. Não vislumbramos, por enquanto, nenhum vaga-lume no fim do túnel e tampouco sabemos se teremos algum "vencedor" nessas disputas, ou mesmo para onde vai caminhar este mundo em transição. Porém, a pandemia confirmou que enquanto não se conseguir enfrentar os problemas estruturais que mantêm e agudizam as enormes iniquidades globais, magnanimamente distribuídas em todos as dimensões e espaços territoriais, continuaremos semeando pestes e contando mortos.

Faz-se urgente, portanto, aprofundar as discussões sobre esses impasses e mudar os termos do debate para fortalecer o interesse público nos enfrentamentos inevitáveis

\section{REFERÊNCIAS}

ADEPOJU, P. Mastercard Foundation donates US $\$ 1.3$ billion to vaccinate 50 million Africans against Covid-19, 9 jun. 202I. Disponível em: <https://healthpolicy-watch.news/mastercard-foundationdonates-I-3b-to-boost-africas-fight-against-covid-19>. Acesso em: 10 jun. 2021.

ALCAZAR, S. E BUSS, P.M. Saúde global na Cúpula do G20 em Roma. Le Monde Diplomatique, São Paulo, I nov. 2021. Disponível em: <https://diplomatique.org.br/saude-global-na-cupula-do-g20em-roma/>. Acesso em: 2 nov. 2021 .

ALMEIDA, C. The treat from health securization: international perspectives on the public health implications of 9/I I, 20 I I. Australian and New Zealand Journal of Public Health, 35(4): 3 I 2, 20 I I.

ALMEIDA, C. Reforma de sistemas de saúde: tendências internacionais, modelos e resultados. In: GIOVANELLA, L. et al. (org.). Políticas e Sistemas de Saúde no Brasil. 2. ed. rev. ampl. Rio de Janeiro: Editora Fiocruz, 2012.

ALMEIDA C. O Banco Mundial e as reformas contemporâneas do setor Saúde. In: PEREIRA, JMM. A. E PRONK, M. (Orgs.). A Demolição de Direitos: um exame das políticas do Banco Mundial para a educação e a saúde (1980-20/3). Rio de Janeiro: Escola Politécnica de Saúde Joaquim Venâncio, 20 I 4. Disponível em: <http://www.epsjv.fiocruz.br/index.php?Area $=$ MaterialETipo $=8 \mathcal{E}$ Num $=240>$. Acesso em: 02 out. 2021. 
ALMEIDA, C. Governança do setor Saúde em um contexto mundial mutante e incerto - Brasil Saúde Amanhã. Rio de Janeiro: Fiocruz, 202I. (Texto para Discussão, 60) Disponível em: <https:// saudeamanha.fiocruz.br/wp-content/uploads/202 I/05/ALMEIDA-C-202 I-Governan\%C3\%A7aSetor-Saude-em-Contexto-Mundial-Mutante-Incerto-Fiocruz-Saude-Amanha-TD060.pdf>. Acesso em: 4 maio 2021.

ALMEIDA, C. \& CAMPOS, R. P. Multilateralismo, ordem mundial e Covid- 19: questões atuais e desafios futuros para a OMS. Saúde em Debate, 44 (n. esp. 4): 13-39, 2020.

AZEVEDO, C. Presidente da Fiocruz vai integrar organização que financia projetos de vacinas. Agência Fiocruz de Notícias, Rio de Janeiro, 16 set. 2021 . Disponível em: < https://agencia.fiocruz.br/presidenteda-fiocruz-vai-integrar-organizacao-que-financia-projetos-de-vacinas >. Acesso em: 16 set. 2021 .

BAKER, D. Beating Inequality \& Covid- I 9: tackle patent and copyright monopolies. News Click, 31 jan. 2021. Disponível em: <www.newsclick.in/dean-baker-beating-inequality-covid-19-tackle-patentand-copyright-monopolies>. Acesso em: 12 mar. 2021.

BAUM, F. et al. Explaining covid- 19 performance: what factors might predict national responses? British Medical Journal, 372(91): I-4, 2021. Disponível em: <www.bmj.com/content/372/bmj.n91 > Acesso em: 10 fev. 2021.

BERMUDEZ, L. \& BERMUDEZ, J. Covid- I 9: o mundo em um "apartheid de vacinas". CEE/Fiocruz, I 0 ago. 202 Ia. Disponível em: < https://naf.ensp.fiocruz.br/pt-br/covid-19-o-mundo-em-um-apartheid-devacinas-por-luana-bermudez-e-jorge-bermudez>. Acesso em: 10 ago. 2021.

BERMUDEZ, J. E BERMUDEZ, L. Molnupiravir para Covid- I9: expandindo o acesso ou ampliando a exclusão? CEE/Fiocruz, 28 out. 202 I b. Disponível em: < http://informe.ensp.fiocruz.br/noticias/52382>. Acesso em: 28 out. 2021.

CASAlí, P.; GOLDSChMiT, A. E CETRÁNGOlO, O. Respuestas de corto plazo a la Covid-I9 y desafíos persistentes en los sistemas de salud de América Latina. In: OFICINA DE LA OIT PARA LOS PAÍSES ANDINOS, enero de 202I, Lima, Perú. Disponível em: <www.ilo.org/lima/publicaciones/ WCMS_768040/lang--es/index.htm>. Acesso em: 3 mar. 2021 .

CHAMAS, C. Inovação, propriedade intelectual e acesso a medicamentos e vacinas: o debate internacional na pandemia da Covid- 19. Liinc em Revista, I6(2): e5338, 2020.

CHAMAS, C. Covid-19, Acordo Trips e flexibilidades. Cadernos do Cris/Fiocruz, 10-21, Saúde Global e Diplomacia da Saúde, I-5 jun. 202 I, p. 73-78. Disponível em: <https://portal.fiocruz.br/sites/portal. fiocruz.br/files/documentos/informe_cris_l0-2I_saude_global_e_diplomacia_da_saude.pdf $>$. Acesso em: 16 jun. 2021 .

COLE, J. E DODDS, K. Unhealthy geopolitics: can the response to Covid- 9 reform climate change policy? Bulletin of World Health Organisation, 99: I48-154, 2021.

COVID-19: PESQUISADOR da Fiocruz integra grupo que promove igualdade no acesso à tecnologia. Agência Fiocruz de Notícias, Rio de Janeiro, 16 set. 2021 . Disponível em: <https://agencia.fiocruz.br/ covid- I 9-pesquisador-da-fiocruz-integra-grupo-que-promove-igualdade-no-acesso-tecnologias $>$. Acesso em: 16 set. 202I.

FIORI, J. L. Babel syndrome and the new security doctrine of the United States. Journal of Humanitarian Affairs, I (I): 42-45, 2019. 
FIORI, J. L. Réquiem para uma utopia defunta. Carta Maior, 19 jul. 2020. Disponível em: <www. cartamaior.com.br/?/Editoria/Pelo-Mundo/Requiem-por-uma-utopia-defunda-as-vesperas-daeleicao-americana/6/48192>. Acesso em: 19 jul. 2020.

FURNEAUX, R.; GOLDHILL, O. E DAVIES, M. How Covax failed on its promise to vaccinate the world. The Bureau of Investigative Journalism, 8 out. 2021. Disponível em: <www.thebureauinvestigates. $\mathrm{com} /$ stories/202 I- I 0-08/how-covax-failed-on-its-promise-to-vaccinate-the-world?utm source $=$ Nature + BriefingEutm_campaign $=7885$ e6f72 I - briefing-dy-202 I I $0 \mathrm{I} 2$ Eutm medium $=$ emailEutm_term=0_c9dfd39373-7885e6f72 I-45466566 >. Acesso em: 10 out. $202 \mathrm{I}$.

GLOBAL HEALTH SECURITY INDEX (GHSI). About GHSI-Global Health Security Index. Disponível em: <www.ghsindex.org/about/>. Acesso em: 20 fev. 2021.

GODLEE, F. NHS reorganisation: we don't need a big bang. British Medical Journal, 372: n464, 202 I.

LAFORTUNE, G. How much do we know about countries preparedness to respond to pandemics? Insights from two country-level indices. Sustainable Development Solutions Network (SDSN), 2020. Disponível em: <www.unsdsn.org/how-much-do-we-know-about-countries-preparedness-torespond-to-pandemics-insights-from-two-country-level-indices>. Acesso em: 15 fev. $202 \mathrm{I}$.

LANG, P. Fiocruz é selecionada como hub da OMS para vacina de mRNA. Agência Fiocruz de Notícias, Rio de Janeiro, 21 set. 2021. Disponível em: <https://agencia.fiocruz.br/fiocruz-e-selecionadacomo-hub-da-oms-para-vacina-de-mrna?utm_source=FacebookEutm_medium=FiocruzEutm_ campaign =campaignEutm_term $=$ termEutm_content $=$ content $>$. Acesso em: $2 \mathrm{I}$ set. $202 \mathrm{I}$.

LIMA, M. R. S. \& ALBUQUERQUE, M. Instituições multilaterais e governança global: cenários de reorganização das estruturas de governança global e perspectivas do multilateralismo nas próximas décadas. Rio de Janeiro: Fiocruz, 2021. (Texto para Discussão n. 59). Disponível em: <https:// saudeamanha.fiocruz.br/wp-content/uploads/202 I/05/LIMA-MRS-e-ALBUQUERQUE-M-202 I Institui\%C3\%A7\%C3\%B5es-Multilaterais-Governan\%C3\%A7a-Global-Fiocruz-Saude-AmanhaTD059.pdf>. Acesso em: 4 maio 2021.

LOUIS, M. ¿Para qué sirve la Organización Mundial de la Salud? Entrevista a Auriane Guilbaud, abr. 2020. Disponível em: <https://nuso.org/articulo/para-que-sirve-la-organizacion-mundial-de-lasalud/>. Acesso em: 15 nov. 2020.

MEDICINE PATENT POOL (MPP). Covid-I9 Technology Transfer Hub, 8 out. 202I. Disponível em: $<$ https://medicinespatentpool.org/covid- I 9/technology-transfer-hub/>. Acesso em: 20 out. 2020.

PAI, M. 10 Images that illustrate the shameful global vaccine inequity, 28 ago. 202I. Disponível em: $<$ https://naturemicrobiologycommunity.nature.com/posts/ I 0-images-that-illustrate-the-shamefulglobal-vaccine-inequity >. Acesso em: 30 ago. 2021.

ROBERTS, A. Pandemics and politics. Survival - Global Politics and Strategy, 62(5): 7-40, 2020. Disponível em: <www.tandfonline.com/doi/full/I 0.1 080/00396338.2020.181964I >. Acesso em: 20 out. 2020.

SOJO, A. Pandemia y/o pandemónium: encrucijadas de la salud pública latinoamericana en un mundo global. (Documentos de Trabajo 37). Madrid: Fundación Carolina, 2020. Disponível em: <www. fundacioncarolina.es/wp-content/uploads/2020/I2/DT_FC_37.pdf >. Acesso em: 12 out. 2020. 
OBSERVATÓRIO DE AMÉRICA LATINA E CARIBE (OBSAL) \& INSTITUTO TRICONTINENTAL DE PESQUISA SOCIAL (TRICONTINENTAL). Dossiê n. 30. América Latina sob o coronachoque: crise social, fracasso neoliberal e alternativas populares. São Paulo, Buenos Aires: Instituto Tricontinental de Pesquisa Social, jul. 2020. Disponível em: <www.thetricontinental.org/pt-pt/dossie-30-coronachoque-eamerica-latina/>. Acesso em: 12 out. 2020.

OUR WORLD IN DATA. Statistics and Research. Coronavirus (Covid-19) Vaccinations. Disponível em: $<$ https://ourworldindata.org/covid-vaccinations>. Acesso em: 9 nov. 2021.

USHER, A. D. A beautiful idea: how Covax has fallen short. The Lancet, 397: 2.322-2.325, 202I. Disponível em: <www.thelancet.com/journals/lancet/article/PIISO I 40-6736(2I)0 I367-2/fulltext>. Acesso em: 9 nov. 2021.

WORLD HEALTH ORGANISATION (WHO). Establishment a Covid- 19 mRNA vaccine technology transfer hub to scale up global manufacturing, 16 abr. 202 Ia. Disponível em: <www.who.int/newsroom/articles-detail/establishment-of-a-covid- I 9-mrna-vaccine-technology-transfer-hub-toscale-up-global-manufacturing >. Acesso em: 20 maio 2021.

WORLD HEALTH ORGANISATION (WHO). New ACT-Accelerator strategy calls for US\$ 23.4 billion international investments to solve inequities in global access to Covid- 19 vaccines, tests $\varepsilon$ treatments, 28 out. 202lb. Disponível em: <www.who.int/news/item/28-10-202I-new-act-acceleratorstrategy-calls-investment>. Acesso em: 30 out. 2021 .

WORLD HEALTH ORGANISATION (WHO) \& DALBERG GLOBAL DEVELOPMENT ADVISORS (WHO \& DALBERG). Strategic Review of the ACT-Accelerator-Final Report: An independent report prepared by Dalberg, 8 out. 202I. Disponível em: <www.who.int/publications/m/item/act-accelerator-strategicreview $>$. Acesso em: 15 out. 2021 . 


\section{Governança, Coordenação e Estratégias de Enfrentamento da Crise Gerada pela Covid-19 lições aprendidas dos casos chinês, alemão e espanhol'} Adelyne Maria Mendes Pereira

A Covid- 9 gera uma crise sanitária, social e econômica que demanda a atuação do Estado. Cabe a este produzir políticas públicas de resposta à crise e compensação das iniquidades, sobretudo porque a Covid-19 afeta desigualmente populações e territórios. Motivada por essa preocupação, neste estudo busquei responder à pergunta “Qual o papel do Estado e as medidas necessárias ao enfrentamento da Covid- I 9?”.

O objetivo foi identificar e analisar, em perspectiva comparada, estratégias e ações políticas desenvolvidas em resposta à Covid-19. Ancorando-me nas contribuições do institucionalismo histórico para a análise de políticas públicas (Pereira, 20 I4), discuto a institucionalidade da atuação governamental em relação à Covid- 19 em cada contexto.

No âmbito deste estudo, institucionalidade corresponde à capacidade dos governos de planejar, formular e implementar ações e estratégias políticas em cinco dimensões: Governança e coordenação nacional, assumida como transversal; Controle da propagação da epidemia; Fortalecimento do sistema de saúde e de vigilância; Apoio social e econômico; e Comunicação com a sociedade.

A análise das características da governança, da direcionalidade da atuação governamental e do contexto estatal favorece a compreensão da maior ou menor governabilidade e dos resultados produzidos em cada caso. A ela, devem-se somar análises de outros fatores político-institucionais, estruturais e conjunturais que também influenciam as respostas nacionais à Covid- 19. Além disso, cabe destacar a análise do contexto, marca-

\footnotetext{
' Atualização das análises presentes na nota técnica "Estratégias de enfrentamento da pandemia pela Covid- 19 no contexto internacional: reflexões para a ação, publicada pela autora no Observatório Covid- 19 da Fiocruz". Disponível em: < https://portal.fiocruz.br/sites/portal.fiocruz.br>.
} 
do por desigualdades nas condições de vida, na dinâmica de distribuição e concentração da riqueza nacional, na estrutura produtiva e de emprego, bem como na organização do sistema sanitário.

Em um estudo multicasos (Mahoney \& Rueschemeyer, 2003), as ações e estratégias em resposta à Covid-19 foram analisadas segundo as dimensões da atuação governamental apresentadas na Figura I. Na análise comparada, foram identificados pontos fortes, limites e lições aprendidas.

Figura I - Institucionalidade, governança e estratégias políticas em resposta à crise gerada pela Covid- 19 no contexto de desigualdades

\section{INSTITUCIONALIDADE DAATUAÇÃO GOVERNAMENTAL}

\begin{tabular}{|c|l|}
\hline & $\begin{array}{l}\text { Estratégias e ações políticas de: } \\
\text { Controle da propagação da } \\
\text { epidemia }\end{array}$ \\
$\begin{array}{c}\text { Governança e } \\
\text { Coordenação } \\
\text { Nacional }\end{array}$ & $\begin{array}{l}\text { Fortalecimento do sistema de } \\
\text { saúde e de vigilância } \\
\text { Apoio social e econômico } \\
\text { Comunicação com a sociedade }\end{array}$ \\
\hline
\end{tabular}

Contexto social, econômico e sanitário

Desigualdades nas condições de vida

Desigualdades na dinâmica de distribuição e concentração da riqueza nacional

Estrutura produtiva e emprego

Estrutura do sistema de saúde

Fonte: elaboração própria.

A seleção dos casos está relacionada à sua situação epidemiológica em abril de 2020, quando o epicentro da pandemia se deslocava da China para a Europa, associada ao fato de serem países populosos e com economias importantes, possuírem sistemas de saúde de diferentes tipos, com participação estatal, e resposta ativa do Estado no enfrentamento da Covid-19. China se configura como um interessante caso de estudo por ter sido o primeiro a enfrentar a pandemia e, logo, o primeiro a desenvolver medidas de enfrentamento; Alemanha e Espanha por estarem entre os países mais afetados durante a primeira onda na Europa, com diferentes resultados em número de óbitos e letalidade.

As técnicas de pesquisa envolveram análise de publicações científicas, legislações, documentos oficiais e relatórios de órgãos governamentais, além de dados secundários disponíveis em bases internacionais de informações comparadas (OECD Stat e WHO) e nacionais. 


\section{CONTEXTO SOCIAL, ECONÔMICO E SANITÁRIO}

Os países analisados partem de diferentes contextos (Tabela I). A República Popular da China é um Estado unitário, constituído por governo nacional e governos provinciais, fortemente centralizado no Executivo nacional e no Congresso Nacional do Povo. Tratase de uma das grandes potências mundiais, com forte estrutura produtiva baseada no socialismo de mercado, no qual se destaca o planejamento centralizado com forte orientação estatal combinado à liberalização de alguns setores (Jabbour $\varepsilon$ Dantas, 2017). Como país mais populoso do mundo, enfrenta consideráveis desigualdades de renda, educação e expectativa de vida (UNDP, 202 I).

Alemanha é uma república federativa parlamentarista, formada por 16 estados (Länder). Seu Poder Executivo é compartilhado entre os governos federal e estaduais. O Legislativo federal se organiza por meio do Conselho Federal (Bundesrat, órgão de representação dos estados) e do Parlamento (Bundestag). O país possui o quarto maior produto interno bruto (PIB) do mundo, estrutura produtiva estável e altamente industrializada, pautada na economia social de mercado com forte regulação estatal (Streeck, 1997). Concentra a maior população da União Europeia (UE) e sustenta alto índice de desenvolvimento humano (IDH), com reduzida desigualdade na educação e na expectativa de vida, mas moderada desigualdade de renda (UNDP, 202I).

Espanha é uma monarquia parlamentarista que funciona como uma federação, onde o Poder Executivo é compartilhado entre o governo central e o das comunidades autônomas. Possui estrutura produtiva e emprego mais vulneráveis, com alta dependência do PIB ao setor de serviços (sobretudo ao turismo) e limitada regulação estatal. É o quinto maior país da UE em população, possui alto IDH, reduzida desigualdade na expectativa de vida, mas importante na educação e distribuição de renda (UNDP, 202 I). 
Tabela I - Contexto social, econômico e sanitário - China, Alemanha e Espanha, 2018

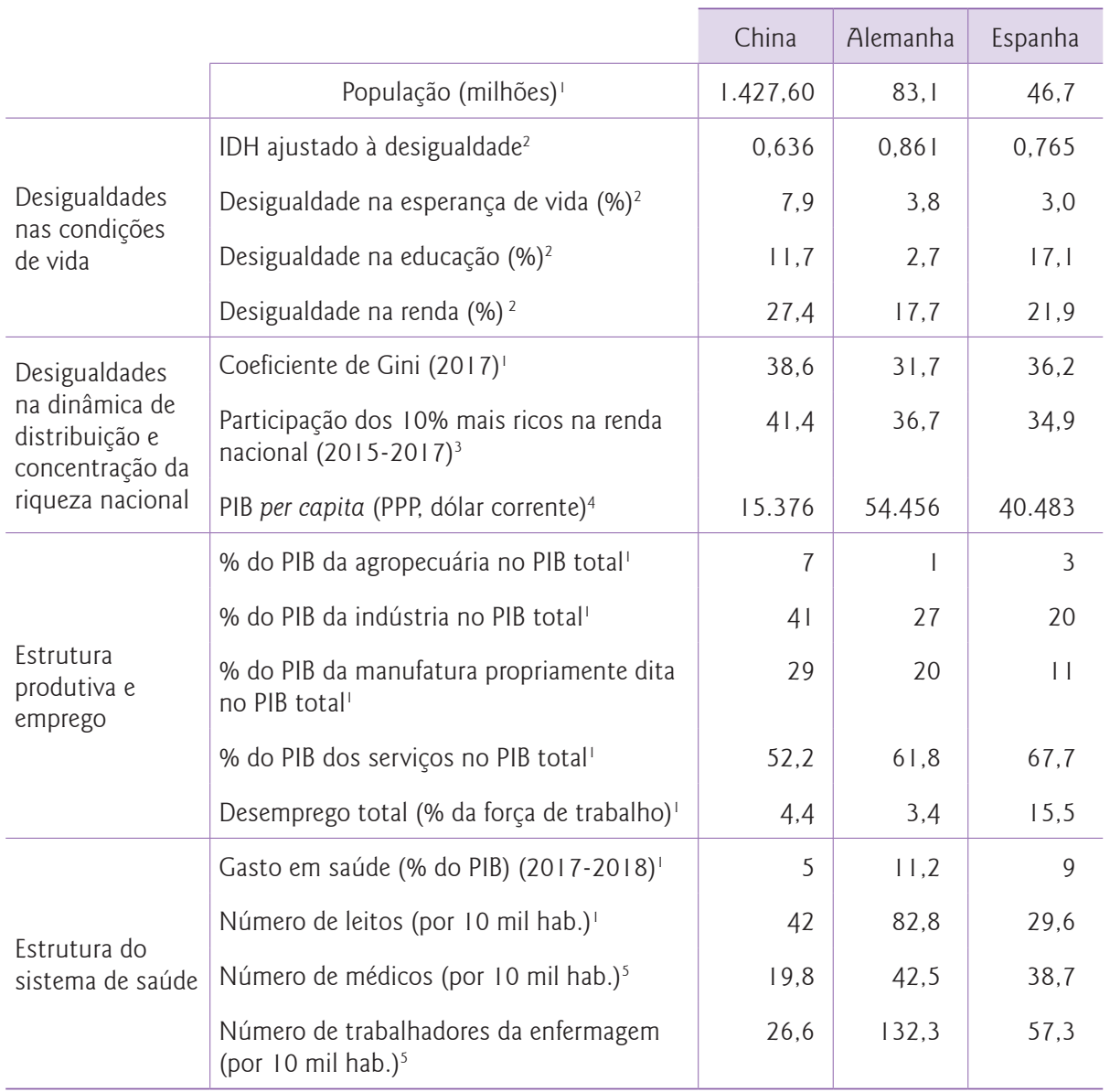

Fontes: ' OECD, 202I; ${ }^{2}$ UNDP, 202I; ${ }^{3}$ WID, 202I; ${ }^{4}$ World Bank, 202I; ${ }^{5}$ WHO, 2021.

Os três países contam com diferentes sistemas de saúde e de vigilância. O sistema de saúde chinês se baseia na organização de seguros compulsórios estratificados, com cobertura variada em três programas e atenção ofertada em hospitais públicos e privados, serviços de atenção primária e de saúde pública (Meng et al., 2015; Nogueira, Bacil $\varepsilon$ Guimarães, 2020). Alemanha possui um sistema público do tipo seguro social que, com alto nível de oferta de serviços, cobre 87\% da população (OECD \& WHO, 20I9). Espanha possui um sistema de saúde universal cuja governança se organiza em dois níveis (nacional e regional), de base territorial regionalizada a partir da Atenção Primária à Saúde (APS), que tem sofrido constrangimentos financeiros (Legido-Quigley, 2020). 
Nos três casos, o sistema de vigilância depende da articulação entre autoridades sanitárias e serviços nos níveis nacional, regional/estadual e distrital/local, com distintos arranjos na relação com o sistema de saúde.

Antes da pandemia, China apresentava reduzido gasto em saúde como proporção do PIB (5\%, sendo cerca de 40\% correspondentes a desembolso direto), estrutura hospitalar moderada e baixa disponibilidade de médicos e trabalhadores da enfermagem por 10 mil habitantes. Alemanha tinha alto gasto em saúde $(11,2 \%$ do PIB, dos quais $15 \%$ correspondentes a desembolso direto), estrutura hospitalar e força de trabalho entre as mais altas da UE. Apesar de o gasto em saúde espanhol situar-se em $9 \%$ do PIB, cerca de 30\% correspondiam a desembolso direto, a estrutura hospitalar era uma das menos robustas da UE e a força de trabalho era moderada (Tabela I) (OECD, 2021; WHO, 2021).

\section{ESTRATÉGIAS E AÇÕES POLÍTICAS EM RESPOSTA À COVID-19}

\section{Governança, coordenação nacional e comunicação com a sociedade}

Um ponto comum entre os casos estudados é o desenvolvimento de estruturas de governança e coordenação nacional da resposta à Covid-19. As diferentes organizações político-territoriais da China, Alemanha e Espanha marcam as características da governança: no caso chinês, notadamente centralizada; no alemão, federativa; e no espanhol, intergovernamental e intersetorial. Nos três casos, a liderança exercida pelo Executivo central favoreceu a proposição de políticas sanitárias, sociais e econômicas articuladas.

Na China, a governança centralizada teve protagonismo do Conselho de Estado (órgão máximo do Executivo central) e da Comissão Nacional de Saúde (análoga ao Ministério da Saúde), por intermédio de duas estruturas: o Grupo de Liderança Central para Resposta à Epidemia e o Mecanismo Conjunto de Prevenção e Controle (WHOChina, 2020). Essa governança foi fundamental para o planejamento e implementação de medidas coordenadas territorialmente, e para a gestão e distribuição de recursos.

A China se valeu da experiência prévia em emergências, de uma legislação nacional e de mecanismos de coordenação das ações de vigilância junto aos departamentos de Saúde Pública das províncias e dos serviços de saúde. A Comissão Nacional de Saúde publicou atualizações do Protocolo para Prevenção e Controle da Covid-19, estabelecendo critérios para a definição de risco epidemiológico territorial (baixo, médio e alto) e ações de controle e prevenção. Também estabeleceu estratégias de comunicação com a sociedade por meio de campanhas publicitárias, novas tecnologias e ações de educação em saúde no nível dos serviços, colaborando para a disseminação das orientações preventivas (China National Health Commission, 202 I). 
Na Alemanha, a governança federativa se baseou nas estruturas do Executivo e Legislativo federais. Um plano nacional foi acordado entre governos federal e estaduais, e monitorado em reuniões regulares do Conselho Federal e do Parlamento. Com base em leis federais (Germany, 202 I a), o Ministério da Saúde coordenou ações de enfrentamento da epidemia e fortaleceu a capacidade do sistema de saúde. A coordenação nacional das ações de vigilância foi feita pelo Instituto Robert Koch (IRK), órgão de saúde pública que desempenha o papel de autoridade sanitária. Com experiência na gestão de emergências sanitárias, nacional e internacionalmente, o IRK coordena a rede que envolve autoridades sanitárias estaduais e distritais/locais, em estreita relação com os serviços de saúde, ponto forte do caso alemão (RKI, 202 I).

Governança federativa e coordenação nacional das ações de vigilância favoreceram a geração de confiança na sociedade alemã. Ações de comunicação foram desenvolvidas: pronunciamentos oficiais dos chefes de governo; manutenção de um painel on-line com informações sobre a situação epidemiológica e capacidade hospitalar; e ações de educação em saúde, com importante papel do Centro Federal de Educação para a Saúde, especialmente sobre vacinação (Germany, $202 \mathrm{l}$ b).

$\mathrm{Na}$ Espanha, a governança intergovernamental e intersetorial se baseou em três estruturas: Reunião dos chefes dos Executivos central e regionais; Conselho de Ministros, reunindo diversos setores; e Conselho Interterritorial, instância regular do sistema de saúde, no qual se reúnem autoridades sanitárias central e regionais. A partir dessa estrutura, foram desenvolvidas comunicações governamentais e rodas de imprensa; divulgação diária da situação epidemiológica e sanitária; e ações de educação em saúde (España, 202 la).

Um instrumento jurídico (estado de alarme) outorgou ao governo central competências para a coordenação nacional da resposta à Covid-19. A centralização dessas competências minimizou a competição por recursos no contexto espanhol de crise e polarização política. Por intermédio do Conselho Interterritorial e com decretos nacionais (España, 202 l b), o Ministério da Saúde coordenou ações de fortalecimento do sistema de saúde e de vigilância. Valeu-se do Centro de Coordenação de Alertas e Emergências Sanitárias, prévio à pandemia, para coordenar a Rede de Vigilância em Saúde Pública, incluindo laboratórios nacionais de referência (España, 202 Ic).

\section{Controle da propagação da epidemia}

Ao longo de 2020, cerca de 95.963 casos de Covid- 19 foram confirmados na China, I ,76 milhão na Alemanha e I,93 milhão na Espanha, tendo sido registrados 4.782 óbitos na China, 33.79 I na Alemanha e 50.837 na Espanha. O número de casos e óbitos foi maior 
durante alguns períodos (ondas da epidemia em cada país), o que representou variações na taxa de letalidade. Em 31 de dezembro de 2020, a taxa de letalidade na China estava em 5\%; na Alemanha, I,9\%; e na Espanha, 2,6\% (Gráficos I) (Our World in Data, 202 I).

Gráficos I - Casos confirmados, óbitos acumulados e taxa de letalidade por Covid- 19

- China, Alemanha e Espanha, 2020

\section{Cumulative confirmed COVID-19 cases}

The number of confirmed cases is lower than the number of actual cases; the main reason for that is limited testing.

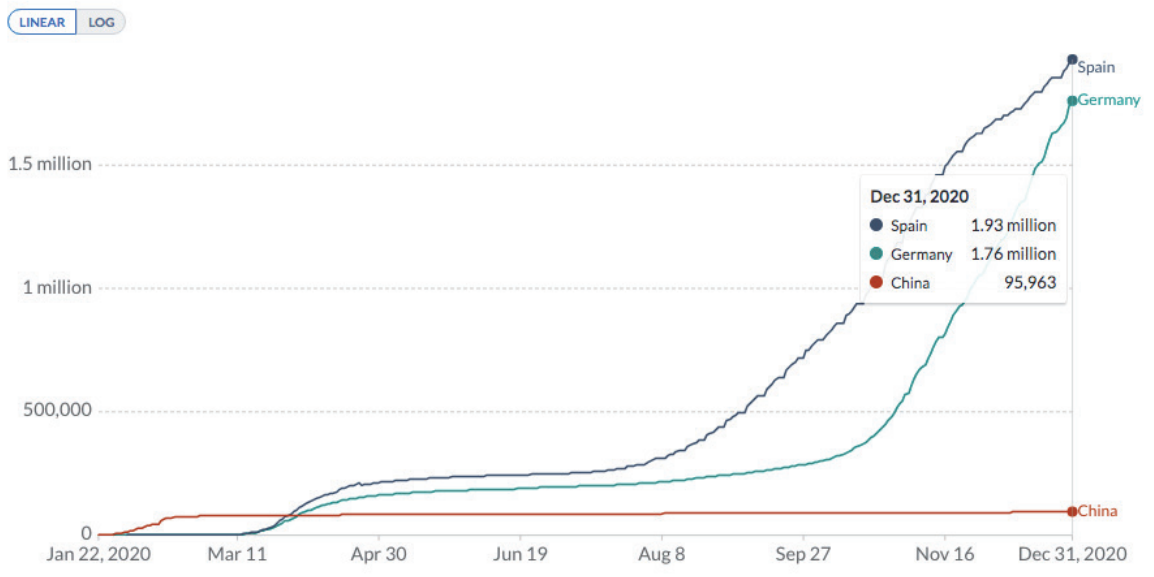

Source: Johns Hopkins University CSSE COVID-19 Data - Last updated 15 February, 21:03 (London time)

Cumulative confirmed COVID-19 deaths

Limited testing and challenges in the attribution of the cause of death means that the number of confirmed deaths may not be an accurate count of the true number of deaths from COVID-19.

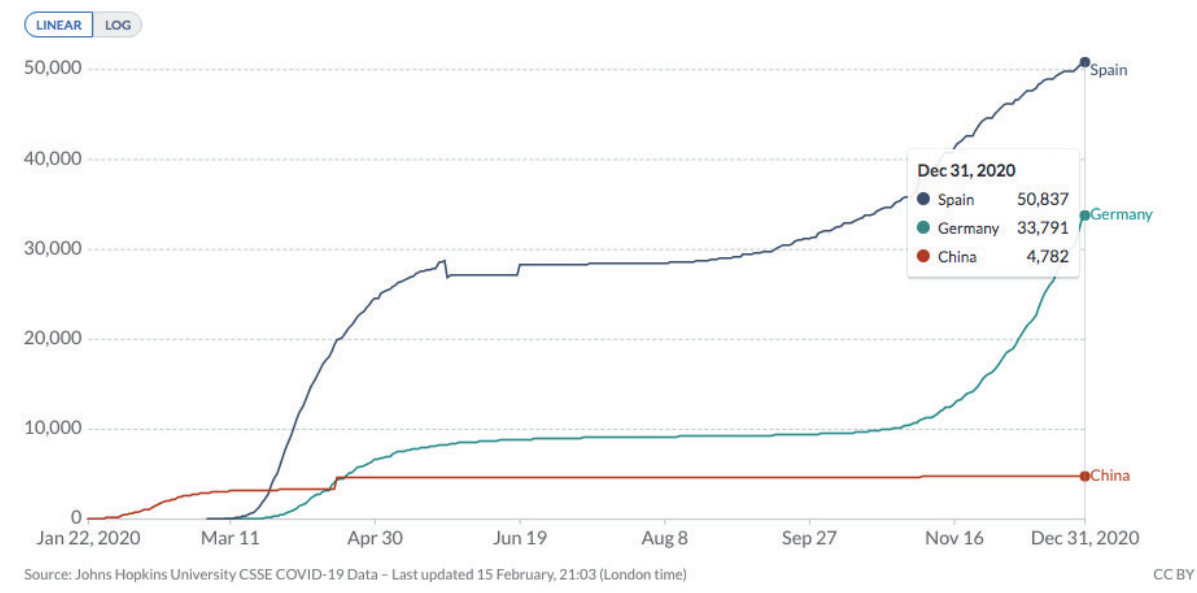


Gráficos I - Casos confirmados, óbitos acumulados e taxa de letalidade por Covid- 19 - China, Alemanha e Espanha, 2020 (continuação)

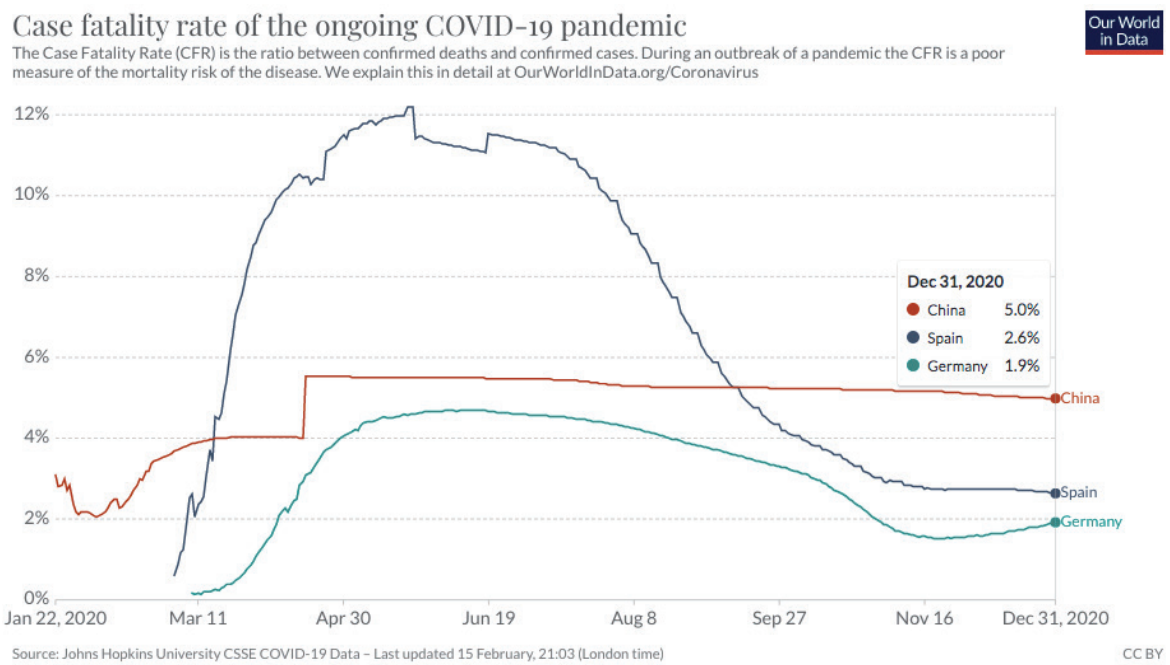

Fonte: Our World in Data, 2021.

$\mathrm{Na}$ China, as ações de investigação epidemiológica foram iniciadas com o fechamento do Mercado Atacadista de Frutos do Mar de Huanan em 31 de dezembro de 2019, a identificação do novo coronavírus em 7 de janeiro de 2020 e a confirmação da transmissão humano a humano em 20 de janeiro, com a inclusão da Covid- 19 como doença de notificação obrigatória (Wu \& McGoogan, 2020).

Três dias depois de confirmada a transmissão humano a humano, o confinamento comunitário (lockdown) foi estabelecido em Wuhan, estendendo-se por 15 cidades da província de Hubei e cerca de 60 milhões de pessoas. Ações do tipo lockdown envolvem o mais alto grau de distanciamento físico, com mobilidade restringida ao acesso ou oferta de serviços essenciais. Em Wuhan e adjacências, tais ações duraram 76 dias; além disso, um feriado nacional foi estendido, e todo o país permaneceu por 17 dias com atividades escolares e laborais suspensas (Tian et al., 2020). Nesse momento, havia casos de Covid- 19 registrados fora de Hubei e em países vizinhos à China (Huang et al., 2020).

A primeira e mais intensa onda na China aconteceu entre janeiro e março de 2020. Entre fins de julho e meados de agosto, houve um aumento leve no número de casos e óbitos, mas em cifras inferiores às da primeira onda. O controle da propagação da epidemia na China e sua relativa estabilidade têm relação com as ações de resposta implementadas, que promoveram, em grande escala, distanciamento físico e confi- 
namento comunitário de acordo com a situação epidemiológica em cada território. As medidas também incluíram o cancelamento de grandes eventos e o controle de fronteiras (China CDC, 2020).

Na Alemanha, o primeiro caso de Covid- 19 foi confirmado em 27 de janeiro de 2020 (RKI, 202 I). A primeira onda da epidemia se deu entre meados de março e fim de abril. Desde o final de setembro, as médias diárias de novos casos e óbitos aumentaram, caracterizando uma segunda onda da epidemia, superior à primeira em número de novos casos e óbitos diários.

$\mathrm{Na}$ Espanha, o primeiro caso de Covid- 9 foi confirmado em 3I de janeiro (España, 202 la). A primeira onda da epidemia se deu entre março e abril. A partir de agosto, as médias diárias de novos casos e óbitos aumentaram, caracterizando uma segunda onda da epidemia, bastante superior à primeira em número de novos casos e óbitos diários, sobretudo entre outubro e novembro.

Tanto na Alemanha quanto na Espanha, estratégias de controle da propagação da epidemia foram implementadas, envolvendo isolamento dos casos, quarentena dos contatos e confinamento comunitário (lockdown) a partir de meados de março, sob coordenação nacional. Foram proibidos grandes eventos e se estabeleceu o controle de fronteiras, com restrição de viagens domésticas e internacionais. A circulação por vias públicas foi liberada apenas para realização de atividades em setores essenciais, como saúde, segurança e alimentação. Estabelecimentos em funcionamento deveriam manter desinfecção regular e medidas de proteção dos trabalhadores e consumidores. $\mathrm{Na}$ Espanha, houve exceção para atividades da construção civil e da indústria, só interrompidas durante 15 dias. Na Alemanha, foram mantidos deslocamentos para atividade física individual (Germany, 202 I a; España, 202 l b).

A estabilidade entre ondas está relacionada às medidas adotadas para controlar a propagação da epidemia durante a primeira onda. Em ambos os casos, após 50 dias de lockdown, houve redução do fator de transmissão e queda no número de novos casos e óbitos, o que permitiu a retomada gradativa das atividades a partir de maio (RKI, $202 \mathrm{I}$; España, 202 Ia). O aumento gradual que culminou na segunda onda tem relação com o incentivo à circulação de pessoas e às atividades turísticas nas férias de verão. Diante da progressão de novos casos e óbitos, medidas de confinamento comunitário e restrição da mobilidade menos ostensivas foram implementadas em outubro e intensificadas em dezembro em diferentes graus (Germany, 202 la; España, $202 \mathrm{l}$ b).

Nos três casos, o lockdown foi acompanhado de medidas de apoio social à população. 


\section{Fortalecimento do sistema de saúde e de vigilância}

A liderança do Ministério da Saúde foi decisiva para o fortalecimento do sistema de saúde e de vigilância nos três casos, com suas especificidades. Por meio de normativas nacionais, esse ministério regulou e coordenou nacionalmente: a notificação compulsória e investigação epidemiológica de casos e contatos; o controle sanitário nas fronteiras; medidas para manutenção do abastecimento básico de medicamentos, equipamentos e testes diagnósticos; normativas para funcionamento de instalações médicas e de cuidados, incluindo flexibilidades legais para ampliação do número de leitos e da força de trabalho.

O alto investimento por parte do governo central chinês foi fundamental para garantir a efetividade das ações de enfrentamento da Covid- 19 e compensar as desigualdades que pudessem ser geradas pela estratificação do sistema sanitário. Para ampliar a capacidade de assistência sanitária, a China construiu dois novos hospitais em Wuhan, com 2.600 leitos de UTI, e três hospitais de campanha, com 12 mil leitos. Essa resposta foi rápida: as obras começaram no segundo dia do lockdown e os hospitais estavam prontos em 10 dias. Para seu funcionamento, cerca de 42.000 profissionais da saúde do restante da China foram deslocados para Hubei (WHO-China, 2020).

Pacientes com Covid- 19 foram isolados e tratados em alas específicas dos hospitais existentes e nos novos hospitais chineses. Contatos de casos foram orientados a permanecer em quarentena domiciliar ou em hotéis adaptados para funcionar como hospitais (Wu \& McGoogan, 2020). Foi ampliada a capacidade de realização de testes diagnósticos (sobretudo para identificação da carga viral por meio do RT-PCR), e visitas domiciliares foram realizadas a todos os residentes de Wuhan para rastreamento de potenciais casos (WHO-China, 2020).

Sob governança centralizada, foram promulgadas regulações sobre pagamento do seguro-saúde, atendimento fora da zona de cobertura e compensação financeira, relevantes para a garantia do acesso, em razão da organização do sistema sanitário na China. Foi lançado um programa de investigação científica para desenvolver diagnósticos, terapias e vacinas, delinear o espectro da Covid- 19 e identificar as características do novo coronavírus. Novas tecnologias foram aplicadas, como o uso de big data e inteligência artificial, para fortalecer o rastreamento de contatos e o monitoramento de populações prioritárias, pontos fortes do caso chinês. Ações de promoção e educação em saúde foram desenvolvidas entre a população no conjunto de medidas de controle e prevenção (WHO-China, 2020; China National Health Commission, 2021). 
Na Alemanha, o governo federal investiu, inicialmente, cerca de 10 bilhões de euros para que hospitais reprogramassem intervenções e mantivessem leitos disponíveis para Covid-19, ampliassem leitos de UTI, força de trabalho e atendimentos ambulatoriais, e adquirissem equipamentos de proteção individual (EPIs) (Germany, 202 Ia). Foram ampliadas as capacidades hospitalar (em cerca de 40\%) e laboratorial (chegando a 650.000 testes RT-PCR semanais), e disponibilizados para o sistema público de saúde mais de 3 milhões de testes sorológicos (baseados na identificação de anticorpos ao Sars-CoV-2), produzidos nacionalmente (Germany, $202 \mathrm{lb}$ ).

Um ponto forte do caso alemão é a estreita coordenação entre serviços de saúde, laboratórios e o IRK, que recebe diretamente os resultados dos testes diagnósticos para coordenar as ações de detecção precoce, articulando sistemas de vigilância sindrômica, genômica e laboratorial. Outro ponto forte foi a manutenção de um sistema digital unificado nacionalmente, permitindo acompanhamento das taxas de ocupação, identificação de leitos disponíveis e transferência de pacientes entre estados, se necessário. No campo da pesquisa e desenvolvimento tecnológico, o governo federal alemão investiu em empresas nacionais para apoiar o desenvolvimento de vacinas e fármacos potenciais, além de participar em investigações epidemiológicas junto com os estados e em colaboração com a Organização Mundial da Saúde (OMS) (RKI, 202 I; Germany, 202 I b).

Na Espanha, estratégias para fortalecer a capacidade de resposta do sistema sanitário começaram no dia seguinte ao início do lockdown. Com base na análise da situação de cada comunidade autônoma, leitos gerais e de UTI foram ampliados (em 75\%), leitos de retaguarda foram preparados eleitos de hospitais privados foram colocados à disposição do sistema público. Tais ações significaram aumento do financiamento público do sistema nacional de saúde e foram fundamentais, já que a capacidade hospitalar do país estava entre as mais baixas da UE. Após essa expansão, 70\% dos leitos de UTI são públicos (España, $202 \mathrm{l}$ a, $202 \mathrm{l}$ b). A governança desenvolvida não foi capaz de promover a transferência de pacientes entre comunidades autônomas, ponto fraco e fator gerador de desigualdades no acesso a leitos.

Todas as comunidades autônomas constituíram centrais de atendimento telefônico, recomendadas como primeiro ponto de contato durante a primeira onda da Covid- 19 na Espanha. Os centros de APS organizaram o fluxo em duplo circuito e implementaram teleatendimento para monitoramento de casos com sintomas respiratórios e pacientes com condições crônicas. Algumas comunidades autônomas criaram unidades volantes de atenção à Covid- 19 e mantiveram serviços de urgência da APS (España, 202 la). 
O alto investimento por parte do governo central espanhol determinou a ampliação da capacidade hospitalar e de testes diagnósticos, o fortalecimento da APS (que assumiu papel central na vigilância comunitária a partir de maio) e a modernização das estruturas de vigilância, considerando a digitalização e a interoperabilidade dos sistemas.

\section{Medidas de apoio social e econômico}

No que diz respeito às estratégias de apoio social e econômico, China implementou medidas de isenção de impostos para pequenas e médias empresas, e o Banco Central criou fundos especiais de empréstimos, totalizando inicialmente cerca de 45 bilhões de dólares para suporte a crédito com taxa de juros preferencial. O governo também ofereceu auxílios financeiros para os cidadãos que estavam em confinamento comunitário, com suspensão da cobrança de serviços de água, energia elétrica e internet, e para aqueles que se encontravam em situação de vulnerabilidade social (Johns Hopkins CRC, 2020).

Alemanha se destaca pela constituição de um programa e um fundo de estabilização econômica, aprovados pelo Parlamento, em clara concertação entre governos federal e estaduais. As medidas somam mais de 650 bilhões de euros, envolvendo: doações para pequenas empresas e autônomos; suporte à liquidez para médias e grandes empresas, com linhas de crédito por intermédio do Banco Nacional de Desenvolvimento Alemão (KFW); e garantias estatais para passivos, investimentos diretos do Estado e refinanciamento de grandes empréstimos pelo KFW. Foram destinados 10 bilhões para expandir esquemas de seguro-desemprego e 7,7 bilhões para assistência social, incluindo auxílio-criança e auxílio à renda (Germany, 202 I c).

Dias antes do início do lockdown, estratégias de apoio social e econômico começaram a ser implementadas na Espanha. Este é um dos pontos fortes do caso espanhol: a construção do chamado escudo social, para o qual foram mobilizados cerca de 200 bilhões de euros. Entre as medidas de proteção aos cidadãos, incluem-se a garantia à moradia, proibição do corte de serviços básicos e ajuda social às famílias e populações vulneráveis; promoção da igualdade e proteção às vítimas de violência machista; e proteção aos trabalhadores e autônomos, com ampliação e flexibilização do acesso ao seguro-desemprego. Em relação à proteção da atividade econômica, destacam-se linhas de crédito e redução de impostos, especialmente para pequenas e médias empresas (75\% dos recursos). Ao fim de maio de 2020, o governo aprovou a renda mínima vital, por meio da qual foram protegidas inicialmente 850 mil famílias em situação de vulnerabilidade (España, $202 \mathrm{lb}$ ). Tais ações são importantes para fortalecer a proteção social e enfrentar o contexto espanhol de desigualdades. 


\section{Institucionalidade da atuação governamental em perspectiva comparada}

A institucionalidade da atuação governamental em resposta à crise gerada pela Covid- 19 foi singular em cada caso, mas convergiu para algumas direções: a presença positiva de uma governança e coordenação nacional, fundamental para a implementação de ações e estratégias de controle da propagação da epidemia; o fortalecimento do sistema sanitário; apoio social e econômico e comunicação com a sociedade. À luz da análise comparada, apresento no Quadro I lições aprendidas em cada uma das dimensões da atuação governamental.

Quadro I - Lições aprendidas: estratégias e ações políticas para enfrentamento da crise gerada pela pandemia da Covid- 19 no contexto internacional

\begin{tabular}{|c|c|}
\hline $\begin{array}{l}\text { Dimensões da atuação } \\
\text { governamental }\end{array}$ & Estratégias e ações de enfrentamento da crise gerada pela Covid- I 9 \\
\hline \multirow{6}{*}{$\begin{array}{l}\text { Governança e } \\
\text { coordenação nacional }\end{array}$} & $\begin{array}{l}\text { Estratégias e ações desenvolvidas com o objetivo de promover a } \\
\text { coordenação nacional das políticas públicas de enfrentamento da crise } \\
\text { gerada pela pandemia, envolvendo: }\end{array}$ \\
\hline & $\begin{array}{l}\text { - formulação de um plano nacional acordado, com definição do } \\
\text { papel de cada nível de governo }\end{array}$ \\
\hline & $\begin{array}{l}\text { - definição de uma estrutura para governança, acompanhamento e } \\
\text { avaliação desse plano }\end{array}$ \\
\hline & $\begin{array}{l}\text { - equilíbrio entre processos de descentralização e centralização das } \\
\text { estratégias e ações }\end{array}$ \\
\hline & $\begin{array}{l}\text { - fortalecimento das capacidades político-institucionais nas } \\
\text { diferentes instâncias de governo }\end{array}$ \\
\hline & $\begin{array}{l}\text { - incremento dos mecanismos de diplomacia e cooperação } \\
\text { intergovernamental }\end{array}$ \\
\hline \multirow{7}{*}{$\begin{array}{l}\text { Controle da propagação } \\
\text { da pandemia }\end{array}$} & $\begin{array}{l}\text { Estratégias e ações desenvolvidas com o objetivo de reduzir a } \\
\text { transmissão da infecção nos territórios por meio da restrição da } \\
\text { mobilidade e do distanciamento físico, envolvendo: }\end{array}$ \\
\hline & - medidas de isolamento de casos e quarentena de contatos \\
\hline & $\begin{array}{l}\text { - medidas de distanciamento físico ou confinamento comunitário, } \\
\text { segundo análise da situação epidemiológica, com }\end{array}$ \\
\hline & $\begin{array}{l}\text { - manutenção da distância de segurança ( } 1,5 \text { a } 2 \text { metros), } \\
\text { recomendação do uso de máscara e de higiene pessoal }\end{array}$ \\
\hline & - cancelamento e/ou adiamento de grandes eventos coletivos \\
\hline & - suspensão (parcial ou total) de atividades não essenciais \\
\hline & $\begin{array}{l}\text { - controle de fronteiras terrestres e aéreas, com restrição da } \\
\text { circulação de pessoas e mercadorias }\end{array}$ \\
\hline
\end{tabular}


Quadro I - Lições aprendidas: estratégias e ações políticas para enfrentamento da crise gerada pela pandemia da Covid- 19 no contexto internacional (continuação)

\begin{tabular}{|c|c|}
\hline $\begin{array}{l}\text { Dimensões da atuação } \\
\text { governamental }\end{array}$ & Estratégias e ações de enfrentamento da crise gerada pela Covid- 19 \\
\hline $\begin{array}{l}\text { Fortalecimento do } \\
\text { sistema de saúde e de } \\
\text { vigilância }\end{array}$ & $\begin{array}{l}\text { Estratégias e ações desenvolvidas com o objetivo de ampliar a } \\
\text { capacidade dos sistemas de saúde para realizar a assistência e a } \\
\text { vigilância em saúde, envolvendo: } \\
\text { - aumento da capacidade de leitos e leitos de UTI } \\
\text { - aumento da capacidade dos laboratórios públicos para realização } \\
\text { de testes diagnósticos (RT-PCR) } \\
\text { - disponibilização de insumos e equipamentos adequados, } \\
\text { incluindo EPls, medicamentos e ventiladores mecânicos } \\
\text { - organização dos serviços de saúde, com definição de fluxos } \\
\text { e pontos de atenção adequados à realidade locorregional, } \\
\text { com destaque para o papel da APS no teleatendimento e no } \\
\text { atendimento domiciliário, sempre que possível } \\
\text { - aumento da força de trabalho, capacitação e proteção dos } \\
\text { trabalhadores } \\
\text { - regulação pública do acesso a bens essenciais (medicamentos, } \\
\text { máscaras e leitos), com regulação nacional de preços } \\
\text { - padronização dos sistemas de registro de dados sobre novos } \\
\text { casos, internações e óbitos, com coordenação nacional } \\
\text { - articulação entre APS e vigilância epidemiológica para implantação } \\
\text { de medidas de deteçãa rápida de possíveis novos surtos, } \\
\text { incluindo a identificação precoce (confirmada por RT-PCR, se } \\
\text { possível) e rastreamento de contatos } \\
\text { - aumento do investimento em ciência e tecnologia para produção } \\
\text { de soluções (terapias e tecnologias) para a crise }\end{array}$ \\
\hline $\begin{array}{l}\text { Apoio social e } \\
\text { econômico }\end{array}$ & $\begin{array}{l}\text { Estratégias e ações desenvolvidas com o objetivo de garantir proteção } \\
\text { social à população, com especial atenção aos mais vulneráveis, e } \\
\text { de favorecer a retomada das atividades produtivas, comerciais e } \\
\text { financeiras, envolvendo: } \\
\text { - políticas de transferência de renda } \\
\text { - apoio à manutenção da moradia, como aluguel social, suspensão } \\
\text { temporária de pagamentos da hipoteca e contenção de ações de } \\
\text { despejo } \\
\text { - garantia de acesso a bens essenciais como água, energia elétrica, } \\
\text { gás e internet } \\
\text { - ampliação do acesso ao seguro-desemprego, incluindo } \\
\text { trabalhadores autônomos e informais } \\
\text { - apoio fiscal e financeiro às empresas }\end{array}$ \\
\hline
\end{tabular}


Quadro I - Lições aprendidas: estratégias e ações políticas para enfrentamento da crise gerada pela pandemia da Covid- 19 no contexto internacional (continuação)

\begin{tabular}{|c|c|}
\hline $\begin{array}{l}\text { Dimensões da atuação } \\
\text { governamental }\end{array}$ & Estratégias e ações de enfrentamento da crise gerada pela Covid- 19 \\
\hline \multirow{4}{*}{$\begin{array}{l}\text { Comunicação com a } \\
\text { sociedade }\end{array}$} & $\begin{array}{l}\text { Estratégias e ações desenvolvidas com o objetivo de dar transparência } \\
\text { às decisões tomadas no âmbito governamental, de modo que a } \\
\text { sociedade possa estar informada e participar do processo, envolvendo: } \\
\text { - publicação e difusão de dados epidemiológicos atualizados } \\
\text { diariamente }\end{array}$ \\
\hline & $\begin{array}{l}\text { - manutenção de um painel público sobre a ocupação de leitos } \\
\text { hospitalares e leitos de UTI }\end{array}$ \\
\hline & $\begin{array}{l}\text { - comunicação governamental sobre as medidas de proteção } \\
\text { individual e coletiva: rodas de imprensa, campanhas publicitárias } \\
\text { e ações de educação em saúde no âmbito dos serviços }\end{array}$ \\
\hline & $\begin{array}{l}\text { - debate nos meios de comunicação sobre as estratégias } \\
\text { governamentais e populares }\end{array}$ \\
\hline
\end{tabular}

Fonte: elaboração própria.

Pontos fortes da gestão e governança das estratégias de enfrentamento da crise, em cada caso, estão relacionados à liderança, ao reconhecimento da gravidade da crise e à capacidade de negociação; à direcionalidade da ação estatal, expressa na destinação de recursos fiscais e financeiros do governo central para as áreas sanitária, social e econômica; e à capacidade de produção nacional de insumos e equipamentos. A ausência ou debilidade desses fatores condiciona negativamente a atuação governamental.

Estruturas e instrumentos de governança favoreceram o acompanhamento e avaliação das estratégias e ações de resposta à Covid- 19; o equilíbrio entre processos de descentralização e centralização; o fortalecimento das capacidades político-institucionais nas diferentes instâncias de governo; o incremento dos mecanismos de diplomacia e cooperação intergovernamental; e a comunicação com a sociedade.

A resiliência dos sistemas de saúde no enfrentamento da Covid- 19 pode ser associada a aspectos estruturais prévios à pandemia: gasto em saúde, particularmente gasto público, disponibilidade de leitos hospitalares e força de trabalho. Todos esses aspectos foram identificados fortemente no caso alemão. Nos casos espanhol (sobretudo na estrutura hospitalar) e chinês (com relação à força laboral e ao gasto público em saúde) se mostraram mais débeis, demandando forte atuação governamental e alto investimento do governo central. 


\section{LIÇÕES APRENDIDAS NO CONTEXTO INTERNACIONAL: REFLEXÕES PARA A AÇÃO FUTURA}

As experiências internacionais analisadas permitem apreender algumas lições:

1. O enfrentamento da crise gerada pela Covid- 19 requer estratégias e ações articuladas em diversos âmbitos das políticas públicas, incluindo: controle da propagação da epidemia, articulando ações de restrição da mobilidade e de vigilância em saúde; fortalecimento do sistema de saúde e vigilância, para ampliar sua capacidade e promover equidade no acesso a bens essenciais; medidas de apoio social e econômico, para garantir proteção à população, com especial atenção aos mais vulneráveis, aos trabalhadores e ao tecido produtivo; comunicação com a sociedade, partícipe desse processo e portadora do direito de acesso às informações; e estrutura de governança e coordenação nacional.

2. A governança e liderança nacional das estratégias de resposta à Covid- I 9 pode ser associada a boas práticas de gestão dessa crise. Governança envolve articulação entre níveis de governo, entre setores da política pública (com destaque para aqueles relacionados a emprego e proteção social) e entre autoridades sanitárias e serviços de saúde. Inclui a articulação com organizações de trabalhadores (sindicatos e afins), empregadores e com a sociedade, além de envolver a negociação entre Executivo e Legislativo. As estruturas de governança e os instrumentos utilizados variam de acordo com as características e a organização político-territorial de cada país, incluindo fóruns intergovernamentais e instrumentos normativos (leis e decretos).

3. A coordenação nacional da resposta setorial à Covid- 19 é fundamental. Alguns fatores podem condicioná-la: pactuação de planos nacionais; papel ativo do Ministério da Saúde; mecanismos de articulação entre autoridades sanitárias de diferentes instâncias de governo; presença de órgãos de coordenação nacional das ações de vigilância e controle da propagação da epidemia. Tal coordenação pode ser favorecida pela experiência prévia na gestão de emergências sanitárias e pela presença de redes e sistemas de alerta precoce capazes de integrar serviços de vigilância e de atenção; e pela capacidade de rastreamento e testagem, apoiada por laboratórios nacionais de vigilância genômica. O conhecimento do território, em sua dinâmica populacional e localização de populações vulneráveis, contribui para a implementação de medidas mais efetivas.

4. Aspectos como a estrutura do sistema de saúde e de vigilância, a disponibilidade de trabalhadores, o sistema nacional de ciência e tecnologia e a capacidade 
de produção e provisão de insumos podem atuar como diferenciais relevantes na resposta à crise da Covid-19. Nesse sentido, destaca-se a importância do investimento público nessas áreas a curto, médio e longo prazos.

5. As consequências humanitárias, sociais e econômicas dessa crise multifacetada são extensas e tendem a aprofundar as desigualdades. As respostas nacionais a tais consequências são fundamentais, mas não prescindem de cooperações globais direcionadas para a equidade.

\section{REFERÊNCIAS}

CHINA CDC. National Health Commission of the People's Republic of China. Protocol for Prevention and Control of Covid-19. China CDC Weekly, 2(19):321-326, 2020. Disponível em: < http://weekly. chinacdc.cn/en/article/doi/l 0.46234/ccdcw2020.082 >. Acesso em abr. 2021 .

CHINA NATIONAL HEALTH COMMISSION. Disponível em: <www.nhc.gov.cn/xcs/yqfkdt/gzbd index.shtml>. Acesso em: abr. 202I.

ESPAÑA. Ministerio de Sanidad. Covid-19. Disponível em: <www.mscbs.gob.es>. Acesso em: abr. 202 Ia.

ESPAÑA. Ministerio de la Presidencia, Relaciones con las cortes y memoria democrática. Boletín Oficial del Estado. Disponível em: <www.boe.es/eli/es/rd/2020/03/l4/463>. Acesso em: abr. 202 lb.

ESPAÑA. Ministerio de Sanidad. Centro de Coordinación de Alertas y Emergencias Sanitarias. Disponível em: <www.mscbs.gob.es>. Acesso em: abr. 202 lc.

GERMANY. Bundesgesetz. Laws to protect the population in an epidemic situation of national scope. Disponível em: <www.bgbl.de>. Acesso em: abr. 202 la.

GERMANY. Bundesministerium für Gesundheit (Federal Ministry of Health). Disponível em: <www. bundesgesundheitsministerium.de $>$. Acesso em: abr. $202 \mathrm{lb}$.

GERMANY. Federal Ministry of Finance. German Stability Programme 2020. Disponível em: <www. bundesfinanzministerium.de>. Acesso em: abr. 202 Ic.

HUANG, C. et al. Clinical features of patients infected with 2019 novel coronavirus in Wuhan, China. The Lancet, 395: 497-506, 2020.

JABBOUR, E. \& DANTAS, A. The political economy of reforms and the present Chinese transition. Brazilian Journal of Political Economy, 37(4): 789-807, 2017.

JOHNS HOPKINS CRC. Coronavirus Resource Center. Disponível em: <https://coronavirus.jhu.edu/>. Acesso em: dez. 2020.

LEGIDO-QUIGLEY, H. et al. The resilience of the Spanish health system against the Covid- I 9 pandemic. The Lancet Public Health, online, 2020. Disponível em: < http://www.thelancet.com/journals/lanpub/ article/PIIS2468-2667(20)30060-8/fulltext>. Acesso em: abr. 202I.

MAHONEY, J. E RUESCHEMEYER, D. Comparative Historical Analysis in the Social Sciences. Cambridge: Cambridge University Press, 2003. 
MENG, Q. et al. People's Republic of China health system review. Geneva, Switzerland:World Health Organization, 20I5. Disponível em: <https://apps.who.int/iris/bitstream/ handle/I 0665/208229/97892906 I 7280_eng.pdf?sequence = I EisAllowed=y >. Acesso em: abr. 202 I .

NOGUEIRA, I.; BACIL, F.; GUIMARÃES, J.V. A caminho de um estado de bem-estar social na China? Uma análise a partir dos sistemas de saúde e de educação. Economia e Sociedade [online], v. 29, n. 2, p. 669-692, 2020. Disponível em: <https://doi.org/I0.1590/I982-3533.2020v29n2artI2>. Acesso em: abr. 2021 .

ORGANIZATION FOR ECONOMIC COOPERATION AND DEVELOPMENT (OECD). Welcome to OECD. Stat. Disponível em: <https://stats.oecd.org>. Acesso em: abr. 2021.

ORGANIZATION FOR ECONOMIC COOPERATION AND DEVELOPMENT (OECD) \& WORLD HEALTH ORGANIZATION (WHO). European Observatory on Health Systems and Policies. State of health in the EU: Germany, 2019. Disponível em: <www.oecd-ilibrary.org>. Acesso em: abr. 2021.

OUR WORLD IN DATA. Site. Disponível em: < https://ourworldindata.org/coronavirus > . Acesso em: abr. 2021 .

PEREIRA, A. M. M. Análise de políticas públicas e neoinstitucionalismo histórico: ensaio exploratório sobre o campo e algumas reflexões. In: GUIZARDI, F. L. et al. (Orgs.). Políticas de Participação e Saúde. Recife: Editora UFPE, 2014.

ROBERT KOCH INSTITUTE (RKI). Covid- 19. Disponível em: <www.rki.de>. Acesso em: abr. 202I.

STREECK, W. German capitalism: does it exist? Can it survive? In: CROUCH, C. \& STREECK, W. (Eds.). Political Economy of Modern Capitalism: mapping convergence and diversity. London: Sage, 1997.

TIAN, H. et al. An investigation of transmission control measures during the first 50 days of the Covid- 19 epidemic in China. Science, 368(6.491), 2020. Disponível em: <www.science.org/doi/10.1126/ science.abb6105>. Acesso em: abr. 2021.

UNITED NATIONS DEVELOPMENT PROGRAMME (UNDP). Site. Disponível em: < http://hdr.undp.org/ en/countries>. Acesso em: abr. 2021.

WORLD BANK. Data. Disponível em: < https://data.worldbank.org >. Acesso em: abr. 2021.

WHO-CHINA JOINT MISSION ON CORONAVIRUS DISEASE. Report of the WHO-China Joint Mission on Coronavirus Disease 2019 (Covid-19), 16-24 Feb. 2020. Disponível em: <www.who.int/docs/ default-source/coronaviruse/who-china-joint-mission-on-covid-19-final-report.pdf>. Acesso em: abr. 2021 .

WORLD HEALTH ORGANIZATION (WHO). Site. Disponível em: <https://www.who.int/data/gho/ data/themes/topics/health-workforce>. Acesso em: abr. 2021 .

WORLD INEQUALITY DATABASE (WID). Site. Disponível em: < https://wid.world/es>. Acesso em: abr. 2021 .

WU, Z. \& MCGOOGAN, J. M. Characteristics and important lessons from the coronavirus disease 2019 (Covid-19) outbreak in China: summary of a report of 72314 cases from the Chinese Center for Disease Control and Prevention. Jama, 323(13): I.239-1.242, 2020. 
Covid-19

por uma aposta radical na saúde, para o bem da sociedade

Pedro Ribeiro Barbosa e Eduardo Kaplan Barbosa

E ste texto é escrito após completarmos mais de um ano e meio das primeiras mortes

L por Covid no Brasil, em março de 2020, e o país chorar por mais de 600 mil mortes. Seria inimaginável estarmos vivendo tal escala da tragédia, sem ainda haver segurança de que realmente chegamos no pior momento! Não é absurdo em 202I seguirmos convivendo com continuada gravidade, apesar do processo de vacinação. Após pouco mais de um ano de pandemia, foram vários os reveses do vírus, culminando com novos picos de casos e mortes. As recentes mutações ainda assustam pesquisadores, dirigentes da saúde e governantes aliados à ciência e à vida.

Está claro, por sua vez, que no Brasil não temos um efeito isolado e natural do vírus, se assim podemos considerar. A condição do país é singular, com medidas, e ausência de medidas, contribuindo para potencializar a pandemia. Já estão estabelecidos consensos em relação às centenas de milhares de doentes, hospitalizações e mortes evitáveis, caso na condução do enfrentamento da doença no país tivessem sido adotadas práticas comuns à maioria absoluta dos países e recomendadas tanto pela Organização Mundial da Saúde (OMS) como pelos principais centros de controle de doenças e instituições científicas mundo afora, incluindo praticamente todas as nacionais (Werneck et al., 2021).

Ao longo do último ano estamos sentindo, e seguramente continuaremos sentindo por vários meses adiante, em nossas rotinas diárias as implicações da pandemia da Covid- 19 como em nenhuma outra crise que as atuais gerações presenciaram. $O$ isolamento físico e social efetivo é negligenciado como política sanitária e pouco adotado desde o início da pandemia no país, com raras exceções. Certamente, sua continuada fragilidade representou uma das importantes razões do quadro a que se chegou. A face mais valorizada do enfrentamento esteve e ainda está no que se convencionou chamar 
de linha de frente, na qual merece destaque a atuação digna e de esforço sem igual de profissionais de unidades de atendimento médico-hospitalar de casos graves. Caso fossem melhor compreendidas a dinâmica e a complexidade das ações de enfrentamento da pandemia, os hospitais seriam linha de retaguarda, e não de frente, pois ali resta mitigar e lidar com a dramática consequência do acometimento.

Independentemente da complexidade sanitária, dos desafios científicos e tecnológicos em saúde, a pandemia expõe conflitos e problemas latentes não apenas de nossos sistemas de saúde ou da economia, mas de nossos modos de morar, nos locomovermos, trabalhar, cuidar, celebrar. Expõe a fragilidade do nosso modo de nos organizarmos e de vivermos em sociedade, local e globalmente. São problemas complexos que não permitem soluções individuais ou segmentadas, e por isso exigem um debate amplo sobre uma radical reinvenção coletiva dos nossos principais arranjos e estruturas sociais, econômicas e políticas.

Neste texto, nosso propósito maior é lidar com esse debate mais amplo. Não se trata de análise do comportamento da pandemia e das medidas tomadas pelo país exclusivamente no campo do seu enfrentamento imediato e cotidiano, embora com ele dialoguemos, seja no caso brasileiro ou em outros países. O objetivo é expor com maior abrangência as possíveis e necessárias interações entre o campo da saúde e diversas outras dimensões do desenvolvimento, procurando articular a saúde como referência basilar e determinante de novas perspectivas de desenvolvimento. Para tanto, consideramos a gravidade e a extensão global da pandemia do Sars-CoV-2 para além da sua dimensão aguda e da ação de combate e controle do vírus.

Desde seus momentos iniciais, a pandemia tem exigido respostas complexas, muitas das quais ainda desconhecidas, que envolvem a combinação de medidas de predição e vigilância epidemiológica, médico-hospitalares, sanitárias, tecnológicas, sociais e econômicas. Caracterização genômica incessante do vírus, testagem na ordem de milhões de cidadãos, oferta de vacinas em diversas bases tecnológicas, ampliação de milhares de unidades de tratamento intensivo (UTIs), distanciamento social, novos mecanismos de proteção social e de manutenção e criação de postos de trabalho. E todas ainda limitadas na contenção da pandemia e suas consequências em inúmeras dimensões da vida humana.

De modo singular, a pandemia da Covid- 19 exige análises e medidas muito além da dimensão sanitária clássica, sobretudo se considerarmos conceitos multidimensionais acerca do processo causal na relação saúde-doença, que demandam articulação dos campos da saúde e das políticas sociais, do ambiente, da economia, da liberdade e da 
democracia, em nome de mais qualidade de vida, em padrões de equidade para todos os indivíduos do planeta. A pandemia da Covid- 19 reúne elementos em todas essas dimensões e permite colocar em xeque o padrão hegemônico de desenvolvimento e de exploração do planeta nas últimas muitas décadas.

O padrão epidemiológico da Covid-19, seu recente recrudescimento e tendências incertas, assim como a perspectiva de surgimento de outras epidemias, indicam que a grande parte das medidas para sua mitigação poderá ser adotada novamente em grande escala, se não de forma permanente, ao menos de forma recorrente, exigindo novos arranjos institucionais.

No caso brasileiro, a omissão e o descaso no enfrentamento da pandemia são agravados pela desconstrução de políticas sociais, ambientais e tecnológicas, bem como pela contínua perda de dinamismo econômico, que em conjunto levam a consequências trágicas. A Covid- 19 não é apenas uma pandemia, mas uma síndrome provocada por um padrão de exploração econômica insustentável. Pesquisadores aplicam à Covid- 19 o conceito de sindemia, neologismo que remete aos conceitos de sinergia e pandemia, tendo em vista que a pandemia ocorre em conjunto com diversas outras condições que convivem e a potencializam, mediante efeitos sinérgicos, sendo o resultado desta condição, a sindemia, superior à mera soma, se assim fosse possível, do conjunto das condições concorrentes (Horton, 2020).

A compreensão nos termos de uma sindemia para a Covid- 19 condiciona os modelos para seu enfrentamento. Estabelecer um novo marco conceitual possibilitaria estratégias distintas para o seu controle, em sua fase aguda, reconhecendo condições causais muito além da capacidade de transmissão do vírus. Envolve o conjunto de outras dimensões, seja de doenças concomitantes e agravantes, seja em outras dimensões da vida - sociais, econômicas e ambientais.

Vejamos um reflexo ou interação com a dimensão ambiental. No momento em que muitos países tomaram medidas de lockdown para a contenção da transmissão e se voltaram para cuidar dos pulmões de seus cidadãos, as veias do planeta se tornaram mais limpas, com a queda da produção de gases de efeito estufa. De forma imprevista, as medidas de prevenção da Covid-19 atenuaram também a doença planetária, explicitando o imbricamento das dimensões sociais e ambientais. Se o aquecimento global é uma doença crônica, que leva à morte certa, porém lenta, a pandemia da Covid- 19 se mostrou um sinal agudo, global, com pico febril planetário e importante letalidade coletiva. De algum modo, como efeito da desregulada expansão da fronteira agropecuária e das manchas urbanas sobre áreas naturais antes preservadas, um padrão 
atípico de interação humana entre indivíduos, sociedade e meio ambiente permite que um vírus "salte" do animal para o humano. Antes de um acidente, esta pandemia é, portanto, decorrência direta de um modelo de desenvolvimento econômico baseado em expansão territorial desregulada, gerador de uma lógica invasiva na relação entre humano, animal e ambiente.

É visível que as respostas à doença aguda da pandemia estão indicando caminhos para resolver a doença crônica das mudanças climáticas. Assim como a respiração mecânica não é a cura do paciente grave de Covid-19, as ações de lockdown ou restrições gerais de mobilidade não são a resposta à crise ambiental. Mas seus efeitos demonstram que identificamos "o alvéolo inflamado": nossa forma de produzir, transportar e consumir, bem como a falta de infraestrutura de moradia e mobilidade de imensa população. Livres da poluição densa de fábricas e motores, cidades redescobriram, ao menos transitoriamente, a vista dos céus e de montanhas vizinhas. Em outros casos, rios e baías de áreas densamente ocupadas, porém pobres de infraestrutura, rapidamente recebem de volta a vida marinha. E, numa escala global, a redução da emissão de $\mathrm{CO}_{2}$ em 2020 resultou num decréscimo de 7\% em relação ao ano de 2019 , a maior redução já registrada (Tholeffson, 202 I).

Outra fonte de esperança está expressa na rapidez com que os países implementaram os mecanismos de proteção contra a pandemia. Mais do que agilidade em criar novos instrumentos de proteção, todos os países com algum grau de sucesso demonstraram capacidade de buscar as respostas em costumes, organizações ou políticas já existentes. Seja a ampliação de renda básica de países europeus, depois seguidas inclusive no Brasil, a reconversão industrial dos americanos ou a oferta de atendimento hospitalar gratuito do Sistema Único de Saúde (SUS) brasileiro, vários países já carregavam as sementes das respostas necessárias para as crises atuais. No entanto, é preciso reconhecer também que, apesar de promissores, os mecanismos acionados ainda são, em sua grande maioria, improvisações momentâneas, compensatórias, que só poderão ser resgatadas para o centro da vida coletiva com profundas adaptações.

Mesmo que escanteados, sobretudo nas três últimas décadas de neoliberalismo, são os arranjos institucionais de saúde universal, seguridade social e flexibilidade do sistema produtivo que apontam, se não saídas da crise, ao menos caminhos para reconversões mais estruturantes e sustentáveis.

No tocante à doença, às mortes e ao sofrimento em escala global, o atual contexto e suas tendências impõem um novo arranjo que fortaleça o papel da saúde na sociedade. Mais do que um direito individual e coletivo, a saúde se prova a cada dia um setor econômico dinâmico potencialmente estruturante e mobilizador de postos de trabalho 
qualificados, inovação e base produtiva. E deve ser entendida, portanto, também como linha mestra de um novo modelo de desenvolvimento sustentável e inclusivo.

Um primeiro passo no redesenho dos arranjos institucionais se deu durante as semanas iniciais da pandemia, quando a urgência em mitigar a mortalidade e preservar a renda das famílias tornou imperativa a adoção de pacotes fiscais. Corretamente, no caso brasileiro, a criação de auxílio emergencial e créditos extras para o SuS tornaram secundária a preocupação com o déficit público. A pandemia impôs o fortalecimento de uma rede de proteção social, mas sua urgência já era há muito apontada por entidades como Banco Mundial e Fundo Monetário Internacional, que reconhecem tal necessidade diante da acelerada transformação tecnológica e de outras fontes de vulnerabilidade (World Bank, 2019; IMF, 2020).

Com a expressiva redução da mortalidade após o início tardio da vacinação e adesão maciça da população, foi possível implementar gradual retorno das atividades e da dinâmica econômica. Em qualquer hipótese, porém, o cenário de baixo dinamismo da economia se tornará ainda mais desafiador para os trabalhadores e pequenos empreendedores, com a falência de muitos negócios e extinção de grande número de postos de trabalho decorrente do impulso da economia digital. A superação da pandemia exigirá a reconfiguração, e não a mera suspensão, dos mecanismos implementados na fase emergencial, orientados para a proteção social e a requalificação dos trabalhadores e, preferencialmente, contrabalançados por uma tributação mais progressiva.

Sozinhos, no entanto, tais mecanismos fiscais de caráter compensatório terão efeitos limitados e decrescentes. Sua viabilidade política e econômica exige uma articulação com um segundo eixo de políticas públicas centradas na promoção de dinamismo econômico para gerar empregos qualificados e suprir as carências tecnológicas para uma atenção plena à saúde.

A dificuldade em adquirir respiradores e outros insumos, além da clara dependência externa de vacinas, expôs uma fragilidade do sistema de saúde e uma lacuna injustificável na capacidade produtiva nacional. "SUS com pés de barro", assim Carlos Gadelha alerta para o déficit comercial do país em saúde, com dependência em praticamente todas as frentes, de medicamentos a equipamentos e materiais médico-hospitalares, além de pagamentos de royalties e serviços (Gadelha E Temporão, 2018).

O desenvolvimento do complexo econômico-industrial da saúde tem o duplo papel de vetor de crescimento econômico e pilar da saúde pública universal. Sem capacidade nacional de pesquisa, desenvolvimento e produção de testes, vacinas, equipamentos e profissionais qualificados, o atendimento aos cidadãos dependentes do SUS será com- 
prometido, continuando vulnerável em "tempos normais" e criando catástrofes sociais nos períodos de pandemia, nos deixando de joelhos diante dos humores do fornecimento internacional. Sem aportes expressivos e contínuos para a pesquisa e o desenvolvimento tecnológico e produtivo nacional, seguiremos com "pés de barro" (Bahia, 2015). Apenas para as vacinas para Covid- 19 em 202I, estima-se que serão aplicados montantes acima de $\mathrm{R} \$ 20$ bilhões, a maior parte em compras internacionais, além de royalties anos à frente (Gadelha, 202 I). Investimentos em pesquisa e desenvolvimento anos atrás, em valores seguramente bem inferiores, teriam propiciado uma vacina inteiramente nacional. No ano de 2021, o déficit da balança comercial em saúde deve ser algo como o dobro daquele dos últimos anos (Gadelha, 202I).

Em outros campos da organização social, a elevada taxa de contágio do Sars-CoV-2 pôs também em xeque os padrões de transporte, habitação e lazer e, sobretudo, a iniquidade de acesso à infraestrutura social. Como já documentado e cada vez mais claro no Brasil, são os moradores de áreas desprovidas de infraestrutura urbana os mais contaminados e com maior taxa de mortalidade (Ribeiro et al., 202I). No passado, epidemias foram decisivas para que as cidades investissem maciçamente em saneamento e incorporassem novos padrões urbanísticos e de serviços públicos. Essa agenda compõe um terceiro eixo de políticas voltadas para a saúde pública e precisa ser urgentemente retomada e adaptada para as necessidades das periferias e comunidades vulneráveis. Impulsionar uma taxa de investimento deverá ser tratado como efeito secundário: o real propósito é viabilizar a atenção à saúde, o que exige lidar com os seus determinantes socioambientais.

A pandemia atual expôs a face aguda e cruel de uma doença crônica com que convivemos: a profunda desigualdade social e o desfazimento dos mecanismos dinamizadores da economia e do desenvolvimento científico e tecnológico nacional. Garantir renda básica, reverter a desindustrialização precoce, viabilizar investimentos em educação, saúde e pesquisa científica ainda são tratados como concessões em prol de uma suposta eficiência econômica, quando são, em essência, objetivos primordiais de uma sociedade, tendo a saúde do planeta e dos indivíduos como condição central e razão de vida.

\section{REFERÊNCIAS}

BAHIA, L. Pés de barro. O Globo, Rio de Janeiro, 13 abr. 20I5. Disponível em: < https://oglobo.globo. com/opiniao/pes-de-barro-I5841069>. Acesso em: 20 abr. 2021.

GADELHA, C. A. G. Reflexão crítica dos desafios e obstáculos para o desenvolvimento de política pública: o CEIS como soberania e como saída para a crise. Apresentação à Comissão de Seguridade Social e Família da Câmara dos Deputados realizada em 10 de maio de 2021. Disponível em: <www2. camara.leg.br/atividade-legislativa/comissoes/comissoes-permanentes/cssf/arquivos/I 3-05-202 I apresentacao-carlos-gadelha>. Acesso em: 27 jun. 2021. 
GADELHA, C. A. G. E TEMPORÃO, J. G. Desenvolvimento, inovação e saúde: a perspectiva teórica e política do Complexo Econômico-Industrial da Saúde. Ciência E Saúde Coletiva, 23(6): I.891-1.902, 2018.

HORTON, N. Offline: Covid- I 9 is not a pandemic. The Lancet, 396(I 0.255): 874, 2020.

INTERNATIONAL MONETARY FUND (IMF). A Strategy for IMF Engagement on Social Spending. IMF Policy Paper, 2019. Disponível em: <www.imf.org/en/Publications/Policy-Papers/lssues/2019/06/I0/AStrategy-for-IMF-Engagement-on-Social-Spending-46975>. Acesso em: 28 abr. 2021 .

RIBEIRO, K. B. et al. Social inequalities and Covid-19 mortality in the city of São Paulo, Brazil. International Journal of Epidemiology, 2021. Disponível em: <https://doi.org/10.1093/ije/dyab022>. Acesso em: 27 jun. 2021.

TOLLEFSON, J. Covid curbed carbon emissions in 2020, but not by much. Nature, 589, 343, 2021. Disponível em: <https://www.nature.com/articles/d4 I 586-02 I-00090-3> Acesso em: 27 jun. 2021 .

WERNECK, G. L. et al. Mortes evitáveis por Covid- 19 no Brasil. Disponível em: < https://idec.org.br/ sites/default/files/mortes_evitaveis_por_covid-19_no_brasil_para_internet_1.pdf >. Acesso em: 27 de jun. 2021.

WORLD BANK. The Changing Nature of Work. World Development Report 2019. Disponível em: <www.worldbank.org/en/publication/wdr2019>. Acesso em: 27 jun. 2021. 

PARTE II

ORGANIZAÇÃO DO CUIDADO NA PANDEMIA DE COVID-19 



\section{Logística para o Enfrentamento de Desastres e Aplicações ao Contexto da Pandemia de Covid-19}

Híngred Ferraz Pereira Resende, Tharcisio Cotta Fontainha e Adriana Leiras

pós mais de um ano da confirmação, em 25 de fevereiro de 2020, do primeiro caso
de Covid- 9 no Brasil, o sistema de saúde nacional ainda enfrenta um dos maiores desafios sanitários deste século (Barreto et al., 2020; Rodriguez-Morales et al., 2020). Os números seguem alarmantes: até a data de 28 de outubro de 2021, o Ministério da Saúde registrou mais de 21,7 milhões de casos confirmados e 606.679 mil óbitos no Brasil (Brasil, 202 Ia).

Esses números espelham o rápido aumento de casos, e consequentes internações (ECDC, 2020), que levam ao estresse das capacidades hospitalares e das operações logísticas para solucionar o problema. Nesse contexto, Grabois e colaboradores (2020) redigiram nota técnica para responder à seguinte pergunta de pesquisa: "Como as organizações de saúde e seus fornecedores poderiam se adaptar para responder à pandemia de Covid- 1 9?". Os autores recorreram a exemplos de diferentes impactos na capacidade hospitalar do sistema de saúde (entre outros, escassez de medicamentos, suprimentos e equipamentos médicos, infecção de profissionais da saúde que precisam ser afastados de suas funções e, em alguns casos, chegam ao óbito) e apresentaram recomendações para os stakeholders envolvidos.

Diante da inexistência de tratamentos terapêuticos, no Brasil uma das principais estratégias atuais de combate à pandemia de Covid- 19 reside na vacinação da população - a sexta maior do mundo -, que se iniciou recentemente (Anvisa, 202 Ia). Lima, Almeida e Kfouri (2020) elencaram diferentes questões logísticas que podem comprometer a eficácia do sistema de vacinação, tais como a fabricação e distribuição das vacinas. Considerando esses desafios, abordamos aqui também a seguinte pergunta de pesquisa: "Como deve ser a gestão logística da cadeia de suprimentos de vacinação durante a resposta à Covid-1 9 ?". 
No presente estudo discutimos os problemas logísticos associados à capacidade hospitalar do sistema de saúde, como em Grabois e colaboradores (2020), e, adicionalmente, aqueles do sistema de vacinação no contexto da pandemia de Covid- 19. Esperamos, assim, contribuir para a reflexão e superação de tais reveses no sistema hospitalar e no sistema de vacinação no tocante ao enfrentamento da pandemia de Covid- 19.

\section{LOGÍ́TICA PARA ADAPTAÇÃO DA CAPACIDADE HOSPITALAR NO COMBATE À PANDEMIA DE COVID-19}

Em casos de pandemia, a capacidade de atendimento dos sistemas de saúde e de cuidados intensivos é extrapolada (Ten Eyck, 2008; Hupert et al., 2009). Trata-se de uma questão apontada desde o início da atual pandemia de Covid- 19 por pesquisadores como Rache e colaboradores (2020), que observam demanda maior por serviços de saúde nos locais mais afetados por essa doença.

Desde o início da pandemia, a Organização Mundial da Saúde (OMS) já começa a se preparar para a escassez de suprimentos essenciais, tais como kits diagnósticos, produtos médicos e equipamentos de proteção individual (EPIs), e desenvolve uma série de ferramentas para realizar estimativas relacionadas à capacidade de mão de obra e suprimentos (WHO, 2020a). Essas ferramentas estão disponíveis para acesso no site da organização.

Além dessas ferramentas, Grabois e colaboradores (2020) destacam que, para atender os pacientes com suspeita ou confirmação de Covid- 19 nesse contexto de crescimento de demanda, as secretarias estaduais de Saúde devem identificar e definir os serviços que cada hospital pode e deve oferecer aos pacientes e atuar diretamente com os fornecedores para garantir os insumos e equipamentos necessários. Essa cadeia de suprimentos hospitalar é apresentada de forma sintetizada na Figura I.

Figura I - Cadeia de suprimentos hospitalar

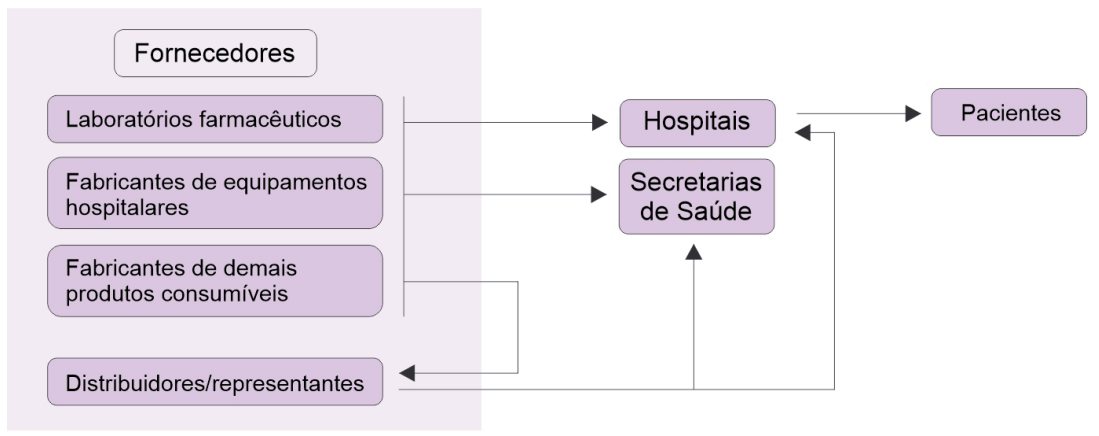

Fonte: adaptada de Barbieri \& Machline, 2009. 
Grabois e colaboradores (2020) registram que o estudo de Hick e colaboradores (20/4) traz uma abordagem que ajuda a apoiar as tomadas de decisão das organizações. Nessa abordagem, são considerados três cenários - convencional, contingência e crise - e seis dimensões - espaço, funcionários, suprimentos, atendimento, objetivo de expansão e abrangência (Quadro I). Na perspectiva da cadeia de suprimentos hospitalar (Figura I) e dos cenários e dimensões de análise (Quadro I), Grabois e colaboradores (2020) apresentam 34 recomendações para os três principais tomadores de decisão (stakeholders), detalhadas no Quadro 2.

Quadro I - Cenários de respostas em diferentes situações

\begin{tabular}{|l|l|l|l|}
\hline \multirow{2}{*}{ Dimensões } & \multicolumn{1}{|c|}{ Cenários } \\
\cline { 2 - 4 } & Espaços usuais & $\begin{array}{l}\text { Contingêncional } \\
\text { Realocação de áreas } \\
\text { de atendimento }\end{array}$ & $\begin{array}{l}\text { Uso de áreas não } \\
\text { tradicionais }\end{array}$ \\
\hline Funcionários & $\begin{array}{l}\text { Pessoal utilizado } \\
\text { conforme necessidade }\end{array}$ & Expansão de pessoal & Pessoal insuficiente \\
\hline Suprimentos & Disponíveis & $\begin{array}{l}\text { Adaptação e } \\
\text { substituição quando } \\
\text { seguros }\end{array}$ & Escassez \\
\hline Atendimento & Atendimentos usuais & $\begin{array}{l}\text { Impactos mínimos } \\
\text { nas práticas usuais }\end{array}$ & $\begin{array}{l}\text { Atendimentos em } \\
\text { massa }\end{array}$ \\
\hline Objetivo de expansão & $\begin{array}{l}20 \% \text { da capacidade } \\
\text { usual }\end{array}$ & $\begin{array}{l}\text { I00\% da capacidade } \\
\text { usual }\end{array}$ & $\begin{array}{l}\text { 200\% da capacidade } \\
\text { usual }\end{array}$ \\
\hline Abrangência & Local & Regional/Estadual & Nacional \\
\hline
\end{tabular}

Fonte: adaptado de Hick et al., 2014; Grabois et al., 2020. 


\section{Quadro 2 - Recomendações para adaptação da capacidade hospitalar}

\begin{tabular}{|c|c|}
\hline Stakeholders & Recomendações \\
\hline \multirow{11}{*}{$\begin{array}{l}\text { Secretarias de } \\
\text { Saúde }\end{array}$} & $\begin{array}{l}\text { \# I. Tomar decisões em conjunto com representantes municipais e lideranças } \\
\text { hospitalares }\end{array}$ \\
\hline & \#2. Incluir especialistas em cuidados intensivos para resposta à pandemia \\
\hline & \#3. Planejar a capacidade de criação de novos hospitais \\
\hline & $\begin{array}{l}\text { \#4. Identificar situações com diferentes percentuais de redirecionamento } \\
\text { de leitos dentro da sua capacidade, sem comprometer ou comprometendo } \\
\text { parcialmente o atendimento em sua/s especialidade/s ou perfil assistencial }\end{array}$ \\
\hline & $\begin{array}{l}\text { \#5. Estudar como as informações são e devem ser compartilhadas } \\
\text { rotineiramente para seu melhor uso }\end{array}$ \\
\hline & $\begin{array}{l}\text { \#6. Permitir que todos os pacientes com necessidade de tratamentos intensivos } \\
\text { recebam igual consideração }\end{array}$ \\
\hline & $\begin{array}{l}\text { \#7. Ter um planejamento referente à capacidade dos hospitais para receber } \\
\text { pacientes que em situações normais não fazem parte do seu perfil assistencial }\end{array}$ \\
\hline & $\begin{array}{l}\text { \#8. Manter comunicação com as organizações internacionais e autoridades } \\
\text { de saúde }\end{array}$ \\
\hline & $\begin{array}{l}\text { \#9. Receber equipes de consultores especializadas para coordenar e auxiliar as } \\
\text { autoridades estaduais e locais }\end{array}$ \\
\hline & $\begin{array}{l}\text { \# I0. Estabelecer sistema de cooperação internacional para lidar conjuntamente } \\
\text { com as principais emergências }\end{array}$ \\
\hline & $\begin{array}{l}\text { \# I I. Melhorar o sistema de compras e distribuição de suprimentos de } \\
\text { emergência, dada prioridade ao pessoal médico }\end{array}$ \\
\hline \multirow{7}{*}{$\begin{array}{l}\text { Gestores } \\
\text { hospitalares }\end{array}$} & \# 12. Organizar respostas assistenciais, de acordo com o nível de gravidade clínica \\
\hline & $\begin{array}{l}\text { \# 13. Tomar precocemente medidas de identificação, acolhimento e cuidado em } \\
\text { áreas específicas }\end{array}$ \\
\hline & $\begin{array}{l}\text { \# I 4. Identificar e planejar a transformação de ambientes de cirurgia e } \\
\text { recuperação em ambientes de terapia intensiva }\end{array}$ \\
\hline & \# 15. Treinar equipes hospitalares para que saibam atuar durante a crise \\
\hline & $\begin{array}{l}\text { \# 16. Implementar triagens externas às unidades de saúde a fim de reduzir/evitar } \\
\text { transmissão da Covid- } 19\end{array}$ \\
\hline & \# 17. Reduzir a exposição de pacientes da síndrome gripal após a triagem externa \\
\hline & $\begin{array}{l}\text { \# I 8. Alocar pacientes de acordo com a gravidade clínica, baseando-se em sinais } \\
\text { vitais, exames laboratoriais e físicos }\end{array}$ \\
\hline
\end{tabular}




\section{Quadro 2 - Recomendações para adaptação da capacidade hospitalar (continuação)}

\begin{tabular}{|c|c|}
\hline Stakeholders & Recomendações \\
\hline \multirow{13}{*}{$\begin{array}{l}\text { Gestores } \\
\text { hospitalares }\end{array}$} & $\begin{array}{l}\text { \# 19. Criar fluxo de circulação e ambientes de cuidados isolados para pacientes } \\
\text { confirmados e suspeitos de Covid- I } 9\end{array}$ \\
\hline & \#20. Disponibilizar equipes de resposta rápida em apoio a estados e municípios \\
\hline & $\begin{array}{l}\text { \#21. Designar para o cuidado de pacientes graves e críticos apenas profissionais } \\
\text { da saúde com treinamento prévio }\end{array}$ \\
\hline & $\begin{array}{l}\text { \#22. Utilizar medidas em colaboração com representantes das equipes de saúde } \\
\text { para lidar com redução de pessoal. }\end{array}$ \\
\hline & $\begin{array}{l}\text { \#23. Implementar medidas para reduzir efeitos evitáveis da redução ou falta de } \\
\text { pessoal }\end{array}$ \\
\hline & $\begin{array}{l}\text { \#24. Supervisionar e orientar os profissionais da saúde inclusive para avaliação } \\
\text { contínua do plano de tratamento }\end{array}$ \\
\hline & $\begin{array}{l}\text { \#25. Estimar as necessidades para que profissionais sejam orientados quanto à } \\
\text { reabilitação e a cuidados prolongados }\end{array}$ \\
\hline & \#26. Monitorar os estoques de suprimentos e recursos para atendimento \\
\hline & $\begin{array}{l}\text { \#27. Incluir comitês hospitalares de planejamento da capacidade e gestão das } \\
\text { operações durante a pandemia }\end{array}$ \\
\hline & $\begin{array}{l}\text { \#28. Realizar atividades de capacitação para os profissionais da saúde voltadas } \\
\text { para o uso adequado dos EPIs de acordo com os ambientes de cuidado e } \\
\text { procedimentos a serem realizados, assim como para as técnicas de paramentação } \\
\text { e de desparamentação }\end{array}$ \\
\hline & \#29. Utilizar o transporte de remoção de pacientes para transportar ativos \\
\hline & $\begin{array}{l}\text { \#30. Empregar ferramentas simples, preestabelecidas e padronizadas de coleta } \\
\text { de dados pelas equipes de resposta }\end{array}$ \\
\hline & $\begin{array}{l}\text { \#31. Utilizar tecnologia como complemento importante para a prestação de } \\
\text { serviços }\end{array}$ \\
\hline \multirow{3}{*}{ Fornecedores } & $\begin{array}{l}\text { \#32. Gerir da melhor forma a cadeia de suprimentos objetivando responder com } \\
\text { eficiência à pandemia }\end{array}$ \\
\hline & $\begin{array}{l}\text { \#33. Aplicar a ferramenta desenvolvida pela Organização Mundial da Saúde para } \\
\text { dimensionamento da necessidade de suprimentos essenciais }\end{array}$ \\
\hline & $\begin{array}{l}\text { \#34. Aplicar medidas de higienização para transportes de suprimentos e } \\
\text { equipamentos }\end{array}$ \\
\hline
\end{tabular}

Fonte: adaptado de Grabois et al., 2020. 
Com essas recomendações pretende-se contribuir para a adaptação das capacidades hospitalares para melhor resposta à pandemia de Covid-19, minimizando os entraves logísticos e, consequentemente, reduzindo o número de pacientes sem atendimento e que vão a óbito.

\section{GESTÃO DA CADEIA DE SUPRIMENTOS NO SISTEMA DE VACINAÇÃO DE COMBATE À PANDEMIA DE COVID-19}

A imunização é considerada um dos recursos dos sistemas de saúde mais econômicos para prevenção e controle de doenças, redução de morbidades, mortalidade e incapacidade em todo o mundo (Abs, 2020). Segundo a OMS, a imunização evita entre 2 e 3 milhões de mortes todos os anos (WHO, 2020b), agindo no treinamento e preparação do sistema imunológico para reconhecer e combater vírus e bactérias quando atacado (WHO, 2020c).

Na pandemia de Covid-19, os recursos humanos e financeiros são considerados essenciais na corrida por uma vacina (Cueto et al., 2020). Atualmente existem mais de duzentas vacinas candidatas, e dessas, mais de sessenta já em desenvolvimento clínico para a Covid- 19 em todo o mundo (WHO, 2020c). Quando uma vacina atinge o estágio de pré-aprovação, ou seja, após a finalização dos ensaios clínicos, ela é avaliada pelo órgão responsável pela regulamentação sanitária quanto ao cumprimento de critérios de qualidade, segurança e eficácia (WHO, 2020d). No Brasil, a Agência Nacional de Vigilância Sanitária (Anvisa) é o órgão regulador federal no assunto, e a aprovação de vacinas é realizada por um comitê multidisciplinar composto por farmacêuticos, médicos, biólogos e estatísticos que avaliam seus aspectos de forma minuciosa (Anvisa, 2020).

Até o dia 9 de novembro de 202 I a Anvisa possui registro de algumas vacinas, sendo algumas com registro definitivo, outras aprovadas para uso emergencial e algumas ainda em análise (Brasil, 202 lb). Há o registro definitivo de duas vacinas: I) Astrazeneca/Oxford, desenvolvida em parceria com a AstraZeneca e a Universidade de Oxford e produzida na Fundação Oswaldo Cruz (Fiocruz, 202 I); e 2) a vacina BNTI62, desenvolvida pela farmacêutica Pfizer em parceira com a BioNTech (Pfizer, 2020). Além disso, estão aprovadas duas vacinas para uso emergencial: 3) CoronaVac, desenvolvida pela farmacêutica Sinovac em parceria com o Instituto Butantan (Instituto Butantan, 202 I), e 4) Covid I 9 Vaccine - Ad26.COVs-S recombinante, desenvolvida pela farmacêutica Janssen em parceria com a Johnson $\&$ Johnson (Anvisa, 202 I b). Além dessas, estão em fase de análise as vacinas: 5) Covaxin, desenvolvida pelo Conselho Indiano de Pesquisa 
Médica em parceria com o Instituto Nacional de Virologia, da cidade de Pune, na Índia (Brasil, 202 I c), e 6) Sputnik-V, desenvolvida pelo Fundo Russo de Investimento Direto e Instituto Gamaleya (Brasil, 202 Id).

Segundo o Ministério da Saúde, o Brasil distribuiu mais de 90,6 milhões de doses para as unidades federativas, das quais mais de 53,7 milhões haviam sido aplicadas até 18 de maio de 202 I; dessas aplicações, 36.464 .179 são de primeira dose e 17.3 I 1.353 de segunda dose (Brasil, 202 I e). Ademais, o Ministério da Saúde afirma que mais de 560 milhões de doses estão previstas até o final de 2021, segundo as entregas contratuais das farmacêuticas e laboratórios (Brasil, 202 l b).

Quanto ao transporte, o Ministério da Saúde (Brasil, 2017) afirma que as vacinas são transportadas por diferentes meios (aéreo, terrestre e aquático, entre outros), dependendo da origem e do destino, do volume e das condições das vias, exceto as produzidas em outros países cujo transporte internacional é realizado exclusivamente por via aérea. Uma das principais preocupações durante esse processo é o controle da temperatura, para que as características do produto não sejam comprometidas (Brasil, 20 I7). Na atual pandemia de Covid-19, observa-se o desenvolvimento de parceria entre o Ministério da Saúde e a Associação Brasileira das Empresas Aéreas (Abear) para o transporte de vacinas e insumos para a Covid- 19 a custo zero. Segundo o Ministério da Saúde (Brasil, 2020a), trata-se de apoio à logística de distribuição, a fim de acelerar o início da vacinação.

Quanto ao armazenamento, as vacinas dependem de refrigeração durante todas as etapas da chamada cadeia de frio, que consiste nos processos de armazenamento, conservação, manipulação, transporte e distribuição, com condições ideais de refrigeração desde os laboratórios produtores até a aplicação na população (Brasil, 20I 7). O armazenamento correto das vacinas nas diferentes instâncias (nacionais, estaduais, regional e municipais/locais) garante a eficácia da vacina. Segundo Costa e colaboradores (2017), a conservação de vacinas é uma das principais preocupações da cadeia de frio, visto que os imunobiológicos são sensíveis a variações de temperatura. Diante desse desafio, o Ministério da Saúde elenca pontos cruciais a serem observados, alguns dos quais listados a seguir:

- Áreas separadas para garantir a proteção dos insumos a partir da preservação das condições climáticas;

- Áreas de armazenamento com capacidade suficiente para materiais e insumos;

- Informações claras para todos da organização sobre os laboratórios produtores; 
- Informações acessíveis a todos das empresas responsáveis pela manutenção dos equipamentos; e

- Protocolos de recebimento, distribuição, monitoramento de temperatura, gerenciamento de estoque e prazo de validade de insumos armazenados (Brasil, 20 I 7).

Esses diferentes aspectos - além dos relacionados à dimensão do país, com regiões de difícil acesso - evidenciam que as cadeias de frio exigem adaptações tecnológicas e projetos que contribuam para a minimização do tempo de transporte e controle de temperaturas, garantindo assim a eficácia da vacina (Netto, 2008; Costa et al., 20 I 7).

Quanto à distribuição e aplicação das vacinas contra a Covid-19, o governo brasileiro se apoia no plano de vacinação preliminar, que contém quatro fases de priorização e envolve 109,5 milhões de doses (Brasil, 2020b), a saber:

I. Trabalhadores da saúde, população idosa ( $\geq 75$ anos), pessoas com mais de 60 anos que vivem em instituições de longa permanência e população indígena;

2. Pessoas entre 60 e 74 anos;

3. Pessoas com comorbidades que apresentam maior chance para agravamento da doença;

4. Professores, forças de segurança e salvamento e funcionários do sistema prisional.

Em 18 de maio de 2021, o plano de vacinação já estava sendo executado na terceira fase, imunizando pessoas com comorbidades que apresentam maior probabilidade de agravamento da Covid- 19 (Brasil, 202le).

A Figura 2 sintetiza a cadeia de suprimentos de vacinação no Brasil e os principais stakeholders.

Figura 2 - Cadeia de suprimentos de vacinação no Brasil

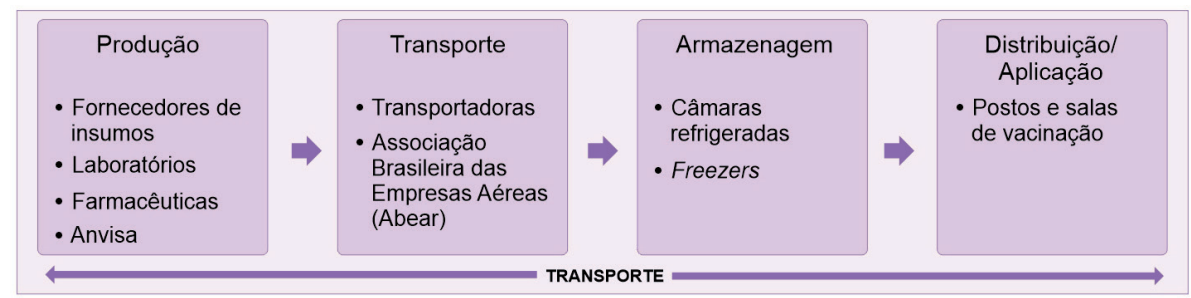

Fonte: adaptada de Costa et al., 2017.

Com base na análise da cadeia de suprimentos de vacinação, na literatura acadêmica e no documento de imunização da Sociedade Brasileira de Imunização (Ballalai \& Bravo, 
2020), são propostas 18 recomendações para os stakeholders ligados ao processo logístico de vacinação se adaptarem com mais eficiência (Quadro 3).

\section{Quadro 3 - Recomendações para a logística de vacinação}

\begin{tabular}{|c|c|}
\hline Stakeholders & Recomendações \\
\hline \multirow[t]{2}{*}{$\begin{array}{l}\text { Fabricantes de } \\
\text { vacinas }\end{array}$} & $\begin{array}{l}\text { I. Criar opções alternativas de embalagens para maximizar a capacidade de } \\
\text { frete (Abs, 2020) }\end{array}$ \\
\hline & $\begin{array}{l}\text { 2. Disponibilizar informações necessárias sobre o armazenamento correto das } \\
\text { vacinas (Costa et al., 20। 7) }\end{array}$ \\
\hline \multirow[t]{9}{*}{$\begin{array}{l}\text { Secretarias de } \\
\text { Saúde }\end{array}$} & $\begin{array}{l}\text { 3. Gerir de forma eficiente a cadeia de suprimentos com a interação de todas } \\
\text { as instâncias - local, municipal e regional (Costa et al., 20। 7) }\end{array}$ \\
\hline & $\begin{array}{l}\text { 4. Disponibilizar informações necessárias sobre os custos das cadeias de } \\
\text { suprimentos em todos os processos (Costa et al., 20I7) }\end{array}$ \\
\hline & $\begin{array}{l}\text { 5. Gerenciar os dados da cadeia de suprimentos de vacinas eficientemente } \\
\text { (Abs, 2020; Ballalai \& Bravo, 2020) }\end{array}$ \\
\hline & $\begin{array}{l}\text { 6. Desenvolver o plano nacional de vacinação para organizar toda a logística } \\
\text { de execução da campanha (Domingues, } 202 \mathrm{I} \text { ) }\end{array}$ \\
\hline & 7. Definir e priorizar os grupos a serem vacinados (Domingues, 202I) \\
\hline & $\begin{array}{l}\text { 8. Priorizar envio de vacinas para localidades conforme demandas do plano de } \\
\text { imunização (Abs, 2020) }\end{array}$ \\
\hline & $\begin{array}{l}\text { 9. Disponibilizar equipe treinada e atualizada em relação aos procedimentos } \\
\text { da vacina (Ballalai \& Bravo, 2020) }\end{array}$ \\
\hline & $\begin{array}{l}\text { 10. Monitorar a temperatura durante o transporte das vacinas (Costa et al., } \\
2017 \text {, Anvisa, 2017) }\end{array}$ \\
\hline & $\begin{array}{l}\text { 11. Buscar estratégias para o enfrentamento aos grupos antivacina } \\
\text { (Domingues, 202 I) }\end{array}$ \\
\hline \multirow{2}{*}{$\begin{array}{l}\text { Secretarias } \\
\text { de Saúde e } \\
\text { fabricantes de } \\
\text { vacinas }\end{array}$} & 12. Monitorar a disponibilidade das vacinas (Abs, 2020) \\
\hline & I3. Aumentar o número de fornecedores (Abs, 2020) \\
\hline \multirow{3}{*}{$\begin{array}{l}\text { Secretarias } \\
\text { de Saúde e } \\
\text { transportadoras }\end{array}$} & $\begin{array}{l}\text { 14. Analisar por completo os riscos, custos e viabilidade da entrega de vacinas } \\
\text { (Abs, 2020) }\end{array}$ \\
\hline & $\begin{array}{l}\text { 15. Escolher o sistema de transporte mais adequado para proteger as vacinas } \\
\text { das condições de temperatura (Anvisa, 2017) }\end{array}$ \\
\hline & $\begin{array}{l}\text { 16. Garantir transporte de vacinas independentemente do fechamento de } \\
\text { rotas comerciais (Abs, 2020) }\end{array}$ \\
\hline \multirow{2}{*}{$\begin{array}{l}\text { Secretarias } \\
\text { de Saúde, } \\
\text { transportadoras } \\
\text { e fabricantes de } \\
\text { vacinas }\end{array}$} & $\begin{array}{l}\text { 17. Conhecer, monitorar, controlar e documentar as atividades de } \\
\text { armazenagem, distribuição e transporte das vacinas (Anvisa, 2017) }\end{array}$ \\
\hline & 18. Realizar exercícios de lições apreendidas (Abs, 2020) \\
\hline
\end{tabular}

Fonte: elaboração própria. 


\section{CONSIDERAÇÕES FINAIS SOBRE AS RECOMENDAÇ̃̃ES DE LOGÍSTICA NO CONTEXTO DA PANDEMIA DE COVID-19}

O enfrentamento da pandemia de Covid- 19 demanda a adaptação da capacidade hospitalar e do sistema de vacinação. No concernente à capacidade hospitalar, a observância das 34 recomendações propostas por Grabois e colaboradores (2020), classificadas de acordo com os stakeholders, permite o aprimoramento da logística do sistema hospitalar no combate a esta pandemia, resultando em diminuição de pacientes sem atendimento no sistema de saúde e do número de óbitos, e pode ser considerada referência para o enfrentamento de futuras pandemias.

No que tange à logística de vacinação contra a Covid-19, uma das questões mais cruciais é o controle da temperatura das doses de vacina ao longo das etapas de transporte, armazenamento e distribuição em toda a extensão do território brasileiro. As 18 recomendações baseadas na literatura acadêmica e no documento sobre imunização da Sociedade Brasileira de Imunização (Ballalai E Bravo, 2020) podem auxiliar os gestores na logística na cadeia de suprimentos de vacinação e ser consideradas como referência para o enfrentamento de futuras pandemias. Sua adoção permite alcançar agilidade e eficiência na cadeia de vacinação contra Covid- 19 em todo o território brasileiro.

\section{REFERÊNCIAS}

ABS, E. Vaccine Supply Chain Resilience: Unicef operation in West and Central Africa during the Covid-19 pandemic disruption and response, 2020. Dissertação de Mestrado, Lugano: Faculdade de Economia, Università della Svizzera italiana.

AGÊNCIA NACIONAL DE VIGILÂNCIA SANITÁRIA (ANVISA). Guia para a qualificação de transporte dos produtos biológicos, 2017. Disponível em: <http://synerhgon.com.br/wp-content/ uploads/2020/I 2/GUIA-PARA-A-QUALIFICA\%C3\%87\%C3\%83O-DE-TRANSPORTE-DOSPRODUTOS-BIOL\%C3\%93GICOS-final.pdf>. Acesso em: I 8 jan. 2021 .

AGÊNCIA NACIONAL DE VIGILÂNCIA SANITÁRIA (ANVISA). Covid- 19: fique por dentro do mapa das vacinas em teste no Brasil, 2020. Disponível em: <www.gov.br/anvisa/pt-br/assuntos/noticiasanvisa/2020/fique-por-dentro-do-mapa-das-vacinas-em-teste-no-brasil>. Acesso em: 5 jan. 2021 .

AGÊNCIA NACIONAL DE VIGILÂNCIA SANITÁRIA (ANVISA). Anvisa aprova por unanimidade uso emergencial das vacinas, 202la. Disponível em: <www.gov.br/anvisa/pt-br/assuntos/noticiasanvisa/202 I/anvisa-aprova-por-unanimidade-uso-emergencial-das-vacinas >. Acesso em: I 8 jan. 202 I.

AGÊNCIA NACIONAL DE VIGILÂNCIA SANITÁRIA (ANVISA). Anvisa aprova uso emergencial da vacina da Janssen, 202 Ib. Disponível em: <www.gov.br/pt-br/noticias/saude-e-vigilancia-sanitaria/202 I/03/ anvisa-aprova-uso-emergencial-da-vacina-da-janssen>. Acesso em: I8 maio 2021 .

BALLALAI, I. E BRAVO, F. (Orgs.). Imunização: tudo o que você sempre quis saber. Rio de Janeiro: RMCOM, 2020. 
BARBIERI. J. C. E MACHILINE, C. Logística Hospitalar: teoria e prática. 2. ed. São Paulo: Saraiva, 2009.

BARRETO, M. L. et al. O que é urgente e necessário para subsidiar as políticas de enfrentamento da pandemia de Covid- I 9 no Brasil? Revista Brasileira de Epidemiologia, 23, 2020. Disponível em: <https:// doi.org/I 0.1590/1980-549720200032 >. Acesso em: 28 out. 2021.

BRASIL. Ministério da Saúde. Manual de Rede de Frio do Programa Nacional de Imunizações. Brasília: Ministério da Saúde, 2017.

BRASIL. Ministério da Saúde. Saúde fecha acordo com todas as aéreas brasileiras para transporte gratuito de vacinas contra a Covid-19, 2020a. Disponível em: <https://www.gov.br/saude/pt-br/ assuntos/noticias/2020/dezembro/vacinacao-contra-a-covid- I 9-sera-feita-em-quatro-fases >. Acesso em: 6 jan. 2021 .

BRASIL. Ministério da Saúde. Plano preliminar de vacinação contra a Covid- 19 prevê quatro fases, 2020b. Disponível em: <www.gov.br/saude/pt-br/assuntos/noticias/vacinacao-contra-a-covid-19-sera-feitaem-quatro-fases $>$. Acesso em: 6 maio 2021.

BRASIL. Ministério da Saúde. Painel Coronavírus, 202 Ia. Disponível em: <https://covid.saude.gov.br/>. Acesso em: 28 out. 2021 .

BRASIL. Ministério da Saúde. Brasil \#pátriavacinada, 202 Ib. Disponível em: <https://www.gov.br/ saude/pt-br/vacinacao>. Acesso em: 18 maio 2021.

BRASIL. Ministério da Saúde. Autorizado estudo clínico da vacina Covaxin no Brasil, 202 Ic. Disponível em: < https://www.gov.br/anvisa/pt-br/assuntos/noticias-anvisa/202I/autorizado-estudo-clinico-davacina-covaxin-no-brasil>. Acesso em: 18 maio 2021.

BRASIL. Ministério da Saúde. O Ministério das Relações Exteriores e o Ministério da Saúde seguem acompanhando o diálogo da Agência Nacional de Vigilância Sanitária (Anvisa) com os responsáveis pela vacina Sputnik V, o Fundo Russo de Investimento Direto e o Instituto Gamaleya, 202 Id. Disponível em: <https:// www.gov.br/saude/pt-br/assuntos/noticias/o-ministerio-das-relacoes-exteriores-e-o-ministerio-dasaude-seguem-acompanhando-o-dialogo-da-agencia-nacional-de-vigilancia-sanitaria-anvisa-com-osresponsaveis-pela-vacina-sputnik-v-o-fundo-russo-de-investimento-direto-e-o-instituto-gamaleya $>$. Acesso em: 18 maio 2021 .

BRASIL. Ministério da Saúde. Vacinômetro - Covid- 19 Vacinação - Doses Aplicadas, 202 I e. Disponível em: $<$ https://www.gov.br/saude/pt-br/vacinacao>. Acesso em: 18 maio 2021.

COSTA, C. G. F. et al. Análise da cadeia de suprimento de vacinas no Brasil. In: CONGRESSO BRASILEIRO DE REDUÇÃO DE RISCOS E DESASTRES, II, 20I7, Rio de Janeiro.

CuetO, M. Covid- I 9 e a corrida pela vacina. História, Ciências, Saúde - Manguinhos, 27(3): 7I 5717, 2020.

DOMINGUES, C. M. A. S. Desafios para a realização da campanha de vacinação contra a Covid- 19 no Brasil. Editorial. Cadernos de Saúde Pública, 37(1), 2021.

EUROPEAN CENTRE FOR DISEASE PREVENTION AND CONTROL (ECDC). Novel Coronavirus Disease 2019 (Covid-19) Pandemic: increased transmission in the EU/EEA and the UK. Stockholm: ECDC, 2020.

FUNDAÇÃO OSWALDO CRUZ (FIOCRUZ). Vacinas contra a Covid- 19, 2021. Disponível em: < https:// portal.fiocruz.br/vacinascovid I9>. Acesso em: 18 maio 2021 . 
GRABOIS, V. et al. Nota técnica. Adaptação da capacidade hospitalar em resposta à pandemia por Covid-19, 2020. Disponível em: < https://portal.fiocruz.br/documento/nota-tecnica-adaptacao-dacapacidade-hospitalar-em-resposta-pandemia-por-covid-19>. Acesso em: 6 jan. 2021.

HICK, J. L. et al. Surge capacity principles: care of the critically ill and injured during pandemics and disasters: CHEST consensus statement. Chest, I46(4): eIS-el6S, 2014.

HUPERT, N. et al. Predicting hospital surge after a large-scale anthrax attack: a model-based analysis of CDC's cities readiness initiative prophylaxis recommendations. Medical Decision Making, 29(4): 424437, 2009.

INSTITUTO BUTANTAN. A parceria tecnológica que fez da CoronaVac a vacina do Brasil, $202 \mathrm{I}$. Disponível em: <https://butantan.gov.br/noticias/a-parceria-tecnologica-que-fez-da-coronavac-avacina-do-brasil >. Acesso em: 18 maio 2021.

LIMA, E. J. F.; ALMEIDA, A. M. E KFOURI, R. A. Vacinas para Covid- 19: perspectivas e desafios. Residência Pediátrica, 10(2): I, 2020. Disponível em: <https://residenciapediatrica.com.br/detalhes/458/ vacinas\%20para\%20covid- 19-\%20perspectivas\%20e\%20desafios >. Acesso em: 28 out. 2021.

NETTO, G. C. Contribuição para Melhorar o Gerenciamento Logístico da Cadeia de Frio de Imunobiológicos no Programa de Imunização do Brasil, 2020. Dissertação de Mestrado, Brasília: Departamento de Engenharia Civil e Ambiental, Universidade de Brasília.

PFIZER. Pfizer e BioNTech unem esforços para desenvolver possível vacina contra covid-19, 2020. Disponível em: <www.pfizer.com.br/noticias/releases/pfizer-e-biontech-unem-esforcos-para-vacinacontra-covid-19>. Acesso em: 18 maio 2021.

RACHE, B. et al. Nota técnica. Necessidades de infraestrutura do SUS em preparo à Covid- 19: leitos de UTI, respiradores e ocupação hospitalar, 2020. Disponível em: <www.epsjv.fiocruz.br/sites/default/ files/files/NT3\%20vFinal.pdf>. Acesso em: 12 jan. 2021.

RODRIGUEZ-MORALES, A. J. et al. Covid- 19 in Latin America: the implications of the first confirmed case in Brazil. Travel Medicine and Infectious Disease, 35, 2020. Disponível em: <www.sciencedirect. com/science/article/abs/pii/S I 477893920300806?via\%3Dihub>. Acesso em: 28 out. 202 I.

TEN EYCK, R. P. Ability of regional hospitals to meet projected avian flu pandemic surge capacity requirements. Prehospital Disaster Medicine, 23(2): 103-I I2, 2008.

WORLD HEALTH ORGANIZATION (WHO). Coronavirus disease (Covid-19) technical guidance: essential resource planning, 2020a. Disponível em: <www.who.int/emergencies/diseases/novelcoronavirus-20 I 9/technical-guidance/covid-19-critical-items>. Acesso em: 5 jan. 2021.

WORLD HEALTH ORGANIZATION (WHO). Immunization coverage, 2020b. Disponível em: <www. who.int/news-room/fact-sheets/detail/immunization-coverage>. Acesso em: 5 jan. 2021.

WORLD HEALTH ORGANIZATION (WHO). Covid-I 9 vaccines, 2020c. Disponível em: <www.who. int/emergencies/diseases/novel-coronavirus-20 I 9/covid-19-vaccines>. Acesso em: 5 jan. 2021.

WORLD HEALTH ORGANIZATION (WHO). Manufacturing, safety and quality control of vaccines, 2020d. Disponível em: <www.who.int/news-room/feature-stories/detail/manufacturing-safetyand-quality-control>. Acesso em: 5 jan. 2021. 


\title{
Desabastecimento, uma Questão de Saúde Pública Global
}

\author{
sobram problemas, faltam medicamentos
}

Luisa Arueira Chaves, Claudia Garcia Serpa Osorio-de-Castro, Michele Costa Caetano, Rafael Almeida da Silva e Vera Lúcia Luiza

\section{ANTECEDENTES}

Entre os desafios desencadeados pela pandemia do Sars-CoV-2 está o desabasteci-

—mento de medicamentos, situação que tem sido vivenciada nos diferentes níveis do sistema de saúde.

No nível da comunidade, portadores de doenças dependentes de medicamentos de uso ambulatorial anunciados para tratamento da Covid- 19, como por exemplo cloroquina e hidroxicloroquina, competiram com a população, que desejava obter e estocar esses produtos. Também tem havido desabastecimento de medicamentos e produtos médicos de uso hospitalar, incluindo desde equipamentos de proteção individual (EPIs) até medicamentos necessários ao manejo de casos moderados e graves. Trazemos aqui algumas reflexões sobre o fenômeno do desabastecimento, visando a contribuir para o debate e enfrentamento da situação.

\section{O QUE É DESABASTECIMENTO?}

O desabastecimento de medicamentos não é um problema novo. Desde a década de 1950 é possível encontrar relatos sobre essa questão em âmbito global. Na época, o desabastecimento era entendido como o resultado de um súbito aumento de demanda ou da fragilidade dos sistemas de saúde, consequência de financiamento insuficiente, compras inadequadas e/ou sistemas de distribuição ineficientes. Nos anos 2000, o desabastecimento passa a afetar também países de alta renda, grandes mercados consumidores com cadeias de suprimento organizadas, obrigando à reformulação de conceitos. O desabastecimento passa, então, a ser entendido de maneira diversa, apre- 
sentando-se não mais como um problema local, mas como resultado da fragilização de cadeias globais de suprimentos (WHO, 20l6a).

Em 2014, a Organização Mundial da Saúde (OMS) passou a reconhecer o desabastecimento como uma questão de saúde global. Desde então, diversos autores e profissionais tentam buscar formas de melhor compreendê-lo, visando a subsidiar estratégias efetivas para superá-lo e garantir o acesso aos medicamentos nos sistemas de saúde.

Embora haja muitas publicações sobre o assunto, poucas versam sobre a investigação de suas causas ou sua definição conceitual (Chaves et al., 2019). Em 2017, a OMS publicou uma definição que abrange duas perspectivas: oferta e demanda. Na perspectiva da oferta, entendeu-se que o desabastecimento ocorre quando o fornecimento de medicamentos, produtos de saúde ou vacinas, identificados como essenciais pelo sistema de saúde, é considerado insuficiente para atender às necessidades da saúde pública e do paciente. Na perspectiva da demanda, o desabastecimento ocorreria quando esta excede a oferta em qualquer ponto da cadeia de suprimento, o que poderá, em última instância, criar uma quebra no estoque (stock-out) no ponto de dispensação ao paciente, caso não possa ser resolvido em tempo hábil (WHO, 20l6b).

No entanto, dois aspectos se destacam. O primeiro é que, a fim de evitar conflitos com agendas de pesquisa e desenvolvimento, a definição proposta pela OMS refere-se apenas a produtos que já foram aprovados e comercializados. O segundo é que a terminologia proposta pela OMS pode levar a confusão conceitual. Na língua inglesa há duas palavras para designar o desabastecimento: shortage e stock-out. Na definição em inglês, ' shortage se refere a dificuldades relacionadas à oferta, ou seja, à cadeia de abastecimento desses produtos, e stock-out a questões da demanda, muitas vezes relacionadas a fragilidades do sistema de saúde. Essa distinção é importante, pois as causas do shortage e do stock-out são diferentes e, portanto, também são distintas as estratégias para enfrentá-los.

Em português não há essa distinção, pois há apenas um termo para ambas as acepções: desabastecimento. Assim, e tendo em vista o foco no desfecho - a falta do

\footnotetext{
I 'No âmbito da oferta, uma 'falta' (ou desabastecimento) ocorre quando a provisão de medicamentos, produtos para a saúde e vacinas identificados como essenciais para o sistema de saúde é considerada insuficiente para atender às necessidades dos pacientes e da saúde pública. Essa definição refere-se tão somente àqueles produtos que já são registrados e vendidos, de forma a evitar conflitos com as agendas de pesquisa e desenvolvimento. No âmbito da demanda, a 'falta' (ou desabastecimento) ocorrerá quando a demanda exceder a oferta em qualquer ponto da cadeia de suprimento, podendo dar origem a 'estoque zerado' no ponto de cuidado (ao paciente), se a causa da falta não puder ser tempestivamente resolvida de forma atender às necessidades clínicas do paciente" (WHO, 20।6b: 10, tradução nossa).
} 
produto para o usuário final -, utilizaremos o conceito amplo de desabastecimento como equivalente tanto a shortage quanto a stock-out.

\section{A PERSPECTIVA DA DEMANDA NO DESABASTECIMENTO}

É possível entender que o desabastecimento está intimamente relacionado à dinâmica de oferta e demanda do mercado farmacêutico. Sendo assim, ocorrerá sempre que houver uma demanda maior do que a oferta, seja em nível global, regional, nacional ou local.

No concernente à demanda, o desequilíbrio da relação ocorre por picos abruptos de consumo de um produto ou de itens. Essa situação pode ser resultante de desastres naturais, guerras, epidemias ou pandemias, mudanças de protocolos clínicos ou de utilização etc. Além disso, problemas relacionados à gestão da assistência farmacêutica $(A F)$, nos processos de aquisição, programação e distribuição, podem também afetar a relação oferta-demanda, causando um desabastecimento de abrangência local ou nacional (Figura I).

Figura I - Modelo de desabastecimento no contexto local ou nacional

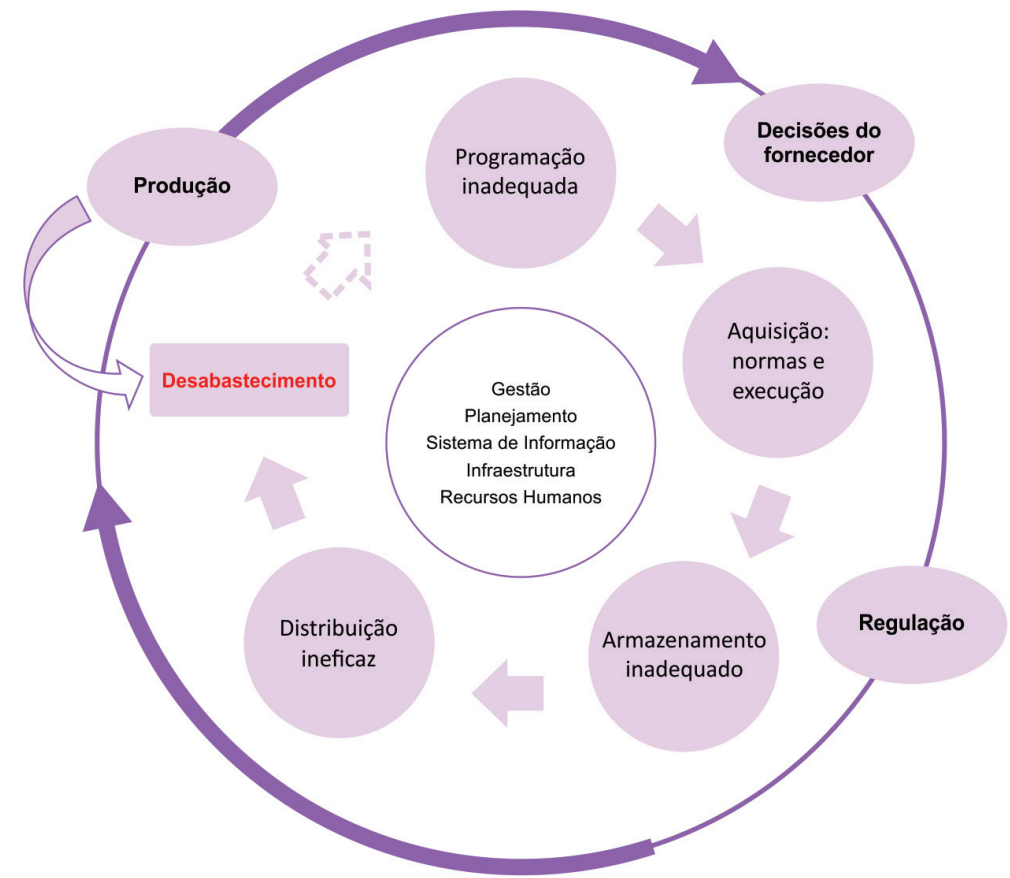

Fonte: Chaves, 2019. 
Os processos logísticos da AF são etapas fundamentais para a garantia da disponibilidade de medicamentos. Para seu sucesso exigem infraestrutura, recursos humanos e materiais adequados. Considerando os processos logísticos da gestão do medicamento no país, o início se dá pela programação - isto é, a identificação das necessidades com base em perfil epidemiológico (balizada em parte pelo histórico de consumo), estoques existentes e disponibilidade orçamentária. Ocorre que, muitas vezes, não é a necessidade que pauta a programação, mas a demanda, mais sujeita a influências de práticas de prescrição e de mercado, trazendo enormes pressões sobre a provisão. A etapa seguinte é a aquisição, crucial para o abastecimento de medicamentos no Sistema único de Saúde (SUS). Como boa prática de aquisição, em especial no setor público, mecanismos que permitam a concorrência e transparência são amplamente recomendados, nacional e internacionalmente (MSH, 20I2).

No Brasil, estabeleceu-se que a compra de medicamentos deve ser feita mediante pregão eletrônico (Brasil, 2002), sendo admitida a inexigibilidade e a dispensa de licitação em casos específicos, como a emergência em saúde pública. O processo licitatório é constituído por diversas etapas complexas e sua execução envolve profissionais de diferentes áreas do conhecimento. A forma como a licitação é conduzida exerce efeito direto no abastecimento de medicamentos. Se alguma etapa atrasa ou falha, todas as demais são afetadas, promovendo efeito direto no tempo de aquisição e, consequentemente, no abastecimento das unidades de saúde.

Licitações consideradas fracassadas e/ou desertas são relatadas como uma das causas de desabastecimento (Silva et al., 2018 ). Licitação fracassada é conceituada como aquela em que as propostas feitas pelos licitantes não são aceitáveis ou quando estes são inabilitados por algum motivo. A licitação deserta ocorre pela falta de interessados no processo licitatório (Tribunal de Contas da União, 2018 ). Seus efeitos podem ser exemplificados pelo caso do estado de Sergipe, que em 2017 relatou não ter conseguido comprar 45 dos 110 medicamentos oncológicos descritos nas licitações devido à existência de itens desertos e fracassados (Sergipe, 20I7). Outro exemplo refere-se às seringas necessárias à vacinação de Covid-19. A compra teria fracassado devido à oferta de preços acima dos valores estimados pelo governo, colocando em risco todo o processo. Esse exemplo permite compreender o encadeamento de ações necessárias ao abastecimento: caso a apuração de quantidades necessárias de seringas e agulhas e de estoques existentes (etapas da programação) tivesse sido realizada tempestivamente, uma aquisição fracassada não teria tido resultado tão preocupante.

O desafio de garantir a disponibilidade de produtos para a abordagem terapêutica da Covid- 9 passa pelo enfrentamento tanto da escassez de produtos no mercado local ou 
nacional quanto das pressões provocadas por aumento da demanda. Esse aumento pode ser temporário, gerando riscos de imobilização de estoques.

Na operação das compras é preciso lidar com os desafios de otimizar os poucos recursos financeiros, com a retração da oferta e com a importância de garantir os melhores preços em situação de urgência, dentro do arcabouço legal brasileiro.

Outra etapa importante para a garantia da disponibilidade de medicamentos nas unidades de saúde é o armazenamento, que tem como principal objetivo a manutenção da qualidade dos medicamentos adquiridos (Guerra Jr. E Camuzi, 20 I 4). Para tal, é necessária infraestrutura física adequada, ferramentas que apoiem o serviço, como um sistema informatizado, e recursos humanos capacitados e em quantidade suficiente, o que ainda não é uma realidade brasileira, especialmente nas regiões Norte e Nordeste (Leite et al., 2017).

No Brasil, as três esferas do governo (federal, estadual e municipal) adquirem medicamentos que podem ser distribuídos para os pontos de dispensação dentro da própria esfera federativa ou entre os diferentes entes (Brasil, 1998). Desse modo, os medicamentos adquiridos por quaisquer das esferas precisam chegar até a unidade de saúde, onde serão dispensados ao paciente ou nele aplicados. O processo da distribuição pode gerar desabastecimento nos pontos de dispensação e/ou nos almoxarifados centrais e depende do funcionamento efetivo das etapas anteriores (programação e aquisição), bem como da rede de armazenamento e distribuição. Os problemas que envolvem o armazenamento e a distribuição de medicamentos variam conforme a região do país, refletindo as iniquidades regionais (Leite et al., 2017 ).

\section{A PERSPECTIVA DA OFERTA NO DESABASTECIMENTO}

A relação entre oferta e demanda é dinâmica. A oferta - incluída a capacidade de aumento de produção - é fator determinante na ocorrência do desabastecimento. Se o aumento da demanda puder ser oportunamente compensado pelo aumento da produção, é possível que o desabastecimento não ocorra. E isso dependerá da capacidade produtiva dos sítios produtores de medicamentos, insumos farmacêuticos ativos (IFAs) e demais matérias-primas necessárias para a sua fabricação.

A capacidade produtiva é um dos determinantes mais importantes da ocorrência de desabastecimento de medicamentos em nível global. As cadeias de produção de medicamentos estão localizadas em poucos locais e unidades de produção no mundo. Isso decorre devido a dois fatores principais: I) alto valor de investimento necessário para a implantação de uma unidade produtiva farmacêutica, e 2) opção da indústria farmacêutica por situar a unidade fabril em países de baixo custo de produção, a fim de maximizar lucros e driblar regulações ambientais mais restritivas (Hasenclever et al., 20 I0). 
Com o tempo, a produção de medicamentos foi se tornando cada vez mais concentrada em poucas empresas. Em 1996, as dez maiores empresas farmacêuticas do mundo eram responsáveis por 30\% do mercado farmacêutico global. Dez anos depois, em 2006, essa cifra aumentou para 43\%. O mesmo ocorre na indústria de medicamentos genéricos, na qual as dez maiores empresas controlavam 18\% do mercado mundial em 1996, passando a $37 \%$ em 2006. É possível dizer que a indústria farmacêutica é oligopolizada e que a tendência é de aumento dessa concentração (Kesic, 20l I).

Na produção de IFAs, essa concentração se mostra ainda mais evidente. Na primeira década dos anos 2000, nove empresas detinham 45\% (em valor de vendas) do mercado global de IFA no mundo (Stafford, 2006). Estima-se que 50\% dos IFAs produzidos no mundo todo têm origem na China (Palmer, 20I6) e que de 80 a 90\% de todos os IFAs necessários para a produção de antibióticos também sejam produzidos pelo país asiático (Cogan, Karrar E lyer, 20 I8).

A concentração da produção em poucas unidades fabris e em poucos locais do mundo é uma grande fragilidade da oferta de medicamentos, pois dificulta o aumento rápido da quantidade produzida em casos de picos de demanda. Problemas que impeçam ou diminuam a produção desses produtos nos poucos países produtores implicarão redução imediata da sua oferta global. Esse, por exemplo, parece ter sido o caso no desabastecimento da piperacilina +tazobactam há alguns anos (Explosion of..., 20 I 7), que teve sua falta notificada em diversos países europeus (Explosion..., 2017; Barber et al., 2016; Davis, 2017; Kessel et al., 2018).

A questão é especialmente relevante para os produtos de baixo valor unitário, tais como os injetáveis de baixo volume (p. ex., anestésicos), antibióticos e medicamentos para saúde mental, que têm sido os itens mais vulneráveis à ocorrência de desabastecimentos globais nos últimos anos. O baixo preço torna sua comercialização desinteressante para a maioria das empresas farmacêuticas e faz com que muitas se retirem da produção desses itens para concentrar esforços em produtos de alto valor unitário e maior retorno, o que tem levado à redução do número de unidades produtivas no mundo.

No Brasil, por exemplo, a empresa Roche declarou, ao anunciar o fechamento de sua fábrica no Rio de Janeiro em 2019, que estava se retirando do mercado de produtos de alto volume e baixa complexidade, pois estariam no "final de seu ciclo de vida" (Farmacêutica..., 2019). Da mesma forma, a companhia farmacêutica Takeda anunciou em 2018 a venda de sua empresa de genéricos no país e reiterou "seu compromisso para manter-se como uma empresa focada no lançamento de produtos inovadores de pesquisa e desenvolvimento" (Takeda..., 2019). 


\section{O CASO DO DESABASTECIMENTO DE ANTIBIÓTICOS}

O desabastecimento de antibióticos contribui com a disseminação de resistência microbiana (AMR), uma vez que a falta dos medicamentos de primeira escolha induz ao uso de alternativas de segunda ou terceira escolha, usualmente de espectro mais amplo. Portanto, o acesso universal a antibióticos é essencial para combater a AMR (WHO, 2019). Segundo relatórios da Organização das Nações Unidas (ONU), ocorrem aproximadamente seis milhões de mortes por ano no mundo devido a doenças infecciosas comuns que poderiam ser tratadas se houvesse acesso adequado aos antibióticos existentes (Daulaire et al., 2015).

Um exemplo crucial foi o caso do desabastecimento de penicilina, principal medicamento para o tratamento da sífilis, que pode ter influenciado o aumento da taxa de incidência de sífilis congênita e do número de óbitos de crianças menores de I ano, entre 2014 e 2019, no Brasil (Araujo, 2019 ; Brasil, 2019). A penicilina é o único medicamento eficaz para a prevenção da transmissão vertical da sífilis na gestação e é a primeira escolha para o tratamento da sífilis congênita e adquirida (Brasil, $2015 \mathrm{a}$ ). Em janeiro de 2016, o desabastecimento de penicilina benzatina atingiu $61 \%$ dos estados brasileiros e o da penicilina cristalina, 100\% (Brasil, 2016).

O Ministério da Saúde publicou, na ocasião, uma nota informativa recomendando um tratamento alternativo à benzilpenicilina para sífilis, exceto para gestantes (Brasil, $2015 b)$. No entanto, a alternativa proposta era mais cara e o tratamento, mais longo e menos eficaz. Ademais, a utilização de outras classes terapêuticas de antibióticos para tratar doenças infecciosas por cepas sensíveis à penicilina promove o aumento da pressão seletiva das bactérias e consequente aumento da AMR.

O desabastecimento da penicilina no Brasil foi resultado tanto da redução da sua oferta, devida, principalmente, à falta do IFA no mercado internacional, como de exigências regulatórias envolvendo registro deste insumo e requisitos para sua produção (Nurse-Findlay et al., 2017 ). O episódio evidenciou a grande dependência do Brasil na aquisição de IFAs em relação a fornecedores internacionais (Rodrigues, Costa $\mathcal{E}$ Kiss, 20I8) e a consequente fragilidade da sua capacidade de manutenção de estoques de medicamentos essenciais.

\section{DESABASTECIMENTO E A PANDEMIA DE COVID-19}

A pandemia do coronavírus tem resultado em desabastecimento para diversos produtos, como EPIs, testes diagnósticos e seus insumos, ventiladores e medicamentos necessários para o cuidado dos pacientes, como anestésicos, antibióticos e antivirais e, como também observamos mais recentemente, para vacinas. 
Segundo o Conselho Nacional de Secretários Estaduais de Saúde, em junho de 2020 , 25 de 27 secretarias estaduais de Saúde relataram falta de II medicamentos para sedação e bloqueio neuromuscular utilizados em pacientes internados com Covid-19, o chamado kit intubação, além de oxigênio (Conass, 2020). A Sociedade Brasileira de Farmácia Hospitalar relatou que $87 \%$ dos profissionais declararam enfrentar problemas de abastecimento de medicamentos e produtos de saúde nas unidades em que trabalham e que as maiores dificuldades de abastecimento estavam relacionadas a medicamentos para sedação, bloqueio neuromuscular e analgesia (SBRAFH, 2020). E segundo a Associação Nacional de Hospitais Privados, o preço do midazolam subiu $287,4 \%$ durante 2020 (Desabastecimento..., 2020).

Entre as regiões brasileiras, o Norte e o Nordeste relataram o maior número de medicamentos em falta (Desabastecimento..., 2020). O estado de Mato Grosso registrou o desabastecimento de 13 medicamentos, e tanto no Ceará como no Maranhão faltaram 12 medicamentos. Além disso, o estado de Pernambuco também mencionou, em 2020, que o estoque existente de oito medicamentos não seria suficiente para um longo período (Valente, 2020).

A Covid- 19 também tem desafiado os sistemas dos países centrais. Tendo em vista os produtos em potencial desabastecimento, esses países estão construindo capacidade para promover rápido aumento da oferta de medicamentos para seus sistemas de saúde, seja por aumento da produção local, seja pela formação de estoques (Rees, 2020).

A pandemia do coronavírus torna-se, nesse contexto, um caso concreto para ilustrar as fragilidades da cadeia de suprimento farmacêutico, em que aspectos tanto da oferta quanto da demanda encontram-se tensionados. Há demanda muito maior que a usual para poucos produtos que, em sua maioria, são de baixo interesse comercial e, portanto, com poucas fontes produtivas no mundo. Dessa forma, a cadeia de suprimento tem pouca margem para absorção do aumento de demanda dos medicamentos necessários para o cuidado dos pacientes em tempo e em quantidades adequadas. Além disso, a grande maioria dos países no mundo tem alta dependência da produção global e baixa capacidade para a produção desses mesmos itens, que contam, todos eles, com as mesmas fontes de obtenção.

Nesse cenário, o que vemos são países em disputa para a aquisição desses produtos e de outros, como as vacinas (EUA..., 2020; EUA compram..., 2020). Aqueles com maior capacidade financeira, política e organizacional terão maior potencial para acessar produtos em tempo, qualidade e quantidade adequados para atendimento da sua demanda. E, como o mercado global é dolarizado, o câmbio torna-se fator importante para 
a capacidade aquisitiva dos países. Para obter sucesso na garantia do acesso, é imprescindível alta capacidade de articulação e negociação no mercado global.

Devido à sua característica de alta dependência das cadeias de produção global de medicamentos, o Brasil só conseguirá garantir seu dever constitucional de prover medicamentos para seus cidadãos com monitoramento efetivo do mercado farmacêutico e das fontes de obtenção de medicamentos essenciais, boa organização e articulação dos processos de aquisição, programação e distribuição de medicamentos entre os diversos entes federativos, além de avanço nas estratégias para a redução, a longo prazo, dessa dependência.

\section{RECOMENDAÇÕES}

- Definir o conceito de desabastecimento em território nacional, de modo a facilitar o mapeamento de suas causas.

- Monitorar, prospectivamente e de forma integral, o processo de notificação da interrupção de produção ou importação de medicamentos, incorporando análises sobre o impacto desta notificação na oferta de medicamentos essenciais no território nacional, produzindo transparência das informações e possibilitando a tomada de decisões em prol da saúde pública.

- Monitorar o mercado farmacêutico e fontes de obtenção dos medicamentos essenciais para identificar fragilidades nas cadeias de suprimento desses produtos.

- Estabelecer mecanismo de comunicação sobre medicamentos em desabastecimento para os entes federativos, com fácil acesso às equipes que manejam as compras e a gestão da rede de serviços.

- Estabelecer lista de medicamentos cruciais para monitoramento constante das fontes de obtenção, estoques e demanda.

- Estabelecer mecanismos de compras conjuntas para medicamentos vulneráveis a desabastecimento.

- Disseminar informações estratégicas a respeito de compras públicas fracassadas ou desertas.

- Publicizar, de forma especialmente ágil, os preços obtidos nas compras públicas para os produtos utilizados na abordagem da Covid-19, de maneira a garantir a transparência e auxiliar na pesquisa de preços em compras futuras.

- Instituir regulamentação efetiva de modo a coibir práticas comerciais contrárias à saúde pública, tal como a majoração indevida de preços de produtos com redução de oferta, entre outras. 
- Aplicar as sanções devidas, já regulamentadas em lei, para empresas que se utilizam de artifícios contrários ou que prejudicam o abastecimento de produtos cruciais para o SUS.

\section{REFERÊNCIAS}

ARAUJO, R. S. A Crise do Desabastecimento da Penicilina Benzatina e o Impacto na Sífilis Congênita: um estudo ecológico no município do Rio de Janeiro, 20 I 9. Dissertação de Mestrado, Rio de Janeiro: Universidade do Estado do Rio de Janeiro. Disponível em: <www.bdtd.uerj.br/tde_busca/processaPesquisa. php?listaDetalhes\%5B\%5D = I l 099Eprocessar=Processar >. Acesso em: 22 jul. 2020.

BARBER, K. E. et al. R. Impact of piperacillin-tazobactam shortage on meropenem use: implications for antimicrobial stewardship programs. Brazilian Journal of Infectious Diseases, 20(6): 63I-634, 2016. Disponível em: <https://doi.org/l 0.10 I6/j.bjid.2016.08.00I >. Acesso em: 22 jul. 2020.

BRASIL. Ministério da Saúde. Portaria n. 3916/MS/GM, de 30 out. 1998. Aprova a Política Nacional de Medicamentos. Brasília, 1998. Disponível em: < https://bvsms.saude.gov.br/bvs/saudelegis/gm/l 998/ prt39l6_30_10_1998.html>. Acesso em: out. 2021.

BRASIL. Lei n. 10.520, de 17 jul. 2002. Institui, no âmbito da União, Estados, Distrito Federal e Municípios, nos termos do art. 37, inciso XXI, da Constituição Federal, modalidade de licitação denominada pregão, para aquisição de bens e serviços comuns, e dá outras providências. Diário Oficial da União, Brasília, 2002. Disponível em: < http://www.planalto.gov.br/ccivil_03/leis/2002/ | | 0520.htm\#: : :text =LEl\%20No\%20 I 0.520\%2C\%20DE\%20 I 7\%20DE\%20JULHO\%20DE\%20 2002.Etext $=$ Institui\%2C\%20no\%20\%C3\%A2mbito\%20da\%20Uni\%C3\%A3o,comuns \%2C \%20 e\%20d\%C3\%A I \%20outras\%20provid\%C3\%AAncias>. Acesso em: 22 jul. 2020.

BRASIL. Protocolo Clínico e Diretrizes Terapêuticas para Atenção Integral às Pessoas com Infecções Sexualmente Transmissíveis (IST). Brasília: Ministério da Saúde, 2015 a.

BRASIL. Nota informativa conjunta n. 109/20/5/GAB/SVS/MS. Orienta a respeito da priorização da penicilina $G$ benzatina para sífilis em gestantes e penicilina cristalina para sífilis congênita no país e alternativas para o tratamento da sífilis, 2015b. Disponível em: < http://www.aids.gov.br/pt-br/ legislacao/nota-informativa-conjunta-no- I09105gabsvsms-gabsctiems>. Acesso em: 23 jul. 2019.

BRASIL. Nota informativa conjunta n. 006/20I6/GAB/DDAHV/SVS/MS. Informa a respeito da importância e urgência na aquisição de penicilina cristalina (ou potássica), tendo em vista que tal medicamento é tratamento padrão para diversas doenças com relevante impacto em saúde pública, 20I6. Disponível em: <http://www.aids.gov.br/pt-br/legislacao/nota-informativa-no-00620l6-gabddahvsvsms>. Acesso em: 23 jul. 2019.

BRASIL. Boletim Epidemiológico Sífilis 2019. Disponível em: <http://saude.gov.br/images/pdf/20I9/ outubro/24/Boletim-S--filis-20 I 9-especial.pdf >. Acesso em: I ago. 2020.

CHAVES, L. A. Desabastecimento de Medicamentos no Brasil e no Mundo: uma reflexão sobre suas causas e estratégias de enfrentamento para a garantia do acesso a medicamentos, 2019. Tese de Doutorado, Rio de Janeiro: Escola Nacional de Saúde Pública, Fundação Oswaldo Cruz.

CHAVES, L. A. et al. Desabastecimento de medicamentos na literatura científica da saúde: uma revisão narrativa. Physis: Revista de Saúde Coletiva, 29: e290 107, 2019. Disponível em: <https://doi. org/l0.1590/s0103-73312019290107>. Acesso em: 22 jul. 2020. 
COGAN, D.; KARRAR, K. \& IYER, J. K. Shortages, stockouts and Scarcity: the issues facing the security of antibiotic supply and the role for pharmaceutical companies, 3I May 20 I8. Disponível em: <https:// accesstomedicinefoundation.org/media/atmf/Antibiotic-Shortages-Stockouts-and-Scarcity_ Access-to-Medicine-Foundation 3 I-May-20 I8.pdf>. Acesso em: 22 jul. 2020.

CONSELHO NACIONAL DE SECRETÁRIOS DE SAúdE (CONASS). Em audiência pública, Conass alerta para a falta de medicamentos para sedação, 14 jun. 2020. Disponível em: <www.conass.org. $\mathrm{br} / \mathrm{em}$-audiencia-publica-conass-alerta-para-a-falta-de-medicamentos-para-sedacao >. Acesso em: 22 jul. 2020.

DAULAIRE, N. et al. Universal access to effective antibiotics is essential for tackling antibiotic resistance. The Journal of Law, Medicine E Ethics, 43(3): I7-21, 2015. Disponível em: < https://journals.sagepub. com/doi/I0. I I I I/jlme.12269>. Acesso em: 6 ago. 2020.

DAVIS, N. Antibiotic shortage puts patients at risk, doctors fear. The Guardian, London, I jul. 2017. Disponível em: <www.theguardian.com/society/20 I7/jul/0 I/antibiotic-shortage-puts-patients-atrisk>. Acesso em: 22 jul. 2020.

DESABASTECIMENTO de medicamentos essenciais no combate à Covid-19 preocupa hospitais. Setor Saúde, 27 jun. 2020. Disponível em: < https://setorsaude.com.br/desabastecimento-de-medicamentosessenciais-no-combate-a-covid- I 9-preocupa-hospitais/>. Acesso em: 22 jul. 2020.

EUA COMPRAM praticamente todo estoque mundial de remdesivir. Veja, São Paulo, I jul. 2020. Disponível em: <https://veja.abril.com.br/mundo/eua-compram-praticamente-todo-estoquemundial-de-remdesivir/>. Acesso em: 14 jul. 2020.

EUA são acusados de "pirataria” e "desvio" de equipamentos que iriam para Alemanha, França e Brasil. BBC News Brasil, São Paulo, 4 abr. 2020. Internacional. Disponível em: <www.bbc.com/portuguese/ internacional-52166245>. Acesso em: I 4 jul. 2020.

EXPLOSION at Chinese antibiotics factory leaves a shortage of lifesaving antibiotics. Bactiguard, I 9 May 2017. Disponível em: <www.bactiguard.se/en/news-press/news/explosion-at-chinese-antibioticsfactory-leaves-a-shortage-of-lifesaving-antibiotics>. Acesso em: 31 maio 2019.

EXPLOSION OF an API Manufacturing Site: Supply of Medicinal Products Endangered. ECA Academy, GMP News, Heidelberg, 8 fev. 2017. Disponível em: <www.gmp-compliance.org/gmp-news/ explosion-of-an-api-manufacturing-site-supply-of-medicinal-products-endangered $>$. Acesso em: 31 maio 2019.

FARMACÊUTICA Roche anuncia que vai fechar fábrica no Brasil. Veja, São Paulo, 26 mar. 2019. Disponível em: <https://veja.abril.com.br/economia/farmaceutica-roche-anuncia-que-vai-fecharfabrica-no-brasil/>. Acesso em: 25 maio 2019.

GUERRA JR., A. A. G. \& CAMUZI, R. C. Logística farmacêutica. In: OSORIO-DE-CASTRO, C. G. S. et al. (Orgs.). Assistência Farmacêutica: gestão e prática para profissionais da saúde. Rio de Janeiro: Editora Fiocruz, 2014.

HASENCLEVER, L. et al. (Orgs.). Economia Industrial de Empresas Farmacêuticas. Rio de Janeiro: E-papers, 2010.

KESIC, D. Strategic development trends in the world pharmaceutical industry. Managing Global Transitions, 9(3): 207-223, 2011 . 
KESSEL, J. et al. Piperacillin/Tazobactam shortage: central restriction and alternative recommendations as effective antibiotic-stewardship intervention at a maximal care hospital. Deutsche Medizinische Wochenschrift, 143(8): e59-e67, 2018. Disponível em: <https://doi.org/I0.1055/s-0043-122706>. Acesso em: 22 jul. 2020.

LEITE, S. N. et al. Infraestrutura das farmácias da atenção básica do Sistema Único de Saúde: análise dos dados da PNAUM-Serviços. Revista de Saúde Pública, 5I, supl. 2, 2017. Disponível em: <www. revistas.usp.br/rsp/article/view/139755>. Acesso em: 10 jan. 2019.

MANAGEMENT SCIENCES FOR HEALTH (MSH). MDS-3 - Managing Access to Medicines and Health Technologies. Arlington: Management Sciences for Health, 20 I2. Disponível em: <www.msh.org/sites/ default/files/mds3-jan20 I4.pdf >. Acesso em: 19 jan. 2021.

NURSE-FINDLAY, S. et al. Shortages of benzathine penicillin for prevention of mother-to-child transmission of syphilis: An evaluation from multi-country surveys and stakeholder interviews. PloS Medicine, I4(I 2): el002473, 2017. Disponível em: <https://doi.org/I0.137I/journal.pmed.I002473>. Acesso em: 22 jul. 2020.

PALMER, E. China drug exports to U.S. rise but companies struggle with quality. FiercePharma, 30 ago. 2016. Disponível em: <www.fiercepharma.com/manufacturing/china-drug-exports-to-u-s-rise-butcompanies-struggle-quality>. Acesso em: 16 jul. 2020.

REES, V. ITC urges UK to ensure drug supply ahead of second Covid-19 wave. European Pharmaceutical Review, 29 jul. 2020. Disponível em: <www.europeanpharmaceuticalreview. com/news/I 248 I 6/trade-committee-urges-uk-to-ensure-drug-supply-ahead-of-second-covidI 9-wave/>. Acesso em: 6 ago. 2020.

RODRIGUES, P. H. A.; COSTA, R. D. F. E KISS, C. A evolução recente da indústria farmacêutica brasileira nos limites da subordinação econômica. Physis: Revista de Saúde Coletiva, 28(I), 2018. Disponível em:

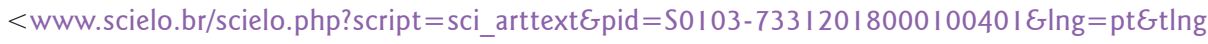
$=$ pt $>$. Acesso em: 23 jul. 2020.

SERGIPE. Secretaria de Estado de Saúde. Licitações desertas de abastecimento de medicamentos e insumos, diz SES, 2017. Disponível em: <www.saude.se.gov.br/?p=13665>. Acesso em: 4 ago. 2020.

SILVA, E. et al. Evaluation of the Electronic Trading as a tool for public hospital pharmaceutical services management. Revista Brasileira de Farmácia Hospitalar e Serviços de Saúde, 9(I): I-6, 20 I 8. Disponível em: <https://doi.org/l 0.30968/rbfhss.2018.091.007>. Acesso em: 22 jul. 2020.

SOCIEDADE BRASILEIRA DE FARMÁCIA HOSPITALAR (SBRAFH). Levantamento nacional sobre o abastecimento de medicamentos e produtos para a saúde durante o enfrentamento da pandemia pela Covid- 19 (Anexo do Ofício n. 037/2020, enviado ao Ministro da Saúde em I 5 jun. 2020), 16 jun. 2020. Disponível em: <www.sbrafh.org.br/inicial/levantamento-nacional-referente-ao-abastecimentode-medicamentos-e-produtos-para-a-saude-durante-o-enfrentamento-da-pandemia-pela-covid19-anexo-do-oficio-no-037-2020-enviado-ao-ministro-da-saude-em>. Acesso em: 6 ago. 2020.

STAFFORD, A. The evolution of the global active pharmaceutical ingredients supply market and the impact on the generic pharmaceuticals business in the United States. Journal of Generic Medicines, 3(4): 295-305, 2006. Disponível em: <https://doi.org/l0.1057/palgrave.jgm.4940132>. Acesso em: 22 jul. 2020. 
TAKEDA coloca à venda divisão de MIPs na América Latina. Panorama Farmacêutico, 4 abr. 2019. Disponível em: <https://panoramafarmaceutico.com.br/2019/04/04/takeda-coloca-a-venda-divisaode-mips-na-america-latina/> . Acesso em: 16 jul. 2020.

TRIBUNAL DE CONTAS DA UNIÃO. Manual de Compras Diretas, 20 I 8. Disponível em: < https://portal. tcu.gov.br/lumis/portal/file/fileDownload.jsp?fileld=8A8 I 82A24D6E86A40 I 4D7 I A8CEA96335>. Acesso em: 8 abr. 2020.

VALENTE, J. Covid- I9: relatório aponta falta de medicamentos nos estados. Agência Brasil, Brasília, 27 jun. 2020. Disponível em: <https://agenciabrasil.ebc.com.br/saude/noticia/2020-06/covid- I9relatorio-aponta-desabastecimento-de-remedios-nos-estados>. Acesso em: 22 jul. 2020.

WORLD HEALTH ORGANIZATION (WHO). Executive Board Meeting, I 40th. EB I 40/I 9. Addressing the global shortage of medicines and vaccines. Report by the Secretariat. Geneva: World Health Organization, 5 dez. 2016 a.

WORLD HEALTH ORGANIZATION (WHO). Meeting Report: technical definitions of shortages and stockouts of medicines and vaccines. Geneva: World Health Organization, 5 out. 20 I6b.

WORLD HEALTH ORGANIZATION (WHO). No time to wait: securing the future from drug- resistant infectons. Report to the Secretary-General of the United Nations. Geneva: World Health Organization, 2019. Disponível em: <www.who.int/antimicrobial-resistance/interagency-coordination-group/ final-report/en/>. Acesso em: I ago. 2020. 

Qualidade do Cuidado e Segurança do Paciente desafios e contribuições diante da pandemia de Covid-19

Bárbara do Nascimento Caldas e Lenice Gnocchi da Costa Reis

\section{BREVE PANORAMA DAS REPERCUSSÕES DA COVID-19 NOS SERVIÇOS DE} SAÚDE DO BRASIL

7 pesar de a epidemia de Covid- 9 ter atingido o mundo todo, cada país sofre suas consequências de modo bastante distinto (Ranzani et al., 202 I). No Brasil, a desigualdade, o subfinanciamento crônico do Sistema único de Saúde (SUS) e de todo o aparato de proteção social (Paim, 2018), o desemprego, o elevado número de pessoas que vivem na extrema pobreza e a inaceitável falta de coordenação nacional afetaram sobremaneira a capacidade de resposta à pandemia, levando ao quadro catastrófico que vivemos.

Os trabalhadores e as populações mais vulneráveis, que dependem do trabalho diário para sua subsistência, não tiveram a possibilidade de adotar medidas de proteção como isolamento ou afastamento social. Desse modo, na vigência de uma doença nova, altamente transmissível, para a qual não há tratamento específico estabelecido e cujas vacinas apenas recentemente foram disponibilizadas, as consequências têm sido extremamente graves, como é possível acompanhar diariamente pelo aumento do número de casos novos e de óbitos pela doença. A isso se alia o fato de que, em nosso país, a quantidade de doses dos imunizantes disponibilizada é muito inferior àquela necessária para uma ação efetiva de bloqueio.

Em meio a tantos impactos da pandemia, o sistema de saúde foi fortemente atingido. O esgotamento da capacidade de internações em leitos de unidades de terapia intensiva (UTIs) é apontado como a ponta do iceberg do colapso de todo o sistema de saúde (Freitas et al., $202 \mathrm{l}$ a). 
Por se tratar de doença cuja fisiopatologia ainda hoje não está completamente elucidada, além de causada por um agente desconhecido, houve dificuldades para o diagnóstico e avaliação dos casos por meio de marcadores clínicos e laboratoriais. Houve também muitos embates, que permanecem nos dias atuais, acerca das medidas terapêuticas mais eficazes. $\mathrm{O}$ uso de medicamentos conhecidos, mas sem comprovação de eficácia para a Covid-19, passou a ser preconizado por alguns, em doses não seguras, o que resultou em eventos adversos importantes (Melo et al., 2020). Tudo isso afetou a qualidade do cuidado e a segurança do paciente e resultou em perda de recursos e de tempo para conter a pandemia em nosso país.

Ao final de março de 2020, já era possível observar um aumento expressivo da demanda por assistência à saúde. Esse aumento se manteve ao longo de todo o curso da pandemia, com breves períodos de pequenas reduções do número de casos, de modo que em alguns momentos o país apresentasse estabilidade, mas com número de casos em patamares bastante elevados (Freitas et al., $202 \mathrm{Ib}$ ).

Esse aumento de demanda em curto tempo, em serviços de saúde com fragilidades em sua estrutura, em especial pelo reduzido quadro de profissionais da saúde, gerou sobrecarga de trabalho e desorganização de processos. Rotinas, fluxos e protocolos precisaram ser rapidamente revistos. Novos leitos foram abertos e nem sempre foi possível que todos os elementos da cadeia de suprimento de materiais e de equipamentos médicos fossem providenciados, seja por indisponibilidade no mercado, seja por falta de planejamento para sua provisão. A falta de respiradores, de medicamentos, de oxigênio medicinal, de máscaras e de outros equipamentos de proteção individual (EPIs) foi amplamente noticiada.

Decerto, em momentos de crise, se não houver uma base prévia, com equipes preparadas e planos de contingência minimamente delineados, torna-se uma tarefa muito mais árdua aliar o improviso a respostas rápidas, efetivas e seguras. Toda a sobrecarga dos serviços de saúde associada à escassez de suprimentos e à necessidade de adaptações rápidas e de preparação de equipes têm impactos sobre a qualidade do cuidado prestado, a seguranca do paciente e a segurança dos trabalhadores da saúde.

\section{A QUALIDADE DO CUIDADO EM SAÚDE E A SEGURANÇA DO PACIENTE}

A qualidade do cuidado em saúde tem sido objeto de preocupação, estudo e pesquisa há décadas, e a partir da segunda metade do século XX este tema ganhou força. Para Avedis Donabedian, um dos seus principais estudiosos, o cuidado de qualidade é aquele que proporciona ao paciente o maior bem-estar possível, considerando o 
balanço entre benefícios e riscos, e se apoia no conhecimento científico mais atual e nas tecnologias de saúde disponíveis (Donabedian, 2003).

A produção teórica e o debate em torno desse tema têm sido muito ricos e os conceitos vêm ganhando densidade. O Institute of Medicine (IOM) propõe que o cuidado em saúde seja observado considerando-se seis dimensões: segurança, efetividade, centralidade no paciente, oportunidade, eficiência e equidade (IOM, 200 I), proposição que tem sido adotada por várias instituições em seus trabalhos.

Neste capítulo, merece destaque a dimensão da segurança, a ser evidenciada como elemento relevante que compõe o complexo conceito de qualidade do cuidado em saúde. A segurança do paciente vem ganhando espaço e traz subsídios importantes, com base em diversos campos do conhecimento. A produção técnica e científica dos últimos anos dá sustentação e direcionalidade para as mudanças organizacionais que visam à melhoria do cuidado e das práticas para que se alcancem resultados mais benéficos para os pacientes e para a sociedade, em geral.

Segurança do paciente foi definida como a redução a um mínimo aceitável de danos desnecessários causados aos pacientes, relacionados à assistência à saúde (Runciman et al., 2009). Esses danos não intencionais, provocados por incidentes, são chamados de eventos adversos (EAs). Podem ocorrer por falha na execução de um plano de ação ou por execução de um plano inadequado ou incorreto. Mais recentemente, a Organização Mundial da Saúde (OMS) apresentou uma definição ampliada para segurança do paciente: um conjunto organizado de atividades, capaz de criar culturas, comportamentos, processos e procedimentos, ambientes e tecnologias para auxiliar, de forma consistente e sustentável, a tornar os erros menos prováveis, a reduzir a ocorrência de eventos e a minimizar seus impactos, caso ocorram (WHO, 202I).

A abordagem para compreensão da ocorrência de eventos adversos que se tem preconizado é aquela que admite que estes resultam de um conjunto de falhas. Para Reason (2000), as falhas podem ser latentes ou ativas. As latentes são resultantes do desenho e dos arranjos organizacionais, e as ativas se ligam à prestação do cuidado em si e, geralmente, guardam relação com as condições de trabalho e de organização. As falhas ativas e latentes se configuram como fatores contribuintes, ou seja, que influenciam na ocorrência de um incidente que pode gerar um EA (Runciman et al., 2009).

Fatores de diferentes naturezas interferem na oportunidade do surgimento de falhas, que podem afetar a qualidade do cuidado e a segurança do paciente. Tais fatores podem ser agrupados de modos distintos, mas, em linhas gerais, estão relacionados às características dos pacientes e dos serviços de saúde e a fatores externos (Vincent, 
Taylor-Adams E Stanhope, 1998; Lawton et al., 2012). Assim, pacientes em estado mais grave, com comorbidades, que demandam cuidados mais complexos, são mais susceptíveis a sofrer EAs (Rothschild et al., 2005); serviços de saúde com estrutura deficiente, que não contam com processos e equipes adequados, também apresentam maior probabilidade de que ocorram falhas e mais eventos adversos (Mitchell $\varepsilon$ Shortell, 1997). Além disso, na vigência de situações externas, como um desastre ou uma epidemia, que resultem em aumento da demanda e sobrecarga dos serviços, também pode haver problemas relacionados à segurança do paciente em todos os níveis do sistema de saúde (Wu et al., 2020).

Quando se analisa um EA, é mais importante saber como e quais elementos e fatores estavam envolvidos em sua ocorrência do que apontar quem cometeu algum erro. Abordar o EA de forma sistêmica (i. e., buscar falhas nos processos, e não culpar pessoas) é primordial para resolver problemas, mitigar danos e aprender para não repetir.

O Brasil vem fazendo esforços, desde o início dos anos 2000, para se incorporar ao movimento mundial em prol da segurança do paciente, liderado pela OMS. O lançamento do Programa Nacional de Segurança do Paciente (PNSP), em 2013, é fruto do investimento de grupos de pesquisa e das organizações de saúde. Seu objetivo é organizar e induzir ações para a melhoria da qualidade do cuidado em saúde e da segurança do paciente (Brasil, 2013). Uma das propostas mais importantes do programa foi a criação, nos estabelecimentos de saúde, de núcleos de Segurança do Paciente (NSPs), responsáveis por elaborar planos locais de segurança, implementar protocolos e notificar incidentes relacionados à segurança do paciente (Anvisa, 20l3). No entanto, além dessas atividades, em algumas organizações os NSPs assumem relevante papel no auxílio aos gestores para que as conheçam melhor e na promoção da cultura da segurança do paciente. Alguns autores afirmam que organizações que se autoconhecem, aprendem e se adaptam ampliam sua capacidade de resiliência (Lengnick-Hall, Beck $\mathcal{E}$ Lengnick-Hall, 20 I I), o que, por certo, implica maior possibilidade de oferecer cuidados com mais qualidade e segurança para os pacientes e melhor ambiente de trabalho para todo o corpo de profissionais.

No momento de uma pandemia como a que está em curso, com as características até o momento conhecidas e diante dos novos tratamentos preconizados, é plausível pensar que o risco de eventos adversos pode aumentar. Para minimizar essa possibilidade, as iniciativas de adaptação de cada um dos hospitais e de outros serviços de saúde são muito importantes, assim como a troca de informação entre os NSPs e entre profissionais e suas associações. 


\section{CONTRIBUIÇÕES DA QUALIDADE DO CUIDADO EM SAÚDE E SEGURANÇA DO PACIENTE PARA O ENFRENTAMENTO DA PANDEMIA}

Ao longo da pandemia, diversos grupos têm se dedicado, sobretudo, a compartilhar informações e difundir iniciativas que contribuem para o enfrentamento da emergência sanitária em que se encontram as organizações de saúde. As primeiras orientações oficiais sobre as medidas de prevenção e de controle no âmbito dos serviços de saúde para fazer frente à pandemia de Covid- 9 foram elaboradas pela Agência Nacional de Vigilância Sanitária. Foram publicadas notas técnicas que orientam sobre diversos aspectos de funcionamento e sobre a adoção das boas práticas (Anvisa, 2020a, 2020b). Sociedades e associações de especialidades médicas e da área da saúde, entidades e outras organizações também deram importantes contribuições nesse sentido (Caldas et al., 2020).

No Quadro I estão sintetizadas algumas dessas medidas conforme o eixo de atuação.

Quadro I - Medidas preconizadas para reorganização dos serviços de saúde

\begin{tabular}{|l|l|}
\hline \multicolumn{1}{|c|}{ Eixo } & \multicolumn{1}{|c|}{ Medidas preconizadas } \\
\hline $\begin{array}{l}\text { Proteção aos profissionais } \\
\text { da saúde }\end{array}$ & $\begin{array}{l}\text { Remanejamento de profissionais mais vulneráveis (em razão da } \\
\text { idade ou de gestação) para funções de apoio } \\
\text { Redução do contingente de profissionais, com a implementação de } \\
\text { atendimento por chamada interna, backup e cobertura de casos } \\
\text { Alterações nas escalas de trabalho para minimizar o risco de } \\
\text { transmissão e permitir que os profissionais mantenham períodos de } \\
\text { quarentena } \\
\text { Avaliação, segundo situação epidemiológica da pandemia, da } \\
\text { necessidade de limitar a internação de pacientes aos casos de } \\
\text { urgência e emergência }\end{array}$ \\
\hline Relação com pacientes & $\begin{array}{l}\text { Triagem e acompanhamento do quadro clínico dos pacientes com } \\
\text { uso de telefones e telemedicina } \\
\text { Cancelamento ou adiamento de consultas, cirurgias e procedimentos } \\
\text { nos casos de pacientes clinicamente estáveis } \\
\text { Orientação aos usuários sobre procedimentos de higiene pessoal, } \\
\text { assim como disponibilização de produtos para esses procedimentos } \\
\text { Suspensão das atividades em grupos de pacientes ou familiares, } \\
\text { assim como de reuniões presenciais, e de visitas, nos casos de } \\
\text { internação } \\
\text { Uso de uma sala de videoconferência a fim de reduzir o contato } \\
\text { físico com os pacientes }\end{array}$ \\
\hline
\end{tabular}


Quadro I - Medidas preconizadas para reorganização dos serviços de saúde (continuação)

\begin{tabular}{|l|l|}
\hline \multicolumn{1}{|c|}{ Eixo } & \multicolumn{1}{c|}{ Medidas preconizadas } \\
\hline $\begin{array}{l}\text { Reorganização do espaço } \\
\text { físico }\end{array}$ & $\begin{array}{l}\text { Entrada monitorada nos serviços de saúde, com a implementação } \\
\text { da higienização das mãos, da aferição da temperatura, do } \\
\text { distanciamento físico, do uso de máscaras e da etiqueta respiratória } \\
\text { Os serviços devem dispor de espaços distintos para pacientes sem } \\
\text { confirmação diagnóstica, mas com sintomatologia, e para pacientes } \\
\text { com diagnóstico positivo para Covid- I9 } \\
\text { Garantia de boa ventilação em todos os ambientes }\end{array}$ \\
\hline $\begin{array}{l}\text { Cuidados com os } \\
\text { pacientes cirúrgicos }\end{array}$ & $\begin{array}{l}\text { Testagem pré-operatória } \\
\text { Área para cirurgia de pacientes com Covid- I } 9 \text { separada } \\
\text { Circulação mínima dos pacientes e profissionais } \\
\text { Planejamento cuidadoso do procedimento anestésico }\end{array}$ \\
\hline
\end{tabular}

Fonte: elaborado pelas autoras com base em Souto et al., 2020.

Todas essas medidas e outras voltadas para a segurança do paciente e dos trabaIhadores da saúde são importantes e contribuem para a reorganização dos serviços de saúde e minimização dos riscos de transmissão do Sars-CoV-2 no ambiente hospitalar. No entanto, precisam ser implementadas corretamente e ter seus efeitos monitorados para a adoção de medidas corretivas, que considerem inclusive o quadro da pandemia no município e na região.

Os hospitais contam com estruturas definidas para empreender essas atividades, como os NSPs, os serviços de Controle de Infecção Hospitalar (SClHs) e outros grupos relacionados às questões da qualidade e segurança. Nas organizações onde esses grupos são atuantes e apoiados pelo gestor, há relatos de resultados promissores (Prates et al., 2019), o que permite supor que, durante a pandemia, contar com eles pode ajudar a proceder às adaptações necessárias, a aumentar a capacidade de resiliência e a obter melhor desempenho.

Com suas habilidades para apoiar organizações, equipes e pacientes, as equipes de qualidade e segurança, como os NSPs, podem contribuir para (Staines et al., 2020):

I. Fortalecer o sistema e o ambiente por meio de ações como avaliar a preparação do serviço (IHI, 2020), reunir experiências e evidências, montar treinamentos de habilidades pouco trabalhadas (p. ex., paramentação e desparamentação 
para profissionais da ponta), orientar e apoiar a liderança distribuída, promover segurança das equipes, incluída a segurança psicológica (Cannon $\varepsilon$ Edmondson, 2005), e reforçar o apoio entre os pares, sobretudo relacionado à ocorrência de eventos adversos ou a dilemas éticos (Greenberg et al., 2020).

2. Apoiar o engajamento e empoderamento de pacientes, familiares e comunidade. Facilitar a produção conjunta de soluções para prevenção, isolamento, tratamento e recuperação. Estabelecer parcerias com pacientes. Otimizar políticas de visita, buscando maximizar o benefício do apoio da família ao mesmo tempo que cumprir com o distanciamento físico. Aconselhar líderes sobre a centralidade do paciente no cuidado durante uma pandemia e sobre questões como a linguagem e considerações éticas.

3. Trabalhar para melhorar o cuidado por meio de ações como a separação dos fluxos, rápidas oficinas sobre trabalho em equipe e o desenvolvimento de apoio à decisão clínica.

4. Reduzir o dano por meio de gerenciamento proativo do risco tanto para pacientes de Covid- I 9 como para aqueles com outros agravos. Auxiliar a equipe do $\mathrm{SCIH}$ na atualização e divulgação das diretrizes. Organizar auditorias de aspectos-chave relacionados ao novo perfil de atendimento. Coordenar identificação do risco, análise e gerenciamento.

5. Impulsionar e ampliar o sistema de aprendizado para identificar oportunidades de melhoria, ajustar rapidamente os processos e desenvolver resiliência.

Esse conjunto de ações e estratégias se beneficia de contribuições empíricas e teóricas para o gerenciamento de risco em contextos de elevada complexidade e condições adversas.

Considerando a abordagem proposta por Amalberti e Vincent (2019), o primeiro passo diante de uma crise é abandonar a ideia de só voltar a trabalhar para melhorar o sistema depois que as coisas "tiverem voltado ao normal". Segundo os autores, a ideia não é ignorar os desafios trazidos pela pandemia, mas sim encarar a nova situação e nos perguntarmos quanto risco pode ser minimizado nesse cenário. Importante lembrar (e aceitar) que não poderemos nunca eliminar todos os riscos e perigos (Western Australia, 2018$)$. Assim, faz-se necessário equilibrar ações preventivas com estratégias de segurança focadas em gerenciar ameaças e pressões dinâmicas (Amalberti $\varepsilon$ Vincent, 2019), processos característicos das organizações de alta confiabilidade, como veremos mais adiante. 
Outro aspecto destacado pelos autores é o foco principal nos problemas e perigos esperados. Lesão por pressão, dimensionamento de pessoal, equipamentos e demanda elevada de atendimentos são inesperados no sentido de que é difícil prever quando irão ocorrer, mas são completamente familiares.

Por fim, Amalberti e Vincent (2019) destacam a importância de reconhecer que quando uma organização inteira está sob estresse, o gerenciamento de risco exige necessariamente o engajamento e a ação de todos os níveis gerenciais. Negociar prioridades, treinamentos e estratégias abrangentes em uma organização sob estresse exige ação coordenada entre executivos, gerentes e equipe da ponta.

Os aprendizados proporcionados pelas organizações de alta confiabilidade (OACs) também se configuram como contribuição importante. O conceito de OAC tem suas raízes em estudos de organizações de diversos setores nas quais as falhas têm consequências drásticas e esforços coordenados são necessários para garantir desfechos seguros (p. ex. aviação comercial, energia nuclear). OACs alimentam uma cultura de confiança, estimulam relações de trabalho fortes e costumam, combinando antecipação e resiliência, apresentar características ou princípios centrais (Quadro 2) que ajudam a manter o desempenho confiável mesmo em face de mudanças contínuas (Weick E Sutcliffe, 2015).

Quadro 2 - Características centrais das organizações de alta confiabilidade

\begin{tabular}{|l|l|}
\hline \multicolumn{1}{|c|}{ Ênfase } & \multicolumn{1}{c|}{ Princípio } \\
\hline \multirow{2}{*}{ Antecipação } & Preocupação com falhas \\
\cline { 2 - 2 } & Relutância em simplificar interpretações \\
\cline { 2 - 2 } & Sensibilidade às operações \\
\hline \multirow{2}{*}{ Resiliência } & Compromisso com a resiliência \\
\cline { 2 - 2 } & Respeito ao conhecimento \\
\hline
\end{tabular}

Fonte: elaborado pelas autoras com base em Weick \& Sutcliffe, 2015.

Para alguns autores, a incorporação dos princípios das OACs corresponde à terceira onda de inovações no cuidado hospitalar com o objetivo de melhorar a segurança do paciente. Organizar-se para a alta confiabilidade nos serviços de saúde exige atenção às práticas e comportamentos dos profissionais da linha de frente, apoio da liderança para responder aos erros e com eles aprender, e mudança cultural em direção ao trabalho em equipe e coordenação do cuidado (Ghaferi et al., 2016). 
Chaferi e colaboradores (2016) argumentam que o trabalho para a melhoria da segurança do paciente não se restringe a aprimorar técnicas (primeira onda) e padronizar procedimentos (segunda onda) para reduzir complicações, mas também abrange os modos como as equipes de saúde organizam seu trabalho para que possam reconhecer problemas a tempo e adaptar sua conduta para salvar o paciente.

Estimular o desenvolvimento dos princípios das OACs envolve fortalecer a cultura da segurança, o que exige tempo e consistência. Porém, a pandemia de Covid- 19 pode ser um momento de intenso aprendizado também sobre a forma como os serviços de saúde respondem a crises, e podemos partir desse referencial para propor ações com potencial contribuição para a segurança, incluindo a de pacientes, familiares e profissionais (Quadro 3).

Quadro 3 - Princípios das organizações de alta confiabilidade aplicados ao enfrentamento da Covid- 19

\begin{tabular}{|l|l|}
\hline \multicolumn{1}{|c|}{ Princípio } & \multicolumn{1}{|c|}{ Exemplos de ações } \\
\hline Preocupação com falhas & $\begin{array}{l}\text { Simulação frequente de processos cruciais } \\
\text { Observação direta da paramentação e } \\
\text { desparamentação }\end{array}$ \\
\hline Relutância em simplificar interpretações & $\begin{array}{l}\text { Consciência de viés cognitivo na tomada de decisão } \\
\text { Compreensão detalhada dos desafios enfrentados } \\
\text { Análise cuidadosa dos perigos e incidentes de } \\
\text { segurança }\end{array}$ \\
\hline Sensibilidade às operações & $\begin{array}{l}\text { Ronda da gestão na linha de frente } \\
\text { Huddles de segurança regulares } \\
\text { Observação planejada de processos cruciais }\end{array}$ \\
\hline Compromisso com a resiliência & $\begin{array}{l}\text { Disposição para mudar decisões à medida que a } \\
\text { informação muda } \\
\text { Bem-estar da equipe explicitamente discutido e } \\
\text { tratado }\end{array}$ \\
\hline Respeito ao conhecimento & $\begin{array}{l}\text { Decisão tomada por aqueles que têm experiência } \\
\text { mais relevante, e não por quem está em posição } \\
\text { superior } \\
\text { Líderes reconhecendo e respeitando a expertise da } \\
\text { linha de frente }\end{array}$ \\
\hline
\end{tabular}

Fonte: adaptado de Thull-Freedman et al., 2020. 


\section{FORTALECIMENTO DA CAPACIDADE GERENCIAL COMO CONDIÇÃO PARA MELHORES RESULTADOS DOS SISTEMAS DE SAÚDE}

Diante da pandemia de Covid- 19, fica evidente a necessidade de um olhar sistêmico que permita preparar os serviços de saúde, em todos os níveis, para que sejam capazes de responder rapidamente, reorganizando o processo de trabalho e a infraestrutura física, estabelecendo mecanismos ágeis de comunicação e de fortalecimento do compromisso e da confiança, com lideranças ativas.

Aprender a lidar com situações críticas e a elas se antecipar é fundamental. Hoje estão disponíveis conhecimentos, instrumentos e técnicas que permitem a formulação de planos de contingência e simulações que orientem as mudanças, organizem os esforços e parcerias para respostas rápidas. Embora não seja novidade, a habilidade que profissionais da saúde têm em improvisar soluções com o que há disponível também pode ser esgotada, com impacto sobre a qualidade do cuidado e a segurança do paciente (Rangachari \& Woods, 2020).

As equipes da qualidade e segurança, como os NSPs, podem contribuir sobremaneira para o enfrentamento da pandemia nos serviços de saúde, tanto na implementação das medidas preconizadas quanto no fortalecimento de outras dimensões da qualidade do cuidado, como a centralidade do paciente (Staines et al., 2020). Porém, a efetividade da atuação dessas equipes depende de fatores como liderança da alta gestão para segurança, dimensionamento adequado e treinamento dos profissionais, e recursos para investimento em melhorias (Caldas et al., 202 I) - contexto pouco frequente nos hospitais públicos e que tende a se deteriorar em decorrência da crise econômica e sanitária.

Certamente as iniciativas individuais de cada um dos hospitais e outros serviços de saúde, ainda que importantes, não são suficientes. A política de saúde precisa fomentar e fortalecer a capacidade gerencial em todos os níveis do sistema, não apenas para prepará-los para as ameaças à saúde, mas para que tenham como horizonte a missão de produzir cuidados com qualidade e segurança, reduzir as iniquidades que permanecem no interior do próprio sistema de saúde e proteger todos os cidadãos, em especial os mais vulneráveis. 


\section{REFERÊNCIAS}

AGÊNCIA NACIONAL DE VIGILÂNCIA SANITÁRIA (ANVISA). RDC n. 36. Institui ações para a Segurança do Paciente em Serviços de Saúde. Diário Oficial da União, Brasília, 26 jul. 2013.

AGÊNCIA NACIONAL DE VIGILÂNCIA SANITÁRIA (ANVISA). Nota técnica GVIMS/GGTES/Anvisa n. 04/2020a. Orientações para serviços de saúde: medidas de prevenção e controle que devem ser adotadas durante a assistência aos casos suspeitos ou confirmados de infecção pelo novo coronavírus (SarsCoV-2). Criada em: 30 jan. 2020. Atualizada em: 26 fev. 2021. Disponível em: <www.gov.br/anvisa/ pt-br/centraisdeconteudo/publicacoes/servicosdesaude/notas-tecnicas/nota-tecnica-gvims_ggtes_ anvisa-04_2020-25-02-para-o-site.pdf/view>. Acesso em: mar. 2021.

AGÊNCIA NACIONAL DE VIGILÂNCIA SANITÁRIA (ANVISA). Nota técnica GVIMS/GGTES/Anvisa n. $08 / 2020 b$. Orientações gerais para implantação das práticas de segurança do paciente em hospitais de campanha e nas demais estruturas provisórias para atendimento aos pacientes durante a pandemia de covid- 1 9. Emitida em: 13 maio 2020. Disponível em: <www.gov.br/anvisa/pt-br/centraisdeconteudo/ publicacoes/servicosdesaude/notas-tecnicas/nota-tecnica-no-08-de-2020-gvims-ggtes-anvisahospitais-de-campanha.pdf/view>. Acesso em: mar. 2021.

AMALBERTI, R. \& VINCENT, C. Managing risk in hazardous conditions: improvisation is not enough. BMJ Quality E Safety, 29(I): 60-63, 20I9. Disponível em: <https:/qualitysafety.bmj.com/ content/29/1/60>. Acesso em: fev. 2021.

BRASIL. Ministério da Saúde. Portaria n. 529, de $1{ }^{\circ}$ abr. 20 I3. Institui o Programa Nacional de Segurança do Paciente (PNSP). Diário Oficial da União, Brasília, 2 abr. 2013

CALDAS, B. N. et al. Segurança do paciente e a pandemia causada pelo Sars-CoV-2. In: BARRETO, M. L. et al. (Orgs.). Construção de Conhecimento no Curso da Pandemia de Covid-19: aspectos biomédicos, clínico-assistenciais, epidemiológicos e sociais. v. 2. Salvador: Edufba, 2020. Disponível em: <https://doi. org/l 0.977I/9786556300757.018>. Acesso em: fev. 2021.

CALDAS, B. N. et al. How can implementation of a large-scale patient safety program strengthen hospital safety culture? Lessons from a qualitative study of national patient safety program implementation in two public hospitals in Brazil. Medical Care Research and Review, July 2021. Disponível em: < https:// pubmed.ncbi.nlm.nih.gov/3425308 I/>. Acesso em: out. 2021 .

CANNON, M. D. \& EDMONDSON, A. C. Failing to learn and learning to fail (intelligently): how great organizations put failure to work to innovate and improve. Long Range Planning, 38(3): 299-319, 2005. Disponível em: <https://doi.org/l 0.10 I 6/j.Irp.2005.04.005>. Acesso em: abr. 202I.

DONABEDIAN, A. An Introduction to Quality Assurance in Health Care. New York: Oxford University Press, 2003.

FREITAS, C. M. et al. Boletim Observatório Covid-19: boletim extraordinário, 6 abr. 202 la. Disponível em: $<$ https://portal.fiocruz.br/documento/boletim-extraordinario-do-observatorio-covid- I 9-pandemiapode-permanecer-em-niveis >. Acesso em: maio 2021.

FREITAS, C. M. et al. Boletim Observatório Covid-19: boletim extraordinário, 14 abr. 202 I b. Disponível em: $<$ https://portal.fiocruz.br/documento/boletim-do-observatorio-covid- I 9-semana-epidemiologica14-de-2021 >. Acesso em: maio 2021.

GHAFERI, A. A. et al. The next wave of hospital innovation to make patients safer. Harvard Business Review, Boston, Aug. 2016. 
GREENBERG, N. et al. Managing mental health challenges faced by healthcare workers during Covid- 19 pandemic. BMJ, 368: mI2II, 2020. Disponível em: <www.bmj.com/content/368/bmj.m I 2 I I/rapidresponses $>$. Acesso em: abr. 2021 .

INSTITUTE FOR HEALTHCARE IMPROVEMENT (IHI). IHI tool: hospital preparedness for a Covid-I 9 surge: assessment tool. Boston, 2020. Disponível em: <www.ihi.org/resources/Pages/Tools/HospitalPreparedness-for-COVID-19-Surge-Assessment-Tool.aspx>. Acesso em: set. 2021 .

INSTITUTE OF MEDICINE (IOM). Crossing the Quality Chasm: a new health system for the 2Ist century. Washington: National Academies Press, $200 \mathrm{I}$.

LAWTON, R. et al. Development of an evidence-based framework of factors contributing to patient safety incidents in hospital settings: a systematic review. BMJ Quality E Safety, 2 I (5): 369-380, 2012.

LENGNICK-HALL, C. A.; BECK, T. E. \& LENGNICK-HALL, M. L. Developing a capacity for organizational resilience through strategic human resource management. Human Resource Management Review, 21: 243-255, 2011.

MELO, J. R. R. et al. Reações adversas a medicamentos em pacientes com Covid- 19 no Brasil: análise das notificações espontâneas do sistema de farmacovigilância brasileiro. Cadernos de Saúde Pública, 37(I): e00245820, 2020. Disponível em: <http://cadernos.ensp.fiocruz.br/csp/artigo/I 298/reacoesadversas-a-medicamentos-em-pacientes-com-covid- I 9-no-brasil-analise-das-notificacoesespontaneas-do-sistema-de-farmacovigilancia-brasileiro>. Acesso em: 9 abr. 202 I.

MITCHELL, P. H. \& SHORTELL. S. M. Adverse outcomes and variations in organization of care delivery. Medical Care, 35(I I): NSI9-NS32, 1997. Disponível em: <www.jstor.org/stable/3767048>. Acesso em: 4 maio 2021.

PAIM, J. S. Sistema Único de Saúde (SUS) aos trinta anos. Ciência E Saúde Coletiva, 23(6): 1.723 I.728, 2018.

PRATES, C. G. et al. Núcleo de Segurança do Paciente: o caminho das pedras em um hospital geral. Revista Gaúcha de Enfermagem, 40(n. esp.): e20180150, 2019. Disponível em: <www.scielo. $\mathrm{br} /$ scielo.php?script $=$ sci_arttextEpid $=$ S I 983 - I 44720 I $9000200800 E I n g=e n E n r m=i s o>$. Acesso em: 28 abr. 2021.

RANGACHARI, P. L. \& WOODS, J. Preserving organizational resilience, patient safety, and staff retention during Covid- 19 requires a holistic consideration of the psychological safety of healthcare workers. International Journal of Environmental Research and Public Health, I7(12): 4.267, 2020. Disponível em: <www.mdpi.com/1660-4601/17/12/4267>. Acesso em: mar. 2021.

RANZANI, O. T. et al. Characterisation of the first 250,000 hospital admissions for Covid- 9 in Brazil: a retrospective analysis of nationwide data. The Lancet Respiratory Medicine, 9(4): 407-4I8, 202 I. Disponível em: <www.thelancet.com/journals/lanres/article/PIIS22 I3-2600(20)30560-9/fulltext>. Acesso em: mar. 2021.

REASON, J. Human error: models and management. BMJ, 320(7.237): 768-770, 2000.

ROTHSCHILD, J. M. et al. The critical care safety study: the incidence and nature of adverse events and serious medical errors in intensive care. Critical Care Medicine, 33(8): I.694-1.700, 2005.

RUNCIMAN, W. et al. Towards an international classification for patient safety: key concepts and terms. Journal of the International Society for Quality in Health Care, 2I (I): 18-26, 2009. 
SOUTO, A. C. et al. Recomendações para procedimentos assistenciais em saúde à luz da segurança do paciente durante a pandemia de Covid-19. 2020. Disponível em: <https://redecovida.org/main-sitecovida/wp-content/uploads/2020/09/Relatorio-Seguran\%C3\%A7a-do-Paciente.pdf>. Acesso em: 9 maio 202 I.

STAINES, A. et al. Covid- 19: patient safety and quality improvement skills to deploy during the surge. International Journal for Quality in Health Care, 2020. Disponível em: < https://academic.oup.com/ intqhc/article/33/1/mzaa050/5836316>. Acesso em: fev. 2021 .

THULL-FREEDMAN, J. et al. Going to the Covid- 19 Cemba: using observation and high reliability strategies to achieve safety in a time of crisis. CJEM, 22(6): 738-74I, 2020. Disponível em: <www. cambridge.org/core/journals/canadian-journal-of-emergency-medicine/article/going-to-thecovid I 9-gemba-using-observation-and-high-reliability-strategies-to-achieve-safety-in-a-time-ofcrisis/D7A53 ICI2ECEC668283CB9C880E443E9>. Acesso em: fev. 2021.

VINCENT, C.; TAYLOR-ADAMS, S. \& STANHOPE, N. Framework for analysing risk and safety in clinical medicine. BMJ, 316(7.138): I.154-1.157, 1998. Disponível em: <www.bmj.com/ content/316/7 I38/II54>. Acesso em: fev. 2021.

WEICK, K. E. \& SUTCLIFFE, K. M. Managing the Unexpected: sustained performance in a complex world. 3. ed. Hoboken: Wiley, 2015.

WESTERN AUSTRAlIA. Department of Health (DoH). Clinical Incident Management Toolkit. Perth: Patient Safety Surveillance Unit, Patient Safety and Clinical Quality Division, 2016 (Rev. 20I8).

WORLD HEALTH ORGANIZATION (WHO). Global Patient Safety Action Plan 2021-2030: towards eliminating avoidable harm in health care. Geneva: WHO, 2021.

WU, A. W. et al. Covid- 19: the dark side and the sunny side for patient safety. Journal of Patient Safety and Risk Management, 25(4): I37-I41, 2020. Disponível em: <https://journals.sagepub.com/doi/ full/I0.1 I77/25160435209571 I6>. Acesso em: fev. 2021. 



\title{
Evolução da Disponibilidade dos Leitos de Terapia Intensiva na Rede Hospitalar do Brasil para o Enfrentamento da Emergência Sanitária
}

\author{
Carla Lourenço Tavares de Andrade, Sheyla Maria Lemos Lima, \\ Claudia Cristina de Aguiar Pereira, Mônica Martins, \\ Fernando Ramalho Gameleira Soares e Margareth Crisóstomo Portela
}

pandemia de Covid- 19 exigiu que os sistemas de saúde de diversos países do mun-
do adaptassem e ampliassem rapidamente a sua capacidade de oferta de serviços para dar resposta ao adoecimento de suas populações. Diferentes pontos de cuidado da rede de serviços de saúde enfrentam novos desafios, nos níveis de atenção primária, secundária e terciária, os quais requerem estratégias que viabilizem o atendimento aos pacientes com Covid- 19 e aos pacientes com outros problemas de saúde, assim como flexibilidade para expandir e retrair os recursos orientados para o cuidado relacionado à epidemia segundo demandas postas por sua dinâmica.

A necessidade de leitos de unidade de terapia intensiva (UTI) para o tratamento de pacientes com Covid- 19 em estado grave se destacou na comparação com as demandas usuais. A disputa acirrada por respiradores, outros equipamentos e insumos ganhou a arena internacional, inclusive com situações de confisco de encomendas de países por outros. Conhecer a capacidade instalada para a provisão de cuidados de saúde complexos e dimensionar a sua expansão tornou-se um objetivo perseguido por pesquisadores e gestores, considerando prospecções sobre a epidemia e factibilidade dadas as condições contextuais.

Nesse contexto é crucial, além de acompanhar a evolução da pandemia, monitorar a capacidade da rede assistencial. Os gestores locais precisam ter acesso a informações precisas e atuais para tomar decisões no sentido de ajustar a oferta da rede às demandas colocadas pela pandemia. Além de conhecer o número de casos diários e as médias semanais ou das duas últimas semanas (estratégia utilizada para minimizar as flutuações), importa acompanhar a taxa de ocupação de leitos gerais e intensivos e a disponibilidade de leitos de tratamento intensivos em seus respectivos territórios. 
Abordamos a necessidade de se dispor de informações acerca da capacidade instalada da rede de serviços de saúde para o atendimento de casos de Covid- 19, com foco em recursos hospitalares. Apesar de suas limitações, o Cadastro Nacional de Estabelecimentos de Saúde (CNES/Ministério da Saúde) proporciona essa informação. E ganha maior importância em emergências sanitárias de caráter nacional, mas cujas particularidades locais precisam ser consideradas no planejamento das ações de saúde, como a pandemia de Covid- 19.

O CNES, onde estão cadastrados todos os estabelecimentos de saúde, públicos e privados, sejam pessoa física ou jurídica, que realizam qualquer tipo de serviço de atenção à saúde no país, provê dados sobre a disponibilidade de leitos, equipamentos e profissionais da saúde. De acesso fácil, público e irrestrito, atualizado continuamente, esse cadastro proporciona ao gestor público ou privado o conhecimento da capacidade instalada de sua rede assistencial, tornando-se uma ferramenta de apoio para a tomada de decisões e o planejamento de ações de saúde. É importante, na alocação de recursos, que além dos vazios assistenciais sejam consideradas as estruturas já existentes que podem ser reforçadas e associadas a outras estratégias necessárias ao funcionamento da rede de atenção.

No estudo aqui apresentado nos alicerçamos nas notas técnicas divulgadas no Observatório Covid- 19 da Fundação Oswaldo Cruz (Fiocruz), baseadas em dados do CNES de fevereiro de 2020, período que coincide com o início da demanda por cuidados relacionados à Covid-19. O CNES fornece o quantitativo de recursos cruciais (leitos de UTI, ventiladores/respiradores, tomógrafos etc.) para a assistência a pacientes graves com Covid- 9 disponíveis nas unidades de saúde do país e tem evidenciando a reduzida ou inexistente disponibilidade desses recursos em grande parte dos municípios brasileiros (Portela et al., 2020a, 2020b, 2020c).

Optamos por focalizar aqui apenas os leitos de UTI para adultos, considerado um recurso muito crucial, sublinhando que o registro do leito de UTI no CNES contempla, por definição, além do leito em si, um conjunto de equipamentos que a ele estão vinculados, e que a disponibilidade de profissionais da saúde capacitados para o cuidado intensivo também precisa ser levada em conta. Revisitamos alguns resultados apresentados nas notas técnicas, adicionando-Ihes dados da evolução da disponibilidade de leitos de UTI no período de fevereiro de 2020 a abril de 2021. Esperamos apresentar um panorama da disponibilidade dos leitos de UTI em face da pandemia da Covid- 19 e sensibilizar governantes e gestores sobre a necessidade de garantir dados fidedignos e atualizados, com vistas ao aprimoramento e uso do CNES na tomada de decisões sobre a rede prestadora de serviços de saúde. 


\section{DISPONIBILIDADE DE LEITOS UTI ADULTOS NO INIICIO DA PANDEMIA}

Considerando a taxa global de disponibilidade de equipamentos médicos - do Sistema Único de Saúde (SUS) e da Saúde Suplementar - por 10 mil habitantes em fevereiro de 2020, observamos que $90,4 \%$ dos municípios no país não contabilizavam leitos de UTI para adultos.' Apenas 42 I municípios, em 25 estados e no Distrito Federal, apresentaram capacidade estrutural inicial ${ }^{2}$ para o atendimento hospitalar de pacientes com Covid- 19 grave, considerado um critério de disponibilidade mínima simultânea de leitos de UTI, tomógrafos, respiradores/ventiladores, monitores de eletrocardiograma (ECG), desfibriladores e bombas de infusão. O estado do Amapá não registrou nenhum município na lista, e os estados do Amazonas, Roraima e Sergipe tiveram, cada um, apenas um município entre os identificados (Portela et al., 2020a). Outros estudos com base no CNES igualmente atestaram a insuficiência da capacidade instalada de equipamentos (leitos clínicos, leitos de UTI, respiradores, laboratórios) no sistema de saúde brasileiro (oferta SUS e não SUS), assim como desigualdades regionais, reportando a necessidade de maiores ou menores ajustes diante do crescimento das curvas de expansão da pandemia (Castro et al., 2020; Costa E Lagos, 2020; Noronha et al., 2020; Rache et al., 2020).

Cidades das regiões Sul e Sudeste mostraram maior disponibilidade de recursos hospitalares complexos, com taxas globais entre I e 5 leitos de UTI por I 0 mil habitantes. Nessas regiões, destacaram-se algumas áreas com taxas acima de 10 leitos de UTI por 10 mil habitantes na Saúde Suplementar (Figura I) (Portela et al., 2020a).

\footnotetext{
' As taxas foram calculadas para equipamentos e leitos de UTI por 10 mil habitantes. Os dados relativos à população e ao número de beneficiários de planos de saúde hospitalares foram obtidos, respectivamente, do Instituto Brasileiro de Geografia e Estatística (estimativas da população de 2019) e da Agência Nacional de Saúde Suplementar (último trimestre de 2019) (IBGE, 2020; ANS, 2020)

${ }^{2}$ Existência de I equipamento por 10 mil habitantes para respiradores/ventiladores, monitores de ECG, desfibriladores e bombas de infusão, e uma taxa positiva de tomógrafos e leitos de UTI.
} 
Figura I - Leitos de UTI por I 0 mil habitantes: taxas globais (equipamentos disponíveis no SUS e na Saúde Suplementar em relação à população total), no SUS (em referência à população exclusivamente dependente do SUS) e na Saúde Suplementar (em referência à população de beneficiários de planos de saúde) - Brasil, fev. 2020
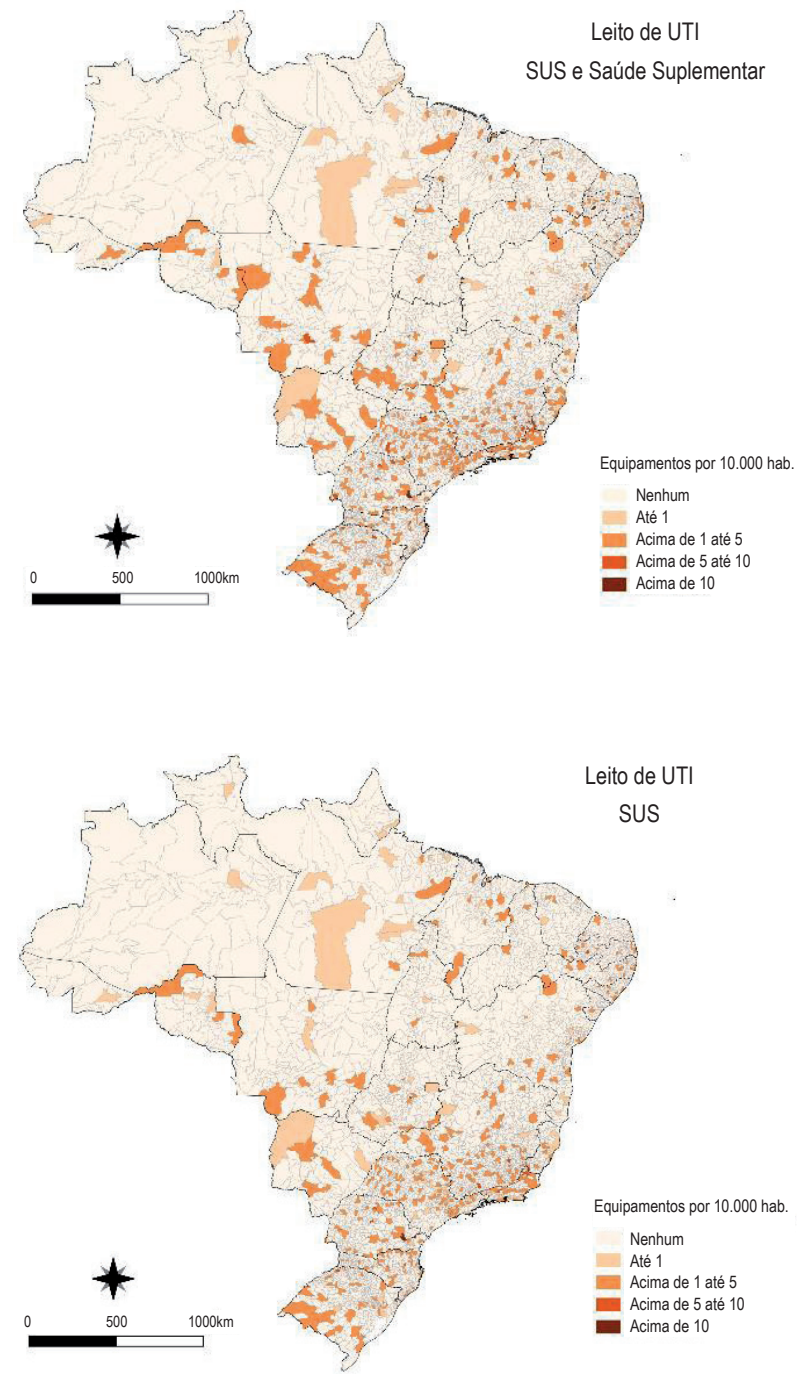
Figura I - Leitos de UTI por I 0 mil habitantes: taxas globais (equipamentos disponíveis no SUS e na Saúde Suplementar em relação à população total), no SUS (em referência à população exclusivamente dependente do SUS) e na Saúde Suplementar (em referência à população de beneficiários de planos de saúde) - Brasil, fev. 2020 (continuação)

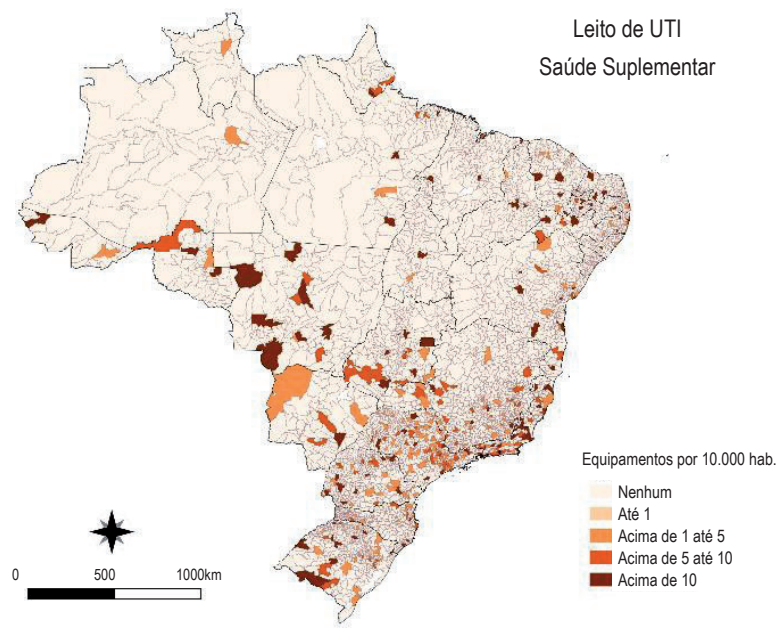

Fonte: Ministério da Saúde - Cadastro Nacional dos Estabelecimentos de Saúde do Brasil.

Considerando as 450 regiões de Saúde (RS) do país, observamos que, em fevereiro de 2020, 239 regiões apresentavam capacidade estrutural inicial para a prestação de cuidados hospitalares mais complexos a pacientes graves com Covid-19. Nenhuma RS no Amapá atendeu ao critério estabelecido, embora se deva sublinhar que a RS Área Central, onde se situa Macapá, dispunha de 40 leitos de UTI (I 2 SUS e 28 não SUS) (Figura 2) (Portela et al., 2020b). 
Figura 2 - Leitos de UTI por 10 mil habitantes nas regiões de Saúde: taxas globais (equipamentos disponíveis no SUS e na Saúde Suplementar em relação à população total), no SUS (em referência à população exclusivamente dependente do SUS) e na Saúde Suplementar (em referência à população de beneficiários de planos de saúde) - Brasil, fev. 2020
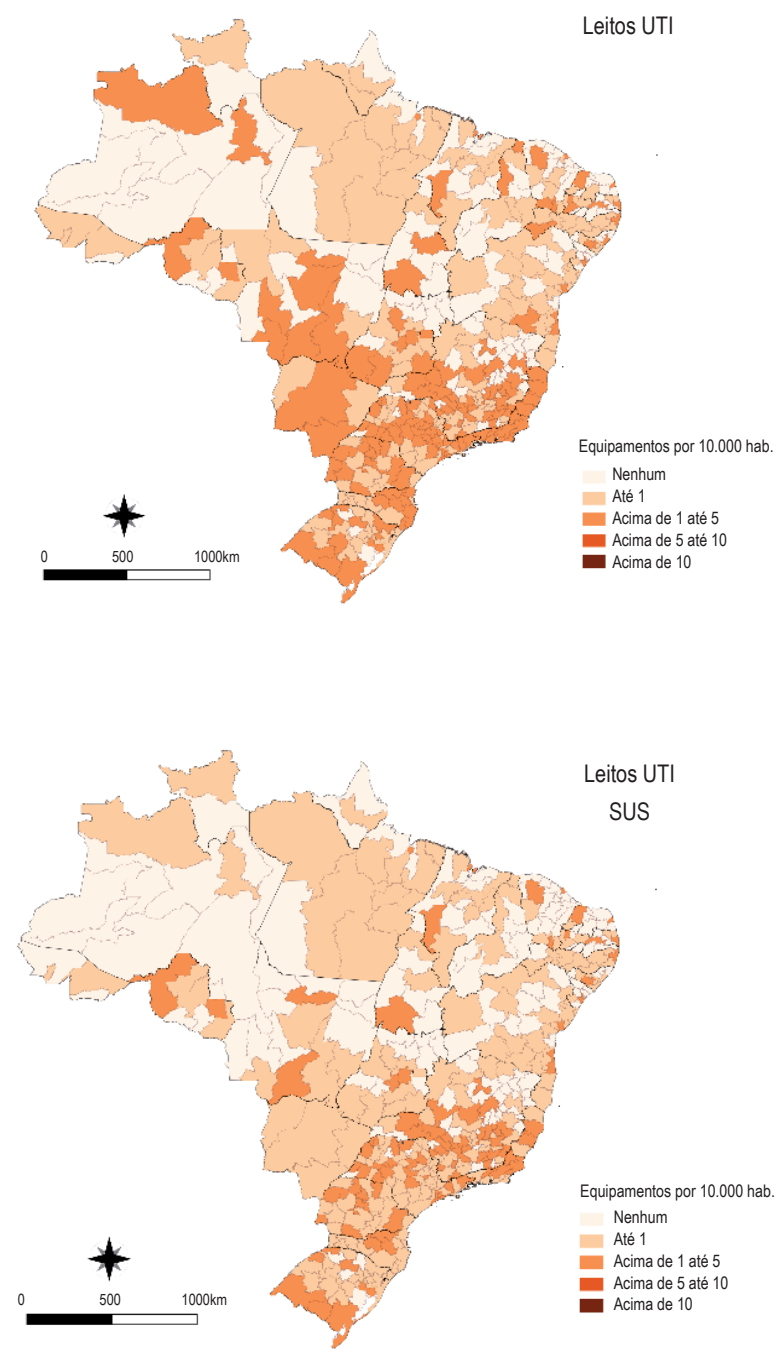
Figura 2 - Leitos de UTI por 10 mil habitantes nas regiões de Saúde: taxas globais (equipamentos disponíveis no SUS e na Saúde Suplementar em relação à população total), no SUS (em referência à população exclusivamente dependente do SUS) e na Saúde Suplementar (em referência à população de beneficiários de planos de saúde) - Brasil, fev. 2020 (continuação)

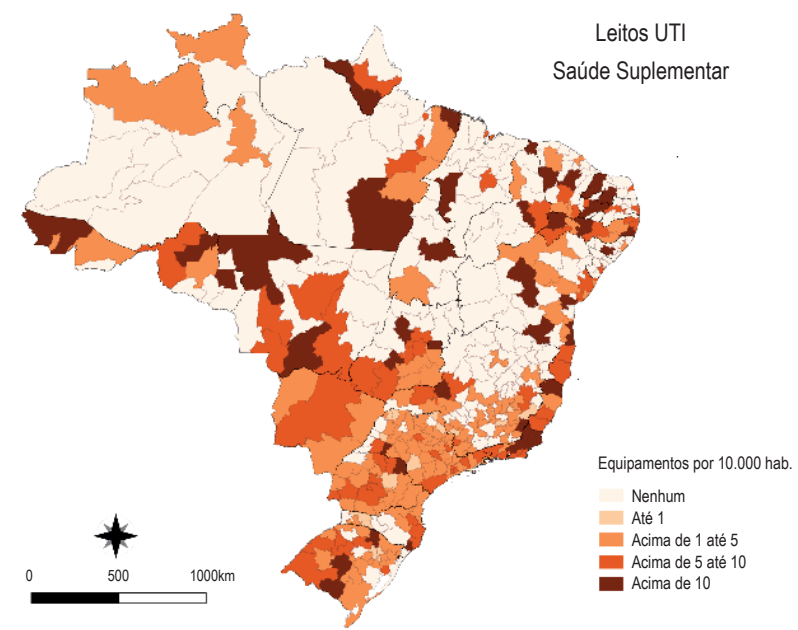

Fonte: Ministério da Saúde - Cadastro Nacional dos Estabelecimentos de Saúde do Brasil.

Destacamos a ausência de leitos de UTI em mais de um quarto das RS porque remetia, na prática, à impossibilidade de acesso de parte da população brasileira a cuidados mais complexos. Havia grandes vazios na oferta de leitos de UTI nas regiões Norte, Nordeste e Centro-Oeste, e alguns pequenos vazios no Sudeste e no Sul (Figura 2) (Portela et al., 2020b).

A contraposição dos mapas na Figura 2 evidencia importante capilaridade do SUS e concentração da Saúde Suplementar (SS), com expressiva oferta para a população de beneficiários de planos de saúde hospitalares em uma parte do país. Tal situação poderia potencializar a oferta de leitos de UTI em algumas áreas das diferentes regiões, mais especialmente no Sudeste, Sul e Centro-Oeste.

As 239 RS identificadas com capacidade instalada inicial agregavam 3.205 municípios ( $57,5 \%$ do total do país). Nessas regiões, a presença de 37 I dos 421 municípios identificados com capacidade instalada inicial sugeriu que eles se constituiriam na sustentação da oferta de serviços complexos nas regiões correspondentes. Os outros 50 municípios teriam capacidade para atender as suas populações, mas não disporiam de recursos suficientes para sustentar as RS em que estão inseridos. As 239 RS e os 
50 municípios adicionais agregavam, respectivamente, $76,4 \%$ e 2,5\% da população brasileira, sugerindo que $78,9 \%$ da população do país teriam, no início da pandemia, condições estruturais mínimas de obter atendimento para casos graves da Covid- I 9 (Portela et al., 2020b), pressupondo-se a possibilidade de dispor dos recursos públicos e privados.

Ao considerar as taxas de disponibilidade de leitos de UTI no SUS e na SS em relação à população exclusivamente dependente do SuS e à população de beneficiários de planos de saúde, respectivamente, observamos que 163 (30,4\%) dos 536 municípios tinham disponibilidade de leitos exclusiva ou mais favorável no SUS. Em contrapartida, 376 (69,6\%) municípios apresentavam taxas de disponibilidade de leitos de UTI mais favoráveis na SS, com 7 I deles apresentando razões entre as taxas na SS e no SUS superiores a 8, e 60 sem leitos no SUS (Tabela I) (Portela et al., 2020c).

Excluindo-se os 60 municípios com recursos somente na SS, a razão entre as taxas de disponibilidade de leitos de UTI na SS e no SUS variou entre 0 e 140,7 (mediana 2, I); $50 \%$ dos municípios apresentaram razão igual ou inferior a 2, I e 75,0\% razão igual ou inferior a 5,2 (Tabela I).

Tabela I - Distribuição dos municípios segundo disponibilidade de leitos de UTI no SuS e na Saúde Suplementar (SS) - Brasil, fev. 2020

\begin{tabular}{l|c|c}
\hline \multirow{2}{*}{\multicolumn{1}{c}{ Recursos }} & \multicolumn{2}{c}{ Disponibilidade de leitos de UTI } \\
\cline { 2 - 3 } & $N$ & $\%$ \\
\hline Nenhum & 5.034 & 90,4 \\
\hline Somente SUS & 130 & 2,3 \\
\hline Mix de recursos SUS e SS & 346 & 6,2 \\
\hline Razão TxSS/TxSUS: $>0$ - I & 33 & 0,6 \\
\hline Razão TxSS/TxSUS: $>$ I-4 & 162 & 2,9 \\
\hline Razão TxSS/TxSUS: $>4-8$ & 80 & 1,4 \\
\hline Razão TxSS/TxSUS: $>8$ & 71 & 1,3 \\
\hline Somente SS & 60 & 1,1 \\
\hline Total & 5.570 & 100,0 \\
\hline
\end{tabular}

Fonte: Ministério da Saúde - Cadastro Nacional dos Estabelecimentos de Saúde do Brasil. TXSS - número de equipamentos não SUS X 10.000/beneficiários de planos de saúde hospitalares TxSUS - número de equipamentos SUS X 10.000/habitantes-beneficiários de planos de saúde hospitalares 
A Figura 3 permite a visualização dos vazios assistenciais quanto à disponibilidade dos leitos de UTI considerados no território nacional, das áreas em que só existiam ou prevaleciam recursos do SUS (razão $\leq$ I) e das outras onde as taxas de disponibilidade na SS assumiam valores algumas vezes maiores do que aquelas no SUS, ou os equipamentos existentes eram exclusivamente do setor privado não conveniado ao SUS. A oferta no SUS mostrou-se mais capilarizada, mas observamos várias áreas de concentração de recursos privados, especialmente nas regiões Sudeste, Sul e Centro Oeste. No Nordeste, tais concentrações foram mais pontuais, e no Norte chamaram atenção municípios no estado de Rondônia.

Figura 3 - Razões entre taxas de disponibilidade de leitos de UTI na Saúde Suplementar e no SUS - Brasil, fev. 2020

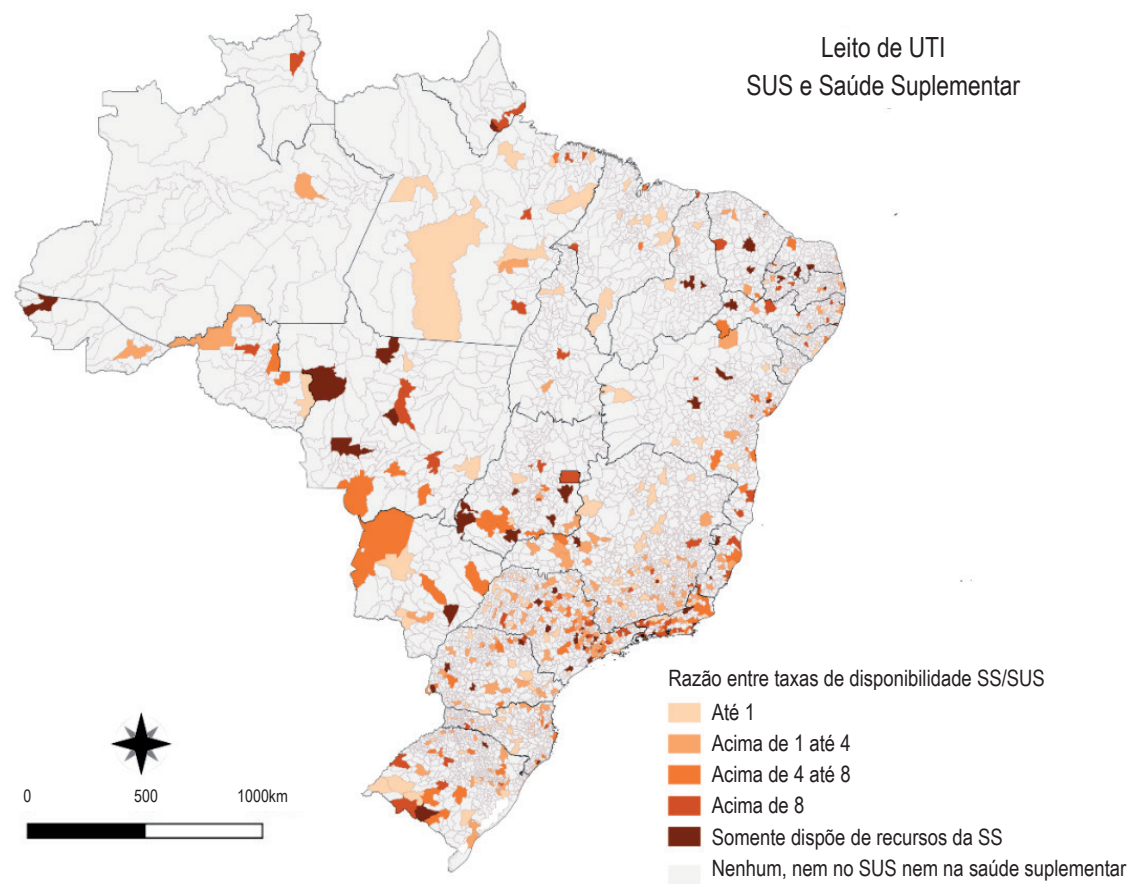

Fonte: Ministério da Saúde - Cadastro Nacional dos Estabelecimentos de Saúde do Brasil. 


\section{EVOLUÇÃO DA DISPONIBILIDADE DOS LEITOS DE UTI DE FEVEREIRO DE 2020 A ABRIL DE 2021}

A Figura 4 evidencia o incremento de leitos de UTI para adultos a partir de março de 2020 em face da necessidade de cobrir demandas trazidas pela Covid-19 (Brasil, 2020). O CNES passou a adotar uma nova categoria de leitos de UTI orientados para a assistência a pacientes com síndrome respiratória aguda grave (Srag), incluindo mais especificamente a Covid-19. Assim, registrou-se, desde março, crescimento da oferta global de leitos de UTI, mais expressivamente materializada pela abertura ou adaptação de leitos para a nova categoria (Figura 4).

Figura 4 - Leitos de UTI Adulto, UTI Adulto Covid- 19 e totais - Brasil, fev. 2020 a abr. 2021

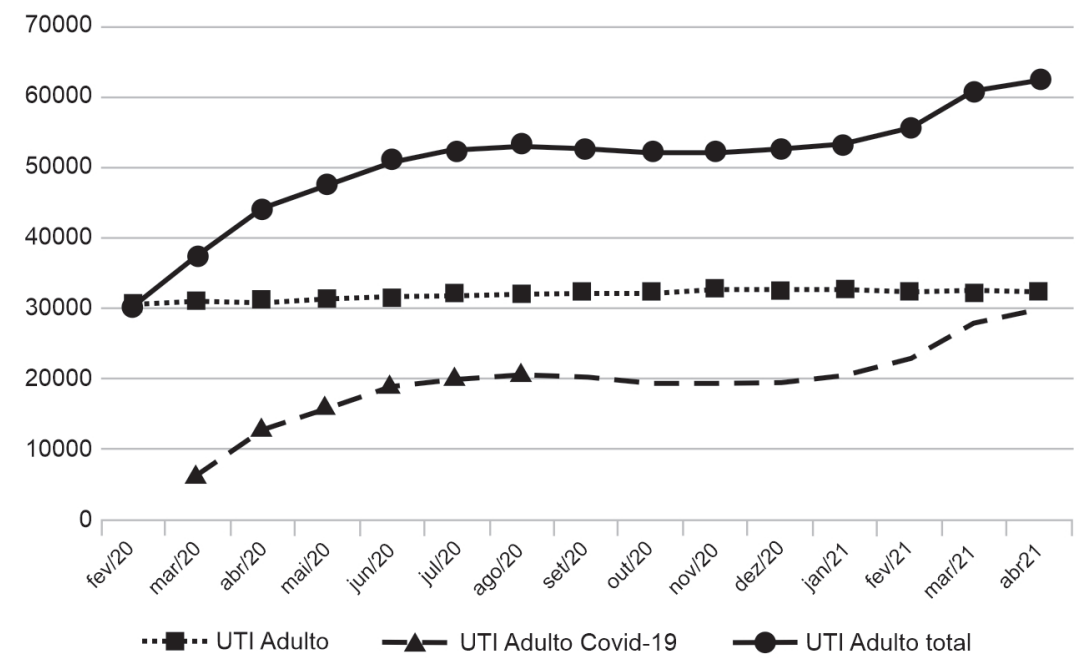

Fonte: Ministério da Saúde - Cadastro Nacional dos Estabelecimentos de Saúde do Brasil.

Muitos estados optaram pela abertura de leitos em hospitais de campanha inaugurados exclusivamente com a finalidade de atender aos pacientes com Covid- 19 , mas a redução da pressão exercida pela pandemia em agosto terminou resultando no fechamento de parte desses leitos. A partir de fevereiro de 2021, observamos novo incremento de leitos de UTI Srag/Covid- I 9, dessa vez não associado necessariamente à abertura de hospitais de campanha. Verifica-se, ainda, no decorrer do período entre fevereiro de 2020 e abril de 202I, discreto aumento na oferta de leitos de UTI nas categorias regulares (Brasil, 2020, 2021). 
Comparada à disponibilidade de leitos de UTI para adultos em fevereiro de 2020, dados de abril de 2021 indicam, no país como um todo, a adição de 1.709 leitos regulares de UTI para adultos e 29.964 leitos Srag/Covid- 19 de UTI para adultos. Entre os leitos regulares novos, $86,8 \%$ foram instalados em municípios e 93,0\% em regiões identificados com condições mínimas para a oferta de cuidados complexos a pacientes com Covid- 19 grave no início da pandemia. Dos leitos Srag/Covid-19, 83,6\% foram instaladas em municípios e $87,8 \%$ em regiões com condições mínimas prévias para o cuidado de alta complexidade. Esse achado é consistente com a expectativa que se tinha na elaboração das notas técnicas que alicerçam este capítulo (Portela et al., 2020a, 2020b), de que o aumento da capacidade instalada de leitos de UTI se daria principalmente em locais que já dispunham de estrutura para a assistência de alta complexidade. O crescimento da oferta desse tipo de recurso depende, além da vontade política e de investimento financeiro, de outras estruturas, equipes de profissionais da saúde capacitados para o cuidado intensivo e capacidade organizacional e assistencial para os processos de cuidado requeridos.

Dos 29.964 leitos de UTI Srag/Covid- 19 abertos, 45, 1 \% foram instalados na região Sudeste, 23,8\% na região Nordeste, 1 5,6\% na região Sul, 8,9\% na região Centro-Oeste e $6,7 \%$ na região Norte. Ainda que ratificando as limitações intrínsecas à abertura de leitos de UTI para a redução das imensas desigualdades verificadas na distribuição de recursos assistenciais complexos no país (Portela et al., 2020c), vale sublinhar que foi especialmente na região Norte que, proporcionalmente, mais leitos de UTI Srag/Covid- 19 foram abertos em municípios sem capacidade instalada inicial para cuidados em casos de Covid- 19 grave. De 2.000 leitos de UTI Srag/Covid- 19 abertos na região Norte, $28,7 \%$ foram instalados em municípios desse tipo. Nas regiões Nordeste e Centro-Oeste, também caracterizadas por alguns vazios assistenciais, 20,5\% dos 7.126 e 20, I \% dos 2.656 novos leitos de UTI para adultos Srag/Covid- 19 , respectivamente, foram instalados em municípios sem capacidade inicial para cuidados em casos de Covid- 19 grave.

O exame retrospectivo dos dados apresentados indubitavelmente remete a reflexões sobre as dificuldades de se compensarem desigualdades como as observadas no Brasil - com sua dimensão continental - em termos de distribuição de recursos assistenciais complexos, em uma situação de desastre como a da pandemia de Covid- 19. Resultados relativos à mortalidade geral e hospitalar por Covid- I 9 no país, entre outros elementos, certamente refletem essas desigualdades, e não se pode deixar de destacar os resultados negativos decorrentes dos imensos problemas de acesso e qualidade do cuidado hospitalar na região Norte, em especial nos estados do Amazonas, Amapá, Acre e Roraima (Andrade et al., 2020; Ranzani et al., 202I). 
Outra importante reflexão diz respeito à opção frequente pela abertura de novos leitos de UTI em hospitais de campanha. Por um lado, reconhecemos que a plasticidade que se exige na adaptação da rede de serviços para dar conta da Covid- I 9 talvez comporte, de fato, a necessidade de estruturas mais flexíveis. Entretanto, precisaria ter sido considerada a oportunidade de criação de estruturas permanentes com a recuperação de leitos já existentes no SUS, o que parece que vem acontecendo desde fevereiro de 2021 , com potencial de proporcionar um fortalecimento mais perene do sistema público de saúde.

Cabe uma reflexão sobre a enorme resistência que se observou no país, por parte seja dos órgãos executivos, seja do Poder Judiciário, à possibilidade de, diante de uma catástrofe, se potencializar a disponibilidade de leitos do setor público com leitos do setor privado, especialmente nas regiões de grande concentração desses recursos voltados exclusivamente para o setor da SS. Apesar do posicionamento de muitos especialistas e de membros da defensorias públicas dos estados a favor da instituição de mecanismos de regulação única, prevaleceu a separação dos leitos públicos e privados para, respectivamente, cidadãos dependentes exclusivamente de recursos do SuS e cidadãos beneficiários de planos de saúde privados. Acreditamos que com mecanismos de regulação comum de leitos públicos e privados se permitiria o acesso dos pacientes a leitos de UTI de forma mais equânime no território nacional.

\section{O APRIMORAMENTO DO CNES É ESTRATÉGICO}

Os dados e reflexões aqui apresentados propiciam uma visão geral da evolução da disponibilidade de leitos de UTI no país no contexto da pandemia de Covid-19, entre fevereiro de 2020 e abril de 2021. Ainda que o CNES frequentemente sofra críticas severas sobre a confiabilidade dos seus dados, é inegável a sua importância e necessidade de aperfeiçoamento para que de forma mais fidedigna possa subsidiar o planejamento e ações relativas à organização da rede de serviços de saúde em condições normais e excepcionais como a da pandemia. Em termos gerais, acreditamos que as análises apresentadas, ainda que possam conter imperfeições acerca de algumas especificidades, permitem uma boa fotografia do cenário geral.

A abordagem adotada com a análise dos dados do CNES certamente simplifica o cenário ao considerar recursos e usuários do SUS e da SS de forma compartimentada, o que não reflete a complexidade das relações entre os setores público e privado e, efetivamente, o fato de o SUS ser universal e, portanto, disponível para todos. Entretanto, permite uma aproximação ao quadro que, na prática, redunda em importantes desigualdades, pelo menos em parte do país, no acesso a serviços relevantes para o cuidado de pacientes 
graves com Covid- 19; obviamente, desigualdades de oferta e acesso já conhecidas, mas que ganharam espaço ímpar na agenda sanitária e da sociedade.

Outro ponto a ser ressaltado é a relevância de sistemas nacionais de informação em saúde coordenados no nível central, como o CNES, o Sistema de Informações Hospitalares, o Sistema de Informações Ambulatoriais, o Sistema de Informação de Mortalidade e o Banco de Dados de Síndrome Respiratória Aguda Grave, entre outros. Tais sistemas são imprescindíveis para oferecer informações necessárias ao planejamento, gestão, monitoramento e avaliação das condições de saúde, oferta, uso e resultados produzidos pelos serviços de saúde. E se tornam ainda mais necessários em situações emergenciais como a da Covid-19. Os diagnósticos propiciados por esses dados serão tão mais precisos quanto mais os gestores municipais e estaduais compreendam que somente com o registro regular, periódico, confiável e válido das informações de sua rede de atenção esses sistemas poderão oferecer subsídios para que decisões sejam tomadas com base sobretudo em evidências.

Possivelmente, ajustes podem e devem ser realizados no CNES e nos demais sistemas de informação oficiais, mas somente com seu uso se evidenciam as lacunas a serem preenchidas e/ou aspectos a serem ajustados. Ademais, com algumas exceções, os sistemas de informação sobre a produção de serviços de saúde incluem apenas os atendimentos no SUS, portanto é necessário conhecer o papel da SS na produção desses serviços.

Em suma, reconhecemos os limites relativos à qualidade dos dados disponíveis no CNES, mas ressaltamos a sua importância como única fonte capaz de propiciar uma apreciação geral da disponibilidade de recursos estruturais disponíveis nos serviços de saúde do país para o direcionamento de ações, a curto prazo, para o enfrentamento da Covid-19. Ademais, supõe-se maior fidedignidade nos dados relativos aos recursos mais complexos, tais como leitos de UTI.

\section{REFERÊNCIAS}

AGÊNCIA NACIONAL DE SAÚDE SUPLEMENTAR (ANS). Dados e indicadores do setor: links e arquivos relativos aos dados e indicadores do setor. Disponível em: <www.ans.gov.br/perfil-do-setor/dados-eindicadores-do-setor >. Acesso em: I abr. 2020.

ANDRADE, C. L. T. et al. Covid- 19 hospitalizations in Brazil's Unified Health System (SUS). PlosOne, 15(I2): e0243 I26, 2020. Disponível em: <https://doi.org/I0.137 I/journal.pone.0243 I26>. Acesso em: 6 jan. 2021.

BRASIL. Ministério da Saúde. Gabinete do Ministro. Portaria n. 414 de 18 mar. 2020. Autoriza a habilitação de leitos de Unidade de Terapia Intensiva Adulto e Pediátrico, para atendimento exclusivo dos pacientes Covid-1 9, 2020. Disponível em <www.in.gov.br/en/web/dou/-/portaria-n-4l 4-de- I8de-marco-de-2020-249025222>. Acesso em: 5 jan. 2021. 
BRASIL. Ministério da Saúde. CNES: Cadastro Nacional de Estabelecimentos de Saúde. Disponível em: $<w w w 2$.datasus.gov.br/DATASUS/index.php?area $=090 \mid$ I $i t e m=\mid$ Eacao $=3 \mid$ I pad $=31655>$. Acesso em: 12 jan. 2021.

CASTRO, M. et al. Demand for hospitalization services for Covid- 9 patients in Brazil. MedRxiu, I abr. 2020. Disponível em: <https://doi.org/I 0. I I 0 I/2020.03.30.20047662>. Acesso em: 9 jan. 202 I.

COSTA, N. R. \& LAGOS, M. J. A disponibilidade de leitos em unidade de tratamento intensivo no SUS e nos planos de saúde diante da epidemia da Covid- 9 no Brasil. Nota técnica. Rio de Janeiro, 19 mar. 2020.

INSTITUTO BRASILEIRO DE GEOGRAFIA E ESTATÍSTICA (IBGE). Estimativas de População 2019. Disponível em: <www.ibge.gov.br/estatisticas/sociais/populacao/9l03-estimativas-de- populacao. html? =Et=downloads $>$. Acesso em: I abr. 2020.

NORONHA, K. et al. Análise de demanda e oferta de leitos hospitalares gerais, UTI e equipamentos de ventilação assistida no Brasil em função da pandemia do Covid-19: impactos microrregionais ponderados pelos diferenciais de estrutura etária, perfil etário de infecção e risco etário de internação. Nota técnica n. I. Belo Horizonte: Cedeplar/UFMG, 2020.

PORTELA, M. C. et al. Limites e possibilidades dos municípios brasileiros para o enfrentamento dos casos graves de Covid- 19. Nota técnica n. I. Rio de Janeiro: Ensp/Fiocruz, 2020a.

PORTELA, M. C. et al. As regiões de saúde e a capacidade instalada de leitos de UTI e alguns equipamentos para o enfrentamento dos casos graves de Covid-19. Nota técnica n. 2. Rio de Janeiro: Ensp/Fiocruz, 2020b.

PORTELA, M. C. et al. Disponibilidade de recursos e razão de dependência entre SUS e Saúde Suplementar. Nota técnica n. 3. Rio de Janeiro: Ensp/Fiocruz, 2020c.

RACHE, B. et al. Necessidades de infraestrutura do SUS em preparo à Covid- 1 9: leitos de UTI, respiradores e ocupação hospitalar. Nota técnica n. 3. São Paulo: leps, 2020.

RANZANI, O. T. et al. Characterisation of the first 250000 hospital admissions for Covid- 19 in Brazil: a retrospective analysis of nationwide data. The Lancet Respiratory Medicine, 9(4): 407-4I8, 202I. Disponível em: <www.thelancet.com/journals/lanres/article/PIIS22 I3-2600(20)30560-9/fulltext>. Acesso em: 10 jan. 2021 . 


\title{
Cenários de Regionalização para Atenção Hospitalar à Covid-19 no Estado do Rio de Janeiro
}

\author{
Ricardo Antunes Dantas de Oliveira, Francisco Viacava, \\ Anselmo Rocha Romão, Mônica Martins, \\ Carolina de Campos Carvalho e Caio de Paula Peixoto
}

— stão sintetizados aqui os principais pontos da nota técnica "Cenários de regionalização

L para atenção ao Covid-19 no estado do Rio de Janeiro", elaborada no âmbito do Projeto de Avaliação de Desempenho do Sistema de Saúde do Laboratório de Informação em Saúde do Instituto de Comunicação e Informação Científica e Tecnológica em Saúde (Proadess/LIS/lcict/Fiocruz) em julho de 2020. Na referida nota técnica, para avaliar como estava se dando a atenção hospitalar aos pacientes com Covid- 19 no estado do Rio de Janeiro (ERJ) foram considerados os recursos disponíveis para o Sistema Único de Saúde (SUS), os municípios de ocorrência e os fluxos de pacientes para internação em outro município que não o de residência (Oliveira et al., 2020). E, com base na identificação da disponibilidade de leitos em unidade de terapia intensiva (UTI) no SUS são propostos arranjos regionais para a atenção aos casos graves, com a finalidade de reduzir a necessidade de deslocamentos de maiores distâncias e a pressão sobre os recursos de alguns municípios, marcadamente na capital fluminense.

Quando o estudo foi iniciado, ao final da $28^{\mathrm{a}}$ semana epidemiológica (SE) da Covid- 19 , haviam sido registrados 124.086 casos e 10.88 I óbitos confirmados no estado, segundo o Sistema de Informação de Vigilância Epidemiológica da Gripe, o Sivep Gripe (acesso em 7 jul. 2020). Os dados das internações por Covid- 19 e síndrome respiratória aguda grave (Srag)' referentes ao período de 01/0 I/2020 a 23/06/2020 demonstravam pouco mais de 36 mil internações, das quais $51,5 \%$ tiveram confirmado o diagnóstico de Covid- 19 (Sivep Gripe, 23 jun. 2020). A capital havia realizado 64\% das

\footnotetext{
' No Sivep Gripe, as internações foram distinguidas em dois tipos: I) Srag - casos com residência no estado do Rio de Janeiro hospitalizados, diagnosticados com "outras Srags" ou em investigação; 2) Covid- 19 - casos com residência no estado do Rio de Janeiro diagnosticados com "Covid- I9" ou "Sars-CoV-2" (Brasil, 2020b).
} 
internações, e frequências relevantes foram também observadas em Niterói, Duque de Caxias e São Gonçalo (Brasil, 2020b).

Em virtude, principalmente, da implementação de medidas de isolamento e distan-

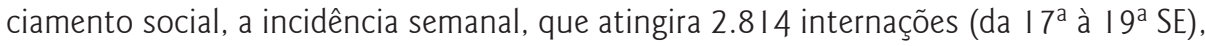
encontrava-se em torno de 718 casos. Grandes reduções haviam ocorrido no número de óbitos semanais, que, de aproximadamente 1.380 nesse período, passaram para 147 na $27^{\text {a }}$ SE. A tendência das internações por Srag, excluídas aquelas por Covid-19, era semelhante. De aproximadamente 2.000 internações diárias na $19^{a}$ SE, passou-se a 239

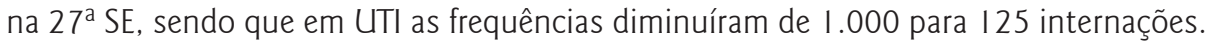
Deve-se observar que dados divulgados pelo Sivep Gripe retratavam o panorama de situações de aproximadamente 15 dias anteriores.

Em razão dessa progressiva redução, o investimento em hospitais de campanha e novos leitos de UTI passou a ser repensado, com fortes indicativos de interrupção dessa estratégia. Outra grande preocupação, naquele momento, dizia respeito à propagação da pandemia para o interior do ERJ, ${ }^{2}$ e, considerando a evolução nas regiões inicialmente atingidas, era oportuno aprimorar o sistema de regulação para viabilizar um fluxo mais efetivo entre os municípios, evitando sobrecarregar determinados serviços.

Diante desse contexto, procurando compreender a regionalização de fato do cuidado em saúde para os casos graves de Covid-19, foram construídos e comparados distintos cenários, atentando-se para a conformação estabelecida e a dinâmica pandêmica, além dos municípios que estavam desempenhando papel de polos. Foram caracterizados como polos os municípios que possuíam maior oferta de recursos de saúde, e assim poderiam atender também a população de outros municípios.

Além da utilização das informações sobre internações do Sivep Gripe, foram utilizadas outros dois dados: I) capacidade instalada da rede, em termos de leitos de UTI disponíveis para o SUS segundo o Cadastro Nacional de Estabelecimentos de Saúde (CNES), tendo como referência o mês de maio de 2020; e 2) municípios mais procurados para utilização de serviços de saúde de alta complexidade segundo a Pesquisa Regiões de Influência das Cidades, do Instituto Brasileiro de Geografia e Estatística, a Regic (IBGE, 20 I 8). ${ }^{3}$

\footnotetext{
${ }^{2}$ Conforme a NT I I do MonitoraCovid- 19, "No entorno do Rio de Janeiro também houve um excesso significativo de óbitos em relação a anos anteriores, observado mesmo com atraso de dados relativos à mortalidade. Nos meses de abril e maio de 2020 foram contabilizados cerca de 7.400 óbitos em excesso" (Fiocruz, 2020: I).

${ }^{3}$ A Regic foi aplicada em 5.503 municípios, de abril a agosto de 2018, coletando respostas de três informantes previamente estabelecidos. Foram excluídos da aplicação municípios que mais geram deslocamentos por atração da população de outros municípios em busca de bens e serviços do que enviam sua própria população para os demais. Esses municípios integram a base como destinos de si mesmos.
} 


\section{OFERTA DE RECURSOS, INTERNAÇÕES POR COVID-19 E REGIONALIZAÇÃO DA ATENÇÃO À SAÚDE NO ESTADO DO RIO DE JANEIRO}

Na Tabela I, observam-se as taxas populacionais do total de leitos de UTI, assim como de leitos de UTI disponíveis para o SUS existentes nos municípios nos quais foram realizadas cerca de 90\% das internações por Covid- 19 e Srag no período de 0 I/0 I/2020 a 23/06/2020, informação importante para se avaliar a efetividade da referência de casos pelo sistema de regulação no ERJ.

Tabela I - Oferta de leitos de UTI total e disponíveis para o SUS, número e taxa por 10 mil habitantes, segundo municípios de internação por Srag ou Covid- 19 - Estado do Rio de Janeiro, maio 2020

\begin{tabular}{|c|c|c|c|c|c|c|}
\hline $\begin{array}{l}\text { Município de } \\
\text { internação }\end{array}$ & $\begin{array}{c}\text { População } \\
\text { de } 20 \text { anos } \\
\text { ou mais }\end{array}$ & $\begin{array}{l}\text { Total de } \\
\text { leitos de } \\
\text { UTI (N) }\end{array}$ & $\begin{array}{c}\text { Leitos } \\
\text { de UTI } \\
\text { disponíveis } \\
\text { para o } \\
\text { SUS (N) }\end{array}$ & $\begin{array}{c}\text { Taxa de } \\
\text { leitos } \\
\text { de UTI/ } \\
\text { I0 mil hab. }\end{array}$ & $\begin{array}{c}\text { Taxa de } \\
\text { leitos de } \\
\text { UTI SUS/ } \\
\text { I0 mil hab. }\end{array}$ & $\%$ SUS \\
\hline Angra dos Reis & 148.048 & 23 & 8 & 1,55 & 0,54 & 34,8 \\
\hline Araruama & 100.432 & 16 & 8 & 1,59 & 0,80 & 50 \\
\hline Cabo Frio & 168.959 & 55 & 22 & 3,26 & $\mathrm{I}, 30$ & 40 \\
\hline $\begin{array}{l}\text { Campos dos } \\
\text { Goytacazes }\end{array}$ & 369.258 & 208 & 88 & 5,63 & 2,38 & 42,3 \\
\hline $\begin{array}{l}\text { Duque de } \\
\text { Caxias }\end{array}$ & 665.483 & 152 & 30 & 2,28 & 0,45 & 19,7 \\
\hline Guapimirim & 43.907 & 0 & 0 & 0 & 0 & * \\
\hline Itaboraí & 177.841 & 18 & 5 & $|, 0|$ & 0,28 & 27,8 \\
\hline Itaguaí & 96.208 & 10 & 0 & 1,04 & 0 & 0 \\
\hline Macaé & 182.947 & 74 & 22 & 4,04 & 1,20 & 29,7 \\
\hline Magé & 176.275 & 0 & 0 & 0 & 0 & * \\
\hline Maricá & 126.323 & 0 & 0 & 0 & 0 & * \\
\hline Mesquita & 129.419 & 0 & 0 & 0 & 0 & * \\
\hline Niterói & 409.387 & 250 & 62 & 6,11 & $|, 5|$ & 24,8 \\
\hline Nova Friburgo & 147.259 & 28 & 18 & I,90 & 1,22 & 64,3 \\
\hline Nova Iguaçu & 596.368 & 68 & 34 & 1,14 & 0,57 & 50 \\
\hline
\end{tabular}


Tabela I - Oferta de leitos de UTI total e disponíveis para o SUS, número e taxa por 10 mil habitantes, segundo municípios de internação por Srag ou Covid- 19 - Estado do Rio de Janeiro, maio 2020 (continuação)

\begin{tabular}{|c|c|c|c|c|c|c|}
\hline $\begin{array}{l}\text { Município de } \\
\text { internação }\end{array}$ & $\begin{array}{l}\text { População } \\
\text { de } 20 \text { anos } \\
\text { ou mais }\end{array}$ & $\begin{array}{l}\text { Total de } \\
\text { leitos de } \\
\text { UTI (N) }\end{array}$ & $\begin{array}{c}\text { Leitos } \\
\text { de UTI } \\
\text { disponíveis } \\
\text { para o } \\
\text { SUS (N) }\end{array}$ & $\begin{array}{c}\text { Taxa de } \\
\text { leitos } \\
\text { de UTI/ } \\
\text { I } 0 \text { mil hab. }\end{array}$ & $\begin{array}{l}\text { Taxa de } \\
\text { leitos de } \\
\text { UTI SUS/ } \\
\text { I } 0 \text { mil hab. }\end{array}$ & $\%$ SUS \\
\hline Petrópolis & 233.274 & 157 & 48 & 6,73 & 2,06 & 30,6 \\
\hline Resende & 97.685 & 41 & 9 & 4,20 & 0,92 & 22,0 \\
\hline Rio Bonito & 45.186 & 10 & 5 & 2,21 & 1,11 & 50 \\
\hline Rio das Ostras & 110.122 & 10 & 0 & 0,91 & 0 & 0 \\
\hline Rio de Janeiro & 5.105 .013 & 2.318 & 499 & 4,54 & 0,98 & 21,5 \\
\hline Saquarema & 67.306 & 15 & 15 & 2,23 & 2,23 & 100 \\
\hline São Gonçalo & 823.643 & 145 & 69 & 1,76 & 0,84 & 47,6 \\
\hline Teresópolis & 138.240 & 30 & 18 & 2,17 & 1,30 & 60 \\
\hline Valença & 58.213 & 20 & 20 & 3,44 & 3,44 & 100 \\
\hline Vassouras & 27.807 & 35 & 25 & 12,59 & 8,99 & 71,4 \\
\hline Volta Redonda & 210.573 & 118 & 19 & 5,60 & 0,90 & 16,1 \\
\hline Subtotal & 10.455 .176 & 3.801 & 1.024 & 3,64 & 0,98 & 26,9 \\
\hline $\begin{array}{l}\text { Total geral } \\
\text { do estado }\end{array}$ & 12.948 .193 & 4.077 & 1.185 & 3,15 & 0,92 & 29,1 \\
\hline
\end{tabular}

Fonte: CNES, maio de 2020 (Brasil, 2020a).

Uma comparação entre a taxas populacionais de internações por Covid- 19 e leitos de UTI disponíveis para o SUS indicou que havia cinco municípios nos quais ocorreram internações com diagnóstico confirmado de Covid- 19 que não dispunham de leitos de UTI SUS: Guapimirim, Itaguaí, Magé, Maricá e Mesquita. Os municípios com maior deficiência desses leitos eram Angra dos Reis, Duque de Caxias, Itaboraí e Rio de Janeiro. Por sua vez, situações de maior disponibilidade ocorriam em Campos dos Goytacazes, Valença, Vassouras, assim como em Itaperuna, que dispunha de boa oferta de leitos (8,28 para 10 mil hab.), mas apenas três internações ocorreram nesse município na $25^{\mathrm{a}}$ semana. A relação entre total de internações por Covid- 19 e leitos de UTI SUS foi considerada relevante pela possibilidade de contratação da rede 
privada em locais onde era baixa a oferta de leitos SUS, como Itaboraí, Angra dos Reis, Nova Iguaçu e, principalmente, Duque de Caxias, onde apenas 19,7\% dos leitos de UTI estavam disponíveis para o SUS.

Municípios como Campos dos Goytacazes, Angra dos Reis e Macaé seriam polos segundo os critérios de disponibilidade de recursos, porém neles praticamente todas as internações por Covid- 19 haviam sido de residentes (Tabela 2). Municípios como Niterói, Volta Redonda, Nova Iguaçu e Cabo Frio, por sua vez, atenderam de 30 a 50\% de não residentes, o que os confirmaria como polos.

Tabela 2 - Municípios de internação e residência de pacientes internados por Covid- 19 e Srag - Estado do Rio de Janeiro, 01 jan. a 23 jun. 2020

\begin{tabular}{|c|c|c|c|}
\hline Município de internação & Município de residência & Internações (N) & $\%$ \\
\hline \multirow{3}{*}{ Angra dos Reis } & Angra dos Reis & 305 & $93,8 \%$ \\
\hline & Outros & 20 & $6,2 \%$ \\
\hline & Total & 325 & $100,0 \%$ \\
\hline \multirow{4}{*}{ Cabo Frio } & Cabo Frio & 97 & $65,5 \%$ \\
\hline & São Pedro da Aldeia & 27 & $18,2 \%$ \\
\hline & Outros & 24 & $16,2 \%$ \\
\hline & Total & 148 & $100,0 \%$ \\
\hline \multirow{3}{*}{ Campos dos Goytacazes } & Campos dos Goytacazes & 190 & $96,0 \%$ \\
\hline & Outros & 8 & $4,0 \%$ \\
\hline & Total & 198 & $100,0 \%$ \\
\hline \multirow{6}{*}{ Duque de Caxias } & Duque de Caxias & 497 & $74,2 \%$ \\
\hline & Rio de Janeiro & 53 & $7,9 \%$ \\
\hline & São João de Meriti & 50 & $7,5 \%$ \\
\hline & Belford Roxo & 37 & $5,5 \%$ \\
\hline & Outros & 33 & $4,9 \%$ \\
\hline & Total & 670 & $100,0 \%$ \\
\hline \multirow{3}{*}{ Macaé } & Macaé & 322 & $90,7 \%$ \\
\hline & Outros & 33 & $9,3 \%$ \\
\hline & Total & 355 & $100,0 \%$ \\
\hline
\end{tabular}


Tabela 2 - Municípios de internação e residência de pacientes internados por Covid- 19 e Srag - Estado do Rio de Janeiro, 0 I jan. a 23 jun. 2020 (continuação)

\begin{tabular}{|c|c|c|c|}
\hline Município de internação & Município de residência & Internações (N) & $\%$ \\
\hline \multirow{7}{*}{ Niterói } & Niterói & 517 & $50,0 \%$ \\
\hline & São Gonçalo & 266 & $25,8 \%$ \\
\hline & Rio de Janeiro & 135 & $13,1 \%$ \\
\hline & Maricá & 33 & $3,2 \%$ \\
\hline & Itaboraí & 23 & $2,2 \%$ \\
\hline & Outros & 59 & $5,7 \%$ \\
\hline & Total & 1.033 & $100,0 \%$ \\
\hline \multirow{4}{*}{ Nova Friburgo } & Nova Friburgo & 137 & $73,3 \%$ \\
\hline & Cachoeiras de Macacu & 18 & $9,6 \%$ \\
\hline & Outros & 32 & $17,1 \%$ \\
\hline & Total & 187 & $100,0 \%$ \\
\hline \multirow{7}{*}{ Nova Iguaçu } & Nova Iguaçu & 302 & $69,6 \%$ \\
\hline & Belford Roxo & 30 & $6,9 \%$ \\
\hline & Mesquita & 27 & $6,2 \%$ \\
\hline & São João de Meriti & 22 & $5,1 \%$ \\
\hline & Queimados & 21 & $4,8 \%$ \\
\hline & Outros & 32 & $7,4 \%$ \\
\hline & Total & 434 & $100,0 \%$ \\
\hline \multirow{5}{*}{ Petrópolis } & Petrópolis & 275 & $70,3 \%$ \\
\hline & Duque de Caxias & 71 & $18,2 \%$ \\
\hline & Magé & 29 & $7,4 \%$ \\
\hline & Outros & 16 & $4,1 \%$ \\
\hline & Total & 391 & $100,0 \%$ \\
\hline \multirow{3}{*}{ Resende } & Resende & 48 & $85,7 \%$ \\
\hline & Outros & 8 & $14,3 \%$ \\
\hline & Total & 56 & $100,0 \%$ \\
\hline
\end{tabular}


Tabela 2 - Municípios de internação e residência de pacientes internados por Covid- 19 e Srag - Estado do Rio de Janeiro, 0 I jan. a 23 jun. 2020 (continuação)

\begin{tabular}{|c|c|c|c|}
\hline Município de internação & Município de residência & Internações (N) & $\%$ \\
\hline \multirow{8}{*}{ Rio de Janeiro } & Rio de Janeiro & 11.060 & $87,2 \%$ \\
\hline & Nova Iguaçu & 306 & $2,4 \%$ \\
\hline & Duque de Caxias & 273 & $2,2 \%$ \\
\hline & São João de Meriti & 235 & ।,9\% \\
\hline & Belford Roxo & 162 & $1,3 \%$ \\
\hline & Nilópolis & 105 & $0,8 \%$ \\
\hline & Outros & 545 & $4,3 \%$ \\
\hline & Total & 12.686 & $100,0 \%$ \\
\hline \multirow{3}{*}{ São Gonçalo } & São Gonçalo & 321 & $83,6 \%$ \\
\hline & Outros & 63 & $16,4 \%$ \\
\hline & Total & 384 & $100,0 \%$ \\
\hline \multirow{3}{*}{ Teresópolis } & Teresópolis & 107 & $86,3 \%$ \\
\hline & Outros & 17 & $13,7 \%$ \\
\hline & Total & 124 & $100,0 \%$ \\
\hline \multirow{5}{*}{ Volta Redonda } & Volta Redonda & 119 & $69,6 \%$ \\
\hline & Barra Mansa & 12 & $7,0 \%$ \\
\hline & Rio de Janeiro & 10 & $5,8 \%$ \\
\hline & Outros & 30 & $17,5 \%$ \\
\hline & Total & 171 & $100,0 \%$ \\
\hline \multicolumn{2}{|l|}{ Total } & 17.162 & \\
\hline
\end{tabular}

Fonte: Sivep Gripe, acesso em 23 jun. 2020 (Brasil, 2020b).

É interessante também observar a diversidade dos municípios de residência dos pacientes internados (Tabela 2). Em Niterói, mais da metade dos pacientes internados era de outros municípios; destes, 83,6\% eram de São Gonçalo. Em casos nos quais de 25 a 30\% dos internados residiam em outros municípios, sobressaíram-se dois locais: Cabo Frio e Nova Friburgo, onde esse percentual praticamente se restringiu a um único município - São Pedro da Aldeia e Cachoeiras de Macacu, respecti- 
vamente. Em outros municípios, como Nova Iguaçu e Duque de Caxias, pacientes se originavam de vários municípios adjacentes.

Do total de internações por Covid-19, 73,9\% foram realizadas no município do Rio de Janeiro, expressando a grande concentração da atenção hospitalar na capital. Mesmo com $87,2 \%$ das internações sendo de residentes no município, havia volume expressivo de residentes da Baixada Fluminense, em número absoluto superior ao de residentes internados na maioria desses municípios. Embora "apenas" 2,4\% das internações na capital tenham sido de residentes em Nova Iguaçu, o número absoluto (306) foi próximo ao das internações ocorridas no próprio município (302) (Tabela 2).

Segundo a Regic 2018, I I municípios se destacam como referências na procura por serviços de saúde de maior complexidade por outros 74 municípios. Nesse estudo, o IBGE identificou os outros sete municípios como autossuficientes ou que têm municípios de outro estado como referência, a exemplo de Juiz de Fora e Muriaé, em Minas Gerais.

Comparando os municípios de referência segundo as fontes de informação sobre recursos disponíveis para o SUS, taxas de internações por Covid- 19 e a Regic, obtivemos distintas combinações (Quadro I). Assim, oito figuraram como referências nas três fontes de informação (Angra dos Reis, Cabo Frio, Campos dos Goytacazes, Macaé, Niterói, Petrópolis, Rio de Janeiro e Volta Redonda). Outro conjunto de municípios (Duque de Caxias, Nova Friburgo, Nova Iguaçu, São Gonçalo e Teresópolis) incluiu aqueles referidos em duas fontes: oferta de recursos e internações por Covid-19. Três Rios, Itaperuna e Vassouras também foram referidos por duas fontes: oferta de recursos e Regic. Resende, Saquarema e Valença emergiram apenas no tocante à oferta de recursos SUS.

Quadro I - Municípios de referência segundo três fontes de informação - Estado do Rio de Janeiro, 2020

\begin{tabular}{|c|l|r|l|c|l|}
\hline \multicolumn{2}{|l|}{ Recursos SUS } & \multicolumn{2}{|c|}{ Internações $^{2}$} & \multicolumn{2}{c|}{ Regic $^{3}$} \\
\hline I & Angra dos Reis & I & Angra dos Reis & I & Angra dos Reis \\
\hline 2 & Cabo Frio & 2 & Cabo Frio & 2 & Cabo Frio \\
\hline 3 & Campos dos Goytacazes & 3 & Campos dos Goytacazes & 3 & Campos dos Goytacazes \\
\hline 4 & Duque de Caxias & 4 & Duque de Caxias & & \\
\hline 5 & Itaperuna & & & 4 & Itaperuna \\
\hline 6 & Macaé & 5 & Macaé & 5 & Macaé \\
\hline 7 & Niterói & 6 & Niterói & 6 & Niterói \\
\hline 8 & Nova Friburgo & 7 & Nova Friburgo & & \\
\hline 9 & Nova Iguaçu & 8 & Nova Iguaçu & & \\
\hline
\end{tabular}


Quadro I - Municípios de referência segundo três fontes de informação - Estado do Rio de Janeiro, 2020 (continuação)

\begin{tabular}{|c|l|r|l|c|l|}
\hline \multicolumn{2}{|l|}{ Recursos SUS } & \multicolumn{2}{|c|}{ Internações $^{2}$} & 7 & Petrópolic \\
\hline 10 & Petrópolis & 9 & Petrópolis \\
\hline 11 & Resende & & & & \\
\hline 12 & Rio de Janeiro & 10 & Rio de Janeiro & 8 & Rio de Janeiro \\
\hline 13 & São Gonçalo & 11 & São Gonçalo & & \\
\hline 14 & Saquarema & & & & \\
\hline 15 & Teresópolis & 12 & Teresópolis & & \\
\hline 16 & Três Rios & & & 9 & Três Rios \\
\hline 17 & Valença & & & & \\
\hline 18 & Vassouras & & & 10 & Vassouras \\
\hline 19 & Volta Redonda & 13 & Volta Redonda & 11 & Volta Redonda \\
\hline
\end{tabular}

Fontes: ' CNES, maio de 2020 (Brasil, 2020a).; ' Sivep Gripe, acesso em 23 jun. 2020 (Brasil, 2020b); ${ }^{3}$ IBGE, 20 I 8.

Repensar a regionalização da rede de serviços de saúde, em especial o acesso a recursos necessários ao cuidado de casos mais graves e sua otimização, requer, a priori, levar em conta as especificidades das fontes de informações trabalhadas. Assim, dados da Regic foram obtidos em 2018, portanto pré-pandemia, de informantes selecionados para tratar da realidade local, que responderam a questões diversas sobre, entre outros aspectos, a busca por serviços de alta complexidade. Municípios como Itaperuna e Vassouras se destacaram tanto pela oferta de serviços de saúde quanto pela Regic, contudo até o momento da análise não apareciam como polos de internação por Covid-19. Por sua vez, Nova Friburgo, Nova Iguaçu, São Gonçalo e Teresópolis, que segundo o CNES teriam recursos e estavam recebendo residentes de outros municípios para internação, não foram percebidos como polos na Regic. Apesar das diferenças entre as fontes de informação, a articulação destas permitiu esboçar cenários alternativos para a identificação de polos e seus arranjos regionais.

As propostas de polos e respectivos arranjos basearam-se nas taxas de leitos de UTI por habitantes em relação às populações locais e dos municípios demandantes. Também são importantes as distâncias e as possibilidades de acesso rodoviário. Assim, evidenciaram-se três outros cenários além das nove regiões de Saúde (RS) do ERJ: Regionalização I (com 15 polos), Regionalização 2 (com 12 polos) e Regionalização 3 (com I I polos), apresentados na Figura I. Vale mencionar que, tomado como ponto de partida as nove RS vigentes, os três cenários alternativos emergiram sequencialmente, 
ou seja, problemas de oferta e distância identificadas no cenário da Regionalização I, por exemplo, foram revistos para o cenário 2 .

Figura I - Regiões de Saúde do estado do Rio de Janeiro e cenários de regionalização para atenção hospitalar à Covid- 19 propostos
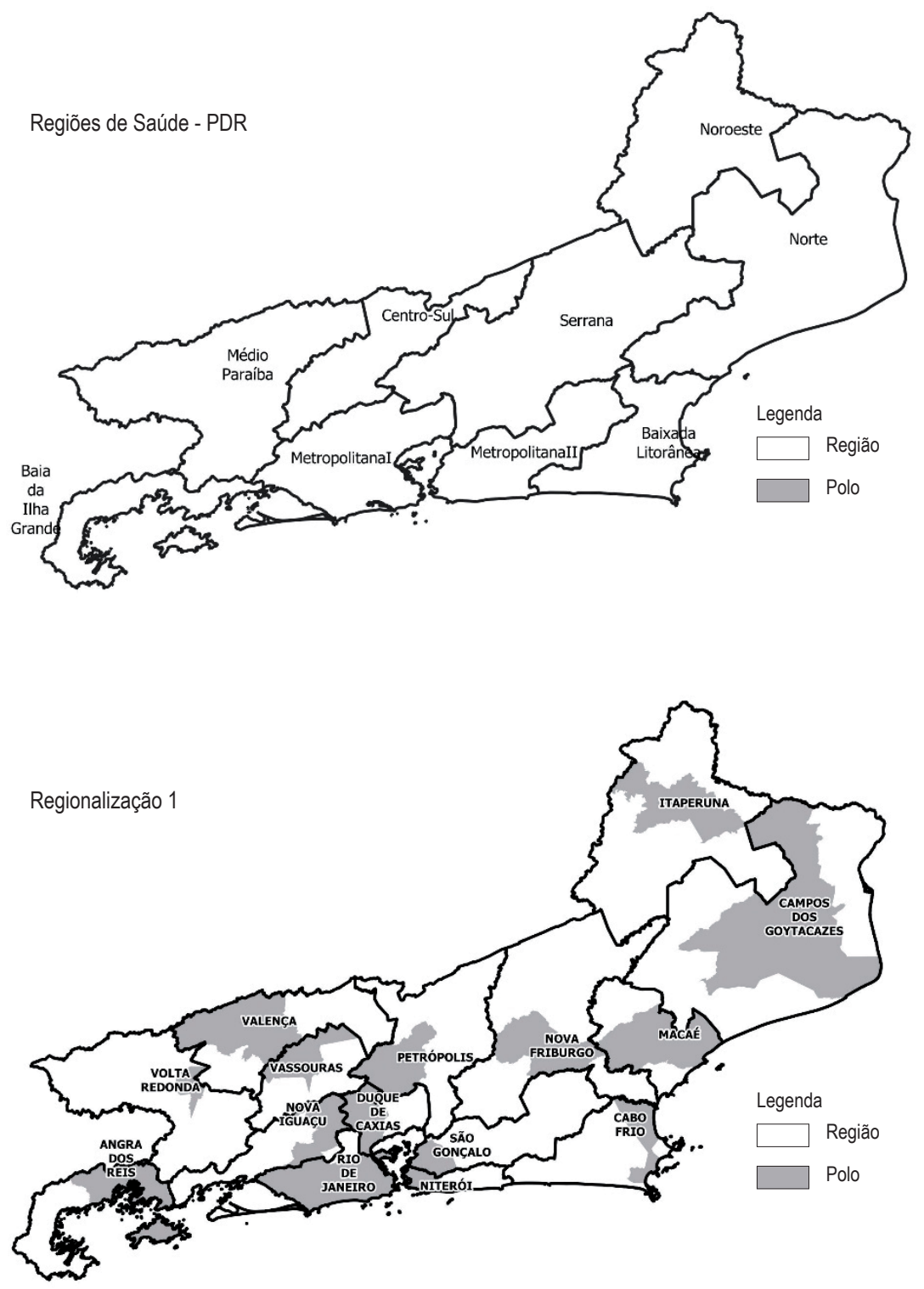
Figura I - Regiões de Saúde do estado do Rio de Janeiro e cenários de regionalização para atenção hospitalar à Covid- 19 propostos (continuação)
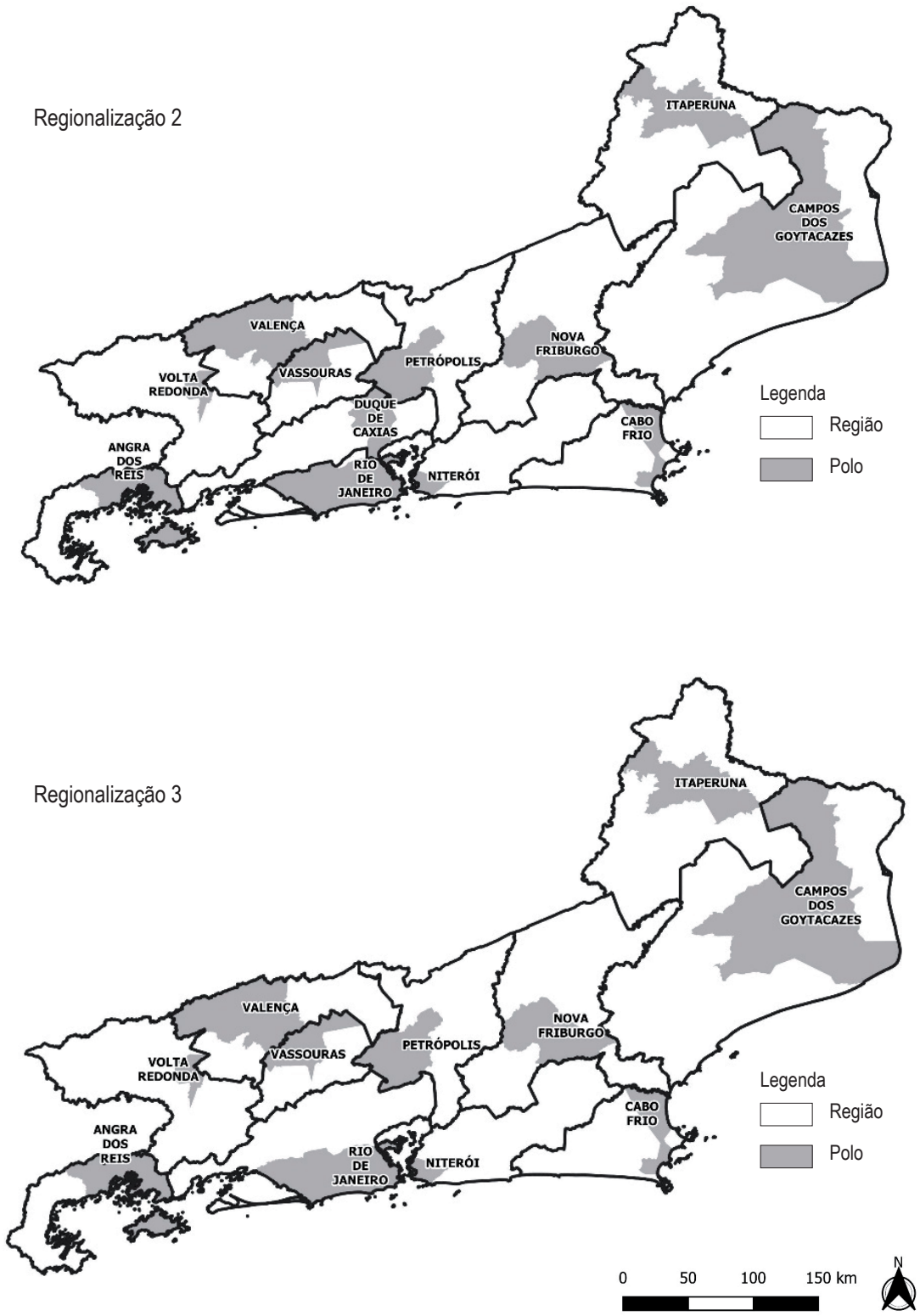

Base cartográfica digital: IBCE - Instituto Brasileiro de Geografia e Estatistica. Produzido pelo Laboratório de Geoprocessamento LIS/Icict/Fiocruz. 
Em cada um dos cenários, para a oferta de leitos de UTI foram consideradas três distintas previsões de disponibilidade: I) leitos de UTI para adultos (categorias CNES 74-76) SUS e total (SUS mais os não SUS); 2) leitos de UTI SUS + Covid- 19 habilitados e total (SUS + não SUS); e 3) leitos de UTI SUS para adultos + Covid- 19 habilitados ou previstos e total (SUS + não SUS). Para exemplificar, segundo essas distintas previsões havia no município do Rio de Janeiro 499 leitos de UTI disponíveis para o SUS; 664 leitos de UTI quando somados os leitos de UTI Covid- 19 habilitados disponíveis para o SUS (incluindo os 499 originais); e I.249 leitos de UTI quando somados todos os leitos de UTI Covid- 19 previstos, caso estivessem disponíveis (incluindo os 664 leitos de UTI + UTI Covid-19). As taxas de disponibilidade de leitos de UTI em cada um dos cenários estão na Tabela 3.

Tabela 3 - Disponibilidade de leitos de UTI por 10 mil habitantes acima de 20 anos nas nove regiões de Saúde e nos três cenários de regionalização propostos para o estado do Rio de Janeiro - 2020

\begin{tabular}{|c|c|c|c|c|c|c|}
\hline \multirow{2}{*}{ Regiões de Saúde } & \multicolumn{2}{|c|}{ Existentes } & \multicolumn{2}{|c|}{$\begin{array}{l}\text { Com UTI Covid- I } 9 \\
\text { habilitados }\end{array}$} & \multicolumn{2}{|c|}{$\begin{array}{l}\text { Com UTI Covid- I } 9 \\
\text { previstos }\end{array}$} \\
\hline & Total UTI & UTI SUS & Total UTI & UTI SUS & Total UTI & UTI SUS \\
\hline Baia da Ilha Grande & 1,19 & 0,40 & 1,19 & 0,40 & 3,18 & 2,39 \\
\hline Baixada Litorânea & $\mathrm{I}, 77$ & 0,80 & ।, 77 & 0,80 & ।, 97 & 1,00 \\
\hline Centro-Sul & 4,14 & 1,66 & 4,46 & 1,99 & 4,99 & 2,51 \\
\hline Médio Paraíba & 3,07 & 1,04 & 3,96 & 1,94 & 6,29 & 4,27 \\
\hline Metropolitana I & 3,49 & 0,77 & 3,82 & 1,10 & 4,74 & 2,02 \\
\hline Metropolitana II & 2,64 & 0,84 & 3,07 & 1,27 & 4,15 & 2,35 \\
\hline Noroeste & 5,00 & 2,99 & 5,39 & 3,39 & 6,77 & 4,76 \\
\hline Norte & 4,60 & 1,87 & 4,67 & 1,94 & 5,48 & 2,75 \\
\hline Serrana & 4,10 & 1,20 & 5,05 & 2,15 & 5,58 & 2,68 \\
\hline Total RJ & 3,38 & 0,93 & 3,75 & 1,31 & 4,73 & 2,28 \\
\hline \multicolumn{7}{|c|}{ Regionalização I - 15 polos } \\
\hline \multirow[t]{2}{*}{ Polos } & \multicolumn{2}{|c|}{ Existentes } & \multicolumn{2}{|c|}{$\begin{array}{l}\text { Com UTI Covid- } 19 \\
\text { habilitados }\end{array}$} & \multicolumn{2}{|c|}{$\begin{array}{l}\text { Com UTI Covid- I } 9 \\
\text { previstos }\end{array}$} \\
\hline & Total UTI & UTI SUS & Total UTI & UTI sus & Total UTI & UTI SUS \\
\hline Angra dos Reis & 1,42 & 0,47 & 1,42 & 0,47 & 3,79 & 2,84 \\
\hline Cabo Frio & 2,07 & 1,04 & 2,07 & 1,04 & 2,34 & 1,30 \\
\hline
\end{tabular}


Tabela 3 - Disponibilidade de leitos de UTI por 10 mil habitantes acima de 20 anos nas nove regiões de Saúde e nos três cenários de regionalização propostos para o estado do Rio de Janeiro - 2020 (continuação)

\begin{tabular}{|c|c|c|c|c|c|c|}
\hline Campos dos Goytacazes & 4,63 & 2,06 & 4,74 & 2,16 & 5,37 & 2,80 \\
\hline Duque de Caxias & 1,79 & 0,37 & 3,11 & $\mathrm{I}, 70$ & 3,51 & 2,10 \\
\hline Itaperuna & 5,00 & 2,99 & 5,39 & 3,39 & 6,77 & 4,76 \\
\hline Macaé & 2,98 & 0,76 & 2,98 & 0,76 & 3,75 & 1,53 \\
\hline Niterói & 4,83 & $|, 0|$ & 5,46 & 1,65 & 5,76 & 1,94 \\
\hline Nova Friburgo & 1,56 & 0,59 & 1,56 & 0,59 & 1,89 & 0,91 \\
\hline Nova Iguaçu & 0,58 & 0,33 & 0,58 & 0,33 & 0,78 & 0,52 \\
\hline Petrópolis & 5,03 & $|, 5|$ & 6,53 & 3,02 & 7,18 & 3,66 \\
\hline Rio de Janeiro & 4,24 & 0,90 & 4,49 & 1,15 & 5,61 & 2,27 \\
\hline São Gonçalo & 1,55 & 0,76 & 1,87 & $\mathrm{I}, 08$ & 3,35 & 2,56 \\
\hline Valença & 2,48 & 2,05 & 3,08 & 2,66 & 3,56 & 3,14 \\
\hline Vassouras & 6,57 & 1,93 & 6,57 & 1,93 & 6,57 & 1,93 \\
\hline Volta Redonda & 3,21 & 0,80 & 4,14 & 1,73 & 7,06 & 4,65 \\
\hline \multicolumn{7}{|c|}{ Regionalização 2 - 12 polos } \\
\hline \multirow{2}{*}{ Polos } & \multicolumn{2}{|c|}{ Existentes } & \multicolumn{2}{|c|}{$\begin{array}{l}\text { Com UTI Covid- I } 9 \\
\text { habilitados }\end{array}$} & \multicolumn{2}{|c|}{$\begin{array}{l}\text { Com UTI Covid- I } 9 \\
\text { previstos }\end{array}$} \\
\hline & Total UTI & UTI SUS & Total UTI & UTI SUS & Total UTI & UTI SUS \\
\hline Angra dos Reis & 1,42 & 0,47 & 1,42 & 0,47 & 3,79 & 2,84 \\
\hline Cabo Frio & 2,07 & 1,04 & 2,07 & 1,04 & 2,34 & 1,30 \\
\hline Campos dos Goytacazes & 4,02 & 1,58 & 4,09 & 1,64 & 4,77 & 2,33 \\
\hline Duque de Caxias & 1,02 & 0,29 & $|, 5|$ & 0,78 & $\mathrm{I}, 74$ & $|, 0|$ \\
\hline Itaperuna & 5,00 & 2,99 & 5,39 & 3,39 & 6,77 & 4,76 \\
\hline Niterói & 2,64 & 0,84 & 3,07 & 1,27 & 4,15 & 2,35 \\
\hline Nova Friburgo & 1,56 & 0,59 & 1,56 & 0,59 & 1,89 & 0,91 \\
\hline Petrópolis & 5,03 & $|, 5|$ & 6,53 & 3,02 & 7,18 & 3,66 \\
\hline Rio de Janeiro & 4,47 & 0,95 & 4,74 & 1,22 & 5,93 & 2,41 \\
\hline Valença & 2,48 & 2,05 & 3,08 & 2,66 & 3,56 & 3,14 \\
\hline
\end{tabular}


Tabela 3 - Disponibilidade de leitos de UTI por 10 mil habitantes acima de 20 anos nas nove regiões de Saúde e nos três cenários de regionalização propostos para o estado do Rio de Janeiro - 2020 (continuação)

\begin{tabular}{|c|c|c|c|c|c|c|}
\hline Vassouras & 6,57 & 1,93 & 6,57 & 1,93 & 6,57 & I,93 \\
\hline Volta Redonda & 3,21 & 0,80 & 4,14 & $\mathrm{I}, 73$ & 7,06 & 4,65 \\
\hline \multicolumn{7}{|c|}{ Regionalização 3 - II polos } \\
\hline \multirow[t]{2}{*}{ Polos } & \multicolumn{2}{|c|}{ Existentes } & \multicolumn{2}{|c|}{$\begin{array}{l}\text { Com UTI Covid- I } 9 \\
\text { habilitados }\end{array}$} & \multicolumn{2}{|c|}{$\begin{array}{l}\text { Com UTI Covid- } 19 \\
\text { previstos }\end{array}$} \\
\hline & Total UTI & UTI SUS & Total UTI & UTI SUS & Total UTI & UTI SUS \\
\hline Angra dos Reis & 1,42 & 0,47 & 1,42 & 0,47 & 3,79 & 2,84 \\
\hline Cabo Frio & 2,07 & 1,04 & 2,07 & 1,04 & 2,34 & 1,30 \\
\hline Campos dos Goytacazes & 4,02 & 1,58 & 4,09 & 1,64 & 4,77 & 2,33 \\
\hline Itaperuna & 5,00 & 2,99 & 5,39 & 3,39 & 6,77 & 4,76 \\
\hline Niterói & 2,64 & 0,84 & 3,07 & 1,27 & 4,15 & 2,35 \\
\hline Nova Friburgo & $\mathrm{I}, 56$ & 0,59 & 1,56 & 0,59 & 1,89 & 0,9 I \\
\hline Petrópolis & 5,03 & $\mid, 51$ & 6,53 & 3,02 & 7,18 & 3,66 \\
\hline Rio de Janeiro & 3,48 & 0,76 & 3,81 & 1,09 & 4,72 & 2,01 \\
\hline Valença & 2,48 & 2,05 & 3,08 & 2,66 & 3,56 & 3,14 \\
\hline Vassouras & 6,57 & 1,93 & 6,57 & 1,93 & 6,57 & I,93 \\
\hline Volta Redonda & 3,21 & 0,80 & 4,14 & 1,73 & 7,06 & 4,65 \\
\hline
\end{tabular}

Fonte: CNS, maio de 2020 (Brasil, 2020a).

\section{Regionalização segundo as regiões de Saúde}

A disponibilidade de recursos físicos e humanos relevantes para a atenção aos casos graves de Covid-19, entre o quais os leitos de UTI, e sua distribuição nas RS e municípios do ERJ foram analisadas na primeira nota técnica do Proadess sobre a pandemia, com informações referentes a fevereiro de 2020 (Viacava et al., 2020). Na Tabela 3 tais informações estão atualizadas e são apresentadas as taxas de disponibilidade de leitos de UTI nas RS do estado, considerando todos os disponíveis, em polos ou não, e destacando as distintas alternativas de ampliação dos leitos de UTI Covid- 19 disponíveis para o SUS registrados no CNES em maio de 2020. 
Característica central da oferta de leitos de UTI foi a diferença entre a oferta total e aquela disponível para o SUS, marcante em todas as RS, exceto naquelas com baixa disponibilidade, como a Baía da Ilha Grande e a Baixada Litorânea. Em nenhuma das duas houve aumento na disponibilidade de leitos, pois ainda não haviam sido habilitados os leitos de UTI Covid- I 9 previstos nos hospitais existentes ou de campanha.

As outras sete RS tiveram leitos de UTI Covid- I 9 habilitados, o que ampliou a disponibilidade, principalmente naquelas em que a oferta já era comparativamente significativa, como a Centro-Sul, Noroeste, Norte e Serrana. No tocante aos leitos habilitados, duas RS se distinguiram pelo crescimento das taxas de oferta, Médio Paraíba e Serrana, em razão do aumento de leitos de UTI disponíveis para o SUS, respectivamente nos municípios de Volta Redonda e Petrópolis.

As RS Médio Paraíba e Noroeste sobressaíram pelo expressivo crescimento do número de leitos de UTI Covid-I 9 a serem habilitados. Nessas RS, nas duas metropolitanas, além da RS Baía da Ilha Grande, a diferença entre leitos de UTI Covid- I 9 já habilitados e previstos era significativa; em outras, como a RS Centro-Sul e a RS Serrana, a maioria dos leitos previstos já havia sido habilitada.

A disponibilidade de leitos de UTI SUS foi ampliada com a habilitação de novos leitos de UTI Covid- 9 na maioria das RS, porém mesmo com o aumento persistiam problemas relacionados a distâncias, dificuldades de deslocamento, concentração de recursos em determinados polos e ausência de recursos SUS em alguns municípios. Três RS se destacaram nesse âmbito: a Serrana, pelas distâncias, pelo relevo e consequentes dificuldades de deslocamento entre diversos municípios e o polo principal (Petrópolis) e sua dependência de um subpolo com disponibilidade mais limitada de recursos SUS (Nova Friburgo); a Médio Paraíba, pela concentração de recursos SUS em Volta Redonda; e a Metropolitana I, pela concentração populacional e de leitos disponíveis para o SUS na capital.

Com base nesse diagnóstico da capacidade instalada, histórica e emergencial, e visando a contribuir para superar esses desafios, reduzir a pressão sobre os recursos em vários polos regionais, foram propostos outros três cenários. Procurou-se valorizar as potencialidades de outros polos, como Duque de Caxias, Valença, Vassouras e Nova Friburgo. Ao passo que já havia leitos de UTI Covid-I 9 nos dois primeiros, no terceiro não estavam previstos novos leitos e a disponibilidade já era significativa; o último se caracterizava pela situação mais complexa, pois não estavam previstos novos leitos, porém se configurava como polo mais acessível para municípios de menor porte e distantes de outros centros urbanos com disponibilidade de leitos de UTI. 


\section{Cenário de regionalização 1 para atenção à Covid-19, com 15 polos}

O primeiro cenário proposto para ampliar o acesso conta com 15 polos, definidos em razão da disponibilidade de leitos de UTI ao SUS e das possibilidades de acesso a partir dos municípios próximos. Além dos nove municípios destacados como polos das RS (Rio de Janeiro, Niterói, Petrópolis, Volta Redonda, Vassouras, Angra dos Reis, Cabo Frio, Campos dos Goytacazes e Itaperuna), foram incluídos outros seis: Duque de Caxias, Nova Iguaçu, São Gonçalo, Valença, Nova Friburgo e Macaé, para:

I. reduzir os efeitos da concentração de recursos na capital e, assim, os fluxos oriundos da Baixada Fluminense;

2. reduzir obstáculos relacionados às distâncias entre municípios no Norte Fluminense e na Região Serrana;

3. minimizar os efeitos da maior dificuldade de acesso rodoviário a polos como Niterói e Angra dos Reis;

4. valorizar a disponibilidade de recursos SUS em municípios como Valença e Vassouras, redistribuindo os fluxos nas regiões do Médio Paraíba e Centro-Sul.

Na Tabela 3 estão as taxas de disponibilidade de leitos de UTI para a população do polo e dos municípios da região. Se forem considerados somente os recursos previamente existentes, dos novos polos propostos apenas Valença teria disponibilidade significativa de leitos de UTI. Os outros novos polos, além de Volta Redonda e da capital, teriam baixa oferta SUS, inferior a I leito de UTI por 10 mil habitantes. Com os leitos que haviam sido habilitados, a situação melhoraria de maneira significativa na maioria dos polos das RS, exceto em Angra dos Reis e Cabo Frio.

A inclusão de leitos de UTI Covid- 19 ampliaria a disponibilidade em São Gonçalo e Duque de Caxias, além de Valença. Em Macaé, Nova Friburgo e Nova Iguaçu não haviam sido habilitados novos leitos de UTI até o período analisado. No município de Nova Iguaçu, mesmo com a possível habilitação dos leitos previstos, a taxa se manteria inferior a I leito de UTI por 10 mil habitantes.

\section{Cenário de regionalização 2 para atenção à Covid-19, com 12 polos}

Diante das limitações evidenciadas na primeira proposta de regionalização para atenção aos casos graves de Covid-19, foi elaborada uma segunda, com 12 polos. Três municípios deixariam de ser polos: Macaé, Nova Iguaçu e São Gonçalo. Os dois primeiros tinham poucos ou nenhum novo leito de UTI, não alterando a disponibilidade, por isso seus arranjos regionais foram incluídos, respectivamente, nos de Campos dos Goytacazes e de Duque de Caxias. Mesmo com os novos leitos, São Gonçalo manteve uma taxa 
de disponibilidade restrita, embora superior a I por 10 mil habitantes; assim, optou-se por agregar os municípios desse arranjo ao polo Niterói, que apresentou importante aumento de leitos de UTI habilitados. Nova Friburgo, mesmo sem novos leitos de UTI SUS, foi mantido como polo pelos motivos de localização geográfica estratégica, pois constitui-se como referência para diversos pequenos municípios distantes de outros polos.

Na Tabela 3, pode-se, também, observar as mudanças nas taxas de disponibilidade de leitos de UTI com a redução do número de polos propostos. Isso ocorreu nos municípios da Baixada Fluminense e no norte do estado. As mudanças levaram à redução nas taxas de disponibilidade nos três polos aos quais foram agregados esses municípios incluídos anteriormente nos polos retirados. Se nos casos de Campos dos Goytacazes e Niterói as alterações causaram diminuições restritas, em Duque de Caxias a taxa passou a ser inferior à de I leito de UTI por 10 mil habitantes. Assim, o intento de reduzir a necessidade de deslocamentos para a capital ficou comprometido neste cenário.

\section{Cenário de regionalização 3 para atenção à Covid-19, com 11 polos}

Com o terceiro cenário, buscou-se propor solução para a questão da polarização na Região Metropolitana do Rio de Janeiro. Dada a concentração prévia de leitos de UTI SUS na capital e o aumento dessa concentração com os novos leitos de UTI Covid- 19 , a alta concentração populacional em diversos municípios com baixa disponibilidade de recursos SUS dificultava a proposição de um arranjo com algum grau de independência em relação ao município do Rio de Janeiro. Por isso, neste cenário, o polo de Duque de Caxias, que no anterior estava articulado ao polo de Nova Iguaçu, foi incluído no Rio de Janeiro, praticamente recompondo a RS Metropolitana I.

As mudanças decorrentes dessa terceira proposta (Tabela 3) estão relacionadas à redução da taxa de disponibilidade de leitos de UTI SUS no polo da capital. Ao menos, a disponibilidade para a Baixada Fluminense e o Rio de Janeiro passou a ser superior a I leito por 10 mil habitantes acima de 20 anos, com os novos leitos de UTI Covid- 19 habilitados até então.

\section{Comparação dos cenários de regionalização propostos}

Considerou-se como mais factível a proposta de Regionalização 2, com 12 polos - Rio de Janeiro, Duque de Caxias, Niterói, Angra dos Reis, Volta Redonda, Vassouras, Valença, Petrópolis, Nova Friburgo, Cabo Frio, Campos dos Goytacazes e Itaperuna -, principalmente pela possibilidade de melhor distribuição da atenção de alta complexidade na Região Metropolitana. Porém, identificaram-se questões e desafios relevantes a serem ponderados. 
O principal é a disponibilidade restrita de recursos no arranjo polarizado por Duque de Caxias, decorrente da limitação de recursos SUS em diversos municípios com grande concentração populacional, como Nova Iguaçu, Belford Roxo e Magé. Em outros dois arranjos regionais relacionados aos cenários desenhados, Angra dos Reis e Nova Friburgo, ocorreram problemas semelhantes, porém a manutenção de sua definição como polos decorreu das dificuldades de acesso rodoviário e da distância em relação a outros polos de atenção à saúde. Em todos, constatou-se a necessidade de ampliação da oferta, mesmo com os leitos de UTI Covid- 19 habilitados em Duque de Caxias e com os previstos nos três polos.

Campos dos Goytacazes e Itaperuna tinham grande disponibilidade de recursos SUS e nesta segunda proposta mantiveram e ampliaram as respectivas RS. Os polos de Niterói e Cabo Frio, por sua vez, também mantiveram suas RS, porém sua disponibilidade de leitos de UTI SUS seria mais restrita.

A oferta significativa de leitos de UTI SUS em dois municípios de menor porte populacional, Valença e Vassouras, possibilitou que ambos constituíssem polos, permitindo desconcentrar a atenção de alta complexidade nas RS do Médio Paraíba e, especialmente, na Centro-Sul.

A Serrana tem grande área territorial e uma concentração de recursos de alta complexidade no SUS em Petrópolis, reforçada pelos novos leitos de UTI Covid-I 9 habilitados e previstos naquele momento. Porém, há diversos pequenos municípios distantes e com acesso rodoviário problemático a Petrópolis. Assim, havia premente necessidade de ampliar os recursos SUS em Nova Friburgo, com o intuito de atender os municípios situados na porção norte da Região Serrana e próximos à fronteira com o estado de Minas Gerais.

\section{A IMPORTÂNCIA E OS DESAFIOS DA REGIONALIZAÇÃO EM SAÚDE}

A regionalização pode ser fato e/ou ferramenta (Ribeiro, 20 I6). Fato por se constituir sem necessariamente estar vinculada às ações hegemônicas do presente. Ferramenta como parte das ações estratégicas de agentes como o Estado, as corporações, os movimentos sociais. A regionalização em saúde é uma ferramenta que precisa incorporar as regiões de fato para constituir estratégias de ampliação do acesso aos serviços de saúde, a cuidados de saúde efetivos, eficientes e resolutivos.

As propostas de regionalização foram elaboradas em virtude do enfrentamento da pandemia de Covid-19, para lidar com obstáculos relacionados ao acesso aos leitos de UTI. Os desafios aqui abordados estão vinculados a fatores como: concentração de 
recursos SUS em alguns polos, marcadamente na capital; distâncias entre municípios e polos regionais; dificuldades de acesso rodoviário a alguns polos, além das concentrações populacionais.

Porém, há outras questões relevantes: há que se desconcentrar recursos de maneira coordenada para reduzir desigualdades, sem desconsiderar critérios de escala e escopo relevantes na prestação da atenção de alta complexidade. No âmbito da governança em saúde, há necessidade de maior colaboração/cooperação técnica e financeira entre os entes das RS, com a criação de um ambiente favorável a acordos para organizar a atenção à saúde e dar resposta às necessidades de saúde da população. Também cabe ressaltar o papel da regulação em saúde, que deve atuar no sentido de garantir o acesso oportuno a cuidados efetivos, especialmente em um momento complexo como o da pandemia.

Ademais, as propostas de regionalização podem contribuir para os debates relativos à atualização da regionalização em saúde, fundado também na necessária hierarquização da atenção, que precisa estar incorporada em qualquer (re)definição de sua organização espacial. Logicamente, essas atualizações precisam estar ancoradas em políticas de investimento no SUS, voltadas para a qualificação e ampliação da oferta de recursos físicos e humanos em saúde.

Por último, é importante ressaltar que esta análise teve, entre os seus desdobramentos, a realização, em agosto de 2020, do seminário on-line Cenários de Regionalização da Saúde no Estado do Rio de Janeiro, no qual foi possível dialogar com representantes da Secretaria de Estado de Saúde do Rio de Janeiro, do Conselho de Secretarias Municipais de Saúde do Estado do Rio de Janeiro (Cosems RJ) e pesquisadores da Fiocruz. Para a equipe do Proadess, estabelecer e consolidar esses canais de interlocução entre diferentes atores das políticas públicas em saúde é fundamental para o cumprimento do seu objetivo de contribuir para a melhoria do desempenho do SUS (Vídeo Saúde Distribuidora da Fiocruz, 2020).

\section{REFERÊNCIAS}

BRASIL. Ministério da Saúde. Cadastro Nacional de Estabelecimentos de Saúde (CNES). Disponível em: $<$ https://datasus.saude.gov.br/cnes-recursos-fisicos >. Acesso em: 31 maio 2020a.

BRASIL. Ministério da Saúde. Sistema de Vigilância Epidemiológica da Gripe (Sivep Gripe). Disponível em: <https://opendatasus.saude.gov.br/dataset/bd-srag-202I >. Acesso em 23 jun. 2020b.

FUNDAÇÃO OSWALDO CRUZ (FIOCRUZ). Óbitos desassistidos no Rio de Janeiro. Análise do excesso de mortalidade e impacto da Covid-19. MonitoraCovid-19. Nota técnica n. II. Rio de Janeiro: Fiocruz, 2020. Disponível em: <https://bigdata-covidI9.icict.fiocruz.br/nota_tecnica_II. pdf>. Acesso em: 8 jul. 2020. 
INSTITUTO DE GEOGRAFIA E ESTATíSTICA (IBGE). Regiões de Influência das Cidades (Regic), 2018. Disponível em: <www.ibge.gov.br/geociencias/cartas-e-mapas/redes-geograficas/I5798-regioesde-influencia-das-cidades.html?=Et=0-que-e $>$. Acesso em: 13 jan. 2021 .

OLIVEIRA, R. D. et al. Nota técnica do Projeto de Avaliação do Desempenho do Sistema de Saúde (Proadess) - Covid-19, n. 2. Cenários de regionalização para atenção ao Covid- 19 no estado do Rio de Janeiro. Rio de Janeiro: LIS/Icict/Fiocruz, jul. 2020. Disponível em: <www.proadess.icict.fiocruz.br/ index.php?pag=boletins $>$. Acesso em: 13 jan. 2021 .

RIBEIRO, A. C. T. Regionalização: fato e ferramenta. In: LIMONAD, E.; HAESBAERT, R. \& MOREIRA, R. (Orgs.). Brasil, Século XXI: por uma nova regionalização? Agentes, processos, escalas. 5. ed. Rio de Janeiro: Letra Capital, 2016.

VIACAVA, F. et al. Nota técnica do Proadess - Covid-19, n. I. Distribuição geográfica dos recursos disponíveis para atenção à Covid-19 em Regiões de Saúde e municípios do Rio de Janeiro. Projeto de Avaliação do Desempenho do Sistema de Saúde (Proadess). Rio de Janeiro: LIS/Icict/Fiocruz, maio 2020. Disponível em: <www.proadess.icict.fiocruz.br/index.php?pag=boletins>. Acesso em: I3 jan. 2021.

VÍDEO SAÚDE DISTRIBUIDORA DA FIOCRUZ. Cenários de Regionalização da Saúde no Estado do Rio de Janeiro. $<$ www.youtube.com/watch?reload $=9 \varepsilon v=$ PnCYfg5JhRgEab_channel $=$ VideoSa\%C3\%B AdeDistribuidoradaFiocruz>. Acesso em: 6 ago. 2020. 


\title{
Proposta de Matriz de Linha de Cuidado Covid-19 na Rede de Atenção à Saúde
}

\author{
Margareth Crisóstomo Portela, Victor Grabois e Claudia Travassos
}

Deto elo potencial de contágio, pelas características de sua evolução e pelo grau de complexidade de cuidados em saúde que pode requerer, a Covid- 19 tem colocado imensos desafios para os sistemas de saúde dos diferentes países onde se propaga. Medidas de contenção e mitigação da pandemia, incluindo distanciamento físico, testagem, isolamento de casos, minimização da circulação de pessoas e uso de máscaras têm sido amplamente preconizadas com vistas a evitar o crescimento descontrolado de casos e o colapso dos sistemas e serviços de saúde (Walensky E Del Rio, 2020; Anderson et al., 2020). Estima-se que cerca de $80 \%$ dos casos de Covid- 9 tenham manifestações leves ou mesmo sejam assintomáticos e $20 \%$ sejam de gravidade moderada ou grave (CDC, 202 I). Desse modo, a Covid- 19 incorre em elevada demanda por cuidados de saúde nos diferentes níveis de atenção, totalmente fora de padrões usuais, com destaque para a demanda a recursos hospitalares altamente complexos para tratamento de cerca de $5 \%$ dos casos graves (Zhou et al., 2020; Garg et al., 2020). Tal demanda concorre com a demanda regular aos serviços de saúde nos diferentes níveis de atenção que, em condições normais, comumente já enfrentam gargalos no país. E impõe preocupações adicionais pelo elevado índice de transmissibilidade do Sars-CoV-2, coronavírus transmissor da doença Covid-19, que expõe profissionais da saúde e pode expor pacientes com outras condições de saúde ao utilizarem os serviços de saúde.

O documento da Organização Mundial da Saúde (OMS) intitulado "Critical preparedness, readiness and response actions for Covid-19” (WHO, 202I) sistematiza quatro cenários de transmissão possíveis: I) não há casos relatados; 2) há casos esporádicos, um ou mais, importados ou localmente adquiridos; 3) há agregados de casos, com a maioria relacionada à transmissão local e envolvendo cadeias de transmissão já existentes; 4) há grande elevação do número de casos com cadeias de transmissão am- 
plamente disseminadas. Nos cenários I e 2, é posta a necessidade de se preparar para o aumento da demanda aos serviços de saúde. No cenário 3, a sobrecarga do sistema de saúde já está estabelecida como uma realidade, havendo necessidade de organizar a ampliação da oferta de serviços e de outros recursos que se façam necessários. No cenário 4, coloca-se a possibilidade de crise no sistema de saúde, havendo necessidade de implementação de planos de aumento das capacidades do sistema de saúde, assim como de ganho de escala e velocidade neste processo.

Em um país de dimensões continentais como o Brasil, marcado por contextos muito diversos e imensas desigualdades regionais na oferta de serviços e desigualdades sociais no acesso, especialmente aos serviços de média e alta complexidades, um dos desafios para o enfrentamento da Covid- 19 é a necessidade de adotar estratégias diversas de mitigação da pandemia, assim como de organização da rede de serviços de saúde disponíveis.

Propomos aqui um arcabouço matricial que permite a conformação de diferentes arranjos assistenciais, adaptados às realidades locorregionais, na organização do cuidado efetivo relacionado à Covid-19, no contexto de ampla diversidade e desigualdade do país. Nessa matriz, os pontos de cuidado articulam-se com a evolução clínica da doença e suas possíveis sequelas, que expressam as necessidades de saúde dos pacientes, considerando também a presença ou não de vulnerabilidade social e econômica. Nela são contemplados o fluxo de pacientes, as funções dos pontos de cuidado, indicandose quando e quais cuidados podem ser prestados em cada ponto e as relações entre eles (referência e contrarreferência). E se define uma linha de cuidado para a Covid-19 harmonizada com a rede de atenção à saúde.

A matriz se inicia com o surgimento da doença, abrange os casos assintomáticos e contatos nas ações de vigilância e se estende ao longo de toda a evolução clínica, incluindo medidas terapêuticas e de reabilitação no caso de possíveis sequelas. Ao ser direcionada ao atendimento de pacientes em uma pandemia, responde à situação de emergência que, na maioria das vezes, requer expansão, modificação e inclusão de pontos de cuidado específicos. Incentiva-se que algumas dessas mudanças sejam orientadas de modo a configurar uma reorganização da oferta de serviços e do modelo de atenção, tornando-se assim em legados para o fortalecimento do Sistema Único de Saúde (SUS). Ao longo da linha de cuidado localizam-se conhecimento e normas (diretrizes clínicas, políticas e procedimentos e demais documentos) necessários para orientar e apoiar os processos decisórios de profissionais e se destacam os insumos estratégicos essenciais para cada etapa e dimensão do cuidado. Detalham-se também o tipo, a geração e o fluxo das informações sobre o paciente (prontuários e notificações) nesse percurso. 
A matriz tem como objetivo a melhoria dos resultados do cuidado prestado aos pacientes, orientando-se pelo emprego de boas práticas, baseadas em evidências científicas, mediante a organização do cuidado em saúde de modo a maximizar as chances de cura e sobrevivência dos pacientes e minimizar a transmissão da doença. Abrange a clínica, aspectos de vigilância, a gestão do processo de cuidado, as organizações prestadoras de serviços e gestoras de saúde, de assistência e proteção social e as organizações comunitárias. Sua implementação deve se fazer em estreita correlação com os cenários epidemiológicos, articulação com as redes de atenção à saúde local e regional e com a comunidade (Conass, 2020). Pode ser empregada também como instrumento orientador da programação de serviços de saúde para estimar a oferta de profissionais da saúde, a capacidade instalada e insumos estratégicos. No mais, deve ser objeto de constante atualização, com base na experiência nacional e internacional com a pandemia e no conhecimento científico produzido ao longo deste processo, incorporando as modificações pertinentes ao aprimoramento da efetividade do controle e cuidado de saúde relacionados à Covid- 19.

A implementação da matriz pressupõe que alternativas de cuidado possam ser combinadas dependendo das estruturas locais e das regiões de Saúde, orientadas pelas diretrizes apresentadas a seguir.

\section{DIRETRIZES BÁSICAS}

1. A matriz é um desenho teórico, genérico e dinâmico. Contém apenas elementos gerais e não expressa nenhum contexto em particular. Deve ser objeto de mudanças segundo o contexto, o cenário da epidemia, as experiências acumuladas, as estruturas de saúde existentes e o conhecimento disponível sobre o Sars-CoV-2 e a Covid- 19.

2. A linha de cuidado Covid- 19 foi concebida para funcionar concomitantemente ao atendimento das demandas rotineiras nos serviços de saúde, especialmente daquelas definidas como essenciais (WHO, 2020) Entretanto, mudanças estratégicas no atendimento de rotina (adiamento ou suspensão de rotina e procedimentos eletivos), a fim de expandir a oferta para a linha de cuidado Covid-19, podem se fazer necessárias nos momentos críticos da epidemia. Arranjos diversos são passíveis de consideração na dependência da duração da pandemia ou sua evolução para o estágio endêmico.

3. Os serviços de saúde de atenção primária têm papel essencial na vigilância epidemiológica, na identificação e mitigação dos efeitos das vulnerabilidades sociais e econômicas da população, na comunicação e orientação da comuni- 
dade acerca dos fluxos relevantes na rede de atenção à saúde e como porta de entrada e continuidade do cuidado em casos de Covid- 19 (Engstrom et al., 2020; Brasil, 2020a, 2020b, 202 I). Também são responsáveis pela operacionalização da vacinação contra a doença, que em janeiro de 2021 passou a se constituir na mais importante medida de controle da pandemia no país. Prevê-se que a Covid- 19 continuará presente como doença endêmica por alguns anos, e aos serviços de saúde de atenção primária continuará cabendo papel relevante no manuseio de pacientes infectados e contatos.

4. Articulações intersetoriais com organismos de proteção social e outros e articulações horizontais com lideranças e organizações comunitárias devem ser estabelecidas para que as necessidades da população sejam atendidas em sua integralidade.

5. Pacientes com síndrome gripal e Covid- I 9 devem estabelecer contato com o mínimo de pontos de cuidado possível, e, em todos os pontos de cuidado, devem ser recebidos, avaliados e atendidos em fluxo separado da demanda regular nos serviços. Os pontos de cuidado na linha de cuidado Covid-19 devem organizar o atendimento conforme coortes de pacientes confirmados e suspeitos (Anvisa, 202I).

6. O atendimento e a transição do paciente de um ponto a outro devem ser orientados por diretrizes clínicas e demais instrumentos voltados para a identificação da síndrome gripal e Covid-19, da presença de vulnerabilidade social, do grau de gravidade da doença e para a detecção precoce da síndrome respiratória aguda grave (Srag).

7. O transporte de pacientes entre os pontos de atenção da rede deve ser pronto e adequado, especialmente nos casos graves, podendo-se lançar mão, em cenários de insuficiência do transporte adequado, de transporte adaptado para pacientes em quadros de menor gravidade.

8. O desenvolvimento da epidemia e outros aspectos epidemiológicos, os indicadores de utilização de serviços e a disponibilidade de recursos - profissionais, testes, leitos, equipamentos estratégicos, equipamentos de proteção individual (EPIs), treinamento, transporte - devem ser monitorados, e os momentos de mudança (disparadores) devem ser previamente definidos e monitorados permanentemente, em sintonia com o funcionamento da rede de atenção à saúde. Um roteiro deve ser desenvolvido para esse fim.

9. Para a execução da diretriz 8, é fundamental a transparência e disponibilização dos dados necessários. 
10. A reposição de recursos humanos afastados por contraírem a doença, em todos os pontos de cuidado, deve ser uma preocupação constante. Ao mesmo tempo, é fundamental que se monitorem as perdas e a capacidade de reposição satisfatória.

II. No curso da pandemia, com a Covid-I 9 se configurando como emergência sanitária, centros de Operações de Emergência (COE-Saúde-Covid-19) devem ser organizados em diferentes esferas de gestão, envolvendo todas as áreas (vigilância, atenção, logística, entre outras), com vistas a monitorar a evolução da própria pandemia e preparar, planejar e integrar ações para o seu enfrentamento, entre as quais a disponibilização e acompanhamento do uso de recursos e a definição da expansão de pontos de cuidado de saúde/ profissionais/insumos. A resposta à pandemia, especialmente no que tange à organização da linha de cuidado, requer gestão permanente e ação coordenada em determinadas bases territoriais.

12. É recomendado que o fluxo de pacientes seja regulado na linha de cuidado, considerando a prontidão adequada e a complexidade necessária ao cuidado dos pacientes que iniciam quadro clínico já com formas graves da doença ou que evoluem para Srag rapidamente. Preferencialmente, essa regulação deve se dar diretamente para os hospitais de referência de pacientes graves, evitando-se atraso ou mesmo perda de oportunidade para a oferta do cuidado adequado.

Resumidamente, na linha de cuidado Covid- 19 os pontos de cuidado se articulam ao estadiamento da doença, refletindo a evolução clínica dos pacientes e o grau de vulnerabilidade social e econômica. Para se evitar a sobrecarga de atendimento nas unidades básicas de saúde (UBS) e o risco de contágio de outras pessoas, a atenção no domicílio deve ser amplamente utilizada, em estreita articulação com os médicos e os demais profissionais da UBS de referência, envolvendo teleatendimento e o suporte de centrais de regulação de leitos e de transporte. Acredita-se que essa conduta também facilite a detecção de situações de agravamento de pacientes, que poderiam de forma mais oportuna ser referenciadas para o cuidado hospitalar. Pacientes, seus contatos e pessoas de alto risco em situação de vulnerabilidade social e econômica devem ser identificados, e locais de alojamento/internação alternativos devem ser buscados, sempre que possível em articulação com serviços de assistência e proteção social locais. O trabalho dos agentes comunitários em saúde (ACS), que compõem as equipes de saúde da família das UBS, é importante para o cuidado na Atenção Primária à Saúde (APS), em particular para a vigilância em saúde, na busca ativa de casos e identificação de suspeitos e seus 
contatos, na identificação de pessoas de alto risco, no apoio ao monitoramento clínico e na testagem nas comunidades, quando for o caso. Os ACS também podem desempenhar papel fundamental na sensibilização, orientação, acompanhamento e busca ativa de pessoas na vacinação contra a Covid-19. Adicionalmente, sempre que necessário e possível, sublinha-se o papel que os ACS podem cumprir na articulação com lideranças comunitárias (Brasil, 2020a).

As equipes do Núcleo Ampliado de Saúde da Família - Atenção Básica (Nasf-AB) e da Atenção Ambulatorial Especializada ( $A A E)$ devem, mediante apoio matricial às equipes da APS e de teleatendimento, atuar no acompanhamento e orientação aos pacientes, por exemplo, com comorbidades associadas, que necessitem de apoio em saúde mental ou demandem reabilitação após a desospitalização. A AAE, por seu papel no cuidado de pacientes portadores de condições crônicas, que são subpopulações de maior risco, pode desempenhar a função de indicar e elaborar diretrizes clínicas e fluxogramas, na orientação da trajetória do paciente na linha de cuidado Covid-19 (Conass, 2020). Diante das múltiplas manifestações da Covid longa, podem também caber às unidades de AAE novas funções no acompanhamento de pacientes.

As unidades de urgência/emergência, entre as quais as unidades de ProntoAtendimento (UPAs), especialmente nos casos em que não há estruturas hospitalares de referência para o tratamento de pacientes que precisem de algum nível de estabilização, podem atuar no cuidado de pacientes com quadro de gravidade de síndrome gripal e Covid-19. Nesses casos, tanto deveriam estar articuladas às centrais de leitos e de transporte como estar preparadas para realizar a contrarreferência às UBS dos pacientes que podem ser tratados no domicílio.

Hospitais intermediários para pacientes de menor gravidade que necessitam de internação ou pacientes com quadro leve e vulnerabilidade social e econômica, e hospitais de referência com capacidade tecnológica para cuidar de pacientes com Srag e outras possíveis complicações graves são os pontos de cuidado mais complexos no atendimento aos pacientes com Covid- 9 (NICE, 2020).

A linha de cuidado estende-se ainda na necessidade de reabilitação de pacientes com sequelas, que demandarão cuidados após a desospitalização. Programas de reabilitação para pacientes devem ser considerados em centros dedicados à Covid longa e em centros de reabilitação em geral, assim como nos Nasfs e na $A A E$, incluindo ações domiciliares ou em unidades de saúde, com disponibilização de transporte para os pacientes. Embora se possa argumentar que a reabilitação ocorre em pontos de cuidado já contemplados na matriz, a sua explicitação como ponto de cuidado em si chama atenção para a sua importância em um cenário em que ainda é pouco discutida. 
Por fim, apresenta-se como relevante a questão do manuseio de corpos de pacientes mortos pela Covid-19, especialmente desafiante em momentos mais críticos da pandemia.

A acomodação da Linha de Cuidado Covid- 9 na Rede de Atenção à Saúde não se dá sem tensões no decorrer do tempo, tanto pelos desafios que a convivência com ela nos serviços de saúde impõe como pelos momentos de expansão e contração que pode requerer. O risco de desassistência a outras condições de saúde precisa continuamente ser evitado, ainda que seja realista admitir a retenção de demandas em momentos de necessidade de expansão dos cuidados para a Covid-19. A resposta às demandas acumuladas, por sua vez, requer o gerenciamento de filas, considerando o risco dos pacientes e a perspectiva de não comprometer a oportunidade do cuidado. Diante da imensa crise sanitária, não há de surpreender que as redes e os serviços de saúde que as compõem vivenciem ainda, em inúmeros momentos, a necessidade de se reorganizar e de inovar para dar conta das necessidades de saúde da população, entre as quais as novas necessidades decorrentes de sequelas da própria Covid-19. O fortalecimento do SuS dever ser o norte.

A matriz é apresentada de forma esquemática a seguir. As cores azul, laranja-escuro e vermelho relacionam a Linha de Cuidado Covid- 9 à gravidade do quadro clínico, com o vermelho indicando as situações mais críticas. O laranja-claro foi associado à transição do paciente com uso de transporte, o verde foi associado aos cuidados de reabilitação e o roxo ao óbito. 


\section{Matriz Linha de Cuidado Covid- I 9 na Rede de Atenção à Saúde}

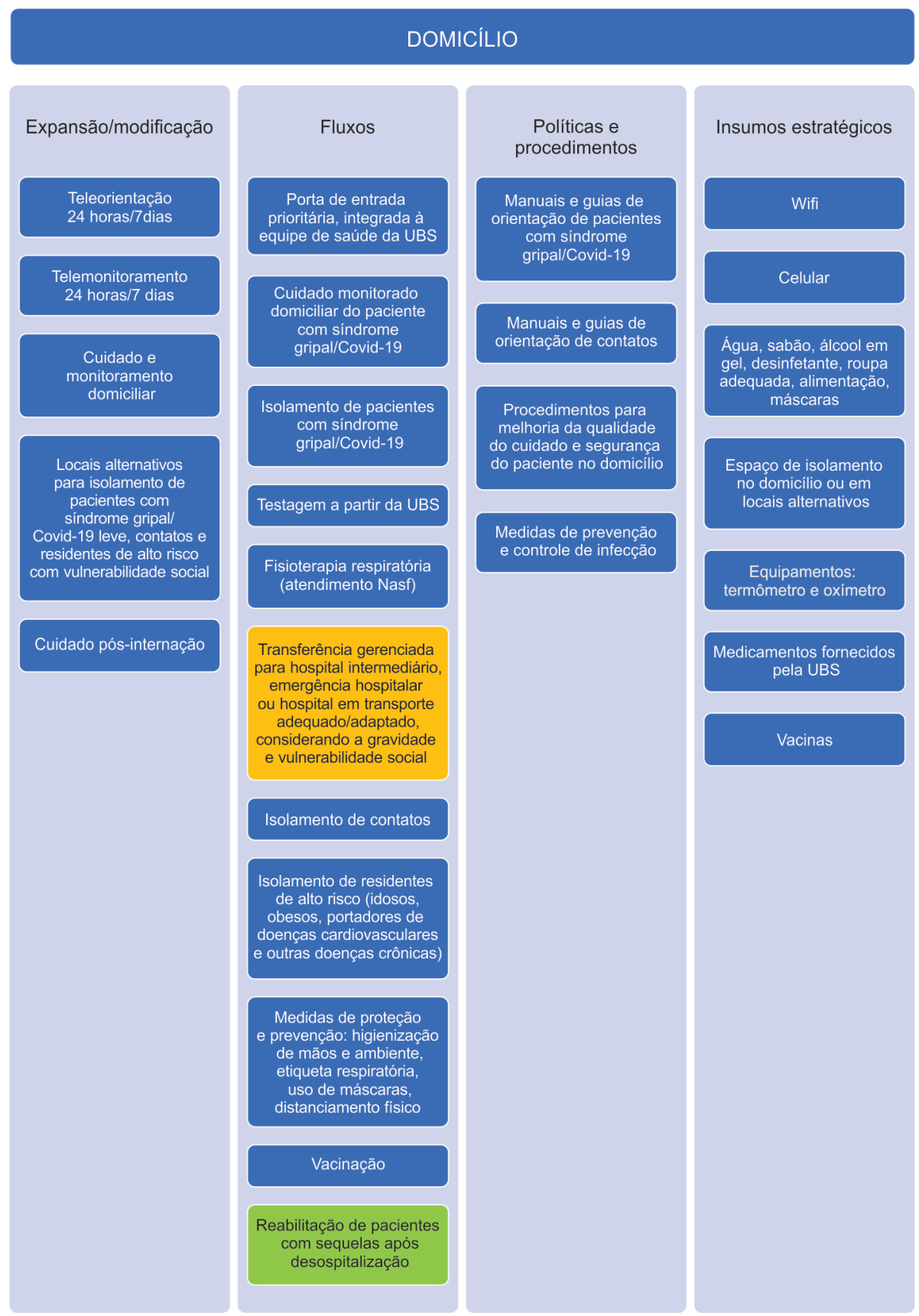




\section{Matriz Linha de Cuidado Covid- 9 na Rede de Atenção à Saúde (continuação)}

\section{ATENÇÃO PRIMÁRIA À SAÚDE AGENTE COMUNITÁRIO DE SAÚDE (ACS)}

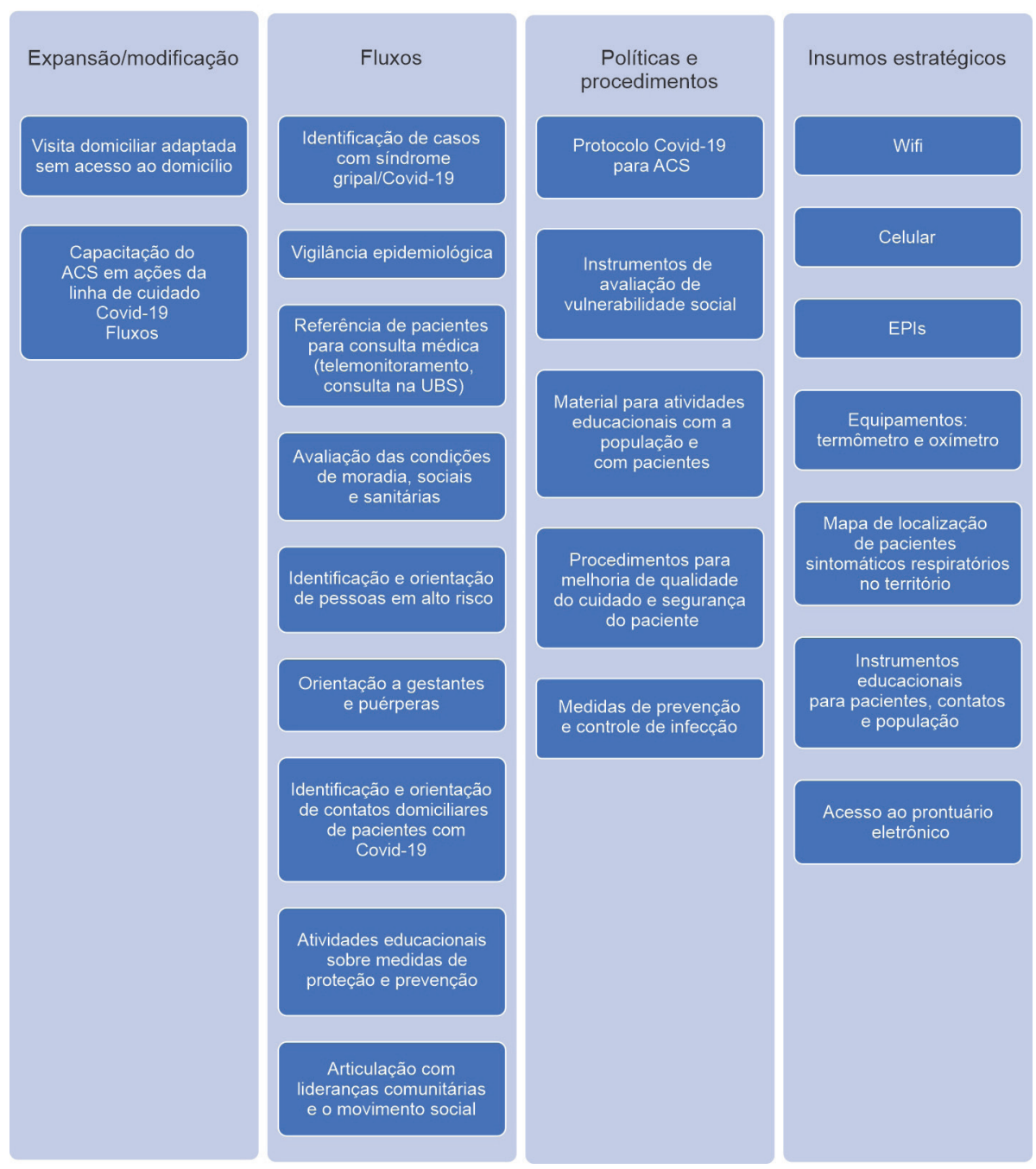




\section{Matriz Linha de Cuidado Covid- I 9 na Rede de Atenção à Saúde (continuação)}

\section{ATENÇÃO PRIMÁRIA À SAÚDE UNIDADE BÁSICA DE SAÚDE (UBS)}

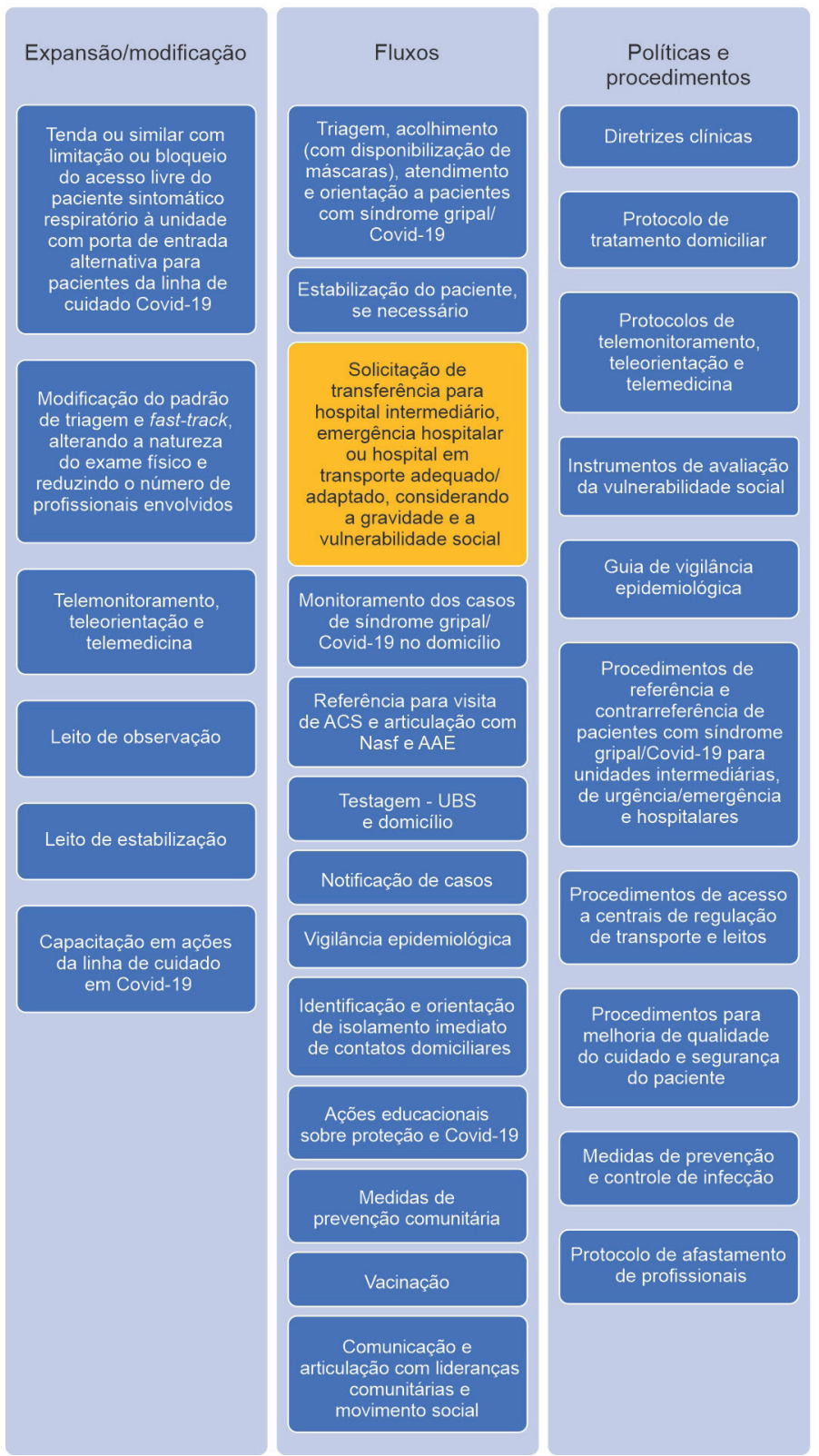

Insumos estratégicos

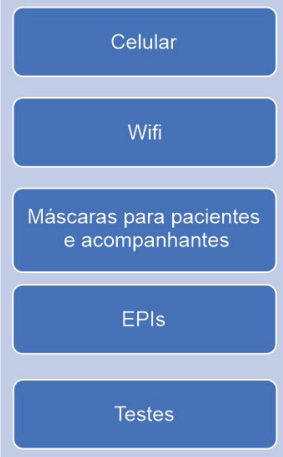

Equipamentos:

termômetro, oximetro,

oxigênio de alto fluxo

intubação (em UBS

preparada para executar

o procedimento),

ECG, outros

Medicamentos analgésicos, antitérmicos, antibióticos (azitromicina) anticuagulantes, outros

Exames laboratoriais

Exames de imagem

Vacinas

Prontuário eletrônico

Medidas de prevenção 
Matriz Linha de Cuidado Covid- I 9 na Rede de Atenção à Saúde (continuação)

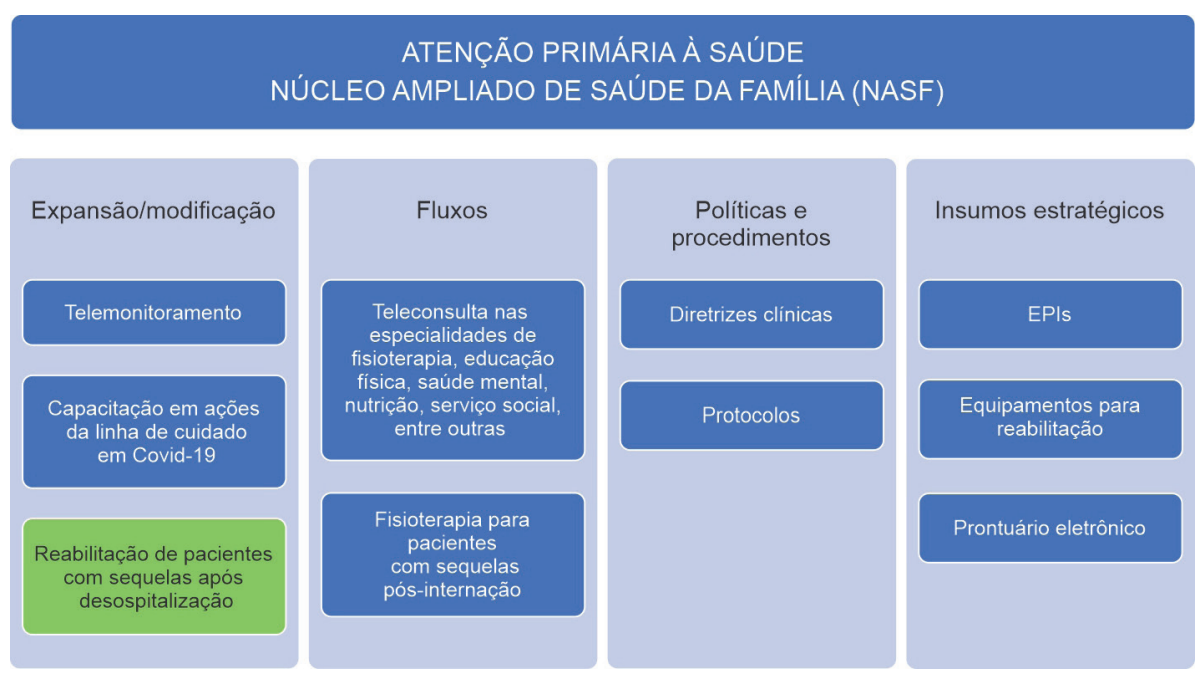




\section{Matriz Linha de Cuidado Covid- 19 na Rede de Atenção à Saúde (continuação)}

\section{AMBULATÓRIO DE ATENÇÃO ESPECIALIZADA (AAE)}

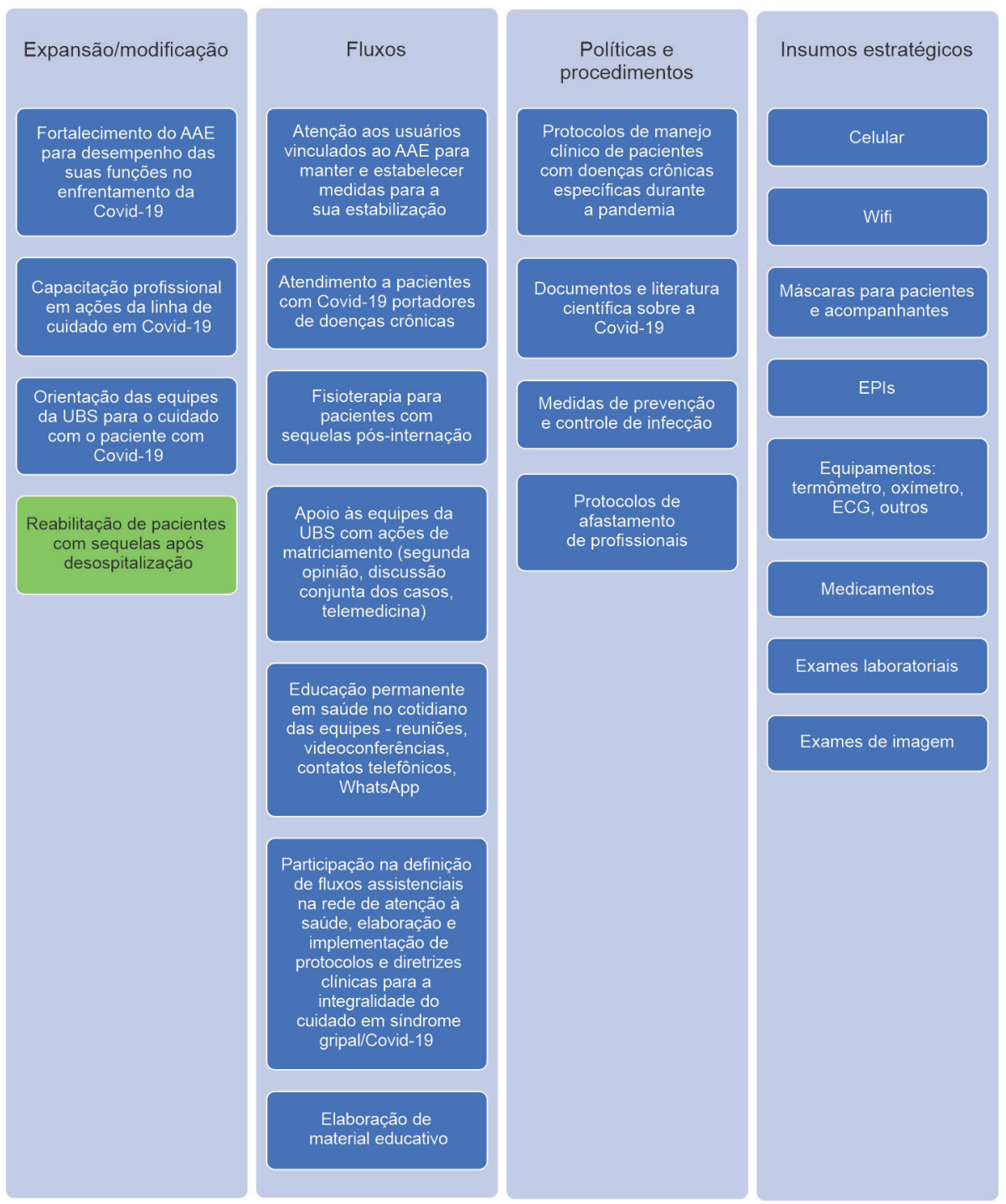




\section{Matriz Linha de Cuidado Covid- 19 na Rede de Atenção à Saúde (continuação)}

\section{TRANSPORTE SANITÁRIO}
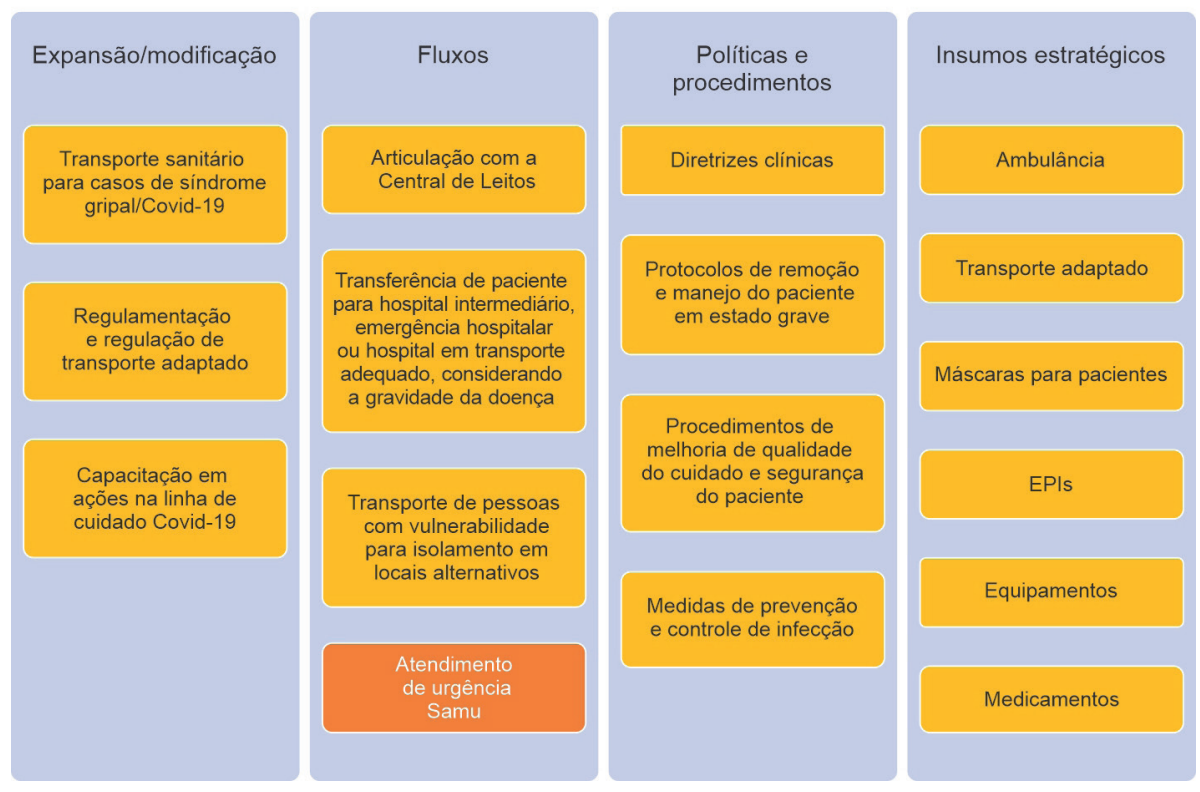


\section{Matriz Linha de Cuidado Covid- 19 na Rede de Atenção à Saúde (continuação)}

\section{URGÊNCIA/EMERGÊNCIA}

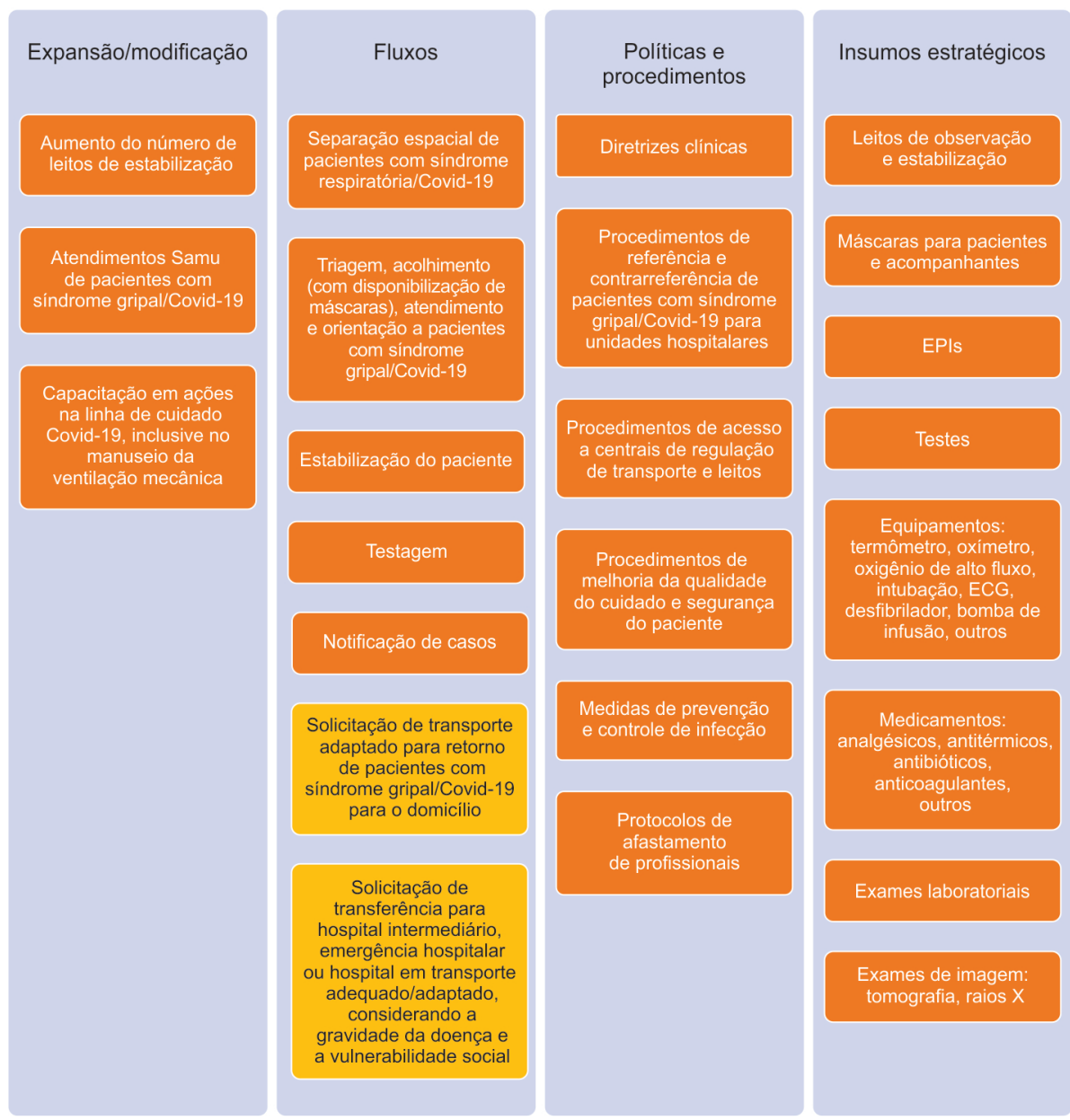




\section{Matriz Linha de Cuidado Covid- 19 na Rede de Atenção à Saúde (continuação)}

\section{HOSPITAL INTERMEDIÁRIO}

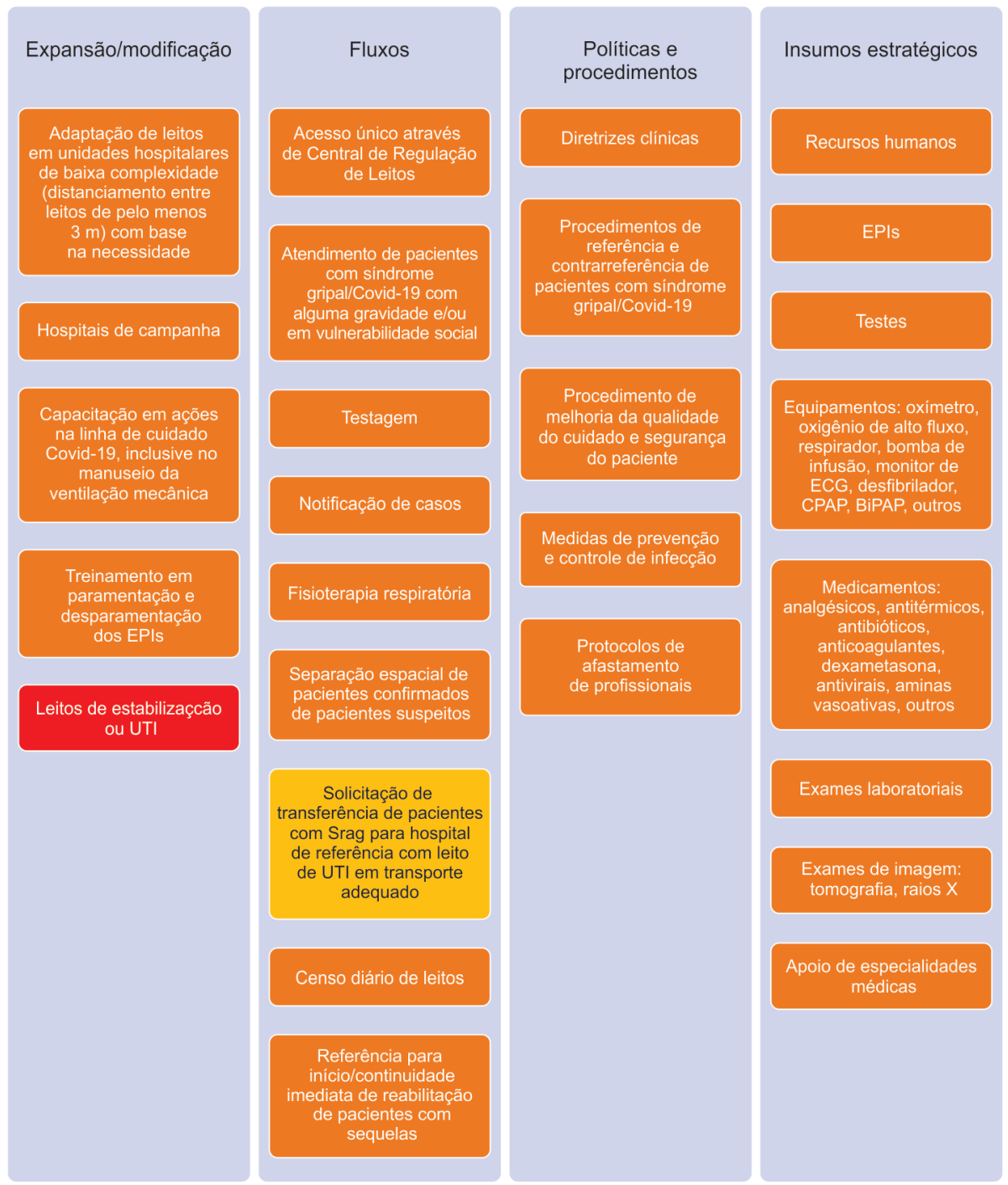




\section{Matriz Linha de Cuidado Covid- I 9 na Rede de Atenção à Saúde (continuação)}

\section{HOSPITAL DE REFERÊNCIA}

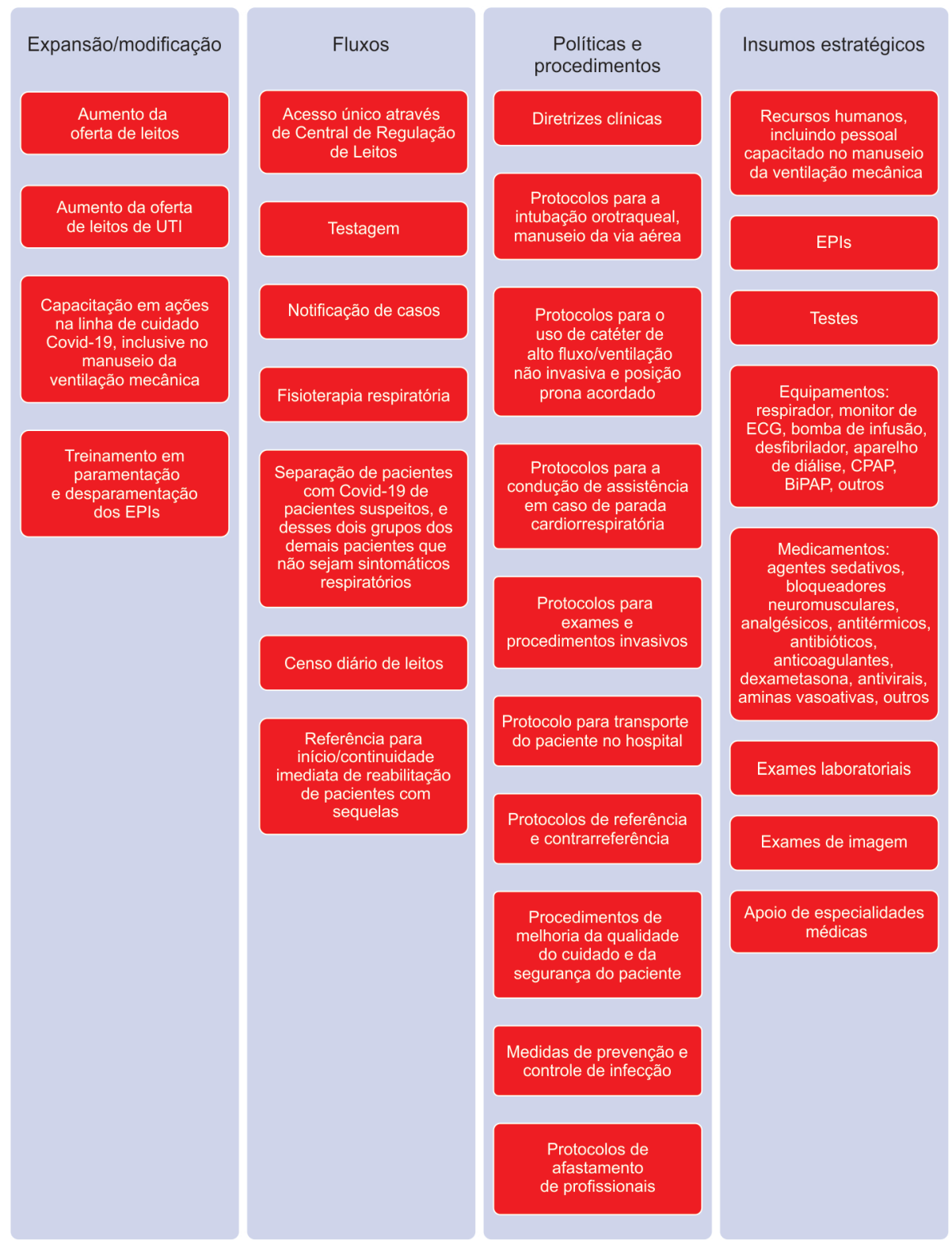




\section{Matriz Linha de Cuidado Covid- I 9 na Rede de Atenção à Saúde (continuação)}

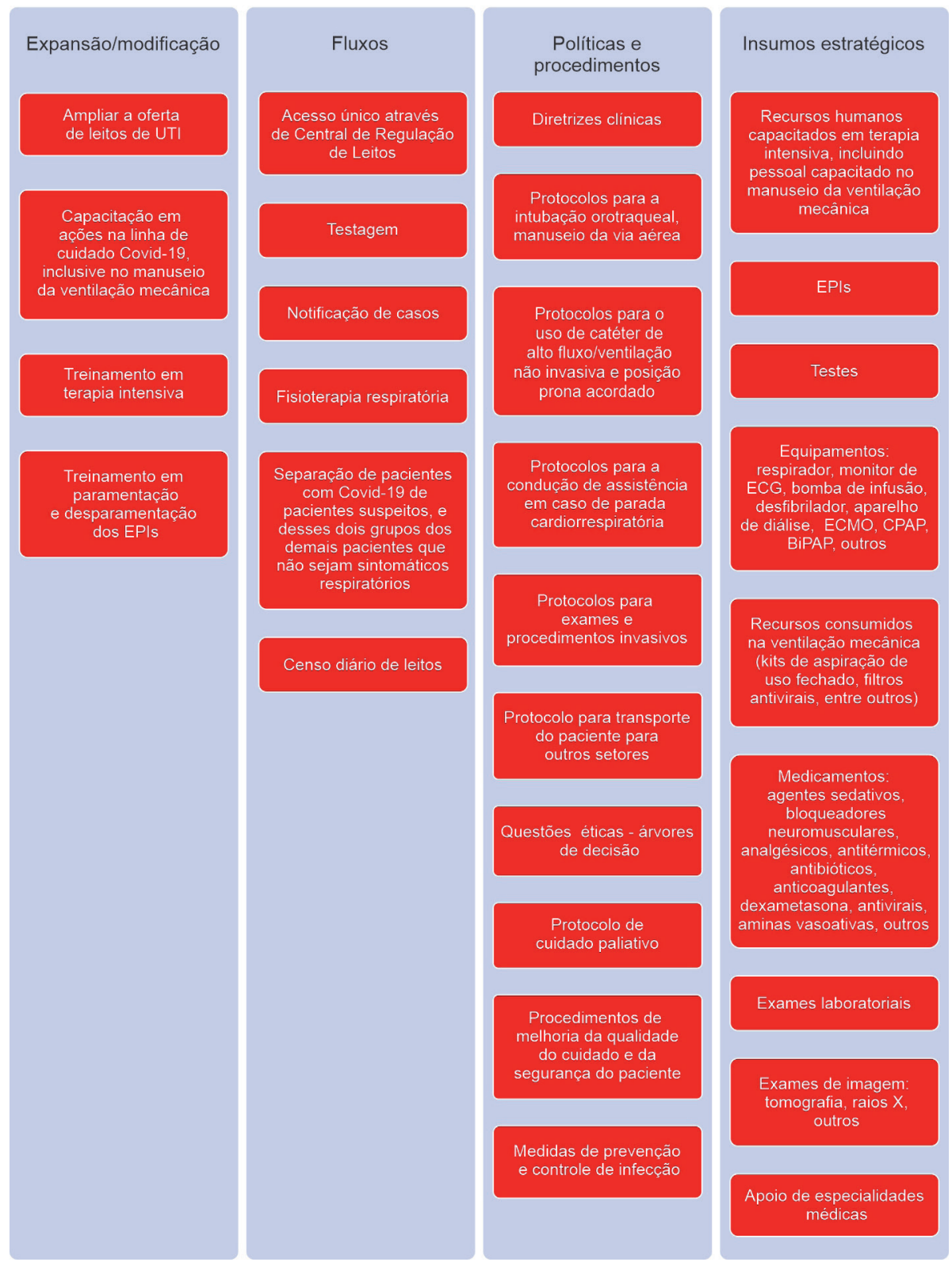




\section{Matriz Linha de Cuidado Covid- I 9 na Rede de Atenção à Saúde (continuação)}

\section{UNIDADE DE REABILITAÇÃO}

\begin{tabular}{|c|c|c|c|}
\hline Expansão/modificação & Fluxos & $\begin{array}{c}\text { Políticas e } \\
\text { procedimentos }\end{array}$ & Insumos estratégicos \\
\hline \multirow{3}{*}{$\begin{array}{c}\text { Unidades de reabilitação } \\
\text { ou desospitalização para } \\
\text { casos elegíveis - sequela } \\
\text { cardiovascular, pulmonar, } \\
\text { renal, neurológica - em } \\
\text { centros de reabilitação } \\
\text { e centros de diálise já } \\
\text { existentes, ambulatórios } \\
\text { de atenção } \\
\text { especializada, Nasf }\end{array}$} & Reabilitação física & Diretrizes clínicas & $\begin{array}{l}\text { Recursos humanos } \\
\text { capacitados }\end{array}$ \\
\hline & Reabilitação respiratória & \multirow[t]{5}{*}{$\begin{array}{l}\text { Procedimentos de } \\
\text { melhoria de qualidade } \\
\text { e segurança do paciente }\end{array}$} & $\begin{array}{l}\text { Equipamentos: aparelho } \\
\text { de diálise, CPAP, } \\
\text { BiPAP, outros }\end{array}$ \\
\hline & Hemodiálise & & \\
\hline & & & \\
\hline \multirow{2}{*}{$\begin{array}{l}\text { Programas de } \\
\text { atendimento domicilar }\end{array}$} & Orientações nutricionais & & \\
\hline & & & $\begin{array}{l}\text { Transporte para } \\
\text { pacientes que não } \\
\text { possam fazer a } \\
\text { reabilitação } \\
\text { em domicilio }\end{array}$ \\
\hline
\end{tabular}

\section{ÓBITO}
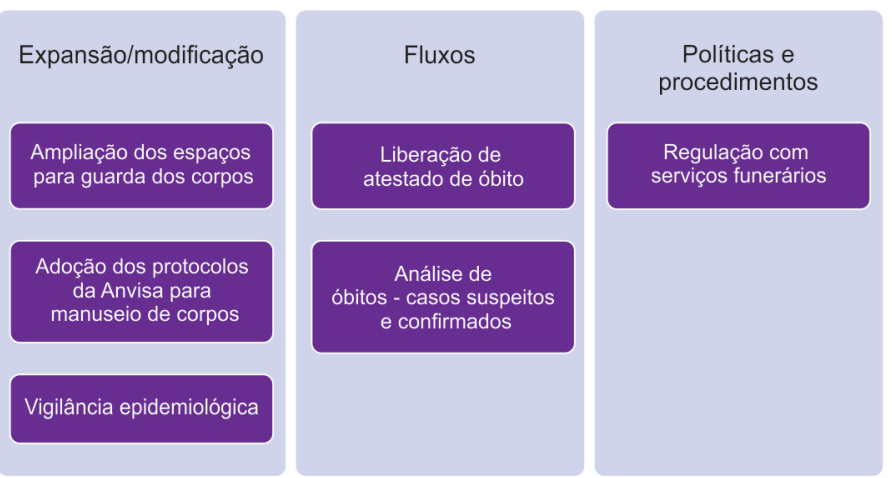

Insumos estratégicos

Covas e túmulos

Articulação entre

sistema de saúde

e sistema funerário 
Agradecimentos

Agradecemos as discussões, leitura e contribuições dos doutores Cássia Righy, Eduardo Melo, Elyne Engstrom, Letícia Janotti, Lenice Gnocchi da Costa Reis e Margareth Dalcolmo.

\section{REFERENNCIAS}

AGÊNCIA NACIONAL DE VIGILÂNCIA SANITÁRIA (ANVISA). Nota técnica GVIMS/GGTES/Anvisa n. 04/2020. Orientações para serviços de saúde: medidas de prevenção e controle que devem ser adotadas durante a assistência aos casos suspeitos ou confirmados de infecção pelo novo coronavírus (SarsCoV-2) - atualizada em 25/02/2021. Brasília: Anvisa, 2021. Disponível em: <https://www.gov.br/ anvisa/pt-br/centraisdeconteudo/publicacoes/servicosdesaude/notas-tecnicas/nota-tecnicagvims_ggtes_anvisa-04_2020-25-02-para-o-site.pdf>. Acesso em: 27 out. 2021 .

ANDERSON, R. M. et al. How will country-based mitigation measures influence the course of the Covid- 19 epidemic? The Lancet, 395(1 0.228): 931-934, 2020.

BRASIL. Ministério da Saúde. Secretaria de Atenção Primária à Saúde. Recomendações para adequação das ações dos agentes comunitários de saúde frente à atual situação epidemiológica referente ao Covid-19. Versão I. Brasília: Ministério da Saúde, 2020a. Disponível em: <www.sbmfc.org.br/wpcontent/uploads/2020/04/Recomendacoes_ACS_COVIDI9_ver00 I_final.pdf.pdf.pdf $>$. Acesso em: 27 out. 2021.

BRASIL. Ministério da Saúde. Secretaria de Atenção Primária à Saúde. Protocolo de Manejo Clínico do Coronavírus (Covid-19) na Atenção Primária à Saúde. Versão 5. Brasília: Ministério da Saúde, 2020b. Disponível em: <https://portalarquivos2.saude.gov.br/images/pdf/2020/marco/24/20200323ProtocoloManejo-ver05.pdf>. Acesso em: 27 out. 2021.

BRASIL. Ministério da Saúde. Secretaria de Vigilância em Saúde. Guia de Vigilância Epidemiológica. Emergência de saúde pública de importância nacional pela doença pelo coronavírus 2019. Covid-19. Brasília: Ministério da Saúde, 202 I. Disponível em: <www.gov.br/saude/pt-br/coronavirus/publicacoestecnicas/guias-e-planos/guia-de-vigilancia-epidemiologica-covid-19>. Acesso em: 27 out. 2021.

CENTERS FOR DISEASE CONTROL AND PREVENTION (CDC). Symptoms of Covid- 19. Updated Feb 22, 202 I. Disponível em: <www.cdc.gov/coronavirus/20 I 9-ncov/symptoms-testing/symptoms.html>. Acesso em: 27 out. 2021.

CONSELHO NACIONAL DE SECRETÁRIOS DE SAÚDE (CONASS). Guia orientador para o enfrentamento da pandemia Covid-I9 na rede de atenção à saúde. Brasília, maio 2020. Disponível em: <www. conasems.org.br/wp-content/uploads/2020/05/Instrumento-Orientador-Conass-ConasemsVERSÃO-FINAL-3.pdf>. Acesso em: 27 out. 2020.

ENGSTROM, E. et al. Recomendações para a organização da Atenção Primária à Saúde no SuS no enfrentamento da Covid-19. Rio de Janeiro: Observatório Covid-19 da Fiocruz, maio 2020. Disponível em: <https://portal.fiocruz.br/sites/portal.fiocruz.br/files/documentos/recomendacoes_aps_no_sus_ para_enfrentamento_da_covid-19_versao_leitura_uma_coluna_I_.pdf > . Acesso em 27 out. 2021 . 
GARG, S. et al. Hospitalization rates and characteristics of patients hospitalized with laboratoryconfirmed coronavirus disease 2019 - Covid-NET, I 4 states, I-30 March 2020. Morbidity and Mortality Weekly Report, 69(15): 458-464, 2020. Disponível em: <www.cdc.gov/mmwr/volumes/69/wr/ mm6915e3.htm?s_cid=mm6915e3_w>. Acesso em: 27 out. 2021.

NATIONAL INSTITUTE FOR HEALTH AND CARE EXCELLENCE (NICE). Covid- I 9 rapid guideline: critical care in adults, 2020. Disponível em: <www.nice.org.uk/guidance/NG I59>. Acesso em: 22 jun. 2020.

WALENSKY, R. P. \& DEL RIO, C. From mitigation to containment of the Covid- I 9 pandemic: putting the Sars-CoV-2 genie back in the bottle. Jama, 323(19): 1.889-1.890, 2020.

WORLD HEALTH ORGANIZATION (WHO). Maintaining essential health services: operational guidance for the Covid- I 9 context: interim guidance, I June 2020. Geneva: WHO, 2020. Disponível em: < https:// www.who.int/publications/i/item/WHO-20I 9-nCoV-essential_health_services-2020.2>. Acesso em: 27 out. 2021. Acesso em: 27 out. 2021.

WORLD HEALTH ORGANIZATION (WHO). Critical preparedness, readiness and response actions for Covid-19: interim guidance, 27 May 202I. Disponível em: <www.who.int/publications/i/item/ critical-preparedness-readiness-and-response-actions-for-covid-19>. Acesso em: 27 out. 2021.

ZHOU, F. et al. Clinical course and risk factors for mortality of adult inpatients with Covid- 19 in Wuhan, China: a retrospective cohort study. The Lancet, 395( I 0.229): I.054-I.062, 2020. 


\section{Organização da Atenção Primária à Saúde no SUS no Enfrentamento da Covid-19}

Elyne Montenegro Engstrom, Eduardo Alves Melo, Ligia Giovanella, Adelyne Maria Mendes Pereira, Victor Grabois e Maria Helena Magalhães de Mendonça

7 presentamos aqui recomendações para a organização dos serviços de Atenção Primária à Saúde (APS) no Sistema Único de Saúde (SUS) para o enfrentamento da pandemia da enfermidade denominada Covid-19, causada pelo vírus Sars-CoV-2. Diante da magnitude e da complexidade desta pandemia, as respostas do setor Saúde devem ser ágeis e integradas, incorporando ações de vigilância, da APS, da média e alta complexidade (CDC, 2020; Portela, Grabois E Travassos, 2020), sustentadas por intervenções estratégicas coordenadas e em articulação intersetorial, para respostas sociais e econômicas.

Experiências internacionais de enfrentamento da pandemia centradas no cuidado individual hospitalar mostraram-se insuficientes, o que indica a importância de modelos de atenção e gestão dos serviços de saúde integrados em rede e coordenados pela APS e, portanto, próximos das comunidades. Tais experiências atestam as potencialidades de uma APS forte e integral no cuidado (Medina et al., 2020).

O número expressivo de mortes por Covid- 10 em 2020 (total=194.976) evidencia o fracasso brasileiro no controle da pandemia, com a disseminação da doença de regiões metropolitanas para municípios menores e a transmissão comunitária do vírus (Fiocruz, 2020a, 2020b). Tal situação sanitária, agravada pelo negacionismo do governo federal e a decorrente resistência a adotar as comprovadas evidências científicas para o controle da Covid-19 acirram a crise humanitária e econômica e as profundas iniquidades sociais já existentes no país, o que se expressa na maior proporção de óbitos entre populações de menor renda e entre pessoas negras (Fiocruz, 2020b; Giovanella et al., 2020). Considerando a determinação social no processo de adoecimento e morte por Covid-19, este agravo é considerado, por alguns autores, como uma sindemia, ou seja, 
uma epidemia que se superpõe ao conjunto de agravos não transmissíveis que afetam com maior intensidade os grupos sociais mais vulneráveis (Singer et al., 2017; Horton, 2020). Por tamanha relação com as desigualdades sociais, a sindemia de Covid- 19 exige abordagens de cuidado ampliadas, que considerem as suas dimensões biopsicossociais.

Nesse contexto, a APS no SUS, em especial a Estratégia Saúde da Família (ESF), tem papel estratégico no enfrentamento da Covid-19, pois sua capilaridade nos territórios Ihe permite identificar situações de risco e vulnerabilidade e exercer a vigilância em saúde. E as unidades básicas de saúde (UBS),' por sua vez, têm papel estratégico no cuidado das pessoas no curso desta epidemia. Para que tal papel se exerça, é preciso que se efetivem atributos e diretrizes para uma APS abrangente, orientada para a integralidade, considerando a necessidade de se estabelecer uma linha de cuidado específica para a Covid- 9 (Brasil, 2020a; WHO, 2020a). Isso implica a definição de fluxos para que as pessoas possam ser cuidadas: no seu local de moradia, no domicílio, nas UBS e nos demais serviços da rede de atenção à saúde. Em um sistema organizado, a APS tem destaque na linha de cuidado, pois possibilita a conformação de trajetórias integrais de cuidado do usuário (Portela, Grabois E Travassos, 2020).

Os atributos que norteiam as ações da APS são: acesso de primeiro contato; vínculo longitudinal; integralidade; coordenação; abordagem familiar e comunitária e competência cultural. No Brasil, diretrizes nacionais de sustentação da APS incluem a necessidade de que esta seja porta de entrada preferencial para o SUS e base para o ordenamento da rede, do trabalho em equipe e da ação nos territórios, na qual se destaca a atuação do agente comunitário de saúde (ACS) (Brasil, 20I2).

Implementar tais referenciais fortalece o papel da APS na prevenção/controle clínico-epidemiológico da epidemia e no apoio social, sem deixar de lado a garantia da atenção aos demais usuários que necessitam de cuidados em saúde (Abrasco, 2020a; 2020b; Vitória \& Campos, 2020). Exige, contudo, modificações na forma de organização das UBS, subsidiadas por informações que permitam monitoramento da situação epidemiológica, planejamento e tomada de decisões, tendo como preocupações centrais a defesa da vida e a segurança de pacientes e profissionais da saúde (Abrasco, 2020a; Brasil, 2020b, 2020c).

Retomando recomendações publicadas em maio de 2020 (Engstrom et al., 2020), evidenciamos aqui a potência da APS na atenção e prevenção da doença, acompanhando

\footnotetext{
' Denominação genérica que inclui os serviços de APS no SUS: centros de Saúde, postos de Saúde, Unidades Básicas, clínicas da Família, unidades de Saúde da Família, entre outras.
} 
e cuidando da maioria dos casos suspeitos ou confirmados e com sintomatologia leve ou moderada (Brasil, 2020b), além de manter o cuidado aos demais usuários adscritos em seus territórios.

\section{EIXOS E DIRETRIZES PARA ATUAÇÃO DA APS NO ENFRENTAMENTO DA COVID-19}

Há diferentes formas de organização da APS nos municípios brasileiros, o que implica considerar as singularidades locais, os recursos e a decisão da gestão, com ações específicas relativas a: organização da porta de entrada; vigilância em saúde; promoção da saúde; cuidado das pessoas e das famílias e gestão compartilhada.

\section{Organização do acesso à unidade básica de saúde}

As unidades precisam se reorganizar como ambiente seguro, estrutura física e insumos adequados, para lidar com os casos de Covid-19 (Brasil, 2020c, 2020d). Algumas das recomendações são:

- Separar os fluxos de pessoas na UBS, criando espaços de acolhimento, espera e triagem na porta de entrada e fluxo de acesso específico para usuários com sintomas respiratórios recentes, em locais específicos (se possível em tendas fora da UBS). Evitar aglomeração e o contato com outros usuários que buscam a unidade, com espaços específicos para o atendimento de usuários sem sintomas respiratórios. Todos devem ser orientados a seguir as regras de etiqueta respiratória e usar máscaras N95 ou PFF2.

- Criar ou adaptar espaço no interior da UBS (p. ex., salas de observação) para assistência ao paciente com quadro moderado ou grave de síndrome gripal ou com síndrome respiratória aguda grave (Srag), com a finalidade de estabilizar e esperar, de forma segura, a remoção para hospital. Esse espaço deve prever ventilação/exaustão adequada (normas da Anvisa), e nele os profissionais devem dispor dos equipamentos de proteção individual (EPIs) compatíveis com a gravidade do estado do paciente e os procedimentos a serem realizados.

- Separar, se possível, parte da equipe para atendimento específico a usuários com sintomas respiratórios (equipes de resposta rápida) em dias ou turnos estabelecidos, para diminuir o risco de contaminação, adoecimento e afastamento de profissionais. 
- Preparar a UBS para imunização, com organização do espaço físico, logística adequada para aplicação da vacina, manutenção e transporte, considerando a cadeia de frio, adequado armazenamento, além de capacitação de pessoal específica para a aplicação das vacinas Covid- 19.

\section{Ações de vigilância em saúde}

O fortalecimento da vigilância em saúde com uma infraestrutura robusta de dados e informações para tomada de decisões, integrada à APS, a torna potente no enfrentamento da crise sanitária atual e de cenários futuros, assim como no subsídio para ações de outros setores (Barreto et al., 2020).

Deve-se conferir ênfase à vigilância epidemiológica, que integra o conjunto de ações de prevenção, bloqueio e controle da Covid- 10 identificando e monitorando os casos e indicadores de saúde da população e produzindo informações ágeis e confiáveis que subsidiem a tomada de decisões. As equipes de Saúde da Família estão presentes nos territórios e conhecem sua população, o que permite a vigilância de casos suspeitos/ confirmados, o rastreio de contatos próximos, a identificação de famílias vulneráveis e a adoção de ações prioritárias, incluindo a imunização da população. Inquérito nacional evidenciou a contribuição do trabalho dos ACS na vigilância: 80,8\% desses profissionais fazem busca ativa de pessoas com maior risco para Covid-19, de forma tanto presencial, por visita peridomiciliar, quanto remota, por meio de telefone ou WhatsApp (Fiocruz, 2020c).

Estudo realizado por Bousquat e colaboradores (2020) entre gestores e profissionais envolvidos no enfrentamento da Covid- 19 nas UBS indicou mudanças nas ações de rotina em torno de $90 \%$; dessas ações, mostraram-se relevantes o incentivo ao isolamento social nos territórios, a notificação, a identificação de contatos e acompanhamento na quarentena, a identificação de grupos prioritários para a continuidade da atenção e a priorização para o contato remoto realizado majoritariamente por telefone do próprio profissional ou mensagem via WhatsApp (Bousquat et al., 2020).

Dentre as recomendações, destacam-se:

- Adotar os critérios mais atualizados para definições de casos suspeitos, confirmados ou descartados de Covid-19 e infecção assintomática, de forma a melhorar a qualidade da notificação.

- Mapear usuários de maior risco para a Covid-19 e reforçar medidas de prevenção domiciliar, acionando redes de apoio social, se necessário. 
- Incentivar e apoiar o isolamento social, o distanciamento físico e o uso de máscaras N95 ou PFF2, imprescindíveis para reduzir o contágio.

- Criar mecanismos de comunicação que facilitem o contato remoto da população com a UBS nos casos suspeitos, acionando ações de vigilância de contatos, monitoramento dos casos e assistência.

- Realizar o rastreamento de novos casos e contatos, mediante ações de vigilância ativa pelas equipes, com destaque para os ACS. Ao identificar casos suspeitos, recomendar isolamento domiciliar por 14 dias como estratégia para reduzir a transmissão comunitária, mantendo-se o monitoramento subsequente.

- Testar casos suspeitos e contatos próximos com teste molecular (RT-PCR), sempre que possível.

- Atentar para a qualidade e segurança dos registros em saúde, quer seja em prontuários eletrônicos ou em meio físico, de modo a permitir a geração de relatórios e consolidados de informações e a notificação de casos.

- Realizar monitoramento periódico da situação epidemiológica local, com base em dados gerados nos atendimentos na APS e/ou fornecidos pela Vigilância (informações sobre os casos notificados e confirmados, pessoas testadas para Sars-CoV-2, sinais e sintomas clínicos, características sociais e demográficas, local de moradia) (Brasil, 2020a).

- Construir espaços de divulgação de informação em sala de situação e/ou painel da situação de saúde do território (virtual ou físico).

- Acionar o potencial das equipes de APS de prover informação, educação e comunicação em saúde em diversos espaços coletivos da comunidade, incluindo estabelecimentos comerciais, instituições de longa permanência como lares de idosos, entre outros, em ação integrada com a vigilância em saúde.

- Organizar a UBS para a imunização contra Covid-19, segundo critérios explicitados em planos nacionais e locais de imunização, considerando: características dos imunobiológicos disponíveis; capacidade de aplicação diária (quantitativo de trabalhadores/espaço físico); organização da fila de acordo com a definição de grupos prioritários; planejamento dos insumos necessários (considerando primeira dose e reforço); preparação do espaço de vacinação; capacitação dos profissionais; orientações sobre a importância da vacina; e organização do fluxo de farmacovigilância no nível municipal (Brasil, 202I). 


\section{Promoção da saúde}

A promoção da saúde tem potencial de contribuir para o alcance da equidade mediante a identificação das iniquidades sociais para que seja possível garantir oportunidades e recursos igualitários aos indivíduos e famílias em maior vulnerabilidade social. Sua ênfase está na abordagem comunitária, nas ações coletivas nos territórios e na articulação de redes de apoio comunitárias e de programas sociais. Para tanto, recomenda-se:

- Realizar ações de informação, educação e comunicação em saúde na comunidade sobre a situação epidemiológica do território, a necessidade de evitar aglomerações e sobre as medidas de proteção comunitárias, domiciliares e pessoais, como distanciamento social, uso de máscaras, higiene pessoal, lavagem de mãos.

- Potencializar recursos de comunicação coletivas existentes na comunidade (rádios comunitárias, grupos de mensagens, carro de som etc.).

- Divulgar orientações e informações sobre a Covid-19, sobre o funcionamento da UBS e da vacinação, para atores e espaços-chave da comunidade, com atenção especial para o esclarecimento de dúvidas em casos de desinformação gerada por fake news.

- Identificar usuários/famílias em extrema pobreza e insegurança alimentar, assim como grupos vulneráveis, como a população em situação de rua, e mobilizar lideranças e organizações sociais para ações de suporte social.

- Mapear possibilidades de outros locais ou estratégias de isolamento para usuários de maior risco para a Covid- 19 que vivem em domicílios com poucos cômodos ou adensamento de moradores.

- Atuar de forma pactuada com os atores e os espaços de participação e controle social, como os conselhos de Saúde, e com a rede intersetorial de serviços públicos e sociais.

\section{Organização do cuidado integral dos usuários e famílias}

\section{Cabe à APS realizar ações}

no âmbito individual e coletivo, de promoção e proteção da saúde, prevenção de agravos, o diagnóstico, o tratamento, a reabilitação, a redução de danos e a manutenção da saúde com o objetivo de desenvolver uma atenção integral que impacte na situação de saúde e autonomia das pessoas e nos determinantes e condicionantes de saúde das coletividades. (Brasil, 20I2) 
Por meio das equipes de saúde e dos núcleos ampliados de Saúde da Família (Nasfs), ações específicas para Covid- 19 envolveriam: prevenção, testagem de casos sintomáticos, manejo clínico, reabilitação e apoio psicossocial aos pacientes, segundo níveis de gravidade, e atenção aos contatos (WHO, 2020b; SBI, 2020). Isso demanda organizar as ações para manter o cuidado dos demais usuários, mediante:

- Revisão das agendas de atividades das equipes, ajustando a oferta de atendimentos programados (grupos prioritários), demanda livre, visitas domiciliares (em casos estritamente necessários), ações comunitárias, atendimentos remotos com usuários (teleatendimentos) e atividades internas (reuniões de equipes e capacitações) (Florianópolis, 2020; Greenhalgh, Koh \& Car, 2020; Caetano et al.; 2020; Brasil, 2016).

- Atendimento de pacientes com suspeita ou confirmação de Covid-19, contemplando também a necessidade de manejo clínico de comorbidades.

- No atendimento inicial do paciente com sintomas respiratórios recentes ou com suspeita de Covid-19, coleta de história e avaliação de sinais clínicos essenciais, como frequência e esforço respiratório, aferição de temperatura e a saturação de $\mathrm{O}_{2}$, evitando ao máximo o prolongamento do tempo de espera e o contato físico paciente-profissional.

- Utilização de protocolos clínicos elaborados por entidades científicas idôneas para identificação da gravidade de sinais e sintomas relacionados à síndrome gripal e seu respectivo manejo clínico. Deve-se considerar a variabilidade de apresentação clínica da doença e não realizar a prescrição de medicamentos sem eficácia comprovada para tratamento da Covid-19, evitando riscos e custos desnecessários aos pacientes, bem como resistência antimicrobiana (SBI, 2020).

- Viabilização de recursos para apoio diagnóstico e assistencial nas UBS, especialmente oxímetro, fontes de $\mathrm{O}_{2}$, eletrocardiograma, exames laboratoriais e exames de imagem.

- Testagem específica para Covid- 19 (testes moleculares RT-PCR, testes sorológicos e testes de antígenos para Sars-(CoV-2) ou encaminhamento dos casos suspeitos para a testagem, garantindo procedimentos de segurança na etapa da coleta e envio para o laboratório. É necessário que a gestão garanta capacidade laboratorial pública para processamento do material coletado com entrega de resultados em tempo oportuno. Testes sorológicos (para presença de anticorpos lgM e $\lg G$ ) devem ser realizados somente no âmbito de estraté- 
gias articuladas entre os setores da Vigilância e da APS, nas esferas municipal e regional, com especial atenção para a especificidade e sensibilidade de cada marca de teste. Com relação aos testes sorológicos, destaca-se sua utilidade para monitoramento do percentual da população que já foi infectada e desenvolveu anticorpos para o Sars-CoV-2 e salienta-se sua reduzida eficácia na identificação de casos, uma vez que apresentam resultados positivos somente após o período de contágio.

- Organização da assistência farmacêutica, considerando recursos terapêuticos para atenção à Covid- 19 na APS, assim como insumos/medicamentos de uso regular na UBS. Tal organização inclui planejar renovação de receitas de usuários em acompanhamento, com maior aprazamento e entrega domiciliar de medicamentos para situações determinadas.

- Manutenção do cuidado dirigido aos demais usuários considerados prioritários, como gestantes, entre outros.

- Atenção ao aumento do consumo de álcool, aos quadros depressivos-ansiosos e à violência doméstica; cuidado em saúde mental dos usuários, com apoio social.

- Mapeamento dos motivos mais comuns da procura espontânea da UBS pelos usuários, buscando modos de prover tais necessidades que dispensem a ida frequente aos serviços de saúde.

- Revisão da realização de visitas domiciliares (VD) (WHO, 2020b), priorizando situações não resolvidas de forma remota, como atenção a idosos com comorbidades, incluindo obesidade, hipertensão e diabetes, além de imunodeprimidos, gestantes, recém-nascidos. Em todas as atividades, devem-se manter distâncias seguras, evitar aglomeração, ofertar máscaras para todos e prover EPI para todos os profissionais, independentemente do motivo da VD.

- Organização de atividades de teleatendimento para acompanhamento de casos suspeitos ou confirmados de Covid- 19 em cuidado domiciliar (Florianópolis, 2020; Greenhalgh, Koh E Car, 2020; Caetano et al., 2020; Brasil, 20 I6), para familiares e também para usuários com outras condições clínicas. Essas atividades podem ser de diferentes modalidades, a depender dos recursos e do planejamento local, como: I) atendimento em centrais de comunicação do SUS com o objetivo de estabelecer canal aberto para a população para orientação clínica e sobre os serviços disponíveis, realizado por meio de aplicativos de computador e/ou contato telefônico direto com profissionais da saúde; 2) atendimento remoto realizado diretamente pelas equipes da APS 
para seus usuários, visando à educação em saúde, à orientação sobre fluxos assistenciais e à realização de monitoramento clínico/epidemiológico e/ ou atendimento virtual. Para tanto, há protocolos específicos para Covid- I9, como o utilizado no Reino Unido (Greenhalgh, Koh E Car, 2020), traduzido por sociedade médica brasileira.

- Garantia, como recurso essencial, da disponibilidade para todas as equipes de um telefone celular, com acesso à internet. Caso não disponível, é fundamental a atuação dos gestores para viabilizá-los.

- Monitoramento por telefone dos usuários em tratamento domiciliar, com pelo menos uma ligação por dia, a cada 24 horas e, se possível, a cada 12 horas, e planejamento de contatos durante os fins de semana.

- Acompanhamento do processo de recuperação do paciente pós Covid-19, estando atento à reabilitação do paciente. Isso é especialmente importante nos casos de sequelas na alta pós-internação, que evoluem com limitações físicas, cognitivas ou psíquicas, como fraqueza muscular e respiratória, fadiga, alterações de sensibilidade, do raciocínio, estresse, depressão. Além da equipe da ESF, é essencial o trabalho colaborativo com os profissionais do Nasf, como fisioterapeuta, terapeuta ocupacional, fonoaudiólogos, educador físico, psicólogo, nutricionista, em reabilitação domiciliar. As ações de reabilitação podem se dar por meio de teleatendimento, atenção em ambientes comunitários, em espaços das UBS ou na atenção domiciliar (AD) do tipo I (por equipes da APS). De acordo com a complexidade do caso, a equipe pode acionar ainda, se disponíveis no município, os serviços de AD com recursos mais especializados para tratamento domiciliar (AD2 e AD3) (Brasil, 2016).

- Em casos com suspeita/confirmação de Covid-19 assistidos pela APS com evolução para óbitos domiciliares, viabilização da emissão de atestado de óbito pelo médico da APS.

\section{Gestão compartilhada do cuidado na rede de atenção à saúde}

O sistema de saúde brasileiro já apresentava uma incoerência na conformação de sua rede, a despeito das mudanças epidemiológicas e demográficas da população que exigiam sistemas integrados para respostas efetivas à complexidade do processo saúdedoença-cuidado (Miranda Jr., 20।4).

Tal situação ficou evidente nas ações iniciais para a Covid-19, com superlotação das unidades de urgência/emergência e falta de integração entre a APS e outros pontos de atenção de maior complexidade tecnológica. Para salvar vidas e tornar as ações 
efetivas em situações clínicas de alta gravidade, disponibilizar leitos hospitalares para casos graves é uma das prioridades; porém, é preciso integração para organizar os caminhos dos usuários entre os serviços, com base em linhas de cuidado e protocolos de regulação. Gestão compartilhada do cuidado significa acompanhamento dos casos e estabelecimento de canais de comunicação e integração com outros serviços da rede de atenção à saúde para referência de casos de maior complexidade, especialmente acesso aos leitos hospitalares, por meio de sistema de regulação e transporte de pacientes. Para tanto, é preciso, entre outros:

- Definir, por parte da gestão municipal/regional, mecanismos de integração de pontos da rede de atenção à saúde que compõem a linha de cuidado em Covid- 19.

- Articular fluxos da APS com os demais componentes da rede de atenção à saúde, notadamente os serviços hospitalares e de urgência e emergência.

- Garantir retaguarda do Serviço de Atendimento Móvel de Urgência (Samu), ou equivalente, para remoção de pacientes nas UBS, bem como canais efetivos para contato entre APS e hospital.

- Definir critérios de encaminhamento para outros serviços da rede.

- Acompanhar à distância a situação de usuários internados e manter canal de comunicação com familiares, evitando que estes procurem o hospital.

No Quadro I estão sistematizadas as recomendações apresentadas nos respectivos campos de atuação da APS. Aspectos relativos à segurança do paciente e do trabalhador da saúde são apresentados no Quadro 2.

Quadro I - Síntese das recomendações para vigilância e atenção no enfrentamento da Covid- 19 na Atenção Primária à Saúde

- Realizar ações individuais e coletivas/comunitárias específicas para a Covid- 19 a partir das UBS, nas áreas da vigilância em saúde, promoção da saúde, cuidado clínico e gestão compartilhada do cuidado com outros serviços da rede

- Incentivar e apoiar o isolamento social, principal maneira de reduzir o contágio

- Reorganizar as agendas dos profissionais e os modos de realização dos atendimentos, para evitar aglomeração e contágio nas UBS, se possível definindo profissionais específicos para o atendimento de usuários com sintomas respiratórios

- Diferenciar fluxos de acesso, bem como espaços de espera e de atendimento, para usuários com sintomas respiratórios e/ou outras condições com suspeita de Covid-19, de preferência em espaço arejado e fora da UBS (tendas) 
Quadro I - Síntese das recomendações para vigilância e atenção no enfrentamento da Covid- 19 na Atenção Primária à Saúde (continuação)

- Garantir infraestrutura e manutenção para as UBS, como espaços físicos/tendas, oxímetros, oxigênio de alto fluxo, além de equipamentos de proteção individual (EPIs) e produtos de higiene

- Realizar ações de cuidado a distância (via teleatendimento, telefone, internet) e, quando oportuno, no território, para diminuir a ida dos usuários às UBS, exceto nas situações que requeiram atenção no próprio serviço

- Para monitoramento dos casos suspeitos/confirmados de Covid-19, manter a equipe atenta à evolução do paciente, em virtude da possibilidade de baixa saturação de oxigênio (sem sintomas) e de agravamento rápido da condição clínica

- Mapear e monitorar usuários e grupos sociais com maior risco e vulnerabilidade à Covid- I 9

- Manter atenção aos usuários com maiores necessidades de cuidados contínuos, independentemente da Covid-19, bem como de acompanhamento pré-natal e de ações de imunização

- Garantir a segurança dos trabalhadores da saúde e dos usuários (máscaras, álcool em gel, avental, luva, água, sabão, desinfecção de ambientes)

- Identificar casos suspeitos e contatos domiciliares e, se possível, contatos comunitários nos últimos I 4 dias para recomendar isolamento domiciliar por 14 dias, como forma de reduzir contágios

- Realizar testes RT-PCR e testes de antígenos para Sars-CoV-2 para confirmação de casos e rastreamento de contatos

- Assegurar o suporte da rede de urgência e emergência (especialmente regulação, transporte por meio de ambulância e remoção pelo Samu) e a comunicação entre os pontos da rede

- Definir, por parte da gestão municipal/regional, a articulação das ações e serviços da rede de atenção que compõem a linha de cuidado específica para Covid- I9, assim como critérios de encaminhamento

- Realizar imunização contra Covid- 9 segundo Plano Nacional (e/ou estadual/municipal) de Imunização, tendo em vista os grupos prioritários nos domicílios/territórios, considerando: capacidade de aplicação diária e organização da fila; planejamento das doses e insumos necessários (considerando primeira e segunda doses); acondicionamento adequado da vacina; comunicação e orientações sobre a importância da vacina; e organização do fluxo de farmacovigilância junto com o nível municipal de gestão

Fonte: elaboração própria. 


\section{Quadro 2 - Recomendações para a segurança do paciente e do trabalhador da saúde}

- Manter a obrigatoriedade do uso de máscaras no interior dos serviços de saúde. Todos os pacientes e acompanhantes devem ser acolhidos, e caso não estejam de máscara deve lhes ser oferecida uma máscara antes do atendimento

- Utilizar equipamentos de proteção individual (EPIs) indicados de forma adequada para o contato com usuários, de acordo com as atividades, procedimentos e ambientes de cuidado. Recomenda-se o uso da máscara N95 ou PFF2 sempre que houver contato com pacientes. A consulta de um paciente com sintomas respiratórios demanda que o profissional da saúde utilize, além da máscara N95 ou PFF2, luvas, avental e gorro ou touca. O mesmo se aplica para procedimentos que gerem aerossóis. Com o surgimento de variantes mais transmissíveis do Sars-Cov-2, é recomendável utilizar máscaras N95 ou PFF2 sempre que possível, inclusive nas atividades que não envolvem cuidado direto

- Em UBS, realizar, em condições ideais, procedimentos que possam gerar aerossóis, incluindo a coleta de swab orofaríngeo ou nasofaríngeo (pois podem provocar tosse ou espirros), em unidade de isolamento respiratório com pressão negativa e filtro Hepa (high efficiency particulate arrestance). Se não for possível, deve-se colocar o paciente em um quarto com portas fechadas e janelas abertas, e restringir o número de profissionais durante a realização desses procedimentos

- Capacitar todos os trabalhadores da saúde no conhecimento das formas de transmissão da doença e das medidas individuais e coletivas de proteção contra o Sars-CoV-2

- Prover condições para adequada higienização das mãos para uso dos pacientes e seus acompanhantes e dos profissionais da saúde, tanto no acolhimento/triagem quanto em outros pontos da UBS

- Definir o trabalho na forma de rodízio, se possível na organização de turnos ou de dias de trabalho, para que apenas parte da equipe esteja voltada para o atendimento específico a usuários com sintomas respiratórios, como forma de diminuir o risco de adoecimento e afastamento de profissionais, reduzir o estresse e permitir que parte da atividade dos profissionais se dê com pacientes que fazem parte dos programas tradicionais

- Orientar os trabalhadores da saúde sobre evitar tocar superfícies próximas ao paciente (p. ex., mobiliário e equipamentos para a saúde) e aquelas fora do ambiente próximo ao paciente, com luvas ou outros EPIs contaminados ou com as mãos contaminadas

- Dedicar atenção especial aos profissionais da limpeza e higienização de ambientes, que têm elevada exposição ao risco. Esses trabalhadores da saúde têm, em geral, menor escolaridade formal e dificuldade no acesso à informação de qualidade. É importante que sejam incluídos nas reuniões realizadas na unidade e que a equipe se responsabilize também por sua capacitação, mesmo que esses trabalhadores estejam a cargo das empresas terceirizadas

- Paramentar-se e desparamentar-se de forma adequada como atitude fundamental na redução do risco de transmissão do Sars-CoV-2 no âmbito das UBS. A capacitação de todos os trabalhadores da saúde e também a observação desses processos por outros profissionais são muito relevantes para garantir que tenham sido realizados de forma segura 
Quadro 2 - Recomendações para a segurança do paciente e do trabalhador da saúde (continuação)

- Monitorar a força de trabalho em suas condições físicas e emocionais é essencial para definir atividades de suporte psicológico e a necessidade de afastamento de trabalhadores. A realização de briefings e debriefings - termos que remetem às reuniões breves entre profissionais, respectivamente no início e no final dos turnos, para avaliação sobre assuntoschave do trabalho - é um recurso já utilizado na segurança do paciente. No contexto da Covid-19, se justifica ainda mais para ações como, por exemplo, a identificação de riscos, problemas, necessidades de insumos, do que deu certo e do que precisa ser revisto.

A necessidade de escuta das preocupações, receios e obstáculos para um cuidado seguro para usuários e profissionais no contexto da pandemia é premente. Essas atividades podem ter impacto positivo na segurança psicológica dos trabalhadores da saúde

- Orientar-se pelas normas do Ministério da Saúde e da Agência Nacional de Vigilância Sanitária (Anvisa), pelas melhores práticas e pela disponibilidade de testagem dos profissionais da saúde para decidir pelo afastamento de trabalhadores por sintomas respiratórios ou por confirmação de Covid- 19

- Realizar a limpeza e desinfecção das superfícies do consultório e de outros ambientes utilizados pelo paciente e de equipamentos e produtos para saúde que tenham sido utilizados na assistência ao paciente

\section{MENSAGEM FINAL}

Uma das lições aprendidas durante a emergência sanitária da Covid- 19 foi a importância do SUS e da APS quando se trata de salvar vidas. Sem uma APS forte e universal, não haverá imunização efetiva da população e controle da doença. A dinâmica da epidemia não pode levar à paralisação do cuidado. A renovação de práticas pede novos investimentos em recursos, insumos e ações para a sua otimização. Em tempo ágil e oportuno, será fundamental assegurar o acesso universal à vacinação contra a Covid- 19 (Brasil, 2021), combinado às ações de isolamento social e de vigilância.

Muito há que se investir para a reestruturação de um sistema de saúde integrado, com coerência epidemiológica e sanitária, de custo-efetividade, para cumprir a missão de cuidar da saúde das pessoas, das famílias e da comunidade. 


\section{REFERÊNCIAS}

ASSOCIAÇÃO BRASILEIRA DE SAÚDE COLETIVA (ABRASCO). Rede de Pesquisa em APS. Desafios da APS no SUS no enfrentamento da Covid-19. Relatório do Seminário Virtual da Rede APS Abrasco, abr. 2020a. Disponível em: <https://redeaps.org.br/wp-content/uploads/2020/04/ Relatorio-Rede-APS-_Semina\%CC\%8 I rio-APS-no-SUS-e-Covid- I 6-Abril-2020-final.pdf > . Acesso em: 12 maio 2020.

ASSOCIAÇÃO BRASILEIRA DE SAÚDE COLETIVA (ABRASCO). Rede de Pesquisa em APS. Fortalecer a ESF no enfrentamento da Covid- 19: posição da Rede APS da Abrasco. Disponível em: <www.abrasco. org.br/site/wp-content/uploads/2020/05/REDE-APS-POSIC\%CC\%A7A\%CC\%83O-SOBRE-A-APSNO-ENFRENTAMENTO-DA-COVID- 19 -final.pdf>. Acesso em: 12 maio $2020 \mathrm{~b}$.

BARRETO, M. L. et al. O que é urgente e necessário para subsidiar as políticas de enfrentamento da pandemia de Covid- I 9 no Brasil? Revista Brasileira de Epidemiologia, 23: E200032, 2020. Disponível em: < https://doi.org/10.1590/1980-549720200032>. Acesso em: 30 abr. 2020.

BOUSQUAT, A. et al. Desafios da Atenção Básica no enfrentamento da pandemia da Covid- I 9 no SUS. Relatório de pesquisa. USP, Fiocruz, Ufba, Ufpel, Opas Brasil. Rio de Janeiro: Rede de Pesquisa em Atenção Primária à Saúde da Abrasco, ago. 2020. Disponível em: < https://redeaps.org.br/2020/08/30/ relatorio-completo-da-pesquisa-desafios-da-ab-no-enfrentamento-da-pandemia-da-covid- I9-nosus>. Acesso em: 12 jan. 2021.

BRASIL. Ministério da Saúde. Secretaria de Atenção à Saúde. Departamento de Atenção Básica. Política Nacional de Atenção Básica. Brasília: Ministério da Saúde, 2012.

BRASIL. Ministério da Saúde. Portaria n. 825, de 25 abr. 20I6. Redefine a Atenção Domiciliar no âmbito do Sistema Único de Saúde (SUS) e atualiza as equipes habilitadas, 2016. Diário Oficial da União, Brasília, 2016. Disponível em: <www.in.gov.br/materia/-/asset_publisher/Kujrw0TZC2Mb/ content/id/22685962/dol-20 I6-04-26-portaria-n-825-de-25-de-abril-de-20 I6-22685827>. Acesso em: 9 fev. 2021.

BRASIL. Ministério da Saúde. Plano de Contingência Nacional para Infecção Humana pelo Novo Coronavírus (Covid-19). Brasília: Ministério da Saúde, Centro de Operações de Emergências em Saúde Pública | COE-Covid-19, fev. 2020a. Disponível em <www.gov.br/saude/pt-br/coronavirus/publicacoestecnicas/guias-e-planos/livreto-plano-de-contingencia-espin-coe-26-novembro-2020>. Acesso em: I 2 maio 2020.

BRASIL. Ministério da Saúde. Secretaria de Atenção Primária à Saúde. Protocolo de manejo clínico do novo coronavírus (Covid-19) na Atenção Primária à Saúde (versão 8). Brasília: Ministério da Saúde, 2020b.

BRASIL. Ministério da Saúde. Nota técnica n. 04/2020 GVIMS/GGTES/Anvisa. Orientações para serviços de saúde: medidas de prevenção e controle que devem ser adotadas durante a assistência aos casos suspeitos ou confirmados de infecção pelo novo coronavírus, 2020c. Versão publicada maio 2020 e atualizada em 25 fev. 2021. Disponível em: <www.gov.br/anvisa/pt-br/centraisdeconteudo/ publicacoes/servicosdesaude/notas-tecnicas/nota-tecnica-gvims_ggtes_anvisa-04_2020-25-02para-o-site.pdf >. Acesso em: 8 mar. 2021. 
BRASIL. Ministério da Saúde. Secretaria de Vigilância em Saúde. Recomendações de proteção aos trabalhadores dos serviços de saúde no atendimento de Covid- 19 e outras síndromes gripais. COE/ SVS/MS, abr. 2020d. Disponível em: <www.gov.br/saude/pt-br/coronavirus/publicacoes-tecnicas/ recomendacoes/recomendacoes-de-protecao-aos-trabalhadores-do-servico-de-saude.pdf/view $>$. Acesso em: 30 maio 2020.

BRASIL. Ministério da Saúde. Secretaria de Vigilância em Saúde. Departamento de Imunização e Doenças Transmissíveis. Coordenação-Geral do Programa Nacional de Imunizações. Plano Nacional de Operacionalização da Vacinação contra a Covid-19. 3. ed. Brasília: Ministério da Saúde, 2021. Disponível em: <www.gov.br/saude/pt-br/media/pdf/202 I/janeiro/29/planovacinacaocovid_v2_29jan2I_nucom. pdf >. Acesso em: 9 fev. 2021.

CAETANO, R. et al. Health education and information: initiatives of telehealth centers to combat Covid- 19. Revista de Enfermagem do Centro-Oeste Mineiro, 10: e3888, 2020.

CENTERS FOR DISEASE CONTROL AND PREVENTION (CDC). Symptoms of coronavirus. Disponível em: <www.cdc.gov/coronavirus/20l9- ncov/symptoms-testing/symptoms.html>. Acesso em: 22 jun. 2020.

ENGSTROM, E. M. et al. Recomendações para a organização da atenção primária à saúde no SUS no enfrentamento da Covid-19. Série Linha de Cuidado Covid-19 na Rede de Atenção à Saúde. Rio de Janeiro: Observatório Covid-19, Fiocruz, maio 2020. Disponível em: <https://portal.fiocruz.br/sites/ portal.fiocruz.br/files/documentos/recomendacoes_aps_no_sus_para_enfrentamento_da_covid-19_ versao_leitura_uma_coluna_I_.pdf > . Acesso em: 20 dez. 2020.

FLORIANÓPOLIS. Prefeitura Municipal de Saúde de Florianópolis, SC. Secretaria Municipal de Saúde. Covid-19: guia para profissionais de saúde da Atenção Primária. $7^{\text {a }}$. versão. Florianópolis, 6 out. 2020. Disponível em: <https://redeaps.org.br/wp-content/uploads/2020/I0/COVID-19_ Guia-para-profissionais-da-atenc\%CC\%A 7a\%CC\%830-prima\%CC\%8Iria_7\%C2\%AAversa\%CC\%830_06out2020.pdf>. Acesso em: 8 fev. 2021.

FUNDAÇÃO OSWALDO CRUZ (FIOCRUZ). Observatório Covid-19. Boletins das semanas epidemiológicas 44 e 45. Rio de Janeiro: Fiocruz, 25-3I out. e I-7 nov. 2020a. Disponível em: <https:// portal.fiocruz.br/sites/portal.fiocruz.br/files/documentos/boletim_covid_semana_44-45.pdf>. Acesso: 16 nov. 2020

FUNDAÇÃO OSWALDO CRUZ (FIOCRUZ). Observatório Covid-19. Boletins das semanas epidemiológicas 48 e 49. Rio de Janeiro: Fiocruz, 22-30 nov. e I-5 dez. 2020b. Disponível em: < https:// portal.fiocruz.br/sites/portal.fiocruz.br/files/documentos/boletim_covid_semana_48-49.pdf > . Acesso em: 23 dez. 2020.

FUNDAÇÃO OSWALDO CRUZ (FIOCRUZ). Escola Politécnica de Saúde Joaquim Venâncio (EPSJV). $2^{\circ}$ boletim da Pesquisa Monitoramento da Saúde dos ACS em Tempos de Covid-19, nov. 2020c. Disponível em: < https://acscovid I 9.fiocruz.br/sites/acscovid I 9.fiocruz.br/files/2o_boletim.pdf>. Acesso em: 8 maio 2020.

GIOVANELLA, L. et al. Negacionismo, desdém e mortes: notas sobre a atuação criminosa do governo federal brasileiro no enfrentamento da Covid- I 9. Saúde em Debate, 44(I 26): 895-90 I, 2020.

GREENHALGH, T.; KOH, G. C. H. \& CAR, J. Covid- I 9: a remote assessment in primary care. BMJ, 368: mI I82, 2020. Disponível em: <www.bmj.com/content/368/bmj.m I I82/rapid-responses>. Acesso em: 12 maio 2020. 
HORTON, R. Offline: Covid-19 is not a pandemic. The Lancet, 396: 874, 2020.

MEDINA, M. G. et al. Atenção primária à saúde em tempos de Covid- 19: o que fazer? Cadernos de Saúde Pública, 36(8): e00149720, 2020.

MIRANDA JR., H. M. Redes de Atenção à Saúde: rumo à integralidade. Divulgação em Saúde para Debate, n. 52, 2014.

PORTELA, M. C.; GRABOIS, V. E TRAVASSOS, C. Matriz de Cuidado Covid-I 9 na Rede de Atenção à Saúde. Série Linha de Cuidado Covid- 19 na Rede de Atenção à Saúde. Rio de Janeiro: Observatório Covid-19, Fiocruz, jul. 2020. <https://portal.fiocruz.br/sites/portal.fiocruz.br/files/documentos/ matrizlinhacuidado.pdf>. Acesso em: 22 dez. 2020.

SINGER, M. et al. Syndemics and the biosocial conception of health. The Lancet, 389: 94 I-950, 2017.

SOCIEDADE BRASILEIRA DE INFECTOLOGIA (SBI). Atualizações e recomendações sobre a Covid- I9, 9 dez. 2020. Disponível em: <https://infectologia.org.br/wp-content/uploads/2020/I2/atualizacoese-recomendacoes-covid-19.pdf>. Acesso em: 21 dez. 2020.

VITÓRIA, A. M. E CAMPOS, G. W. S. Só com APS forte o sistema pode ser capaz de achatar a curva de crescimento da pandemia e garantir suficiência de leitos UTI. São Paulo: Cosems-SP, 2020. Disponível em: <www.cosemssp.org.br/wp-content/uploads/2020/04/So-APS-forte-para-ter-leitos-UTI-.pdf>. Acesso em: 8 maio. 2020.

WORLD HEALTH ORGANIZATION (WHO). Infection prevention and control during health care when Covid-I9 is suspected: interim guidance, 19 March 2020a. Disponível em: <www.who. int/publications-detail/infection-prevention-and-control-during-health-care-when-novelcoronavirus-(ncov)-infection-is-suspected-20200 I25 >. Acesso em: I2 maio 2020.

WORLD HEALTH ORGANIZATION (WHO). Home care for patients with Covid-I 9 presenting with mild symptoms and management of their contacts: interim guidance, 17 Mar. 2020b. Disponível em: <https://apps.who.int/iris/bitstream/handle/l 0665/33 I 473/WHO-nCov-IPC-HomeCare-2020.3eng.pdf? sequence $=\mathrm{I}$ EisAllowed $=\mathrm{y}>$. Acesso em: I2 maio. 2020. 


\title{
Desafios da Atenção Básica no Enfrentamento da Pandemia de Covid-19 no SUS
}

\author{
Ligia Giovanella, Aylene Bousquat, Maria Guadalupe Medina, \\ Maria Helena Magalhães de Mendonça, Luiz Augusto Facchini, \\ Renato Tasca, Fúlvio Borges Nedel, Juliana Gagno Lima, \\ Paulo Henrique dos Santos Mota e Rosana Aquino
}

A pandemia de Covid- 19 representa um grande desafio para a sociedade, para os sistemas de saúde, para os governos e para a ciência, por exigir um conjunto de respostas articuladas. No caso brasileiro, não é tarefa simples responder às demandas decorrentes da pandemia de Covid- 19 em consonância com os princípios fundamentais do Sistema Único de Saúde (SUS), considerando-se que, assim como ocorreu em outros países, a resposta sanitária esteve centrada nos serviços hospitalares, com ações para ampliação do número de leitos, especialmente, de unidades de tratamento intensivo e de respiradores pulmonares. Nesse enfrentamento, é crucial reconhecer o papel que a Atenção Primária à Saúde (APS) tem a desempenhar. Sem desconsiderar a importância da adequada estruturação da atenção especializada voltada para os casos mais graves de Covid-19, é preciso reconhecer o enorme conjunto de ações e estratégias que podem ser implementadas no âmbito da APS para prevenção, cuidado e controle da epidemia.

A reorganização dos serviços de APS é imperativa. Os casos infectados são, em sua maioria, assintomáticos ou apresentam formas leves da doença, com indicação de isolamento domiciliar, busca ativa de contatos e apoio à quarentena, e devem ser monitorados pela APS e encaminhados a outros serviços da rede SUS oportunamente, conforme necessidade. Ademais, em inúmeros municípios o único serviço de saúde disponível são as unidades básicas de saúde (UBS), o que reforça essa preocupação.

Adicionalmente, os serviços de APS, por sua capilaridade e atuação no território, são responsáveis pelo desenvolvimento de ações de promoção, prevenção e cuidado em enorme gama de problemas de saúde que não podem ser descontinuadas. Isso impõe medidas que promovam a sustentabilidade da APS, garantindo a segurança tanto de seus usuários quanto de seus trabalhadores durante o período da pandemia. Em epi- 
demias anteriores ficou evidente que o foco exclusivo na doença emergente pode ter efeitos desastrosos na morbidade e mortalidade por outros problemas de saúde, quando se reduz o acesso ao cuidado de outras condições e agravos de que a APS se ocupa cotidianamente (Dunlop et al., 2020; Minué, 2020).

O enfrentamento da pandemia Covid-19, além da garantia do cuidado individual, requer uma abordagem comunitária de vigilância em saúde. Os serviços de atenção primária do SUS, especialmente as equipes da Estratégia Saúde da Família (ESF), por seus atributos de responsabilidade territorial, orientação comunitária e forte capilaridade em todo o território nacional, são os mais adequados para essa abordagem. Mais que nunca, faz-se necessária a articulação do individual com o coletivo, a atuação integrada no âmbito das unidades de saúde com os territórios, a comunidade e seus equipamentos sociais. É importante que a reorganização do processo de trabalho na APS no contexto da epidemia se faça de modo a preservar os seus atributos de acesso, longitudinalidade, coordenação do cuidado, abordagens familiar e comunitária. Ademais, é necessário manter o contato das pessoas com os profissionais da saúde que cuidam delas diariamente, seja para deteç̧ão precoce da infecção por Covid- 19 e seu monitoramento, seja para atendimento a qualquer outro problema de saúde, garantindo a continuidade dos cuidados e o apoio social aos grupos vulneráveis, ao mesmo tempo que se asseguram as condições de proteção dos trabalhadores e da população (Medina et al., 2020).

Dialogando com essa necessidade, Universidade de São Paulo (USP), Fundação Oswaldo Cruz (Fiocruz), Universidade Federal da Bahia (Ufba) e Universidade Federal de Pelotas (Ufpel) conduziram a Pesquisa Desafios da Atenção Básica no Enfrentamento da Pandemia da Covid- 19 no SUS, uma iniciativa da Rede de Pesquisa em Atenção Primária da Associação Brasileira de Saúde Coletiva (Abrasco, 202I).

\section{A PESQUISA}

A pesquisa teve como objetivo identificar os principais constrangimentos e as estratégias de reorganização utilizadas pelas equipes de APS no enfrentamento da Covid- 9 nos municípios brasileiros, e dessa identificação extrair aprendizados que possam contribuir para a formulação de políticas mais efetivas e adequadas a diferentes contextos no combate à Covid- 19 no país.

Foi realizado estudo transversal por meio de um inquérito on-line (websurvey) entre 25 de maio e 30 de junho de 2020 com profissionais da saúde dos serviços de atenção básica e gestores e gerentes das secretarias municipais de Saúde brasileiras. Foram elaborados questionários para profissionais e para gestores com questões similares, com as quais se procurou apreender suas experiências sobre a atuação da APS no cenário da 
pandemia quanto a: vigilância em saúde, cuidado dos usuários com Covid- I 9, continuidade do cuidado ofertado pela APS, ação comunitária e apoio social, além de aspectos de infraestrutura das UBS e disponibilidade de insumos para o combate à Covid- 19.

O estudo foi aprovado no Comitê de Ética em Pesquisa da Faculdade de Saúde Pública da USP (CAAE 3 I 4 I 4420.8.0000.542 I). O inquérito on-line cumpriu os requisitos internos propostos no Checklist for Reporting Results of Internet E-Surveys (Cherries), com exceção do bloqueio de IP (Eysenbach, 2004).

Os participantes da pesquisa somaram 2.566 indivíduos, sendo 1.908 profissionais da saúde da $A P S / A B$ e 658 gestores, distribuídos em todos os estados da federação e Distrito Federal, em 1.000 municípios, em todas regiões brasileiras, com alguma correspondência entre a proporcionalidade da distribuição de respondentes da pesquisa e população de cada região. No momento da investigação, a maioria dos respondentes já relatava a existência de casos $(87,6 \%)$ e óbitos (52,6\%) por Covid- 19 nas áreas de abrangência das UBS, o que justificava novas estratégias de intervenção. Cabe lembrar que em virtude das características do território brasileiro, a pandemia teve um comportamento heterogêneo, com diversas ondas que atingiram capitais, municípios do interior e estados em diferentes tempos e intensidades. Até junho de 2020, a maior parte dos casos de Covid- 19 concentrava-se nas regiões metropolitanas. A partir de julho observou-se sincronização dos tempos epidêmicos de regiões metropolitanas e cidades do interior (Fiocruz, 2020).

\section{A ATUAÇÃO DA APS NO CENÁRIO DA PANDEMIA}

A apresentação da atuação da APS no SUS no cenário da pandemia em junho de 2020, tema da pesquisa aqui relatada, se inicia com a infraestrutura das UBS e disponibilidade de insumos para o combate à Covid- 19 e prossegue com os eixos em torno dos quais tal atuação se estrutura: vigilância em saúde; cuidado dos usuários com Covid-19; continuidade do cuidado ofertado pela APS; e ação comunitária e apoio social.

\section{Infraestrutura e disponibilidade de insumos e equipamentos}

As unidades da rede básica alcançadas eram majoritariamente urbanas, organizavam-se no modelo da ESF com até duas equipes por UBS, dispunham de 2 a 3 consultórios e insuficiente acesso à internet. A disponibilidade de internet foi precária ou inexistente para quase $60 \%$ dos respondentes, e celulares institucionais estavam disponíveis nas UBS de apenas $28 \%$ dos entrevistados. Não obstante, $72 \%$ dos profissionais usavam seu próprio celular para contato com o usuário, com maior frequência nas regiões Norte e Nordeste (82\%), o que atesta sua responsabilização pelo cuidado dos usuários (Tabela I). 
Em junho de 2020, observava-se importante escassez de insumos e acesso a testes necessários para diagnóstico, vigilância e cuidado de doentes. Não estavam disponíveis em quantidade suficiente nas UBS para a grande maioria dos profissionais: oxímetro (64\%), termômetro infravermelho (81\%) e oxigênio (65\%) (Tabela I).

O acesso nas UBS a testes RT-PCR, que permitem o diagnóstico oportuno na fase contagiante e a notificação, era inexistente para mais da metade dos profissionais (55\%) e não estava disponível na maioria das UBS de seu município para $57 \%$ dos gestores (Tabela I). Destacam-se as importantes desigualdades regionais: 69\% dos profissionais no Norte e Nordeste e $46 \%$ no Sul informaram não dispor de acesso a teste de RT-PCR para seus pacientes.

A disponibilidade de equipamentos de proteção individual (EPIs), essenciais para o enfrentamento da pandemia e a segurança de profissionais e pacientes, na APS era ainda insuficiente depois de três meses de pandemia. Apenas 24\% dos profissionais assinalaram estar sempre disponível o conjunto de EPIs (proteção facial, ocular, luvas e avental) nas UBS (Tabela I).

Foi muito marcante a falta de capacitação entre os profissionais da APS: apenas 34\% realizaram capacitação sobre o uso de EPIs e sobre a Covid- 19. Os valores se mostraram um pouco melhores quando analisados separadamente: $41 \%$ receberam capacitação para EPIs e 54\% sobre Covid-19. Gestores informaram ter ofertado capacitação mais frequentemente $(81 \%)$, que foi insuficiente para alcançar a maioria dos profissionais.

Tabela I - Disponibilidade de recursos, insumos nas unidades básicas de saúde e oferta de capacitação para o enfrentamento da Covid-19, segundo profissionais e gestores - Brasil e regiões, jun. 2020

\begin{tabular}{|l|c|c|c|c|c|c}
\hline \multicolumn{1}{|c|}{ Indicadores } & Brasil & Norte & Nordeste & Sudeste & Sul & $\begin{array}{c}\text { Centro- } \\
\text { Oeste }\end{array}$ \\
\hline Profissionais & $\mathrm{n}=1.908$ & $\mathrm{n}=156$ & $\mathrm{n}=548$ & $\mathrm{n}=706$ & $\mathrm{n}=275$ & $\mathrm{n}=223$ \\
\hline
\end{tabular}

Recursos de comunicação

\begin{tabular}{l|c|c|c|c|c|c}
\hline Telefone fixo & 68,0 & 30,1 & 42,3 & 81,1 & 97,8 & 78,9 \\
\hline Sem acesso à internet & 8,5 & 24,4 & 13,9 & 4,7 & 2,9 & 3,6 \\
\hline Acesso a internet de boa qualidade & 40,0 & 26,9 & 33,9 & 41,4 & 53,1 & 43,9 \\
\hline Celular na UBS & 27,8 & 26,9 & 15,1 & 33,7 & 36,0 & 30,9 \\
\hline $\begin{array}{l}\text { Uso de celular particular para } \\
\text { contatar pacientes }\end{array}$ & 71,6 & 81,4 & 82,1 & 67,0 & 50,5 & 79,8
\end{tabular}


Tabela I - Disponibilidade de recursos, insumos nas unidades básicas de saúde e oferta de capacitação para o enfrentamento da Covid-19, segundo profissionais e gestores - Brasil e regiões, jun. 2020 (continuação)

\begin{tabular}{|c|c|c|c|c|c|c|}
\hline Indicadores & Brasil & Norte & Nordeste & Sudeste & Sul & $\begin{array}{l}\text { Centro- } \\
\text { Oeste }\end{array}$ \\
\hline \multicolumn{7}{|l|}{ Insumos } \\
\hline Suficiência de oxímetros & 35,6 & 20,5 & 24,8 & 37,7 & 55,8 & 40,8 \\
\hline $\begin{array}{l}\text { Suficiência de termômetro } \\
\text { infravermelho }\end{array}$ & 18,7 & 14,7 & 13,7 & 17,7 & 28,8 & 24,2 \\
\hline Suficiência de oxigênio & 34,7 & 13,5 & 14,2 & 43,1 & 59,9 & 42,2 \\
\hline $\begin{array}{l}\text { Acesso a teste RT-PCR para } \\
\text { diagnóstico de Covid- } 19\end{array}$ & 44,9 & 30,8 & 30,7 & 52,2 & 53,6 & 55,6 \\
\hline \multicolumn{7}{|l|}{ Disponibilidade permanente de EPIs } \\
\hline Luva cirúrgica & 85,7 & 79,5 & 80,8 & 86,7 & 93,5 & 89,2 \\
\hline Máscara (cirúrgica, N95 ou PFF2) & 67,2 & 59,0 & 61,3 & 67,6 & 84,4 & 65,5 \\
\hline Óculos ou anteparo facial (elmo) & 62,7 & 41,9 & 55,8 & 64,9 & 77,5 & 69,1 \\
\hline Avental impermeável & 31,9 & 35,9 & 23,9 & 31,3 & 43,6 & 36,3 \\
\hline Todos os EPIs & 24,1 & 18,7 & 16,1 & 23,8 & 38,5 & 30,9 \\
\hline \multicolumn{7}{|l|}{ Capacitação dos profissionais em } \\
\hline Covid- 19 & 54,2 & 53,2 & 48,4 & 57,9 & 55,1 & 57,0 \\
\hline EPI & 41,1 & 32,7 & 29,7 & 45,5 & 49,3 & 50,7 \\
\hline EPI e Covid- I 9 & 34,4 & 27,6 & 23,9 & 38,3 & 40,9 & 44,4 \\
\hline Gestores & $n=658$ & $\mathrm{n}=57$ & $n=227$ & $n=186$ & $n=102$ & $\mathrm{n}=86$ \\
\hline \multicolumn{7}{|l|}{ Recursos de comunicação } \\
\hline Sem acesso à internet & 10,3 & 31,6 & 16,7 & 4,3 & 1,0 & 3,5 \\
\hline Acesso a internet de boa qualidade & 45,3 & 29,8 & 37,9 & 44,6 & 67,6 & 50,0 \\
\hline $\begin{array}{l}\text { Celular na UBS (antes da pandemia } \\
+ \text { chips e aparelho disponibilizado } \\
\text { na pandemia) }\end{array}$ & 38,8 & 26,3 & 30,4 & 42,5 & 55,8 & 40,7 \\
\hline
\end{tabular}


Tabela I - Disponibilidade de recursos, insumos nas unidades básicas de saúde e oferta de capacitação para o enfrentamento da Covid-19, segundo profissionais e gestores - Brasil e regiões, jun. 2020 (continuação)

\begin{tabular}{|c|c|c|c|c|c|c|}
\hline Indicadores & Brasil & Norte & Nordeste & Sudeste & Sul & $\begin{array}{l}\text { Centro- } \\
\text { Oeste }\end{array}$ \\
\hline \multicolumn{7}{|l|}{ Insumos na maioria das UBS } \\
\hline Oxímetro & 62,9 & 40,4 & 48,5 & 71,0 & 88,2 & 68,6 \\
\hline Termômetro infravermelho & 34,6 & 19,3 & 26,5 & 34,4 & 53,9 & 43,0 \\
\hline Oxigênio & 48,5 & 15,8 & 27,3 & 63,4 & 80,4 & 55,8 \\
\hline $\begin{array}{l}\text { Acesso a teste RT-PCR para } \\
\text { diagnóstico de Covid- } 19\end{array}$ & 42,7 & 22,8 & 34,1 & 47,0 & 52,9 & 57,0 \\
\hline \multicolumn{7}{|l|}{ Equipamentos de proteção individual } \\
\hline $\begin{array}{l}\text { Levantamento de necessidade de } \\
\text { EPIs para a atenção básica }\end{array}$ & 97,0 & 94,7 & 96,9 & 97,8 & 98,0 & 95,3 \\
\hline Distribuição de EPIs para UBS & 97,7 & 93,0 & 98,2 & 97,3 & 100,0 & 97,7 \\
\hline \multicolumn{7}{|l|}{ Capacitação dos trabalhadores em } \\
\hline Covid- 19 & 87,7 & 86,0 & 84,6 & 90,3 & 90,2 & 88,4 \\
\hline EPI & 81,8 & 80,7 & 78,9 & 80,6 & 87,3 & 86,0 \\
\hline EPI e Covid- I 9 & 80,9 & 79,6 & 79,4 & 80,8 & 84,3 & 81,9 \\
\hline
\end{tabular}

Fonte: Pesquisa Desafios da AB no Enfrentamento da Pandemia de Covid- 9 no SUS (Bousquat et al., 2020).

Em contraponto, mas coerentemente com as rotinas políticas e fluxos operacionais consolidados no SUS em todo o território nacional, a maioria dos gestores informou a elaboração de planos de contingência municipal (96,8\%); a análise do impacto da epidemia nos serviços de AB/APS no município (81,5\%); o planejamento da reorganização de serviços de AB/APS em razão da pandemia (94,5\%); o levantamento de necessidades de apoio logístico e operacional para a AB/APS $(89,2 \%)$ e o levantamento de necessidades de insumos e equipamentos para as UBS $(96,2 \%)$, com pouca variação regional.

\section{Vigilância em saúde}

A vigilância em saúde é um dos principais componentes da abordagem coletiva no enfrentamento de qualquer epidemia e integra o modelo assistencial da ESF. Entre as ações desenvolvidas pelas UBS foi relevante o incentivo ao isolamento social nos territórios, informado pela quase totalidade dos profissionais (92\%) e dos gestores (92\%), assim 
como as ações de manejo clínico e epidemiológico: notificação de casos (94\%), busca ativa dos contatos (91\% dos gestores) e acompanhamento de quarentena (86\%) (Tabela 2).

No entanto, foi reduzida a indicação de apoio para a realização de ações de vigilância em lares para idosos e orfanatos no território. Tema candente em face da elevada mortalidade entre idosos residentes em instituições de longa permanência em outros países. Ações de vigilância sanitária haviam sido pouco incorporadas no fazer das equipes (35\%), ainda que presentes na ação da gestão municipal (91\%). Atividades educativas em farmácias e mercados eram realizadas somente segundo 34\% dos profissionais e $51 \%$ dos gestores (Tabela 2).

Nem sempre as UBS eram informadas sobre casos em seu território. Essa ação, que deveria ser rotineira para possibilitar o acompanhamento, foi confirmada por $71 \%$ dos profissionais.

Agentes comunitários de saúde (ACS) poderiam, em seu fazer cotidiano no território, atuar na vigilância ativa com a identificação precoce de casos suspeitos e ações educativas. No entanto, chamou atenção o fato de que no período de realização da pesquisa apenas $37 \%$ dos profissionais e $55 \%$ dos gestores informaram que os ACS estavam atuando prioritariamente nos territórios, com maior presença nos territórios no Nordeste (Tabela 2).

Tabela 2 - Ações de vigilância em saúde desenvolvidas pelas equipes de Atenção Primária à Saúde no enfrentamento da Covid-19, segundo profissionais e gestores Brasil e regiões, jun. 2020

\begin{tabular}{l|c|c|c|c|c|c}
\hline \multicolumn{1}{c|}{ Ações } & Brasil & Norte & Nordeste & Sudeste & Sul & $\begin{array}{c}\text { Centro- } \\
\text { Oeste }\end{array}$ \\
\hline Profissionais & $\mathrm{n}=1.836$ & $\mathrm{n}=15 \mathrm{I}$ & $\mathrm{n}=526$ & $\mathrm{n}=68 \mathrm{I}$ & $\mathrm{n}=26 \mathrm{I}$ & $\mathrm{n}=216$ \\
\hline Incentivo ao isolamento social & 91,7 & 92,1 & 93,5 & 91,6 & 90,8 & 90,7 \\
\hline Notificação de casos de Covid-19* & 94,0 & 91,8 & 92,7 & 96,2 & 94,1 & 92,0 \\
\hline $\begin{array}{l}\text { Acompanhamento da quarentena } \\
\text { de contatos* }\end{array}$ & 85,7 & 81,8 & 84,2 & 86,1 & 89,1 & 87,5 \\
\hline $\begin{array}{l}\text { UBS informada sobre casos } \\
\text { suspeitos e confirmados* }\end{array}$ & 71,1 & 68,0 & 66,9 & 71,6 & 76,2 & 77,2 \\
\hline $\begin{array}{l}\text { Atividades educativas em } \\
\text { equipamentos sociais }\end{array}$ & 33,7 & 40,4 & 39,3 & 27,4 & 29,8 & 40,9 \\
\hline Atividades de vigilância sanitária & 34,9 & 36,4 & 32,1 & 38,6 & 31,3 & 33,8 \\
\hline ACS prioritariamente no território & 36,9 & 43,0 & 48,6 & 27,5 & 30,2 & 41,9
\end{tabular}


Tabela 2 - Ações de vigilância em saúde desenvolvidas pelas equipes de Atenção Primária à Saúde no enfrentamento da Covid-19, segundo profissionais e gestores Brasil e regiões, jun. 2020 (continuação)

\begin{tabular}{l|c|c|c|c|c|c}
\hline \multicolumn{1}{c|}{ Ações } & Brasil & Norte & Nordeste & Sudeste & Sul & $\begin{array}{c}\text { Centro- } \\
\text { Oeste }\end{array}$ \\
\hline Gestores & $\mathrm{n}=63 \mathrm{I}$ & $\mathrm{n}=54$ & $\mathrm{n}=215$ & $\mathrm{n}=178$ & $\mathrm{n}=99$ & $\mathrm{n}=85$ \\
\hline Incentivo ao isolamento social** & 91,6 & 85,2 & 93,5 & 94,4 & 93,9 & 82,4 \\
\hline Busca ativa de contatos & 90,6 & 84,9 & 90,5 & 88,0 & 96,8 & 92,7 \\
\hline $\begin{array}{l}\text { UBBS informada sobre casos } \\
\text { suspeitos e confirmados* }\end{array}$ & 76,1 & 64,8 & 79,5 & 77,8 & 77,3 & 69,5 \\
\hline $\begin{array}{l}\text { Atividades de vigilância sanitária } \\
\text { Atividades de vigilância em } \\
\text { instituições de longa permanência } \\
\text { para idosos }\end{array}$ & 41,3 & 31,6 & 28,3 & 59,1 & 47,5 & 36,0 \\
\hline $\begin{array}{l}\text { Atividades educativas em } \\
\text { equipamentos sociais** }\end{array}$ & 51,4 & 37,0 & 58,6 & 45,3 & 49,5 & 51,9 \\
\hline \begin{tabular}{l} 
ACS prioritariamente no território \\
\hline
\end{tabular} & 54,7 & 48,1 & 69,7 & 44,2 & 41,3 & 56,1 \\
\hline
\end{tabular}

Fonte: Pesquisa Desafios da AB no Enfrentamento da Pandemia de Covid- 19 no SUS (Bousquat et al., 2020).

* Excluídas as respostas dos locais sem casos.

** Respostas referentes à maioria das UBS.

\section{Organização da APS para o cuidado em Covid-19}

A análise da organização das UBS para enfrentamento da Covid- 19 indicou mudanças a partir da separação de fluxos de atendimento na UBS, segundo 89,5\% dos profissionais e $80 \%$ dos gestores, e da criação de espaços exclusivos para sintomáticos respiratórios (Tabela 3).

O monitoramento e manejo de casos suspeitos e confirmados pelas equipes de APS exigiu a adaptação de rotinas para o acompanhamento remoto, realizado majoritariamente por telefone ou mensagem do WhatsApp, informado por mais de 95\% dos profissionais. Visitas domiciliares ou adaptadas para área peridomiciliar para acompanhamento de casos foram relatadas por $38 \%$ dos profissionais e por $61 \%$ dos gestores.

Segundo $77 \%$ dos gestores, havia serviços de referência definidos para encaminhamento dos casos graves e moderados mais frequentemente em âmbito regional do que 
no município, onde se observou maior carência de recursos físicos e de equipamentos. Todavia, apenas metade dos profissionais da APS (49\%) informou sempre conseguir atendimento dos pacientes encaminhados ao serviço de referência (Tabela 3).

Tabela 3 - Organização do cuidado para pacientes Covid- 19 pelas equipes de Atenção Primária à Saúde, segundo profissionais e gestores - Brasil e regiões, jun. 2020

\begin{tabular}{|c|c|c|c|c|c|c|}
\hline Ações & Brasil & Norte & Nordeste & Sudeste & Sul & $\begin{array}{l}\text { Centro- } \\
\text { Oeste }\end{array}$ \\
\hline Profissionais & $\mathrm{n}=1.836$ & $n=|5|$ & $n=526$ & $n=68 I$ & $n=26 I$ & $n=216$ \\
\hline $\begin{array}{l}\text { Separação de fluxos para atendimento de } \\
\text { casos suspeitos }\end{array}$ & 89,5 & 87,4 & 87,5 & 90,9 & 93,9 & 86,1 \\
\hline Espaços exclusivos na UBS & 79,9 & 64,9 & 74,0 & 85,6 & 86,3 & 79,2 \\
\hline Acompanhamento de casos & 83,9 & 82,2 & 83,9 & 85,7 & 83,6 & 79,7 \\
\hline Visita peridomiciliar ou domiciliar & 38,3 & 48,4 & 41,1 & 36,5 & 31,1 & 39,3 \\
\hline $\begin{array}{l}\text { Acompanhamento remoto por telefone, } \\
\text { WhatsApp ou teleconsulta }\end{array}$ & 96,8 & 93,5 & 96,4 & 96,9 & 99,1 & 97,1 \\
\hline Definição de serviço de referência* & 84,3 & 95,1 & 85,8 & 90,2 & 93,7 & 91,0 \\
\hline $\begin{array}{l}\text { Obtenção de atendimento dos pacientes } \\
\text { encaminhados ao serviço de referência }\end{array}$ & 49,1 & 41,7 & 41,8 & 52,7 & 59,5 & 50,0 \\
\hline Gestores & $n=631$ & $\mathrm{n}=54$ & $n=215$ & $\mathrm{n}=178$ & $\mathrm{n}=99$ & $\mathrm{n}=85$ \\
\hline $\begin{array}{l}\text { Separação de fluxos para sintomáticos } \\
\text { respiratórios** }\end{array}$ & 80,2 & 81,5 & 72,6 & 87,6 & 83,8 & 78,8 \\
\hline Espaços exclusivos na UBS** & 63,1 & 56,1 & 54,2 & 69,4 & 74,5 & 64,0 \\
\hline $\begin{array}{l}\text { Acompanhamento de pacientes em } \\
\text { quarentena }\end{array}$ & 94,6 & 92,6 & 94,6 & 95,3 & 95,7 & 93,4 \\
\hline Visita peridomiciliar ou domiciliar & 60,6 & 59,6 & 66,1 & 55,9 & 54,9 & 64,0 \\
\hline $\begin{array}{l}\text { Acompanhamento remoto por telefone, } \\
\text { WhatsApp ou teleconsulta }\end{array}$ & 87,4 & 87,7 & 87,2 & 88,2 & 89,2 & 83,7 \\
\hline $\begin{array}{l}\text { Definição de serviço de referência para } \\
\text { quadros moderados ou graves }\end{array}$ & 77,0 & 78,4 & 88,0 & 75,2 & 74,7 & 80,3 \\
\hline
\end{tabular}

Fonte: Pesquisa Desafios da AB no Enfrentamento da Pandemia de Covid- 19 no SuS (Bousquat et al., 2020).

* Serviços de referência localizados no próprio município ou na região.

** Respostas referentes à maioria das UBS. 


\section{Continuidade da atenção de rotina}

Em diferentes epidemias foi observado excesso de mortes por outras causas, de pacientes que deixaram de ser atendidos e podem superar aquelas pela doença emergente. Grávidas, hipertensos e diabéticos continuam precisando de atenção, ao mesmo tempo que integram os grupos de maior risco para Covid-19. As respostas ao conjunto das questões relativas à continuidade da atenção por ações rotineiras ofertadas na APS e a adaptação destas indica preocupação com a preservação da saúde dos usuários e dos grupos prioritários.

As atividades de rotina das UBS, inicialmente em parte suspensas, estavam sendo gradualmente adaptadas. Em junho de 2020 haviam sido modificadas (reduzidas ou adaptadas) em decorrência da Covid-I 9 na maior parte das UBS do país. Segundo a metade dos profissionais (53\%) e dos gestores (50\%), o conjunto das atividades de rotina nas UBS havia sido reduzido. A manutenção com estratégias adaptadas em razão da Covid- 19 foi relatada por $34 \%$ dos profissionais e $44 \%$ dos gestores, e sua suspensão foi informada por $10 \%$ dos profissionais e $5 \%$ dos gestores (Bousquat et al., 2020). Na média nacional, somente $37 \%$ dos profissionais e $45 \%$ dos gestores afirmaram não ter ocorrido alguma redução de atividades (Tabela 4).

Para quase a totalidade dos profissionais, a atenção pré-natal, a vacinação de rotina e a atenção a doentes crônicos foram mantidas ou adaptadas (Tabela 4). Para dar conta da continuidade, com menor risco de contágio, formas remotas de acompanhamento de grupos prioritários (telefone, WhatsApp, consulta on-line) foram introduzidas na maioria das UBS segundo $60 \%$ dos profissionais e $40 \%$ dos gestores.

Listas de usuários de grupos prioritários, instrumento que permite busca ativa e acompanhamento, encontravam-se disponíveis segundo 83\% dos profissionais. Para garantir a continuidade do cuidado especialmente para portadores de enfermidades crônicas que demandam medicação de uso contínuo, o prazo de dispensação das receitas foi ampliado (83\%), permitindo a manutenção do tratamento sem muitas idas à UBS. Ademais, de acordo com um terço dos entrevistados (33\%) medicamentos eram entregues em casa pelo ACS (Tabela 4).

Aqui se destaca a manutenção parcial das atividades dos ACS na busca ativa dos grupos prioritários, especialmente a gestante, e a introdução da visita peridomiciliar ( $51 \%$ dos profissionais e $65 \%$ dos gestores) para acompanhamento dos grupos prioritários. Nessas atividades os ACS conversavam com moradores na parte externa das residências, sem entrar no domicílio, para reduzir o risco de contágio (Tabela 4). 
Tabela 4 - Continuidade do cuidado pelas equipes de Atenção Primária à Saúde durante a pandemia, segundo profissionais e gestores - Brasil e regiões, jun. 2020

\begin{tabular}{|c|c|c|c|c|c|c|}
\hline Ações & Brasil & Norte & Nordeste & Sudeste & Sul & $\begin{array}{c}\text { Centro- } \\
\text { Oeste }\end{array}$ \\
\hline Profissionais & $\mathrm{n}=1.709$ & $\mathrm{n}=135$ & $\mathrm{n}=486$ & $n=641$ & $n=246$ & $n=201$ \\
\hline Atividades de rotina não reduzidas & 36,9 & 45,6 & 32,1 & 31,4 & 44,7 & 50,8 \\
\hline $\begin{array}{l}\text { Acompanhamento remoto de grupos } \\
\text { prioritários (telefone, WhatsApp, } \\
\text { consulta on-line) }\end{array}$ & 60,4 & 56,3 & 56,0 & 684,6 & 63,4 & 57,2 \\
\hline $\begin{array}{l}\text { Disponibilidade de listas de usuários de } \\
\text { grupos prioritários }\end{array}$ & 83,4 & 79,3 & 81,7 & 87,4 & 79,3 & 82,6 \\
\hline $\begin{array}{l}\text { Atendimento a hipertensos e } \\
\text { diabéticos* }\end{array}$ & 87,5 & 94,0 & 84,1 & 84,8 & 91,9 & 94,5 \\
\hline Pré-natal* & 96,6 & 93,4 & 95,7 & 97,8 & 96,1 & 97,5 \\
\hline Vacinação* & 93,9 & 83,7 & 93,8 & 96,0 & 93,1 & 95,0 \\
\hline Puericultura* & 67,4 & 56,3 & 44,5 & 78,1 & 81,7 & 78,6 \\
\hline $\begin{array}{l}\text { Ampliação do prazo de dispensação de } \\
\text { receitas }\end{array}$ & 83,3 & 72,6 & 80,0 & 85,2 & 91,5 & 82,6 \\
\hline $\begin{array}{l}\text { Entrega de medicamentos em casa para } \\
\text { usuários com doenças crônicas** }\end{array}$ & 32,6 & 44,4 & 33,1 & 34,1 & 24,4 & 28,9 \\
\hline Visita peridomiciliar pelo ACS & 50,6 & 46,2 & 51,8 & 47,4 & 49,4 & 62,4 \\
\hline Gestores & $\mathrm{n}=605$ & $\mathrm{n}=52$ & $n=211$ & $n=166$ & $\mathrm{n}=94$ & $\mathrm{n}=82$ \\
\hline Atividades de rotina não reduzidas & 45,3 & 42,3 & 48,8 & 33,7 & 57,5 & 47,5 \\
\hline $\begin{array}{l}\text { Acompanhamento remoto de grupos } \\
\text { prioritários (telefone, WhatsApp, } \\
\text { consulta on-line) }\end{array}$ & 38,9 & 28,1 & 37,9 & 41,4 & 42,2 & 39,5 \\
\hline $\begin{array}{l}\text { Atendimento a hipertensos e } \\
\text { diabéticos* }\end{array}$ & 93,3 & 92,3 & 91,5 & 92,9 & 93,6 & 98,8 \\
\hline Pré-natal* & 98,5 & 96,2 & 97,6 & 100 & 98,9 & 98,8 \\
\hline Vacinaç̧ão* & 98,8 & 92,4 & 99,1 & 99,4 & 100 & 100 \\
\hline Puericultura* & 85,6 & 80,7 & 75,4 & 94,1 & 92,5 & 89,0 \\
\hline $\begin{array}{l}\text { Entrega de medicamentos em casa para } \\
\text { usuários com doenças crônicas** }\end{array}$ & 64,0 & 71,2 & 67,5 & 62,4 & 53,2 & 66,7 \\
\hline Visita peridomiciliar pelo ACS & 65,1 & 57,9 & 70,0 & 60,6 & 57,4 & 75,6 \\
\hline
\end{tabular}

Fonte: Pesquisa Desafios da AB no Enfrentamento da Pandemia de Covid- 19 no SUS (Bousquat et al., 2020).

* Acompanhamento de grupos prioritários de rotina não reduzido (mantidas ou adaptadas).

** Resposta referente a algumas UBS e à maioria das UBS. 
Chamou atenção a ausência de núcleos ampliados de Saúde da Família e Atenção Básica (Nasf-AB) nas UBS segundo 29\% dos profissionais, bastante expressiva no Norte (46\%). De acordo com 40\% dos profissionais, as atividades do Nasf-AB foram adaptadas e $28 \%$ informaram terem sido suspensas, com maior frequência de suspensão no Nordeste (38\%). No entanto, $66 \%$ dos respondentes informaram que os profissionais do Nasf-AB apoiavam as ações de enfrentamento da Covid- 19 (Bousquat et al., 2020). A consulta odontológica destacou-se entre as atividades suspensas, segundo $42 \%$ dos profissionais, com provável realocação de odontólogos para apoio em atividades de enfrentamento da Covid-19, relatada por 68\% dos profissionais (Bousquat et al., 2020).

\section{Ações de apoio social}

No processo de trabalho da APS, os diversos profissionais podem atuar para conter o espraiamento da epidemia e ao mesmo tempo antecipar ações no território que articulem os princípios de integralidade e solidariedade. São ações de apoio social de diversas dimensões - doações, assistência à saúde emocional, acesso a benefícios e acolhimento específico - necessárias para compensar restrições econômicas e sociais e promover adesão ao distanciamento social e a quarentenas.

Ações sociais dependem da identificação de grupos com maior vulnerabilidade social, o que foi referido por $60 \%$ dos profissionais e $79 \%$ dos gestores. As ações de apoio social não se restringiram ao espaço das UBS, mas alguns municípios têm nelas uma referência. Parte dos profissionais no âmbito das UBS prestou apoio para acesso ao Cadastro Único (35\%) e apoio psicológico às mulheres vítimas de violência (47\%) e aos profissionais da saúde (38\%). Os gestores, para quem algumas dessas ações eram parte de um elenco de políticas públicas da gestão municipal, destacaram distribuição de cestas básicas (89\%), acesso ao Cadastro único (86\%), apoio aos usuários para obtenção do auxílio emergencial (76\%) e apoio psicológico a mulheres vítimas da violência (72\%) (Tabela 5). No entanto, a organização de abrigos para vulneráveis para propiciar o isolamento em quarentenas com apoio da gestão municipal foi informado por apenas um terço dos gestores (36\%) (Bousquat et al., 2020). 
Tabela 5 - Ações de apoio social pelas equipes de Atenção Primária à Saúde durante a pandemia, segundo profissionais e gestores - Brasil e regiões, jun. 2020

\begin{tabular}{|c|c|c|c|c|c|c|}
\hline Ações & Brasil & Norte & Nordeste & Sudeste & Sul & $\begin{array}{c}\text { Centro- } \\
\text { Oeste }\end{array}$ \\
\hline Profissionais & $\mathrm{n}=1.628$ & $n=132$ & $\mathrm{n}=458$ & $n=610$ & $n=234$ & $\mathrm{n}=194$ \\
\hline $\begin{array}{l}\text { Identificação de grupos de maior } \\
\text { vulnerabilidade social }\end{array}$ & 59,5 & 67,5 & 58,4 & 60,6 & 59,5 & 56,9 \\
\hline Distribuição de cestas básicas* & 23,2 & 15,9 & 21,6 & 25,7 & 26,1 & 20,1 \\
\hline Distribuição de itens de higiene pessoal* & 17,8 & 9,8 & 18,2 & 20,8 & 15,4 & 15,5 \\
\hline Apoio a idosos para compras* & 4,1 & 3,8 & 4,8 & 4,6 & 2,6 & 2,6 \\
\hline $\begin{array}{l}\text { Apoio no preenchimento do Cadastro } \\
\text { Único para o Programa Bolsa Família* }\end{array}$ & 35,1 & 22,7 & 26,9 & 43,1 & 38,0 & 34,0 \\
\hline $\begin{array}{l}\text { Apoio aos usuários para obtenção do } \\
\text { auxílio emergencial* }\end{array}$ & 17,9 & 12,9 & 15,1 & 19,6 & 24,4 & 14,9 \\
\hline Apoio às mulheres vítimas de violência* & 47,1 & 30,3 & 40,7 & 53,2 & 54,3 & 45,9 \\
\hline $\begin{array}{l}\text { Atenção psicológica aos trabalhadores } \\
\text { da saúde* }\end{array}$ & 37,7 & 30,3 & 33,9 & 39,8 & 39,7 & 42,3 \\
\hline Gestores & $\mathrm{n}=57 \mathrm{I}$ & $\mathrm{n}=48$ & $\mathrm{n}=199$ & $\mathrm{n}=158$ & $\mathrm{n}=90$ & $\mathrm{n}=76$ \\
\hline $\begin{array}{l}\text { Identificação de grupos de maior } \\
\text { vulnerabilidade social }{ }^{* * *}\end{array}$ & 79,4 & 74,1 & 80,5 & 79,2 & 80,8 & 78,8 \\
\hline Distribuição de cestas básicas** & 88,6 & 79,2 & 92,5 & 88,6 & 86,7 & 86,8 \\
\hline $\begin{array}{l}\text { Distribuição de itens de higiene } \\
\text { pessoal** }^{* *}\end{array}$ & 62,3 & 66,7 & 64,8 & 60,1 & 60,0 & 60,5 \\
\hline Apoio a idosos para compras** & 23,1 & 18,8 & 27,1 & 13,9 & 27,8 & 28,9 \\
\hline $\begin{array}{l}\text { Identificação de famílias para } \\
\text { cadastramento no Programa Bolsa } \\
\text { Família** }\end{array}$ & 86,2 & 79,2 & 86,4 & 86,7 & 91,1 & 82,9 \\
\hline $\begin{array}{l}\text { Apoio aos usuários para obtenção do } \\
\text { auxílio emergencial** }\end{array}$ & 75,7 & 70,8 & 81,9 & 67,7 & 82,2 & 71,1 \\
\hline $\begin{array}{l}\text { Apoio às mulheres vítimas de } \\
\text { violência** }\end{array}$ & 70,2 & 64,6 & 71,4 & 75,3 & 78,9 & 63,2 \\
\hline $\begin{array}{l}\text { Atenção psicológica aos trabalhadores } \\
\text { da saúde** }\end{array}$ & 76,9 & 85,4 & 80,4 & 71,5 & 78,9 & 71,1 \\
\hline
\end{tabular}

Fonte: Pesquisa Desafios da AB no Enfrentamento da Pandemia de Covid- 19 no SUS (Bousquat et al., 2020).

* Ações desenvolvidas com o apoio da UBS.

** Ações desenvolvidas com apoio da gestão municipal.

*** Resposta referente à maioria das UBS. 
O inquérito on-line incluiu algumas perguntas abertas, para comentários dos respondentes sobre suas dificuldades e iniciativas. As principais preocupações dos profissionais e gestores foram expressas em termos de falta e insuficiência. Suas iniciativas denotaram reorganização e ampliação das formas de atendimento e monitoramento, incluindo equipes de acompanhamento por WhatsApp e disque-Covid ou disque-vigilância, destinação de unidades específicas para atendimento de sintomáticos respiratórios, barreiras sanitárias, comunicação em saúde, distribuição de máscaras e materiais de higiene.

\section{APS NO SUS: REINVENÇÃO LOCAL E DESCASO DO GOVERNO FEDERAL}

Os resultados da pesquisa mostraram a potência da APS para o enfrentamento da pandemia, dado o tamanho da rede de equipes de Saúde da Família (eSF) e a diversidade de agentes que a compõem para exercer suas funções de vigilância em saúde e cuidado integral e universal. As carências e divergências nas visões de profissionais e gestores refletem o estresse advindo do esforço de responder de forma adequada e com qualidade à grave crise sanitária. A presença de instituições e políticas públicas consolidadas nos diferentes níveis de governo não suprime a ausência de coordenação nacional para sustentar a ação pública. O Ministério da Saúde está, com sua inoperância, desperdiçando uma rede de mais de 45.000 eSF e de 400 mil ACS e agentes de endemias, cujo trabalho poderia reduzir a propagação da pandemia pelo interior e nas periferias das grandes cidades.

Reiteramos que a ESF, com ação comunitária nos territórios, apoiando e realizando vigilância em saúde e cuidado integral, contribui de maneira efetiva para conter a pandemia, mas para isso necessita de mais investimentos. A pesquisa aqui brevemente relatada mostrou que a APS no SUS está se reinventando, fazendo vigilância, descobrindo novas formas de cuidado a distância por telefone, por WhatsApp, por visitas peridomiciliares dos ACS, mas faltam recursos, insumos, internet, EPIs, acesso a testes RT-PCR e educação permanente para os profissionais.

O propósito principal da pesquisa foi buscar informações que pudessem orientar a gestão na implementação de medidas para apoiar as eSF no seu fazer cotidiano, fortalecendo o SUS no enfrentamento da Covid- 19. Assim, listamos recomendações de ações urgentes no apoio, qualificação e valorização das eSF.

- Fortalecer a capacitação e educação permanente de todos os profissionais das equipes por meio de estratégias ágeis e amplas de comunicação a distância de forma rotineira e contínua, atualizando conhecimentos sobre uso de EPIs, abordagem da Covid-19, novas formas de atenção remota e ação no território, para incrementar a vigilância em saúde na APS. 
- Intensificar a vigilância em saúde em todos os municípios. A vigilância em saúde, com enfoque comunitário e ativa, com identificação oportuna dos casos, o rastreamento e busca ativa de contatos e seu isolamento são medidas efetivas e imprescindíveis para o controle da propagação da doença.

- Ampliar o acesso aos testes moleculares RT-PCR e testes de antígeno. Incrementar a capacidade de testagem por RT-PCR e testes de antígenos é crucial para a vigilância em saúde com diagnóstico oportuno e rastreio de contatos como forma de reduzir contágio, casos e mortes.

- Preparar a APS para a vacinação contra Covid-19. As equipes de atenção primária, com sua capilaridade, das capitais aos municípios rurais remotos, têm capacidade para vacinar a população, conforme prioridades, com agilidade a depender da disponibilidade de vacinas. Os resultados do terceiro ciclo do Programa de Melhoria do Acesso e Qualidade na Atenção Básica (Pmaq-AB), com avaliação de mais de 30 mil UBS, mostraram que $77 \%$ das UBS ofertavam vacinação regular e dispunham de geladeira exclusiva para vacinas em 2018.

- Valorizar e qualificar o trabalho dos ACS. A ação comunitária do ACS no enfrentamento da epidemia é crucial no apoio social, na vigilância comunitária, na educação em saúde, no acompanhamento por visita peridomiciliar e/ou a distância por WhatsApp e telefone, na continuidade do cuidado.

- Ampliar a disponibilidade de celulares e acesso à internet de profissionais nas UBS e para comunidades e usuários, para viabilizar as novas formas de comunicação e cuidado a distância.

- Equipar as UBS com oxímetro, termômetro infravermelho, oxigênio, acesso a testes moleculares e de antígeno e EPIs suficientes e sempre disponíveis.

Para o controle da pandemia é imprescindível ativar os atributos comunitários das equipes multiprofissionais da ESF e do Nasf; associar-se às iniciativas solidárias das organizações comunitárias e articular-se intersetorialmente para apoiar a população em suas diversas vulnerabilidades; garantir a continuidade das ações de promoção, prevenção e cuidado, criando novos processos de trabalho na vigilância em saúde, no apoio social e sanitário aos grupos vulneráveis e na continuidade da atenção rotineira para quem dela precisa. 


\section{REFERÊNCIAS}

ASSOCIAÇÃO BRASILEIRA DE SAÚDE COLETIVA (ABRASCO). Rede de Pesquisa em Atenção Primária. Disponível em: < https://redeaps.org.br>. Acesso em: nov. 2021 .

BOUSQUAT, A. et al. Desafios da Atenção Básica no Enfrentamento da Pandemia da Covid-I 9 no SUS. Relatório de pesquisa. Rio de Janeiro: USP, Fiocruz, Ufba, Ufpel, Opas Brasil, Rede de Pesquisa em Atenção Primária à Saúde da Abrasco, ago. 2020. Disponível em: < https://redeaps.org.br/2020/08/30/ relatorio-completo-da-pesquisa-desafios-da-ab-no-enfrentamento-da-pandemia-da-covid-19-nosus/>. Acesso em: 12 jan. 2021.

DUNLOP, C. et al. The coronavirus outbreak: the central role of primary care in emergency preparedness and response. BJGP Open, 4(I), 2020. Disponível em: <https://bjgpopen.org/content/4/I/ bjgpopen20XI0I04I>. Acesso em: 28 maio 2020.

EYSENBACH, G. Improving the quality of web surveys: the Checklist for Reporting Results of Internet e-Surveys (Cherries). Journal of Medical Internet Research, 6(3): e34, 2004. Disponível em: < https://doi. org/10.2196/jmir.6.3.e34>. Acesso em: 12 jan. 2021.

FUNDAÇÃO OSWALDO CRUZ (FIOCRUZ). Observatório Covid- 19. O fim do ciclo de interiorização, a sincronização da epidemia e as dificuldades de atendimento nos hospitais. Nota técnica 9. Rio de Janeiro: Observatório Covid-19, dez. 2020. Disponível em: <https://portal.fiocruz.br/documento/ nota-tecnica-o-fim-do-ciclo-de-interiorizacao-sincronizacao-da-epidemia-e-dificuldades-0>. Acesso em: 12 jan. 2021 .

GIOVANELLA, L. et al. A contribuição da atenção primária à saúde na rede SuS de enfrentamento à Covid-19. Saúde em Debate, I-21, 2020. Disponível em: <https://preprints.scielo.org/index.php/ scielo/preprint/view/1286/2009>. Acesso em: 12 jan. 2021.

MEDINA, M. G. et al. Atenção Primária à Saúde em tempos de Covid- 19: o que fazer? Cadernos de Saúde Pública, 36(8): e00 I49720, 2020. Disponível em: <http://cadernos.ensp.fiocruz.br/csp/artigo/I I 40/ atencao-primaria-a-saude-em-tempos-de-covid-19-o-que-fazer>. Acesso em: 30 ago. 2020.

MINUÉ, S. L. La pandemia Covid- I 9: lo que hemos aprendido hasta ahora desde España. APS, 2(I): 28 22, 2020. Disponível em: < https://apsemrevista.org/aps/article/view/66>. Acesso em: 14 ago. 2020. 


\section{A Assistência Hospitalar de Nível de Complexidade Intermediário na Linha de Cuidado Covid-19}

Leticia Janotti

$\mathrm{O}$ objetivo do Observatório Fiocruz ao elaborar a Matriz da Linha de Cuidado Covid- 9 na rede de atenção à saúde foi ampliar a capacidade de atendimento de forma organizada, integrada e escalonada, considerando a especificidade do atendimento aos pacientes com suspeita ou confirmação de Covid- 19 (Portela et al., 2020).

À medida que a pandemia por Covid- 19 se estende, o conhecimento acerca do vírus aumenta, o que tem permitido avanços relacionados à certificação de boas práticas na produção do cuidado, mesmo em sistemas por vezes sobrecarregado ou sem preparo estrutural (Anvisa, 2020a, 2020b, 2020c). Por sua vez, a crise sanitária causada pela pandemia se agravou, fazendo surgir a necessidade de uma assistência hospitalar de nível intermediário de complexidade na Linha de Cuidado Covid- 19.

Os hospitais intermediários desempenham duplo papel nessa assistência, atuando seja no cuidado do quadro agudo da doença, em pacientes sem necessidade de internação em unidade de terapia intensiva (UTI), seja no cuidado das sequelas provocadas pela doença, também chamada de Covid longa ou síndrome pós-Covid, naqueles pacientes que ainda demandam cuidado especializado hospitalar.

Nalbandian e colaboradores (202I) apresentaram recentemente uma nova definição das fases da doença, baseada na sintomatologia, conforme demonstrado na Figura I. A Covid- 19 aguda tem duração de até 4 semanas a partir do início dos sintomas, com detecção do Sars-CoV-2 no isolado viral. A Covid- 19 pós-aguda, aquela em que os sintomas persistem com complicações tardias da infecção por Sars-CoV-2 após 4 semanas do início dos sintomas, se divide em duas categorias: I) Covid- 19 sintomática subaguda, que inclui sintomas e anormalidades presentes de 4 a 12 semanas além da Covid- 19 aguda; e 2) Covid longa ou síndrome pós-Covid-19, que inclui sintomas e anormalida- 
des persistentes ou presentes além de 12 semanas do início da Covid- 19 aguda e não atribuíveis a diagnósticos alternativos (Ayoubkhani, 2021; Gupta et al., 2020).

Figura I - Linha do tempo da Covid-I 9 pós-aguda

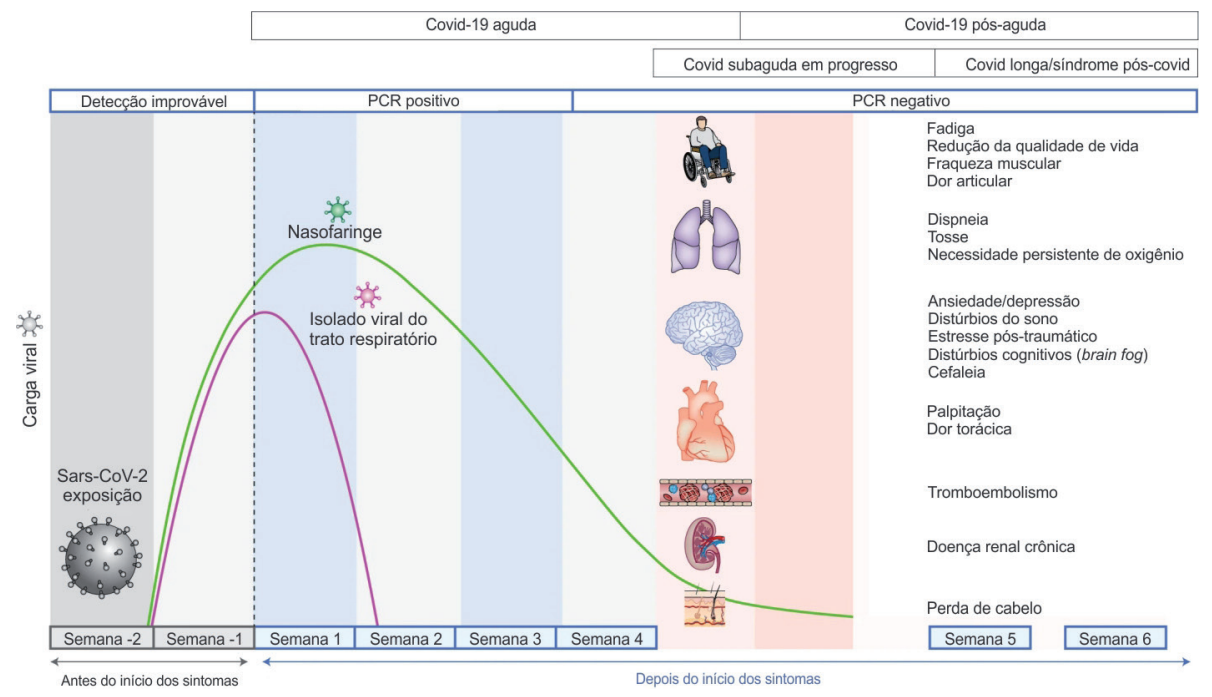

Fonte: Nalbandian et al., 202I.

Pacientes de cuidados intensivos portadores de Covid- 19 apresentam maior risco de complicações trombóticas, lesão renal aguda, enzimas hepáticas elevadas e lesão cardíaca, além de distúrbios psicossociais causados pelo isolamento social prolongado devido a políticas de visitação rígidas e estadias prolongadas em UTI (Gupta et al., 2020). Barker-Davies e colaboradores (2020) trazem uma classificação de longo prazo da infecção por Covid-19, considerando, além da fase aguda, uma fase intermediária, na qual a doença pode resultar em morbidade significativa por 3 a 6 meses, e a fase crônica, naqueles que necessitam de serviços especializados e reabilitação por 12 meses ou mais.

Segundo Zhou (2020), a taxa de hospitalização na China é de 19\% dos pacientes, num total de 1.099 diagnosticados com Covid- 19. Na admissão, 84\% dos pacientes tinham forma leve da doença e $16 \%$ tinham forma grave, demonstrando a importância do estadiamento clínico como critério para a elegibilidade de pacientes durante o processo de gerenciamento de leitos.

Outro estudo realizado na Inglaterra demonstra uma série de intervenções implementadas para aumentar a capacidade do hospital em resposta à pandemia. As intervenções de provisão hospitalar implementadas incluíram a aquisição de equipamento, 
o estabelecimento de instalações hospitalares adicionais e a redistribuição de pessoal, entre outros recursos, com necessidade contínua de aumentar a capacidade de cuidados intensivos de acordo com o cenário epidemiológico da pandemia (McCabe, 2020).

Vale ressaltar que pacientes em situações de vulnerabilidade social e condições crônicas de saúde requerem um redesenho dos fluxos e modalidades de atendimento no Sistema Único de Saúde (SUS), de forma a garantir a longitudinalidade e continuidade do cuidado. Além disso, pacientes Covid- 19 em recuperação podem apresentar comprometimentos físicos, psicológicos e cognitivos, disfunção pulmonar, perda de mobilidade e dificuldade com as atividades da vida diária.

Assim, a assistência hospitalar de nível intermediário de complexidade baseia-se na estratificação de gravidade dos casos suspeitos de Covid- 19 em casos leves, moderados e graves, sendo os casos moderados elegíveis para os hospitais intermediários, conforme sugerido no Quadro I.

Quadro I - Estratificação de gravidade quanto à rede de atenção à saúde

\begin{tabular}{|l|l|}
\hline \multicolumn{1}{|c|}{ Gravidade } & \multicolumn{1}{c|}{ Rede de atenção à saúde } \\
\hline Casos leves & $\begin{array}{l}\text { Aqueles que podem ser acompanhados completamente no âmbito da } \\
\text { unidade básica de saúde devido à menor gravidade }\end{array}$ \\
\hline Casos moderados & $\begin{array}{l}\text { Condições de vulnerabilidade social e condições clínicas suspeitas de } \\
\text { Covid-19, que necessitam de avaliação em hospital intermediário, porém } \\
\text { não apresentam sinais de síndrome respiratória aguda grave }\end{array}$ \\
\hline Casos graves & $\begin{array}{l}\text { Aqueles que necessitam encaminhamento a centro de referência/UTI para } \\
\text { intervenções que exijam maior suporte clínico e tecnológico }\end{array}$ \\
\hline
\end{tabular}

Fonte: Portela et al., 2020.

A Matriz Linha de Cuidado Covid- 9 proposta pelo Observatório Fiocruz (Portela et al., 2020) também organiza os diferentes níveis de cuidado na rede de serviços de saúde conforme quatro dimensões: expansão, fluxos, políticas, procedimentos e insumos estratégicos. Alguns elementos da atenção em hospitais intermediários são detalhados a seguir:

1. A expansão, do ponto de vista dos hospitais intermediários, impõe a adaptação de leitos em unidades hospitalares de baixa complexidade com a ampliação destes, seja por meio da construção de hospitais de campanha ou da otimização da utilização de leitos anteriormente não utilizados, com infraestrutura adequada. 
2. O fluxo do atendimento impõe, entre outros: a) o gerenciamento de leitos, por intermédio da Central de Regulação, e a definição das unidades de referência e contrarreferência por município de residência do paciente, com atualização do censo diário; b) a triagem adequada dos pacientes, com testagem e notificação compulsória dos casos suspeitos e confirmados; c) separação espacial (coorte ou agrupamento de pacientes) segregada na rede com informações adequadas quanto aos casos contactantes, suspeitos e confirmados de Covid- 19; d) referência para início ou continuidade da reabilitação de pacientes com sequelas.

3. No tocante a políticas e procedimentos, ressaltam-se as diretrizes clínicas e a implantação de protocolos prioritários para o adequado funcionamento de um hospital intermediário, relacionados sobretudo às medidas de prevenção e controle de infecção e segurança do paciente, conforme preconizado pelos manuais e normativas do Ministério da Saúde, a saber:

- Prevenção e controle de infecção hospitalar, incluindo controle de disseminação de germes multirresistentes e uso racional de antimicrobianos;

- Protocolos de segurança do paciente (identificação, risco de queda, prevenção de lesão por pressão, cirurgia segura, segurança na medicação e hemocomponentes, notificação de eventos adversos, investigação de óbitos evitáveis);

- Utilização racional de equipamentos de proteção individual (EPIs);

- Coorte ou agrupamento de pacientes contactantes, suspeitos e confirmados Covid- 19;

- Fluxo de notificação compulsória e coleta de amostra para diagnóstico laboratorial;

- Recomendações para manejo de resíduos e processamento de artigos e roupas;

- Cuidados com o corpo e declaração, em caso de óbito;

- Protocolos clínicos de diagnóstico e tratamento, com monitoramento de sinais de gravidade e transferência de paciente para leito de estabilização;

- Transição do cuidado para hospitais com leitos de UTI ou hospitais de referência, quando houver necessidade;

- Transição do cuidado pós-alta para acompanhamento pela equipe da unidade básica de saúde até o restabelecimento completo do usuário e continuidade do plano de cuidados para as condições crônicas; 
- Transição de cuidado de reabilitação;

- Transição de cuidado em pacientes dialíticos;

- Triagem reversa mediante alta ou transferência de pacientes estáveis para liberar leitos do hospital e otimizar a utilização das equipes, realizada em contexto de superlotação;

- Admissão de pacientes recuperados provenientes dos hospitais de referência.

4. Não menos importantes, os insumos estratégicos devem ser disponibilizados, considerando-se os recursos humanos dimensionados para o atendimento com equipe multiprofissional e o quantitativo de EPIs, equipamentos essenciais (monitores, ventilação mecânica, bomba de infusão, desfibrilador, oxímetro, entre outros), medicamentos, testes diagnósticos e exames complementares laboratoriais e radiológicos.

A demanda de leitos para pacientes moderados é uma realidade. As listas de espera para internação em leitos de baixa e média complexidades são significativas na maioria dos estados brasileiros e variam de acordo com a taxa de transmissão de cada região. Nesse contexto, a estratégia para organização da rede de atenção à saúde por linhas de cuidado tem o intuito de garantir o acesso desde a unidade básica de saúde (UBS) ou a Unidade de Pronto Atendimento (UPA)/Emergência até a internação nos hospitais de referência definidos nos planos estaduais e regionais em todo o território nacional. Assim, uma assistência hospitalar no nível intermediário de complexidade torna-se prioritária no planejamento da rede de atenção, permitindo a otimização da gestão de leitos em situações de insuficiência da capacidade instalada local. Além da internação dos casos considerados como de gravidade moderada, os hospitais intermediários podem ser utilizados como unidades de retaguarda para a transferência de pacientes que, embora tenham recebido alta da UTI, ainda necessitam de cuidados hospitalares.

Recentemente, a Organização Mundial da Saúde (OMS) produziu um formulário padronizado para o relato dos dados clínicos de pacientes individuais após a alta hospitalar ou após a fase aguda da doença, com vistas a identificar consequências, de médio e longo prazos, da Covid- 19 (Opas, 202 I). Gupta e colaboradores (2020) relataram experiência em Nova York em que foi estabelecida uma unidade de recuperação para fornecer atendimento hospitalar a populações de pacientes clinicamente complexos pós-UTI e pós-intubação. Foram definidos critérios para elegibilidade do paciente para a unidade de recuperação, resumidos no Quadro 2. 
Quadro 2 - Critérios para elegibilidade do paciente para unidade de recuperação

\begin{tabular}{|c|c|}
\hline Critérios para inclusão & Critérios para exclusão \\
\hline $\begin{array}{l}\text { Estabilidade clínica, com necessidade de } \\
\text { reabilitação e cuidados médicos }\end{array}$ & $\begin{array}{l}\text { Ideação suicida ativa, demência grave e delírio } \\
\text { ativo }\end{array}$ \\
\hline Antecipação da alta para reabilitação & Necessidade de acompanhante \\
\hline $\begin{array}{l}\text { Capacidade de interagir bem com a equipe e } \\
\text { outros pacientes }\end{array}$ & $\begin{array}{l}\text { Pacientes acamados com pouca expectativa } \\
\text { de melhora na mobilidade/condicionamento } \\
\text { físico ou previamente incapacitados }\end{array}$ \\
\hline & $\begin{array}{l}\text { Pacientes em ventilação mecânica } \\
\text { dependentes de oxigênio (> } 6 \text { litros) ou com } \\
\text { necessidade crescente de oxigênio }\end{array}$ \\
\hline
\end{tabular}

Fonte: adaptado de Gupta et al., 2020.

No cenário atual, sabe-se que indivíduos provenientes da UTI pós-Covid- 19 apresentam maiores taxas de mortalidade e readmissão do que aqueles não admitidos na UTI (Ayoubkhani, 2021). Os principais fatores associados às formas mais graves da doença são doença cardiovascular prévia, hipertensão arterial, procalcitonina elevada em pacientes internados na UTI e diabetes mellitus (Rodriguez-Morales, 2020; Yang, 2020).

Antes da pandemia já era conhecida a condição de perda da qualidade plena de vida após a hospitalização em pacientes sobreviventes à doença crítica aguda, a chamada síndrome pós-cuidados intensivos (PICS, post intensive care syndrome). Essa síndrome caracteriza-se por alterações físicas, cognitivas e psiquiátricas e tem potencial para reduzir a qualidade de vida dos pacientes e, por conseguinte, também de seus familiares (Oyen et al., 2020). Mais recentemente, com o estudo de casos de síndrome pós-Covid ou Covid longa, essa condição tem sido observada nesse grupo de pacientes, porém também em pacientes provenientes de unidades não críticas.

Muitos pacientes com síndrome pós-Covid necessitam de suporte para mobilidade e desempenho funcional. Gupta e colaboradores (2020) sistematizaram algumas recomendações para a organização de unidades de recuperação de Covid- 19, com vistas à redução da ansiedade por meio de suporte psicológico e neurológico e reabilitação precoce no atendimento aos pacientes internados em UTI. O trabalho integrado e o papel desempenhado pela equipe permitiram a criação de uma unidade de internação com monitorização dos pacientes. Duas academias temporárias foram criadas na unidade e uma sala de conferências foi convertida em local de encontro de pacientes, 
para estimular a socialização e a comunicação. Em tal relato se enfatiza a importância da intervenção precoce e do trabalho da equipe multidisciplinar na recuperação dos pacientes ainda no ambiente hospitalar.

Algumas condições estão mais relacionadas à síndrome pós-Covid e requerem um tratamento especial que pode ser iniciado nos hospitais intermediários. Reabilitação pulmonar e reabilitação cardíaca devem ser consideradas em pacientes pós-Covid que apresentam algum grau de comprometimento e limitação funcional. Em relação à reabilitação neurológica, deve ser realizada triagem cognitiva com profissional especializado, considerando-se o risco de sintomas neurológicos imediatos ou tardios. Quanto ao retorno às atividades físicas pós-Covid, recomenda-se fortalecimento muscular e avaliação cardiovascular. Reabilitação psicológica está indicada nos casos de sintomas moderados a graves de transtorno de estresse agudo pós-traumático. Outras complicações podem ser observadas, incluindo consequências hepáticas, renais, hematológicas, dermatológicas, reumatológicas e endócrinas (Barker-Davies, 2020).

No Brasil, também foram previstas situações de risco e, considerando-se o pior cenário epidemiológico, a necessidade de implementar medidas para aumentar o número de leitos no sistema de saúde, foi disponibilizado pelo Ministério da Saúde o Plano de Resposta Hospitalar à Covid-19, que prevê utilização de ferramentas de qualidade em apoio ao planejamento e gestão da pandemia, prioritariamente para organização da equipe, equipamentos, estrutura e espaço (Projeto Lean..., 2020). E, apesar da escassez de diretrizes baseadas em evidências sobre a reabilitação em pacientes pós-Covid, sabese que a reabilitação deve ser realizada durante todo o cuidado do paciente, desde a admissão, passando pelo atendimento na UTI e na enfermaria, até o período pós-alta.

A atual crise sanitária nos desperta para uma realidade ainda pouco conhecida, mas fica patente que as necessidades em saúde de pacientes com sequelas de Covid-19 continuarão a aumentar no futuro próximo.

A importância da linha de cuidado de nível intermediário de complexidade como atuação estratégica no cuidado aos pacientes Covid e pós-Covid e seu papel prioritário na rede de atenção do SUS são inegáveis. O grande desafio para profissionais e formuladores de políticas será garantir assistência em todos os níveis da atenção à saúde no contexto da pandemia Covid-19. Isso exigirá o aproveitamento da infraestrutura dos hospitais intermediários como desenvolvimento de modelos de saúde escalonável Covid- 19 a longo prazo e como alternativa permanente de transição de cuidado para sistemas de maior ou menor complexidade e otimização de recursos em cenários menos favorecidos. 


\section{REFERÊNCIAS}

AGÊNCIA NACIONAL DE VIGILÂNCIA SANITÁRIA (ANVISA). Andamento da análise das vacinas na Anvisa, 10 dez. 2020a. Disponível em: <www.gov.br/anvisa/pt-br/assuntos/noticias-anvisa/2020/ andamento-da-analise-das-vacinas-na-anvisa>. Acesso em: 3 nov. 2021.

AGÊNCIA NACIONAL DE VIGILÂNCIA SANITÁRIA (ANVISA). Nota técnica GVIMS/GGTES/Anvisa n. 4/2020. Orientações para serviços de saúde: medidas de prevenção e controle que devem ser adotadas durante a assistência aos casos suspeitos ou confirmados de infecção pelo novo coronavírus (SarsCoV-2). Brasília, 2020b. Disponível em: <www.gov.br/anvisa/pt-br/centraisdeconteudo/publicacoes/ servicosdesaude/notas-tecnicas/nota-tecnica-gvims_ggtes_anvisa-04_2020-25-02-para-0-site. pdf>. Acesso em: nov. 2021.

AGÊNCIA NACIONAL DE VIGILÂNCIA SANITÁRIA (ANVISA). Nota técnica GVIMS/GGTES/Anvisa n. 7/2020. Orientações para prevenção e vigilância epidemiológica das infecções por Sars-CoV-2 (Covid-19) dentro dos serviços de saúde, 17 set. 2020c. Disponível em: <www.gov.br/anvisa/ptbr/centraisdeconteudo/publicacoes/servicosdesaude/notas-tecnicas/nota-tecnica-gvims-ggtesanvisa-no-07-2020>. Acesso em: nov. 2021.

AYOUBKHANI, D. et al. Post-covid syndrome in individuals admitted to hospital with Covid-19: retrospective cohort study. BMJ, 372, 202I. Disponível em: <www.bmj.com/content/372/bmj. n693 >. Acesso em: nov. 2021.

BARKER-DAVIES, R. M. et al. The Stanford Hall consensus statement for post-Covid- 9 rehabilitation. British Journals of Sports Medicine, 54(I 6): 949-959, 2020.

GUPTA, R. et al. A Paradigm for the pandemic: a Covid-I9 recovery unit. NEJM Catalyst, 2020. Disponível em: < https://catalyst.nejm.org/doi/full/10.1056/cat.20.0238>. Acesso em: nov. 2021.

MCCABE, R. et al. Adapting hospital capacity to meet changing demands during the Covid- I 9 pandemic. BMC Medicine, 18: 329, 2020.

NALBANDIAN, A. et al. Post-acute Covid-19 syndrome. Nature Medicine, 27: 601-615, 2021. Disponível em: <www.nature.com/articles/s41591-021-01283-z>. Acesso em: nov. 2021.

NATIONAL INSTITUTE FOR HEALTH AND CARE EXCELLENCE (NICE). Rehabilitation after critical illness in adults. Clinical Guideline, 2009. Disponível em: <www.nice.org.uk/guidance/cg83>. Acesso em: 3 jan. 2021.

ORGANIZAÇÃO PAN-AMERICANA DA SAÚDE (OPAS). Plataforma Clínica Global da Covid-19. Ficha clínica (Case Report Form, CRF) para quadro pós-Covid (Post Covid- 9 CRF). 202I. Disponível em: $<$ https://iris.paho.org/handle/I0665.2/54I26>. Acesso em 8 nov. 202I.

OYEN, S. G. et al. Quality of life after intensive care: a systematic review of the literature. Critical Care Medicine, 38(I2): 2.386-2.400, 2020.

PORTELA, M. C. et al. Matriz Linha de Cuidado Covid- 19 na Rede de Atenção à Saúde. Rio de Janeiro: Observatório Covid-19, Fiocruz, 2020. (Série Linha de Cuidados Covid-19 na Rede de Atenção à Saúde). Disponível em: < https://portal.fiocruz.br/sites/portal.fiocruz.br/files/documentos/matrizlinhacuidado. pdf $>$. Acesso em: 3 jan. 2021. 
PROJETO LEAN nas Emergências. Plano de Resposta Hospitalar ao Covid- I 9. Disponível em: <www. leannasemergencias.com.br/wp-content/uploads/2020/03/Book_Plano_de_Catastrofe_0505_Lean. pdf>. Acesso em: 3 jan. 2021.

RODRIGUEZ-MORALES, A. et al. Clinical, laboratory and imaging features of Covid-19: a systematic review and meta-analysis. Travel Medicine and Infectious Disease, 2020.

YANG, J. et al. Prevalence of comorbidities in the novel Wuhan coronavirus (Covid-19) infection: a systematic review and meta-analysis. International Society for Infectious Diseases, 94(I 2): 9| -95, 2020.

ZHOU, F. et al. Clinical course and risk factors for mortality of adult inpatients with Covid- 19 in Wuhan, China: a retrospective cohort study. The Lancet, 395: I.054-1.062, 2020. 



\section{Maternidades e Covid-19 atenção às gestantes e recém-nascidos no contexto da pandemia}

Maria Auxiliadora de Souza Mendes Gomes, Cynthia Magluta, Luiza Beatriz Acioli e Lidianne Albernaz

A emergência sanitária em razão da pandemia da Covid-19 trouxe, entre seus inúmeros desafios, aqueles decorrentes de uma doença emergente em âmbito global e aqueles inerentes ao seu impacto nos processos de cuidado das gestantes e recémnascidos. Nesse contexto, inúmeras dúvidas relacionadas à organização dos fluxos assistenciais e à prática clínica foram surgindo, a partir do início de 2020, em relação ao cuidado perinatal.

Apesar das ações de qualificação e organização do cuidado obstétrico e neonatal dessa rede de atenção integrarem, nas últimas décadas, de forma contínua as políticas implementadas no Sistema Único de Saúde (SUS) tanto no âmbito federal quanto nos estados e municípios, o impacto da pandemia na atenção à gestação, ao parto e ao nascimento e puerpério e ao recém-nascido deve ser contextualizado no cenário dos problemas que ainda persistem.

A partir de 201 I, as ações para a ampliação, qualificação e organização em rede da atenção pré-natal e nas maternidades se concentraram e foram amplamente trabalhadas por meio da Rede Cegonha (RC) (Brasil, 20l4), incluindo recursos financeiros para melhoria de estrutura para a atenção obstétrica e neonatal e esforços para a mudança no modelo de atenção ao parto e nascimento e ao recém-nascido em contraponto ao modelo predominante no Brasil até o final do século XX, caracterizado pelo excesso de intervenções desnecessárias ou prejudiciais no cuidado obstétrico e neonatal (Leal et al., 2018 ; Ventura, 2008).

O último ciclo avaliativo da RC evidenciou, em 2017, alguns avanços em termos de acolhimento em obstetrícia e boas práticas de atenção ao parto e nascimento (Bittencourt et al., 202I). Na comparação com dados da Pesquisa Nascer no Brasil, a avaliação da 
Rede Cegonha (2017) também demonstrou maior presença de acompanhantes, menor utilização de práticas desnecessárias e maior participação da enfermagem na atenção ao parto e nascimento de risco habitual (Leal et al., 2020a).

No que se refere às práticas de humanização na atenção neonatal, a implantação da Atenção Humanizada ao Recém-Nascido de Baixo Peso - Método Canguru, a partir do final da década de 1990, foi responsável por mudanças significativas no modelo de cuidado nas unidades neonatais, com a incorporação de práticas como o acolhimento e suporte à família, acesso livre dos pais, estímulo à posição canguru e internação em leitos da Unidade de Cuidado Intermediário Canguru (UCINCa) (Brasil, 20I7a; Sanches, 2015).

Apesar desse histórico de iniciativas para a melhoria do acesso, da organização da rede de atenção e das práticas clínicas, em perspectiva nacional, em 2018 a razão de mortalidade materna, RMM (59, I óbitos maternos por 100 mil nascidos vivos) e a taxa de mortalidade na infância, TMI ( 15,2 óbitos de crianças menores de 5 anos por total de nascidos vivos) ainda estavam distantes das metas dos Objetivos do Desenvolvimentos Sustentável 2016-2030 (ONU Brasil, 2015). A análise do período de 2000 a 2018 mostra uma redução das três metas, mais intensa para TMI e taxa de mortalidade neonatal (TMN) do que para RMM. A persistência de inadequações importantes na estrutura e nos processos da atenção tem sido destacada como responsável pela alta RMM no país (Pacagnella, 20 I 9). Outro elemento que caracteriza o contexto da atenção perinatal no Brasil é o cenário de diferenças regionais significativas entre as usuárias dos serviços públicos no que diz respeito ao acesso ao atendimento pré-natal e ao parto e à qualidade destes (Leal et al., 2020b).

No final de março de 2020 registram-se as primeiras informações, por meio dos boletins epidemiológicos da Covid-19 e também dos relatos de secretarias de Saúde, que suscitaram questões preocupantes em relação ao cenário da atenção ao parto e nascimento nas maternidades brasileiras. Informações sobre possíveis fechamentos e/ ou transferências de leitos obstétricos e leitos neonatais para a atenção a pacientes com Covid-19; diminuição da presença de gestantes às consultas de pré-natal; especificidades da conduta clínica no ciclo gravídico puerperal, e o próprio desconhecimento da manifestação e tratamento adequado dos casos de Covid- 19 começaram a ser analisados e problematizados entre os gestores do Ministério da Saúde (MS), das secretarias de Saúde e das maternidades, os profissionais da assistência e pesquisadores da área da saúde materna e infantil.

No contexto brasileiro percebeu-se, desde os primeiros meses da pandemia, a ocorrência de óbitos maternos em números mais elevados do que o relatado em outros 
países da Europa e na China (Diniz \& Carino, 2020; Estrela, 2020). Esse fato foi, desde então, analisado à luz dos desafios já existentes e deflagradores de alta RMM no Brasil, entre os quais:

- prevalência de gestantes e puérperas com comorbidades e controle insuficiente de seus fatores de risco maior do que a dos países que nos relatavam, no início da pandemia, baixo risco de Covid- 19 para as gestantes, diferentemente do HINI;

- dificuldades no acesso e na qualidade da Atenção Primária à Saúde, ainda enfrentados no SUS, neste momento agravados no contexto de isolamento social, com estruturas limitadas de controle e acompanhamento remoto de aspectos cruciais do pré-natal;

- insuficiências já existentes no acesso ao cuidado obstétrico, clínico e especialmente nas situações de morbidade materna que demandam cuidado clínico e de terapia intensiva, assim como em sua qualidade;

- agravamento dos pontos críticos no acesso e qualidade da atenção à gestação, parto e nascimento, puerpério e ao recém-nascido em planos de contingência para o enfrentamento da Covid-19, com ênfase na oferta de leitos de UTI para os adultos e idosos;

- composição demográfica da população brasileira com milhões de gestantes/ ano, parâmetros sociais, índices de vulnerabilidade social e desempenho do sistema de saúde diferentes daqueles de países com sistemas universais de saúde no hemisfério norte.

O enfrentamento do impacto direto e indireto da pandemia Covid- 9 sobre a saúde materna e neonatal se configurou como uma das demandas prioritárias para a atuação da Fundação Oswaldo Cruz, por intermédio do Instituto Nacional de Saúde da Mulher, da Criança e do Adolescente Fernandes Figueira (IFF/Fiocruz), unidade definida como órgão auxiliar do Ministério da Saúde no desenvolvimento, na coordenação e na avaliação das ações integradas para a saúde da mulher, da criança e do adolescente no Brasil (Brasil, 2010).

A partir de março de 2020, a Coordenação de Ações Nacionais e de Cooperação do IFF/Fiocruz buscou intensificar o trabalho conjunto com as áreas do MS mais diretamente envolvidas no apoio à organização dos serviços e na qualificação da assistência, com as secretarias estaduais de Saúde e instituições como o Conselho Nacional de Secretários de Saúde (Conass), a Federação Brasileira das Associações de Ginecologia e Obstetrícia (Febrasgo) e a Sociedade Brasileira de Pediatria (SBP). No mesmo período, essa atuação 
se deu em torno de dois eixos, com o foco na redução do impacto direto e indireto da pandemia na morbimortalidade materna e neonatal:

- Intensificação do processo de apoio sistemático e contínuo a estados, municípios e maternidades por meio de reuniões on-line com os gestores das secretarias de Saúde e dos serviços obstétricos e neonatais com foco no apoio à organização dos processos de trabalho diante da Covid-1 9 e maior ênfase no Mato Grosso, Pará, Amapá, Roraima, Amazonas, Bahia, Ceará, Maranhão, Piauí e Sergipe, estados nos quais já estava em curso a Estratégia QualiNEO, voltada para a melhoria de práticas de atenção e redução da mortalidade neonatal (Fiocruz, 202 la);

- Direcionamento de uma plataforma digital de disseminação do conhecimento com o objetivo de melhorar práticas clínicas, em curso desde 2017, denominada Portal de Boas Práticas em Saúde da Mulher, da Criança e do Adolescente para temas sobre Covid- 19 (Fiocruz, $202 \mathrm{lb}$ ).

\section{APOIO E TRABALHO CONJUNTO COM GESTORES ESTADUAIS E DE MATERNIDADES NA REORGANIZAÇÃO DOS FLUXOS E PROCESSOS DE CUIDADO: LIÇÕES APRENDIDAS E APORTES}

O processo de trabalho com as secretarias de Saúde e maternidades, visando à reorganização do cuidado de gestantes, parturientes e recém-nascidos, foi estruturado em torno de dois eixos temáticos: Fortalecimento das competências gestoras no planejamento e programação da rede de atenção à saúde no cuidado perinatal; e Qualificação da prática clínica. No primeiro eixo foram tratadas as questões estruturantes e emergenciais da organização dos serviços e dos territórios regionalmente organizados, intensificando o debate nos serviços de referência, a continuidade do cuidado e a análise e recomendações para que a gestão pudesse garantir os insumos e equipamentos estratégicos.

No segundo eixo foram desenvolvidas as principais ações de qualificação da prática clínica, indispensáveis para o cuidado adequado: na atenção obstétrica foi reforçada a necessidade de manutenção das boas práticas de atenção ao parto normal e cesáreas (Brasil, 2016, 20I7b) e a adequação da ambiência para isolamento dos casos de Covid-19; a comunicação com os usuários e familiares e seu acompanhamento remoto; e na atenção neonatal foi ressaltada a importância de que prioridades para a melhoria do cuidado neonatal já definidas pela Estratégia QualiNEO (Fiocruz, 202 I a) sejam garantidas. 
O debate sobre o conteúdo das agendas de apoio à gestão da rede de atenção ao pré-natal e ao parto e nascimento com secretarias de Saúde e maternidades contou com a participação de cerca de 15 profissionais e gestores em cada estado. Nas discussões focalizou-se a realização de análises e recomendações baseadas nas evidências científicas para a prevenção da contaminação e para o manejo clínico em gestantes e recém-nascidos, considerando as informações iniciais de baixo risco de transmissão vertical. Foram priorizadas ações de: reorganização dos fluxos de acesso nas portas de entrada das maternidades responsáveis pelos processos de acolhimento e classificação de risco; definição de áreas isoladas e sinalizadas para casos suspeitos, confirmados sintomáticos e assintomáticos; uso de equipamentos de proteção individual (EPIs); higienização das mãos e dos espaços físicos; controle e acompanhamento de casos; suporte aos profissionais da saúde; acolhimento das usuárias e familiares; e também o alerta para a importância da manutenção de serviços obstétricos e neonatais existentes, sob o risco do que foi definido como impacto indireto da pandemia, qual seja, o aumento da morbimortalidade materna e neonatal por restrição de acesso e piora da qualidade do cuidado prestado.

A perspectiva, inicialmente apresentada em algumas regiões do país, de desativação de leitos obstétricos e neonatais para ampliação do número de leitos Covid- 19 foi enfaticamente desestimulada em razão de suas consequências na redução do acesso e no prejuízo na qualidade e segurança da atenção às gestantes e ao recém-nascido. Dúvidas quanto à centralização de maternidades de referência para pacientes com suspeita de Covid- 19 foram analisadas e ponderadas quanto a sua ineficiência assistencial, tendo em vista a heterogeneidade dos casos e da organização territorial para o acesso oportuno. Com esse entendimento, as orientações se concentraram no objetivo de que todas as maternidades estivessem organizadas e com seus fluxos redefinidos para receber gestantes com suspeita ou quadros leves de Covid- 19. Outro elemento trabalhado foi a necessidade de definir serviços de referência para os casos moderados e graves em gestantes e puérperas, com suporte clínico e de terapia intensiva.

O impacto da desativação de leitos obstétricos em hospitais com unidades neonatais foi outro elemento considerado no contexto dos planos locais para o enfrentamento da pandemia. Existem evidências significativas sobre a ampliação do risco pelo transporte do recém-nascido (Fiocruz, 202 Ib; Marba, 2019). A desativação de leitos obstétricos nesses serviços seria responsável por riscos neonatais ampliados para além daqueles inerentes à prematuridade ou outras situações perinatais. Mesmo diante da premência da reconfiguração da rede para o enfrentamento da pandemia, a capacidade de atendimento de maternidades precisava ser preservada. A desativação 
ou desorganização desses pontos de atenção acarreta o que se define como impacto negativo indireto da pandemia, comprometendo a qualidade e a segurança do cuidado prestado ao conjunto das mulheres e neonatos, grupos em que já há as situações de risco inerentes ao momento do seu ciclo de vida, cabendo ao sistema de saúde, em todas as circunstâncias, minimizar tais riscos.

A desativação de leitos das Unidades de Cuidado Intermediário Canguru (UCINca), espaços nos quais as mães permanecem 24 horas com incentivo à presença dos pais e familiares, foi também um ponto debatido em diferentes regiões do país. A importância dessa modalidade de cuidado para a evolução dos neonatos elegíveis e para a racionalização na utilização dos leitos neonatais foi destacada no apoio aos estados, assim como as orientações para reorganização de fluxos, procedimentos e precauções que garantissem segurança no momento da pandemia. A ênfase na garantia de leitos nos três componentes - Unidade de Terapia Intensiva Neonatal, Unidade de Cuidado Intermediário Neonatal e Unidade de Cuidado Intermediário Canguru - em unidades neonatais tem sido pauta das ações do MS, especialmente no que se refere à ampliação dos leitos intermediários, particularmente os de cuidado intermediário canguru. Estudo realizado em 2017 demonstrou que a oferta desses leitos para o cuidado intermediário é significativamente menor do que a dos leitos intensivos (Augusto, 2017). Temos, portanto, nesse aspecto específico, uma modalidade de cuidado ainda não plenamente implantada e submetida a riscos de desativação/desorganização sem bases técnicas que a justifiquem.

Os elementos de base local trabalhados com as gestões estaduais ao longo de 2020 confirmam a análise apresentada no artigo "A tragédia da Covid- 19 no Brasil: I 24 mortes maternas e ainda continuando" (Takemoto, 2020), no qual os números de óbitos maternos por Covid- 19 no período de fevereiro a junho de 2020 trazem à tona a evidência de que a pandemia agrava os problemas crônicos prejudiciais ao cuidado obstétrico e influem nos resultados maternos e perinatais no Brasil, tais como

(i) baixa qualidade do pré-natal; (ii) recursos insuficientes para o manejo das situações de emergência e de terapia intensiva; (iii) disparidades raciais no acesso aos serviços; e (iv) violência obstétrica. (Takemoto, 2020: 154, tradução nossa)

Nas agendas de trabalho com os gestores dos estados, as coordenações de Saúde da Mulher e da Criança e da Atenção Especializada das secretarias de Saúde foram atores estratégicos, que contribuíram para a formulação de recomendações e notas técnicas e aproximaram o conhecimento científico das necessidades dos gestores para a organização dos serviços e qualificação da prática clínica. Nesse contexto, a articu- 
lação do cuidado obstétrico com a atenção clínica e de terapia intensiva para os casos moderados e graves de gestantes ou puérperas com diagnóstico de síndrome respiratória aguda grave (Srag) ou com Covid- 19 confirmada mostrou-se fundamental para a melhoria dos resultados em termos de morbimortalidade materna. Desse trabalho integrado dependem o cuidado em tempo oportuno e a redução de riscos associados ao transporte ou ao menor conhecimento sobre a fisiopatologia da doença no período gravídico-puerperal.

Infelizmente, o Brasil observou expressivo aumento de casos de morte materna por Covid-19 em 202I (tabelas I e 2). Nesse período, as dúvidas iniciais sobre a reorganização da atenção e a garantia das boas práticas obstétricas e neonatais, mesmo que não totalmente superadas, já não ocupavam a agenda de prioridades de gestores e profissionais. Entretanto, as inadequações e insuficiências na estrutura e nos processos na atenção pré-natal, no monitoramento dos casos com detecção oportuna dos sinais de agravamento e na atenção aos casos moderados e graves estavam mantidas. Como estratégia de intensificação das ações para conter esse elevado número de óbitos, o trabaIho de apoio aos estados, de todas as regiões brasileiras, teve como foco a identificação e superação dos pontos críticos no enfrentamento da mortalidade materna por Covid- 19. Essa agenda, iniciada em maio de $202 \mathrm{I}$, possibilitou o encontro e o debate entre os gestores das secretarias de Saúde e especialistas do Grupo de Trabalho Assistência à Gestante e Puérpera Frente à Pandemia de Covid-19, responsável pelas recomendações do Ministério da Saúde para o manejo da doença em gestantes e puérperas (Brasil, 202 I) e pela estratégia de discussão de casos clínicos de gestantes e puérperas com Covid- 19 em todos os estados brasileiros, sob a coordenação geral do Departamento de Ações Programáticas Estratégicas em Saúde/Secretaria de Atenção Primária em Saúde/MS.

Tabela I - Óbitos de gestantes e puérperas - Brasil, 2020 e 202 I

\begin{tabular}{l|c|c}
\hline \multicolumn{1}{c|}{ Gestantes/Puérperas } & 2020 & $2021^{*}$ \\
\hline Óbitos por Covid-19 & 453 & 751 \\
\hline Semanas & 45 & 20 \\
\hline Percentual & 10,1 & 37,5 \\
\hline
\end{tabular}

Fonte: Rodrigues, Lacerda E Francisco, 2021.

* Dados preliminares. 
Tabela 2 - Óbitos de gestantes e puérperas e acesso a UTI - Brasil, 2020 e 2021

\begin{tabular}{l|r|r}
\multicolumn{1}{c|}{ Gestantes/Puérperas } & \multicolumn{1}{c|}{2020} & \multicolumn{1}{c}{202 । $^{*}$} \\
\hline UTI não & $88(1,9 \%)$ & $125(4,5 \%)$ \\
\hline UTI sim & $316(22,8 \%)$ & $539(30,8 \%)$ \\
\hline NA (indica os casos faltantes ou ignorados) & $49(6,0 \%)$ & $60(10,1 \%)$ \\
\hline Total & 453 & 724 \\
\hline
\end{tabular}

Fonte: Rodrigues, Lacerda \& Francisco, 2021.

* Dados preliminares.

A partir do início da vacinação no Brasil, a inclusão de todas as gestantes e puérperas como grupos prioritários no Programa Nacional de Imunizações (PNI) ocupou espaço central nas estratégias de prevenção da mortalidade materna, entendendo-se que, diante do cenário brasileiro, os benefícios da vacinação ultrapassam quaisquer riscos. Essa recomendação, endossada pelo Observatório Fiocruz e discutida nos espaços de apoio aos estados, ainda não se configurava como uma realidade, em escala nacional, até o fim de maio de 2021.

\section{O PAPEL DO PORTAL DE BOAS PRÁTICAS EM SAÚDE DA MULHER, DA CRIANÇA E DO ADOLESCENTE NO CONTEXTO DA PANDEMIA}

O Portal de Boas Práticas (Fiocruz, 202 Ib) tem como objetivo a disseminação do conhecimento para a melhoria da prática clínica nas áreas da saúde da mulher, da criança e do adolescente, com temas relevantes para a redução da morbimortalidade de mulheres e crianças, e webinários semanais denominados Encontros com Especialistas, que possibilitam a interação e respostas ao vivo das perguntas enviadas pelos participantes.

A partir de março de 2020, foram realizados oito Encontros com Especialistas voltados para abordar o impacto da Covid- 19 na organização e no processo de trabalho nas maternidades e unidades neonatais, contando, cada um, com cerca de cinco especialistas em atenção obstétrica e neonatal e em controle de infecções. Nesses encontros, que duraram, cada um, cerca de duas horas e meia, tempo médio 100\% maior que o das sessões realizadas fora da pandemia, foram respondidas mais de 900 perguntas encaminhadas pelos 5.300 participantes. No primeiro encontro, em 26 de março de 2020, participaram on-line cerca de mil profissionais.

A análise do conjunto das perguntas enviadas pelos participantes indicou padrão semelhante ao das questões tratadas na agenda de trabalho direta com as secretarias 
de Saúde e maternidades. Predominaram as questões sobre as características da doença (formas de diagnóstico, perfil de gravidade em gestantes, puérperas e recém-nascidos e evidências sobre transmissão vertical); medidas de prevenção e controle, com ênfase em utilização dos EPIs, higienização e cuidados com ambientes; e o cuidado intensivo neonatal no qual o suporte ventilatório é prática frequente. Volume expressivo das perguntas enviadas referiu-se às práticas de atenção no momento do parto e nascimento, particularmente diante das situações de risco habitual. Receios e dúvidas em relação à presença do acompanhante e às boas práticas imediatas de cuidado, como contato pele a pele no local e amamentação na primeira hora, assim como à indicação de práticas indesejáveis como o banho do recém-nascido imediatamente após o nascimento (pelo eventual risco de transmissão vertical), foram apresentados com frequência pelos profissionais participantes. Em relação ao cuidado nas unidades neonatais, os especialistas responderam muitas questões sobre a garantia do acesso livre dos pais, resguardando-se as medidas de precaução do contexto epidemiológico da pandemia e do distanciamento social, bem como sobre os fluxos e as adaptações necessárias à preservação das internações nas UCINCa.

A significativa frequência de questionamentos sobre práticas baseadas em evidências na atenção ao parto e nascimento levou à necessidade de enfatizar sua importância nos resultados de saúde materna e infantil. As ameaças de suspensão das boas práticas precisaram ser enfrentadas com informações qualificadas, no âmbito gestor e clínico, sobre sua relevância e pertinência mesmo que com os ajustes exigidos pela pandemia.

Outro elemento importante das perguntas enviadas ao portal são as incontáveis dúvidas sobre medidas de precaução e controle diante de uma doença que, embora emergente, tem transmissão respiratória, como as doenças causadas por outros vírus já conhecidos. Na análise, tal elemento foi considerado um alerta para a necessidade de maior atenção e investimentos na educação permanente, na estrutura e nos processos de cuidado em maternidades.

O acervo do portal foi orientado pelas demandas identificadas nas sessões ao vivo dos Encontros com Especialistas e também no trabalho com as secretarias de Saúde e maternidades. Com esse objetivo, foram disponibilizados de imediato documentos orientadores, protocolos e diretrizes do Ministério da Saúde, da Agência Nacional de Vigilância Sanitária (Anvisa), da Organização Mundial da Saúde, documentos nacionais da SBP e da Febrasgo e documentos elaborados pela Coordenação de Conteúdo do Portal de Boas Práticas com base nas dúvidas e pontos críticos mais prevalentes.

Foram publicadas 31 postagens voltadas para a saúde das mulheres e de recémnascidos (Quadro I). 
Quadro I - Postagens do Portal de Boas Práticas em Saúde da Mulher, da Criança e do Adolescente sobre atenção à saúde das mulheres e de recém-nascidos - fev. a dez. 2020

I. Coronavírus: prevenção, controle e notificação

2. Manejo clínico de gestantes, adultos e idosos na Atenção Especializada

3. Covid-19: atenção à saúde da mulher

4. Covid-19: atenção às gestantes

5. Subsídios para a organização de maternidades em tempos de Covid- 19

6. Covid- I 9: orientações da Federação Brasileira das Associações de Ginecologia e Obstetrícia para atendimento na gestação, parto, puerpério e abortamento

7. Medidas de prevenção e controle da Covid-19: limpeza, desinfecção e tipos de precaução

8. Recomendações acerca da atenção puerperal, alta segura e contracepção durante a pandemia da Covid- 19

9. Diretrizes do Ministério da Saúde para diagnóstico e tratamento da Covid-I 9

10. Principais questões sobre Covid- 19 e o cuidado obstétrico

I I. Coronavírus: cuidado clínico de gestantes e puérperas

12. Principais questões sobre Covid-1 9 e morbidade materna grave

13. Covid- 19: o que muda nos fluxos de acolhimento e classificação de risco em maternidades?

14. Principais questões sobre Covid-I 9 e gestação: atenção pré-natal e em maternidades

15. Principais questões sobre violência contra a mulher na pandemia e após

16. Manual de Recomendações para a Assistência à Gestante e Puérpera Frente à Pandemia de Covid- 19 (Brasil, 2020)

17. Covid- 19 e gestação

18. Covid- 19: orientações da Anvisa para serviços de saúde (NTs 4, 6 e 7)

19. Atenção à saúde do recém-nascido no contexto da infecção pelo novo coronavírus (Sars-CoV-2)

20. Principais questões sobre Covid- I 9 no cuidado neonatal e no seguimento do recém-nascido de risco

21. Atenção ao recém-nascido em tempos da pandemia de Covid- 19: cuidados respiratórios e uso de filtros bacterianos/virais

22. Atenção ao recém-nascido em tempos da pandemia de Covid- 19: recomendações para a sala de parto 
Quadro I - Postagens do Portal de Boas Práticas em Saúde da Mulher, da Criança e do Adolescente sobre atenção à saúde das mulheres e de recém-nascidos - fev. a dez. 2020 (continuação)

23. Atenção ao recém-nascido em tempos da pandemia de Covid- I9: recomendações para o Método Canguru

24. Como higienizar corretamente as mãos e antebraços?

25. Unidades neonatais em tempos de Covid-19: aspectos psicoafetivos do cuidado ao recémnascido, família e equipe

26. Amamentação em tempos da pandemia de Covid-19

27. Paramentação e desparamentação dos profissionais de saúde em tempos da pandemia de Covid- 19

28. Atenção ao recém-nascido em tempos da pandemia de Covid-19: recomendações para o alojamento conjunto

29. Covid- 19: orientações da SBP sobre infecção em mães e recém-nascidos em hospitaismaternidade

30. Covid- I 9 e aleitamento materno: orientações do Ministério da Saúde, da Sociedade Brasileira de Pediatria e da Rede Brasileira de Bancos de Leite Humano

31. Atenção Primária: orientações do Ministério da Saúde sobre Covid- I 9

Essas postagens tiveram, ao todo, quase 216 mil visualizações, conforme dados do canal do Portal de Boas Práticas no SlideShare (Fiocruz, 202 I c) e do Google Analytics. Nesse período o acesso ao Portal de Boas Práticas triplicou, ultrapassando os 170 mil usuários mensais a partir de maio de 2020 (Gráfico I) e alcançando mais de 2 milhões de usuários de todos os estados brasileiros.

Gráfico I - Número de usuários por mês - Portal de Boas Práticas em Saúde da Mulher, da Criança e do Adolescente, out. 2017 a dez. 2020

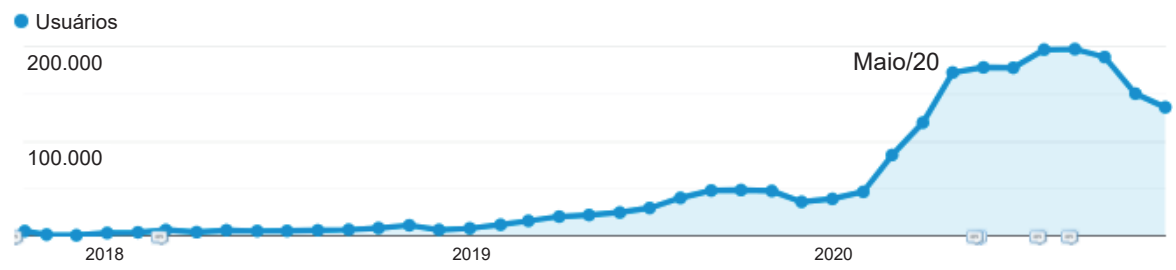

Fonte: Google Analytics. 


\section{DISSEMINAÇÃO DE CONHECIMENTO COMO BASE PARA DECISÃO CLÍNICA E DE GESTÃO DE REDE}

A pandemia de Covid - 9 foi responsável por uma grave crise sanitária e teve impacto direto e indireto na saúde de mulheres e recém-nascidos no Brasil. Os eventos de parto e nascimento no contexto de maternidades brasileiras passaram a ocorrer em um cenário inicial de incertezas sobre os mecanismos de transmissão e impressões não confirmadas de menor morbimortalidade materna associada à infecção pelo novo coronavírus, assim como de rara ou inexistente transmissão vertical. Esse cenário inicial foi pautado pela busca de informações sobre procedimentos de prevenção e controle da doença e sobre a revisão de fluxos e procedimentos para seu enfrentamento em maternidades. Ao longo da pandemia o impacto avassalador na mortalidade materna ficou evidente, confirmando os problemas estruturais para o cuidado oportuno e com qualidade e segurança nas situações de morbidade materna grave.

Nesse sentido, a capacidade de apoio na perspectiva de boas práticas de gestão e de disseminação de conhecimento baseado em evidências como norte para as decisões de reorganização da rede foi estratégica e bem acolhida por gestores de secretarias de Saúde e de maternidades, bem como por milhares de profissionais da saúde de todo o país.

Esse processo foi também importante para alertar sobre o risco de desmobilização de leitos obstétricos, no contexto dos planos de contingência para ampliação da capacidade instalada para atendimento clínico de pacientes com Covid-19, assim como sobre a importância da articulação do cuidado obstétrico com o cuidado clínico-intensivo nos casos moderados e graves de Covid- 19 em gestantes e puérperas.

A atuação em rede, viabilizada por plataformas digitais de comunicação e disseminação do conhecimento, possibilitou a ampliação do debate e interação próxima com os gestores das secretarias de Saúde, das maternidades e das sociedades científicas, a identificação ágil de pontos críticos e orientações necessárias na atenção à gestação, parto, nascimento e recém-nascidos durante a pandemia. O processo ampliado do debate resultando em proposições compartilhadas pode ser identificado na participação ativa de gestores e profissionais da saúde nas agendas de trabalho com as secretarias de Saúde e maternidades e no aumento significativo do número de usuários e acesso ao Portal de Boas Práticas de forma geral e, em especial, nos Encontros com os Especialistas referentes ao tema da Covid- 19. 


\section{REFERÊNCIAS}

AUGUSTO, L. Implantação do Cuidado Intensivo Neonatal: análise da oferta de leitos no SUS, 2017. Dissertação de Mestrado, Rio de Janeiro: Instituto Nacional de Saúde da Mulher da Criança e do Adolescente Fernandes Figueira, Fundação Oswaldo Cruz.

BITTENCOURT, S. D. A. et al. Atenção ao parto e nascimento em maternidades da Rede Cegonha: avaliação do grau de implantação das ações. Ciência E Saúde Coletiva, 26(3): 801-821, 2021. Disponível em: <www.cienciaesaudecoletiva.com.br/artigos/atencao-ao-parto-e-nascimento-emmaternidades-da-rede-cegonha-avaliacao-do-grau-de-implantacao-das-acoes/I7663>. Acesso em: 19 jan. 2021.

BRASIL. Ministério da Saúde. Gabinete do Ministro. Portaria n. 4.159, de 21 dez. 2010. Define o Instituto Fernandes Figueira da Fundação Oswaldo Cruz (Fiocruz), como Instituto Nacional de Saúde da Mulher, da Criança e do Adolescente Fernandes Figueira da Fiocruz, para atuar como órgão auxiliar do Ministério da Saúde no desenvolvimento, na coordenação e na avaliação das ações integradas para a saúde da mulher, da criança e do adolescente no Brasil. Brasília, 20 I0. Disponível em: < http://bvsms. saude.gov.br/bvs/saudelegis/gm/20l0/prt4I59_2I_I2_20l0.html >. Acesso em: 4 mar. 202I.

BRASIL. Ministério da Saúde. Secretaria de Atenção à Saúde. Implantação das Redes de Atenção à Saúde e Outras Estratégias da SAS. Brasília: Ministério da Saúde, 20I4. Disponível em: <https://bvsms.saude. gov.br/bvs/publicacoes/implantacao_redes_atencao_saude_sas.pdf>. Acesso em: 4 mar. 202 I.

BRASIL. Ministério da Saúde. Diretrizes de Atenção à Gestante: a operação cesariana. Brasília: Ministério da Saúde, 2016. Disponível em: < http://conitec.gov.br/images/Consultas/Relatorios/20 I6/Relatorio_ Diretrizes_Cesariana_NI79.pdf>. Acesso em: 4 mar. 2021.

BRASIL. Ministério da Saúde. Secretaria de Atenção à Saúde. Atenção Humanizada ao Recém-Nascido: Método Canguru - manual técnico. Brasília: Ministério da Saúde, 20I7a. Disponível em: <https:// bvsms.saude.gov.br/bvs/publicacoes/atencao_humanizada_metodo_canguru_manual_3ed.pdf $>$. Acesso em: 4 mar. 2021.

BRASIL. Ministério da Saúde. Diretrizes Nacionais de Assistência ao Parto Normal: versão resumida. Brasília: Ministério da Saúde, 20I7b. Disponível em: <https://bvsms.saude.gov.br/bvs/publicacoes/ diretrizes_nacionais_assistencia_parto_normal.pdf>. Acesso em: 4 mar. 2021 .

BRASIL. Ministério da Saúde. Manual de Recomendações para a Assistência à Gestante e Puérpera Frente à Pandemia de Covid-19. Nota informativa 13/2020 SE/GAB/SE/MS. Brasília: Ministério da Saúde, 2020. Disponível em: <http://189.28.128.100/dab/docs/portaldab/documentos/corona/manual_ recomendacoes_gestantes_covid I9.pdf > . Acesso em: 2021 .

DINIZ, D. E CARINO, G. Saúde reprodutiva e a Covid- I 9: o escândalo da morte materna. El País Brasil, São Paulo, 18 maio 2020. Disponível em: <https://brasil.elpais.com/opiniao/2020-05-17/saudereprodutiva-e-a-covid-19-0-escandalo-da-morte-materna.html>. Acesso em: 18 mai. 2021.

ESTRELA, F. et al. Gestantes no contexto da pandemia da Covid-19: reflexões e desafios. Physis: Revista de Saúde Coletiva, 30(2), 2020. Disponível em: <www.scielo.br/j/physis/a/ zwPkqzqfcHbRqyZNxzfrg3g/?lang=pt>. Acesso em: 16 jun. 2021 .

FUNDAÇÃO OSWALDO CRUZ (FIOCRUZ). Instituto Nacional de Saúde da Mulher, da Criança e do Adolescente Fernandes Figueira (IFF). Estratégia QualiNEO: 10 passos para o cuidado neonatal. Versão completa. Disponível em: < https://portaldeboaspraticas.iff.fiocruz.br/biblioteca/I0-passos-para-ocuidado-neonatal-versao-completa/>. Acesso em: I 6 jun. 202 la. 
FUNDAÇÃO OSWALDO CRUZ (FIOCRUZ). Instituto Nacional de Saúde da Mulher, da Criança e do Adolescente Fernandes Figueira (IFF). Portal de Boas Práticas em Saúde da Mulher, Criança e Adolescentes. Disponível em: < https://portaldeboaspraticas.iff.fiocruz.br/busca-avancada/?post_ types $=$ mulherE_sf_s $=$ covid $>$. Acesso em: 14 jun. $202 \mathrm{I} \mathrm{b}$.

FUNDAÇÃO OSWALDO CRUZ (FIOCRUZ). Instituto Nacional de Saúde da Mulher, da Criança e do Adolescente Fernandes Figueira (IFF). Canal do Portal de Boas Práticas no SlideShare. Agosto Dourado 2021: proteger a amamentação. Disponível em: <www2.slideshare.net/portaldeboaspraticas>. Acesso em: 16 jun. 202 Ic.

LEAL, M. C. et al. Saúde reprodutiva, materna, neonatal e infantil nos 30 anos do Sistema Único de Saúde (SUS). Ciência E Saúde Coletiva, 23: 1.915-1.928, 2018.

LEAL, M. C. et al. Redução das iniquidades sociais no acesso às tecnologias apropriadas ao parto na Rede Cegonha. Ciência E Saúde Coletiva, 26(3), 2020a. Disponível em: < http://cienciaesaudecoletiva. com.br/artigos/reducao-das-iniquidades-sociais-no-acesso-as-tecnologias-apropriadas-ao-partona-rede-cegonha/l 7657?id=17657>. Acesso em: 4 mar. 2021.

LEAL, M. C. et al. Assistência pré-natal na rede pública do Brasil. Revista de Saúde Pública, 54: 8, 2020b.

MARBA, S. Principais questões sobre transporte neonatal, 5 jan. 2019. Disponível em: <https:// portaldeboaspraticas.iff.fiocruz.br/atencao-recem-nascido/principais-questoes-sobre-transporteneonatal>. Acesso em: I 4 jun. 2021.

ORGANIZAÇÃO DAS NAÇÕES UNIDAS BRASIL (ONU BRASIL). Transformando nosso mundo: a Agenda 2030 para o Desenvolvimento Sustentável, 2015. Disponível em: <https://nacoesunidas.org/ pos20I5/agenda2030/>. Acesso em: II set. 2019.

PACAGNELLA, R. C. et al. Mortalidade materna no Brasil: propostas e estratégias para sua redução. Revista Brasileira de Ginecologia e Obstetrícia, 40(9): 50I -506, 2019.

RODRIGUES, A.; LACERDA, L. \& FRANCISCO, R. P. V. Brazilian Obstetric Observatory. arXiv:2015.06534, 2021. Disponível em: <https://arxiv.org/pdf/2 105.06534.pdf>. acesso em: 26 nov. 2021.

SANCHES, M. T. C. et al. Método Canguru no Brasil: 15 anos de política pública. São Paulo: Instituto de Saúde, 20 15. (Temas em Saúde Coletiva, 19). Disponível em: <www.saude.sp.gov.br/instituto-desaude/producao-editorial/temas-em-saude-coletiva>. Acesso em: 4 mar. 2021.

TAKEMOTO, M. L. S.et al. The tragedy of Covid- I 9 in Brazil: I 24 maternal deaths and counting. International Journal of Gynecology and Obstetrics, I 5 I (1): 154-156, 2020.

VENTURA, M. A mortalidade materna: a persistente violação do direito de proteção da vida e autonomia feminina. Revista Bioética, 16: 21 7-228, 2008. 


\section{Impacto da Covid-19 na Saúde da Criança e do Adolescente}

Marcio Fernandes Nehab e Lívia Almeida de Menezes

A pandemia pelo novo coronavírus, Sars-Cov-2, trouxe diversos problemas para toda a sociedade. E, embora as crianças e adolescentes tenham apresentado quadros clínicos mais amenos e menor morbimortalidade quando comparados a adultos, idosos e pessoas com comorbidades, o impacto indireto da pandemia em sua saúde é enorme.

O Brasil, país com o terceiro maior número de casos confirmados e o segundo maior número de óbitos no mundo até maio de 2021 , tem diversas peculiaridades que tornam a pandemia por Covid- 19 um desafio à parte (JHU, 202 I). Para o enfrentamento dessa pandemia em território brasileiro, alguns fatores devem ser considerados:

I. Composição demográfica da população brasileira, com elevado número de crianças e adolescentes. Até 2018 , de acordo com a Fundação Abrinq, esse grupo entre 0 e 19 anos de idade era estimado em 68,8 milhões, e para cada 5 residentes no país dessa faixa etária quase 2 se concentravam na região Sudeste. No entanto, a região Norte era a que apresentava a maior proporção de crianças e adolescentes, superando $41 \%$ de sua população (Fundação Abrinq, 2019).

2. Contingente de crianças com condições crônicas com controle insuficiente.

3. O acesso ao cuidado com qualidade na Atenção Primária à Saúde (APS).

4. Desafios no acesso ao cuidado pediátrico de maior complexidade e na garantia de sua qualidade, particularmente em tempos de grande pressão sobre o sistema hospitalar, que tem, inclusive, levado à desativação de leitos pediátricos.

5. Aumento da vulnerabilidade social. 


\section{EPIDEMIOLOGIA}

Crianças e adolescentes de todas as faixas etárias são suscetíveis à infecção pelo SarsCoV-2, e como as informações sobre o vírus e suas manifestações clínico-epidemiológicas estão em constante evolução, é fundamental estar atento à produção científica e aos dados que são disponibilizados.

O espectro da apresentação clínica na infância e adolescência é amplo e inclui uma miríade de sinais e sintomas com envolvimento de órgãos e sistemas variados, desde a forma assintomática até uma apresentação muito grave como a síndrome inflamatória multissistêmica pediátrica (SIM-P), temporalmente associada à Covid-19, que requer hospitalização e cuidados intensivos. Além disso, os indivíduos dessa faixa etária são susceptíveis à síndrome respiratória aguda grave (Srag).

No Boletim Epidemiológico Especial 44 do Ministério da Saúde (MS), foram notificados no Brasil I.078.25 I casos de Srag hospitalizados até a Semana Epidemiológica (SE) 53 de 2020 e registrados no Sistema de Informação da Vigilância Epidemiológica da Gripe (Sivep Gripe). Na faixa etária de 0 a 19 anos foram registrados 14.638 casos de Srag hospitalizados e confirmados por Covid-19 até 24 de outubro de 2020, o que corresponde a aproximadamente $2,5 \%$ dos casos totais de Srag hospitalizados por Covid- 19 em nosso país (Brasil, 2020a).

Ainda de acordo com esse Boletim Epidemiológico 44 do MS, quase 80\% (68.7II) dos casos de Srag hospitalizados na faixa etária de 0 a 19 anos não têm agente etiológico definido (não especificado ou em investigação). Em apenas $21 \%$ dos casos de Srag hospitalizados (18.579) foi possível a identificação etiológica e, nesse grupo, a Covid- 19 foi responsável pela extensa maioria (79\%) dos casos. Em seguida, encontramos outros vírus respiratórios (15\%), influenza (4\%) e demais agentes etiológicos (2\%) como agentes causais (Brasil, 2020a).

Com base nos dados disponíveis, é possível inferir que o número de casos de Srag hospitalizados por Covid- 19 na faixa etária de 0 a 19 anos pode estar subestimado em 3 a 4 vezes em relação ao número atual.

A distribuição de casos de Srag hospitalizados confirmados por Covid- 19 por faixa etária foi a seguinte: $3.463(23,6 \%)$ em $<$ I ano, 4.103 (28\%) entre I e 5 anos e 7.072 (48\%) entre 6 e 19 anos.

Fato a ser considerado é que se o número de casos "não especificados" somado aos "em investigação" respeitasse a mesma proporção dos casos com diagnóstico confirmado (Covid-19 + influenza + outros vírus respiratórios + outros agentes etiológicos), teríamos, na verdade, em menores de I ano 15.650 casos (7I,3\% do total de casos 
de Srag hospitalizados nessa faixa etária seriam por Covid-19), na faixa de I a 5 anos 23.848 casos ( $69 \%$ do total de casos de Srag hospitalizados nessa faixa etária seriam por Covid-19) e de 6 a 19 anos, 30.777 casos (90,3\% do total de casos de Srag hospitalizados nessa faixa etária seriam por Covid-19). Dessa forma, o número mais provável de casos de Srag hospitalizados na faixa etária pediátrica no país seria de 67.289.

Situação semelhante acontece com os óbitos por Covid- 19 nessa faixa etária. Os óbitos por Srag confirmados por Covid- 19 (1.203) correspondem a 0,6\% dos óbitos totais no país. Entretanto, apenas 40\% (1.340) dos óbitos por Srag no Brasil nessa faixa etária tem agente etiológico definido e, neste grupo, a Covid- 19 foi responsável por 89\% dos casos no ano de 2020, seguido por outros vírus respiratórios (6\%), influenza (3\%) e outros agentes etiológicos (2\%).

Considerando que 60\% dos óbitos por Srag nessa faixa etária (2039) não têm agente etiológico definido e fazendo o mesmo raciocínio anterior, a partir da vigilância epidemiológica dos vírus respiratórios no ano de 2020, é possível que os números de óbitos por Covid- I 9 na faixa etária de 0 a 19 anos estejam subestimados em 2,5 vezes.

Devemos ainda acrescer aos óbitos por Covid-19 aqueles causados pela SIM-P. Segundo o Boletim Epidemiológico 45 do MS, até a SE 43 foram confirmados 5 I I casos da SIM-P temporalmente associada à Covid- 19 em crianças e adolescentes de 0 a 19 anos e 35 óbitos (Brasil, 2020b).

Para termos uma ideia real do número de mortes por Covid- 19 na faixa etária pediátrica, deveríamos somar aos óbitos por Srag os óbitos por SIM-P. Segundo o Boletim Epidemiológico 45 do MS, até a SE 43 foram confirmados 51 I casos da SIM-P temporalmente associada à Covid- 19 em crianças e adolescentes de 0 a 19 anos e 35 óbitos. Dessa forma, podemos estimar que o número total de óbitos por Covid- 19 na população pediátrica no Brasil em 2020 foi de aproximadamente 3.014 óbitos por Srag e 35 por SIM-P, somando o impressionante número de 3.049 vidas perdidas para o vírus.

De acordo com o relatório publicado pela Academia Americana de Pediatria, entre 6 e 18\% dos testes positivos para Covid- 19 nos Estados Unidos da América (EUA) são realizados em menores de 19 anos. Nesse mesmo documento consta a informação de que 0,2-3,1\% de todos os casos de Covid- 19 em pediatria resultaram em internação hospitalar. A necessidade de tratamento em terapia intensiva é também rara. As crianças somam 12,4\% de todos os casos de Covid- 19 naquele país. São 2.828 casos para cada 100 mil crianças. Foram 2.128.587 casos confirmados em uma população de 75.266 .842 de crianças e adolescentes. O total de óbitos nos EUA país foi de 179 crianças (AAP, 202I). 
Há diferenças expressivas entre os números de casos e de óbitos nos EUA e no Brasil, o que pode se dever a diversas razões. Entre estas, diferenças na oferta de testes diagnósticos, veracidade no número de notificações, rede assistencial incluindo leitos hospitalares e vagas em unidades de terapia intensiva, número de profissionais da saúde diretamente envolvidos no cuidado dos pacientes infectados, insumos, investimentos em logística de transporte e até mesmo fatores ambientais ou genéticos.

\section{MANIFESTAÇÕES CLÍNICAS}

As manifestações clínicas da Covid-19 na faixa etária pediátrica podem envolver quaisquer aparelhos e sistemas. São relatados desde quadros assintomáticos até óbitos. Os sintomas respiratórios são os mais frequentemente relatados, além dos gastrointestinais. Recentemente foram descritas as síndromes inflamatórias associadas à Covid- 19.

Entre os sinais e sintomas respiratórios, os mais frequentes na pediatria são os do resfriado comum/infecção das vias aéreas superiores: coriza, obstrução nasal, prurido nasal, odinofagia, tosse, laringite e faringite com ou sem febre. A infecção também pode acometer o trato respiratório inferior, e neste caso, com manifestações semelhantes às dos quadros clássicos de pneumonia, laringotraqueobronquite, bronquite e bronquiolite. Broncoespasmo, taquipneia, dispneia, hipoxemia, insuficiência respiratória e, em alguns casos, com injúria pulmonar aguda (síndrome da angústia respiratória aguda) e necessidade de ventilação mecânica (não invasiva ou invasiva) também foram divulgados. Vale destacar que crianças e adolescentes com patologias pulmonares subjacentes (doença pulmonar crônica e/ou asma grave) podem ter apresentações mais severas, assim como em outras doenças virais agudas - VSR (vírus sincicial respiratório), adenovírus, sarampo e influenza (Fiocruz, 2020a).

O trato gastrointestinal pode ser acometido isoladamente ou não. Os sinais e sintomas como inapetência, vômitos, diarreia, dor abdominal, com ou sem desidratação (leve, moderada ou grave) já foram descritos. Manifestações neurológicas e/ou psiquiátricas diversas como meningoencefalites, encefalopatias, psicoses, encefalomielite disseminada aguda, mielites, acidentes vasculares cerebrais, síndrome de Guillain Barré, plexopatias braquiais, neurites (anosmia e ageusia), retinites, entre outras, também já foram descritas na população infantil. Diversas manifestações cutâneas foram relatadas na literatura, entre elas as chamadas acrossíndromes (acometimento de dedos e/ou extremidades), lesões exantemáticas, urticariformes, vesiculares, eczematosas, purpúricas, papulares e petequeais (Fiocruz, 2020a).

As chamadas síndromes inflamatórias associadas à Covid- 19 foram recentemente descritas na literatura e constituem um desafio diagnóstico para os pediatras que se 
deparam com uma síndrome febril aguda em um paciente com sinais de gravidade clínica em meio à pandemia. Isso porque a SIM-P surge como uma apresentação clínica incomum de uma doença ainda considerada recém-chegada no cenário mundial. Trata-se de uma doença multissistêmica com amplo espectro de sinais e sintomas, caracterizada por febre persistente acompanhada de um conjunto de sintomas que podem incluir gastrointestinais (com importante dor abdominal), conjuntivite, exantema (rash cutâneo), erupções cutâneas, edema de extremidades, hipotensão, entre outros. Os sintomas respiratórios não estão presentes em todos os casos. Há importante elevação dos marcadores inflamatórios e o quadro clínico pode evoluir para choque e coagulopatia.

À medida que a pandemia progride, um número maior de crianças e adolescentes está sendo infectado. E não sabemos se esse crescimento nos casos de Covid- 19 nessa faixa etária também acarretará aumento dos casos de SIM-P em um futuro próximo. Esses pacientes podem evoluir com gravidade clínica, elevação de vários marcadores inflamatórios, como proteína C reativa (PCR), procalcitonina (PCT), ferritina e D-dímero, e de disfunção miocárdica, como pró-peptídeo natriurético tipo-B (proBNP), troponina, $\mathrm{CK}$ e CK-MB, que quase sempre demandam suporte de terapia intensiva, além de acompanhamento multiprofissional com infectologista, cardiologista e reumatologista.

De forma didática, podemos dividir as síndromes inflamatórias associadas à Covid- 19 em três grupos com características clínicas por vezes sobrepostas, de tal forma que alguns autores acreditam tratar-se de um espectro clínico diverso de uma mesma doença. No primeiro grupo estão as crianças que apresentam uma síndrome febril aguda associada a alterações laboratoriais com marcadores inflamatórios elevados. No segundo grupo, elas preenchem critérios para a doença de Kawasaki (DK), seja em sua forma clássica ou incompleta. E, no terceiro, apresentam uma doença sistêmica cujo acometimento cardiovascular é grave e em que o choque cardiogênico pode estar presente, além de um amplo espectro de sintomas. Relato de presença de miocardite com ou sem necrose miocárdica já foi publicado em países europeus e nos EUA, com descrições inclusive de dilatações e aneurismas de coronárias.

As manifestações clínicas da SIM-P são semelhantes, portanto, às de outras entidades inflamatórias, tais como: DK, choque tóxico por estafilococos e estreptococos, sepse bacteriana, síndrome hematofagocítica linfoproliferativa secundária e síndrome de ativação macrofágica. A SIM-P pode apresentar-se também como abdome agudo - simulando quadros de apendicite e peritonite -, sempre associada à presença de marcadores inflamatórios elevados.

Portanto, quando se deve pensar em SIM-P e que exames devem ser solicitados diante da suspeição, seja no ambulatório ou na emergência? Na maioria das vezes, há 
o relato de contato recente (até quatro semanas) com indivíduo sabidamente infectado por Covid-19. Entretanto, a ausência dessa história não exclui a suspeita diagnóstica, uma vez que o contato pode ter sido com pessoas assintomáticas, que desconheciam seu status infeccioso, ou até mesmo a própria criança pode ter desenvolvido uma forma assintomática/oligossintomática da Covid-19, na época não valorizada como tal, antes do surgimento dos sinais inflamatórios sistêmicos.

A criança que apresenta febre persistente ( $\geq 3$ dias) e está moderada a gravemente doente ou com sinais clínicos de disfunção orgânica (gastrointestinal, respiratória, cardíaca, cutânea ou neurológica) deve ser avaliada imediatamente, e nestes casos devese aventar a suspeita diagnóstica. Em alguns relatos, registrou-se que um sinal precoce desse evento seria a presença de taquicardia relativa para a idade sem outra explicação aparente, como a febre (Fiocruz, 2020a).

Nessa avaliação inicial, deve-se incluir a medição dos sinais vitais, a avaliação da perfusão e a saturação de oxigênio. Deve-se considerar ainda a consulta precoce com os especialistas em doenças infecciosas pediátricas e em reumatologia, bem como a coordenação do caso junto com o centro pediátrico de referência mais próximo, para testes e manejo ideais.

A triagem laboratorial inicial para inflamação sistêmica deve incluir hemograma com diferencial, análise de urina, avaliação da função renal e hepática, VHS, PCR, ferritina, LDH, albumina, D-dímero, proBNP, IL-6, troponina e fibrinogênio. O diagnóstico requer a identificação de infecção aguda por Covid-19 - com RT-PCR ou exames sorológicos ou antigênicos em laboratórios certificados. Os exames complementares de imagem serão solicitados de acordo com o quadro clínico apresentado.

Para investigar a real incidência da SIM-P e sua relação com a Covid- 1 9, a Organização Mundial da Saúde (OMS) disponibilizou um registro mundial on-line para que pediatras de todo o mundo pudessem inserir os dados de casos suspeitos. Conforme estabelecido pela OMS e posteriormente validado pelo MS e pelas sociedades brasileiras de Pediatria, de Infectologia, de Reumatologia e de Cardiologia, para que se confirme o caso de SIM-P é preciso verificar:

I. Crianças e adolescentes de 0 a 19 anos com febre por mais de 3 dias (pelo Centers for Disease Control and Prevention, CDC > 24 horas).

2. $E$ ao menos dois dos seguintes sintomas: a) conjuntivite não purulenta, erupção cutânea bilateral ou sinais de inflamação mucocutânea (orais, nas mãos ou nos pés); b) hipotensão ou choque; c) características de disfunção miocárdica, pericardite, valvulite ou anormalidades coronárias, incluindo achados do 
ecocardiograma ou elevação de troponina/proBNP; d) evidência de coagulopatia (por TAP, PTT, d-dímero elevado); e) problemas gastrointestinais agudos (diarreia, vômito ou dor abdominal).

3. E associação com marcadores de inflamação elevados, como VHS, PCR ou procalcitonina.

4. E nenhuma outra causa microbiana óbvia de inflamação, incluindo sepse bacteriana, síndromes de choque estafilocócica ou estreptocócica.

5. E evidência de Covid-19 (RT-PCR, teste antigênico ou sorologia positiva) ou provável contato com pacientes com Covid- 19 no último mês (WHO, 2020a; SBP, 2020).

Diante da suspeição, o paciente deve ser tratado com medidas de suporte ventilatório, inotrópico e fluidoterapia, sempre que necessário, e agentes anti-inflamatórios como a infusão venosa de gamaglobulina (lvig) na dose de $1-2 \mathrm{~g} / \mathrm{kg} /$ dia associada à corticoterapia. Casos refratários podem necessitar do uso de outras drogas imunomoduladoras como anti-TNF, anti-IL-I e anti-IL-6.

Esses pacientes necessitam de acompanhamento com ecocardiograma para identificação precoce de lesão de coronárias, requerendo, assim, terapia anticoagulante com ácido acetilsalicílico. E, depois, seguimento ambulatorial.

Alguns aspectos importantes da SIM-P:

I. É uma manifestação pediátrica incomum, embora descrita em diversos países.

2. Atualmente, é uma das condições clínicas em que a sorologia para Sars-CoV- 2 é valorizada para o diagnóstico.

3. Os marcadores inflamatórios devem ser sempre solicitados.

4. O acometimento cardíaco é frequente. Complicações como aneurisma de coronária podem ocorrer, tal como observado na DK, logo recomenda-se rotineiramente a realização de ecocardiograma.

5. Os sintomas gastrointestinais são mais frequentes nessa forma de apresentação clínica que os tradicionais sintomas respiratórios da Covid- 19.

6. Até o desenvolvimento de protocolos mais específicos, as drogas antiinflamatórias, em especial o corticosteroide e a imunoglobulina, devem ser consideradas.

7. Para o diagnóstico de SIM-P, é necessária a exclusão de outras entidades diagnósticas que podem se manifestar de forma muito semelhante. 
8. Com o aumento do número de casos de Covid- 19 na população pediátrica, pode vir a ocorrer o aumento também dos casos de SIM-P e, portanto, as unidades de terapia intensiva pediátrica devem estar preparadas.

Quase um ano após a primeira descrição da SIM-P na literatura, as perguntas ainda são mais frequentes que as respostas. Temos uma imagem clara dessa nova doença? Ou de apenas parte dela? Quais são suas causa e patogênese? Existem fatores de risco específicos para essa entidade? Como deve ser diagnosticada e tratada? Os critérios diagnósticos precisam de refinamento para captar um espectro ainda maior dessa doença? Existem marcadores que indicam uma evolução clínica tão desfavorável como essa? Que tratamentos podem evitar a evolução do choque, da falência múltipla de órgãos ou dos aneurismas coronarianos?

\section{EFEITOS INDIRETOS DA COVID-19}

Os efeitos indiretos da Covid-I 9 na criança e no adolescente podem ser maiores que o número de mortes causadas pelo vírus de forma direta.

Tedros Adhanom Ghebreyesus, diretor-geral da Organização Mundial da Saúde

Os efeitos diretos e indiretos da pandemia têm impactos na infância. Os efeitos diretos dizem respeito às manifestações clínicas da Covid- 19 e foram resumidos anteriormente. Os efeitos indiretos são descritos a seguir.

I. Prejuízos no ensino, na socialização e no desenvolvimento, visto que creches, colégios, escolas técnicas e de idiomas, faculdades e universidades tiveram que ser fechadas.

2. O afastamento do convívio familiar ampliado, com amigos e com toda rede de apoio, que agrava vulnerabilidades.

3. O estresse (e sua toxicidade associada), que afeta enormemente a saúde mental de crianças e adolescentes, gerando claro aumento de sintomas de depressão e ansiedade (Fiocruz, 2020a).

4. Aumento da violência contra a criança, o adolescente e a mulher, e a consequente diminuição da procura por atendimento nos serviços de proteção.

5. Quedas nas coberturas vacinais em todo o mundo, levando a efeitos devastadores em conquistas de anos de investimento e planejamento na erradicação e diminuição de doenças imunopreveníveis.

6. Queda na cobertura de programas de triagem universais, como o teste do pezinho. 
7. Aumento da epidemia de obesidade e de fome.

8. Exagero no uso de mídias/telas, como televisão, computadores, tablets e smartphones, e aumento da epidemia de sedentarismo.

9. Consequências, sofridas por crianças e adolescentes, do enorme impacto socioeconômico nas famílias, com aumento do desemprego e, em serviços não essenciais, impossibilidade de trabalhar.

10. Aumento da fome e do risco alimentar, em parte pelo fechamento das escolas e das creches, além de perdas na receita das famílias.

II. Impedimento da circulação da população e dos meios de transporte para serviços não essenciais, aliado ao medo da Covid- 19 e à reconfiguração dos sistemas de saúde, e a decorrente redução no acesso aos serviços tanto da APS quanto da Atenção Especializada, incluindo a redução de cirurgias eletivas e até mesmo tratamentos oncológicos e cuidados de emergências em saúde.

12. Fechamento de creches, escolas e universidades, com consequências devastadoras no ensino, na cognição e na expectativa de vida.

No último item, o que está em questão é a essencialidade da escola, que vai além das atividades curriculares. A escola é o meio no qual o aluno tem um ambiente muito singular para se desenvolver, se descobrir, se individualizar e se enturmar, é o contato social mais precoce e profundo além da família. Quando a criança, o jovem ou o adulto é retirado das atividades presenciais nas escolas, perde-se um recurso fundamental para o seu desenvolvimento; portanto, a escola deve ser considerada um serviço essencial. Com isso, deve haver um preparo emergencial para a reabertura das escolas, assim como houve com os hospitais para receber os doentes com Covid-19. Há disponíveis, inclusive, documentos da OMS e da Fundação Oswaldo Cruz (Fiocruz) que orientam essa preparação (WHO, 2020b; Fiocruz, 2020b).

Diante desse cenário, o fortalecimento da capacidade de atenção à saúde da criança e adolescente no âmbito do Sistema Único de Saúde (SUS) deve ser prioridade em todo o país. Esse esforço deve estar articulado a outras políticas de proteção social e engloba desde a produção de bons diagnósticos, baseados em análise dos bancos de dados, até a consolidação de orientações para os diferentes níveis de atenção, fornecendo informação de boa qualidade para a capacitação de todos os profissionais e para a sociedade de forma geral. Nesse processo, alguns pontos merecem destaque:

1. Divulgação e análise dos dados sobre síndromes gripais em crianças e adolescentes. 
2. Análise de cenários considerando as realidades locais nas regiões e estados brasileiros (composição demográfica, cobertura da APS e capacidade instalada de urgência e emergência e atenção hospitalar pediátrica, com ênfase em leitos intensivos).

3. Disponibilização de diretrizes clínicas e notas técnicas nacionais sobre o manejo clínico dos quadros agudos e tardios, com ênfase nos sinais de alerta para quadros graves e definição de estrutura necessária em cada ponto de atenção.

4. Ampla disseminação de conhecimento sobre o manejo clínico da Covid- 19 e suas complicações em crianças e adolescentes.

5. Estratégias de atuação oportuna e resolutiva da APS visando: a) ao alcance da cobertura vacinal; b) ao alcance dos testes de triagem neonatal; c) à condução inicial e acompanhamento dos casos leves e à identificação de sinais de alerta; d) ao mapeamento de crianças em situações de maior vulnerabilidade; e) à promoção da saúde com ênfase na minimização do impacto indireto da pandemia no crescimento e desenvolvimento e na saúde mental de crianças e adolescentes.

6. Estratégias de qualificação profissional para a assistência de urgência e hospitalar a crianças com síndromes respiratórias graves (quadros agudos) e síndromes inflamatórias multissistêmicas, incluindo cursos de suporte avançado de vida em pediatria.

7. Articulação e atuação conjunta com as políticas de educação, assistência social, cultura e esportes.

\section{REFERÊNCIAS}

AMERICAN ACADEMY OF PEDIATRICS (AAP). Children and Covid-19: state-level data report, 202I. Disponível em: <https://services.aap.org/en/pages/2019-novel-coronavirus-covid-19-infections/ children-and-covid-19-state-level-data-report/>. Acesso em: 8 fev. 2021.

BRASIL. Ministério da Saúde. Secretaria de Vigilância em Saúde. Doença pelo coronavírus Covid- 19. Boletim Epidemiológico Especial 44, 2020a. Disponível em: <www.gov.br/saude/pt-br/centrais-deconteudo/publicacoes/boletins/boletins-epidemiologicos/covid-19/202 I/boletim_epidemiologico_ covid_44.pdf/view>. Acesso em: 8 fev. 2021.

BRASIL. Ministério da Saúde. Secretaria de Vigilância em Saúde. Doença pelo coronavírus Covid- 19. Boletim Epidemiológico Especial 45, 2020b. Disponível em: <www.gov.br/saude/pt-br/media/pdf/2020/ novembro/20/boletim_epidemiologico_svs_45.pdf >. Acesso em: 8 fev. 2021.

FUNDAÇÃO ABRINQ. Cenário da Infância e Adolescência no Brasil, 2019. Disponível em: <www.fadc. org.br/sites/default/files/2019-05/cenario-brasil-2019.pdf>. Acesso em: 8 fev. 2021. 
FUNDAÇÃO OSWALDO CRUZ (FIOCRUZ). Instituto Nacional de Saúde da Mulher, da Criança e do Adolescente Fernandes Figueira. Covid-I 9 e Saúde da Criança e do Adolescente, ago. 2020a. Disponível em: < https://portaldeboaspraticas.iff.fiocruz.br/atencaocrianca/covid- I 9-saude-criancae-adolescente $>$. Acesso em: 8 fev. 2021.

FUNDAÇÃO OSWALDO CRUZ (FIOCRUZ). Recomendações para o planejamento de retorno às atividades escolares presenciais no contexto da pandemia de Covid-19, 2020b. Disponível em: $<$ https://portal.fiocruz.br/sites/portal.fiocruz.br/files/documentos/contribuicoes_para_o_retorno_ escolar_I $7122020 . p d f>$. Acesso em: 8 fev. 2021.

JOHNS HOPKINS UNIVERSITY (JHU). Center for Systems Science and Engineering. Covid- 19 Dashboard, 2021. Disponível em: <https://coronavirus.jhu.edu/map.html>. Acesso em: 8 fev. 2021.

SOCIEDADE BRASILEIRA DE PEDIATRIA (SBP). Síndrome inflamatória multissistêmica em crianças e adolescentes provavelmente associada à Covid-19: uma apresentação aguda, grave e potencialmente fatal. Nota de alerta, 20 maio 2020.

WORLD HEALTH ORGANIZATION (WHO). Multisystem inflammatory syndrome in children and adolescents temporally related to Covid-19. Scientific brief, 15 maio 2020a. Disponível em: <www. who.int/news-room/commentaries/detail/multisystem-inflammatory-syndrome-inchildren-andadolescents-with-covid-19>. Acesso em: 8 fev. 2021.

WORLD HEALTH ORGANIZATION (WHO). Checklist to support schools re-opening and preparation for Covid- 9 resurgences or similar public health crises. Geneva: World Health Organization, 2020b. Disponível em: <www.who.int/publications/i/item/97892400 I 7467>. Acesso em: 8 fev. 202 I. 



\section{Produção, Disseminação e Pronta Resposta de Amplo Acesso para Equipes de Saúde Mental e Atenção Psicossocial na Pandemia de Covid-19}

Débora da Silva Noal, Maria Fabiana Damásio Passos, Bernardo Dolabella Melo, Carlos Machado de Freitas, Juliana Fernandes Kabad, Nicolly Papacidero Magrin,

Michele Souza e Souza, Michele Rocha El Kadri,

Carolyne Cesar Lima, Fernanda Serpeloni,

Daphne Rodrigues Pereira, Sara da Silva Meneses e

Beatriz Schmidt

A formação acadêmica dos profissionais brasileiros que atuam com Saúde Mental e Atenção Psicossocial (Smaps) em situações de desastres no país é bastante lacunar. Estudos sobre a vulnerabilidade das populações e respectivos fatores socioculturais nas intervenções em desastres e emergências não têm sido contemplados em parte expressiva das universidades brasileiras, notadamente nos cursos da área da saúde. Disciplinas relacionadas à temática dos desastres e pandemias não são comumente ofertadas nas grades curriculares, tampouco os projetos político-pedagógicos dessas instituições contemplam, até este momento, a temática da atenção psicossocial e saúde mental na gestão integral de riscos e de desastres (Magrin et al., 2016 ; Noal, 2018 ).

Na área da psicologia, a inclusão desse conteúdo nos cursos de graduação se mostra pertinente, por se tratar de importante campo de pesquisa, formação e intervenção profissional, principalmente para aqueles que atuam (ou almejam atuar) em emergências sanitárias em qualquer uma das cinco fases de um desastre: prevenção, preparação, mitigação, resposta e reconstrução.

Na última década, universidades e centros de referência em pesquisas e intervenções no Brasil passaram a desenvolver, de maneira significativa, pesquisas e/ou grupos de estudo nesta área, o que tem contribuído para alguns avanços recentes em sua ampliação e consolidação no âmbito acadêmico. Contudo, ainda é necessário consolidar conheci- 
mentos e estratégias de intervenção específicas para o cuidado em atenção psicossocial e saúde mental na gestão integral de riscos e de desastres.

O cenário de insuficiência de profissionais devidamente capacitados para atuar na área de desastres e pandemias, bem como de falta de serviços públicos de saúde estruturados e articulados para atender a tal demanda, reflete diretamente na qualidade da resposta de enfrentamento. Assim, quando declarada, em março de 2020, a emergência do novo coronavírus (Covid-19) pela Organização Mundial de Saúde (OMS), inúmeras foram as dificuldades para lidar com as dinâmicas decorrentes da pandemia, o que teve impactos na saúde mental da população e na atenção psicossocial a ela dirigida.

A esse contexto, soma-se a falta de estrutura dos serviços para a realização de atendimentos por meios remotos e, em casos mais extremados, até mesmo de produtos de limpeza para higienização dos espaços e equipamentos de proteção individual (EPIs) para os profissionais. Nesse aspecto, a pandemia desencadeou uma série de impactos e consequências, inclusive para a saúde mental da população geral em todo o mundo (Fontanesi et al., 2020; Liu et al., 2020; Spinelli et al., 2020).

Entre os impactos sobre a saúde mental relatados na literatura mais recente estão o aumento, na população mundial, de reações e sintomas depressivos e ansiosos (WHO, 2020; Turna et al., 2021; Veldhuis, 2021; Zhang et al., 2020; Wang et al., 2020). Tais estudos têm relacionado essas condições a fatores como: medidas sanitárias de distanciamento social; medo de infecção pelo novo coronavírus; falecimento de membros da rede socioafetiva; perda de emprego ou renda durante a pandemia; fragilização do apoio social e institucional, além da sobrecarga de atividades (Coyne et al., 2020; Enumo et al., 2020; OMS, 2020; Schmidt et al., 2020). Considerando o contexto de crise provocado pela Covid-19, em que populações inteiras têm sido impactadas, intervenções e estratégias de atenção psicossocial têm sido recomendadas como elemento central, "a fim de evitar o prolongamento do sofrimento psíquico e agravos secundários no período de pandemia e pós-pandemia” (Moreira et al., 2020: 4).

Até março de 2020, era escassa a produção de guias, protocolos e referências técnicas em Smaps nas situações de pandemia. O guia organizado pela Organização Pan-Americana da Saúde (Opas) havia se estabelecido como uma das poucas referências a serem utilizadas pelos trabalhadores da saúde (Opas, 2009). Todavia, a conjuntura da pandemia impulsionou no Brasil o estabelecimento de parcerias entre instituições de ensino e pesquisa destinadas a produzir reflexões e orientações práticas para que nesta emergência sanitária a atenção seja integral, criativa e humanitária. 
Diante desse cenário de calamidade pública, destaca-se o desenvolvimento de intervenções de cuidados em saúde mental com base em evidências científicas e no diálogo com a sociedade, por meio da formação de um grupo de trabalho (GT) em Saúde Mental e Atenção Psicossocial na Pandemia de Covid-19, construído de maneira voluntária e colaborativa na Fundação Oswaldo Cruz (Fiocruz) (Kabad et al., 2020). Será relatado aqui processo de trabalho do GT que possibilitou a construção e execução do Curso Nacional de Saúde Mental e Atenção Psicossocial, além de outras estratégias audiovisuais para disseminação do conhecimento a respeito da saúde mental e emergências sanitárias.

\section{PERCURSO DO TRABALHO COLABORATIVO}

Entre março e dezembro de 2020, o GT colaborativo da Fiocruz desenvolveu diversas intervenções teórico-práticas em Smaps no contexto da Covid-19. Neste relato, sistematizamos as informações sobre o processo de trabalho do GT para o desenvolvimento das linhas de ações que consistiram na produção de materiais técnicos, organização de curso nacional e difusão rápida de informações via podcasts e redes sociais.

O GT foi coordenado por três pesquisadores localizados em diferentes unidades da Fiocruz e composto por nove pesquisadores do campo da saúde mental, incluindo psicólogos, psiquiatras e cientistas sociais, com o objetivo de orientar respostas rápidas para a prática profissional no contexto da pandemia. Colaboradores externos também compuseram a equipe, no total de 117 pesquisadores vinculados a 25 instituições nacionais e internacionais, com produção e experiência em temas centrais e caros a esse cenário (Kabad et al., 2020; Noal et al., 2020).

Sem a possibilidade de encontros presenciais em razão das necessárias medidas de distanciamento social impostas pela pandemia e pelo fato de os participantes do grupo se encontrarem em estados e países diferentes, o trabalho foi integralmente articulado via grupo na rede social WhatsApp para os acordos sobre os temas, as novas demandas e o alinhamento sobre a participação. Aliado ao grupo virtual, também foram utilizados e-mails, compartilhamento de arquivos via Google Docs por meio da conta Gmail, além de reuniões virtuais realizadas nas plataformas Meet e Zoom.

O grupo trabalhou para a elaboração de ações estratégicas e rápidas com as quais se pudesse dar respostas aos profissionais da linha de frente, à sociedade e às esferas de governo em três fases: Produção de vinte documentos técnicos norteadores; Disponibilização de curso virtual público e gratuito; Produção de podcasts a serem disponibilizados nas principais plataformas digitais e de aulas livres, e Publicação de artigos científicos e livro, de acordo com a Figura 1. 
Figura I - Desenvolvimento em três fases das atividades do GT em Saúde Mental e Atenção Psicossocial na Pandemia de Covid-19 - Mar. a dez. 2020

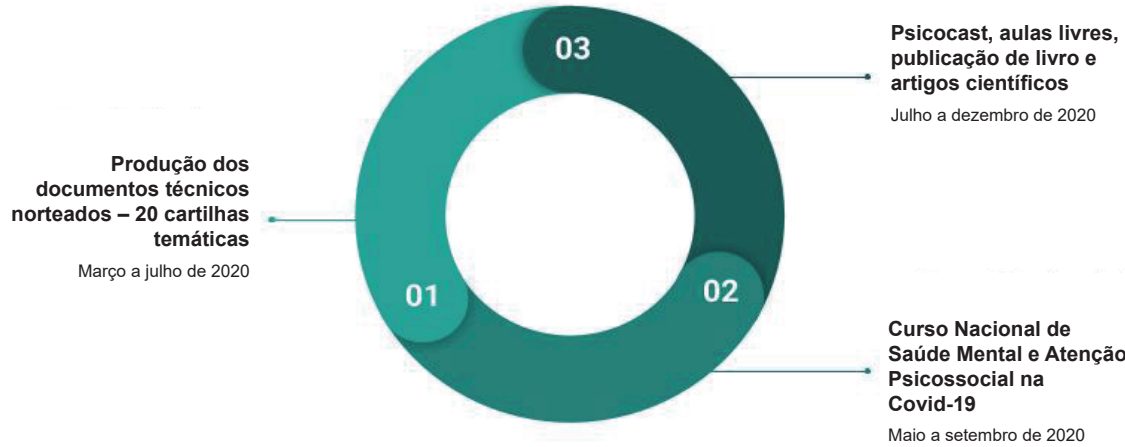

Fonte: elaboração própria.

\section{PRODUÇÕES DERIVADAS DO GRUPO DE TRABALHO}

Na orientação e condução do trabalho, foi preciso reunir um conjunto de pesquisadores engajados no enfrentamento da pandemia e profissionais especialistas em saúde mental e desastres, além de obter suporte institucional para as plataformas virtuais, redes sociais e estrutura de comunicação social, fundamentais para a difusão do conhecimento entre diferentes públicos e regiões do país.

As produções do GT começaram pela elaboração de vinte cartilhas sobre temáticas variadas, contendo diretrizes sobre a atuação em Smaps na pandemia. Alguns dos temas abordados foram luto, suicídio, idosos, crianças, quarentena, população indígena.

A seleção dos temas se baseou na demanda dos profissionais da linha de frente e na análise dos temas emergentes presentes nas publicações científicas de outros países que se encontravam em um estágio mais avançado da pandemia ou haviam tido vivências significativas em outras epidemias e crises sanitárias. Todas as cartilhas foram disponibilizadas virtualmente para acesso livre na página virtual Fiocruz Brasília (Gerência Regional de Brasília - Gereb), que atuou como coordenadora e deu suporte ao GT.

Após a publicação das cartilhas, foi editado o livro Recomendações e Orientações em Saúde Mental e Atenção Psicossocial na Covid-19, com o intuito de reunir as cartilhas em um único documento digitalizado e disponibilizado virtualmente, ' para facilitar o acesso rápido do público. Além do livro, foram publicados em revistas científicas do campo

\footnotetext{
I Página de acesso da Gereb, onde está hospedado o livro: <www.fiocruzbrasilia.fiocruz.br/wp-content/ uploads/2020/I0/livro_saude_mental_covid I9_Fiocruz.pdf >. Acesso em: 15 mar. 2021.
} 
da saúde coletiva dois artigos com resultados parciais do trabalho: "A experiência do trabalho voluntário e colaborativo em saúde mental e atenção psicossocial na Covid- I 9" (Kabad et al., 2020) e "Capacitação nacional emergencial em saúde mental e atenção psicossocial na Covid- 19: um relato de experiência" (Noal et al., 2020).

Em seguida, foi estruturado e implementado o Curso Nacional de Saúde Mental e Atenção Psicossocial na Covid- 9 (Fiocruz, 2020a), que contou com participantes do Brasil e de outros países. O curso, com 40 horas de duração, foi ofertado na modalidade a distância via Campus Virtual da Fiocruz ${ }^{2}$ em parceria com 37 docentes e contou com o suporte da Universidade Aberta do SUS e do Núcleo de Educação a Distância da Fiocruz Brasília. Foi estruturado em 16 módulos, cada qual contendo um documento técnico norteador (cartilha), videoaula, fórum de discussão e encontro virtual síncrono transmitido via YouTube. As videoaulas foram disponibilizadas no canal da Fiocruz Brasília (Gereb) no YouTube.

O curso nacional teve início no dia 12 de maio de 2020 e terminou em 29 de setembro de 2020. Seu encerramento foi prorrogado por três vezes devido a solicitações de grupos, instituições e profissionais interessados em acessá-lo. Alguns números relevantes: 69.256 alunos, 4.978 perguntas e comentários nos fóruns, 485.000 visualizações das aulas dos cursos disponíveis no canal da Fiocruz (até 25/4/02 I), 42 profissionais e/ou pesquisadores voluntários envolvidos, 10 semanas de lives, alunos oriundos das 27 unidades federativas e de outros países (Fiocruz, 2020b) e 17.785 certificados emitidos. A maior parte dos alunos inscreveu-se tendo em vista um aprendizado rápido relacionado às suas próprias necessidades do campo de trabalho, ancorado em evidências, e não necessariamente uma certificação para futuros trabalhos ou para uma formação ampliada em campos que não incluíam o seu processo no momento da pandemia. Procurou-se transmitir os conteúdos com uma multiplicidade de métodos, mas privilegiou-se uma prática interativa e dinâmica, em que os desafios e os anseios dos profissionais da saúde funcionaram como fio condutor para a organização e o caráter das atividades.

A diversidade territorial, a quantidade de inscritos e a pluralidade na formação dos profissionais demonstram a capilaridade do curso e evidenciam também a crescente demanda relacionada à saúde mental nesse período. O número de inscritos atesta o anseio dos trabalhadores da saúde e gestores por orientações sobre como lidar com a pandemia e seus efeitos sociais e psíquicos, além da busca urgente desses atores por espaços de diálogo e escuta sobre suas angústias, medos e dores.

\footnotetext{
2 Página de acesso ao curso do Campus Virtual da Fiocruz: Curso de Saúde Mental e Atenção Psicossocial em situação de Pandemia COVID- 19 - $1^{\circ}$ Oferta - 2020 | Campus Virtual Fiocruz. Acesso em: 15 mar. 2021.
} 
Observou-se a necessidade de respostas rápidas e eficientes para uma conjuntura que se modificava diariamente. Mesmo com as diversas desigualdades regionais de acesso à internet, o acesso ao curso indicou a sua capacidade de extensão para todo o território nacional, permitindo a interação com as múltiplas realidades enfrentadas pelos trabalhadores da saúde. Importante considerar também que no primeiro ano da pandemia observou-se aumento no número de eventos e encontros virtuais, o que também pode ter ocasionado sobrecarga de informações e aumento da concorrência sobre a atenção dos indivíduos.

Para lidar com a complexidade e abrangência do tema, o desenho do curso foi aprimorado, disponibilizando-se mais orientações e propiciando-se o contato mais próximo com os alunos, mediante a produção de podcasts e de aulas virtuais livres. Com o Psicocast, o podcast do Curso Nacional em Saúde Mental e Atenção Psicossocial, buscou-se responder a dúvidas dos alunos que não haviam sido respondidas nos chats e plataformas. Os Psicocasts foram disponibilizados também em plataformas como Spotify e Deezer, como forma de ampliar o acesso em período posterior ao curso.

Ao final dos módulos oferecidos, foram acrescidas aulas abertas sobre temáticas extras solicitadas pelos alunos ao longo da capacitação, ampliando o acesso dos interessados nessa produção. Por fim, produziu-se um vídeo de encerramento com um balanço das produções e parcerias estabelecidas ao longo do curso (Dolabella, 2021).

Toda a produção técnico-teórica do GT esteve alinhada com as políticas públicas, o Sistema Único de Saúde (SUS) e o Sistema Único da Assistência Social (Suas), além de ter sido disponibilizada em tempo hábil e com informações apresentadas de forma acessível e facilmente compreensível pela população.

Conforme o Quadro I, ao longo do ano de 2020 o GT trabalhou, através de rede colaborativa, com 24 temáticas consideradas não exploradas na prática da atenção psicossocial na Covid- 19, por meio das cartilhas, do curso on-line e dos podcasts, visando a minimizar os danos oriundos da lacuna na organização prévia dos serviços de saúde e de ações de formação dos profissionais da saúde. 


\section{Quadro I - Conteúdos e temáticas abordadas pelo GT por meio de cartilhas, curso} on-line e podcasts, por ordem de produção

\begin{tabular}{|c|c|c|c|c|c|}
\hline \multirow{2}{*}{$\begin{array}{l}\text { Temáticas Smaps trabalhadas pelo GT } \\
\text { / Formato e veículo em que o material } \\
\text { está disponibilizado* }\end{array}$} & \multirow{2}{*}{$\begin{array}{c}\begin{array}{c}\text { Documentos } \\
\text { técnicos } \\
\text { norteadores }\end{array} \\
\text { Cartilhas } \\
\text { / Página } \\
\text { Fiocruz } \\
\text { Brasília }\end{array}$} & \multicolumn{3}{|c|}{ Curso on-line } & \multirow{2}{*}{$\begin{array}{c}\text { Podcasts } \\
\\
\text { Psicocats } \\
\text { / Spotify e } \\
\text { Deezer }\end{array}$} \\
\hline & & $\begin{array}{l}\text { Módulos } \\
\text { do curso** } \\
\text { / Campus } \\
\text { Virtual }\end{array}$ & Lives & $\begin{array}{l}\text { Aulas } \\
\text { abertas / } \\
\text { YouTube }\end{array}$ & \\
\hline \multicolumn{6}{|l|}{ 1. Recomendações gerais } \\
\hline \multicolumn{6}{|l|}{ 2. Recomendações para gestores } \\
\hline \multicolumn{6}{|l|}{$\begin{array}{l}\text { 3. Recomendações para crianças em } \\
\text { situação de isolamento hospitalar }\end{array}$} \\
\hline \multicolumn{6}{|l|}{$\begin{array}{l}\text { 4. Recomendações aos psicólogos para } \\
\text { o atendimento on-line }\end{array}$} \\
\hline \multicolumn{6}{|l|}{$\begin{array}{l}\text { 5. Cuidados paliativos, orientações } \\
\text { aos profissionais da saúde }\end{array}$} \\
\hline \multicolumn{6}{|l|}{$\begin{array}{l}\text { 6. A quarentena na Covid-19: } \\
\text { orientações e estratégias de cuidado }\end{array}$} \\
\hline \multicolumn{6}{|l|}{$\begin{array}{l}\text { 7. Recomendações para os } \\
\text { consultórios na rua e a rede de } \\
\text { serviços que atuam junto com a } \\
\text { população em situação de rua }\end{array}$} \\
\hline \multicolumn{6}{|l|}{$\begin{array}{l}\text { 8. Orientações às/os psicólogas/os } \\
\text { hospitalares }\end{array}$} \\
\hline \multicolumn{6}{|l|}{$\begin{array}{l}\text { 9. Recomendações aos trabalhadores e } \\
\text { cuidadores de idosos }\end{array}$} \\
\hline \multicolumn{6}{|l|}{$\begin{array}{l}\text { 10. Violência doméstica e familiar na } \\
\text { Covid-19 }\end{array}$} \\
\hline \multicolumn{6}{|l|}{$\begin{array}{l}\text { 11. Covid-19 e população privada de } \\
\text { liberdade }\end{array}$} \\
\hline \multicolumn{6}{|l|}{$\begin{array}{l}\text { 12. Pessoas migrantes, refugiadas, } \\
\text { solicitantes de refúgio e apátridas }\end{array}$} \\
\hline 13. Crianças na pandemia & & & & & \\
\hline
\end{tabular}


Quadro I - Conteúdos e temáticas abordadas pelo GT por meio de cartilhas, curso on-line e podcasts, por ordem de produção (continuação)

\begin{tabular}{|c|c|c|c|c|c|}
\hline \multirow{2}{*}{$\begin{array}{l}\text { Temáticas Smaps trabalhadas pelo GT } \\
\text { / Formato e veículo em que o material } \\
\text { está disponibilizado* }\end{array}$} & \multirow{2}{*}{$\begin{array}{c}\begin{array}{c}\text { Documentos } \\
\text { técnicos } \\
\text { norteadores }\end{array} \\
\text { Cartilhas } \\
\text { / Página } \\
\text { Fiocruz } \\
\text { Brasília }\end{array}$} & \multicolumn{3}{|c|}{ Curso on-line } & \multirow{2}{*}{$\begin{array}{c}\text { Podcasts } \\
\text { Psicocats } \\
\text { / Spotify e } \\
\text { Deezer }\end{array}$} \\
\hline & & $\begin{array}{l}\text { Módulos } \\
\text { do curso** } \\
\text { / Campus } \\
\text { Virtual }\end{array}$ & Lives & $\begin{array}{l}\text { Aulas } \\
\text { abertas / } \\
\text { YouTube }\end{array}$ & \\
\hline \multicolumn{6}{|l|}{ I4. Psicofármacos na Covid-I 9} \\
\hline \multicolumn{6}{|l|}{ 15. Suicídio na pandemia } \\
\hline \multicolumn{6}{|l|}{$\begin{array}{l}\text { 16. Processo de luto no contexto da } \\
\text { Covid- } 19\end{array}$} \\
\hline \multicolumn{6}{|l|}{$\begin{array}{l}\text { 17. Povos indígenas no contexto da } \\
\text { Covid- I } 9\end{array}$} \\
\hline \multicolumn{6}{|l|}{$\begin{array}{l}\text { 18. Orientações aos trabalhadores dos } \\
\text { serviços de saúde }\end{array}$} \\
\hline \multicolumn{6}{|l|}{$\begin{array}{l}\text { 19. Trabalhadoras/es e gestoras/es do } \\
\text { Sistema de Assistência Social (Suas) } \\
\text { para ações na pandemia Covid- I } 9\end{array}$} \\
\hline \multicolumn{6}{|l|}{$\begin{array}{l}\text { 20. Suas na Covid- I 9: proteção social } \\
\text { a grupos vulnerabilizados }\end{array}$} \\
\hline \multicolumn{6}{|l|}{$\begin{array}{l}\text { 21. Sistema Único de Assistência } \\
\text { Social (Suas) na Covid-19 }\end{array}$} \\
\hline \multicolumn{6}{|l|}{$\begin{array}{l}\text { 22. Volta às aulas e Covid- } 19 \text { : } \\
\text { perspectivas e possibilidades }\end{array}$} \\
\hline \multicolumn{6}{|l|}{$\begin{array}{l}\text { 23. Cuidado à população ribeirinha na } \\
\text { Covid- } 19\end{array}$} \\
\hline $\begin{array}{l}\text { 24. Cuidado à população negra na } \\
\text { Covid- } 19\end{array}$ & & & & & \\
\hline
\end{tabular}

* A variação de grafia no nome das cartilhas ocorreu devido à multiplicidade de grupos que trabalharam em sua confecção e à necessidade de rápida publicação do material.

** Em alguns módulos do curso utilizou-se mais de uma cartilha como referencial técnico. 
Nessas estratégias de disseminação do conhecimento sobre Smaps foram utilizados diferentes formatos, valendo-se de espaços virtuais institucionais da Fiocruz de amplo acesso, bem como de páginas virtuais e redes sociais para transmissão dos materiais audiovisuais, tanto no YouTube como no Instagram. ${ }^{3}$ Para o curso virtual, em específico, foram utilizadas diferentes técnicas de ensino e aprendizagem, desde formas dinâmicas até metodologias clássicas de ensino, buscando alcançar o maior número de pessoas com diferentes habilidades de aprendizagem e oriundas de diferentes contextos de trabalho. A leitura estava disponível nas cartilhas, a audição nos Psicocasts, a visão nas videoaulas, a conversa entre pares nos fóruns de discussões, a proximidade entre professor e aluno nas lives semanais e nos fóruns, e a proximidade entre as moderadoras e os alunos nos chats, fóruns e lives. Possibilitou-se, dessa maneira, uma formação em massa gratuita e qualificada.

Além da formação dos trabalhadores da saúde para o enfrentamento de emergências sanitárias, a sensibilização e o preparo dos gestores se fazem fundamentais para que os serviços possam se adequar às recomendações propostas no material produzido $e$ disponibilizado pelo GT. Devido a essa necessidade de capacitação e orientações não só individuais, mas também institucionais, foi produzido material específico para gestores, para a condução de equipes e organização do espaço. Nesse sentido, além de apoiar cientificamente os profissionais na resposta à Covid- 19 , as iniciativas conduzidas pelo GT serviram como ancoramento de esperança, empatia, novos sentidos e experiências que permitiram que esses serviços essenciais seguissem de forma mais segura.

Em razão dessas diversas iniciativas, além da participação dos membros em lives e eventos, foram estabelecidas parcerias para a colaboração na produção de outros materiais e cursos virtuais - com destaque para a capacitação de uma equipe de aproximadamente 170 psicólogos para orientação psicossocial on-line na cidade de Brasília, e para o Curso Bem-Viver: saúde mental indígena, produzido pelo Fundo das Nações Unidas para a Infância (Unicef) em parceria com o Instituto Leônidas e Maria Deane - Fiocruz Amazônia e a Coordenação das Organizações Indígenas da Amazônia Brasileira (Coaib), disponibilizado no Campus Virtual Fiocruz (202I).

\footnotetext{
${ }^{3}$ Página de acesso ao Instagram da Gereb para divulgação dos materiais audiovisuais e lives do curso: Fiocruz Brasília (@fiocruzbrasilia)• Fotos e vídeos do Instagram. Acesso em: 15 mar. 2021.
} 


\section{DESAFIOS, POTENCIALIDADES E PERSPECTIVAS FUTURAS}

No processo de construção e execução das estratégias desenvolvidas no primeiro ano da pandemia pelo GT de Saúde Mental e Atenção Psicossocial na Covid- I 9, a singularidade do cenário determinou a urgência da divulgação de conhecimento oportuno e em tempo hábil, demarcando o lugar da ciência e do pesquisador na produção de respostas à altura da sua gravidade (Kabad et al., 2020). Foram necessárias orientações práticas, bem elaboradas, respaldadas em evidências e factíveis no momento, considerandose os conhecimentos técnicos relacionados tanto ao cuidado em saúde para evitar o agravamento dos casos quanto ao apoio psicossocial àqueles mais vulneráveis, seus familiares e comunidades.

O novo cenário epidemiológico que se desenhou com o surgimento de doenças transmissíveis e um padrão de propagação e contaminação extremamente agressivo, como é o caso do novo coronavírus, torna necessária a adequação e aprimoramento de práticas de cuidado e assistência, além de capacitação dos profissionais da saúde para o atendimento adequado neste contexto específico.

A longa duração da pandemia, o elevado número de mortes, o estresse enfrentado diariamente pelos trabalhadores da saúde e o colapso do Sistema único de Saúde tornam imprescindível que a capacitação dos profissionais seja iniciada ainda nos cursos de graduação e adquira caráter permanente, dada a multiplicidade de situações vivenciadas em eventos extremos. Por isso, é importante desenvolver ações voltadas tanto para minimizar e/ou reduzir as dores e fragilidades psicossociais vivenciadas por profissionais da saúde (especialmente os que trabalham na linha de frente assistencial) quanto para ajudá-los no melhor manejo das demandas de grupos e indivíduos por apoio e atenção psicossocial nesta emergência sanitária.

Diante de uma pandemia viral, a organização e implementação de medidas rápidas e conscientes para preservar a população são primordiais, principalmente as destinadas a grupos mais vulneráveis do ponto de vista físico e/ou psíquico, tais como idosos, pessoas com doenças crônicas, enfermidades mentais graves ou deficiências, povos indígenas, população em situação de rua, entre outros abordados nos materiais do GT.

Espera-se que os efeitos positivos dessas iniciativas contribuam para o planejamento de estratégias de atenção psicossocial voltadas para a mitigação de impactos, reações e consequências negativas de uma crise epidemiológica, assim como para o fornecimento aos trabalhadores da saúde de ferramentas que lhes permitam atuar em situações que envolvam risco de vida e emergências, incluindo o sofrimento psíquico. 


\section{REFERÊNCIAS}

COYNE, L. W. et al. First things first: parent psychological flexibility and self-compassion during Covid- I 9. Behavior Analysis in Practice, 2020. Disponível em: <https://doi.org/I 0. I 007/s406 I 7-02000435-w>. Acesso em: 15 mar. 2021.

DOLABELLA, B. Curso Nacional de Saúde Mental e Atenção Psicossocial, 5 mar. 2021. Disponível em: $<$ https://youtu.be/4vBNdou-9PA>. Acesso em: 15 mar. 2021.

ENUMO, S. R. F. et al. Enfrentando o estresse em tempos de pandemia: proposição de uma cartilha. Estudos de Psicologia, 37: e200065, 2020. Disponível em: <http://dx.doi.org/10.1590/19820275202037e200065 >. Acesso em: 15 mar. 2021.

FONTANESI, L. et al. The effect of the Covid- 19 lockdown on parents: a call to adopt urgent measures. Psychological Trauma: Theory, Research, Practice, and Policy, I2(SI), S79-S8I, 2020. Disponível em: <http://dx.doi.org/I 0.1037/tra0000672>. Acesso em: I 5 mar. 2021.

FUNDAÇÃO OSWALDO CRUZ (FIOCRUZ). Saúde Mental e Atenção Psicossocial na Covid- 19. Curso de atualização na modalidade de ensino a distância. Rio de Janeiro, 2020a. Disponível em: <www. unasus.gov.br/cursos/curso/4624I >. Acesso em: 15 mar. 2021.

FUNDAÇÃO OSWALDO CRUZ (FIOCRUZ). Escola de Governo Fiocruz Brasília. Núcleo de Educação a Distância. Painel de Monitoramento do Curso Nacional de Saúde Mental e Atenção Psicossocial na Covid- 19. Brasília: Fiocruz Brasília, 2020b. Indicadores eletrônicos.

FUNDAÇÃO OSWALDO CRUZ (FIOCRUZ). Campus Virtual. Bem-Viver: saúde mental indígena, 202I. Disponível em: <https://campusvirtual.fiocruz.br/portal/?q=node/600 I2>. Acesso em: I 5 mar. 202 I .

$\mathrm{KABAD}$, J. F. et al. A experiência do trabalho voluntário e colaborativo em saúde mental e atenção psicossocial na Covid-19. Cadernos de Saúde Pública, 36(9): e00132120, 2020. Disponível em: <https://doi.org/I0.1590/0102-31IX00132120>. Acesso em: 15 mar. 202I.

LIU, C. H. et al. Evidence for elevated psychiatric distress, poor sleep, and quality of life concerns during the Covid-19 pandemic among US young adults with suspected and reported psychiatric diagnoses. Psychiatry Research, 292, II3345, 2020. Disponível em: <https://doi.org/10.1016/j. psychres.2020.113345>. Acesso em: 15 mar. 2021.

MAGRIN, N. P. et al. Identificando e mapeando as disciplinas de psicologia em desastres e catástrofes no Brasil: será que elas existem? Congresso Brasileiro de Redução de Riscos de Desastres: Gestão Integrada em RRD no Brasil e o Marco de Sendai. Sendai, Japão, 20I6. Disponível em: < https://abp-rrd.com.br/ files/anais_20I6.pdf>. Acesso em: I 5 mar. 202I.

MOREIRA, W. C. et al. Intervenções em saúde mental em tempos de Covid- 19: scoping review. Scielo Preprint, 2020. Disponível em: <https://preprints.scielo.org/index.php/scielo/preprint/view/I007/ version/1066>. Acesso em: 15 mar. 2021.

NOAL, D. S. Atenção Psicossocial e Saúde Mental: analisando diretrizes e ações para uma gestão integral de riscos e de desastres, 2018. Tese de Doutorado, Brasília: Universidade de Brasília. Disponível em: $<$ https://repositorio.unb.br/handle/I0482/32630>. Acesso em: 15 mar. 2021 .

NOAL, D. S. et al. Capacitação nacional emergencial em saúde mental e atenção psicossocial na Covid- 19: um relato de experiência. Saúde em Debate, 44: 293-305, 2020. Disponível em: <https:// www.arca.fiocruz.br/handle/icict/43909>. Acesso em: 15 mar. 2021. 
ORGANIZAÇÃO PANAMERICANA DA SAÚDE (OPAS). Proteção da saúde mental em situações de epidemias, 2009. (Unidade de Saúde Mental, de Abuso de Substâncias, e Reabilitação; Tecnologia e Prestação de Serviços de Saúde Organização Pan-Americana da Saúde). Disponível em: <www.paho. org/hq/dmdocuments/2009/Protecao-da-Saude-Mental-em-Situaciones-de-Epidemias--Portugues. pdf>. Acesso em: 15 mar. 2021.

SCHMIDT, B. et al. Saúde mental e intervenções psicológicas diante da pandemia do novo coronavírus (Covid-19). Estudos de Psicologia, 37: e200063, 2020. Disponível em: <http://dx.doi. org/l 0.1590/1 982-0275202037e200063 >. Acesso em: I5 mar. 2021.

SPINELLI, M. et al. Parents' stress and children's psychological problems in families facing the Covid- 19 outbreak in Italy. Frontiers in Psychology, I I (1.7 I3): 1-7, 2020. Disponível em: <https://doi. org/10.3389/fpsyg.2020.01713>. Acesso em: 15 mar. 2021.

TURNA, J. et al. Anxiety, depression and stress during the Covid- 19 pandemic: results from a crosssectional survey. Journal of Psychiatric Research, 137: 96-103, 2021. Disponível em: <https://doi.org/ https://doi.org/10.1016/j.jpsychires.2021.02.059>. Acesso em: I 5 mar. 2021.

VELDHUIS, C. B. et al. Addressing the critical need for long-term mental health data during the Covid- 19 pandemic: changes in mental health from April to September 2020. Preventive Medicine, I46: 106465 , 202 I. Disponível em: < https://doi.org/https://doi.org/l 0. I 0 I6/j.ypmed.202 I. I 06465 >. Acesso em: 15 mar. 2021.

WANG, C. et al. Immediate psychological responses and associated factors during the initial stage of the 20 I 9 coronavirus disease (Covid- 19) epidemic among the general population in china. International Journal of Environmental Research and Public Health, I7(5): I.729, 2020. Disponível em: <http://dx.doi. org/10.3390/ijerph I 7051729>. Acesso em: 15 mar. 2021.

WORLD HEALTH ORGANIZATION (WHO). Substantial investment needed to avert mental health crisis, 2020. Disponível em: <www.who.int/news-room/detail/I4-05-2020-substantial-investmentneeded-to-avert-mental-health-crisis>. Acesso em: 15 mar. 2021.

ZHANG, C. et al. Survey of insomnia and related social psychological factors among medical staff involved in the 2019 novel coronavirus disease outbreak. Frontiers in Psychiatry, II (306): I-9, 2020. Disponível em: <http://dx.doi.org/l0.3389/fpsyt.2020.00306>. Acesso em: 15 mar. 202I. 
Covid-19

revendo processos para uma campanha de vacinação

Maria de Lourdes de Sousa Maia, Márcia Vieira Leite, Jaqueline Toledo de Oliveira Figueira, Patrícia Mouta Nunes de Oliveira, Letícia Kegele Lignani e Beatriz de Castro Fialho

A emergência da pandemia da Covid- I 9 tem apresentado inúmeros desafios em escala global, desde a vigilância epidemiológica, passando por medidas não farmacológicas fundamentais para o controle da transmissão, até o desenvolvimento de tratamentos eficazes nos diferentes estágios da doença e vacinas voltadas para a prevenção.

No caso das vacinas, um dos principais problemas enfrentados pelo mundo inteiro tem sido como assegurar o acesso às vacinas seguras e de qualidade. Essa necessidade levou organismos multilaterais, como Organização Mundial da Saúde (OMS) e Gavi Alliance, e instituições da sociedade civil, como a Coalizão para Inovações em Preparação para Epidemias (Cepi), Fundação Bill e Melinda Gates, Wellcome Trust e outras, a propor programas visando a acelerar o desenvolvimento de vacinas, como o ACT Accelerator, de financiamento à aquisição junto com um mecanismo de ampliação de acesso equitativo, como o Covax Facility. Alguns países e blocos regionais também instituíram mecanismos próprios com a mesma finalidade. No entanto, ainda se está muito aquém de assegurar o acesso equitativo da população mundial às vacinas para Covid-19. Ao passo que alguns países mais ricos foram capazes de estabelecer acordos de compra antecipada de doses de vacinas em número muito superior ao tamanho de sua população, países com menor poder aquisitivo e menor capacidade industrial instalada ainda têm pela frente vários obstáculos ao acesso.

O Brasil está diante de um grande desafio: a campanha de vacinação contra Covid- 19. Essa não é a primeira grande campanha que o país realiza. Nos seus 47 anos, o Programa Nacional de Imunizações (PNI), do Ministério da Saúde, realizou várias campanhas de vacinação com o objetivo de controlar, eliminar e erradicar doenças imunopreveníveis (Brasil, 2003). Essa é uma ação de caráter coletivo que visa a pro- 
mover a saúde e o acesso equitativo às vacinas seguras e eficazes contra a Covid- I 9 , fortalecendo a imunização de rotina e levando à interiorização de técnicas, de tecnologias e da atenção primária.

O PNI, programa governamental, de referência mundial, é peça-chave na imunização contra a Covid-19, com vacinas seguras e eficazes, autorizadas pela Agência Nacional de Vigilância Sanitária (Anvisa). O PNI foi criado em 1973 - antes, portanto, do Programa Ampliado de Imunizações da Organização Pan-Americana da Saúde (Opas) -, e suas campanhas de vacinação são reconhecidas por seu pioneirismo e abrangência. Antes de sua criação, o Brasil já acumulava experiências importantes na saúde pública, em campanhas de vacinação contra doenças como varíola, febre amarela e poliomielite, e realizava heterogeneamente vacinação de rotina. O Calendário Nacional de Vacinação, introduzido em 1977, foi fundamental na consolidação das estratégias de imunização e na assistência à população brasileira desde as comunidades mais isoladas até os centros urbanos e ganhou reconhecimento e credibilidade. A partir dele, foi implementada a vacinação de rotina em grande escala e foram introduzidas novas indicações e novos grupos-alvo, conforme o risco epidemiológico. Contribuiu-se, desse modo, para o aprimoramento da vigilância epidemiológica e avançou-se na metodologia de vacinação em massa, que por sua mobilização ousada e seus importantes resultados ganhou reconhecimento internacional. A atenção básica foi também fortalecida, pois foram capacitadas equipes que, com seu trabalho, Ihe conferiram grande capilaridade, contribuíram para o seu avanço e agregaram credibilidade para outras ações de saúde pública (Brasil, 20 I 3a).

Para que o programa fosse sustentável, fazia-se vital a participação de laboratórios públicos que garantissem os insumos necessários para a manutenção e atualização do calendário vacinal, conforme critério epidemiológico. Para tanto, em 1985 foi criado o Programa de Autossuficiência Nacional em Imunobiológicos (Pasni), visando a fortalecer a produção e ampliar a diversidade das vacinas produzidas nacionalmente, estabelecendo parcerias bem-sucedidas entre o PNI e os laboratórios públicos produtores (Brasil, 2003). O êxito dessa iniciativa está no fato de que nos oferece as bases para o desenvolvimento e a produção de vacinas, inclusive contra a Covid-19, no país.

\section{PLANEJANDO E VIABILIZANDO UMA CAMPANHA DE VACINAÇÃO}

Uma campanha de vacinação vai muito além da proteção individual, pois pode controlar, eliminar e/ou erradicar doenças, além de reduzir a morbimortalidade, a hospitalização de casos graves e prevenir sequelas graves/incapacitantes. As campanhas de vacinação do PNI baseiam-se em conhecimentos científicos para avaliação das vacinas e na experiência de profissionais sobre a diversidade geopolítica e geográfica do país, que tem 
influência em sua operacionalização (Domingues et al., 2015). Assim, o alinhamento entre as entidades federativas é crucial para a vacinação de rotina e para campanhas específicas coordenadas pelo PNI.

No caso do Sars-CoV-2, como em qualquer outro vírus causador de doença imunoprevenível, é imperativo atingir altas e homogêneas coberturas vacinais, visando a alcançar a imunidade coletiva e o controle da pandemia de Covid- 19. Entretanto, até março de 202 I não havia ainda ampla disponibilidade da vacina em vários países, inclusive no Brasil, e o objetivo principal da vacinação passou a ser a redução da morbimortalidade, mediante acesso sustentável às vacinas. Outros aspectos devem ser considerados: campanha com vacinas diversas requerendo duas doses com intervalos diferenciados, e necessidade de comunicação clara e acessível com toda a população, isto é, contemplando diferentes grupos.

O Brasil é um país de dimensões continentais, grande diversidade geográfica, cultural, demográfica e socioambiental, e conta com 212,58 milhões de habitantes (IBGE, 202 I) e extensa área de fronteira com populações flutuantes advindas de países vizinhos, o que requer planejamento multinacional e parceria com a Opas para definição das melhores estratégias de vacinação e monitoramento.

Dos 5.570 municípios brasileiros, aproximadamente 68\% têm menos de 20 mil habitantes e baixa densidade demográfica (Brasil, 202 la), requerendo estratégias e planejamento específicos que comportem deslocamento de equipe, logística de transporte, guarda e aplicação da vacina, com acompanhamento para eventos adversos. Destaca-se nesse contexto o papel fundamental dos agentes comunitários de saúde (ACS) e dos agentes indígenas de saúde (AIS) juntamente com os Distritos Sanitários Especiais Indígenas (DSEls) na garantia de acesso equânime das comunidades das áreas mais remotas do país às ações de vacinação (Brasil, 202 Ib). Em grandes metrópoles, por sua vez, a dificuldade de acesso a algumas comunidades torna grande o potencial de gerar aglomerações, o que é preciso evitar. Portanto, em cada local é preciso atenção às especificidades de infraestrutura, cultura, hábitos e dinâmica territorial.

Para o bom resultado de uma campanha, a rede de frio é outro fator importante, pois para assegurar a potência da vacina deve-se mantê-la em condições adequadas de conservação, com temperatura controlada e em conformidade com as orientações dos fabricantes. A exposição acumulada da vacina a temperatura mais quente ou mais fria, ou à luz, em qualquer etapa, pode gerar uma perda de potência que não será restaurada (Brasil, 20 I3b). No Brasil, a rede de frio, referência mundial, é caracterizada por complexa cadeia de armazenamento, distribuição e manutenção de vacinas em temperaturas adequadas em todos os níveis, conforme Figura I. 
Figura I - Rede de frio para distribuição de vacinas no Brasil

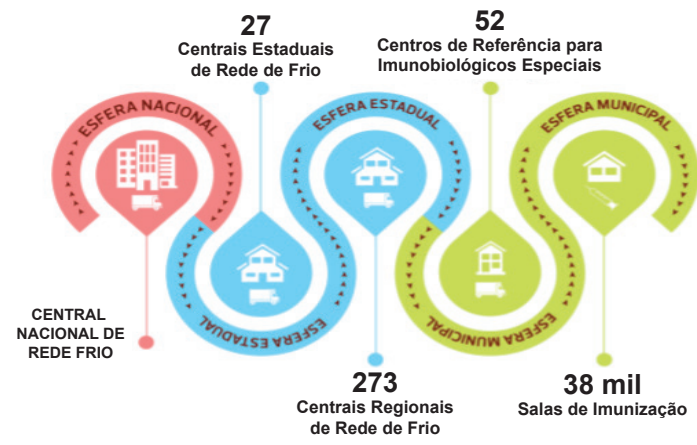

Fonte: Brasil, $202 \mathrm{Ib}$.

Portanto, para uma campanha de vacinação com imunizantes que podem requerer diferentes condições ambientais, são necessários: I) previsão das vacinas e insumos a serem utilizados, definição sobre quem será responsável pela compra, e cronograma de distribuição; 2) diagnóstico da rede de frio, plano de contingência para emergências, readequação da rede; e 3) logística de distribuição adequada para chegada dos imunizantes às centrais estaduais e regionais.

Das vacinas registradas para uso emergencial no mundo, duas requerem condições diferenciadas para manutenção em rede de frio, fora dos padrões utilizados no Brasil, a da Pfizer/BioNTech (FDA, $202 \mathrm{I}$ a) e a da Moderna (FDA, $202 \mathrm{llb}$ ). As demais disponíveis até o momento podem ser acondicionadas em temperatura de $2^{\circ} \mathrm{C}$ a $8^{\circ} \mathrm{C}$, portanto, para se obter êxito com a vacinação é preciso o monitoramento de toda a movimentação do imunizante, garantindo sua segurança e qualidade no local onde será aplicado, assim como capacitação e atualização dos profissionais (Brasil, 202 l c).

A infraestrutura de gestão da informação é crucial. Nesta campanha de vacinação contra Covid- 19, o registro da dose aplicada será nominal, e os usuários serão identificados pelo número do Cadastro de Pessoas Físicas (CPF) ou do Cartão Nacional de Saúde (CNS) (Brasil, 202 I c). Isso possibilita a identificação, o controle e o monitoramento das pessoas vacinadas, evitando duplicidade e permitindo acompanhar eventos adversos pós-vacinação (EAPVs), assim como identificação do lote, do produtor e da dose aplicada. Dada a precariedade de internet em alguns pontos do país, métodos já adotados na rotina para demais vacinas certamente serão utilizados, contanto que a informação sobre doses aplicadas seja fidedigna, oportuna, segura e encaminhada nos prazos para melhor gestão. 
Outro fator importante é o fato de a campanha de vacinação ter se iniciado após eleições municipais, pois as mudanças na gestão e no quadro dos trabalhadores da saúde acabam por se constituir em mais um obstáculo ao seu bom funcionamento, podendo ser mais um fator de atrasos ou inadequações. Neste sentido, considerando que a gestão do Sistema Único de Saúde (SUS) é tripartite, é preciso boa coordenação nacional que permita lançar mão de todos os recursos existentes em todas as esferas, de modo a minimizar o impacto nas rotinas de vacinação

Como coordenador de um processo que não se limita à normatização, o PNI tem como responsabilidade a condução nacional. E, desse modo, é fundamental que interaja com os produtores de vacinas, com o Instituto Nacional de Controle de Qualidade em Saúde (INCQS) e com estados e municípios. Precisa também interagir com as organizações responsáveis pelos estudos clínicos e com todas as partes interessadas. Isso permite contínua atualização sobre as diferentes dimensões que afetam a campanha, de forma a assegurar sua efetividade e sustentabilidade.

\section{QUALIDADE E REGISTRO DAS VACINAS}

O desenvolvimento de uma vacina para o enfrentamento da pandemia de Covid- 19 mobilizou diversos países. A capacidade que tem o agente viral de continuar circulando e, desse modo, manter o curso da pandemia é reduzida quando se atinge uma proteção coletiva, o que pode acontecer por meio do uso expandido de vacinas eficazes, ou por ondas de infecção natural, até que a população suscetível desenvolva imunidade.

O desenvolvimento de vacinas é um processo de alto custo e demorado, podendo levar 10 a 15 anos, ou mais, a depender do conhecimento sobre o mecanismo da doença e das tecnologias e recursos disponíveis. Para acelerar esse desenvolvimento, muitas etapas são realizadas em paralelo; embora aumente seu risco e sua complexidade, esse procedimento Ihe confere celeridade, conforme apresentado na Figura 2. 
Figura 2 - Etapas de desenvolvimento convencional e acelerado

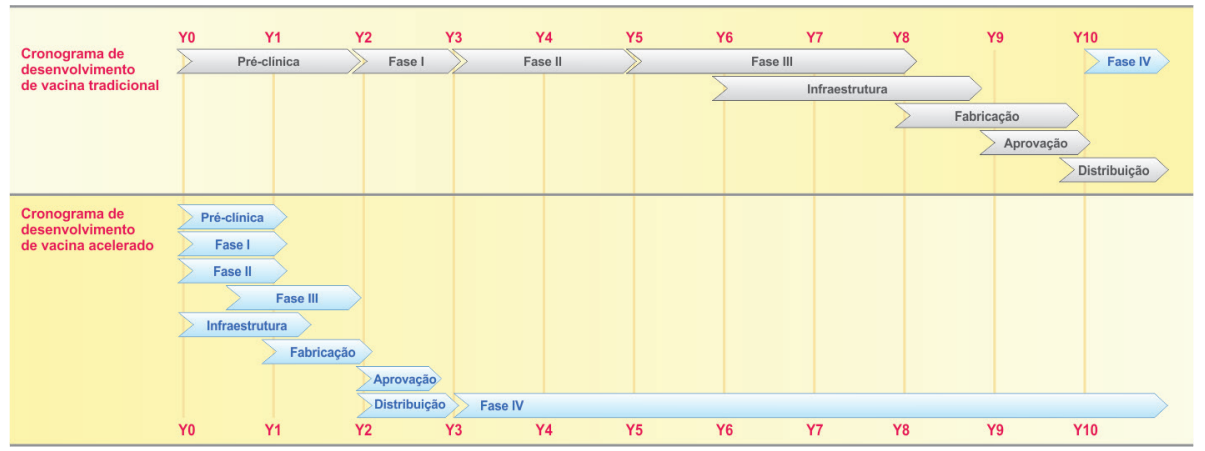

Fonte: Lurie et al., 2020.

Nessa abordagem, estudos de fase I e fase II geralmente são iniciados quase que em paralelo aos estudos pré-clínicos em primatas não humanos, e os estudos de fase II ocorrem, em regra, paralelamente aos estudos de fase III. Os estudos de fase IV, que ocorrem após o registro, podem ser iniciados sem que os resultados da fase III estejam concluídos conforme requisitos do target product profile (TPP) estabelecidos pelo órgão regulador, em um processo de contínua submissão regulatória para fins de registro (Lurie et al., 2020; WHO, 2020a).

No caso das vacinas registradas para uso emergencial ou das vacinas candidatas em estágio mais avançado e/ou próximas à fase do pré-registro, essa simultaneidade só foi possível em razão do conhecimento acumulado com as epidemias de síndrome respiratória do Médio Oriente (Mers) e síndrome respiratória aguda grave (Sars), da disponibilização de informações sobre a doença quase que em tempo real e do avanço tecnológico de algumas abordagens mais modernas, como as vacinas baseadas em ácido nucleico $e$ em adenovírus (Ball, 202 I). Os acordos de colaboração para o desenvolvimento e escalonamento da produção de vacinas também permitiram acelerar esse processo (Monrad, Sandbrink \& Cherian, 202I).

Tal estratégia tornou possível o desenvolvimento de vacinas em tempo recorde, com a primeira vacina, da Pfizer/BioNTech, tendo sido autorizada para uso emergencial menos de um ano após o início da pandemia, seguida pelas vacinas da Moderna e da Oxford/AstraZeneca. Do início da pandemia até meados de abril de 2021, quase 400 vacinas candidatas entraram em desenvolvimento, mas a maioria ainda se encontra em fase pré-clínica (Fiocruz, 202 Ia). 
Outro fator importante foi a excepcionalidade para autorização de uso emergencial pelas principais agências reguladoras internacionais e pela OMS. No Brasil, a Anvisa precisou revisitar as normas de submissão de registro, aprovando uma instrução normativa que institui o processo de submissão continuada em novembro de 2020 (Anvisa, 2020a) e a autorização temporária para uso emergencial, a RDC n. 444, em dezembro de 2020. A adesão do Brasil, por intermédio da Anvisa, ao Pharmaceutical Inspection Cooperation Scheme (PIC/S), também foi importante para agilizar o reconhecimento de inspeções em boas práticas de fabricação (BPF) realizadas por outras agências (Anvisa, 2020b).

\section{VIGILÂNCIA DE EVENTOS ADVERSOS PÓS-VACINAÇÃO (EAPVS) E EVENTOS ADVERSOS DE INTERESSE ESPECIAL (EAIES)}

Como qualquer medicamento, nenhuma vacina é isenta do risco de provocar eventos adversos. Mas esses riscos são muito menores do que os das complicações das doenças contra as quais elas conferem proteção; basta lembrarmos as altas taxas de mortalidade e sequelas permanentes por doenças hoje controladas por vacinas, como poliomielite, tétano, sarampo, entre outras.

A avaliação da segurança é feita durante todo o desenvolvimento de uma vacina. No caso da introdução das vacinas contra Covid-19, os dados de segurança dos ensaios clínicos disponíveis no momento da solicitação de autorização para uso emergencial eram insuficientes para a detecção de eventos adversos raros, para certas populações e para eventos adversos com tempo de latência maior do que o período dos ensaios clínicos. Um exemplo são os casos de trombose associada a trombocitopenia reportados na fase de pós-comercialização com as vacinas Oxford/AstraZeneca e Janssen. Foi o monitoramento pós-comercialização que tornou possível a rápida detecção, investigação e as atualizações necessárias em textos de bula e orientações para profissionais da saúde. Ademais, todo o sistema de farmacovigilância foi mobilizado para que os devidos alertas fossem publicizados. Esse tipo de ação, a informação com transparência de questões de segurança, é fundamental para garantir a confiança da população e dos profissionais da saúde na vacina e no programa de vacinação.

No Quadro I estão resumidos os dados de segurança publicados até o primeiro trimestre de 202 I para vacinas candidatas em fase mais avançada de desenvolvimento. Importante observar que nem todas têm dados disponíveis em publicações científicas para fases já concluídas ou em andamento. 
Quadro I - Características das principais vacinas contra Covid- 19 registradas, em uso emergencial ou em estágio de pré-registro

\begin{tabular}{|c|c|c|c|}
\hline Desenvolvedor & Plataforma & Especificações & Efeitos adversos \\
\hline Pfizer/BioNtech & $\begin{array}{l}\text { mRNA } \\
\text { (3a geração) }\end{array}$ & $\begin{array}{l}\text { Apresentação: solução } \\
\text { injetável; frasco-ampola } \\
\text { Indicação de uso: } \\
\geq 16 \text { anos } \\
\text { Esquema: } 2 \text { doses com } \\
\text { intervalo de } 21 \text { dias }\end{array}$ & $\begin{array}{l}\text { Dor no local, fadiga, dor de cabeça, dor } \\
\text { muscular, calafrios, dor nas articulações, } \\
\text { febre, inchaço no local da injeção, } \\
\text { vermelhidão no local da injeção, náuseas, } \\
\text { mal-estar e linfadenopatia } \\
\text { Reações alérgicas graves, incluindo anafilaxia } \\
\text { e outras reações de hipersensibilidade (por } \\
\text { exemplo, erupção cutânea, prurido, urticária, } \\
\text { angioedema), diarreia, vômito e dor nas } \\
\text { extremidades (braço) }\end{array}$ \\
\hline Oxford/AstraZeneca & $\begin{array}{l}\text { Vetor viral } \\
\text { (3ª geração) }\end{array}$ & $\begin{array}{l}\text { Apresentação: solução } \\
\text { injetável; frasco-ampola } \\
\text { Indicação de uso: } \geq \\
\text { 18 anos } \\
\text { Esquema: } 2 \text { doses com } \\
\text { intervalo de } 28 \text { dias }\end{array}$ & $\begin{array}{l}\text { Muito comuns: cefaleia, náusea, mialgia, } \\
\text { artralgia, sensibilidade no local de injeção, } \\
\text { dor no local de injeção, sensação de calor no } \\
\text { local de injeção, prurido no local de injeção, } \\
\text { equimose no local de injeção, fadiga, mal- } \\
\text { estar, pirexia, calafrios } \\
\text { Comuns: vômito, diarreia, inchaço no local } \\
\text { de injeção, eritema no local de injeção, } \\
\text { endurecimento no local de injeção, sintomas } \\
\text { semelhantes aos da influenza } \\
\text { Incomuns: linfadenopatia, redução do } \\
\text { apetite, tontura, sonolência, dor abdominal, } \\
\text { hiperidrose, prurido, erupção cutânea } \\
\text { Desconhecidos: anafilaxia, angioedema } \\
\text { Combinação muito rara e grave de trombose } \\
\text { e trombocitopenia (com frequência inferior a } \\
\text { I/I00.000), em alguns casos acompanhada } \\
\text { de hemorragia, foi observada, incluindo } \\
\text { trombose venosa em locais incomuns, como } \\
\text { trombose dos seios venosos cerebrais, } \\
\text { trombose da veia esplênica e trombose } \\
\text { arterial, concomitante com trombocitopenia }\end{array}$ \\
\hline
\end{tabular}




\section{Quadro I - Características das principais vacinas contra Covid- I 9 registradas, em uso emergencial ou em estágio de pré-registro (continuação)}

\begin{tabular}{|c|c|c|c|}
\hline Desenvolvedor & Plataforma & Especificações & Efeitos adversos \\
\hline Coronavac & $\begin{array}{l}\text { Vírus inativado } \\
\text { (2 } 2^{\mathrm{a}} \text { geração) }\end{array}$ & $\begin{array}{l}\text { Apresentação: solução } \\
\text { injetável; seringa } \\
\text { preenchida ou frasco- } \\
\text { ampola } \\
\text { Indicação de uso: } \\
\geq 18 \text { anos } \\
\text { Esquema: } 2 \text { doses com } \\
\text { intervalo de } 14 \text { dias }\end{array}$ & 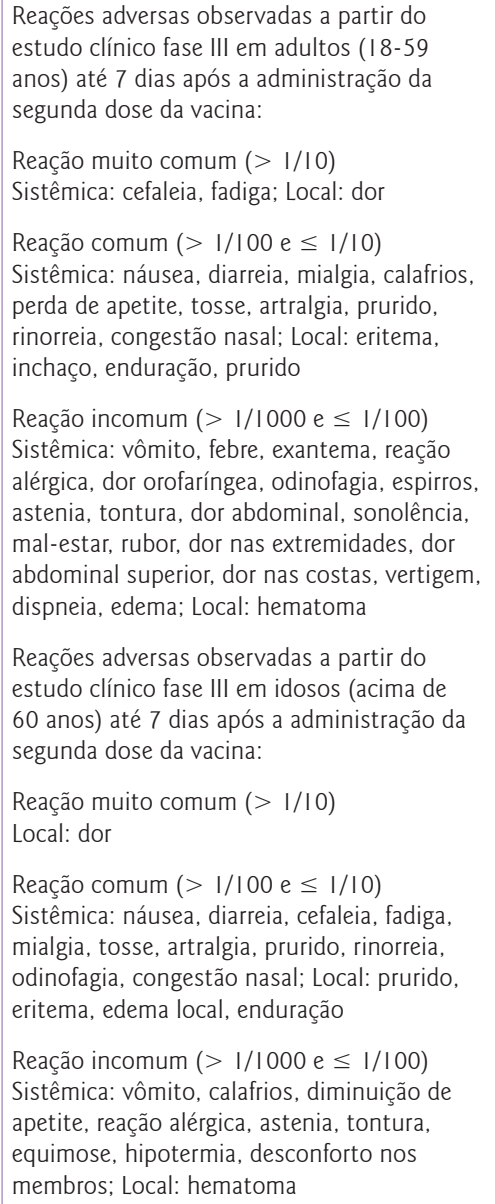 \\
\hline Gamaleya & $\begin{array}{l}\text { Vetor viral } \\
\left(3^{a} \text { geração) }\right.\end{array}$ & $\begin{array}{l}\text { Apresentação: solução } \\
\text { injetável; frasco-ampola } \\
\text { Indicação de uso: } \\
\geq 18 \text { anos } \\
\text { Esquema: } 2 \text { doses com } \\
\text { intervalo de } 7 \text { dias }\end{array}$ & $\begin{array}{l}\text { EA graves: não observados } \\
\text { EA locais comuns: dor no local da injeção } \\
\text { EA sistêmicos comuns: febre, cefaleia, astenia, } \\
\text { mialgia, artralgia, palpitação (subjetiva) }\end{array}$ \\
\hline
\end{tabular}


Quadro I - Características das principais vacinas contra Covid- 19 registradas, em uso emergencial ou em estágio de pré-registro (continuação)

\begin{tabular}{|l|l|l|l|}
\hline \multicolumn{1}{|c|}{ Desenvolvedor } & \multicolumn{1}{|c|}{ Plataforma } & \multicolumn{1}{|c|}{ Especificações } & \multicolumn{1}{|c|}{ Efeitos adversos } \\
\hline Moderna & $\begin{array}{l}\text { mRNA } \\
\left(3^{a} \text { geração) }\right.\end{array}$ & $\begin{array}{l}\text { Apresentação: } \\
\text { suspensão injetável } \\
\text { Indicação de uso: } \\
\geq 18 \text { anos } \\
\text { Esquema: } 2 \text { doses com } \\
\text { intervalo de 28 dias }\end{array}$ & $\begin{array}{l}\text { Dor no local da injeção, fadiga, dor de cabeça, } \\
\text { mialgia, artralgia, calafrios, náusea, vômito, } \\
\text { inchaço, sensibilidade axilar, febre, inchaço no } \\
\text { local da injeção e eritema no local da injeção } \\
\text { Foram notificadas reações alérgicas graves, } \\
\text { incluindo anafilaxia, após a administração da } \\
\text { vacina Moderna Covid- I9 durante a vacinação } \\
\text { em massa fora dos ensaios clínicos }\end{array}$ \\
& $\begin{array}{l}\text { Vetor viral (3a } \\
\text { geração) }\end{array}$ & $\begin{array}{l}\text { Apresentação: } \\
\text { suspensão para injeção } \\
\text { intramuscular } \\
\text { Indicação de uso: } \\
\geq 18 \text { anos } \\
\text { Esquema: dose única }\end{array}$ & $\begin{array}{l}\text { Dor no local da injeção, dor de cabeça, fadiga, } \\
\text { mialgia, náusea, febre, eritema no local da } \\
\text { injeção e inchaço no local da injeção } \\
\text { Em estudos clínicos, reações alérgicas graves, } \\
\text { incluindo anafilaxia, foram relatadas após a } \\
\text { administração da vacina Janssen Covid- } 19\end{array}$ \\
\hline
\end{tabular}

Fontes: elaboração própria com base em Fiocruz, 202 I a, 202 I b; FDA, 202 I a, 202 I b, 202 I c; Instituto Butantan, 202 I e Gamaleya, 202 I.

Mesmo ensaios clínicos robustos podem não detectar eventos adversos raros ou muito raros, em frequências menores que 1:1000. Por isso, é importante monitorar a segurança desses eventos, que podem ocorrer somente quando milhões de pessoas são vacinadas. Assim, o monitoramento de segurança durante a introdução dessas vacinas permitirá detecção precoce, investigação e análise de EAPVs e de eventos adversos de interesse especial (EAIEs) (Brasil, 2020). Assegurar coleta de dados e notificação de eventos adversos é essencial, pois minimiza impactos negativos na saúde dos indivíduos e nos programas de imunizações, mantendo a confiança dos profissionais da saúde e da população, e possibilitando resposta rápida às preocupações da sociedade (WHO, 2020b). Alguns conceitos básicos essenciais dos sistemas de vigilância de eventos adversos são detalhados no Quadro 2. 
Quadro 2 - Características dos sistemas de vigilância e notificação de eventos adversos

\begin{tabular}{|c|c|c|}
\hline Tipo de vigilância & Características & Sistema de notificação \\
\hline Vigilância passiva & $\begin{array}{l}\text { Os casos não são procurados ativamente; } \\
\text { os locais de vacinação ou unidades de } \\
\text { saúde notificam passivamente quando } \\
\text { encontram um EAPV }\end{array}$ & $\begin{array}{l}\text { No Brasil, a notificação ocorre, } \\
\text { atualmente, pelo sistema do Programa } \\
\text { Nacional de Imunizações e pelo sistema } \\
\text { da Anvisa. Em alguns países, incluindo o } \\
\text { Brasil, a vigilância passiva também inclui } \\
\text { notificações espontâneas pelos próprios } \\
\text { pacientes }\end{array}$ \\
\hline Vigilância ativa & $\begin{array}{l}\text { Envolve a visita de funcionários designados } \\
\text { a unidades de saúde, para falar com } \\
\text { profissionais da saúde e revisar os } \\
\text { registros médicos para identificar casos } \\
\text { suspeitos de EAIEs. Isso também pode ser } \\
\text { feito remotamente, em bancos de dados } \\
\text { eletrônicos de saúde }\end{array}$ & $\begin{array}{l}\text { Quando os casos são identificados, o } \\
\text { estado de vacinação é determinado }\end{array}$ \\
\hline $\begin{array}{l}\text { Vigilância passiva } \\
\text { estimulada }\end{array}$ & $\begin{array}{l}\text { Os prestadores de cuidados em saúde são } \\
\text { treinados para incentivar notificaçốes e } \\
\text { acompanhamento dos vacinados por meio } \\
\text { de canais definidos, como, por exemplo, } \\
\text { telefonema, e-mail, relatório de visita } \\
\text { domiciliar de EAPV }\end{array}$ & $\begin{array}{l}\text { A notificação passiva estimulada pode } \\
\text { ser útil para monitoramento próximo de } \\
\text { EAPVs graves e sinais de segurança após } \\
\text { a introdução das vacinas Covid- } 19 \text { e } \\
\text { campanha de vacinação em massa }\end{array}$ \\
\hline $\begin{array}{l}\text { Vigilância } \\
\text { sentinela }\end{array}$ & $\begin{array}{l}\text { Sistema usado quando, para determinada } \\
\text { doença, são necessários dados de alta } \\
\text { qualidade, que não podem ser obtidos por } \\
\text { meio de um sistema passivo }\end{array}$ & $\begin{array}{l}\text { Unidades de notificação selecionadas, } \\
\text { com alta probabilidade de atender } \\
\text { pacientes com a doença, boas instalações } \\
\text { laboratoriais e equipe experiente e bem } \\
\text { qualificada para identificar e relatar casos }\end{array}$ \\
\hline
\end{tabular}

Fonte: elaboração própria com base em Brasil, 2014.

EAPV - Evento adverso pós-vacinação

EAIE - Evento adverso de interesse especial

No caso da vacinação contra Covid-19, é fundamental lançar mão de todas as estratégias, detalhando cada registro. Com mais de um tipo de vacina em uso, é importante que os sistemas de vigilância sejam capazes de coletar informações sobre qual vacina foi administrada a cada pessoa, para permitir rastreabilidade do processo e a avaliação de possíveis EAPVs. O registro de todo o procedimento de vacinação (vacina, lote e fabricante) é fundamental também porque, até o momento, não existem estudos que embasem a intercambialidade entre diferentes vacinas para Covid-19. Logo, se o esquema é iniciado com determinada vacina, deve ser completado com a mesma. E, se isso não ocorrer, o caso deve ser registrado como erro de imunização e acompanhado. 
A comunicação é peça-chave em toda ação de saúde de caráter coletivo, a qual deve ser ágil e abordar quaisquer eventos e preocupações do público, a fim de manter a confiança nas vacinas em um cenário de grande atenção ao tema. Para se alcançar o máximo de cobertura vacinal e o controle da pandemia, será essencial desenvolver estratégia de comunicação efetiva e acessível sobre os benefícios, a segurança e a importância das vacinas contra Covid- 19.

No caso da Covid-19, conforme o desenvolvimento das vacinas candidatas avançava, a divulgação dos resultados dos ensaios clínicos acabou levando à familiarização da população com conceitos relacionados a esse processo. Diferentemente de outras emergências de saúde pública, o volume de dados e conhecimento sobre a pandemia que tem sido gerado e logo disseminado quase em tempo real resulta muitas vezes em excesso de informações, nem sempre de boa qualidade e confiáveis, o que se denominou como infodemia (Opas, 2020). Se por um lado o conhecimento gerado sobre esses temas tem se tornado público e acessível, contribuindo de maneira significativa para o desenvolvimento de produtos e estratégias de combate à epidemia, por outro se observa que a proliferação de notícias falsas e desinformação coloca em risco o seu enfrentamento, principalmente em razão do impacto das redes sociais no comportamento das pessoas (Cinelli et al., 2020). A circulação de notícias falsas contribui para descrédito na ciência e em ações de promoção da saúde sobre bases científicas (SBIM, 2019). Portanto, é de suma importância considerar esse fator em ações de comunicação, e que estas sejam reforçadas também por outros veículos e reiteradas para conscientização geral.

Outro fator importante são grupos hesitantes em relação à vacinação, fenômeno observado já há algum tempo (WHO, 2014$)$. Esses grupos disseminam informações sem comprovação científica, gerando mais insegurança e incertezas na população (Carrion-Alvarez E Tijerina-Salinas, 2020). No caso da Covid- 9 não tem sido diferente. Embora o Brasil tenha ficado em segundo lugar, somente atrás da China, em um estudo internacional sobre aceitação das vacinas consideradas seguras e eficazes contra Covid- 9 (Lazarus et al., 2020), pesquisa recente aponta que essa disposição talvez esteja caindo (Data Folha, 2020). Portanto, é imperativo fazer eco a informações sobre eficácia e segurança das vacinas baseadas na ciência, rompendo crenças negativas e gerando consenso popular positivo sobre esse imunizante. Isso é fundamental para manter a tranquilidade no processo, garantir maior adesão à vacinação e, assim, permitir que se alcancem resultados e metas almejadas, não colocando em risco as conquistas já obtidas no controle e eliminação de doenças. 
Nesse contexto, profissionais da saúde e governo têm o papel relevante de inspirar confiança e disseminar informações corretamente. Pessoas que os têm como referência mostram-se mais seguras, ainda que tenham contato com notícias falsas em seus círculos sociais. Os ACS que atuam como mediadores entre comunidade e serviços de saúde, por exemplo, têm importante papel na disseminação de informações fidedignas em linguagem acessível e de forma oportuna (Garnelo et al., 2019).

\section{CONCLUSÕES}

Historicamente, as dimensões do Brasil atraem interesses diversos no mercado internacional. O tamanho da população, o volume de vendas e a universalidade do acesso à saúde em um país de dimensões continentais são características que exercem forte atração sobre as empresas produtoras que fazem parte do parque produtor internacional e nacional na área da saúde. Além disso, o Brasil tem sido um dos países pioneiros na introdução, de forma ágil, de novos imunizantes no Calendário Nacional de Vacinação, assegurando acesso e melhorando a saúde da população.

Tratamos, neste capítulo, de algumas particularidades e necessidades do Brasil a serem consideradas no processo de imunização de sua população: extensão territorial do país, com suas especificidades geográfica, cultural, demográfica, social e ambiental; a busca da equidade no acesso; a importância do alinhamento entre as entidades federativas; utilização de diferentes vacinas e intervalos; ausência de informação sobre intercambialidade; população flutuante abrangendo indígenas e habitantes de áreas fronteiriças; troca de gestores e trabalhadores da saúde em decorrência de eleições municipais; infraestrutura de rede de frio suficiente e adequada para suportar o acondicionamento das vacinas de rotina; sistema de vigilância de eventos adversos que garanta notificação e investigação; registro das doses aplicadas com diferentes instrumentos e capacitação dos profissionais. Para cada um deles serão necessárias abordagens diferenciadas e multidisciplinares.

Garantir a disponibilidade e acesso equitativo às vacinas e insumos, sustentabilidade e condições de operacionalização, assegurando a qualidade da vacinação, isto é fundamental. Para tanto, os três níveis de gestão do SuS precisam conjuntamente ampliar e capacitar as equipes, com microplanejamentos voltados para as suas realidades, promovendo o diálogo entre todas as partes interessadas. Um plano de comunicação eficaz que permita o acesso à informação de boa qualidade e de forma clara torna-se peça-chave para o alcance de cobertura vacinal homogênea, com estratégias para engajamento da população. A realidade nacional requer um plano dinâmico e flexível ao longo do processo. 
A experiência exitosa do PNI, desde a sua criação, reitera a importância da ação articulada entre as diferentes esferas de governo, os conselhos nacionais, os laboratórios produtores, as equipes de vigilância epidemiológica, as sociedades médicas de especialidades, as universidades, os institutos de pesquisa e a sociedade civil organizada, para que a campanha de vacinação contra Covid- I 9 seja efetiva. O planejamento de ações para todas essas dimensões e seu monitoramento são essenciais. Segurança, boa informação, credibilidade e adesão à vacinação ao longo da campanha beneficiarão a todos e darão nova dimensão aos esforços para o enfrentamento da Covid- 19.

Finalmente, queremos destacar o papel fundamental que os anônimos vacinadores tiveram para o êxito do Programa Nacional de Imunizações em toda a sua trajetória.

\section{REFERÊNCIAS}

AGÊNCIA NACIONAL DE VIGILÂNCIA SANITÁRIA (ANVISA). Resolução de Diretoria Colegiada RDC n. 444, de 10 dez. 2020. Estabelece a autorização temporária de uso emergencial, em caráter experimental, de vacinas Covid- 19 para o enfrentamento da emergência de saúde pública de importância nacional decorrente do surto do novo coronavírus (Sars-CoV-2). Diário Oficial da União, Brasília, 2020a. Disponível em: <http://antigo.anvisa.gov.br/documents/I0181/6I34216/RDC_444_2020_. pdf/f23f3e74-e0da-4672-ac53-d24ffeb24a85>. Acesso em: 25 abr. 2021.

AGÊNCIA NACIONAL DE VIGILÂNCIA SANITÁRIA (ANVISA). Aprovada submissão contínua de dados para registro de vacina. Brasília: Anvisa, 2020b. Disponível em: <www.gov.br/anvisa/pt-br/ assuntos/noticias-anvisa/2020/anvisa-e-aprovada-para-cooperacao-em-inspecao-farmaceutica2013 -pic-s >. Acesso em: 8 dez. 2021.

BALL, P. What the lightning-fast quest for Covid vaccines means for other diseases. Nature, 589: I6- I8, 202I. Disponível em: <https://pubmed.ncbi.nlm.nih.gov/333400 I8/>. Acesso em: 25 abr. 202 I.

BRASIL. Ministério da Saúde. Secretaria de Vigilância em Saúde. Programa Nacional de Imunizações (PNI): 30 anos. Brasília: Ministério da Saúde, 2003. Disponível em: < https://bvsms.saude.gov.br/bvs/ publicacoes/livro_30_anos_pni.pdf> Acesso em: 10 jan. 2021.

BRASIL. Ministério da Saúde. Secretaria de Vigilância em Saúde. Departamento de Vigilância das Doenças Transmissíveis. Programa Nacional de Imunizações (PNI): 40 anos. Brasília, 2013a. Disponível em: $<$ https://bvsms.saude.gov.br/bvs/publicacoes/programa_nacional_imunizacoes_pni40.pdf $>$. Acesso: 10 jan. 2021.

BRASIL. Ministério da Saúde. Secretaria de Vigilância em Saúde. Departamento de Vigilância das Doenças Transmissíveis. Manual de Rede de Frio do Programa Nacional de Imunizações. 4. ed. Brasília: Ministério da Saúde, 20I3b. Disponível em:<http://bvsms.saude.gov.br/bvs/publicacoes/manual_rede_frio4ed. pdf> Acesso: 10 jan. 2021.

BRASIL. Ministério da Saúde. Secretaria de Vigilância em Saúde. Departamento de Vigilância das Doenças Transmissíveis. Manual de Vigilância Epidemiológica de Eventos Adversos Pós-Vacinação. Brasília: Ministério da Saúde, 2014. Disponível em: <https://bvsms.saude.gov.br/bvs/publicacoes/manual_ vigilancia_epidemiologica_eventos_adversos_pos_vacinacao.pdf>. Acesso em: 25 abr. $202 \mathrm{I}$. 
BRASIL. Ministério da Saúde. Secretaria de Vigilância em Saúde. Estratégia de Vacinação contra o Vírus Sars-Cov-2 Covid-19. Brasília: Ministério da Saúde, 2020. Disponível em: <www.gov.br/saude/pt-br/ media/pdf/2020/dezembro/2 I/estrategia_vacinacao_covid I 9.pdf>. Acesso: I 8 jan. 202 I .

BRASIL. População brasileira chega a 213,3 milhões de habitantes, estima IBGE. Notícias. Governo do Brasil, 202 la. Disponível em <https://www.gov.br/pt-br/noticias/financas-impostos-e-gestaopublica/202 I/08/populacao-brasileira-chega-a-2 I3-3-milhoes-de-habitantes-estima-ibge >. Acesso em: 8 dez. 2021.

BRASIL. Ministério da Saúde. Secretaria Especial de Saúde Indígena. Relatório das ações realizadas pela Sesai para enfrentamento da pandemia da Covid-19. Brasília, 202 Ib. Disponível em: <https:// saudeindigena I.websiteseguro.com/coronavirus/pdf/Relatorio\%20Resumido_SESAI_Coronavirus. pdf>. Acesso em: 29 abr. 2021 .

BRASIL. Ministério da Saúde. Secretaria de Vigilância em Saúde. Departamento de Vigilância das Doenças Transmissíveis. PNI. Plano Nacional de Operacionalização da Vacinação Contra a Covid- 19: $5^{a}$ versão. Brasília, 202 I c. Disponível em: <www.conasems.org.br/wp-content/uploads/202 I/04/5aEdic\%CC\%A7a\%CC\%830-Plano-Vacinac\%CC\%A7a\%CC\%830-contra-Covid_V5_2I mar-2I.pdf $>$. Acesso em: 8 dez. 2021 .

CARRION-ALVAREZ, D. E TIJERINA-SALINAS, P. X. Fake news in Covid- 19: a perspective. Health Promotion Perspectives, 10(4), 2020. Disponível em: <www.ncbi.nlm.nih.gov/pmc/articles/PMC7722992/>. Acesso em: 25 abr. 2021.

CINELLI, M. et al. The Covid-I 9 social media infodemic. Scientifics Reports, 10, 2020. Disponível em: $<$ https://pubmed.ncbi.nlm.nih.gov/33024I52/>. Acesso em: 10 jan. 2021.

DATA FOLHA, Instituto de Pesquisa. Pesquisa Nacional Covid-19. Data Folha. Folha de S.Paulo, São Paulo, dez. 2020. Disponível em:<http://media.folha.uol.com.br/datafolha/2020/I2/14/ ad8a599a43kj9u94hu9hv9u94j99no278vc.pdf>. Acesso em: 10 de jan. 2021 .

DOMINGUES, C. M. A. S. et al. Programa nacional de imunização: a política de introdução de novas vacinas. Revista Eletrônica Gestão \& Saúde, 6(4): 3.250, 20I5. Disponível em: <www.researchgate. net/publication/3 17402779 _Programa_nacional_de_imunizacao_a_politica_de_introducao_de_ novas_vacinas $>$. Acesso em: 10 jan. 2021.

FOOD AND DRUG ADMINISTRATION (FDA). Emergency use authorization (EUA) of the Pfizer-Biontech Covid- I 9 vaccine to prevent coronavirus disease 2019 (Covid- 19), 202 Ia. Disponível em: <www.fda. gov/media/l 444 I3/download >. Acesso em: 25 abr. 202 I.

FOOD AND DRUG ADMINISTRATION (FDA). Emergency use authorization (EUA) of the Moderna Covid- I 9 vaccine to prevent coronavirus disease 2019 (Covid- 19), 202 Ib. Disponível em: <www.fda. gov/media/l 44637/download>. Acesso em: 25 abr. 2021 .

FOOD AND DRUG ADMINISTRATION (FDA). Emergency use authorization (EUA) of the Janssen Covid- I 9 vaccine to prevent coronavirus disease 2019 (Covid- I9), 202 Ic. Disponível em: <www.fda. gov/emergency-preparedness-and-response/coronavirus-disease-20 I 9-covid-19/janssen-covid19-vaccine >. Acesso em: 30 abr. 2021.

FUNDAÇÃO OSWALDO CRUZ (FIOCRUZ). Instituto de Tecnologia em Imunobiológicos, BioManguinhos. Grupo de Trabalho de Prospecção Vacinas Covid- 19. Cenário de vacinas para Covid-19, I 4 de abr. 202 Ia. 
FUNDAÇÃO OSWALDO CRUZ (FIOCRUZ). Instituto de Tecnologia em Imunobiológicos, BioManguinhos. Vacina Covid-I 9 (recombinante). Rio de Janeiro, 202 lb. Disponível em: <www.bio. fiocruz.br/index.php/br/produtos/vacinas/covid- I 9-recombinante>. Acesso em: 29 abr. 202 I .

GAMALEYA. Vacina S-Sputnik V. 202 I. Disponível em: <www.gamaleya.org>. Acesso em: 25 abr. 2021.

GARNELO, L. et al. Atenção Diferenciada: a formação técnica de agentes indígenas de saúde do Alto Rio Negro. Rio de Janeiro: Editora Fiocruz, 2019 (Fazer Saúde). Disponível em: < https://books.scielo.org/ $\mathrm{id} / \mathrm{m} 32 \mathrm{qk}>$ Acesso em: 8 dez. $202 \mathrm{l}$.

INSTITUTO BRASILEIRO DE GEOGRAFIA E ESTATÍ́STICA (IBGE). Projeções e estimativas da população do Brasil e das unidades da federação, 202I. Disponível em: <www.ibge.gov.br/apps/populacao/ projecao/index.html> Acesso em: 7 dez. 2021.

INSTITUTO BUTANTAN. Vacina adsorvida Covid-19 (inativada). São Paulo, 2021. Disponível em: $<$ https://vacinacovid.butantan.gov.br/assets/arquivos/Bulas_Anvisa/2021.04.23\%20-\%20 Bula\%20profissional\%20da\%20sa\%C3\%BAde.pdf>. Acesso em: 25 abr. 2021.

LAZARUS, J. V. et al. A global survey of potential acceptance of a Covid- I 9 vaccine. Nature Medicine, 27: 225-228, 2021. Disponível em: <www.nature.com/articles/s4I591-020-1I24-9>. Acesso: 18 jan. 2021 .

LURIE, N. et al. Developing Covid-I 9 vaccines at pandemic speed. New England Journal of Medicine, 382: I.969-1.973, 2020. Disponível em: <https://pubmed.ncbi.nlm.nih.gov/32227757/>. Acesso em: 18 jan. 2021.

MONRAD, J. T.; SANDBRINK, J. B. \& CHERIAN, N. G. Promoting versatile vaccine development for emerging pandemics. npj Vaccines, 6, 202 I. Disponível em: <www.nature.com/articles/s4 I 54I-02 I00290-y>. Acesso em: 25 abr. 2021.

ORGANIZAÇÃO PAN-AMERICANA DA SAÚdE (OPAS). Organização Mundial da Saúde (OMS). Entenda a infodemia e a desinformação na luta contra a Covid-19. Brasília, 2020. Disponível em: $<$ https://iris.paho.org/handle/I 0665.2/52054?locale-attribute=pt>. Acesso em: I 8 jan. 202 I.

SOCIEDADE BRASILEIRA DE IMUNIZAÇÕES (SBIM). Sete a cada dez brasileiros acreditam em informações falsas sobre vacinação. São Paulo, 2019. Disponível em: < https://sbim.org.br/noticias/l I39-sete-acada-dez-brasileiros-acreditam-em-informacoes-falsas-sobre-vacinacao>. Acesso: 10 jan. 2021.

WORLD HEALTH ORGANIZATION (WHO). Report of the Sage Working Group on Vaccine Hesitancy. Geneva: WHO, 2014. Disponível em: <www.who.int/immunization/sage/meetings/20 I 4/october/ I _ Report_WORKING_GROUP_vaccine_hesitancy_final.pdf>. Acesso: 10 jan. 2021.

WORLD HEALTH ORGANIZATION (WHO). A Coordinated Global Research Roadmap: 2019 novel coronavirus. Geneva: WHO, 2020a. Disponível em: <www.who.int/publications/m/item/acoordinated-global-research-roadmap >. Acesso em: 25 abr. 2021.

WORLD HEALTH ORGANIZATION (WHO). Covid- 19 Vaccines: safety surveillance manual. Module: Establishing surveillance systems in countries using Covid- 19 vaccines (Public Consultation). Geneva: WHO, 2020b. Disponível em: <www.who.int/vaccine_safety/committee/Module_Establishing _ surveillance_systems.pdf?ua $=\mathrm{I}>$. Acesso em: 10 jan. 2021 . 
PARTE III

\section{OS PROFISSIONAIS DA SAÚDE E A PANDEMIA DE COVID-19}





\section{Perfil e Condições de Trabalho dos Profissionais da Saúde em Tempos de Covid-19}

a realidade brasileira

Maria Helena Machado, Mônica Wermelinger, Antônio Vieira Machado, Filipe Leonel Vargas, Everson Justino Pereira e Wilson Aguiar Filho

7 Organização Mundial da Saúde (OMS) divulgou, em janeiro de 2020, informações sobre uma série de casos de pneumonia ocorrida em dezembro de 2019 na província de Wuhan, Hubei, na China, e tornou pública a sequência genética do novo coronavírus, denominado Coronavirus disease-2019 (2019-nCoV), obtida de material coletado de amostras do trato respiratório inferior (WHO, 2020a; Huang et al., 2020; Wang et al., 2020). Pouco tempo depois, em 30 de janeiro de 2020, dada a propagação do vírus a OMS declarou que "o surto da doença causada pelo novo coronavírus (Covid-19) constitui uma Emergência de Saúde Pública de Importância Internacional - o mais alto nível de alerta da Organização, conforme previsto no Regulamento Sanitário Internacional” (WHO, 2020a). Em I I de março de 2020, o diretor-geral da OMS declarou a situação como pandemia (WHO, 2020b).

Ainda no final de fevereiro, o Ministério da Saúde brasileiro passa a monitorar os primeiros quatro casos suspeitos de infecção pelo novo coronavírus, três em São Paulo e um no Rio de Janeiro, e confirma o primeiro caso da doença no país: homem de $6 \mathrm{I}$ anos de idade, recém-chegado da Itália (Brasil, 2020).

Segundo estimativas do Instituto Brasileiro de Geografia e Estatística (IBGE, 20 I 7), a população brasileira em 2020 é de mais de 21 I,7 milhões de habitantes. Para atender a uma população tão numerosa e diversa, espalhada de forma desigual em um território com dimensões continentais, o Brasil possui um complexo e sólido Sistema Único de Saúde (SUS), com 329.854 estabelecimentos de saúde, ambulatoriais e/ou hospitalares, além de contar com 447.510 leitos, dos quais 34.318 dedicados à unidade de terapia intensiva (UTI) para o atendimento de pacientes em estado crítico (Brasil, 202 la). 
O SUS emprega, diretamente, mais de 3,5 milhões de profissionais da saúde, médicos de diversas especialidades, enfermeiros, farmacêuticos, fisioterapeutas, odontólogos, nutricionistas e psicólogos, bem como técnicos e auxiliares de enfermagem, de laboratório, de radiologia etc., compondo uma força de trabalho (FT) tão numerosa quanto diversa, capaz de intervir de várias formas para a manutenção ou recuperação da saúde dos cidadãos. Além disso, essa estrutura - o SUS e sua FT - está presente e atua em todos os 5.570 municípios das cinco regiões do país. É com ela que o Brasil tem enfrentado a pandemia da Covid-19, com uma equipe multiprofissional de primeira linha (Machado, Carvalho \& Campos, 2020).

Entretanto, a pandemia no Brasil tem evoluído em um cenário de grande gravidade e preocupação. Dados atualizados das secretarias estaduais de Saúde e compilados pelo Ministério da Saúde (Brasil, 202 l b) mostram que em março em 2020 o Brasil registrava 5.717 casos acumulados e 20 I óbitos; em julho já contabilizava 2.662 .485 casos acumulados e 92.475 óbitos; em agosto havia 3.908.272 casos acumulados e 121.38 I óbitos e em dezembro o número de casos passou para 7.675.973 e o de óbitos para 194.949. Já nos cinco primeiros meses de 202 I , o país havia acumulado o inacreditável número de 15.732.836 casos e 439.050 óbitos (Quadro I).

Quadro I - Dados gerais da pandemia - Brasil, mar. 2020 a maio 2021 *

\begin{tabular}{|l|c|}
\hline \multicolumn{2}{|c|}{ Casos confirmados } \\
\hline 3 I de março de 2020 & 5.717 \\
\hline 3 I de julho de 2020 & 2.662 .485 \\
\hline 31 de agosto de 2020 & 3.908 .272 \\
\hline 3 I de dezembro de 2020 & 7.675 .973 \\
\hline 31 de janeiro de 202 I & 9.204 .73 I \\
\hline 28 de fevereiro de 202 I & 10.551 .259 \\
\hline 31 de março de 202 I & 12.748 .747 \\
\hline 30 de abril de 202 I & 14.659 .01 I \\
\hline I8 de maio de 202 I & 15.732 .836 \\
\hline
\end{tabular}


Quadro I - Dados gerais da pandemia - Brasil, mar. 2020 a maio 202I * (continuação)

\begin{tabular}{|l|c|}
\hline \multicolumn{2}{|c|}{ Óbitos acumulados } \\
\hline 3 I de março de 2020 & 20 I \\
\hline 3 I de julho de 2020 & 92.475 \\
\hline 3 I de agosto de 2020 & I21.38 I \\
\hline 3 I de dezembro de 2020 & 194.949 \\
\hline 3 I de janeiro de 202 I & 224.504 \\
\hline 28 de fevereiro de 202 I & 254.942 \\
\hline 3 I de março de 202 I & 321.515 \\
\hline 30 de abril de 202 I & 403.78 I \\
\hline I 8 de maio de 202 I & 439.050 \\
\hline
\end{tabular}

Fonte: elaborado a partir dos dados compilados pelo Ministério da Saúde (Brasil, 202 I b).

* Dados atualizados em 18 de maio de 2021 .

Será discutida aqui a situação dos profissionais da saúde em tempos de Covid- 19 à luz da realidade brasileira, com base nos primeiros dados da Pesquisa Condições de Trabalho dos Profissionais de Saúde no Contexto da Covid- 19 no Brasil, realizada na Fundação Oswaldo Cruz (Fiocruz) (Machado, 202I).

\section{FORÇA DE TRABALHO EM SAÚDE NO PERÍODO PRÉ-PANDEMIA}

Dados atualizados dos conselhos profissionais sobre a força de trabalho em saúde (FTS) atestam que o Brasil conta com 611.133 enfermeiros (Cofen, 2021); 561.432 médicos (CFM, 202 I); 336.358 cirurgiões-dentistas (CFO, 202 I); 234.30 I farmacêuticos (CFF, 202 I); 206.170 fisioterapeutas (Coffito, 202 I; Matsumura et al., 20 I8); 393.497 psicólogos (CFP, 202I); 161.952 nutricionistas (CFN, 2020) e aproximadamente 200 mil assistentes sociais (CFESS, 202I) (Quadro 2). A esse contingente somam-se mais de 2 milhões de trabalhadores de nível técnico, auxiliar e de apoio: 1.867 .433 auxiliares e técnicos de enfermagem; 179.754 de saúde bucal; 29.000 de laboratório; 20.467 de nutrição; 84.686 de radiologia, além de milhares que apoiam e dão suporte, compondo essa enorme FTS diretamente inserida na assistência. Além desses trabalhadores, há, na saúde, outro contingente que atua cotidianamente nos diversos setores de apoio, tais como pessoal administrativo e pessoal de segurança, recepção, nutrição e alimentação, limpeza e manutenção de equipamentos, entre outros. 
Quadro 2 - Dados gerais do SUS - Brasil, 202I*

\begin{tabular}{|l|r|}
\hline \multicolumn{2}{|c|}{ Dados de saúde } \\
\hline Estabelecimentos de saúde & 329.854 \\
\hline Leitos & 447.510 \\
\hline Leitos de UTI & 34.318 \\
\hline \multicolumn{1}{|c|}{ Profissionais da saúde de nível superior } \\
\hline Enfermeiros & 611.133 \\
\hline Médicos & 561.432 \\
\hline Cirurgiões-dentistas & 336.358 \\
\hline Farmacêuticos & 234.301 \\
\hline Fisioterapeutas & 206.170 \\
\hline Psicólogos & 393.497 \\
\hline Nutricionistas & 161.952 \\
\hline Assistentes sociais & 200.000 \\
\hline & 84.686 \\
\hline Puxiliares e técnicos de enfermagem & 1.867 .433 \\
\hline Auxiliares e técnicos em saúde bucal & 179.754 \\
\hline Técnicos de laboratório & 29.000 \\
\hline Técnicos de nutrição & 20.467 \\
\hline Técnicos de radiologia & 8 da saúde de níveis médio e técnico \\
\hline
\end{tabular}

Fontes: elaborado com base no Cadastro Nacional de Estabelecimentos de Saúde (Brasil, 202 la) e em dados do Conselho Federal de Enfermagem (Cofen, 202I), Conselho Federal de Medicina (CFM, 202I), Conselho Federal de Odontologia (CFO, 202I), Conselho Federal de Farmácia (CFF, 202I), Conselho Federal de Fisioterapia e Terapia Ocupacional (Coffito, 20 I 8), Conselho Federal de Psicologia (CFP, 202 I), Conselho Federal de Nutricionistas (CFN, 2020) e Conselho Federal de Serviço Social (CFESS, 202 I).

* Dados atualizados em 30 de abril de 2021.

Um estudo feito com a equipe de enfermagem no Brasil, realizado pela Fiocruz e o Conselho Federal de Enfermagem (Cofen) (Machado, 2017), mostra que

Nestas últimas duas décadas, os profissionais de Enfermagem no Brasil têm experimentado mudanças importantes no mundo do trabalho. O mercado de trabalho tem se mostrado com sinais claros de assalariamento com vinculação do salário a diversas 
formas: por plantão, por hora trabalhada, contratos curtos e temporários, gerando precarização e com total ausência de vinculação institucional. Esses aspectos do MTS tornam cada vez mais frequentes o multiemprego e a insegurança no ambiente de trabalho. A discussão sobre trabalho decente tem se tornado um tema recorrente entre as entidades sindicais que representam os trabalhadores. (Machado et al., 2020: I I0)

No entanto, como afirmam Machado e Ximenes Neto (2018: 1.977),

Se por um lado podemos nos orgulhar do gigantismo do SUS em termos de capacidade instalada - número de estabelecimentos de saúde (ambulatoriais e hospitalares), leitos e empregos de saúde, com mais de 3,5 milhões de trabalhadores atuando em equipes multiprofissionais, qualificadas e especializadas, por outro, é fato também que esse setor se mantém crescendo e gerando novos postos de trabalho. Contudo, há problemas estruturais que ainda persistem, especialmente na gestão do trabalho, tais como: desequilíbrio entre oferta e demanda, escassez de profissionais no interior do país, precarização do trabalho, terceirização dos serviços de saúde e, consequentemente, da mão de obra especializada (médicos, enfermeiros, técnicos em geral, dentre outros). O trabalho precário é uma situação que atinge significativo contingente da saúde

Algumas características marcam o contexto em que essa FTS se encontrava no período pré-pandemia, ou seja, em que condições de trabalho, saúde e vida esses profissionais se encontravam quando assumiram a linha de frente no combate à pandemia.

No que se refere à FTS, o primeiro aspecto interessante a mencionar é o fato de que $70 \%$ são do sexo feminino. O segundo é a baixa remuneração, que, insuficiente para o seu sustento, gera a necessidade de multiemprego. O terceiro aspecto é a crescente adoção do prolongamento das jornadas de trabalho para compensar os baixos salários. O quarto é a prática, pela gestão, de pagamentos avulsos aos profissionais pelo trabalho prestado, o que não gera vínculo formal. O quinto aspecto são condições de trabalho precárias, com vínculo precário, gerando instabilidade, cansaço, esgotamento e desgaste profissional, o sexto é o aumento no número de acidentes de trabalho, o sétimo é o significativo percentual de licenças médicas e o oitavo são as queixas constantes de cansaço, estresse, desgaste profissional e muitos casos de suicídio ou de tentativas, todos sinais de adoecimento físico e psíquico dessa FTS. O nono é o fato de que em algumas áreas do conhecimento a adoção do ensino a distância tem formado on-line legiões de profissionais por vezes incapazes de lidar com as situações que se apresentam no ambiente real do sistema de saúde.

A Organização Internacional do Trabalho (OIT) contrapõe trabalho precário a trabalho decente, apontando as dimensões inter-relacionadas de precariedade: 
- Insegurança do mercado de trabalho, significando a falta de emprego;

- Insegurança do trabalho temporário e sem proteção em caso de demissão;

- Insegurança do emprego, o que significa falta de clareza e de definição sobre as atividades a serem desempenhadas no processo de trabalho;

- Insegurança quanto à integridade física e de saúde pelas más condições de trabalho;

- Insegurança de renda em razão dos salários baixos e da falta de expectativa de melhoria;

- Insegurança de representação sindical, com participação acanhada ou até mesmo a ausência do movimento sindical no cotidiano do mundo do trabalho;

- Insegurança gerada pela falta de educação básica, ou seja, pelas poucas oportunidades de formação profissional adequada (Machado $\varepsilon$ Ximenes Neto, 2018).

É possível afirmar que trabalho precário é aquele em que o trabalhador é mal pago, inseguro, desprotegido e com renda insuficiente para sustentar a si próprio e a um domicílio. Estamos nos afastando da premissa da OIT sobre trabalho decente e caminhando, perigosamente e a passos largos, para a trágica situação de trabalho precário. Segundo Pochmann (2020: 98),

No sentido geral de avanços nos trabalhos por conta própria e emprego assalariado informal, despossuído do acesso aos direitos sociais e trabalhistas, percebe-se também a expansão recente das taxas de desemprego e de subutilização da mão de obra disponível no mercado de trabalho brasileiro. Tanto a ausência de dinamismo econômico como a desregulação do mercado de trabalho têm sido responsáveis pelo registro das maiores parcelas da força de trabalho distante do acesso ao sistema público de proteção social e trabalhista.

Dau (2009), por sua vez, observa que a partir da década de 1990 a terceirização se tornou elemento central das estratégias empresariais e passou a abranger todos os setores produtivos, deixando de ser uma prática complementar voltada para atividades de apoio, como segurança e conservação.

\section{OS TRABALHADORES DA SAÚDE E A PANDEMIA}

Dos mais de 3,5 milhões de trabalhadores da saúde no SUS, estima-se que na linha de frente estão mais de 2 milhões prestando assistência a milhões de contaminados e vivenciando milhares de óbitos em todo o país, num ritmo insustentável. 
Se não bastasse a crise sanitária do país, o que se viu nas matérias jornalísticas ao longo da pandemia foram os trabalhadores da saúde tendo que lidar com, além da grande demanda por atendimento, a falta de equipamentos de proteção individual (EPIs), de infraestrutura e de condições de trabalho adequadas, vínculos de trabalho precários etc. Os trabalhadores da saúde da linha de frente estão submetidos, por vezes, a um trabaIho extenuante, ou seja, atividades intensas, sob tensão, que põem em risco a saúde e a vida do trabalhador, o que nem sempre está associado a longas jornadas de trabalho.'

Com a adoção de mais novos contratos de trabalho temporários, essa FTS, em boa parte precarizada, virá a constituir legiões de trabalhadores adoecidos, como fruto de sequelas da pandemia associadas a comorbidades preexistentes, desempregados e por vezes inaptos para o trabalho. O cenário que se avizinha é de uma FTS cansada, estressada e com sinais de esgotamento e desgaste profissional.

\section{CONDIÇÕES DE TRABALHO NO CONTEXTO DA COVID-19}

Para correlacionar a situação dos profissionais da saúde no período pré-pandemia com a do momento atual, buscou-se conhecer a realidade desses profissionais na conjuntura da pandemia por meio da Pesquisa Condições de Trabalho dos Profissionais de Saúde no Contexto da Covid- 19 no Brasil. Trata-se de pesquisa on-line, realizada em todo o país. Os resultados ora apresentados retratam a realidade de mais de 15 profissões da saúde das 27 unidades da federação em mais de 2.200 municípios brasileiros. Alguns dados sobre essa FTS durante a pandemia:

- A maioria (77\%) da FTS é constituída de profissionais do sexo feminino;

- 60\% trabalham em hospitais públicos de referência para Covid-1 9 e nas unidades de atenção primária;

- A maioria absoluta tem jornadas de até 60 horas semanais e sente-se sobrecarregada;

- Menos da metade (43\%) experimenta sentimento de proteção contra a Covid- 19 no seu ambiente de trabalho; alega-se falta, escassez e/ou inadequação dos EPIs, medo generalizado de se contaminar no trabalho em razão do contato com pacientes e com colegas com suspeita de Covid-19, estruturas e infraestruturas inadequadas (Machado, 202I).

\footnotetext{
' Ver as pesquisas: Condições de Trabalho dos Profissionais de Saúde no Contexto da Covid- I 9 no Brasil e Trabalhadores Invisíveis da Saúde: condições de trabalho e saúde mental no contexto da Covid- 19 no Brasil, que estão sendo realizadas na Fiocruz sob a coordenação de Maria Helena Machado com o propósito de desvendar a situação desses trabalhadores da saúde e os efeitos do trabalho na linha de frente em sua vida pessoal, física e psíquica.
} 
A pesquisa expõe também queixas recorrentes, por parte dos profissionais, relacionadas ao suposto despreparo técnico de colegas da equipe que estão atuando na pandemia e à insensibilidade da gestão às necessidades dos trabalhadores da saúde no seu cotidiano de trabalho. Muitas vezes, trata-se de demandas simples e de fácil solução, como o acesso fácil e constante a água potável durante o plantão (por estarem isolados em setores com alto índice de contaminação) e espaços internos de descanso entre atendimentos de plantão extenuantes, mas há outras mais complexas, como acesso a transporte de ida e volta entre casa e trabalho, por exemplo.

Outros pontos de destaque encontrados na pesquisa dizem respeito às mudanças na rotina de trabalho dos profissionais impostas pela pandemia: trabalho extenuante, que leva ao limite da exaustão; medo da morte em decorrência de contaminação; imposição de um processo de trabalho mais complexo e rígido; privação do convívio familiar; privação da liberdade de ir e vir e do convívio social entre amigos e claro risco de perda de cidadania do trabalhador, com a supressão de direitos já existentes, tais como adicionais de insalubridade, adicionais salariais e até mesmo férias, por exemplo. Na opinião de Pochmann (2020: 98),

O resultado de tudo isso tem sido a predominância de massivo desemprego aberto, acompanhado da ampliação da subutilização da força de trabalho e da generalização da precarização nas ocupações. A polarização crescente no interior da sociedade revela não apenas a destruição dos postos de trabalho de classe média, como a expansão de empregos não assalariados de maior remuneração, sem acesso à proteção social e trabalhista.

Segundo análise feita por Teixeira, Machado, Freire e Pereira no Inventário de Óbitos de Profissionais de Saúde por Covid- 19 no Brasil,

até o dia 22 de março de 2021, foram notificados 207.919 casos de Síndrome Gripal (SC) suspeitos de Covid-19 em profissionais de saúde no "e-SUS Notifica", 28, I\% confirmados como Covid-19. As profissões de saúde com maiores registros dentre os casos confirmados de SG por Covid- 19 foram: técnicos/auxiliares de enfermagem (29,6\%), enfermeiros (17,0\%), médicos (II,1\%), farmacêuticos $(5,2 \%)$ e agentes comunitários de saúde (5,0\%) (Figura I). Os dados de casos e óbitos de Síndrome Respiratória Aguda Grave (SRAG) hospitalizados (...) são um recorte dos casos graves e não apresentam o total dos acometidos pela doença no país. Até a Semana Epidemiológica (SE) II (I 4/3 a 20/3/202 I), foram notificados 925 casos de SRAG hospitalizados em profissionais de saúde no Sivep Gripe. Destes, 67, I\% foram por Covid-19. Dentre as profissões, segundo a Classificação Brasileira de Ocupações (CBO), as com maior número de registros dentre os SRAG hospitalizados pela Covid-19, 23,5\% eram técnicos/auxiliares de enfermagem, 21,9\% médicos e 14,0\% enfermeiros. (Teixeira et al., 2021: 30) 
Figura I - Ranking dos profissionais da saúde com casos confirmados de síndrome gripal por Covid- 19 - Brasil, 22 mar. 2021

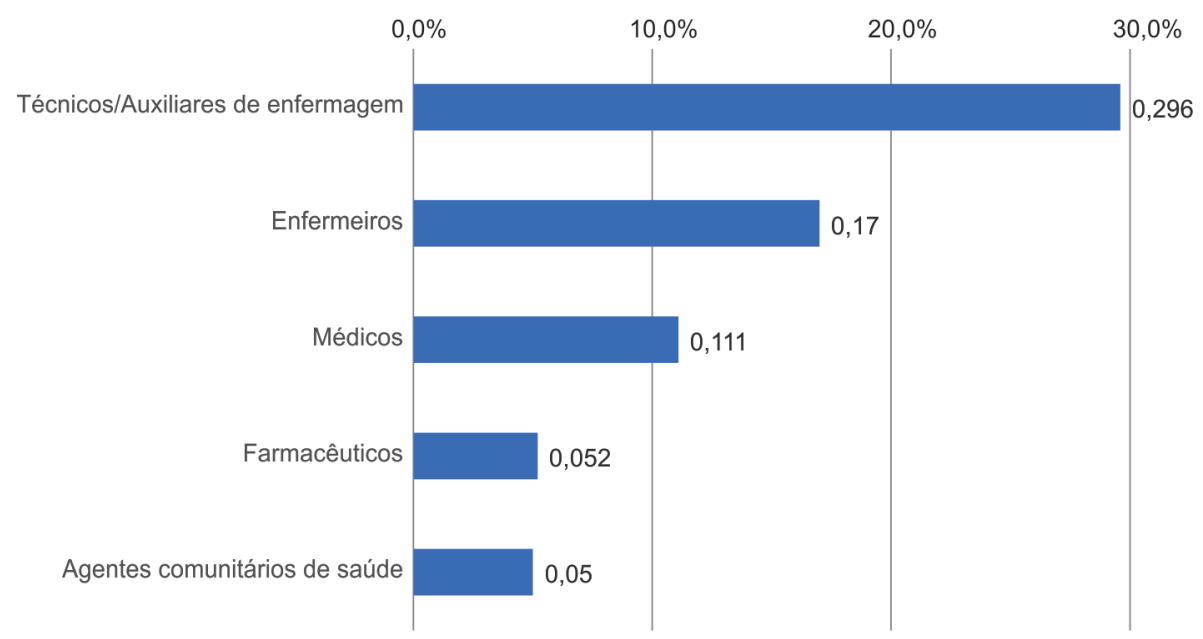

Fonte: Machado et al., 2021.

É possível vislumbrar para os trabalhadores da saúde um cenário de severos problemas mentais gerados pelo medo, ansiedade e desproteção social. Os agravos e efeitos deletérios da pandemia deixarão marcas, inexoravelmente, nos corpos e mentes de todos. Para tanto, contribui de forma importante o fato de que o "baixo nível de mobilização das organizações da classe trabalhadora repercute na pouca efetividade das estruturas de controle social para garantir a priorização de ações de atenção em ST [saúde do trabalhador] nos planos estaduais e municipais de saúde" (Gomez, Vasconcellos $\mathcal{E}$ Machado, 2018: 1.968).

Matéria jornalística publicada na página eletrônica da Escola Nacional de Saúde Pública Sergio Arouca por ocasião do Dia do Trabalhador cita os efeitos da pandemia na vida não só dos trabalhadores da saúde, mas de todos aqueles considerados essenciais durante o período de emergência sanitária (Leonel, 202I). No texto "No I ${ }^{\circ}$ de Maio, especialistas e trabalhadores lamentam danos provocados pela pandemia", o autor apresenta o discurso dos próprios trabalhadores, que lamentam a falta de reconhecimento da população, os transtornos no deslocamento para o local de trabalho, o adoecimento e morte de colegas e o desemprego no país, que já atinge mais de 14 milhões de pessoas, segundo dados coletados pela Pesquisa Nacional por Amostra de Domicílios (Pnad Covid-19) e divulgados pelo IBGE (2020). Os especialistas ouvidos pelo autor da matéria destacam a essencialidade desses trabalhadores e a falta de medidas efetivas do governo para enfrentamento da pandemia e suporte aos trabalhadores. 
Além da grave realidade dos profissionais da saúde que estão na linha de frente da Covid- 19 apresentada pela pesquisa da Fiocruz (Machado, 202 I), Leonel (202I) mostra as condições adversas e o aumento do número de mortes daqueles trabalhadores formais que não puderam ficar em casa em nenhum momento da pandemia. Na comparação entre os óbitos entre janeiro e fevereiro de 2020, pré-pandemia, e os ocorridos nos dois dos piores meses da crise sanitária, no início de 2021 , houve um salto de $68 \%$ nas mortes de frentistas de postos de gasolina, por exemplo. Também houve aumento de $67 \%$ das mortes entre os operadores de caixa de supermercado, de $62 \%$ entre motoristas de ônibus e $59 \%$ de mortes a mais entre os vigilantes. Os dados expostos demonstram os graves efeitos da pandemia de Covid- 9 no mundo do trabalho (Soares, 2021).

É imperioso reverter esse quadro em que se encontram os trabalhadores da saúde e que se agravará no pós-pandemia, visto o caráter essencial do serviço que prestam na atenção à população.

No campo específico das condições de trabalho e saúde do trabalhador, é possível vislumbrar ganhos importantes ao longo dos anos de construção do SUS. Como afirmam Gomez, Vasconcellos e Machado (20 I 8: 1.968), trata-se de desafios que, contudo,

ditam rumos, encetam estratégias, infundem desejos criativos, encenam novas parcerias, induzem a reposicionamentos éticos e fomentam a necessidade de procurar outros conhecimentos ou outras saídas. 30 anos não é pouca coisa, mas também não é muita, quando se pretende investir na dignidade no trabalho, pela via da saúde do trabalhador. É só o começo.

Nunca, na história da humanidade, esteve tão claro para a sociedade quais são os profissionais cujo trabalho diário, enfrentando o risco de doença e/ou morte, é necessário e indispensável para reduzir o número de mortes. A pandemia trouxe à tona verdades inexoráveis, como a necessária atuação de múltiplos profissionais, em equipe, com vistas à recuperação da saúde dos indivíduos que foram infectados, e a necessidade de uma Força Nacional de Saúde, criada como carreira federal e facilmente mobilizável quando alguma região deste nosso país-continente estiver com dificuldades de responder a uma emergência desse tipo. Desvelou, também, a necessidade de reverter e rever conceitos, processos de trabalho e até mesmo a noção do que seja trabalhador da saúde e do que o diferencia do profissional da saúde:

- Trabalhadores da saúde devem ser considerados, formal e legalmente, como bem público do sus;

- Como o SUS, seus trabalhadores devem ser considerados patrimônio nacional; 
- Os que cuidaram e cuidam de todos nós durante a pandemia e no pós-pandemia devem receber maior cuidado e proteção;

- É preciso (re)conceituar profissionais da saúde como aqueles que, com formação específica, lidam diretamente com a assistência, e trabalhadores da saúde como aqueles que ampliam seu âmbito e abrangência;

- Os sindicatos de profissionais da saúde devem ser fortalecidos em sua organização por natureza da atividade, saúde, e não mais por profissões, com base no entendimento de que saúde, o bem maior, é produzida por equipes multiprofissionais hierárquica e tecnicamente constituídas;

- A organização sindical é a saída, com fortalecimento de sindicatos amplos e inclusivos. A organização sindical dos trabalhadores da saúde, em seu (re)conceito ampliado, é o futuro e a esperança.

A pandemia tem mostrado esse caminho e dado sinais de que só com união, cooperação e solidariedade mútuas sairemos dessa crise sanitária brasileira e mundial.

\section{REFERÊNCIAS}

BRASIL. Ministério da Saúde. Brasil possui quatro casos confirmados de coronavírus, 2020. Notícias. Disponível em: < www.gov.br/saude/pt-br/assuntos/noticias/brasil-possui-quatro-casos-confirmadosde-covid-19>. Acesso em: 19 abr. 2021.

BRASIL. Ministério da Saúde. Cadastro Nacional dos Estabelecimentos de Saúde, 202 Ia. Página inicial. Disponível em: <http://cnes. datasus.gov.br/>. Acesso em: I 9 abr. 2021 .

BRASIL. Ministério da Saúde. Painel Coronavírus, 202 lb. Página inicial. Disponível em: < https://covid. saude.gov.br/>. Acesso em: 30 abr. 2021 .

CONSELHO FEDERAL DE ENFERMAGEM (COFEN). Enfermagem em números, 2021. Enfermagem em números. Disponível em: <www.cofen.gov.br/enfermagem-em-numeros>. Acesso em: 30 abr. 2021 .

CONSELHO FEDERAL DE FARMÁCIA (CFF). Dados 2020 consultados em 202I. Disponível em: <www. cff.org.br/pagina.php?id=80 I Emenu $=80 \mathrm{I}$ Etitulo=Dados $+2020>$. Acesso em: 30 abr. $202 \mathrm{I}$.

CONSELHO fEDERAL DE FISIOTERAPIA E TERAPIA OCUPACIONAL (COFFITO). Página inicial. Disponível em: <www.coffito.gov.br/nsite/>. Acesso em: 30 abr. 202I.

CONSELHO FEDERAL DE MEDICINA (CFM). Número de médicos, 202I. Número de médicos. Disponível em: <https://portal.cfm.org.br/numero-de-medicos>. Acesso em: 30 abr. 2021.

CONSELHO FEDERAL DE NUTRICIONISTAS (CFN). Quadro estatístico: 4 trimestre de 2020, 2020. Estatística. Disponível em: <www.cfn.org.br/index.php/estatistica>. Acesso em: 30 abr. 2021.

CONSELHO FEDERAL DE ODONTOLOGIA (CFO). Quantidade geral de profissionais e entidades ativas, 202I. Estatísticas. Disponível em: <https://website.cfo.org.br/estatisticas/quantidade-geral-deentidades-e-profissionais-ativos/>. Acesso em: 30 abr. 2021. 
CONSELHO FEDERAL DE PSICOLOGIA (CFP). A psicologia brasileira apresentada em números, $202 \mathrm{I}$. A psicologia em números. Disponível em: <http://www2.cfp.org.br/infografico/quantos-somos/>. Acesso em: 30 abr. 2021.

CONSELHO FEDERAL DE SERVIÇO SOCIAL (CFESS). Atualmente, qual é o número de assistentes sociais no Brasil?, 2021. Perguntas frequentes. Disponível em: <www.cfess.org.br/visualizar/menu/local/ perguntas-frequentes $>$. Acesso em: 30 abr. 2021 .

DAU, D. M. A expansão da terceirização no Brasil e a estratégia da CUT de enfrentamento à precarização do trabalho. In: DAU, D. M.; RODRIGUES, I. J. \& CONCEIÇÃO, J. J. (Orgs.). Terceirização no Brasil: do discurso da inovação à precarização do trabalho (atualização do debate e perspectivas). São Paulo: Annablume, 2009

GOMEZ, C. M.; VASCONCELLOS, L. C. F. \& MACHADO, J. M. H. Saúde do trabalhador: aspectos históricos, avanços e desafios no Sistema Único de Saúde. Ciência E Saúde Coletiva, 23(6): 1.963I.970, 2018.

HORTON, R. Offline: Covid- 19 is not a pandemic. The Lancet, 396(I0.255): 874, 2020. Disponível em: <www.thelancet.com/action/showPdf?pii $=$ SOI 40-6736\%2820\%2932000-6>. Acesso em: 22 abr. 2021.

HUANG, C. et al. Clinical features of patients infected with 2019 novel coronavirus in Wuhan, China. The Lancet, 395(10.223): 497-506, 2020. Disponível em: <www.thelancet.com/journals/lancet/ article/PIISOI 40-6736(20)30 I 83-5/fulltext>. Acesso em: 26 abr. 202I.

INSTITUTO BRASILEIRO DE GEOGRAFIA E ESTATíSTICA (IBGE). IBGE Cidades, 20I7. Panorama. Disponível em: <https://cidades.ibge.gov.br/brasil/panorama>. Acesso em: 17 abr. 2021.

INSTITUTO BRASILEIRO DE GEOGRAFIA E ESTATÍSTICA (IBGE). Pesquisa Nacional por Amostra de Domicílios - PNAD Covid- 19, 2020. Disponível em: < https://covid I 9.ibge.gov.br/pnad-covid/>. Acesso em: 28 abr. 2021.

LEONEL, F. No $I^{\circ}$ de Maio, especialistas e trabalhadores lamentam danos provocados pela pandemia. Portal Ensp, Rio de Janeiro, 30 abr. 202I. Disponível em: <http://informe.ensp.fiocruz.br/secoes/ noticia/4500 I/5132I >. Acesso em: nov. 2021.

MACHADO, M. H. (Coord.). Pesquisa Perfil da Enfermagem no Brasil. Relatório final. Rio de Janeiro: Nerhus-Daps-Ensp/Fiocruz, 2017

MACHADO, M. H. (Coord.). Pesquisa Condições de Trabalho dos Profissionais de Saúde no Contexto da Covid- 19 no Brasil. Relatório preliminar. Rio de Janeiro: Fiocruz, 2021.

MACHADO, M. H. \& XIMENES NETO, F. R. G. Gestão da educação e do trabalho em saúde no SUS: trinta anos de avanços e desafios. Ciência E Saúde Coletiva, 23(6): I.97 I-1.980, 2018.

MACHADO, M. H.; CARVALHO, A. I. \& CAMPOS, F. E. Com a palavra, os profissionais. Radis, 24 ago. 2020. Disponível em: <https://radis.ensp.fiocruz.br/index.php/home/reportagem/com-a-palavraos-profissionais >. Acesso em: 22 abr. 2021.

MACHADO, M. H. et al. Mercado de trabalho e processos regulatórios: a enfermagem no Brasil. Ciência E Saúde Coletiva, 25(1): 101-112, 2020. 
MATSUMURA, E. S. S. et al. Distribuição territorial dos profissionais fisioterapeutas no Brasil. Fisioterapia e Pesquisa, 25(3): 309-314, 2018.

POCHMANN, M. Tendências estruturais do mundo do trabalho no Brasil. Ciência E Saúde Coletiva, 25(I): 89-99, 2020.

SOARES, M. Mortes entre caixas, frentistas e motoristas de ônibus aumentaram 60\% no Brasil no auge da pandemia. El País, São Paulo, 5 abr. 202 I. Disponível em: < https://brasil.elpais.com/brasil/202 I-04-05/ caixas-frentistas-e-motoristas-de-onibus-registram-60-a-mais-de-mortes-no-brasil-em-meio-aoauge-da-pandemia.html>. Acesso em: 28 abr. 2021 .

TEIXEIRA, E. G. et al. Inventário de Óbitos de Profissionais de Saúde por Covid- I 9 no Brasil. Relatório final. Rio de Janeiro: Fiocruz, 2021.

WANG, C. et al. A novel coronavirus outbreak of global health concern. The Lancet, 395(I 0.223): 470473, 2020. Disponível em: <www.thelancet.com/journals/lancet/article/PIISO I 40-6736(20)30 I 859/fulltext>. Acesso em: 20 abr. 2021.

WORLD HEALTH ORGANIZATION (WHO). Emergencies preparedness, response: novel coronavirus China. Disease outbreak news: Update, 2020a. Disponível em: <www.who.int/csr/don/I2-january2020-novel-coronavirus-china/en/>. Acesso em: II abr. 2021 .

WORLD HEALTH ORGANIZATION (WHO). WHO Director-general's opening remarks at the media briefing on Covid-19, 2020b. Disponível em: <www.who.int/dg/speeches/detail/who-directorgeneral-s-opening-remarks-at-the-media-briefing-on-covid- I 9--- I I-march-2020>. Acesso em: I I abr. 2021 . 



\title{
Insegurança e Medo na Atenção Primária
}

\author{
os agentes comunitários de saúde e a pandemia \\ da Covid-19 nas favelas do Brasil
}

Nilson do Rosário Costa, Hugo Bellas, Paulo Roberto Fagundes da Silva,

Paulo Victor Rodrigues de Carvalho, Deborah Uhr,

Cristine Vieira e Alessandro Jatobá

I a Política Nacional de Atenção Básica, o agente comunitário de saúde (ACS) tem papel destacado no mapeamento do território, na coleta de dados sobre condições de vulnerabilidade e na vigilância epidemiológica ativa (Bousquat et al., 2017; Giovanella, 2006).

Especialmente em situações de crise que estressam o sistema de saúde, como surtos de doenças (casos de dengue, febre amarela, chicungunha e zika) e grandes epidemias (HINI e, mais recentemente, Covid-19), o papel dos ACS dentro do arcabouço da Atenção Primária à Saúde (APS) é realçado, uma vez que ele pode atuar na sensibilização da população sobre ações de saúde para mitigar o risco de comunidades pobres se tornarem grandes focos de disseminação.

A percepção sobre a pandemia da Covid- 19 por parte dos ACS que atuam em comunidades pobres ou favelas no Brasil como membros da equipe da APS no Sistema Único de Saúde (SUS) é o tema do estudo realizado em 2020 que será aqui relatado. Com desenho observacional e exploratório, o estudo foi realizado com o objetivo de oferecer evidências que ajudem na compreensão da dinâmica social da pandemia da Covid- 9 nas comunidades pobres e permitam fornecer recomendações para a atuação segura e efetiva dos ACS no enfrentamento da pandemia nesses territórios. Para tanto, foi aplicado um questionário entre ACS atuantes em favelas que constavam em base de dados utilizada em pesquisa anterior (Bellas et al., 2019). Os ACS indicaram outros colegas, seguindo procedimento de "bola de neve" (Goodman, 1961). A pesquisa contempla uma amostra aleatória simples de 775 ACS que atuam em 368 municípios dos 26 estados e no Distrito Federal, com nível de confiança de 95\% e erro amostral de $4 \%$. Detalhes complementares sobre os procedimentos metodológicos adotados neste estudo podem ser vistos em Costa e colaboradores (2020). A pesquisa foi aprovada 
pelo Comitê de Ética em Pesquisa do Instituto Oswaldo Cruz/Fiocruz, conforme parecer 4.029.043, emitido em 14 de maio de 2020.

Cabe notar que a trajetória descontrolada da pandemia no país gera preocupação, especialmente em razão da falta de unidade da ação estatal e do negacionismo do governo central. Pouco se sabe a respeito dos impactos da conduta errática do governo nacional sobre a sustentabilidade da atividade dos agentes públicos e a adesão da população ao distanciamento social.

Como elemento adicional para o enfraquecimento da mobilização social, a falta de consenso científico sobre as orientações do campo biomédico para o controle da pandemia também alimenta a escalada do negacionismo messiânico. A intervenção estritamente farmacológica (vacinas e antiviral específico), que definiu os parâmetros legitimados para a intervenção biomédica nas epidemias, não estava disponível para controle da disseminação ou redução da letalidade do Sars-CoV-2 até dezembro de 2020. Como observado na experiência internacional, restou aos governos nacionais a implantação de soluções não farmacológicas que dependiam da adesão voluntária dos indivíduos ao distanciamento social e quarentena.

\section{PRINCIPAIS ACHADOS}

O perfil dos ACS participantes apresenta forte convergência com outros estudos com desenho amostral (Barreto et al., 20 I8) ou qualitativo (Justo, Gomes $\&$ Silveira, 20I5), os quais revelam que a categoria profissional é predominantemente feminina e de alta escolaridade (Barreto et al., 2018; Simas \& Pinto, 2017). Os estudos com amostras por julgamento atestam também que a idade média dos ACS está situada entre 40 e 45 anos (Simas \& Pinto, 2017; Moreira et al., 2019). De fato, como indicado na Tabela I, a amostra dos ACS que respondeu à pesquisa é dominantemente feminina, com idade média de 43 anos e longa experiência no exercício das funções de burocracia de nível de rua. Na pesquisa, estimou-se que $50 \%$ ou mais dos ACS trabalham no SUS há mais de 13 anos. Dois em cada dez ACS trabalham na saúde há mais de 20 anos.

Ao longo da pandemia, $76 \%$ dos ACS realizaram visitas domiciliares, apesar de apenas pequena proporção (34\%) ter recebido treinamento para orientar sobre distanciamento social e higiene individual e, assim, melhor lidar com a Covid- 19.

No período da pesquisa, $61 \%$ dos ACS afirmaram ter recebido equipamentos de proteção individual (EPIs) para o exercício de atividades no território e 33\% das unidades básicas de saúde (UBS) funcionavam de modo parcial ou estavam desativadas. Chama atenção na Tabela I a proporção expressiva de ACS (18\%) que informou sintomas da Covid- 19 (febre, cansaço e falta de ar) nos 14 dias anteriores à data de resposta ao 
questionário. A percepção de medo prevalecia entre os informantes: $87 \%$ afirmaram que exerciam as atividades com insegurança, ainda que as UBS tenham suspendido o cumprimento das metas que as secretarias municipais de Saúde estabelecem para este tipo de dispositivo da rede pública (apenas 27\% mantiveram a exigência de cumprimento).

Tabela I - Perfil dos respondentes e condição de atuação dos agentes comunitários de saúde (ACS) durante a pandemia da Covid- 19 no Brasil $(n=775)$ - 25 maio a 17 jun. 2020

\begin{tabular}{|c|c|c|}
\hline Variável & $\%$ & $\begin{array}{c}\text { Intervalo de } \\
\text { confiança (95\%) }\end{array}$ \\
\hline \multicolumn{3}{|l|}{ Sexo } \\
\hline Mulher & 84 & {$[81 ; 86]$} \\
\hline Homem & 16 & {$[13 ; 19]$} \\
\hline \multicolumn{3}{|l|}{ Escolaridade } \\
\hline Ensino médio completo & 65 & {$[61 ; 68]$} \\
\hline Ensino superior completo & 30 & {$[27 ; 33]$} \\
\hline Ensino fundamental completo & 6 & [04; 08] \\
\hline \multicolumn{3}{|l|}{ Idade } \\
\hline Igual ou menor que 32 anos & 10 & {$[08 ; 12]$} \\
\hline Igual ou maior que 4 I anos & 50 & {$[46 ; 54]$} \\
\hline Igual ou maior que 50 anos & 20 & {$[17 ; 23]$} \\
\hline \multicolumn{3}{|l|}{ Tempo na profissão } \\
\hline Trabalha como ACS há I 3 anos ou mais & 50 & {$[46 ; 54]$} \\
\hline Trabalha como ACS há 20 anos ou mais & 20 & {$[17 ; 23]$} \\
\hline \multicolumn{3}{|l|}{ Condição de atuação durante a pandemia da Covid-19 } \\
\hline Unidade funcionando normalmente & 67 & {$[64 ; 70]$} \\
\hline Salário em dia & 96 & {$[94 ; 97]$} \\
\hline Meta da unidade mantida & 27 & {$[24 ; 30]$} \\
\hline Realizou visita domiciliar nos últimos 14 dias & 76 & {$[73 ; 79]$} \\
\hline $\begin{array}{l}\text { Recebeu treinamento para orientar sobre distanciamento social e } \\
\text { higiene individual }\end{array}$ & 34 & {$[30 ; 37]$} \\
\hline A unidade de saúde forneceu equipamento de proteção individual & 61 & {$[57 ; 64]$} \\
\hline Teve tosse, febre, cansaço e falta de ar nos últimos 14 dias & 18 & {$[15 ; 21]$} \\
\hline Insegurança no exercício da atividade & 87 & {$[84 ; 89]$} \\
\hline
\end{tabular}

Fonte: elaboração própria. 
Na Tabela 2 vê-se que a percepção dos ACS sobre a mobilização contra a Covid- 19 da população residente em favela é pessimista, porque apenas $22 \%$ identificam algum tipo de ação coletiva, somente I $4 \%$ assinalam que a adesão ao distanciamento social é alta ou muito alta e $86 \%$ consideram a adesão ao distanciamento social entre regular e inexistente.

Apesar disso, os ACS respondem afirmativamente quando perguntados se a sensação de medo na população das favelas diante da pandemia da Covid- 9 é muito presente: dois em cada três participantes associam a queda na frequência às atividades da UBS ao medo da Covid-19. Do mesmo modo, metade dos informantes registra a sensação de que a população tem evitado a interação com eles nas áreas onde atuam.

Segundo avaliação dos ACS, a necessidade de trabalhar, a influência da televisão, o negacionismo e a desinformação corrente nas novas mídias sociais são as causas determinantes da decisão de aderir de modo frouxo ao distanciamento social. Ademais, eles têm a percepção de que seu trabalho pouco influencia a decisão da população em relação ao distanciamento social. Apenas $2 \%$ dos entrevistados assinalaram que seu aconselhamento tem alguma influência nessa decisão.

Tabela 2 - Mobilização social, medo e adesão ao distanciamento social nas favelas segundo a percepção dos ACS $(n=775)$ - 25 maio a 17 jun. 2020

\begin{tabular}{l|c|c}
\hline \multicolumn{1}{c|}{ Variável } & $\%$ & $\begin{array}{c}\text { Intervalode } \\
\text { confiança (95\%) }\end{array}$ \\
\hline Mobilização coletiva & 78 & {$[75 ; 80]$} \\
\hline Não & 22 & {$[19 ; 25]$} \\
\hline Sim & & \\
\hline Evitação do contato com ACS & 5 I & {$[47 ; 57]$} \\
\hline Não & 49 & {$[45 ; 52]$} \\
\hline Sim & & \\
\hline Medo de frequentar a UBS & 33 & {$[29 ; 36]$} \\
\hline Não & 67 & {$[63 ; 70]$} \\
\hline Sim & & \\
\hline
\end{tabular}


Tabela 2 - Mobilização social, medo e adesão ao distanciamento social nas favelas segundo a percepção dos ACS $(n=775)$ - 25 maio a 17 jun. 2020 (continuação)

\begin{tabular}{l|c|c}
\hline \multicolumn{1}{c|}{ Variável } & $\%$ & $\begin{array}{c}\text { Intervalode } \\
\text { confiança (95\%) }\end{array}$ \\
\hline Nível de adesão ao distanciamento social & 40 & {$[36 ; 43]$} \\
\hline Baixo & 46 & {$[42 ; 50]$} \\
\hline Médio & 14 & {$[11 ; 16]$} \\
\hline Alto & & \\
\hline Determinantes da decisão sobre o distanciamento social na favela & 37 & {$[33 ; 40]$} \\
\hline Necessidade de trabalhar & 23 & {$[20 ; 26]$} \\
\hline Influência da televisão e rádio & 13 & {$[10 ; 15]$} \\
\hline Negacionismo & 12 & {$[10 ; 14]$} \\
\hline Mídias sociais & 7 & {$[05 ; 09]$} \\
\hline Influência dos vizinhos & 6 & {$[04 ; 08]$} \\
\hline Medo de adoecer & 2 & {$[01 ; 03]$} \\
\hline Influência dos ACS & & \\
\hline
\end{tabular}

Fonte: elaboração própria.

Na Figura I vê-se que a insegurança dos ACS para exercer suas atividades é inversamente proporcional à adesão da população das favelas ao distanciamento social. Quando a adesão ao distanciamento social é baixa, a insegurança dos ACS é superior a 90\%; quando a adesão ao distanciamento é regular, a insegurança dos ACS é superior a $85 \%$, e quando a adesão ao distanciamento é alta, a insegurança dos ACS cai para um percentual abaixo de $80 \%$. 
Figura I - Insegurança nas atividades de ACS e adesão da população das favelas ao distanciamento social - 25 maio a 17 jun. 2020

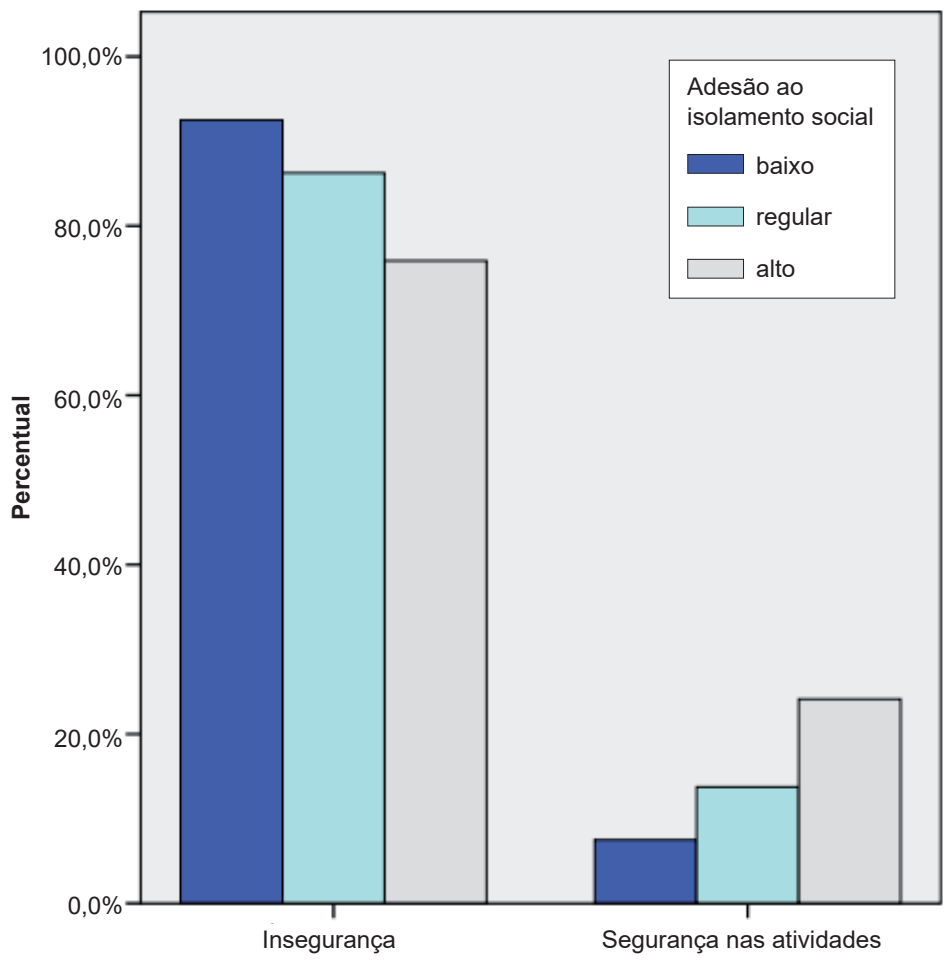

Fonte: elaboração própria.

A Figura 2 mostra que a insegurança dos ACS em realizar suas atividades é reduzida de forma diretamente proporcional à percepção da mobilização coletiva da população nas favelas contra a Covid- 19 como elevada. Quando não há nenhuma mobilização por parte da comunidade, mais de $85 \%$ dos ACS respondentes atestam insegurança; quando há mobilização coletiva da comunidade, ela cai para um percentual abaixo de $80 \%$. Contudo, ainda permanece em valores referenciais elevados, o que sugere o alto grau de consciência desses agentes comunitários sobre os riscos de contrair a doença e suas consequências. 
Figura 2 - Insegurança nas atividades e mobilização coletiva da população nas favelas -25 maio a 17 jun. 2020

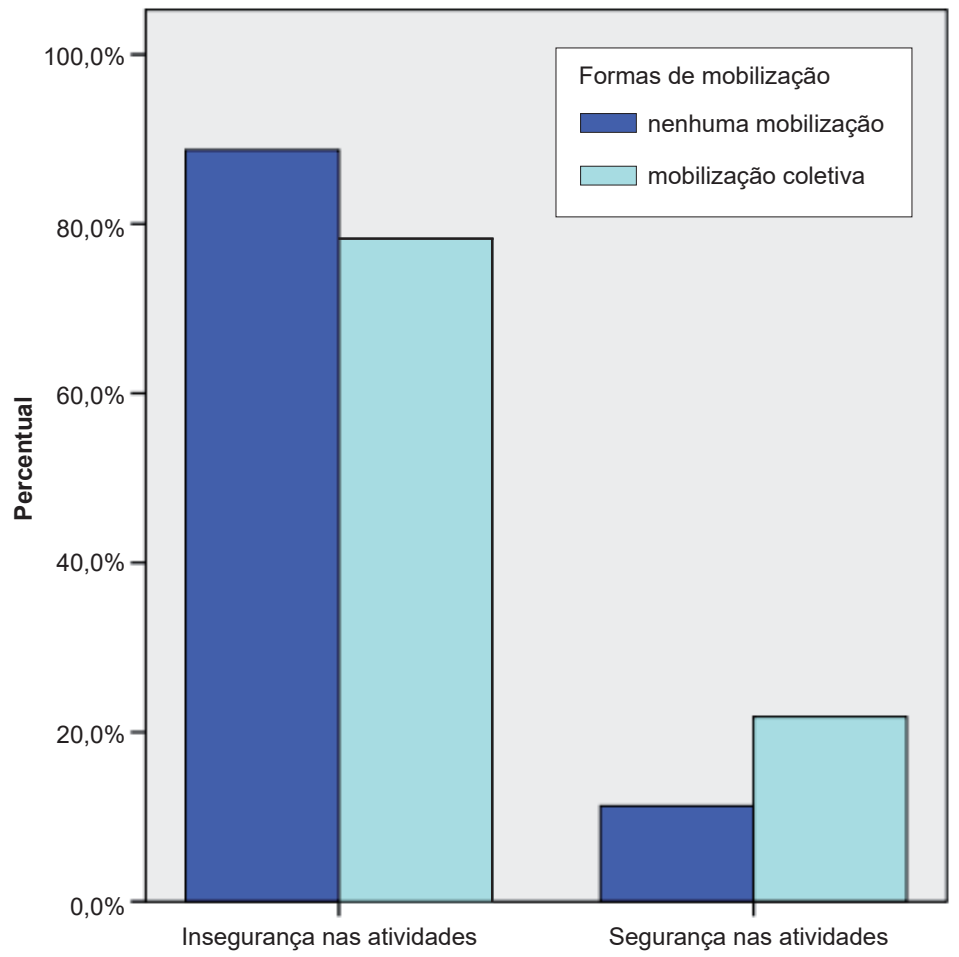

Fonte: elaboração própria.

A Tabela 3 traz o resultado do cálculo de odds ratio tendo como variável independente a variável categórica insegurança na atividade durante a pandemia. A probabilidade de - ACS expressar condição de insegurança nas atividades é 2,2 vezes maior quando ele percebe que a população não está mobilizada e 2,6 vezes maior quando percebe baixa adesão ao distanciamento. A condição subjetiva associada à rejeição da comunidade, à falta de capacitação ou à informação de sintomatologia da Covid- 19 também afeta de modo significativo a percepção de insegurança. 
Tabela 3 - Odds ratio para a percepção de insegurança dos agentes comunitários de saúde que atuam em favela durante a pandemia de Covid- 19 - Brasil, 2020

\begin{tabular}{l|c|c}
\hline \multicolumn{1}{c|}{ Condição informada ou percebida pelo ACS } & Odds ratio & Intervalo de confiança \\
\hline Percebe que a população evita o contato & 1,6 & $(1,2 ; 2,1)^{\star}$ \\
\hline Não teve treinamento* & 1,9 & $(1,1 ; 2,7)^{\star}$ \\
\hline Percebe a inexistência de mobilização coletiva* & 2,2 & $(1,3 ; 3,7)^{\star}$ \\
\hline Informa que teve sintomas da Covid-19 & 2,4 & $(1,2 ; 4,3)^{\star}$ \\
\hline Percebe a baixa adesão ao distanciamento social* & 2,6 & $(1,2 ; 4,7)^{\star}$ \\
\hline
\end{tabular}

Fonte: elaboração própria.

* Valor de p: 0,05

\section{REFLEXÕES PARA 0 DEBATE}

A pesquisa oferece elementos para compreensão das possibilidades e dos limites para a atuação dessa burocracia de nível de rua no contexto da pandemia (Lotta, 20 I 5). O curso da pandemia impõe desafios inesperados aos modos usuais de interação dos agentes da saúde pública com comunidades pobres. A pesquisa traz evidência de que esses embaraços têm sido ignorados ou minimizados nas prescrições de políticas para a APS no contexto da pandemia.

Os dados indicam que os desafios para a atividade dos ACS são aguçados por força da agenda negacionista do Executivo central e dos governos subnacionais. O negacionismo do Executivo central, em especial, tem impedido a construção de consenso social sobre as medidas preventivas necessárias para o distanciamento social (Da 'Gripezinha'..., 2020).

Nesse cenário, é desaconselhável pensar o avanço da pandemia nas favelas como um problema cuja solução deverá vir de ações locais. É importante considerar que a intermitência das iniciativas nacionais, regionais e locais para a mitigação da pandemia prejudica a resposta do conjunto da sociedade aos riscos extremos. As favelas estão especialmente expostas à Covid- 19 (Barbon, 2020), demonstrando que a desorientação da política pública para a pandemia afeta tragicamente a população pobre.

Os resultados mostram que o negacionismo também constrange a capacidade de ação da burocracia de nível da rua e afeta a capacidade de mobilização social das comunidades pobres, criando um ambiente de insegurança e medo de interação social com os agentes públicos. Chama atenção o fato de que parcela majoritária dos ACS atua 
sem que os sistemas locais ou regionais tenham promovido treinamento sobre os riscos da Covid-19. Nessa condição, a maioria informa que se sente insegura no exercício das funções rotineiras.

Os entrevistados informam que a população tem evitado o contato pessoal com os ACS, o que indica uma crise de confiança em relação à estrutura de atendimento à saúde no nível primário.

Mesmo diante da difusão massiva nas mídias tradicionais da necessidade de fornecimento de EPIs para os profissionais da saúde que atuam em contato direto com a população, a alta frequência de ACS que informaram não os ter recebido das suas respectivas UBS compromete a proteção e favorece a transmissão da doença no âmbito do cuidado em saúde. O risco associado a essa falha de provisão se expressa no fato de 2 em cada 10 ACS terem informado sintomas indicativos de infecção pela Covid-19, sendo que a maioria dos sintomáticos relata ter realizado visitas domiciliares.

A Organização Mundial da Saúde (OMS) recomenda o uso de EPIs não somente para os profissionais que prestam atendimento nos serviços de saúde, mas também nos cuidados domiciliares. Segundo a OMS, as precauções relacionadas ao contato devem ser adotadas pelos profissionais da saúde que cuidam dos doentes com Covid- 19 em todos os momentos (WHO, 2020).

Embora a utilização de EPIs seja o controle mais visível utilizado para prevenir a propagação da infecção, precauções adicionais podem proteger os trabalhadores da saúde e outros contra a exposição ao Sars-CoV-2, como o distanciamento social e a correta higiene pessoal. Como já exposto, poucos ACS receberam treinamento para a prevenção da Covid- 19 na realização das visitas domiciliares. Além de a atividade de capacitação ser crucial para a proteção dos ACS, eles são multiplicadores e podem informar aos moradores das favelas quanto à higiene pessoal e limpeza das superfícies da moradia e possivelmente sensibilizar as pessoas para a importância de permanecer em casa.

A falta de treinamento e de equipamentos, a condição de insegurança e o medo generalizado da população podem tornar inviável a vigilância em saúde ativa, especialmente a requisição de informação aos indivíduos. Nesse contexto, a requisição de informação privada aos moradores deve ser tratada com máxima cautela, ainda que as tarefas de cadastramento de usuários estejam previstas na Política Nacional de Atenção Básica, sendo parte das rotinas de vigilância em saúde dos ACS.

No contexto da pandemia, a possibilidade da interferência dos ACS nas condutas da população em relação ao distanciamento social é informada nesta pesquisa como nula. A despeito da pobreza, os moradores das favelas informam que são influenciados 
pelas redes sociais e pela mídia tradicional, especialmente pela televisão. Ademais, a negação do risco extremo da Covid- 19 também é informado como endêmico nas favelas. A baixa escolaridade dos moradores dessas comunidades associada ao grande número de desempregados e de trabalhadores informais representam um obstáculo à plena adesão ao distanciamento social em um contexto de negacionismo por parte de autoridades governamentais, especialmente na esfera do Executivo federal.

Grande proporção dos ACS percebe que as dificuldades para aderir ao distanciamento social dos moradores da favela têm como causa a necessidade de trabalhar. Não há dúvida de que a baixa cobertura da política nacional de transferência de renda favorece a hesitante adesão ao distanciamento social nas comunidades. A perda da renda durante a pandemia está associada ao risco da fome no Brasil em 2020. Nesse contexto, a busca diária de renda no mercado informal de trabalho colabora com o aumento da circulação de pessoas nas favelas, ampliando a possibilidade de disseminação do novo coronavírus. E as condições das habitações dificultam a permanência dentro de casa e a completa renúncia à circulação em ambientes públicos, como os bares.

Assim, os ACS percebem que a mobilização social e a adesão ao distanciamento social nas favelas são residuais. Entretanto, o estudo indica que, quando a mobilização social é assinalada, seu efeito é muito expressivo na redução da percepção de insegurança e medo no exercício das rotinas dos agentes.

É possível concluir que as atividades dos ACS nas favelas durante a pandemia mantêm as mesmas condições de complexidade observadas em tempos normais. Os territórios em que os ACS atuam são usualmente marcados por transição demográfica acelerada, situação epidemiológica de alta carga de doenças infecciosas, presença hegemônica forte de condições crônicas, além de uma carga importante de causas externas, como a violência (Bellas et al., 2019; Jatobá et al., 2018, 2020). Esse cenário teve, no entanto, sua complexidade acentuada pela pandemia, o que representa ainda mais pressão sobre o sistema de saúde e consequentemente sobre os ACS, que atuam na ponta deste sistema.

Medidas de disseminação em massa de informação sobre o risco extremo da Covid- 19 nas redes sociais e mídias tradicionais podem favorecer o ambiente de receptividade ao trabalho do ACS e ampliar a adesão ao distanciamento social nas favelas. Porém, a promoção de medidas de distanciamento social não faz parte da agenda do Executivo federal, apesar de a infecção pelo Sars-CoV-2 ter atingido fortemente os moradores das favelas (Barbon, 2020). 


\section{RECOMENDAÇÕES}

Quatro pontos são cruciais na percepção dos ACS em relação à pandemia de Covid- I9:

I. A necessidade de massificação da distribuição de EPIs, visto que a ausência de tais equipamentos, aliada à continuidade da realização das visitas, afeta as condições de trabalho percebidas pelos ACS e é também um risco para as comunidades.

2. A ampliação da capacitação dos ACS sobre a Covid- 19.

3. A necessidade de distanciamento social dos ACS que apresentem sintomas da Covid-19. Em suas diretrizes, o Ministério da Saúde recomenda que o ACS que apresente febre e qualquer sintoma respiratório (tosse, coriza, dor de garganta, falta de ar) deve permanecer em distanciamento domiciliar conforme orientação da equipe de saúde.

4. A necessidade de cautela na recomendação da atividade de vigilância ativa para os ACS por meio de requisição de informação privada aos moradores.

\section{REFERÊNCIAS}

BARBON, J. Coronavírus infectou I 7\% em favelas e em bairros pobres do Rio de Janeiro. Folha de S. Paulo, São Paulo, 23 jun. 2020. Disponível em: < https://www I.folha.uol.com.br/equilibrioesaude/2020/06/ coronavirus-infectou- I7-em-favelas-e-em-bairros-pobres-do-rio-de-janeiro.shtml>. Acesso em: 26 jun. 2020.

BARRetO, I. C. H. C. et al. Complexidade e potencialidade do trabalho dos Agentes Comunitários de Saúde no Brasil contemporâneo. Saúde em Debate, 42(esp. I): II4-I29, 2018.

BELLAS, H. C. et al. Effects of urban violence on primary healthcare: the challenges of community health workers in performing house calls in dangerous areas. Journal of Community Health, 44(3): 569-576, 2019.

Bousquat, A. et al. Atenção Primária à Saúde e coordenação do cuidado nas regiões de saúde: perspectiva de gestores e usuários. Ciência E Saúde Coletiva, 22(4): I. I 4 I-1.154, 2017.

COSTA, N. R. et al. Community health workers' attitudes, practices and perceptions towards the Covid- I 9 pandemic in Brazilian low-income communities. Work (Preprint), I-9, 2020.

DA 'GRIPEZINHA' às 50 mil mortes pela Covid-19. O Globo, Rio de Janeiro, 22 jun. 2020. Disponível em: $<$ https://oglobo.globo.com/opiniao/da-gripezinha-as-50-mil-mortes-pela-covid-19-1-24491286>. Acesso em: 26 jun. 2020.

GIOVANELLA, L. A atenção primária à saúde nos países da União Europeia: configurações e reformas organizacionais na década de 1990. Cadernos de Saúde Pública, 22(5): 951-963, 2006.

GOODMAN, L. A. Snowball sampling. Annals of Mathematical Statistics, 32(1): 148- I70, 196 I. 
JATOBÁ, A. et al. Patient visits in poorly developed territories: a case study with community health workers. Cognition, Technology E Work, 20(I): I25-152, 20 I 8.

JATOBÁ, A. et al. Assessing community health workers' conditions for delivering care to patients in low-income communities. Applied Ergonomics, 82: I02944, 2020.

JUSTO, C. M. P.; GOMES, M. H. A. \& SILVEIRA, C. Limites e imposições dos instrumentos de controle do trabalho de agentes comunitários de saúde da Estratégia Saúde da Família. Saúde e Sociedade, 24(2): 594-606, 2015.

LOTTA, G. Burocracia e Implementação de Políticas de Saúde: os agentes comunitários na Estratégia Saúde de Família. Rio de Janeiro: Editora Fiocruz, 2015. Disponível em: <http://www.jstor.org/ stable/I 0.7476/97885754I548I >. Acesso em: 26 jun. 2020.

MOREIRA, D. C. et al. Atuação do Núcleo de Apoio à Saúde da Família no fortalecimento da Atenção Primária: experiências dos agentes comunitários. Physis: Revista Saúde Coletiva, 29(3): e290304, 20 I 9. Disponível em: $<$ http://www.scielo.br/scielo.php?script=sci_arttextEpid=S0 I 03-733 I 2019000300600 Etlng $=$ pt $>$. Acesso em: 25 jun. 2020.

SIMAS, P. R. P. E PINTO, I. C. M. Trabalho em saúde: retrato dos agentes comunitários de saúde da região Nordeste do Brasil. Ciência \& Saúde Coletiva, 22(6): I.865-1.876, 2017.

WORLD HEALTH ORGANIZATION (WHO). Rational use of personal protective equipment for coronavirus disease (Covid-19) and considerations during severe shortages: interim guidance. Geneva: WHO, Apr. 2020. Disponível em: < https://apps.who.int/iris/handle/I0665/33 I695>. Acesso em: 25 jun. 2020. 


\title{
A Morte Contaminada
}

\author{
a experiência da morte por Covid-19 na \\ perspectiva de profissionais da saúde
}

Marcia Grisotti, Daniel Granada, Priscila Pavan Detoni, Maria Conceição de Oliveira e Eliana Elisabeth Diehl

\begin{abstract}
A morte não tem segredos. Não abre portas. É o fim de uma pessoa. O que sobrevive é o que ela ou ele deram às outras pessoas, o que permanece nas memórias alheias.
\end{abstract}

Norbert Elias em $A$ Solidão dos Moribundos, 1982

$\mathrm{N}$ as sociedades ocidentais, urbanas e contemporâneas, o evento do fim da vida, ainda que situação indesejável e incômoda, faz parte do ofício dos profissionais da saúde e da rotina dos hospitais desde o surgimento destas instituições (Foucault, 2013). A transferência da morte em casa para a morte nos hospitais inevitavelmente remete à perda de autonomia do doente para gerir seu final de vida e sua morte (Kovács, 2010). Em trabalhos clássicos nas ciências sociais, entre os quais os de Van Gennep, Marcel Mauss e Norbert Elias, refletiu-se sobre as representações e rituais humanos relacionados à morte, extrapolando a objetiva experiência de morte biológica.

Morrer por Covid-19, no entanto, tem colocado novos desafios à reflexão sobre o processo e a experiência da morte e elaboração do luto, tanto para familiares e amigos, em razão da proibição de cerimônias fúnebres tradicionais, que impede o contato físico nos rituais de despedida, tornando a morte solitária, asséptica, isolada, próxima do que foi vivenciado na epidemia do ebola, quanto para os trabalhadores da saúde, que precisam ser treinados e atualizados com as informações sobre os protocolos, encaminhamento e comunicação dos óbitos e sobre formas de evitar o seu próprio contágio.

Desde o começo da pandemia os hospitais foram um importante espaço para a transmissão viral. Richterman, Meyerowitz e Cevik (2020) relatam exemplos, em diferentes 
países, do potencial devastador da transmissão de Sars-CoV-2 em profissionais da saúde e do risco envolvido na atenção de rotina a pacientes com Covid-19, especialmente devido às incertezas sobre os meios de transmissão do vírus. De acordo com esses autores, o uso universal de máscaras em profissionais e pacientes tornou-se uma medida simples, mas efetiva, na redução da transmissão hospitalar, apesar das dificuldades em manter distância física dentro deste ambiente.

Em editorial de 30 de janeiro de 202 I, a revista The Lancet informa que, segundo a Anistia Internacional, mais de 7.000 trabalhadores da saúde em todo o mundo haviam morrido de Covid- 19 até setembro de 2020 (Health..., 202 I). No Brasil, de acordo com o Observatório da Enfermagem (2021), em 5 de maio de 2021 havia 54.990 casos da doença e 777 óbitos entre os profissionais da enfermagem (enfermeiros, técnicos e auxiliares), a maioria dos quais do sexo feminino ( $85 \%$ dos casos e $70 \%$ dos óbitos), marca da feminilização do cuidado em saúde (Yannoulas, 20l I). Além das mortes de pacientes, os profissionais da saúde têm lidado com um número importante de falecimentos de colegas que atuam no enfrentamento da Covid- 19 e têm sido contaminados.

Nesse contexto, o Ministério da Saúde (MS) elaborou vários protocolos com a finalidade de guiar as ações de cuidado e manejo dos corpos de pacientes com Covid- 19 (Brasil, 2020). No documento que reúne esses protocolos, o MS alerta que a transmissão de doenças infecciosas também pode ocorrer na manipulação dos corpos, em especial em equipamentos de saúde, e que a ausência ou o uso inadequado de equipamentos de proteção individual (EPIs) pode agravar o risco de transmissão e contágio, expondo os profissionais a riscos de infecção. Além disso, recomenda que funerais de pacientes confirmados ou suspeitos de Covid- 19 não sejam realizados, devido à aglomeração de pessoas em ambiente fechado, que exporia ao risco de contágio os familiares e amigos do morto, e afirma que a autópsia é desnecessária, não devendo ser realizada caso haja a confirmação ante mortem por Covid-19. Como consequência desses procedimentos, em várias localidades ocorrem "enterros-relâmpago, parentes desolados, luto frustrado" (Silva, 2020: 534), que não favorecem a elaboração do luto, como aconteceu na cidade de Manaus, por exemplo, onde caixões foram empilhados devido à falta de espaço para enterrar as vítimas da Covid-I9 (wwwl.folha.uol.com.br/cotidiano/2020/04/semespaco-para-enterrar-as-vitimas-da-covid- I 9-manaus-empilha-caixoes.shtml).

O MS recomenda também o registro e monitoramento de todos os trabalhadores que participaram dos cuidados post mortem, inclusive da limpeza do quarto. Com relação aos familiares e responsáveis pelo morto, enfatiza a necessidade de que lhes sejam oferecidas explicações adequadas sobre os cuidados com o corpo do falecido, destacando a recomendação de que a comunicação do óbito seja realizada preferen- 
cialmente por equipes da atenção psicossocial e/ou da assistência social, com auxílio sobre os procedimentos referentes à despedida do ente (Brasil, 2020). A execução desses protocolos na preparação e encaminhamento dos corpos dos falecidos para as famílias e agências funerárias gera tensões.

Baseando-nos em reflexões sobre a morte na perspectiva das ciências sociais, analisamos, por meio de pesquisa exploratória preliminar, o processo de morrer por Covid- I 9 na perspectiva de profissionais da saúde (médicos, enfermeiros, assistentes sociais, técnicos de enfermagem, psicólogos e fisioterapeutas) que atuam direta ou indiretamente com pacientes da Covid- 19 em duas unidades de tratamento intensivo (UTIs) de dois municípios do estado de Santa Catarina.

As entrevistas ( 12 no total), realizadas por videoconferência, por meio do aplicativo Jitsi ${ }^{\circledR}$, foram guiadas por um roteiro semiestruturado e flexível, que permitiu a emergência de novas questões. Cada participante foi informado sobre a pesquisa e deu seu consentimento para a coleta e a gravação de seu depoimento. Entrevistas mediadas pela tela do computador suscitam problemas teóricos e metodológicos, tanto para o grupo de pesquisadores quanto para os profissionais sujeitos da pesquisa, que não discutiremos aqui. Apenas convém indicar que as questões epistemológicas e seus impactos na coleta de dados devem ser objeto de reflexão, pois a própria produção do conhecimento também é afetada pela crise sanitária vigente.

\section{A MORTE, AS MORTES}

Fato social por excelência, a morte se impõe a todos nós, com uma força da qual não podemos escapar. Tem, portanto, as características de coerção, generalidade e exterioridade (Durkheim, 1972). Marcel Mauss (2004) se dedicou a analisar os efeitos físicos da ideia de morte no indivíduo, induzida pela coletividade, explorando as relações entre o social, o biológico e o psicológico em seus estudos sobre os povos da Nova Zelândia e da Polinésia. Nesse estudo, Mauss explorou o tema da eficácia simbólica, chamando a atenção para a morte provocada pela pressão social, que fazia com que os indivíduos fossem levados a acreditar que iriam morrer. Ou seja, a influência do social sobre o corpo físico passa pela mediação do psicológico.

No verbete sobre a morte do Dicionário de Etnologia e Antropologia, Bonte e Izard (2004) lembram que a consciência da morte (unicamente humana entre os seres vivos) suscita, desde a pré-história, representações e práticas de uma diversidade surpreendente. De acordo com esses autores, em determinadas sociedades a morte, mais que um fim, é considerada como uma viagem que convém preparar com cuidado para que o defunto 
parta só e contente do mundo dos vivos, ao passo que nas sociedades industrializadas a morte tornou-se dissimulada: a recusa a vivenciar a emoção física provocada pelo corpo morto, a importância dada ao corpo e o declínio das concepções espirituais convergiram para fazer da morte não mais um rito de passagem, mas um evento que escondemos e que se passa, em geral, longe de casa.

Ivan Illich (1975), em sua reflexão crítica sobre os efeitos contraprodutivos da instituição médica, ressalta que o processo de morrer passou a ser mediado pela tecnologia e pelo aparato hospitalar em detrimento da morte no contexto da vida cultural, e que a tentativa de reduzir o sofrimento aumentou a dependência dos indivíduos/pacientes em relação à tecnologia e à instituição médica. Nesse contexto, a morte que ocorre no hospital, fenômeno técnico por excelência, suscita novas inquietações, especialmente no nosso caso de estudo, em tempos de pandemia.

A noção de corpos dóceis elaborada por Foucault (1995), segundo a qual os pacientes são regulados por meio de estritas medidas de supervisão e controle, é frequentemente aplicada à análise das instituições de cuidado em saúde. No entanto, a perda de autonomia é sentida de formas diferentes na atenção básica e na atenção hospitalar, mais especificamente no âmbito das UTIs. Na primeira, a autonomia do paciente pode ser preservada mediante a relação entre médico e paciente, que no caso da Covid- I 9 foi influenciada pela polêmica sobre o tratamento precoce e pelas fake news, como relatado pelos profissionais. Nas UTIs, a autonomia dos pacientes é praticamente eliminada e a vivência do processo de morrer passa essencialmente pela caracterização de duas trajetórias para a morte, como identificado por Kovács (2010: 422):

Uma em que se observa o lento apagar das funções do corpo até o óbito e outra acompanhada de delírio, confusão mental, agitação, dor intensa. A "boa morte" envolve a consciência de sua aproximação; manutenção do controle da situação; dignidade e privacidade; alívio de sintomas; escolha do local da morte; acesso à informação e esclarecimento; suporte emocional, social e espiritual; presença de pessoas significativas; direitos preservados; despedidas; não ter a vida prolongada indefinidamente. Morte difícil é aquela que não é aceita, com revolta e conflito entre familiares, e sentimentos de abandono ou solidão.

Nessas trajetórias de pacientes em estado crítico com desfecho de morte (boa ou difícil), instituições médicas e profissionais da saúde são agentes intermediários e informantes-chave sobre as relações entre o biológico e o social. 


\section{OS PROFISSIONAIS DA SAÚDE E AS MORTES POR COVID-19}

Usualmente, nos hospitais e nas UTIs são os profissionais da equipe de enfermagem que mais mantêm contato, direto e prolongado, com os pacientes, atendendo a suas necessidades, estabelecendo vínculos afetivos e acompanhando por maior tempo aqueles em processo de terminalidade (Santos E Hormanez, 20 I3: 2.758). Na pandemia de Covid-19, esse aspecto se transforma, pois os profissionais da fisioterapia e médicos acabam tendo, igualmente, contato muito intenso e prolongado, principalmente, com os pacientes internados em UTIs:

Nunca tinham vivido pacientes tão graves, por tanto tempo, dificuldade da equipe, internações longas, principalmente com profissionais da enfermagem. Frustração, perda, luta muito e é muito grave. Nunca tinham acompanhado paciente com medicamento vasoativo por muito tempo. (Profissional I)

Os profissionais da saúde relataram que a morte por Covid- 19 em pessoas internadas é enquadrada como uma "morte difícil", em que se combinam sentimentos de abandono e solidão em razão dos protocolos que restringem o contato tanto dos familiares quanto da equipe de saúde com o paciente, bem como da permanência prolongada dos pacientes que necessitam de ventilação mecânica em UTI. O momento do acompanhamento dos familiares é percebido como crítico aos olhos desses profissionais:

Eu acompanhei uma família que foi identificar o corpo de um Covid, e foi bem chocante pra mim aquilo, sabe? Assim, eu não sei dizer o que a gente expõe à família naquela situação. Porque o corpo tem que sair lá do Centro de Doenças Respiratórias, lá da clínica, dentro de um saco, e esse saco não é aberto. Ele tem que entrar dentro daquele saco e tem que enterrar dentro do saco, dentro do caixão, sem a família abrir e olhar. Mas como tem pessoa de fora, de outros lugares, então a família tem que reconhecer o corpo. Então a gente, como enfermeiro, fez o quê? Se paramentou todo, paramentou os familiares, com todo aquele material que a gente falou. 0 avental, o face shield, a N95, a máscara, a luva, tudo! Tudo paramentado, e a gente leva o familiar paramentado, mostrando só a cabeça do saco. Só ali onde fica a face da pessoa, e ela olha. Reconhece a pessoa e ela não pode ficar muito tempo. Não pode abraçar. (Profissional 2)

A relação com os corpos e com os ritos que acompanham o fim da vida em situações ordinárias, dentro das rotinas dos hospitais, acaba sendo alterada em razão da pandemia. Os protocolos diferenciados de segurança para óbitos em casos de Covid- 19 tendem a objetificar ainda mais o processo de morte, acentuando as tendências mais 
gerais de individualização e afastamento de idosos e moribundos do convívio com as pessoas mais jovens. Na percepção dos trabalhadores, no caso da Covid- 19 as restrições impostas tornam o fim da vida ainda mais sofrido:

É muito triste. Mas como profissional, tem que ir na raça: "Olha, infelizmente, a gente tem que ir", e a família quer ficar ali, quer chorar, é processo de luto, sabe? É muito triste! Normalmente, famílias que são de [outras] cidades, eles recebem ligação do telefone por um assistente social, eles não recebem ao vivo. Porque como eles são de fora, como você vai esperar a pessoa vir aqui, para dar a notícia que ela morreu para depois voltar no município buscar tudo? Então, o serviço assistencial do hospital aborda o familiar por telefone. Onde se comunica tudo o que aconteceu, se foi reanimado, se não foi, e daí o familiar já vem preparado com a funerária. E essa funerária também tem que trazer um saco do município. Eu falo assim porque é o que acontece mesmo, para esse saco repor o do hospital, para se precisar no próximo óbito. Mas é bem triste! Daí a funerária chega, coloca o corpo dentro do caixão e leva, e a família não vê mais aquele familiar e outros familiares também não, a não ser que queiram reconhecer. (Profissional 3)

O processo de cuidar dos pacientes com Covid- 19 tem, de certa forma, impactado o programa de humanização do Sistema Único de Saúde (SUS), especialmente em relação às formas de acolhimento e contato com os pacientes:

A partir do momento que a gente soube da doença, a gente teve que passar por alguns treinamentos, para poder aprender a lidar com essa situação (...). A gente teve que novamente reaprender todo esse atendimento que se fazia, a gente sempre acolhendo, procurar ser bem acolhedor com as famílias (...). Nesse momento você tem que ser acolhedor, mas ao mesmo tempo manter esse distanciamento social. Então, foi uma situação um pouco difícil pra gente. (Profissional 4)

Paralelamente aos relatos de tristeza pela morte de pacientes, uma profissional relatou que telefonou para os familiares de um doente para comunicar a morte e só depois de muitas horas soube que a família estava na praia. Nesse relato, ficou evidente a crítica social a uma parte da sociedade que opera na negação das mortes pela Covid 19, não levando em conta a gravidade da doença e a necessidade de isolamento físico, mesmo quando se perde um familiar.

No ambiente hospitalar há pacientes com doenças infectocontagiosas. Por isso, protocolos de biossegurança e controle de infeções fazem parte da rotina dos serviços. A pandemia de Covid-19, no entanto, exacerbou a necessidade do rígido cumprimento 
desses protocolos (e outros específicos), tornando visível o cotidiano hospitalar e o fortalecimento da atuação multiprofissional:

Antigamente, na enfermagem era feito o tamponamento das pessoas que morriam. Então, tampa o nariz, os orifícios, enfim. E o paciente de Covid segue esse protocolo antigo. A enfermagem, quando pega ele em óbito, só faz o tamponamento e já coloca ele dentro desse saco, coloca em cima da maca e leva para o necrotério. E esse necrotério tem que ficar fechado por duas horas para depois a equipe de limpeza vir limpar, ou então para eles limparem o lugar onde ficou o corpo. Eles têm que estar todos paramentados. Isso acontece em todo lugar do hospital. Se teve paciente com Covid, a pessoa que vai limpar tem que estar paramentada, ou na ação ou depois de duas horas ela pode entrar e limpar. Então, quando chega o corpo, ele tem que fazer toda a desinfecção do lugar, por mais que ficou dentro do saco. Então, é bem pesado, tem que ser bem rígida a limpeza. Tem que tomar cuidado com a limpeza, com a paramentação, com o corpo. (Profissional 3)

O uso de máscaras e de roupas especiais foi relatado como essencial para evitar a contaminação e praticado por todos os profissionais, embora tenham reconhecido como ponto mais sensível o momento de relaxamento da equipe, em geral nos refeitórios, onde retiram as máscaras para se alimentar, deixando aberta a possibilidade de contaminação:

Eu acho que consigo contar umas 30 pessoas conhecidas assim que foram infectadas. Na verdade, a gente sente que é mais na área não Covid do que na Covid que as pessoas estão se infectando, porque nessas áreas de pacientes não Covid a tendência é paramentar diferente, não ser uma coisa tão rígida. (Profissional 5)

O ato de entubar o paciente de Covid- 19 (em situação de coma induzido) é percebido pelos trabalhadores da saúde como um momento dramático, socialmente representado tanto pelo paciente (e familiares) quanto pelos profissionais que o acompanham como iminência da morte. Uma vez constatada a insuficiência respiratória do doente e a impossibilidade da respiração espontânea, o médico decide que se deve recorrer à respiração artificial. O problema para a equipe é que todos sabem que, uma vez ocorrida a entubação, a taxa de recuperação (real ou imaginária) é baixa. Assim, a equipe da assistência social e o serviço de psicologia de um dos hospitais decidiram fazer videochamadas com os familiares, buscando amenizar o impacto desse processo e permitir o contato (em alguns casos o último) do paciente com seus parentes. Esse momento tem sido visto pelos profissionais como o de maior emoção nos processos de adoecimento por Covid-19; nas videochamadas, por vezes realizadas com equipamentos dos próprios 
profissionais, frequentemente envolvendo o doente e seus familiares (como filhos, netos, cônjuge), há sofrimento e inclusive choro deles, abafado pelos EPIs:

É algo bem complicado, porque a família às vezes faz algumas perguntas que o prontuário por si só não vai dizer. Eàs vezes são perguntas de cunho bem emocional, às vezes a família pergunta "Ah doutor, mas a minha mãe perguntou de mim?", "Quando você foi falar com a minha mãe ela demonstrou que tá com saudade da gente?". Então, com tudo isso, essa central telefônica também fazia contato com a gente: "Olha, a gente percebe que tem uma família que tá mais angustiada, que precisa entender outros tipos de questões". Então veio esse tipo de demanda. (Profissional 5)

Em nossa pesquisa, os protocolos de manejo dos doentes e dos mortos, da mesma forma que as restrições de contato com os familiares e a mediação para reconhecimento do cadáver, têm sido identificados como pontos de tensão importante nas percepções dos trabalhadores da saúde sobre a Covid- 19. A intersecção do decesso com as rígidas regras de manuseio dos cadáveres como forma de conter a propagação do vírus da Covid- 19 provocou evidente sofrimento psíquico e desconforto entre os profissionais da saúde nas equipes.

Os profissionais entrevistados, suas equipes e seus colegas precisaram reinventar formas de auxiliar os pacientes e seus familiares a lidarem com a morte. Sobre esse tema, Crepaldi e colaboradores (2020) assinalam a importância de potencializar formas alternativas e respeitosas de ritualização dos processos vividos, que permitam ressignificar as perdas pela Covid- 19 .

Em nossa investigação, foi possível observar uma mudança na relação dos profissionais com as famílias de pacientes em estado crítico, marcada pela espiritualidade como estratégia para a elaboração do luto. Surgiu uma preocupação dos familiares dos pacientes com a equipe de saúde, em certo sentido uma reciprocidade do cuidado, como relata um dos profissionais médicos entrevistados:

Para te falar a verdade, é muito estranho. A gente ficou muito mais próximo dessas famílias por telefone do que ao vivo. Então houve até uma proximidade, grande mesmo, com essas famílias: "Tá. E aí, como é que você está, como é que vai a filha, como é que vai?". Então, teve uma proximidade muito grande. Acho que o lado espiritual também, sabe, acho que pelo fato das famílias nos passarem muito essa esperança, essa fé deles, também nos atingiam, e eles desejavam muitas coisas pra gente: "Ai, doutora, nossa, que Deus te abençoe, que dê tudo certo aí com vocês, 
manda um abraço para os técnicos, porque vocês são uns anjos, queiram ou não". Mesmo quem não tinha muito essa espiritualidade acabou desenvolvendo assim, com um simples contato com as famílias, acho que foi bem intenso. (Profissional 6)

A espiritualidade tem sido evocada pelos profissionais da saúde como um recurso para lidar com situações-limite e manter o compromisso profissional. Nascimento e Caldas (2020) a consideram uma forma de promoção da saúde psíquica que exerce influência sobre as demais dimensões humanas, sendo parte da integralidade do cuidado em saúde. Tema a ser explorado em outro momento.

\section{À GUISA DE CONCLUSÃO}

A experiência social e existencial vivenciada na pandemia serve como mais um marcador histórico para se abordar o tema da morte, que é difícil e gera muitos incômodos tanto nos participantes da pesquisa quanto nos pesquisadores, como observamos nesta investigação preliminar. De um lado a naturalização das mortes por Covid-19, de outro a falta dos processos de ritualização que comprovadamente auxiliam na elaboração do luto. Segundo Philippe Ariès em sua História da Morte no Ocidente, o moribundo tem um duplo papel a desempenhar: deve superar seu transtorno e colaborar gentilmente com médicos e enfermeiros, ao mesmo tempo que, como sobrevivente, deve esconder seu sofrimento e continuar sua vida de relações sociais, de trabalho e de lazer. A negação do sofrimento e da vivência do luto, segundo esse autor, é uma decorrência da "loucura" pelo trabalho e pela produtividade nas sociedades contemporâneas, que, mantendo os indivíduos e grupos ocupados, não permite viver o luto, produzindo assim a indiferença à perda de um ente (Ariès, 2017). Essa interdição do luto e do direito de chorar pelos mortos é anterior ao fenômeno da Covid-19, mas é agora potencializada pela violência estrutural que opera, em parte, relacionada com os desdobramentos da pandemia que evidenciaram políticas institucionais mais bem entendidas pelo conceito de necropolítica, que naturaliza e inclusive provoca a morte de populações mais vulneráveis' (Mbembe, 201 6; Cepedisa E Conectas - Direitos Humanos, 202 I).

Para Norbert Elias (200 I), nas sociedades industriais desenvolvidas a morte passa pelo isolamento emocional do morto e dos moribundos, reforçado pelos avanços tecnológicos que permitem o prolongamento da vida e possibilitam a terceirização dos cuidados com os velhos, encobrindo-se dessa forma o processo de adoecer e morrer. Para esse autor, um constrangimento compartilhado com relação à finitude da vida leva à separação

\footnotetext{
' Sobre as políticas institucionais que favoreceram a propagação da pandemia no Brasil, ver especialmente Cepedisa E Conetas - Direitos Humanos, 2021.
} 
entre os moribundos e os vivos, e somente as rotinas institucionalizadas dos hospitais ofereceriam alguma forma de estruturação social para a situação de morrer, embora, na maioria das vezes, tais rotinas, destituídas de sentimento, acabem contribuindo para o isolamento do moribundo. Segundo as narrativas dos profissionais da saúde, diante do problema da Covid-19 se intensifica de modo radical esse isolamento do moribundo, tanto em relação aos seus familiares quanto em relação aos próprios profissionais, que interagem com os pacientes portando EPIs que causam receio aos internados. Também a virtualização dos processos de despedida é uma nova forma, radical, de experenciar o processo de morrer, que paradoxalmente aproxima as pessoas sem o encontro físico que até então caracterizava os rituais funerários.

No editorial da The Lancet aqui mencionado enfatiza-se que 2020 "foi um ano traumático e de testes para a força de trabalho em saúde globalmente" (Health..., 2021: 347), e que em vista da contribuição e lutas desse segmento, a Organização Mundial da Saúde (OMS) designou 202 I como o Ano Internacional dos Trabalhadores da Saúde. A campanha da OMS destaca a necessidade de investimentos por parte dos governos na força de trabalho para atuar na saúde, na educação e na aprendizagem para gerenciar a pandemia de Covid-19, visando a manter os serviços de saúde e a preparar esses profissionais para a disponibilização de vacinas. Os governos também têm o dever de proteger os trabalhadores da saúde, priorizando a sua vacinação, e, a longo prazo, de resolver o déficit substancial na força de trabalho em saúde em todo o mundo.

Acrescentamos que é urgente que disciplinas na área da formação em saúde abordem formas de lidar com a morte e de evitar contaminações no ambiente hospitalar. Também é urgente reorganizar os espaços de convívio e relaxamento no âmbito hospitalar (como os refeitórios e áreas de lazer) por onde circulam os profissionais da saúde, de modo a torná-los seguros e aprazíveis, bem como manter um suporte psicossocial efetivo para aqueles que estão na linha de frente da pandemia.

\section{REFERÊNCIAS}

ARIÈS, P. A História da Morte no Ocidente: da Idade Média aos nossos dias. Rio de Janeiro: Nova Fronteira, 2017.

BRASIL. Ministério da Saúde. Manejo de corpos no contexto do novo coronavírus: Covid- 19. Brasília: Ministério da Saúde, 2020. Disponível em: <www.saude.gov.br/images/pdf/2020/marco/25/manejocorposcoronavirus-versao I-25mar20-rev5.pdf>. Acesso em: 30 nov. 2020.

BONTE, P. \& IZARD, M. (Eds.). Dictionnaire de l'Ethnologie et de l'Anthropologie. 2. ed. Paris: Presses Universitaires de France, 2004. 
CENTRO DE ESTUDOS E PESQUISAS DE DIREITO SANITÁRIO (CEPEDISA) \& CONECTAS - DIREITOS HUMANOS. Direitos na pandemia: mapeamento e análise das normas jurídicas de resposta à Covid- 19 no Brasil, boletim n. 10, 20 jan. 202I. Disponível em: <www.conectas.org/publicacoes/download/ boletim-direitos-na-pandemia-no-10>. Acesso em: 29 jan. 2021.

CREPALDI, M. A. et al. Terminalidade, morte e luto na pandemia de Covid- 19: demandas psicológicas emergentes e implicações práticas. Estudos de Psicologia, 37: I- 12, 2020. Disponível em: <www.scielo. br/pdf/estpsi/v37// 982-0275-estpsi-37-e200090.pdf>. Acesso em: 6 set. 2020.

DURKHEIM, E. As Regras do Método Sociológico. 6. ed. São Paulo: Editora Nacional, 1972.

ELIAS, N. A Solidão dos Moribundos, Seguido de Envelhecer e Morrer. Rio de Janeiro: Jorge Zahar, 200 I.

FOUCAULT, M. O sujeito e o poder. In: DREYFUS, H. E. \& RABINOW, P. Michel Foucault: uma trajetória filosófica. Rio de Janeiro: Forense Universitária, 1995.

FOUCAULT, M. Microfísica do Poder. 26. ed. São Paulo: Graal, 2013.

HEALTH and care workers are owed a better future. Editorial. The Lancet, 397: 347, 30 jan. 202I.

ILLICH, I. A Expropriação da Saúde: Nêmesis da medicina. Rio de Janeiro: Nova Fronteira, 1975.

KOVÁCS, M. J. Sofrimento da equipe de saúde no contexto hospitalar: cuidando do cuidador profissional. O Mundo da Saúde, 34 (4): 420-429, 2010.

MAUSS, M. Sociologie et Anthropologie. 2. ed. Paris: Quadrige, 2004.

MBEMBE, A. Necropolítica. Arte e Ensaios, 32: I23- I5I, 2016. Disponível em: < https://revistas.ufrj.br/ index.php/ae/article/view/8993>. Acesso em: 6 set. 2020.

NASCIMENTO, A. K. C. \& CALDAS, M. T. Dimensão espiritual e psicologia: a busca pela inteireza. Revista da Abordagem Gestáltica, 26(I): 74-89, 2020. Disponível em <http://pepsic.bvsalud.org/scielo. php? script $=$ sci_arttextEpid $=$ S I 809-68672020000 I00008EIng $=p t E n r m=i s o>$. Acesso em: I 7 fev. 2021.

OBSERVATÓRIO DA ENFERMAGEM. Profissionais infectados com Covid- 19 informado pelo serviço de saúde. Disponível em: <http://observatoriodaenfermagem.cofen.gov.br/>. Acesso em: 29 jan. 202 I .

RICHTERMAN, A.; MEYEROWITZ, E. A. \& CEVIK, M. Hospital-acquired Sars-CoV-2 infection: lessons for public health. American Medical Association, 324(21): 2020. Disponível em: <https://jamanetwork. com/journals/jama/fullarticle/2773128>. Acesso em: 30 nov. 2020.

SANTOS, M. A. \& HORMANEZ, M. Atitude frente à morte em profissionais e estudantes de enfermagem: revisão da produção científica da última década. Ciência E Saúde Coletiva, I8(9): 2.757-2.768, 2013. Disponível em: <www.scielo.br/j/csc/a/JM3Hv9YZB8gPDJ39svnSWqM/abstract/?lang=pt>. Acesso em: nov. 2021.

SILVA, A. V. Velórios em tempos de Covid- I 9. In: GROSSI, M. P. \& TONIOL, R. (Orgs.). Cientistas Sociais e o Coronavírus. São Paulo, Florianópolis: Anpocs, Tribo da Ilha, 2020.

YANNOULAS, S. C. Feminização ou feminilização? Apontamentos em torno de uma categoria. Temporalis, I I (22): 27 I-292, 20 I I. 



\title{
Agentes de Combate às Endemias
}

\author{
uma população em risco no enfrentamento da Covid-19
}

Luiz Claudio Meirelles, Leandro Vargas Barreto de Carvalho, Marcus Vinícius Corrêa dos Santos, Ana Cristina Simões Rosa, Victor Oliva Figueiredo, Priscila Jeronimo da Silva Rodrigues Vidal,

Ana Paula das Neves Silva, Dominique Marçal Mattos, Antônio Carlos dos Santos Cardoso, Monica Regina Martins,

Maria de Fátima Ramos Moreira, Eline Simões Gonçalves, Isabele Campos Costa-Amaral, Luciana Gomes, Liliane Reis Teixeira, Maria Blandina Marques dos Santos, Alexandre Pessoa Dias,

Edilene de Menezes Pereira, Gladys Miyashiro Miyashiro, Gracia Maria de Miranda Gondim, Juliana Valentim Chaiblich,

Maurício Monken, Priscila Almeida Faria, Tatiana Nascimento Docile e Ariane Leites Larentis

\section{CONTEXTO EPIDEMIOLÓGICO, PROCESSO DE TRABALHO, ADOECIMENTO E MORTE DOS AGENTES DE COMBATE ÀS ENDEMIAS NO ESTADO DO RIO DE JANEIRO}

7 pandemia de Covid- 9 tem afetado toda a população, em especial os que se encontram em situação de vulnerabilidade, como os trabalhadores e trabalhadoras de atividades essenciais da área da saúde. Os/as agentes de combate às endemias (ACEs) atuam no "combate"' a vetores de doenças utilizando agrotóxicos e estão submetidos à exposição contínua a esses produtos, sem acompanhamento médico, o que tem resultado em processos de adoecimento e mortes. Alguns dos sinais e sintomas relacionados a essa exposição podem ser semelhantes aos de outras doenças, como a Covid-19. As condições de trabalho colocam os/as ACEs em risco de Covid- I 9 devido à circulação frequente e à sua necessidade de entrar nas residências. Além disso, a se-

\footnotetext{
' O termo "combate" remete à abordagem utilizada no país há décadas para enfrentamento das arboviroses, em campanhas de "eliminação" de vetores, empregando agrotóxicos como principal arma, o que tem se mostrado ineficaz ao longo do tempo e exposto a população a seus efeitos negativos (ver mais detalhes desta discussão no boletim SaúdeETrabalho Mata Mosquitos, 202I).
} 
melhança entre os sintomas da Covid e os sintomas da exposição aos agrotóxicos pode prejudicar a adoção das medidas de prevenção e retardar o diagnóstico e o tratamento, agravando o quadro de saúde (SaúdeETrabalho Mata Mosquitos, 2020).

O Centro de Estudos em Saúde do Trabalhador e Ecologia Humana da Escola Nacional de Saúde Pública Sergio Arouca da Fundação Oswaldo Cruz (Cesteh/Ensp/ Fiocruz) divulgou, em abril de 2020, por meio do projeto multicêntrico Estudo do Impacto à Saúde de Agentes de Combate às Endemias/Guardas de Endemias pela Exposição a Agrotóxicos no Estado do Rio de Janeiro, uma nota técnica (Cesteh, 2020) desaconselhando as visitas domiciliares pelos/as ACEs adoecidos/as e/ou imunocomprometidos/as (como resultado da exposição a agrotóxicos no processo de trabalho), enquanto durasse a pandemia, pois o distanciamento físico associado ao uso de máscaras adequadas e à vacinação são as principais medidas de proteção à saúde, segundo o conhecimento científico atual. Na nota técnica também se recomenda a implementação de estratégias de orientação realizadas remotamente para prevenção de doenças transmitidas por vetores.

Esse projeto multicêntrico é desenvolvido pelo Cesteh/Ensp/Fiocruz em conjunto com vários parceiros: Instituto Nacional de Câncer José Alencar Gomes da Silva (Inca), Instituto Aggeu Magalhães (IAM/Fiocruz Pernambuco), Escola Politécnica de Saúde Joaquim Venâncio (EPSJV/Fiocruz), Universidade Federal do Estado do Rio de Janeiro (Unirio), Universidade Federal do Rio Grande do Norte (UFRN), Fundação Centro Universitário Estadual da Zona Oeste (Uezo) e sindicatos da categoria - Sindicato dos Trabalhadores em Saúde, Trabalho e Previdência Social do Estado do Rio de Janeiro (Sindsprev/RJ), Sindicato dos Trabalhadores no Combate às Endemias e Saúde Preventiva no Estado do Rio de Janeiro (SintsaúdeRJ) e Sindicato dos Trabalhadores do Serviço Público Federal no Estado do Rio de Janeiro (Sintrasef). Esse amplo conjunto de parceiros evidencia um processo com o qual se busca avançar na construção de uma comunidade científica ampliada com a participação de trabalhadores/as, estudantes e pesquisadores/as (Larentis et al., 2020).

Os/as ACEs têm lutado permanentemente para garantir direitos trabalhistas, como o acesso a medidas de prevenção de intoxicações, que incluem treinamento, equipamentos de proteção individual (EPIs) adequados e acesso a exames periódicos para avaliação das condições de saúde, principalmente em razão da exposição a agrotóxicos empregados no processo de trabalho, que tem levado ao adoecimento e a mortes precoces (Meirelles et al., 2021; Larentis et al., 202I). 
As doenças crônicas e os quadros de imunocomprometimento manifestados pelos/as ACEs, somados às condições de insalubridade dos locais de trabalho e demais formas de precarização trabalhista, tornam estes/as trabalhadores/as mais suscetíveis a doenças infecciosas, tal como a Covid-19, podendo agravar ainda mais sua situação de saúde (Cesteh, 2020). Instituições de saúde americanas, como o Centers for Disease Control and Prevention (CDC) e a Occupational Safety and Health Administration (Osha), reconhecem que pessoas de qualquer idade com sérias condições médicas subjacentes e presença de condições médicas crônicas devem receber amplos cuidados (CDC, 2021; Osha, 2020). Assim, é fundamental reforçar os serviços de saúde para prevenção e acompanhamento desses/as trabalhadores/as e seus familiares, incluindo a atenção às sequelas oriundas da Covid- 19.

\section{A ATUAÇÃO DO/A AGENTE DE COMBATE ÀS ENDEMIAS E DO/A TÉCNICO/A DE VIGILÂNCIA EM SAÚDE}

As ações de vigilância e "combate" às endemias de arboviroses (dengue, zika, chicungunha) e a outras doenças como malária, doença de Chagas, leishmaniose etc. vêm sendo desenvolvidas no Brasil ao longo de quase 75 anos por trabalhadores e trabaIhadoras de nível fundamental e médio, hoje denominados/as, em sua maioria, no país, agentes de combate às endemias (Barbosa, Gondim E Oliveira, 2016 ; Meirelles et al., 2021 ; Larentis et al., 2021 ).

O complexo cenário da atuação desses/as trabalhadores/as de campo é marcado pelo grande número de denominações, devido à diversidade de cargos (como agente de saúde, agente de saúde pública, agente de combate às endemias, guarda de endemia etc.), para designar esse/a profissional, sendo ACE a mais usual. Mais recentemente ocorreram mudanças nas atribuições dos/das trabalhadores/as técnicos/as de nível médio, o que possibilitou sua inserção nas estruturas operacionais da Vigilância em Saúde, com ênfase na promoção da saúde, e assim foi preciso redefinir o perfil desses/as trabalhadores/as e ampliar suas atribuições, o que levou à sua redenominação como técnicos/as de vigilância em saúde (TVS). Outro aspecto problemático para esse grupo de trabalhadores/as é a grande diversidade de tipos de contrato de trabalho (celetistas, Regime Jurídico Único, terceirizados por organizações sociais) e os diferentes vínculos institucionais - municipal, estadual e federal -, com regimes de trabalho diferenciados. Também o grande contingente de trabalhadores/as com idade avançada distingue a categoria (Gondim, Monken E Pereira, no prelo; Meirelles et al., 202I). 
Os/as ACEs são profissionais que acompanharam a história da saúde pública do país e hoje, junto com os TVS, são fundamentais nas ações de controle de endemias e epidemias, pois trabalham com as equipes da Estratégia Saúde da Família (ESF) da Atenção Primária à Saúde (APS), auxiliando na integração entre as vigilâncias epidemiológica, sanitária, ambiental e da saúde do trabalhador.

O processo de trabalho do/a ACEs e TVS está estruturado com base no conhecimento epidemiológico, no saber popular, no planejamento estratégico situacional e na comunicação como ferramentas fundamentais para se dialogar e agir com a população e demais atores visando à produção social de saúde nos territórios. Permite ainda que eles/as identifiquem condições de vida e situação de saúde - problemas e potencialidades -, para desenvolver ações em conjunto com diferentes atores, recursos sociais e setores de atuação governamental (Gondim E Monken, 2017).

O trabalho conjunto e complementar entre os/as ACEs/TVS e os/as agentes comunitários de saúde (ACS) em uma base territorial comum é estratégico e desejável quando se trata de identificar os problemas de saúde-doença da comunidade e neles intervir oportunamente, facilitar o acesso da população às ações e serviços de saúde e prevenir doenças (Gondim, Monken \& Pereira, no prelo).

Diante das múltiplas determinações do processo saúde-doença-cuidado, é preciso ressignificar o processo de trabalho, o que exige: novo olhar para o território; novas configurações e arranjos assistenciais mais pautados em necessidades do que em demandas; e, sobretudo, novos sujeitos articuladores territoriais, que estabeleçam, sistematicamente, pontes entre os usuários, as equipes de saúde e demais setores sociais envolvidos com a produção social da vida (Gondim, Monken \& Pereira, no prelo).

\section{PRECARIZAÇÃO DAS CONDIÇÕES DE TRABALHO, EXPOSIÇÃO AOS AGROTÓXICOS E SOFRIMENTO MENTAL}

Apesar do potencial e da importância destes/as trabalhadores/as em sua atuação na saúde dos territórios, a situação que enfrentam é a imposição, por diferentes níveis governamentais, de processos de trabalho centrados não na perspectiva do processo saúde-doença, mas no "combate" às doenças mediante o uso de agrotóxicos para "eliminação" de mosquitos e outros vetores, que não necessariamente levam ao controle efetivo das doenças (Augusto et al., 2016; Meirelles et al., 2021). O resultado são condições de trabalho precarizadas, com exposição por décadas a diferentes classes de agrotóxicos e sem avaliação periódica de saúde, que deveria ser obrigatória (Brasil, 2019 a), levando a processos de adoecimento e morte, situação que tem se intensificado nos últimos anos (SaúdeETrabalho Mata Mosquitos, 2020; Larentis et al., 202I). 
Além de todo o contexto de exposição, adoecimento e morte, as condições de trabalho precarizadas e sobrecarga de trabalho, a realidade socioeconômica do país, o desemprego e a violência armada nos territórios são importantes fatores de sofrimento mental nessa categoria. Uma pesquisa constatou que os/as ACS e os/as ACEs foram as categorias que mais relataram medo do novo coronavírus (91,3\%), percentual maior que o observado entre os/as profissionais de enfermagem (84,3\%). Em relação à percepção do preparo para lidar com a crise, apenas 7,6\% dos/das ACS e ACEs se sentiam preparados/as para atuar no enfrentamento da pandemia (Lotta et al., 2020).

Os/as ACEs e TVS são alocados/as em pontos de apoio, na maioria inadequados para a garantia de segurança das suas atividades cotidianas com agrotóxicos e para medidas de higiene e proteção contra a transmissão do novo coronavírus. Em relação aos EPIs, sabe-se que raramente são fornecidos e, quando os há, em muitos casos são de má qualidade e/ou inadequados para as atividades realizadas pelos agentes de campo, por não oferecerem a proteção requerida (Cesteh, 2020; Meirelles et al., 2021; Larentis et al., 202 I). O local para troca de roupas e manejo de material e equipamento contaminados requer áreas devidamente planejadas de acordo com as diretrizes de biossegurança. Como agravante, tais equipamentos perdem validade e/ou se desgastam, sem substituição em tempo hábil.

Essas condições de trabalho tornam um desafio seguir as recomendações das autoridades de saúde pública para o controle e bloqueio das cadeias de transmissão do novo coronavírus.

\section{CONDIÇÕES DE SAÚDE DA POPULAÇÃO EXPOSTA A AGROTÓXICOS}

Os/as ACEs e TVS são alvos de riscos biológicos, mecânicos, físicos e principalmente químicos, devido à nocividade do processo de trabalho caracterizado pela exposição contínua a diversos tipos de agrotóxico, o que pode significar danos reversíveis ou permanentes à saúde. Ao longo das últimas décadas, identificou-se que esses/as trabalhadores/as vêm sofrendo exposição continuada a produtos neurotóxicos e/ou cancerígenos, como os organoclorados (BHC e DDT, atualmente proibidos no Brasil), organofosforados (temefós, fenitrotiona e malationa), carbamatos (bendiocarbe), piretroides (deltametrina), benzoilureias (diflubenzuron), alguns dos quais já banidos em outros países ou restritos por acordos internacionais (Cesteh, 2020; Larentis et al., 2021).

Pelas alterações de saúde observadas e por serem imunocomprometidos devido à exposição aos agrotóxicos (Lee $\varepsilon$ Choi, 2020), essa população está potencialmente mais suscetível a infecção pelo novo coronavírus, quadro agravado ainda mais pelas condições de insalubridade e precarização dos locais de trabalho desses agentes de campo (CDC, 
2021 ; Osha, 2020; Cesteh, 2020). Essas condições os tornam potencial grupo de risco para a Covid-19 e a transmissão do novo coronavírus (Brasil, 2019a; Cesteh, 2020; SaúdeETrabalho Mata Mosquitos, 2020).

Diante da nocividade da exposição aos agrotóxicos para a saúde humana, o princípio da precaução deve ser aplicado imediatamente, para resguardar a saúde dos/das ACEs e TVS, não se permitindo o manuseio desses produtos no controle vetorial. Devem ser adotados métodos alternativos, não centrados no uso desses venenos, tais como remoção mecânica, armadilhas para redução e controle de população de mosquitos, educação em saúde para a população e/ou manejo integrado de vetores (SaúdeETrabalho Mata Mosquitos, 2020).

No estado do Rio de Janeiro, desde o último concurso para a categoria, em 1994, o quadro de ACEs, em diferentes cargos, chegou a 10 mil servidores/as. Hoje, segundo o Ministério da Saúde (MS), são cerca de 6.200 trabalhadores/as, devido às aposentadorias e mortes (SaúdeETrabalho Mata Mosquitos, 2020). Dados de uma série histórica de 1942 até outubro de 2018 fornecidos pelo Núcleo Estadual do MS no Rio de Janeiro (Nerj/MS) demonstraram aumento significativo no número de óbitos nessa categoria nos últimos anos. Até 2010 , eram menos de 5 óbitos/ano e este número aumentou para cerca de 40 óbitos/ano a partir de 2015. Do total de 318 óbitos identificados nesse levantamento, 70\% ocorreram após 2011 e 50\% de 2015 até outubro de 2018. Vários tipos de doença causaram 5.024 afastamentos do trabalho, segundo dados extraídos do Sistema Integrado de Atenção à Saúde do Servidor (Siass), também fornecidos pelo Nerj. Embora o número de trabalhadores/as em atividade profissional em cada um dos anos seja aproximado, pode-se observar o aumento expressivo tanto em números absolutos quanto em proporção do número de trabalhadores/as na ativa. A avaliação das declarações de óbitos fornecidas por familiares de ACEs (Larentis et al., 2021) indicou que 75\% estavam em idade produtiva (40-59 anos), com média de 54 anos, isto é, abaixo da expectativa de vida dos/das brasileiros/as (IBGE, 2018). As principais causas de morte desses/as trabalhadores/as foram doenças do apareIho circulatório (39\%, incluindo insuficiência cardíaca, hipertensão arterial sistêmica, infarto agudo do miocárdio e doença isquêmica crônica do coração) e câncer (15\%). De acordo com o documento Saúde Brasil 2018, as doenças cardíacas também são a primeira causa de morte no Brasil e no mundo, e o câncer é a décima causa no Brasil e sexta no mundo; entretanto, nessa população de ACEs o câncer é a segunda causa de morte (Brasil, 20 l 9b). 


\section{PERSPECTIVAS DE ATUAÇÃO DOS/DAS AGENTES DE COMBATE ÀS ENDEMIAS E TÉCNICOS DE VIGILÂNCIA SANITÁRIA NO CENÁRIO DE ENFRENTAMENTO DA COVID-19}

Há limitação nas estratégias vigentes de enfrentamento das arboviroses, das quais se destaca o uso intensivo de agrotóxicos adotado por diferentes esferas governamentais, e fica igualmente claro que as origens do problema não estão meramente na dispersão do vetor, mas se articulam aos determinantes sociais da saúde (Fernandes et al., 20 I8). Além disso, o elevado número de casos de Covid-19, juntamente com o de casos de arboviroses, pode aumentar a procura por atendimento nas unidades de saúde, o que faz aumentar o risco de contágio pelo novo coronavírus (Lorenz, Azevedo $\mathcal{E}$ Chiaravalloti-Neto, 2020).

Neste período de pandemia causada pelo novo coronavírus, os/as ACEs podem, em seu importante trabalho territorializado, desenvolver atividades de vigilância em saúde emergencial para elaboração e implementação de planos de ação educativo, de comunicação e de manejo integrado de vetores para as arboviroses e outras endemias, identificando os recursos da comunidade, a localização de populações vulneráveis e utilizando a linguagem local, de modo a divulgar informações para o enfrentamento da Covid- 19. Isso porque, mesmo com todas as atenções voltadas para o novo coronavírus, as autoridades e a população não devem se descuidar da ameaça das arboviroses, que ronda a população há longo tempo, com possibilidade de epidemias periódicas.

As atividades em campo dos/das ACEs e TVS devem ser adaptadas de modo a garantir a proteção e segurança da população e também dos/das trabalhadores/as, com orientação clara sobre medidas de proteção coletiva e individual e asseguração de EPIs para os profissionais. Além disso, deve-se seguir a recomendação que consta na nota informativa n. 8 do MS (Brasil, 2020), de que, quando possível, a visita domiciliar seja realizada apenas na área peridomiciliar (frente, laterais e fundo do quintal ou terreno). Além disso, os/as ACEs e TVS considerados/as em situação de risco devem ser afastados/as de suas atividades laborais realizadas no campo, enquanto durar a pandemia. Inserir os/as ACEs e TVS nos grupos de risco prioritários para a vacinação contra Covid- 19 é necessário para a proteção desses/as trabalhadores/as, para que eles/as possam auxiliar a população no enfrentamento da pandemia. 


\section{RECOMENDAÇÕES PARA PROTEÇÃO DOS/DAS AGENTES DE SAÚDE DE CAMPO (ACE E TVS), E DA POPULAÇÃO, NO PROCESSO DE TRABALHO DURANTE A PANDEMIA DE COVID-19}

Para o trabalho desenvolvido pelos/as ACEs e TVS, diante da pandemia, da vulnerabilidade e dos riscos devem ser empregados planos e protocolos de biossegurança e de saúde do/a trabalhador/a específicos e adequados ao novo cenário, nos quais se leve em conta a incorporação de mudanças no processo de trabalho, orientações quanto a medidas de proteção coletiva e individual e a disponibilização de equipamentos e EPIs apropriados, como forma de prevenir a transmissão do coronavírus ou de quaisquer outros que venham a surgir.

A vigilância em saúde, para organização e efetividade da rede de atenção à saúde do SUS, precisa ser ativa para os/as seus próprios/as trabalhadores/as, visando à saúde do/a trabalhador/a e à promoção da saúde da população em geral. Isso implica ações emergenciais e estratégicas para os diversos tempos epidêmicos e, posteriormente, endêmicos da Covid-19 e de outras doenças emergentes e reemergentes. Assim, seguem-se algumas recomendações.

I. Manter o máximo possível de distanciamento físico em todas as atividades realizadas, a fim de observar as medidas de proteção da saúde dos trabalhadores/as e da população assistida.

2. Reestruturar, fornecer e assegurar condições para o trabalho, e que este possa ser realizado, quando possível, de forma remota. As estratégias de orientação (organizada pelos próprios/as trabalhadores/as), comunicação e educação em saúde da população devem ser prioritariamente realizadas a distância (por telefone e internet), de forma a manter os programas de redução da infestação por vetores e das doenças por eles transmitidas.

3. Sobre o trabalho no campo/visitas domiciliares

3. I. Priorizar e/ou contratar trabalhadores/as que estejam fora dos grupos de risco (por idade, adoecimento, imunocomprometimento etc.) para atender às demandas do campo, uma vez que, em muitos locais, o número desses profissionais é insuficiente, o que acarreta sobrecarga de trabalho para aqueles que muitas vezes precisam cobrir áreas que estão sem atendimento por falta de pessoal;

3.2. Aperfeiçoar o levantamento de índice do Aedes aegypti empregado durante o tratamento dos imóveis a cada ciclo, mantendo a continuidade, assim como a notificação de arboviroses durante a pandemia, desen- 
volvendo estratégias adequadas de comunicação popular. Se necessário, contratar novos/as trabalhadores/as fora dos grupos de risco para realização do levantamento;

3.3. Reestruturar as visitas domiciliares, que devem assumir nova feição e ser realizadas no peridomicílio, em local aberto, usando-se os EPIs necessários à proteção contra o novo coronavírus e mantendo-se o distanciamento físico preconizado;

3.4. Reestruturar os ambientes de trabalho dos/das ACEs e TVS, que devem ser modificados segundo as recomendações da Osha (2020) e do MS (Brasil, 2020), de forma a permitir a realização das medidas de higienização dos materiais e equipamentos utilizados, assim como das mãos, e todas as demais medidas necessárias aos/as trabalhadores/as, como paramentação, troca de roupas, banhos e manejo de resíduos perigosos, entre outras. Além disso, a disponibilidade de EPIs é essencial para proteger tanto os/as profissionais e suas famílias quanto as pessoas a serem visitadas, impedindo que eles/as se transformem em elos de transmissão da Covid-19. Devem também ser seguidos os preceitos para a proteção à saúde desses/as trabalhadores/as registrados no documento do MS (Brasil, 20 I 9a), o que não tem ocorrido;

3.5. Desenvolver ações de qualificação e de atualização para o manejo das águas e dos resíduos, tanto nas instalações laborais como nas comunitárias e domiciliares (peridomiciliar e intradomiciliar), necessário para a efetividade das barreiras sanitárias múltiplas dos/das trabalhadores/as e para orientação da população. As ações de limpeza das mãos, higiene pessoal, higiene alimentar, cuidados com instalações hidrossanitárias e saneamento domiciliar requerem, para sua efetividade, o acesso aos componentes da triangulação água, sabão (saneantes) e orientações de higiene (educação em saúde).

4. Organizar junto com a ESF/APS o manejo integrado dos vetores com ações combinadas de controles jurídico, educacional, epidemiológico, físico, genético e biológico, de acordo com as especificidades do território, suas condições de vida, seus atores sociais e os recursos comunitários disponíveis.

5. Garantir o acompanhamento psicológico aos/as trabalhadores/as, devido ao sofrimento mental gerado pelo processo de trabalho, pela convivência com a violência no território e com a pandemia, assim como pela possibilidade de contágio pelo novo coronavírus. 
6. Providenciar transporte dos/das trabalhadores/as para deslocamento até os territórios e disponibilizar materiais adequados para o desenvolvimento de suas atividades (conforme detalhado no item 3).

7. Garantir afastamento das ações de campo dos/das trabalhadores/as com mais de 60 anos, com comorbidades, adoecimento e imunocomprometimento devido à exposição a agrotóxicos, e das trabalhadoras grávidas.

8. Readequar as práticas dos/das ACEs e TVS, que se inserem na rede de forma periférica, fragmentada e desarticulada, em decorrência dos atuais modelos operacionais, cuja estruturação se limita às ações de inspeção e a campanhas direcionadas, de acordo com agravos territoriais como dengue, zika e doença de Chagas, por exemplo.

9. Desenvolver capacitação emergencial dos/das ACEs e TVS sobre as medidas de proteção aos/as trabalhadores/as e de atuação (já expostas aqui), para o enfrentamento no campo e remotamente, junto com a APS e a população, por meio da organização de ações educativas e comunicativas.

10. Desenvolver ações conjuntas com ACS nas visitas domiciliares, quando for possível, sobretudo para os/as idosos/as, pessoas com doenças preexistentes, gestantes e outros grupos de risco, para prevenção das arboviroses e outras endemias nos peridomicílios e nos espaços públicos.

I I. Desenvolver junto com a ESF/APS e a população ações de campo que favoreçam a observância das medidas preconizadas pelas autoridades sanitárias, voltadas para o distanciamento físico, a proteção individual e a higiene pessoal e coletiva.

12. Desenvolver junto com a ESF/APS e a população ações de mobilização para distribuição de cestas básicas, produção (e/ou arrecadação) e distribuição de refeições prontas com entidades civis (ONGs, grupos socioculturais, igrejas, clubes e outros) e públicas (escolas e outros) no território.

13. Desenvolver de forma remota ações organizadoras do trabalho da equipe no território (nas microáreas da ESF, quando for o caso, e nos bairros e comunidades); na produção de materiais comunicativos; na identificação e contato com lideranças locais e entidades civis; na formulação de vídeos de orientação; na produção e divulgação de matérias e músicas em jornal comunitário, programas em rádios comunitárias, carro de som, redes virtuais, e na construção de grupos de troca de mensagens com usuários para disseminar informações e acompanhar as pessoas, em articulação com lideranças comunitárias que administram canais de comunicação nas redes sociais do território. 
14. Desenvolver ações de comunicação em saúde, esclarecendo a população sobre a importância do trabalho dos/das ACEs e TVS.

15. Garantir acompanhamento médico permanente a todos/as os/as ACEs, TVS e ACS que atuam no combate às endemias e no enfrentamento das pandemias.

Com a nota técnica que deu base para a elaboração deste capítulo, o Cesteh (2020) buscou fornecer respaldo científico à proteção dos/das ACEs na pandemia e fortalecer a luta dos/das trabalhadores/as e sindicatos por melhores condições de trabalho e contra a redução salarial decorrente de cortes nas rubricas orçamentárias do trabalho de campo. E trouxe elementos para orientar as negociações com os/as gestores/as de alguns municípios para a organização do trabalho em forma de rodízio, permitindo que trabalhadores/as alternassem trabalho remoto e presencial, uma a duas vezes na semana, durante a pandemia.

Apesar de toda a luta dos/das trabalhadores/as, que contou com o apoio dos/das pesquisadores/as, o trabalho de campo com uso de agrotóxicos continua sendo realizado em muitos municípios, com um novo ciclo que se iniciou em janeiro de 2021, em pleno recrudescimento da pandemia. Se o trabalho dos os/as ACEs e TVS tivesse se orientado pela perspectiva da educação em saúde e vigilância entre as populações e territórios, o cenário de enfrentamento da Covid-19 poderia ter sido diferente, assim como o de outras doenças em que os/as trabalhadores/as atuam e continuaram existindo durante a pandemia.

\section{Agradecimentos}

Agradecemos aos/às agentes de combate às endemias/guardas de endemias e aos/às pesquisadores/as do Inca, do IAM/Fiocruz Pernambuco, da Unirio, da UFRN, da Uezo e do Instituto de Estudos de Saúde Coletiva da Universidade Federal do Rio de Janeiro (lesc/UFRJ) que participam da construção coletiva do projeto multicêntrico, assim como à equipe do Ambulatório do Cesteh, pelo atendimento dos/das ACEs do estado do Rio de Janeiro.

O projeto conta com financiamento da Secretaria de Vigilância em Saúde do Ministério da Saúde (SVS/MS). Os/As mestrandos/as e doutorandos/as do Programa de Saúde Pública e Meio Ambiente/Ensp/Fiocruz contam com suporte de bolsas da Ensp/Fiocruz, Capes e Faperj Nota 10. 


\section{REFERÊNCIAS}

AUGUSTO, L. G. A. et al. Aedes aegypti control in Brazil. The Lancet, 387(I 0.023): I.052-1.053, 2016.

BARBOSA, I. C.; GONDIM, G. M. M. E OLIVEIRA, M. S. História e contexto atual dos agentes de vigilância em saúde no Brasil. In: BORNSTEIN, V. J. et al. (Orgs.). Curso de Aperfeiçoamento em Educação Popular em Saúde: textos de apoio. Rio de Janeiro: EPSJV/Fiocruz, 2016.

BRASIL. Ministério da Saúde. Secretaria de Vigilância em Saúde. Departamento de Saúde Ambiental, do Trabalhador e Vigilância das Emergências em Saúde Pública. Manual sobre Medidas de Proteção à Saúde dos Agentes de Combate às Endemias. v. I: Arboviroses Transmitidas pelo Aedes aegypti. Brasília: Ministério da Saúde, 2019a. Disponível em: <https://www.gov.br/saude/pt-br/centrais-deconteudo/publicacoes/publicacoes-svs/dengue/manual_protecao_agentes_endemias.pdf/view $>$. Acesso em: 5 mar. 2021.

BRASIL. Ministério da Saúde. Secretaria de Vigilância em Saúde. Departamento de Vigilância de Doenças e Agravos Não Transmissíveis e Promoção da Saúde. Saúde Brasil 2018, uma Análise de Situação de Saúde e das Doenças e Agravos Crônicos: desafios e perspectivas. Brasília: Ministério da Saúde, 20l9b. Disponível em: <https://pesquisa.bvsalud.org/bvsms/resource/pt/mis-40352>. Acesso em: 5 mar. 2021.

BRASIL. Ministério da Saúde. Nota informativa n. 8/2020 de 26 mar. 2020. CGARB/DEIDT/SVS/MS. Recomendações aos Agentes de Combate a Endemias (ACE) para adequação das ações de vigilância e controle de zoonoses frente à atual situação epidemiológica referente ao Coronavírus (Covid-19), 2020. Disponível em: <www.gov.br/depen/pt-br/arquivos/Nota_Informativa_8__Coronavirus_ APS_Prisional.pdf >. Acesso em: 5 mar. 2021.

CENTERS FOR DISEASE CONTROL AND PREVENTION (CDC). Covid- 19 Information for Specific Groups of People, 2021. Disponível em: <www.cdc.gov/coronavirus/20I9-ncov/need-extra-precautions/ index.html>. Acesso em: 23 nov. 2021 .

CENTRO DE ESTUDOS DA SAÚDE DO TRABALHADOR E ECOLOGIA HUMANA (CESTEH). Nota técnica Cesteh/Ensp/Fiocruz. Agentes de combate às endemias, uma população em risco frente à Covid-19, abr. 2020. Disponível em: <www.sintsauderj.org.br/noticia/covid I9-fiocruz-divulga-nota-tecnicacontra-trabalho-de-campo-de-agente-de-combate-as-endemias $>$ e $<$ https://sindsprevrj.org/notatecnica-da-fiocruz-recomenda-que-aces-suspendam-trabalho-presencial-durante-pandemia-dacovid-19/>. Acesso em: 5 mar. 202I.

FERNANDES, V. R. et al. Desnaturalizar as "endemias de estimação": mobilização social em contextos das arboviroses no Brasil. In: SALAZAR, L. M. E LUJÁN VILLAR, R. C. (Eds.). Globalization and Health Inequities in Latin America. s. I.: Springer, 2018.

GONDIM, G. M. M. E MONKEN, M. Geografia e saúde no âmbito da educação profissional técnica de nível médio: 20 anos formando trabalhadores para o SUS. In: MAGALHÃES, S. C. M. E PEREIRA, M. P. B (Orgs.). Pesquisa e Extensão em Geografia da Saúde: entre a teoria e a prática. Montes Claros: Unimontes, 2017.

GONDIM, G. M. M.; MONKEN, M. E PEREIRA, E. M. Técnico de vigilância em saúde. In: GOMES, U. A. F. et al. (Orgs.). Dicionário de Saneamento e Saúde. Belo Horizonte: Editora da UFMG, no prelo. 
INSTITUTO BRASILEIRO DE GEOGRAFIA E ESTATÍSTICA (IBGE). Em 20I7, expectativa de vida era de 76 anos. IBGE Estatísticas Sociais, 20 I8. Disponível em: < https://agenciadenoticias.ibge.gov.br/agenciasala-de-imprensa/20 I 3-agencia-de-noticias/releases/23200-em-20 I 7-expectativa-de-vida-era-de76-anos >. Acesso em: 5 mar. 2021.

LARENTIS, A. L. et al. Crítica à abordagem toxicológica nas avaliações de exposições de trabalhadores a substâncias químicas a partir da perspectiva do Modelo Operário Italiano (MOI). In: ODDONE, I. et al. Ambiente de Trabalho: a luta dos trabalhadores pela saúde. 2. ed. rev. ampl. São Paulo: Hucitec, 2020.

LARENTIS, A. L. et al. Adoecimento e mortes de agentes de combate às endemias no estado do estado do Rio de Janeiro expostos a agrotóxicos: crítica ao processo de trabalho e construção coletiva de estratégias de enfrentamento. In: PINA, J. A. et al. (Orgs.). Saber Operário, Construção de Conhecimento e a Luta dos Trabalhadores pela Saúde. São Paulo: Hucitec, 202I. (Saúde em Debate, 33I)

LEE, G. H. \& CHOI, K. C. Adverse effects of pesticides on the functions of immune system. Comparative Biochemistry and Physiology C, Toxicology Pharmacology, 235: 108789, 2020.

LORENZ, C.; AZEVEDO, T. S. \& CHIARAVALLOTI-NETO, F. Covid- 19 and dengue fever: a dangerous combination for the health system in Brazil. Travel Medicine and Infectious Disease, 35: I0I659, 2020.

LOTTA, G. et al. A pandemia de Covid- I 9 e os profissionais de saúde pública no Brasil: nota técnica. Rio de Janeiro: Fundação Getulio Vargas, Núcleo de Estudos da Burocracia, maio 2020. Disponível em: $<$ https://ieps.org.br/wp-content/uploads/2020/06/rel0 I-saude-covid-I9-depoimentos.pdf>. Acesso em: 5 mar. 2021.

MEIRELLES, L. C. et al. Agentes de combate às endemias expostos a agrotóxicos no estado do Rio de Janeiro: relação entre saúde, trabalho e ambiente, in: A necessária integração trabalho-ambiente: problemas emblemáticos e lições aprendidas, capítulo 7, coord. Hermano Albuquerque de Castro e Lia Giraldo da Silva Augusto. In: VASCONCELLOS, L. C. F. et al. (Orgs.). Saúde do Trabalhador em Tempos de Desconstrução: caminhos de luta e resistência. Rio de Janeiro: Centro Brasileiro de Estudos de Saúde, 2021.

OCCUPATIONAL SAFETY AND HEALTH ADMINISTRATION (OSHA). Diretrizes para a Preparação dos Locais de Trabalho para o Covid-19. Departamento de Trabalho dos EUA, Administração de Saúde e Segurança Ocupacional, 2020. Disponível em: <www.abho.org.br/wp-content/uploads/2020/03/ DiretrizesdaOSHA3990-TRAD-CORONAVIRUS.pdf>. Acesso em: 24 nov. 2021.

SAÚdeEtrabalho MATA MOSQuitos. Estudo do Impacto à Saúde de Agentes de Combate às Endemias - RJ. Boletim, ano III, n. 3, ago. 2020. Disponível em: <www.cesteh.ensp.fiocruz.br/ boletins-informativos-do-projeto-guardas-de-endemias>. Acesso em: 5 mar. 2021. 



\title{
Sofrimento Mental e Trabalho na Pandemia de Covid-19
}

\author{
com a palavra, profissionais da saúde de UTIs \\ e emergências no Rio de Janeiro \\ Lúcia Rotenberg, Simone Santos Oliveira, \\ Joseane Pessanha Ferreira, Raíla de Souza Santos,
}

Davi da Silveira Barroso Alves, Aline Silva-Costa e Rosane Härter Griep

\section{$\mathrm{O}$} estudo que relataremos aqui baseia-se em relatório e apresentação sobre a atuação de profissionais da saúde durante a pandemia de Covid- 19. Analisamos os fatores que afetam sua saúde mental com base em sua própria vivência dos riscos e adversidades no trabalho. Abordamos mudanças na atividade profissional em decorrência da pandemia e ressaltamos os aspectos que afetaram a saúde mental, considerando a visão desses profissionais sobre o que fariam se tivessem total autonomia para promover mudanças em seu trabalho. Dessa forma, procuramos subsidiar ações voltadas para atenuar as adversidades e o inevitável sofrimento mental dessa categoria em futuras pandemias e situações similares.

Desde as primeiras notícias sobre a nova doença, a experiência acumulada em países da Ásia nos surtos de síndrome respiratória aguda grave (Sars) e síndrome respiratória do Médio Oriente (Mers) foi essencial como aporte importante para o novo desafio em saúde pública. Tratava-se não só de questões de infraestrutura e insumos necessários à assistência aos pacientes, mas também da preocupação com a força de trabalho no que tange à prevenção da transmissão nosocomial e a medidas voltadas para o bem-estar mental (Phua et al., 2020). No Brasil, o Grupo de Trabalho em Saúde Mental e Atenção Psicossocial (GT Smaps), que envolve o Centro de Pesquisas em Emergências e Desastres em Saúde da Fundação Oswaldo Cruz (Cepedes/Fiocruz), o Programa de Pós-Graduação em Saúde Pública da Escola Nacional de Saúde Pública Sergio Arouca (PPGSP/Ensp/ Fiocruz) e a Fundação Oswaldo Cruz de Brasília (Fiocruz Brasília), também se utilizou de evidências da literatura científica sobre as emergências sanitárias decorrentes da Sars e da Mers (Noal, Passos E Freitas, 2020). 
O material que ora apresentamos baseia-se na Pesquisa Saúde Mental em Profissionais de Saúde Frente à Pandemia de Covid- 19: informação para ações em saúde do trabalhador, realizada em colaboração com a Policlínica Piquet Carneiro, da Universidade do Estado do Rio de Janeiro (Uerj), um dos primeiros centros de referência em testagem para Covid- 19 no Rio de Janeiro. Tendo em vista a priorização dos testes para profissionais da saúde, a pesquisa abrange trabalhadores de várias categorias profissionais que atuam em todos os níveis de complexidade da saúde, incluindo unidades básicas de saúde, unidades de pronto atendimento, clínicas, secretarias de Saúde e, principalmente, hospitais gerais e especializados públicos e privados, incluindo hospitais de campanha.

\section{A SAÚDE MENTAL DOS PROFISSIONAIS DA SAÚDE EM SITUAÇÕES DE SURTOS E PANDEMIAS}

A Covid- 19 passou rapidamente de emergência de saúde pública de importância internacional a pandemia, gerando preocupação em organismos internacionais e instituições de pesquisa em todo o mundo. No Brasil, já no primeiro semestre de 2020 foram estruturadas redes de colaboração científica e social relacionadas a esta emergência sanitária, como a Rede CoVida - Ciência, Informação e Solidariedade e o Observatório Fiocruz Covid- 19 - Informação para a Ação, entre outras.

Nessa ocasião, diversas publicações registravam o impacto da pandemia sobre a saúde mental dos profissionais da saúde, identificando as fontes de seu sofrimento mental (Lai et al., 2020; Rolim Neto et al., 2020). No tocante à doença em si, salientamse a facilidade de transmissão, a alta morbidade e seu potencial efeito fatal. Na lida com os pacientes, as equipes se deparam com uma doença que se agrava rapidamente, casos graves em pacientes de todas as idades, contato com colegas de trabalho que se contaminam, podendo adoecer gravemente ou morrer, a própria contaminação, riscos de infectar familiares e a necessidade de cumprir protocolos que se modificam rapidamente em razão do desconhecimento da patologia e seu tratamento (Ayanian, 2020). Dilemas éticos e morais em situações de pressão extrema também se incluem entre os fatores que geram o desgaste emocional enfrentado pelos profissionais da saúde (Greenberg, Docherty \& Gnanaprag, 2020). Em conjunto, os riscos de infecção, o desgaste psicológico e a sobrecarga de trabalho promovem situações de medo e angústia que podem vir a gerar patologias, como depressão e ansiedade (Ornell et al., 2020).

As recomendações e orientações para o enfrentamento do impacto sobre a saúde mental dos profissionais da saúde focalizam tanto o autocuidado dos trabalhadores como medidas voltadas para os gestores (Noal, Passos E Freitas, 2020). Entre as 
recomendações, estão: disponibilizar e garantir o treinamento em relação aos equipamentos de proteção individual, os EPIs (Heliotério et al., 2020; Teixeira et al., 2020), promover mudanças na organização do trabalho buscando alternar atividades de alta e baixa tensão, e assegurar momentos e espaços adequados para a alimentação e o descanso (Noal, Passos \& Freitas, 2020), que devem ser garantidos inclusive para trabalhadores com vínculos mais frágeis (Noal, Passos \& Freitas, 2020). Incluem-se, ainda, a redução da jornada, caso possível, além da testagem regular dos profissionais da saúde (Heliotério et al., 2020).

Há reconhecimento unânime quanto à necessidade de prover apoio psicológico e de investir na comunicação contínua com os trabalhadores, em um esforço para mapear e divulgar as ações de cuidado com a saúde mental disponíveis em cada local (Noal, Passos E Freitas, 2020; Heliotério et al., 2020). De um ponto de vista mais amplo, cabe assinalar a recomendação de se considerar a Covid- 19 como doença relacionada ao trabalho, principalmente para grupos ocupacionais mais expostos, como propõem Heliotério e colaboradores (2020).

\section{A PERSPECTIVA DOS TRABALHADORES DA LINHA DE FRENTE CONTRA A COVID SOBRE 0 TRABALHO}

\section{Breve descrição do estudo}

O material aqui apresentado resultou de estudo qualitativo que se seguiu a um estudo epidemiológico baseado em um questionário on-line sobre a percepção de riscos, o comprometimento da saúde mental e a organização do trabalho. Os trabalhadores eram convidados a preencher o questionário na plataforma Saúde Mental e Trabalho em Saúde na Pandemia de Covid- 19 ao chegar à Policlínica Piquet Carneiro/Uerj para realizar a testagem (ou por e-mail, no caso dos que já haviam sido testados). Ao terminar o preenchimento, o profissional era convidado a participar da segunda etapa, que consiste em uma entrevista remota. O estudo foi realizado de maio a agosto de 2020.

Do banco de dados geral, constituído por 4.904 trabalhadores, I.306 (27\%) são de interesse para este relato, por atuarem em unidades de tratamento intensivo (UTIs) e emergências dos hospitais. Destes, a maioria é do sexo feminino (81,6\%), com escolaridade mínima de ensino superior $(77,5 \%)$. Aproximadamente a metade tem idade superior a 40 anos $(52,2 \%)$, é casada ou vive em união (57,3\%), cuida de criança ou idoso $(52,3 \%)$ e trabalha em plantões diurnos e noturnos $(54,9 \%)$. Com relação à sua atividade profissional, a maioria a considera um trabalho de risco $(85,2 \%)$. Proporção superior a $70 \%$ refere que desde o início da pandemia houve aumento no ritmo de 
trabalho, na realização simultânea de atividades diferentes, na ocorrência de situações imprevistas e de situações contraditórias, de novos métodos ou instrumentos e no número de atendimentos realizados.

A etapa qualitativa do estudo compôs-se de entrevistas individuais remotas com profissionais da saúde e de encontros remotos que reuniam pesquisadores e profissionais da saúde, denominados Encontros sobre o Trabalho (Masson, Gomes \& Brito, 2015).

Foram realizadas 80 entrevistas individuais, conduzidas por 13 entrevistadores, que participaram de três sessões de treinamento. O roteiro de entrevista abordava o tipo de unidade de saúde, o setor e a função, considerando a possibilidade de o profissional ter mais de um vínculo, oportunidades de dialogar com a equipe e com os gestores, mudança que proporia no trabalho se tivesse total autonomia e a descrição, em uma palavra, do sentimento sobre este momento de pandemia, entre outras questões. Nos casos de profissionais da saúde com mais de um vínculo de trabalho, a solicitação era de que considerassem aquele no qual os riscos de contaminação lhe parecessem maiores. Ao final, o profissional da saúde era consultado sobre o interesse em participar dos Encontros sobre o Trabalho.

Houve cinco Encontros sobre o Trabalho, com a participação de 16 profissionais da saúde. Neles, recorreu-se a dinâmicas em que se colocava em debate a atividade dos profissionais da saúde na pandemia. Solicitava-se que cada trabalhador escrevesse três palavras que remetessem ao seu trabalho na pandemia, e depois se discutia acerca dos seus diversos sentidos no grupo, compartilhando assim suas vivências e sentimentos. Finalmente, pedia-se que dissessem que situação gostariam de mudar em seu ambiente de trabalho e como o fariam, caso tivessem total autonomia para isso, reforçando uma pergunta das entrevistas que pareceu bastante potente para inspirar possíveis ações para a saúde dos trabalhadores.

Tendo em vista limitações de espaço e das análises realizadas, os resultados apresentados aqui se referem a 29 profissionais da saúde que atuam em UTIs e emergências - 13 enfermeiras/os, 8 técnicos/as de enfermagem, 4 médicos/as e 4 fisioterapeutas -, bem como a relatos oriundos dos Encontros sobre o Trabalho.

\section{Aporte de resultados}

De maneira geral, os textos derivados das entrevistas são fluidos, no sentido de o diálogo retornar a alguns pontos, reafirmando questões abordadas anteriormente. Os fatores aos quais os trabalhadores atribuem o sofrimento psíquico emergem quando o diálogo aborda as mudanças no trabalho decorrentes da pandemia, assim como quando 
tratam do que modificariam se tivessem autonomia. Por exemplo, uma enfermeira de UTI de hospital público precisou mudar de setor diversas vezes por falta de recursos humanos, pois boa parte da equipe adoecera. Ela se refere à necessidade de usar máscara que aperta o rosto, face shield, capote e luva por 12 horas, e às vezes por 24 horas, quando precisa dobrar o turno, "então a gente se sentia, de uma forma geral, muito sobrecarregado". Tais situações se articulam ao que ela modificaria no trabalho se tivesse total autonomia, pois se refere a I) contratar profissionais da enfermagem, médicos e fisioterapeutas, pois não adiantaria comprar materiais e insumos sem que houvesse "os profissionais ali para poder estar atuando", e 2) "pensar em maneiras de fazer uma escala diferenciada, talvez ofertar algumas folgas pras pessoas terem um pouco mais de alívio diante da rotina”.

Aumentar a força de trabalho não só reduz a sobrecarga, mas pode permitir à gestão oferecer dias de folga para aliviar o cansaço físico e mental decorrente do trabalho. Além disso, a ampliação da equipe permite introduzir pausas durante os plantões, tão necessárias para a recuperação e alimentação (Ornell et al., 2020). A esse respeito, é essencial prover espaços adequados para o descanso e alimentação, incluindo o fornecimento de água potável (Noal, Passos \& Freitas, 2020), como observado por mais de um profissional. Trata-se de necessidades básicas dos profissionais da saúde, que devem ser identificadas e supridas, de acordo com a Organização Mundial da Saúde (WHO, 2020).

Cabe destacar o papel das pausas durante o plantão na redução do desgaste decorrente do processo de paramentação e desparamentação (Machado et al., 2020). A esse respeito, um técnico de enfermagem de UTI de hospital público elogia a chefe do setor por adotar a estratégia de dividir a equipe e fazer um intervalo no qual os trabalhadores ficam fora da unidade, se revezando: "Foi alternado, então, foi uma forma de contornar isso, a dificuldade de estar paramentado o tempo todo. Acho que funcionou, não me senti esgotado".

Os riscos decorrentes do trabalho se expressam no sentimento de impotência diante da doença. Como observa uma enfermeira de emergência de hospital público, há uma desesperança ligada à sensação "de que você vai se contaminar e não tem essa segurança de que terá um caso grave ou leve, você não sabe quem da sua família pode ir ou se você mesmo não corre esse risco, então você fica realmente vulnerável a qualquer acontecimento".

São muitas as situações em que os profissionais se ressentem da reduzida preocupação com a saúde dos trabalhadores e aos riscos por estes assumidos, como na orientação de "não usar máscara no início da pandemia para não assustar a população" 
(médica de emergência de hospital público), ou na restrição da testagem para Covid- 19 apenas a situações graves, no caso de trabalhadores do hospital (técnica de enfermagem de UTI de hospital de campanha). A testagem dos profissionais da saúde, inclusive os assintomáticos, é medida recomendada para viabilizar a busca ativa de infecção por Covid- 19 (Heliotério et al., 2020).

Outro aspecto que traduz o descaso com os trabalhadores, expressão usada por vários deles, é a falta de acolhida ao profissional que está afastado (enfermeira de UTI de hospital público). A seu ver, ela merecia mais do que apenas "seu atestado acabou" quando cobrada quanto à volta ao trabalho. Situações de retorno ao trabalho ainda com sintomas de Covid- 19 foram mencionadas por uma fisioterapeuta de UTI de hospital privado. A fala a seguir exemplifica a vivência dos profissionais em relação a sua própria saúde.

Eu fiz duas infecções urinárias nesse período porque eu não conseguia sair pra beber água por conta da paramentação e não conseguia ir ao banheiro quando eu tinha vontade (...). Eu precisei me ausentar dois dias exclusivos do trabalho e tive que voltar antes da resolução da doença. (...) Então, assim a gente não tinha suporte, "e aí, como é que você está, está precisando de alguma coisa? Você está melhor? Você quer que a gente troque a sua escala pra um outro dia?" (...) Então foi mais ou menos assim, eu acho que muita gente caiu, ficou mal por conta disso, entendeu? Por essa falta de suporte. (Médica de UTI de hospital público)

De maneira geral, os profissionais da saúde se ressentem da falta de apoio psicológico nos hospitais. Para uma técnica de enfermagem de emergência de hospital privado, "quando você é responsável por um hospital, você é responsável por quem está ali dentro"; se tivesse autonomia, ela colocaria "uma assistente social, uma psicóloga, disponível para os profissionais da saúde" para que pudessem "tratar o psicológico, não só no Covid, mas enquanto estiver trabalhando ali”. Ao mencionar o apoio psicológico aos profissionais da saúde que promoveria se tivesse autonomia, uma médica de UTI de hospital público lembra que "sempre tem alguém que surta (...) é muita carga, é muita pressão em cima da gente”. Uma enfermeira da emergência que atua nas redes pública e privada confirma:

Nós não tivemos suporte emocional de maneira nenhuma, nenhuma, nenhuma, nenhuma, tá? Foi zero, tanto para os que saíram infectados quanto para os que permaneceram dentro da unidade hospitalar, em nenhum momento nós fomos visitados, ou alguém entrou em contato, até mesmo via remota. 
A disponibilização do apoio psicológico parece fazer toda a diferença quando se trata de evitar que o sofrimento psíquico venha a desencadear uma manifestação psicopatológica (Noal, Passos \& Freitas, 2020). Uma enfermeira de UTI de hospital público foi afastada por estar com Covid e ficou "bem arrasada, um mês de licença, ainda tive a parte psicológica, que ficou superabalada com toda essa movimentação e essa falta de tato que eu acho que eles tiveram" (refere-se ao hospital) (...) "Quase que eu entro de licença pela psiquiatria”. Ela informa que ao longo desse período foi acompanhada por uma psicóloga de uma instituição que semanalmente fazia uma hora de terapia on-line e "fez um trabalho muito bacana. E aí, quando terminou o meu atestado por Covid, eu consegui retornar".

Observamos, no entanto, situações em que o suporte psicológico a distância parece não ser suficiente para atender às necessidades dos profissionais da saúde. Uma médica de UTI e emergência de hospitais públicos, ao falar de seu isolamento em relação à família e aos amigos, salienta que

... a gente não tinha nenhum espaço físico no hospital em que a gente literalmente pudesse fazer essa catarse. (...) Afinal, todo mundo estava participando de home office, psicologia, serviço social. Então, sentimos falta dos profissionais lá dentro na batida, junto com a gente.

Na mesma linha, uma técnica de enfermagem de UTI de hospital público se manifesta sobre a importância de reunir a equipe no próprio local de trabalho, enfatizando que os trabalhadores não estavam acostumados a ver tanta morte: "Então, galera, ah, toda semana, uma vez na semana você tem meia hora com um grupo de apoio aí embaixo, depois do plantão".

A demanda por um grupo de apoio remete à sensação de alívio advinda quando é possível se expressar, com palavras escritas e faladas, em situações de muita angústia. Além disso, a ênfase em contar com grupo de apoio no local de trabalho e com a própria equipe remete à sugestão de realizar reuniões curtas no início dos plantões, que "podem aumentar a sensação de estamos juntos e diminuir a ansiedade da equipe" (Noal, Passos E Freitas, 2020: 48).

Situações sentidas como de grande injustiça contribuem fortemente para o sofrimento mental dos profissionais da saúde:

O fato de estar trabalhando nesse hospital, que é uma grande rede de medicina privada, contribuiu muito para o meu sofrimento pessoal, emocional e psíquico, porque eu via muitas injustiças e não me conformava com isso. (...) O hospital 
privado, eu vi que ele era totalmente voltado para o capitalismo, e isso me entristecia muito no sentido de que, se eu tinha dois pacientes que precisavam de UTI, o que ia ter a vaga mais rápido era aquele que tinha um plano melhor; o que tinha o plano mais simples poderia até ser que ele estivesse mais grave, como já aconteceu, só que ele iria aguardar porque o plano era mais simples e estava em busca de vaga, mas todos os locais estavam lotados. (Enfermeira de emergência de hospital)

O próprio treinamento em relação aos EPIs, considerado uma recomendação essencial (Heliotério et al., 2020), pode não surtir o efeito desejado se não houver real preocupação em atingir toda a força de trabalho, como salienta um técnico de enfermagem de UTI de hospital público. Ao comentar sobre o treinamento ofertado pela instituição, ele observa a falta de preocupação com a disponibilidade dos trabalhadores, seja porque o treinamento se deu fora do dia de seu plantão, seja porque ocorreu no dia de seu plantão, porém sem que houvesse como viabilizar a saída do setor naquele momento. Evidencia-se, ainda, a preocupação de trabalhadores com o fato de que os treinamentos não eram oferecidos a profissionais da saúde contratados posteriormente.

A falta de treinamento foi mencionada por uma enfermeira de emergência de hospital público, que a atribuiu ao fato de, "talvez, ser plantão noturno". Segundo a trabaIhadora, o fluxo de informações é prejudicado nos plantões noturnos, o que confirma observações de outros autores (Amante et al., 20ll); na pandemia essa situação não se mostra diferente.

Alguns profissionais abordam a falta de reconhecimento, tão relevante para a saúde no trabalho (Dejours \& Abdoucheli, 20 I0), como nesta menção ao fato de o seu conhecimento frequentemente não ser considerado nas ações dos gestores:

Então eu acho que essa questão de ouvir as equipes já seria um ponto altíssimo, pois a supervisão, no desespero de dar resposta, acaba mexendo aqui e ali sem perguntar a ninguém, sai fazendo, a gente se sentiu pedra de xadrez. (Enfermeira de emergência de hospital público)

Quando perguntados sobre o que pode ser melhorado no trabalho, os profissionais da saúde trazem elementos que beneficiariam a própria saúde mental e física, como o apoio psicológico no hospital. Mas também proposições voltadas para a melhoria da assistência ao paciente, como a preocupação com a humanização, trazida por vários trabalhadores. Por exemplo, quando questionada sobre mudanças que faria no trabalho, uma técnica de enfermagem de hospital de campanha respondeu que promoveria a "humanização do paciente", conjecturando sobre "ter um canal ou qualquer coisa que alguém fizesse para poder... a família tem que ter esse contato!”. Uma fisioterapeuta de 
emergência mudaria o fluxo no hospital, se pudesse, pois considera "muito desumana a relação paciente-família, hospital-família (...) a gente não tem uma assistência social que pudesse conversar com esse familiar para dar esse suporte, entendeu?".

A preocupação com a humanização do cuidado remete ao anseio por prover uma boa assistência e ao senso de responsabilidade por um trabalho bem feito, que emerge na fala dos profissionais da saúde. Em contrapartida, a sensação de não atender ao paciente em todas as suas necessidades leva o trabalhador a sofrer e, possivelmente, a adoecer, o que permite dizer que a má assistência é fator de sofrimento.

Como assinalam Lancman e Sznelwar (2004) em análise sobre a psicodinâmica do trabalho proposta por Dejours, o trabalho nunca é neutro em relação à saúde, pois tanto a favorece quanto pode ser patogênico. A esse respeito, uma enfermeira de UTI de hospital público observa

... esta questão psicológica... porque no primeiro dia em que eu trabalhei naquele hospital eu fui dormir chorando. Era muita negligência com os pacientes (...). Não havia ventilação mecânica para todos que precisavam, então tínhamos que praticamente assistir ao paciente ir para lá, morrendo, sem ter o que fazer.

Muitos problemas provêm do chamado "SUS real" decorrente do subfinanciamento crônico (Paim, 20I8), problemas que a enfermeira sintetiza na frase "Porque não foi apenas a Covid que matou os pacientes, foi a falta de cuidados adequados".

\section{A ASSISTÊNCIA À SAÚDE NA PANDEMIA DE COVID-19: QUE LIÇÕES EXTRAIR SOBRE A SAÚDE DOS TRABALHADORES?}

A questão central da pesquisa aqui relatada, a assistência a pacientes de Covid- 19 em um momento sanitário emergencial na perspectiva de médicas/os, enfermeiras/os, técnicas/os de enfermagem e fisioterapeutas que atuam em UTIs e emergências de hospitais no Rio de Janeiro, nos chama à responsabilidade. O total despreparo das unidades de saúde reafirma a necessidade de extrair lições que venham a favorecer o enfrentamento da doença e o cuidado com a saúde dos trabalhadores em emergências futuras.

Duas lições principais emergem do material empírico. A primeira é a concepção de que como o sofrimento mental e físico dos trabalhadores é inevitável em razão das características da doença e das relações do profissional da saúde com o seu trabalho, a inexorabilidade desse sofrimento implica uma demanda por ações voltadas para atenuá-lo.

A segunda lição se refere a situações em que as recomendações para o enfrentamento da pandemia são seguidas, mas podem não atingir seu objetivo por não res- 
peitarem peculiaridades do cotidiano do trabalho em saúde. Um exemplo é o fato de trabalhadores não conseguirem usufruir do treinamento no uso de EPIs no próprio hospital, porque este é realizado nos dias convenientes para a instituição, e não para o trabalhador. A comunicação interna nos hospitais - ainda mais essencial em momentos de mudanças de protocolos - é outro exemplo, pois o fluxo de informações é prejudicado, especialmente nos plantões noturnos.

Lutar pela saúde dos profissionais da saúde no contexto da pandemia de Covid-19 se impõe como um dever ético. Concordamos com Barroso e colaboradores (2020) sobre o quanto a atual pandemia demanda a atualização dos princípios do SUS de universalidade, integralidade e equidade, bem como a garantia dos direitos dos trabalhadores. Trata-se de assegurar o "direito ao acesso a serviços de saúde; à proteção social, nos casos de impossibilidade de exercer suas atividades de trabalho; ao trabalho digno, instrumentalizado e protegido aos trabalhadores e trabalhadoras da saúde" (Barroso et al., 2020: 1.100).

É apenas no contexto de respeito à vida e ao trabalho que a voz dos profissionais da saúde (e o atendimento a suas demandas) poderá fazer sentido em futuras situações de desastres e emergências sanitárias.

\section{Agradecimentos}

Os autores agradecem a Claudia Comaru, Cristina Villaça, Denize Nogueira, Gilmara Silva, Hugo Gama, Manuella Pessanha, Marina Pamplona, Samara Leal, Talita Nascimento e Thaís Cândido, que integraram a equipe de entrevistadores, por disponibilizarem seu tempo e competência para a pesquisa.

\section{REFERENNCIAS}

AMANTE, L. N. et al. Reflexões sobre o poder do enfermeiro do plantão noturno. In: SEMINÁRIO NACIONAL DE PESQUISA EM ENFERMAGEM, 16, 201 I, Campo Grande.

AYANIAN, J. Z. Mental health needs of health care workers providing frontline Covid- I 9 care. Journal of the American Medical Association - Health Forum, 2020. Disponível em: < https://jamanetwork.com/ journals/jama-health-forum/fullarticle/2764228>. Acesso em: 23 nov. 2021.

BARROSO, B. I. L. A saúde do trabalhador em tempos de Covid-19: reflexões sobre saúde, segurança e terapia ocupacional. Cadernos Brasileiros de Terapia Ocupacional, 28(3): I.093-1 I I02, 2020.

DEJOURS, C. \& ABDOUCHELI, E. Itinerário teórico em psicopatologia do trabalho. In: DEJOURS, C.; ABDOUCHELI, E. \& JAYET, C. (Orgs.). Psicodinâmica do Trabalho: contribuições da escola dejouriana à análise da relação prazer, sofrimento e trabalho. São Paulo: Atlas, 2010. 
GREENBERG, N.; DOCHERTY, M. \& GNANAPRAG, S. Managing mental health challenges faced by healthcare workers during covid- I 9 pandemic. British Medical Journal, 368: I.21 I, 2020

HELIOTÉRIO, M. C. et al. Covid- 19: por que a proteção da saúde dos trabalhadores e trabalhadoras da saúde é prioritária no combate à pandemia? Trabalho, Educação e Saúde, 8(3): e00289 I 21, 2020.

LAI, J. et al. Factors associated with mental health outcomes among health care workers exposed to coronavirus disease. Jama Network Open, 3(3): e203976, 2020.

LANCMAN, S. E SZNELWAR, L. I. (Orgs.). Christophe Dejours: da psicopatologia à psicodinâmica do trabalho. Rio de Janeiro, Brasília: Editora Fiocruz, Paralelo I5, 2004.

MACHADO, W. C. A. et al. Covid- 19 nos movimentos de paramentação de vestir-se e desvestir-se dos enfermeiros: Nightingale, a pioneira, tinha razão! Research, Society and Development, 9(7): I-23, 2020.

MASSON, L. P.; GOMES, L. \& BRITO, J. Encontros sobre o Trabalho: reflexões sobre o uso desta ferramenta metodológica em pesquisas em unidades de tratamento intensivo neonatais. Laboreal, I I (I), 20 I5.

NOAL, D. S.; PASSOS, M. F. D. E FREITAS, C. M. Recomendações e orientações em saúde mental e atenção psicossocial na Covid-19. Brasília: Ministério da Saúde, Fundação Oswaldo Cruz, Escola de Governo, 2020.

ORNELL, F. et al. "Pandemic fear" and Covid- 19: mental health burden and strategies. Brazilian Journal of Psychiatry, 2020.

PAIM, J. S. Sistema Único de Saúde (SUS) aos trinta anos. Ciência E Saúde Coletiva, 23(6): I.723I.728, 2018.

PHUA, J. et al. Asian Critical Care Clinical Trials Group: intensive care management of coronavirus disease 2019 (Covid- 19): challenges and recommendations. The Lancet Respiratory Medicine, 2020.

ROLIM-NETO, M. L. When health professionals look death in the eye: the mental health of professionals who deal daily with the 2019 coronavirus outbreak. Psychiatry Research, 288, 2020.

TEIXEIRA, C. F. S. et al. A saúde dos profissionais de saúde no enfrentamento da pandemia de Covid- 19. Ciência E Saúde Coletiva, 25(9), 2020.

WORLD HEALTH ORGANIZATION (WHO). Covid- I 9 Public Health Emergency of International Concern (PHEIC) Global Research and Innovation Forum: towards a research roadmap, 2020. (RED Blueprint). Disponível em: <www.who.int/publications/m/item/covid-19-public-health-emergency-ofinternational-concern-(pheic)-global-research-and-innovation-forum>. Acesso em: 23 nov. 2021 . 



\title{
A Saúde dos Trabalhadores da Saúde
}

\author{
a experiência do Centro Hospitalar do \\ Instituto Nacional de Infectologia \\ Simone Santos Oliveira, Lúcia Rotenberg, Denize Nogueira, \\ Eliane Chaves Vianna, Jorge Mesquita Huet Machado, \\ Joseane Pessanha Ferreira, Luciana Bicalho Cavanellas, \\ Manuella Pessanha, Marcello Rezende, Maria Cristina Strausz, \\ Maria de Jesus Fonseca, Marisa Augusta de Oliveira, \\ Rosane Härter Griep e Sônia Gertner
}

$\mathrm{O}$ surto da Covid-19 passou, em 40 dias, de emergência de saúde pública de importância internacional a pandemia, o mais alto nível de alerta da Organização Mundial da Saúde (OMS) conforme o Regulamento Sanitário Internacional, declarada em II de março de 2020.

Devido ao grande avanço da doença no Brasil, principalmente na região Sudeste, fez-se necessária uma rápida reestruturação no sistema de saúde pública com o objetivo de atender à nova demanda e impedir o colapso dos serviços de saúde nos três níveis de atenção, o primário, o secundário e o terciário. Como retaguarda, foram construídos hospitais de campanha e foi ampliado o número de leitos em todo o país. No Rio de Janeiro, além dessas modalidades, foi construído o novo Centro Hospitalar para Pandemia de Covid- I 9, vinculado ao Instituto Nacional de Infectologia da Fundação Oswaldo Cruz (INI/Fiocruz), que tem caráter permanente (Câmera E Fuchs, 2020).

Nesse cenário de crise sanitária, milhares de profissionais da saúde diretamente responsáveis pelo enfrentamento da doença estão frequentemente expostos ao vírus. Segundo o Boletim Epidemiológico Especial n. 44 (Brasil, 2020), da Semana Epidemiológica 53 (27/I 2/2020 a 02/0I/202 I), até o dia 2 de janeiro de 2021 foram notificados no e-SUS Notifica 442.285 casos confirmados de Covid- 19 em profissionais da saúde. As profissões da saúde com maiores ocorrências foram técnicos/as e auxiliares de enfermagem ( 48.007 ; 33,5\%), seguidos de enfermeiros/as (67.072; 15,2\%) e médicos/as (48.859; $11 \%)$. 
A alta taxa de contaminação dos profissionais da saúde tem gerado elevado índice de afastamentos e mortes. Entretanto, não só a contaminação é preocupante para esses/as trabalhadores/as. Estresse, angústia, depressão, fadiga, longas jornadas também podem comprometer o bem-estar desses/as que são essenciais na luta contra a pandemia. Diversos estudos têm mostrado que profissionais da saúde da linha de frente envolvidos/as nos cuidados relacionados à Covid- 9 têm maior risco de desenvolver sintomas de depressão, ansiedade, insônia e angústia (Lai et al., 2020; Walton, Murray \& Christian, 2020).

São apresentados aqui resultados da Pesquisa Saúde Mental dos Trabalhadores e Trabalhadoras da Saúde em Contexto de Emergência Sanitária: Covid-19, realizada no Centro Hospitalar para Pandemia de Covid-19, do INI/Fiocruz,' com a qual se objetivou analisar as condições e os aspectos psicossociais e de saúde mental relacionados ao trabalho, na perspectiva de gerar ações de apoio aos/às trabalhadores/as. Essas ações são viabilizadas mediante a contribuição e articulação da pesquisa com a Coordenação de Saúde do Trabalhador (CST/Fiocruz) e a direção do INI/Fiocruz.

O desenvolvimento da pesquisa-intervenção se realizou mediante: I) aplicação de questionário sobre a percepção de risco, uso de equipamentos de proteção, organização do trabalho e comprometimento da saúde mental durante a pandemia; e 2) promoção de diálogo em Grupos de Encontros sobre o Trabalho (GEST) no qual se consideram a complexidade do trabalho e a experiência prática dos/as trabalhadores/as fundamental para a prevenção de adoecimentos e para a promoção da saúde. Com base no conceito de atividade oriundo da ergonomia da atividade (Guérin et al., 200 I) e desenvolvido pela ergologia (Schwartz \& Durrive, 20l0), trabalho é aqui considerado como ato de gerir defasagens, atividade guiada por uma prescrição, mas nunca se restringindo a ela, e sempre modificada por um sujeito no curso da ação.

Propõe-se que, após sistematizados, os resultados da pesquisa sejam validados junto com os profissionais, tendo em vista estabelecer práticas no campo da saúde do/a trabalhador/a. Dessa forma, compõem o grupo de pesquisa profissionais da CST/ Fiocruz e do Núcleo de Saúde do Trabalhador do INI (Nust/INI/Fiocruz), na perspectiva da construção de uma vigilância permanente.

\footnotetext{
' Projeto aprovado pelos comitês de Ética da Escola Nacional de Saúde Pública Sergio Arouca (CEP/Ensp/Fiocruz) e do Instituto Nacional de Infectologia Evandro Chagas (CEP/INI/Fiocruz), CAAE n. 3I 264820.5.0000.5240.
} 


\section{CENTRO HOSPITALAR PARA A PANDEMIA DE COVID-19}

O Centro Hospitalar para a Pandemia de Covid- I9/INI foi uma das inúmeras ações de enfrentamento da pandemia do novo coronavírus lideradas pela Fiocruz. Destinado a pacientes em estado grave diagnosticados com a doença, foi construído em menos de dois meses na sede da Fiocruz, no Rio de Janeiro, fornecendo ao Sistema Único de Saúde (SUS) 195 leitos para tratamento da doença.

A inauguração do Centro Hospitalar ocorreu em 19 de maio de 2020, embora em fevereiro desse ano o INI/Fiocruz já fosse referência para casos suspeitos da doença no estado do Rio de Janeiro. Sua história traz a marca do legado da Fiocruz em seus 120 anos de defesa da vida e da população em grandes epidemias como as da peste bubônica, da febre amarela, da varíola e da gripe espanhola.

O Centro Hospitalar ocupa área total de 9,8 mil metros quadrados, com entrada exclusiva para ambulâncias e heliponto, e sua força de trabalho é composta por mais de mil profissionais, entre médicos/as, enfermeiros/as, técnicos/as de enfermagem, fisioterapeutas, farmacêuticos/as, psicólogos/as, assistentes sociais e outras categorias de apoio. Assim, muitas histórias de vida e trabalho compõem seus alicerces e reforçam sua importância no combate à pandemia e na defesa da vida.

A equipe da CST tem participado na intermediação entre a organização internacional Médicos Sem Fronteiras (MSF), a Vice-Presidência de Ambiente, Atenção e Promoção da Saúde (Vpaaps), a Vice-Presidência Gestão e Desenvolvimento Institucional (VPGDI) e a Coordenação-Geral de Gestão de Pessoas (Cogepe) da Fiocruz no intuito de estabelecer parceria para troca de experiências em situações de emergência, além da capacitação de profissionais do INI considerados referência para que atuem como multiplicadores/as dos conhecimentos adquiridos para os novos trabalhadores/as.

Por seu caráter permanente, o hospital tem características específicas que o diferem das unidades de campanha que foram erguidas pelo país para funcionamento temporário (confira aqui uma vista 3D). Nele, também são realizadas ações do ensaio clínico Solidariedade (Solidarity), da OMS, liderado no Brasil pela Fiocruz. A iniciativa tem como objetivo investigar a eficácia de quatro tratamentos para a Covid- 19. O Estudo Solidarity é uma conjugação de esforços em todo o mundo para dar uma resposta rápida sobre os medicamentos que são eficazes no tratamento da Covid-19 e os que são ineficazes e não devem ser utilizados. 


\section{ANÁLISE PRELIMINAR DA PESQUISA: COMPREENDER PARA TRANSFORMAR}

A aplicação dos questionários ocorreu em três momentos, com intervalos de 20 dias entre um e outro:

- Momento I - Expectativas de atuação no contexto de emergência; os impactos da Covid-1 9 na saúde dos/das trabalhadores/as, amigos/as e familiares; depressão, ansiedade e estresse, com base na Depression Anxiety and Stress Scale (DASS-2 I) (Vignola \& Tucci, 20 I 4);

- Momento 2 - Inventário sobre Trabalho e Risco de Adoecimento (Itra), com o qual se propõe avaliar o contexto psicossocial do trabalho e sua relação com o adoecimento, composto por quatro escalas interdependentes (Mendes $\varepsilon$ Ferreira, 2007);

- Momento 3 - Maslach Burnout Inventory (MBI), instrumento com 22 itens que avaliam índices de burnout (Maslach, 2009).

Serão apresentados aqui somente os resultados parciais do primeiro e segundo momentos.

Tabela I - Participantes no Momento I, segundo as principais categorias profissionais $(n=219)$

\begin{tabular}{|c|c|c|c|c|c|c|}
\hline & $\begin{array}{c}\text { Total } \\
(\mathrm{n}=2 \mid 9)\end{array}$ & $\begin{array}{l}\text { Médicos/as } \\
(n=24)\end{array}$ & $\begin{array}{l}\text { Enfermeiros/as } \\
\quad(n=4 \mathrm{I})\end{array}$ & $\begin{array}{c}\text { Técnicos/as de } \\
\text { enfermagem } \\
(n=62)\end{array}$ & $\begin{array}{l}\text { Fisioterapeutas } \\
\qquad(\mathrm{n}=34)\end{array}$ & $\begin{array}{l}\text { Outros } \\
(n=58)\end{array}$ \\
\hline Idade média (DP) & $36(8)$ & $38(7.1)$ & $37(6.5)$ & $35(8.0)$ & $35(6.4)$ & $36(8.5)$ \\
\hline Sexo & $\%$ & $\%$ & $\%$ & $\%$ & $\%$ & $\%$ \\
\hline Masculino & 27,1 & 37,5 & 17,1 & 25,8 & 23,5 & 32,8 \\
\hline Feminino & 72,9 & 62,5 & 82,9 & 74,2 & 76,5 & 67,2 \\
\hline \multicolumn{7}{|l|}{ Situação conjugal } \\
\hline Casados/unidos/as & 59,8 & 62,5 & 65,8 & 66,1 & 52,9 & 52,7 \\
\hline Não casados/as & 40,9 & 37,5 & 34,2 & 33,9 & 47,1 & 48,3 \\
\hline \multicolumn{7}{|c|}{$\begin{array}{l}\text { Trabalhou antes na área } \\
\text { da saúde }\end{array}$} \\
\hline Sim & 91,7 & 100,0 & 100,0 & 100,0 & 100,0 & 69,0 \\
\hline Não & 8,3 & 0,0 & 0,0 & 0,0 & 0,0 & 31,0 \\
\hline \multicolumn{7}{|l|}{$\begin{array}{l}\text { Tempo de atuação na } \\
\text { mesma função do INI }\end{array}$} \\
\hline Até 5 anos & 30,6 & 12,5 & 21,9 & 33,8 & 26,5 & 43,1 \\
\hline De 5 a 10 anos & 30,1 & 37,5 & 36,6 & 29,1 & 26,5 & 25,9 \\
\hline Mais de 10 anos & 39,3 & 50,0 & 41,5 & 37,1 & 47,0 & 31,0 \\
\hline
\end{tabular}


Tabela I - Participantes no Momento I, segundo as principais categorias profissionais ( $n=219)$ (continuação)

\begin{tabular}{|c|c|c|c|c|c|c|}
\hline & $\begin{array}{c}\text { Total } \\
(\mathrm{n}=219)\end{array}$ & $\begin{array}{c}\text { Médicos/as } \\
(n=24)\end{array}$ & $\begin{array}{l}\text { Enfermeiros/as } \\
\quad(n=4 \mathrm{I})\end{array}$ & $\begin{array}{l}\text { Técnicos/as de } \\
\text { enfermagem } \\
\quad(n=62)\end{array}$ & $\begin{array}{l}\text { Fisioterapeutas } \\
\qquad(n=34)\end{array}$ & $\begin{array}{l}\text { Outros } \\
(n=58)\end{array}$ \\
\hline \multicolumn{7}{|l|}{ Diagnóstico de Covid-19 } \\
\hline Não & 62,4 & 54,2 & 60,9 & 58,1 & 61,8 & 70,7 \\
\hline Teste positivo & 19,7 & 29,2 & 21,9 & 21,0 & 20,6 & 13,8 \\
\hline $\begin{array}{l}\text { Diagnóstico médico, } \\
\text { sem teste }\end{array}$ & 4,6 & 8,3 & 2,4 & 4,8 & 2,9 & 5,2 \\
\hline $\begin{array}{l}\text { Sintomas, sem } \\
\text { diagnóstico/teste }\end{array}$ & 13,3 & 8,3 & 14,6 & 16,1 & 14,7 & 10,3 \\
\hline \multicolumn{7}{|l|}{$\begin{array}{l}\text { Apreensivo/a por } \\
\text { trabalhar na pandemia }\end{array}$} \\
\hline Sim / Concordo & 29,3 & 54,2 & 26,8 & 29,0 & 29,4 & 20,7 \\
\hline $\begin{array}{l}\text { Nem concordo nem } \\
\text { discordo }\end{array}$ & 13,44 & 8,3 & 14,6 & 8,1 & 11,8 & 20,7 \\
\hline Não / Discordo & 57,3 & 37,5 & 58,6 & 62,9 & 58,8 & 58,6 \\
\hline \multicolumn{7}{|l|}{$\begin{array}{l}\text { Mais estressado/a do que } \\
\text { antes da pandemia }\end{array}$} \\
\hline Sim / Concordo & 51,8 & 95,8 & 48,8 & 40,3 & 58,8 & 44,8 \\
\hline $\begin{array}{l}\text { Nem concordo nem } \\
\text { discordo }\end{array}$ & 10,1 & 4,2 & 9,8 & 14,5 & 14,7 & 5,2 \\
\hline Não / Discordo & 38,1 & 0,0 & 41,4 & 45,2 & 26,5 & 50,0 \\
\hline \multicolumn{7}{|l|}{ Estresse } \\
\hline Não / Leve & 84,5 & 45,8 & 90,8 & 95,2 & 73,5 & 91,4 \\
\hline Moderado & 10,0 & 37,5 & 4,6 & 3,2 & 14,7 & 6,9 \\
\hline Grave & 5,5 & 16,7 & 4,6 & 1,6 & 11,8 & 1,7 \\
\hline \multicolumn{7}{|l|}{ Ansiedade } \\
\hline Não / Leve & 81,3 & 62,5 & 82,9 & 91,9 & 64,7 & 86,2 \\
\hline Moderada & 10,9 & 12,5 & 12,2 & 6,5 & 23,5 & 6,9 \\
\hline Grave & 7,8 & 25,0 & 4,9 & 1,6 & 11,8 & 6,9 \\
\hline \multicolumn{7}{|l|}{ Depressão } \\
\hline Não / Leve & 91,3 & 75,0 & 95,0 & 100,0 & 85,3 & 89,7 \\
\hline Moderada & 6,9 & 16,7 & 2,5 & 0,0 & 14,7 & 10,3 \\
\hline Grave & 1,8 & 8,3 & 2,5 & 0,0 & 0,00 & 0,00 \\
\hline
\end{tabular}

Fonte: elaboração própria.

Participaram do primeiro momento do estudo 219 trabalhadores de todas as categorias profissionais, com maior número técnicos/as de enfermagem (28\%), seguidos/as de enfermeiros/as (18,7\%), fisioterapeutas (15,5\%) e médicos/as (10,9\%). A média de 
idade foi $36 \pm 8$ anos (variando de 35 a 38 anos), sendo fisioterapeutas e técnicos/as de enfermagem um pouco mais jovens. O sexo feminino e a situação conjugal casados predominou em todas as categorias profissionais.

Exceto os do grupo Outros (composto por diversas categorias), todos os profissionais já haviam trabalhado na saúde antes de trabalharem no hospital do INI, e a maioria tinha mais de 5 anos de experiência. Mais da metade dos profissionais não teve diagnóstico de Covid-19, no entanto observou-se alta frequência de relatos de diagnóstico/suspeita da doença, variando de 29,3\% a 45,9\% (outras categorias e médicos, respectivamente). A referência a sentir-se apreensivo/a por trabalhar na pandemia foi frequente em todas as categorias, sobretudo entre os/as médicos/as - mais da metade deles/as relatou essa condição (54,2\%). Interessante destacar que quase todos/as os/as médicos/as referiram se sentir mais estressados/as do que antes da pandemia; para outras categorias essas proporções se situaram em torno de 50\%.

A classificação de estresse, ansiedade e depressão baseou-se no questionário DASS2I, adaptado para o português brasileiro (Vignola \& Tucci, 20I4). Observaram-se frequências altas de estresse, ansiedade e depressão moderados e graves sobretudo para os/as médicos/as ( $54,2 \%, 37,5 \%$ e $25 \%$, respectivamente), seguidos dos/as fisioterapeutas da amostra $(26,5 \%, 35,3 \%$ e $14,7 \%$, respectivamente).

No segundo momento da pesquisa, que contou com a participação de 133 trabalhadores/as, ressaltou-se a alta frequência de Covid-19 na rede social dos/as trabalhadores/as, entre colegas próximos de trabalho $(88,7 \%)$ e em uma proporção menor, mas importante, de familiares $(38,8 \%)$ que tiveram a doença. Com relação às perdas por Covid-19,3,8\% referiram perdas de familiares e 16,4\% informaram perdas de amigos. Quando as perdas foram analisadas por categorias profissionais, chamaram a atenção as perdas de amigos/as, com os maiores percentuais para enfermeiros/as ( $31,8 \%)$, técnicos/as de enfermagem (25,7\%) e médicos/as (20,0\%) (dados não mostrados em tabelas).

A estratificação dos resultados da escala DASS-2 I levou à identificação de 20 trabaIhadores que alcançaram níveis críticos de sintomas de estresse, depressão e ansiedade. Essa escala considera sensações e sentimentos vivenciados pelas pessoas nos 7 dias antecedentes à sua realização, não podendo ser considerado um instrumento de diagnóstico para transtorno mental. Esses/as trabalhadores/as pertenciam às seguintes categorias: médico/a (7), fisioterapeuta (5), enfermeiro/a (2), farmacêutico/a (2), nutricionista ( I), técnico/a de enfermagem (I), técnico/a em radiologia (I) e auxiliar administrativo/a (I). Somente após a constatação do nível crítico de gravidade dos sintomas, conforme previsto no Termo de Consentimento Livre Esclarecido (TCLE), esses/as profissionais foram 
identificados/as e contatados/as pelos/as pesquisadores/as. Aqueles/as que foram contatados/as reagiram positivamente, reconhecendo a ação como de cuidado e zelo.

O contato ocorreu em dois períodos: julho e outubro de 2020, de acordo com a análise das respostas. A primeira tentativa de contato foi via telefone e, nos casos sem sucesso, a busca ocorreu por meio do aplicativo WhatsApp ou de e-mail. Dos vinte contatos realizados, dez tiveram retorno. Desse grupo, quatro trabalhadores/as expressaram desejo de contar com suporte profissional, os outros já faziam algum tipo de acompanhamento em saúde mental. Posteriormente, os/as trabalhadores/as que tiveram interesse foram encaminhados/as à equipe de psicologia do Nust/INI, visando à continuidade do suporte e cuidado.

Como expresso no fluxograma a seguir, a oferta de apoio especializado pressupôs o contato prévio de pesquisadores/as com os/as trabalhadores/as que apresentaram níveis expressivos (graves e muitos graves) de sintomas de transtornos mentais comuns.

Figura I - Fluxograma de contato com os participantes da pesquisa

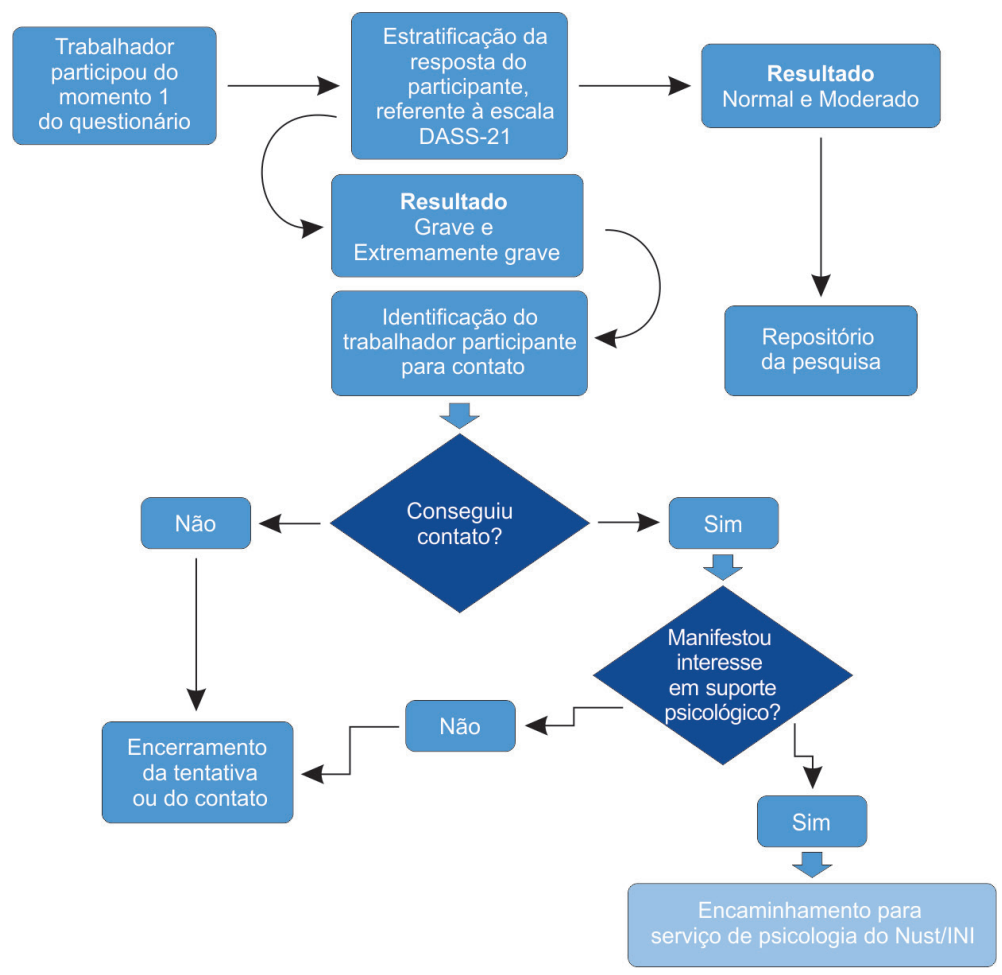

Fonte: elaboração própria. 
Para o diálogo com trabalhadores/as e gestores/as, foi elaborado um infográfico e posteriormente um boletim com os resultados parciais da pesquisa, visando a, além de apresentá-los aos/às participantes, estimular o aumento da participação no preenchimento dos questionários.

Figura 2 - Infográfico

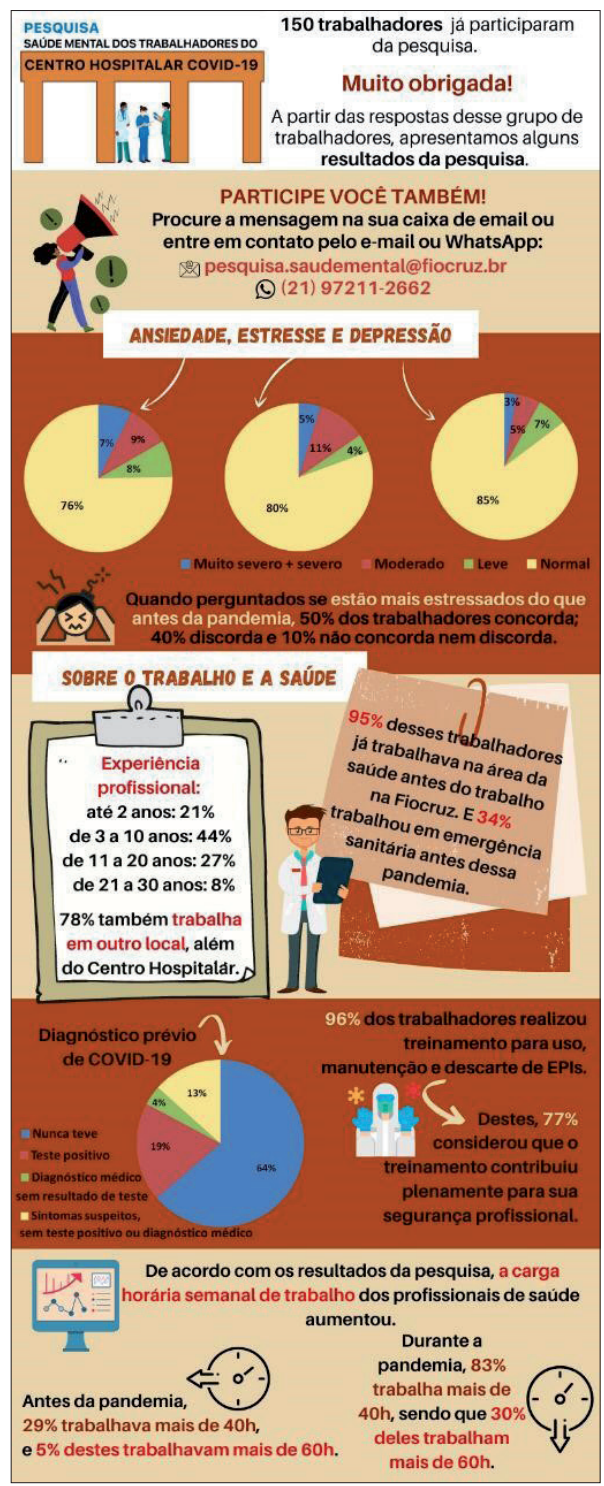

Fonte: elaboração própria. 
Para construir uma relação dialógica com foco na atividade de trabalho e sua relação com a saúde, cinco grupos de Encontros sobre o Trabalho se reuniram: dois com equipes de enfermeiros/as, dois com técnicos/as de enfermagem e um com enfermeiro/as e técnicos/as. Os encontros ocorreram no próprio Centro Hospitalar, durante a jornada de trabalho, com duração média de I hora e a participação de cinco a oito trabalhadores/ as indicados/convidados/as pela chefia imediata. Neles, buscou-se adotar uma postura ético-epistemológica, colocando em debate os diferentes saberes, o da experiência prática dos/as trabalhadores/as e o do conhecimento técnico-científico, para a produção de novos saberes, ancorada no Dispositivo Dinâmico de Três Polos (DD3P) desenvolvido na perspectiva ergológica (Schwartz E Durrive, 20I0). E, dessa forma, compreender para transformar a realidade de trabalho.

Também foram realizadas conversas com dois fisioterapeutas que trouxeram importantes contribuições sobre a experiência do trabalho. Pretende-se dar continuidade à realização dos encontros com outras categorias profissionais.

Os diálogos estabelecidos nos encontros deram visibilidade ao grande desafio vivenciado pelos/as trabalhadores/as neste momento de pandemia. Desafio diverso, de muitas facetas e que, no caso, do Centro Hospitalar, inaugurou-se no olho do furacão da pandemia, o da constituição das equipes e recebimento dos pacientes simultaneamente, muito bem expresso por uma das enfermeiras:

Imagina que você cismou de construir uma casa, mas ao mesmo tempo você quer morar dentro da casa (...) estamos levantando as paredes e já morando dentro, querendo usar o sanitário e colocando laje, e a casa está pronta. (GEST I)

Essas equipes foram formadas por profissionais oriundos de diferentes inserções e experiências, às vezes nenhuma em emergência, terapia intensiva ou mesmo hospitalar:

O hospital abriu e vai (...) a gente não se conhecia, estavam três rotinas (...) e não conhecíamos os enfermeiros, os técnicos, pois nunca tínhamos visto eles na vida, a gente não sabia se eles eram capazes de receber os pacientes ou não, e foi assim. Você tem experiência, vai para lá ou para cá, e desce paciente, foi desse jeito, desesperador. A vontade que a gente tinha era de pintar a cara como se fosse guerra mesmo, porque a gente não sabia como iria funcionar. (GEST 2)

Para os que participaram de seu início, esse processo foi muito desgastante, por exigir correção permanente dos problemas e aprimoramento constante: 
Quando eu desci para cá, que começou a chegar paciente (eu fico na entrada, pois sou da triagem), foi um inferno; com quatro técnicos e duas enfermeiras, a gente não sabia onde botava nossa cabeça, literalmente. (GEST 5)

Além disso, os procedimentos e protocolos foram sendo criados no decorrer do trabalho:

Como falei, está sendo bem desafiador, pois cada dia é uma novidade e a gente vem participando de tudo desde o início do processo, fazendo os fluxos do hospital, das rotinas (...) estamos sempre ali, tentando melhorar os processos. (GEST I)

Uma questão considerada muito mobilizadora e estressante foi a das dificuldades com o ambiente completamente informatizado, sistemas digitais diferenciados e comunicação via tablet, uma vez que não é permitido o uso de papel na área interna do hospital:

A questão da informatização, trabalhar com tablet, venho do hospital (...) de onde não tinha isso nos últimos cinco anos; então, para mim, quando vem uma demanda tenho que me adaptar e está sendo um desafio, pois estamos em uma era, no atual momento que estamos vivendo, do pessoal dizendo "vamos fazer uma live", "vamos falar com a família". Até eu me adaptar a essas coisinhas foi um desafio. (GEST I)

Pela natureza da pandemia, a contaminação gera medo e insegurança, que se expressa principalmente no manejo dos equipamentos de proteção individual (EPIs). $O$ ato de se paramentar e desparamentar é importante, pois além do risco de contaminação gera constrangimento quando é necessário usar o banheiro e realizar pausas:

O desafio maior é conseguir se acostumar com essa paramentação, acho que até hoje não estamos acostumados; por exemplo, não tem uma cadeira ou mesa para a gente sentar, não tem o momento que a gente senta, relaxa. E tem plantão que é extremamente pesado, pois você tem um paciente que está ali e de repente ele para, assim vai, e você não descansa. Estar paramentada e às vezes querer ir ao banheiro fazer xixi e não poder... (GEST 5)

Para irmos ao banheiro precisamos entrar em um ambiente, tirar toda a paramentação (...) e depois colocar uma paramentação toda nova; então, por exemplo, às vezes acabamos segurando mais por conta de todo esse trabalho ou seguramos também porque o plantão está mais puxado e aí você não perde esse tempo. (GEST 5) 
A qualidade, a adequação e a quantidade dos EPIs contribuem para o equilíbrio da saúde mental, além de garantir as condições de trabalho e pausas regulares. No Centro Hospitalar, em suas falas nos encontros os/as trabalhadores/as afirmaram ver características do ambiente da Fiocruz como um diferencial. Poder integrar a Fiocruz traz orgulho, prazer de trabalhar e motivação para fazer cada dia melhor:

Essa questão de estar trabalhando na Fiocruz mexe com a cabeça das pessoas, pois a pessoa fala "aqui na Fiocruz não pode...", então é realmente muito gratificante você estar trabalhando, ter materiais de qualidade, e aqui a gente tem tudo à mão, não pode reclamar. (GEST I)

Quando chego em casa falo com minha filha "trabalhei o dia inteiro, pois a gente não para", mas eu saio daqui realizada, totalmente diferente do outro lugar onde trabalho, porque lá parece que você vai com um peso e não consegue atuar na sua área. Aqui a gente consegue atuar com técnico de enfermagem, o enfermeiro, o médico, você vê a felicidade de salvar uma vida. Quando o paciente cruza a porta para ir embora você percebe a felicidade de todos, desde o pessoal da limpeza até os médicos, e isso é maravilhoso. (GEST 4)

O bom ambiente de trabalho e sua cultura organizacional compõem um dos ingredientes da competência (Schwartz, 1998) e abrem espaço para a constituição de coletivos coesos e cooperativos:

O grupo é muito coeso, nós conseguimos em pouco tempo, até brinco com eles que em pouco tempo conseguimos produzir muita coisa e ter muita afinidade (...) eles representam a construção disso aqui. Tudo que conseguimos até hoje foi construído por cada um que está aqui, eles chegaram com um papel em branco e foram montando cada pedacinho, cada coisa foi pensada por eles. (GEST I)

No entanto, nas relações interpessoais e na comunicação entre as equipes há conflitos comuns entre categorias dos ambientes hospitalares:

A questão dos médicos se adequarem e não ficarem a pretexto do ego. A gente tenta equilibrar as equipes multi, tanto enfermagem como fisioterapeuta, enfim... E assim ir caminhando, pois cada hora eles pedem uma coisa e às vezes a instituição não tem aquilo protocolado e eles não querem entender, então para mim é uma luta diária com relação a isso. (GEST I) 
Apesar de também ser destacado como algo positivo e motivador, o valor da remuneração não evita que muitos profissionais necessitem de outros vínculos para complementar sua renda, o que gera sobrecarga laboral:

O piso salarial daqui é um pouco melhor que os outros, mas ainda acho que pode melhorar, para que a gente não precise ter outro emprego e possa se sustentar só com o daqui. (GEST 5)

A questão é polêmica: acho que a grande maioria daqui trabalha em dois lugares, então tem essa sobrecarga. (GEST 5)

Conheço gente que trabalha em três. (GEST 5)

Eu conheço alguém que trabalha em quatro e não sei como consegue. (GEST 5)

Às vezes a própria sobrecarga de trabalho faz a pessoa ficar muito mecanizada, porque quem tem três ou quatro empregos pensa "não vou ficar de risinho, estou aqui para trabalhar, fazer o meu, que é medicação, trocar fralda, ver dieta, e vou embora para o outro". E às vezes isso se perde, mas não podemos deixar esquecer, pois estamos lidando com uma vida, com quem sente dor, com alguém que tem medo da morte e que espera da gente um bom dia. (GEST 2)

0 trabalho aqui é bem duro, não acordava mais esse horário, acordo 5 horas da manhã e estou todos os dias aqui. Então é muito cansativo, porque meu dia não termina agora à I hora, vou atendendo paciente até umas 8 ou 9, e quando saio tenho um milhão de coisas para fazer daqui. 0 trabalho não acaba aqui, temos três reuniões semanais fora do horário de trabalho; ontem, por exemplo, teve uma depois do plantão. (FISIO I)

A diversidade de proveniências profissionais demandou, principalmente para os/ as profissionais oriundos/as da iniciativa privada, adequação ao ambiente do Centro Hospitalar: "A gente sofria tanto assédio lá fora que para a gente já era normal aquilo" (GEST I). Tais questões não devem ser desmerecidas pela gestão, pois o maior desafio é ter coragem de voltar para mais um dia de trabalho:

Teve plantão que tinha três pacientes e dois óbitos, o outro já estava indo. Como você vai para casa desse jeito? Você sabe o que tem que fazer, mas aquele paciente é a mãe, o pai, a vida de alguém. A gente está batalhando, mas ter noção de que você chegou a um dia de trabalho com três pacientes, dois óbitos, eu fiz dois corpos em um dia e o outro vai daqui a pouco, no próximo plantão. O que essa doença está fazendo com a gente? (GEST 5) 
O reconhecimento é essencial para o equilíbrio da saúde psíquica dos trabalhadores/as, capaz de transformar o sofrimento em prazer (Dejours, 2004). Salvar vidas faz parte desse reconhecimento:

A parte mais gratificante foi semana passada, que nós tivemos uma paciente com 90 e poucos anos (...) quando ela teve alta a tiramos da cama, colocamos ela sentadinha na cadeira, e íamos sair, nisso ela falou "Espera", e ela rezou o Pai-Nosso, pedindo para abençoar todos os funcionários; foi uma coisa gratificante. (GEST 3)

É muito gratificante você ouvir o paciente te agradecendo pelo cuidado que você está tendo. Uma das pacientes, ainda brinquei com ela, falei assim: "Logo, logo você vai estar fora daqui, vai para sua casa", e ela falou assim: "Eu quero, mas às vezes eu não quero, pois vou sentir muito a falta de vocês". Ouvir isso é muito gratificante, aquela sensação de dever cumprido, de que você está fazendo um bom trabalho. (GEST 3)

O necessário cuidado para com os/as trabalhadores/as da saúde fortalece a dinâmica do reconhecimento, que pode ser acionada e mantida pelos/as usuários/as, pela sociedade, pelos/as colegas de trabalho e fundamentalmente pela hierarquia.

\section{REFLEXÕES FINAIS: LUGARES E TEMPOS DO CUIDADO}

O trabalho em saúde e seus lugares são espalhados em uma rede múltipla de serviços. São lugares de cuidados - clínicos, cirúrgicos, afetivos -, de contato direto com as pessoas, em conexão com todas as atividades humanas.

Os trabalhadores e trabalhadoras da saúde percorrem uma trajetória de oscilações e ameaças, de escolhas sobre por onde andar e que vínculos estabelecer. Como dar suporte emocional ao/à cuidador/a? O mesmo espaço em que promovem o cuidado é também o espaço em que necessitam receber o cuidado. O elemento gerador de uma mobilização de proteção, mecanismo de múltiplas formas de apoio, é a escuta qualificada dos trajetos afetivos e técnicos desses/as profissionais, que pode transformar suas angústias em cuidado. Em sua dimensão técnica e social, nas situações de trabalho há relativa adequação das prescrições e da proteção aos protocolos e procedimentos que precisam ser partilhados. Isso nem sempre acontece, especialmente porque umas categorias são mais protegidas e socialmente mais valorizadas, inclusive do ponto de vista econômico.

Constata-se maior risco de contaminação nas equipes de enfermagem entre os/as que atuam nos hospitais de referência para a Covid- I9, o que evidencia vulnerabilidades 
desiguais. Cabe, a esse respeito, materializar múltiplas formas de cuidado para com os/ as cuidadores/as. A discussão entre os grupos internos, a gestão e instâncias de apoio cria os mecanismos e espaços desse contato de escuta pedagógica e de proteção. Em suma, ações de suporte aos/às trabalhadores/as da saúde que atuam no enfrentamento da Covid- 19 devem ser estruturadas em diálogo com estes/as e com os/as gestores/as, voltado para a conformação de um potente coletivo destinado ao cuidado com a sua própria saúde.

\section{REFERÊNCIAS}

BRASIL. Ministério da Saúde. Secretaria de Vigilância em Saúde. Boletim Epidemiológico Especial n. 53 - Doença pelo coronavírus Covid-19, 2020. Disponível em: <https://covid I 9-evidence.paho.org/ handle/20.500.12663/62I >. Acesso em: dez. 2021.

CÂMERA, A. \& FUCHS, A. Covid-19: Centro Hospitalar da Fiocruz entra em funcionamento. Portal Fiocruz, Rio de Janeiro, 19 maio 2020. Disponível em: <https://portal.fiocruz.br/noticia/covid-19centro-hospitalar-da-fiocruz-entra-em-funcionamento>. Acesso em: 16 nov. 2020.

DEJOURS, C. Da psicopatologia à psicodinâmica do trabalho. In: LANCMAN, S. E SZNELWAR, L. (Orgs.). Christophe Dejours: da psicopatologia à psicodinâmica do trabalho. Rio de Janeiro, Brasília: Editora Fiocruz, Paralelo I5, 2004.

GUÉRIN, F. et al. Compreender o Trabalho para Transformá-lo: a prática da ergonomia. São Paulo: Edgard Blücher, 200I.

LAI, J. et al. Factors associated with mental health outcomes among health care workers exposed to coronavirus disease 2019. Journal of the American Medical Association, 3(3): 1 - 12, 2020.

MASLACH, C. Comprendiendo el burnout. Ciencia E Trabajo, I I (32): 37-43, 2009.

MENDES, A. M. E FERREIRA, M. C. Inventário sobre trabalho e riscos de adoecimento - Itra: instrumento auxiliar de diagnóstico de indicadores críticos no trabalho. In: MENDES, A. M. (Org.). Psicodinâmica do Trabalho: teoria, método, pesquisas. São Paulo: Casa do Psicólogo, 2007.

SCHWARTZ, Y. Os ingredientes da competência: um exercício necessário para uma questão insolúvel. Educação E Sociedade, II 9 (65), 1998.

SCHWARTZ, Y. \& DURRIVE, L. Trabalho e Ergologia: conversas sobre atividade humana. Niterói: EdUFF, 2010

VIGNOLA, R. C. B. \& TUCCI, A. Adaptation and validation of the Depression, Anxiety and Stress Scale (DASS) to Brazilian Portuguese. Journal of Affective Disorders, 155: 104-109, 2014.

WALTON, M.; MURRAY, E. \& CHRISTIAN, M. D. Mental health care for medical staff and affiliated healthcare workers during the Covid- 9 pandemic. European Heart Journal - Acute Cardiovascular Care, 9(3): $241-247,2020$. 


\title{
Violência Doméstica e Familiar na Covid-19
}

\author{
capacitação emergencial on-line durante a pandemia
}

Fernanda Serpeloni, Fernanda Mendes Lages Ribeiro,

Débora da Silva Noal, Bernardo Dolabella Melo,

Júlia Fortes Guimarães de Moura, Bianca Caroline Pickler,

Michele Souza e Souza, Ionara Vieira Moura Rabelo e

Simone Gonçalves de Assis

A

violência é um importante problema de saúde pública e diversos estudos têm alertado para o seu agravamento em razão da pandemia da Covid-19. Contudo, pouco se sabe sobre as dificuldades dos profissionais da saúde em lidar com esse problema e as suas demandas. Tendo isso em vista, com o presente relato apresentamos as questões levantadas no módulo de Violência Doméstica e Familiar na Covid- 9 do Curso Nacional de Saúde Mental e Atenção Psicossocial na Covid- 9 (Smaps), realizado pela Fiocruz Brasília entre II de maio e 28 de setembro de 2020 (Noal, Passos E Freitas, 2020). O curso foi criado com o objetivo de abranger trabalhadores da saúde de todo o país e contou com um total de 69.240 participantes de diversas áreas de atuação, dos 26 estados brasileiros e Distrito Federal.

As medidas de biossegurança, como o distanciamento social, consideradas essenciais para o controle da transmissão do vírus, trouxeram mudanças bruscas para a vida das famílias e da população em geral. Muitos homens e mulheres passaram a trabalhar de forma remota ou mesmo a estar impossibilitados de trabalhar, o que implica sobrecarga de tarefas, insegurança financeira, dificuldades na conciliação de rotinas e exigências com a casa e com os cuidados de crianças e outros familiares (Noal, Passos E Freitas, 2020). A redução do convívio comunitário tem impactos sobre a coesão social, o acesso aos serviços públicos e sobre as instituições que compõem as redes de suporte das pessoas, o que pode favorecer a manutenção e o agravamento de situações de violência. Estresse, medo e preocupação diante das incertezas trazidas pela pandemia são reações esperadas, mas podem trazer sofrimento a longo prazo se não forem manejadas com cuidado.

O fechamento de serviços não essenciais e restrições à circulação de pessoas estiveram entre as principais medidas sanitárias implementadas por diversos países na tentativa 
de conter o avanço da doença, resultando em um cenário similar de enfraquecimento das redes socioafetivas e de proteção. Apesar de as medidas apresentarem um efeito inicial positivo na redução de registros de casos de crimes violentos contra estranhos, como homicídios e agressões, o mesmo não ocorreu em relação às agressões ocorridas no ambiente familiar (Eisner $\&$ Nivette, 2020). O enfraquecimento de redes, aliado ao aumento de estresse e a um possível aumento de uso de substâncias psicoativas (Barbosa et al., 2020), constitui um campo favorável para o agravamento de situações de violência doméstica e familiar (Boxall, Morgan $E$ Brown, 2020). Esse incremento foi também observado no cenário internacional e afeta grupos variados. Além da violência doméstica, deve-se chamar atenção também para a ocorrência de agressões que envolvem pessoas pertencentes a um grupo familiar, mas extrapolam o espaço da casa.

Em algumas experiências internacionais registram-se mudanças na ocorrência de violência doméstica e intrafamiliar durante a pandemia. Nos Estados Unidos, na fase inicial da pandemia o número de ligações para as linhas de atendimento de denúncias de violência doméstica e de abusos contra crianças e adolescentes aumentou (Boserup, Mckenney \& Elkbuli, 2020). As ligações realizadas no período de isolamento foram breves e sucintas, sugerindo que a falta de privacidade e o contato constante com o abusador poderia estar inibindo as denúncias. Na Itália, por sua vez, foi observada diminuição no número de registros nos serviços de denúncia de violência, o que não significa redução de casos, visto que o afastamento das redes de proteção e o confinamento com o abusador dificultam a denúncia (Sacco et al., 2020). Na Índia, foi observado que o aumento da violência doméstica acompanhou o rigor das medidas restritivas (Ravindran $\varepsilon$ Shah, 2020). Na União Europeia, foi reportado aumento de 60\% no número de denúncias de violência doméstica nos serviços de emergência (Mahase, 2020). Internacionalmente, estima-se que cada três meses da implementação das medidas de restrições de circulação e de fechamento de serviços não essenciais possam gerar 15 milhões de novos casos de violência doméstica, o que representa um aumento de 20\% (UNFPA, 2020).

Apesar das diferenças consideráveis entre contextos de emergências e contextos de desastres, é possível observar um padrão de aumento das agressões após um evento extremo (Parkinson, 2019). Contudo, a violência não foi um problema contemplado no conjunto de ações do Plano de Contingência Nacional para Infecção Humana pelo Novo Coronavírus do Brasil (Brasil, 2020). No Brasil, nas primeiras semanas de pandemia houve aumento no número de atendimentos de violência doméstica e feminicídio pela Polícia Militar por meio do Disque 190. Ao mesmo tempo, houve decréscimo nos registros dos boletins de ocorrência nas delegacias, atividade realizada de forma prioritariamente presencial (Fórum Brasileiro de Segurança Pública, 2020). Em relação 
à violência contra crianças e adolescentes, houve redução do número de denúncias durante os primeiros meses da pandemia (Campbell, 2020). Grande parte das denúncias de abuso ou negligência contra crianças é feita por profissionais que prestam serviços às vítimas e que atuam na área da educação; logo, o fechamento de escolas e de outras organizações comunitárias limita a capacidade dos principais parceiros das comunidades de intervir nos casos de violência contra essa parcela da população, ou seja, perdem-se oportunidades de detecção, denúncia e intervenção, o que torna impossível afirmar a existência de queda real da incidência de agressões (Fiocruz, 2020).

Os idosos compõem outro grupo vulnerável, suscetível a violações de direitos que podem ser agravadas durante o isolamento. Parte expressiva desse grupo tem sua vida marcada por variadas situações de vulnerabilidade e problemas de saúde. E aqueles que envelhecem sem quaisquer rendimentos ou têm suas rendas comprometidas com gastos em saúde, bem como aqueles que residem em zonas de vulnerabilidade social, caracterizadas pela baixa oferta de serviços públicos essenciais, estão mais sujeitos a violência doméstica. Ademais, muitos sofrem abandono, negligência e maus-tratos de seus cuidadores, sobretudo familiares, situações que têm se agravado e avolumado no contexto pandêmico. O cenário de distanciamento social e as mudanças na dinâmica familiar, bem como a maior convivência com os cuidadores familiares que podem se cansar das demandas mais frequentes dos idosos diante da necessidade de ficar em casa por mais tempo, tendem a aumentar o risco de violência física, verbal e econômica (SBGG, 2020). Além disso, esses idosos, muitas vezes isolados em suas casas, ou mesmo evitando ir aos serviços de saúde por medo de contaminação, podem estar com acesso ainda mais restrito aos serviços de proteção.

Também os profissionais estão expostos à preocupação com a sua saúde e de sua família, à estigmatização, à sobrecarga, ao estresse e à violência (Rodríguez-Bolaños et al., 2020). Assim como nos casos de violência doméstica, a violência contra trabalhadores da saúde existe fora de crises, mas tende a aumentar a partir da ocorrência de um evento crítico (Devi, 2020).

$\mathrm{O}$ atendimento aos casos de violência doméstica e familiar durante a pandemia sofreu também impacto das condições de trabalho no setor Saúde. Observaramse no contexto laboral dos trabalhadores da área ausência e/ou precariedade dos equipamentos de proteção individual; continuidade das atividades de trabalho mesmo com comorbidades; adoecimento e mortes; tensões e medo de serem infectados/as e de lidar com o adoecimento e morte de colegas; dificuldades em obter acesso aos testes de Covid- 19 e autorização para afastamento do trabalho para tratamento; desistência 
das atividades; e a necessidade de atualização rápida para o cuidado em saúde (Edovato et al., 2020), Destaca-se também o sofrimento profissional e o desencadeamento de problemas mentais (Zhu et al., 2020).

Considerando as dificuldades que a pandemia trouxe para os serviços de saúde, inúmeras questões se impõem para a reflexão e a prática profissional no que tange à violência. Seus reflexos têm sido percebidos e representam enorme desafio econômico e social relacionado aos cuidados necessários, à complexidade dos atendimentos e à falta de preparo e capacitação de alguns trabalhadores da saúde para acolher a demanda, entre outros fatores.

\section{RELATO DE EXPERIÊNCIA}

Na reflexão sobre perguntas apresentadas no Curso Nacional de Saúde Mental e Atenção Psicossocial na Covid- 19 (Smaps), profissionais da saúde identificaram em sua prática cotidiana desafios relacionados ao tema da violência doméstica e familiar durante esta pandemia, alguns dos quais serão relatados e discutidos aqui.

O módulo sobre Violência Doméstica e Familiar na Covid-19 teve por referência uma cartilha informativa de mesmo nome (Fiocruz, 2020),' uma videoaula de 30 minutos (www.youtube.com/watch?v=KK3PPGvoGsuElist=PLPyO8qVoPmBRLyv GOq4GEiK3iCWyWW5WEindex=II Et=409s) e o Fórum Pergunte ao/à Professor/a, disponibilizado na plataforma on-line do curso (Curso de Saúde Mental e Atenção Psicossocial em Situação de Pandemia Covid- 19 - $1^{\circ}$ Oferta - 2020 | Campus Virtual Fiocruz). O módulo também contou com uma live na plataforma YouTube da Fiocruz Brasília (www.youtube.com/watch?v=S3SAukJUce8\&feature=youtu.be), com duração de uma hora e meia, realizada em 17 de junho de 2020. Na ocasião, além de aprofundar o tema a partir das perguntas feitas pelos alunos previamente, houve amplo espaço para a formulação de perguntas ao vivo, com a disponibilização de dois canais para que os alunos pudessem enviá-las: o fórum na plataforma do curso e um canal síncrono durante a live. A combinação de estratégias síncronas e assíncronas no curso possibilitou o acesso a estratégias de formação dos profissionais durante um período de distanciamento social (Noal et al., 2020).

Foram extraídas todas as perguntas publicadas no Fórum Pergunte ao/à Professor/a e no bate-papo da live. Na live foram apresentados temas de dois módulos do curso,

\footnotetext{
' Todas as cartilhas foram disponibilizadas virtualmente para acesso livre na página virtual da Fiocruz Brasília (Gerência Regional de Brasília): <www.fiocruzbrasilia.fiocruz.br/coronavirus/saude-mental-em-temposde-coronavirus/>. Acesso em: 18 maio 2021.
} 
violência doméstica e familiar e violência autoinfligida, mas apenas as perguntas sobre o tema da violência doméstica e familiar foram categorizadas. Ao todo, foram identificadas 200 perguntas, das quais 8 foram excluídas por mencionarem exclusivamente o comportamento suicida. Dessa forma, 192 postagens foram incluídas no relato de experiência.

As postagens foram assim categorizadas: natureza da postagem (pergunta, comentário ou relato de experiência no serviço de saúde), tipo de violência, formação profissional e conteúdo da questão. A revisão das categorias foi acordada entre pelo menos dois autores. Para identificar os temas mais abordados, criou-se uma nuvem de palavras, ou seja, um gráfico digital para análise qualitativa dos dados que mostra o grau de frequência das palavras em um texto. As palavras foram categorizadas em recorrentes e pontuais (citadas mais e menos de sete vezes, respectivamente). No total foram incluídas 106 palavras recorrentes. Quanto mais utilizada foi a palavra, mais chamativa é a sua representação no gráfico (De Paolo E Wilkinson, 20l4). Os artigos, pronomes e conjunções foram excluídos e as palavras agrupadas qualitativamente, como, por exemplo, mesma palavra no singular e plural, masculino e feminino. Optou-se por nomear as categorias seguindo a palavra que aparecesse com maior frequência. Os termos LGBT $(n=1)$, LGBT+ $(n=1)$, LGBTI $(n=1)$ foram agrupados em LGBTQI. Nas 192 postagens, as palavras mais frequentemente citadas pelos participantes foram: violência $(n=201)$, doméstica $(n=82)$, mulher $(n=77)$, pandemia $(n=59)$, vítima $(n=46)$, social $(n=40)$, agressor ( $n=38)$, notificação $(n=38)$, aumento $(n=37)$, familiar $(n=37)$ e situação $(n=37)$, como mostrado na Figura 1 .

Figura I - Gráfico de nuvem de palavras com os termos mais recorrentes nas perguntas do módulo Violência Doméstica e Familiar do Curso Nacional Smaps

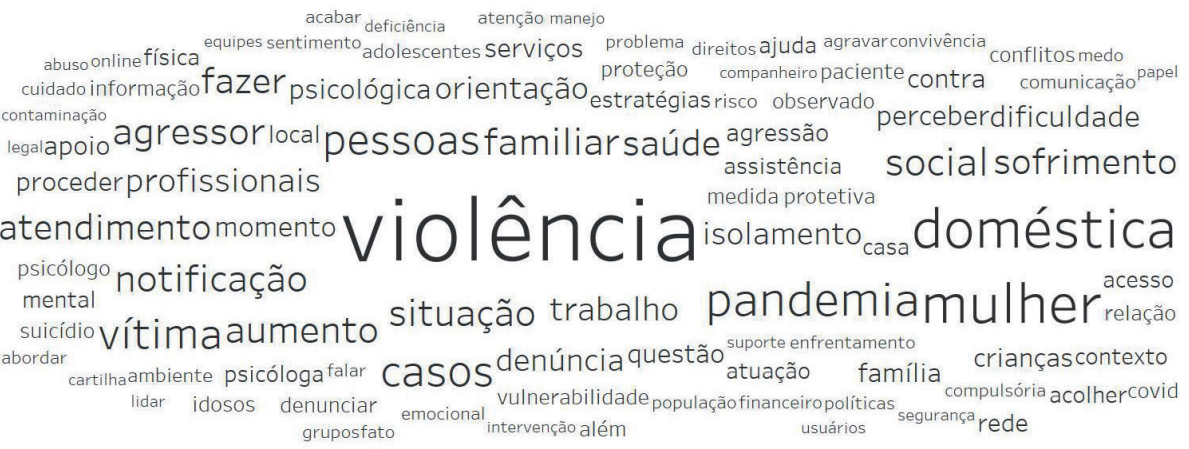

Fonte: elaboração própria. 
Entre as 192 postagens, 89\% tinham a forma de perguntas. Dessas, uma pequena parte incluiu também um comentário (12,9\%) ou relato de experiência (8,2\%). Quanto ao tipo de violência, conforme mostra a Tabela I, os termos violência doméstica e violência contra a mulher foram usados na maioria das formulações $(58,8 \%)$. O segundo tipo mais citado foi contra criança e adolescente (10,3\%), seguido por violência autoinfligida $(6,2 \%)$.

Tabela I - Frequência da citação dos diferentes tipos de violência nas perguntas e comentários do módulo de Violência Doméstica e Familiar na Covid- 19 do curso Nacional de Saúde Mental e Atenção Psicossocial na Covid- 9 (Smaps) - Fiocruz Brasília, II maio a 28 set. 2020

\begin{tabular}{l|c}
\hline \multicolumn{1}{c|}{ Tipo de violência } & $\begin{array}{c}\text { Frequência de citação dos } \\
\text { tipos de violência }(\mathrm{N}=288)\end{array}$ \\
\hline Mulher/violência doméstica & 58,8 \\
\hline Criança e adolescente & 10,3 \\
\hline Autoinfligida & 6,2 \\
\hline Idoso/a & 4,0 \\
\hline Pessoa com deficiência & 2,7 \\
\hline LGBQTI & 1,3 \\
\hline População negra & 1,3 \\
\hline Profissionais da saúde & 0,9 \\
\hline Privados de liberdade & 0,5 \\
\hline Sem especificar & 14,0 \\
\hline
\end{tabular}

Fonte: elaboração própria.

Mais de um tipo de violência foi citado em uma mesma postagem, por isso a soma das citações é maior do que o total de perguntas (192).

Com relação à formação ou área de atuação, destacam-se psicólogos (44,4\%), seguidos por assistentes sociais (19,4\%), distribuídos em serviços de saúde, educação e assistência social. Sobre o conteúdo, foram apresentadas perguntas sobre a atuação do profissional nos atendimentos a casos de violência (76\%), com destaque para notificações, denúncias, funcionamento das redes intra e intersetorial, risco de contaminação nos abrigos, percepção sobre o aumento do número de casos de violência atendidos nos 
serviços, realização de atendimento remoto/on-line e forma de abordar a violência nos atendimentos. Pequena parte das perguntas referiu-se especificamente à prevenção da violência $(4,9 \%)$. Os temas impacto da violência na saúde mental, estresse psicológico provocado pelo confinamento e possibilidades de tratamento foram citados nos contextos de atuação tanto nos casos de violência quanto na prevenção $(5,9 \%)$. Outros conteúdos (13,2\%) abordaram dúvidas sobre como identificar abuso emocional/psicológico, atuação com os autores de agressão, cuidados com a saúde mental dos profissionais que atendem casos de violência, segurança dos profissionais da saúde e demandas endereçadas a estes na atuação com a violência no contexto pós-pandemia.

\section{LIÇÕES APRENDIDAS}

As perguntas e comentários permitiram compreender que o tema da violência suscita muitas dúvidas e desafios. A análise das postagens indica dificuldades no acolhimento, atendimento, cuidado e encaminhamento dos casos de agressão. Do que se depreende a urgência de incluir nos currículos dos cursos de saúde a abordagem da violência, suas manifestações, naturezas e formas de enfrentamento. Mais especificamente, é preciso que os trabalhadores da saúde sejam sensibilizados e capacitados sobre as reações de sofrimento psíquico esperadas e sobre os agravos associados à violência durante uma situação de crise. A maior parte dos profissionais abordou temas relacionados às agressões contra a mulher e contra crianças e adolescentes. Para outros grupos populacionais, como os idosos, o curso contou com módulos próprios em que foram trabalhadas outras temáticas, além da violência.

As dúvidas referentes a tratamento e encaminhamento para a rede refletem a necessidade de apoio para os profissionais e de diálogo entre os serviços de atendimento a situações de violência e de saúde mental, bem como sinalizam que um atendimento mais especializado pode ser necessário. Durante uma situação de crise, é comum que pessoas com história pregressa de sofrimento psíquico desencadeiem um processo de cronificação (Noal et al., 2020). O mesmo pode ocorrer com aquelas que já passaram por situações prévias de violência e procuram de forma recorrente serviços de atenção primária com queixas relacionadas à saúde física, como dificuldades de respirar, taquicardia e insônia, sintomas que podem se intensificar na situação extrema vivenciada na pandemia.

Frequentemente, o nexo causal e ações e eventos possivelmente desencadeadores de instabilidade física e psíquica não são investigados e estabelecidos. Dessa forma, muitas pessoas passam por intervenções ineficazes e não protetivas. Indicadores psicossociais de sofrimento e violência poderiam ser incluídos nas anamneses, para que se considere 
e incorpore um suporte interdisciplinar voltado para a integralidade do cuidado. No que concerne à gestão de políticas públicas, a falta desse cuidado integral, além de colocar a vida dos atendidos em risco, acaba por gerar sobrecarga e um custo alto para os serviços e para a saúde dos profissionais.

Parte expressiva dos trabalhadores apresenta dúvidas sobre como e quando realizar as notificações dos casos de violência. Em muitos comentários não há diferenciação entre notificação e denúncia. A sensibilização e a formação em políticas públicas na área da violência precisam ser contínuas, visto que desde 201 I a notificação de violência doméstica, sexual e outras agressões tornou-se compulsória para todos os serviços de saúde, públicos ou privados, e que em 2014 a notificação de casos de violência sexual e tentativa de suicídio passou a ser imediata (em até 24 horas) para as secretarias municipais de Saúde (Brasil, 20I7).

A preocupação com a biossegurança nos espaços coletivos de abrigamento foi um tema importante trazido pelos participantes. A falta de abrigamentos para mulheres vítimas de violência nos municípios brasileiros já era uma realidade, bem como as dificuldades em solicitar medidas restritivas para agressores. Essas barreiras indicam que seria necessário estabelecer protocolos para uma definição mais ágil sobre tais medidas, tendo em vista a convivência contínua com o agressor. Nos casos em que for necessário o abrigamento, é importante a garantia da testagem de funcionários e das famílias para a proteção da equipe e das pessoas em situação de violência.

A transferência dos atendimentos presenciais para o meio remoto não apenas dificultou a detecção e o acompanhamento dos casos de violência doméstica, mas também despertou dúvidas sobre como manejar essas situações à distância. Os profissionais são instados a desenvolver novas estratégias de criação e manutenção de vínculos de confiança e de fornecimento de proteção, assim como de manejo dos casos. No que diz respeito à utilização de sinais para avisar sobre uma situação de violência, é necessário capacitar os profissionais para orientar a pessoa a utilizar palavras-código, identificar o local da chamada e a proximidade do agressor, e recomendar planos de segurança e construção de passos para que a pessoa atendida seja protegida imediatamente.

A mobilização para apoiar trabalhadores da saúde durante a pandemia tem sido percebida em todo o mundo (WHO, 2020). A escassez de informação sobre as consequências da pandemia sobre esses profissionais ficou subsumida no relato até aqui apresentado em razão do grave quadro de falhas na assistência. Porém, a busca por capacitação no tema por parte de 69.240 profissionais brasileiros fala por si. A necessidade de instá-los a refletir sobre como lidar com as situações trazidas pela pandemia e as angústias que vivenciam no trabalho indicam a importância de que as políticas públicas 
e do Sistema Único de Saúde (SUS) no que concerne à atenção às pessoas em situação de violência sejam fortalecidas. O evidente desamparo dos profissionais constatado nas frágeis condições em que trabalham se deve também ao cenário nebuloso das políticas públicas no Brasil, no qual o agravamento pela pandemia convive, no setor Saúde, com questões básicas como as medidas sanitárias adotadas e o precário apoio financeiro ao SUS (Marques et al. 2020). A Organização Mundial da Saúde adverte que os gestores precisam cuidar da segurança e da saúde dos profissionais em geral e daqueles que atuam com pessoas em situação de violência, providenciando suporte social, incentivos não baseados em desempenho e segurança no transporte e cuidado dos filhos e familiares destes profissionais que estão diariamente atuando nos serviços (WHO, 2020).

As dúvidas e comentários apresentados, assim como os estudos sobre o aumento da violência devido a eventos extremos, apontam para a diminuição, ou mesmo ineficiência, das redes de proteção tradicionais. Quando em distanciamento social, as vítimas, ou potenciais vítimas de violência doméstica e familiar, encontram-se isoladas juntamente com seu potencial agressor. Denunciar, então, se torna mais difícil devido à falta de privacidade e da presença de outras redes protetivas, como amigos, familiares, colegas de trabalho e profissionais de serviços de saúde. Os trabalhadores da saúde relatam que a suspensão de visitas domiciliares e a falta de recursos tecnológicos são obstáculos à detecção e monitoramento de casos atendidos na rede de proteção a pessoas em situação de violência, pois tanto dificultam o acesso dos usuários aos serviços quanto impedem o conhecimento da dimensão do problema.

Em eventos críticos, é de se esperar que as vulnerabilidades da população atingida aumentem, assim como os recursos diminuam. É preciso, portanto, construir planos de ação e políticas públicas que permitam o funcionamento da rede de cuidado e proteção da pessoa em situação de violência em diversos cenários. Não simplesmente para manter a eficiência vigente em momentos anteriores ao desastre, mas para aumentar a capacidade dessa rede de proteção e cuidado para que possa chegar até as pessoas que já não têm mais possibilidade de contatá-las.

\section{Agradecimentos}

Agradecemos ao Programa Pós-Doutorado Nota 10 da Fundação Carlos Chagas Filho de Amparo à Pesquisa do Estado do Rio de Janeiro e ao Pós-Doutorado Junior 2019 do Conselho Nacional de Desenvolvimento Científico e Tecnológico. 


\section{REFERÊNCIAS}

BARBOSA, D. J. et al. Relação entre o consumo de drogas psicoativas e Covid- 19: síntese de evidências. Journal of Management E Primary Health Care, 12: I -9, 31 2020.

BOSERUP, B.; MCKENNEY, M. \& ELKBULI, A. Alarming trends in US domestic violence during the Covid- I 9 pandemic. The American Journal of Emergency Medicine, 2020.

BOXALL, H.; MORGAN, A. \& BROWN, R. The prevalence of domestic violence among women during the Covid-I 9 pandemic. Australian Institute of Criminology, 7.302: I - 19, 2020.

BRASIL. Ministério da Saúde. Portaria de Consolidação n. 4, de 28 set. 2017.Consolodação das normas sobre os sistemas e os subsistemas do Sistema Único de Saúde. Diário Oficial União, Brasília, 3 out. 2017. Disponível em: <http://bvsms.saude.gov.br/bvs/saudelegis/gm/2017/prc0004_03_10_2017. html >. Acesso em: 10 nov. 2020.

BRASIL. Ministério da Saúde. Plano de Contingência Nacional para Infecção Humana pelo Novo Coronavírus Covid-19. Centro de Operações de Emergências em Saúde Pública. Brasília: Ministério da Saúde, fev. 2020. Disponível em: <https://covid I9-evidence.paho.org/handle/20.500.12663/62I>. Acesso em: 10 nov. 2020.

CAMPBELL, A. M. An increasing risk of family violence during the Covid- I 9 pandemic: Strengthening community collaborations to save lives. Forensic Science International: Reports, 100089, 2020. Disponível em: <www.ncbi.nlm.nih.gov/pmc/articles/PMC7I529I2/>. Acesso em: nov. 2021.

DE PAOLO, C. A. \& WILKINSON, K. Get your head into the clouds: using word clouds for analyzing qualitative assessment data. TechTrends, 58(3): 38-44, 2014.

DEVI, S. Covid-I 9 exacerbates violence against health workers. The Lancet, 396(I0.252): 658, 2020. Disponível em: <https://doi.org/10.1016/S0140-6736(20)3 I 858-4>. Acesso em: nov. 2021.

EDOVATO, T. G. et al. Trabalhadores/as da saúde e a Covid- I9: condições de trabalho à deriva? Revista Brasileira de Saúde Ocupacional, 46: 1-15, 2020.

EISNER, M. P. \& NIVETTE, A. Violence and the pandemic: urgent questions for research. HFG Research and Policy in Breif, I- 10, 2020.

FUNDAÇÃO OSWALDO CRUZ (FIOCRUZ). Saúde mental e atenção psicossocial na pandemia Covid- I9: violência doméstica e familiar na Covid-19, 2020. Disponível em: <https://portal.fiocruz. $\mathrm{br} /$ sites/portal.fiocruz.br/files/documentos/saude-mental-e-atencao-psicossocial-na-pandemiacovid-19-violencia-domestica-e-familiar-na-covid-19.pdf>. Acesso em: 22 jul. 2020.

FÓRUM BRASILEIRO DE SEGURANÇA PÚBLICA. Nota técnica. Violência doméstica durante a pandemia de Covid-19. Fórum Brasileiro de Segurança Pública em parceria com Decode, 2020. Disponível em: $<$ https://forumseguranca.org.br/wp-content/uploads/20 I 8/05/violencia-domestica-covid- I 9-v3. pdf>. Acesso em: 29 out. 2020.

MAHASE, E. Covid-19: EU states report 60\% rise in emergency calls about domestic violence. BMJ, 369: $\mathrm{mI} 872,2020$.

MARQUES, E. S. et al. A violência contra mulheres, crianças e adolescentes em tempos de pandemia pela Covid- 19: panorama, motivações e formas de enfrentamento. Cadernos de Saúde Pública, 36: e00074420, 2020 . 
NOAL, D. S.; PASSOS, M. F. D. E FREITAS, C. M. (Orgs.). Recomendações e Orientações em Saúde Mental e Atenção Psicossocial na Covid-19. Brasília: Fundação Oswaldo Cruz, 2020.

NOAL, D. S. et al. Capacitação nacional emergencial em saúde mental e atenção psicossocial na Covid- 19: um relato de experiência. Saúde em Debate, 44: 293-305, 2020.

PARKINSON, D. Investigating the increase in domestic violence post disaster: an Australian case study. Journal of Interpersonal Violence, 34(I I): 2.333-2.362, 2019.

RAVINDRAN, S. E SHAH, M. Unintended consequences of lockdowns: Covid-19 and the shadow pandemic. Cambridge: National Bureau of Economic Research, 2020. Disponível em: <www.nber.org/ system/files/working_papers/w27562/w27562.pdf>. Acesso em: 29 out. 2020.

RODRÍGUEZ-BOLAÑOS, R. et al. The urgent need to address violence against health workers during the Covid- I 9 Pandemic. Medical Care, 58(7): 663, 2020.

SACCO, M. A. et al. The impact of the Covid- I 9 pandemic on domestic violence: the dark side of home isolation during quarantine. The Medico-Legal Journal, 88(2): 7I-73, 2020.

SOCIEDADE BRASILEIRA DE GERIATRIA E GERONTOLOGIA (SBGG). A Covid- I 9 não pode ser mais um motivo para falta de assistência digna aos idosos brasileiros, 2020. Disponível em: <https://sbgg.org. br/wp-content/uploads/2020/07/COVID-19_SGGG-v5.pdf>. Acesso em: 29 out. 2020.

UNITED NATIONS POPULATION FUND (UNFPA). Impact of the Covid- I 9 pandemic on family planning and ending gender-based violence, female genital mutilation and child marriage. Interim technical note, Apr. 2020. Disponível em: <www.unfpa.org/resources/impact-covid-19-pandemic-family-planningand-ending-gender-based-violence-female-genital>. Acesso em: 29 out. 2020.

WORLD HEALTH ORGANIZATION (WHO). Addressing violence against children, women and older people during the Covid-19 pandemic: key actions. Geneva: World Health Organization, 2020. Disponível em: <www.who.int/publications/i/item/WHO-20 I 9-nCoV-Violence_actions-2020.I > .

$\mathrm{ZHU}$, J. et al. Prevalence and influencing factors of anxiety and depression symptoms in the first-line medical staff fighting against Covid- 19 in Gansu. Frontiers in Psychiatry, II, 2020. 

PARTE IV

EXPERIÊNCIAS BRASILEIRAS NA PANDEMIA DE COVID-19

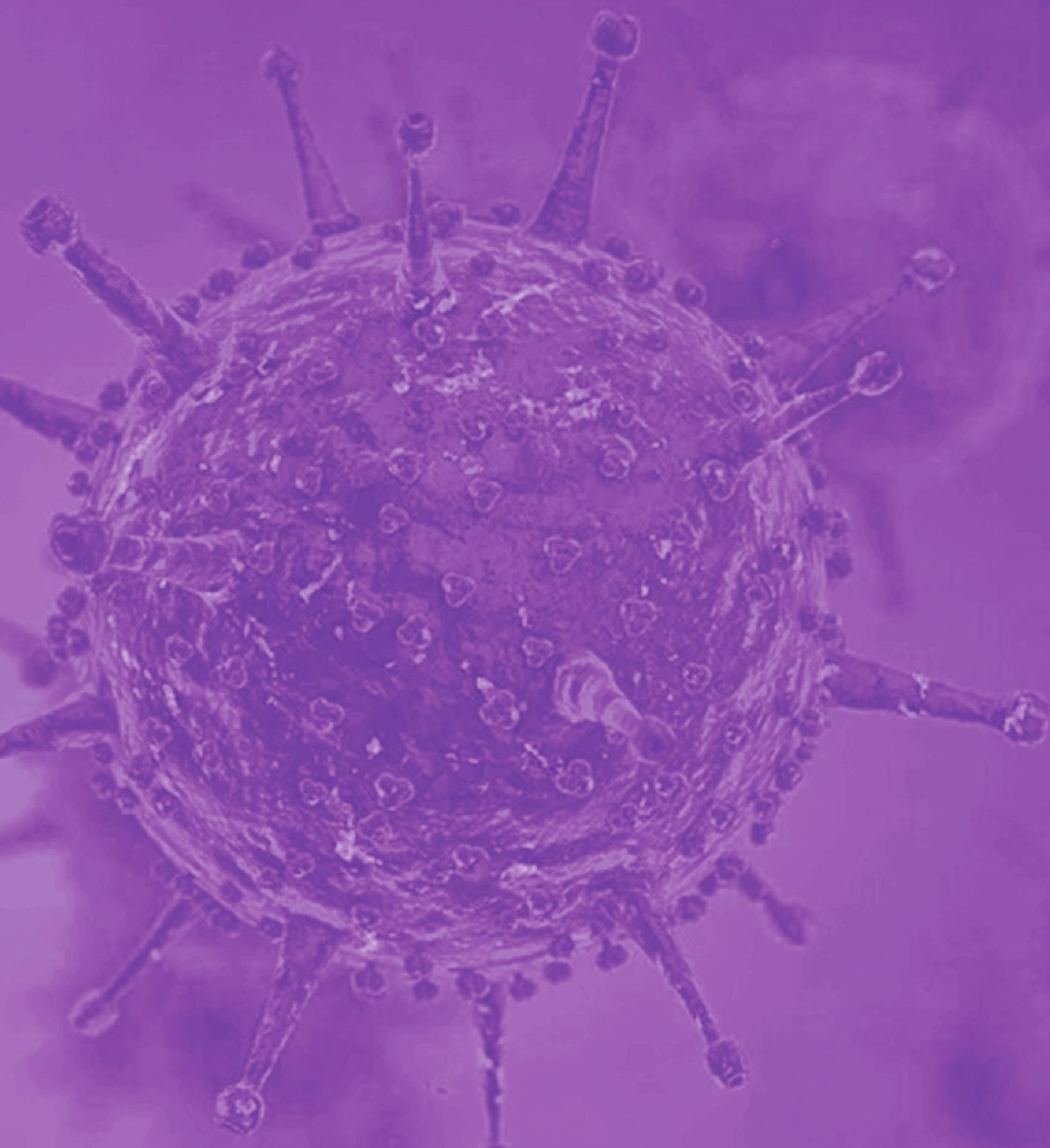





\title{
Atuação da Defensoria Pública na Pandemia
}

\author{
a luta por melhor organização e \\ priorização da assistência à saúde
}

Thaísa Guerreiro Souza

\begin{abstract}
7 tuar com saúde coletiva na Defensoria Pública do Estado do Rio de Janeiro (DPRJ) nunca foi tarefa fácil. A litigância nessa área tão sensível, cara ao estado democrático
\end{abstract} de direito (art. I $^{\circ}$, III, da CRFB/88) e irrenunciável, pois que diretamente relacionada ao núcleo duro da Constituição, os direitos fundamentais à saúde e à vida (Brasil, 1988), sempre exigiu uma postura combativa e incansável dos defensores públicos que se dedicam ao tema. Para ser efetiva, uma assistência jurídica que envolve o próprio direito à vida precisa ser humanizada, irretocável e célere, responsabilidade à qual é inerente enorme desgaste psicológico.

Nos últimos anos, a desvirtuada crítica à judicialização da saúde (Souza, 2018) aliada à crescente teoria do consequencialismo jurídico,' já vinha dificultando o acesso à justiça e à saúde mediante a imposição de sucessivos requisitos para o ajuizamento de demandas judiciais na área e questionável deferência dos órgãos julgadores ao poder público. Mas nunca antes na história a luta pela garantia do acesso à saúde foi tão árdua e sofrida como ao longo da pandemia da Covid- 19. Exatamente quando se esperava, de todos os poderes, em todas as esferas (federal, estadual e municipal), a união de esforços pela vida.

\footnotetext{
' No Brasil, o consequencialismo jurídico foi positivado, em 2018, no art. 20 da Lei de Introdução às Normas do Direito Brasileiro ("nas esferas administrativa, controladora e judicial, não se decidirá com base em valores jurídicos abstratos sem que sejam consideradas as consequências práticas da decisão"). Entretanto, a teoria vem sendo invocada pelos gestores como argumento para reforçar o projeto político de austeridade fiscal e redução dos investimentos em políticas sociais. E aplicada por grande parte dos magistrados de forma abstrata, genérica e distorcida, com enfoque apenas em supostas repercussões econômicas que servem, no fundo, para legitimar a tese de impossibilidade do controle judicial mesmo em casos de omissões inconstitucionais do Estado na concretização de direitos fundamentais.
} 
Na contramão das recomendações n. I e 4 da Comissão Interamericana de Direitos Humanos (CIDH, 2020), que reafirmam a importância do controle do Poder Judiciário e da garantia do acesso à justiça na pandemia, o Conselho Nacional de Justiça expediu a recomendação n. 66/2020 (CNJ, 2020), orientando os magistrados de todo o país a avaliar as demandas judiciais em saúde com deferência em relação aos gestores públicos e a evitar as intimações, sanções pessoais, multas e bloqueios de verbas públicas. Portanto, desde o início, já se esperava que a luta pela garantia do acesso à saúde e à vida dos mais vulneráveis seria, como nunca antes, contramajoritária.

Apresento aqui, em breves linhas, parte do caminho já percorrido pela DPRJ para mitigar os duros impactos da pandemia da Covid-19 e garantir, ao máximo, melhor assistência aos cidadãos mais vulneráveis em um contexto adverso e agravado por um projeto de desigualdade social em curso.

\section{A LITIGÂNCIA ESTRATÉGICA PARA UMA ASSISTÊNCIA MELHOR}

Em fevereiro de 2020, quando a descoberta do novo coronavírus e o risco sério e grave de uma pandemia mundial invadiam os noticiários de todo o mundo, as principais preocupações dos defensores públicos eram: I) diante de um cenário de histórica escassez em recursos humanos e materiais (leitos, equipamentos, insumos, medicamentos, entre outros) no Sistema Único de Saúde (SUS), elaborar uma litigância estratégica efetiva que compelisse estados e municípios ao adequado planejamento, monitoramento e execução de medidas de enfrentamento da pandemia que desse conta da atual e da futura demanda por ações e serviços de saúde; 2) robustecer a força de trabalho da DPRJ de modo a atender, com eficiência, as demandas da população de todo o estado do Rio de Janeiro; e 3) buscar uma atuação coordenada e estratégica com os demais órgãos de controle a fim de evitar ações contraditórias que confundem os gestores e enfraquecem a defesa dos mais vulneráveis.

Há pelo menos dez anos a DPRJ tem denunciado a elevada judicialização individual do acesso a leitos de terapia intensiva, ${ }^{2}$ a insuficiência dessa cobertura assistencial, as deficiências na regulação do acesso a leitos no estado, assim como a falta de planejamento e de pactos necessárias à organização das redes interfederativas de atenção à saúde, com importantes vácuos assistenciais no território fluminense.

\footnotetext{
${ }^{2}$ Desde 2013, são elaborados relatórios sobre as demandas judiciais propostas pela DPRJ no Plantão Judiciário Noturno a fim de monitorar a demanda por cuidados intensivos no estado. Em 2018, com base nos relatórios, a DPRJ denunciou à CIDH a insuficiência de leitos de terapia intensiva no estado.
} 
Na capital fluminense houve, a partir de 2017, drástica redução nos investimentos em saúde e consequente retrocesso no grau de desempenho do sistema de saúde local, sobretudo na atenção básica, coordenadora do cuidado dos cidadãos. Tal aspecto foi denunciado de modo reiterado pela Defensoria Pública por meio de três ações civis públicas propostas em 2017, 2018 e 2019 (TJRJ, 2017-2019).

Nesse cenário, era previsível que sem uma mudança radical nos rumos da política pública de saúde no estado do Rio de Janeiro, os impactos da pandemia da Covid- 19 seriam devastadores e muitos faleceriam de forma invisível para o sistema, em suas casas e em vias públicas, ou em unidades básicas e pré-hospitalares, sem acesso digno ao tratamento de saúde necessário.

Preocupada, já em 18 de março de 2020 a Coordenadoria de Saúde da DPRJ instaurou procedimento administrativo com a finalidade de monitorar e fomentar, de forma coordenada e estratégica, ${ }^{3}$ o planejamento e a execução da política pública de enfrentamento da Covid - I 9 no estado, seguindo a lógica do planejamento ascendente e regionalizado do SUS.

Compreendia-se que somente a partir da elaboração dos planos municipais de contingência por todos os municípios seria possível ao estado identificar os vácuos assistenciais de referência para Covid-19 e coordenar um efetivo planejamento regionalizado, no âmbito das comissões Intergestores Regionais (CIRs), e estadual, no âmbito da Comissão Intergestores Bipartite (CIB/RJ). Nesse passo, a DPRJ expediu recomendações a todos os municípios fluminenses de que fomentassem extrajudicialmente a elaboração e a implementação dos planos municipais de contingência pautando-se nos oito eixos de medidas de enfrentamento da Covid- 19 previstas no Plano de Contingência Nacional para Infecção Humana pelo Novo Coronavírus Covid- I 9 do Ministério da Saúde: Vigilância; Suporte laboratorial; Medidas de controle de infecção; Assistência; Assistência farmacêutica; Vigilância sanitária - Medidas de saúde em pontos de entrada (portos, aeroportos e passagens de fronteiras); Comunicação de risco; Gestão (Brasil, 2020a).

\footnotetext{
${ }^{3}$ E aqui faço uma homenagem aos bravos colegas Alessandra Glória, Samantha de Oliveira, Tiago Abud, Raphaela Jahara, João Helvécio, Rodrigo Azambuja e Eliane Arese, que encararam, ao meu lado, na tutela coletiva, o início do pior momento da pandemia. A Isabel Fonseca e Luiza Maciel, que vieram somar valorosos esforços. E aos nobres colegas Larissa Davidovich, Cristian Barcellos, Alessandra Bentes, Luiz Fabiano de Faria, Lúcio Campinho, Lucas Sant'Anna, Mirela Assad, Andrea Carius, Marcílio Brito, Flavio Lethier, Renata Duarte, Andrea Vidal, Rita Franco e Bernardo de Castro, que, a partir de outubro de 2020, em um projeto de expansão da tutela coletiva da Defensoria Pública, somaram-se a essa jornada.
} 
Foram propostas, ainda, 56 ações civis públicas em face dos munícipios que não elaboraram ou não haviam publicizado os seus planos de contingência extrajudicialmente.

Acredita-se que o resultado foi positivo, pois muitos municípios não conheciam a política pública e ainda não tinham elaborado o seu Plano de Contingência, sob a alegação equivocada de que não o possuíam ou de que eram poucos os casos confirmados de Covid-19. O fomento provocado pela atuação capilarizada e simultânea da DPRJ em todo o estado impulsionou o planejamento local, regionalizado e a primeira pactuação bipartite do Plano de Resposta de Emergência ao Coronavírus no Estado do Rio de Janeiro, mediante a deliberação conjunta CIB/Cosems-Rj n. 7 I/2020 (CIB-RJ, 2020a).

Uma vez monitorada, por intermédio dos planos municipais de contingência, toda a assistência planejada e efetivamente implementada por cada município em cada Região de Saúde (RS), a DPRJ conseguiu calcular, com base em parâmetros de cobertura assistencial no SUS e nas condições de organização local e regional dos serviços, os déficits de leitos de enfermaria e de terapia intensiva de cada município e de cada RS. E cobrar, judicialmente, a suplementação de tais vácuos assistenciais dos municípios e, principalmente, do estado, a fim de garantir o direito fundamental de acesso integral à saúde.

À luz de tais parâmetros, verificou-se, por exemplo, que nas RS historicamente deficitárias, como Metropolitana I, II e Baixada Litorânea (TJRJ, 2020a), nem mesmo os leitos suplementares programados pelo estado nos hospitais de campanha seriam suficientes para acolher, com dignidade, todos os casos de Covid- 19 que necessitassem de internação hospitalar.

Como o estado não inaugurou os hospitais de campanha no tempo e do modo programados, a DPRJ propôs seis ações coletivas, solicitando a implementação de todos os leitos, devidamente estruturados, prometidos nos hospitais de campanha de Nova Iguaçu (incluindo o hospital modular), Casimiro de Abreu, Campos, São Gonçalo, Maracanã e Rio Centro, os quatro últimos em parceria com o Ministério Público do Estado (TJRJ, 2020b). Nas RS deficitárias, postulou-se, ainda, a suplementação dos leitos transitórios mediante estratégias de contratualização no setor privado, expansão de estruturas hospitalares existentes ou otimização de áreas ociosas. Além disso, a DPRJ interveio nas ações coletivas ajuizadas pelo Ministério Público Federal, cobrando a implantação do Hospital de Campanha de Nova Friburgo, e pelo Ministério Público Estadual, cobrando, entre outros a operacionalização dos leitos do Hospital de Campanha de Duque de Caxias (TJRJ, 2020c). 
Não foi a DPRJ quem elegeu a abertura de leitos em hospitais de campanha como a principal alternativa para a expansão da oferta hospitalar de referência para Covid- 19 no estado. Essa foi a opção da própria administração pública, expressamente pactuada pelo estado e por todos os municípios fluminenses em esfera bipartite. Logo, as ações coletivas objetivaram, apenas, sem qualquer interferência no juízo de conveniência e oportunidade do gestor, cobrar a implementação do próprio planejamento público.

Quanto às pessoas privadas de liberdade, grupo hipervulnerável em razão das inadequadas condições de habitação, da circulação restrita e da inviabilidade de adoção de medidas não farmacológicas efetivas, foi proposta, em parceria com o Ministério Público do Estado do Rio de Janeiro, ação coletiva objetivando, em geral, medidas de enfrentamento da pandemia específicas para essa população (TJRJ, 2020d). Infelizmente, o pleito liminar não foi acolhido pelo Poder Judiciário, nem em primeira nem em segunda instância.

Foram grandes os esforços, inclusive na via judicial, para que, enquanto não fossem implantados os hospitais de campanha, outras medidas fossem adotadas pelo poder público, como a requisição de leitos ociosos na rede privada e a otimização dos leitos impedidos na rede pública de saúde. De igual modo, buscou-se arduamente evitar que os hospitais de campanha do Riocentro, Maracanã e São Gonçalo fossem desmontados sem que houvesse planejamento e estudo prévio para a devida compensação dos leitos fechados nas redes próprias municipais e estadual. O entrave judicial persiste até hoje, em grau de recurso no Tribunal de Justiça. O resultado prático, denunciado inúmeras vezes pela DPRJ com base no monitoramento das sucessivas versões do Plano de Contingência Estadual (www.cib.rj.gov.br/deliberacoes-cib.html), do portal da transparência de leitos do município do Rio de Janeiro (https://web2.smsrio.org/hospitalar/censoPublico/\#/) e do aumento da fila de espera para internação em leitos não Covid, ${ }^{4}$ é que os leitos fechados ainda não foram efetivamente compensados mediante a inauguração de leitos novos ou estavam bloqueados/impedidos na rede própria.

Por isso, a questão foi submetida à apreciação do Poder Judiciário em nova ação civil pública proposta pela DPRJ em março de 2021 . Na demanda, postulou-se não só a atualização e publicização ampla e regular do Plano Estadual de Contingência, como a condenação do estado a elaborar, no prazo máximo de 30 dias, nos termos da deliberação CIB-RJ n. 6.248/2020 (CIB-RJ, 2020b), um plano de ação com medidas a curto, médio e longo prazos necessárias à reorganização da rede hospitalar voltada para o atendimento digno de pacientes com e sem Covid- 19 no território fluminense (TJRJ, 202I).

${ }^{4}$ Dados informados à DPRJ pela Secretaria de Saúde do Estado do Rio (SES-RJ) inseridos nos autos n. 0072216 19.2021.8.19.000I (TJRJ, 202I). 
De outro lado, era certo que a luta por melhor assistência não englobava apenas a expansão da oferta de leitos de referência para Covid-19. Era indispensável que estado e municípios sincronizassem essa expansão com medidas de modulação do distanciamento social embasadas em evidências científicas e análises sobre informações estratégicas em saúde, como determinam o art. $3^{\circ}, \S 1^{\circ}$, da lei n. 13.979/2020 e o Supremo Tribunal Federal em importantes precedentes relativos à pandemia, destacando-se as ações diretas de inconstitucionalidade n. 6.341, 6.343, 6.422, 6.421, 6.428, 6.425, 6.427, 6.431 e 6.424 (STF, 2020). De fato, não há leito que baste se o poder público não intensificar as ações de vigilância em saúde, reforçar a estratégia de testagem de casos suspeitos e seus contatos, e adotar medidas de restrição de atividades que promovem a interação e infecção de grupos suscetíveis.

Nessa frente, a DPRJ monitorou a evolução da testagem e fomentou e participou da elaboração dos planos de retomada de diversos municípios fluminenses. E também propôs inúmeras ações coletivas questionando a modulação do distanciamento social conduzida por entes públicos sem respaldo em critérios técnicos e científicos.

Na capital, destacam-se duas ações coletivas propostas pela DPRJ em face do estado e do município do Rio (TJRJ, 2020e), que, segundo importantes instituições científicas - Fundação Oswaldo Cruz (Fiocruz), Universidade Federal do Rio de Janeiro (UFRJ), Universidade do Estado do Rio de Janeiro (Uerj) e Universidade Federal Fluminense (UFF) - iniciaram a flexibilização social de forma prematura, sem uma criteriosa análise do risco em saúde pública. Não se pode olvidar, pois que os efeitos de tal postura se arrastam até hoje, que estado e município do Rio iniciaram o seu processo de flexibilização social quando I) ainda não havia queda sustentada dos casos de Covid; 2) a taxa de letalidade era uma das maiores do Brasil, de 12,8\%; 3 ) o índice de testagem era baixíssimo, inviabilizando o adequado monitoramento do novos casos, rastreio e isolamento, e havia um atraso de até 52 dias no sistema de notificação, como apontado em estudo da Fiocruz; 4) a taxa de ocupação hospitalar ultrapassava 90\%; 5) a fila de espera por leitos de referência para Covid- 19 totalizava quase 300 pessoas; 6) os gestores descumpriam o próprio projeto de ampliação de leitos; e 7) o SUS não apresentava capacidade para acolher e tratar com dignidade as vítimas da Covid-19.5

Acredita-se que as ações da DPRJ impulsionaram a elaboração pelos entes públicos de planos de retomada mais adequados, do ponto de vista técnico e científico. O estado

\footnotetext{
${ }^{5}$ Dados acostados na ação coletiva proposta em face do estado do Rio de Janeiro e fornecidos à DPRJ pela SES/ RJ e extraídos das notas técnicas "O tempo dos dados: explorando a cobertura e oportunidade do Sivep Gripe e o e-SUS VE" e "Importância das medidas de distanciamento social no contexto atual da covid- I 9 no Rio de Janeiro", elaboradas pela Fiocruz (Fiocruz, 2020a, 2020b).
} 
do Rio só elaborou e aperfeiçoou o seu Plano de Retomada após a judicialização do tema. Foram incorporados, por exemplo, alguns indicadores e estratégias citados pela DPRJ como necessários no curso do processo judicial, como o monitoramento das taxas de ocupação de leitos municipais e regionais (e não só dos estaduais) e dos atendimentos de casos suspeitos de Covid- 19 nas unidades pré-hospitalares.

Para demonstrar a importância desse segundo indicador, a DPRJ analisou informações encaminhadas por 11 I unidades públicas de saúde, básicas e pré-hospitalares, com relação a um período de 90 dias no período de abril a agosto de 2020 (DPRJ, 2020). No relatório se registrou que: $20 \%$ das unidades de saúde oficiadas não tinham acesso ao Sistema Estadual de Regulação (SER); em 44,5\% dos casos que necessitaram de transferência para um leito para síndrome respiratória aguda grave, os pacientes faleceram na unidade pré-hospitalar ou básica à espera da transferência ou durante o transporte; e em quase 3\% dos casos o óbito ocorreu antes mesmo que o paciente fosse inserido no SER. Nas palavras de Matta e colaboradores na publicação Os Impactos Sociais da Covid-19 no Brasil: populações vulnerabilizadas e respostas à pandemia, sobre esse pano de fundo se desenrola como cena principal a mistanásia, ou seja, a morte precoce, previsível, evitável, causada por abandono, gerada tanto pela negligência quanto pela falta de interesse do Estado (Matta et al., 2020).

Ao final de 2020 e início de 2021, a DPRJ propôs mais duas ações coletivas relativas ao tema, pois estado e município do Rio passaram a modular o distanciamento social em desconformidade com as diretrizes do seu próprio corpo técnico e científico (TJRJ, 2020-202I).

Por fim, não se pode olvidar a importância da imunização dos grupos mais vulneráveis ao agravamento e óbito por Covid- 19 para a diminuição da pressão sobre a rede assistencial e para o aperfeiçoamento da assistência. Por isso, a DPRJ expediu ofícios e recomendações a todos os municípios fluminenses para que fossem elaborados e executados os planos municipais de vacinação conforme os parâmetros do Plano Nacional de Operacionalização da Vacinação contra a Covid- 19 (PNO) (Brasil, 2020b) e monitora o processo de imunização em todo o estado, cotejando o quantitativo e a destinação social dos imunizantes encaminhados pelo Ministério da Saúde com o quantitativo distribuído a cada município pelo estado e os calendários locais.

Para garantir a segurança jurídica, a higidez e a eficiência do PNO em território estadual e nacional, a DPRJ postulou judicialmente, em parceria com o Ministério Público, a declaração de nulidade do decreto estadual n. 47.547/202 I (Rio de Janeiro, 2020), que, em um cenário de escassez e sem qualquer motivação técnica (peculiaridades e especifi- 
cidades regionais) e prévia pactuação em $\mathrm{CIB} / \mathrm{RJ}$, antecipou a vacinação dos profissionais das forças de segurança, salvamento, das Forças Armadas e da educação em detrimento dos grupos prioritários de idosos, pessoas com comorbidades e deficiência. A atuação culminou com o ajuizamento pela DPRJ da exitosa reclamação n. 46.965 junto à Corte Maior, a qual assentou que qualquer decisão concernente à ordem de prioridade da vacinação deve estar embasada em critérios técnicos e científicos, nos termos do art. $3^{\circ}$, § $I^{\circ}$, da lei 13.979/2020 (STF, 202 I).

Houve, ainda, inúmeras outras importantes atuações da DPRJ que não é possível detalhar neste reduzido espaço.

Toda essa luta não seria possível sem o sentimento de solidariedade, empatia e cooperação que uniu todos os defensores públicos em prol de uma atuação harmônica voltada para os mais vulneráveis. Foi, ainda, de fundamental importância o fortalecimento das parcerias já existentes com o Ministério Público do Estado, o Ministério Público Federal, a Defensoria Pública da União, o Conselho Regional de Medicina, o Ministério Público do Trabalho, a Rede de Controle dos Tribunais de Contas do Estado e da União, a Fiocruz, ${ }^{6}$ a UFRJ, a Uerj, a UFF, a Comissão de Saúde Pública da Assembleia Legislativa do Estado e, é claro, a sociedade civil e nossa ouvidoria externa.

A troca de dados, informações, experiências e a união de esforços, mediante, inclusive, a divisão estratégica de tarefas e/ou a complementação de olhares e perspectivas diferentes sobre um mesmo tema, por todos esses atores deram, sem sombra de dúvida, um sopro de esperança para a população fluminense. Os elementos que retardaram o efeito catalisador dos interesses políticos que atravessaram a técnica, a ciência e o direito na pandemia da Covid- 19.

\section{OS DESAFIOS IMPOSTOS PELA MERCANTILIZAÇÃO E POLITIZAÇÃO DA VIDA: ATÉ QUANDO?}

Não foram poucos os desafios enfrentados pelos defensores públicos que assumiram a luta por melhor assistência para os mais vulneráveis durante a pandemia da Covid- 19. O contexto marcado pelos efeitos do subfinanciamento no SUS e pelas históricas deficiências no planejamento, na implementação das redes regionalizadas de atenção à saúde, na vigilância e na assistência prenunciavam, de certa forma, as dificuldades que adviriam de uma pandemia cujo enfrentamento demandava, exatamente, bases sólidas de um sistema interfederativo ainda em construção no Estado.

\footnotetext{
${ }^{6} \mathrm{~A}$ Fiocruz expediu relevantíssima nota técnica em apoio à demanda coletiva por restabelecimento da eficácia do PNO no estado do Rio.
} 
Os tempos seriam difíceis, sem sombra de dúvida. Mas o maior abalo moral coletivo, decorrente do sentimento imposto de desapreço, de descaso, de perda de valores essenciais a uma vida justa e digna e, arrisco dizer, à própria condição humana, foi constatar que, exatamente quando os direitos fundamentais mais básicos e caros ao estado democrático de direito (o direito à saúde e à própria vida) eram colocados em xeque, o poder público, em inúmeras esferas federativas, mais uma vez fracassou.

A luta é ainda maior e mais árdua quando a corrupção, a política, o prestígio social e interesses ilegítimos atravessam e ditam escancaradamente a atuação da administração pública, distanciando-a de sua própria razão de ser (proteger os cidadãos), da ciência, dos valores morais e da própria humanidade.

\section{REFERÊNCIAS}

BRASIL. Constituição da República Federativa do Brasil. Brasília: Senado Federal, 1988.

BRASIL. Ministério da Saúde. Plano de Contingência Nacional para Infecção Humana pelo Novo Coronavírus Covid-19. I a versão. Brasília: Ministério da Saúde, 2020a. Disponível em: <www.gov. br/saude/pt-br/coronavirus/publicacoes-tecnicas/guias-e-planos/livreto-plano-de-contingenciaespin-coe-26-novembro-2020>. Acesso em: 20 dez. 2020.

BRASIL. Ministério da Saúde. Plano Nacional de Operacionalização da Vacinação contra a Covid- 19. $I^{\text {a }}$ versão. Brasília: Ministério da Saúde, 2020b. Disponível em <www.gov.br/saude/pt-br/media/ pdf/2020/dezembro/I6/plano_vacinacao_versao_eletronica-1.pdf >. Acesso em: 20 dez. 2020.

COMISSÃO INTERGESTORES BIPARTITE (CIB-RJ). Secretaria de Estado de Saúde. Deliberação Conjunta CIB/Cosems-RJ n. 7 I, de I de abril de 2020. [Norma na internet]. 2020a. Disponível em: <www.cib. rj.gov.br/deliberacoes-conjuntas/346-cib-cosems/6767-deliberacao-conjunta-cib-cosems-rj-n-7 Ide-0I-de-abril-de-2020.html>. Acesso em: 2 fev. 2021.

COMISSÃO INTERGESTORES BIPARTITE (CIB-RJ). Secretaria de Estado de Saúde. Deliberação CIB-RJ n. 6.248, de 10 de setembro de 2020. [Norma na internet]. 2020b. Disponível em <www.cib.rj.gov. br/deliberacoes-cib/682-2020/agosto/69 I 5-deliberacao-cib-rj-n-6-248-de-I0-de-agosto-de-2020. html >. Acesso em: 2 fev. 2021 .

CONSELHO INTERAMERICANO DE DIREITOS HUMANOS (CIDH). Resoluções n. I, de 10 de abril de 2020, e n. 4, de 27 de julho de 2020. [Normas na internet]. 2020. Disponíveis em: <www.oas.org/ pt/cidh/decisiones/pdf/Resolucao- I-20-pt.pdf e <www.oas.org/es/cidh/decisiones/pdf/Resolucion-420-es.pdf >. Acesso em: 2 fev. 2021.

CONSELHO NACIONAL DE JUSTIÇA (CNJ). Recomendação n. 66, de 13 de maio de 2010 [Norma na internet]. 2020. Disponível em <https://atos.cnj.jus.br/atos/detalhar/33 I 8>. Acesso em: 2 fev. 202 I .

DEFENSORIA PÚBLICA DO ESTADO DO RIO DE JANEIRO (DPRJ). Relatório desenvolvido pela Diretoria de Estudos e Pesquisas de Acesso à Justiça da Defensoria Pública do Rio de Janeiro, 9 out. 2020. Disponível em: <http://sistemas.rj.def.br/publico/sarova.ashx/Portal/sarova/imagem-dpge/public/ arquivos/relat\%C3\%B3rio_respostas_unidades_de_sa\%C3\%BAde_Covid_09.10.20_(3)_( I).pdf >. Acesso em: 2 fev. 2021. 
FUNDAÇÃO OSWALDO CRUZ (FIOCRUZ). O tempo dos dados: explorando a cobertura e oportunidade do SIVEP-Gripe e o e-SUS VE. Nota técnica. Rio de Janeiro, 2020a. Disponível em: <https://portal. fiocruz.br/sites/portal.fiocruz.br/files/documentos/nota_tecnica_I3.pdf > . Acesso em: 2 fev. 2021 .

FUNDAÇÃO OSWALDO CRUZ (FIOCRUZ). Importância das medidas de distanciamento social no contexto atual da Covid-I 9 no Rio de Janeiro. Nota técnica. Rio de Janeiro, 2020b. Disponível em: $<$ https://agencia.fiocruz.br/sites/agencia.fiocruz.br/files/u91/nota_tecnica_sobre_criterios_e_ medidas_de_distanciamento_social_covid-19_28_05_2020.pdf >. Acesso em: 2 fev. 202 I.

MATTA, G. C. et al. (Orgs.). Os Impactos Sociais da Covid-19 no Brasil: populações vulnerabilizadas e respostas à pandemia [online]. Rio de Janeiro: Observatório Covid 19, Editora Fiocruz, 202 I . (Informação para Ação na Covid- 19). Disponível em <https://doi.org/l 0.7476/9786557080320>. Acesso em: 2 fev. 2021.

RIO DE JANEIRO. Decreto estadual n. 47.547/202I. Dispõe sobre a criação do Calendário Único de Vacinação da Secretaria de Estado de Saúde para as ações de imunização da campanha da vacinação contra a Covid- 19 em todo o Estado do Rio De Janeiro. Diário Oficial do Estado do Rio de Janeiro, Rio de Janeiro, 30 mar. 202I. Disponível em: <www.mprj.mp.br/documents/20184/540394/decreto_ estadual_47547_ntegra.pdf >. Acesso em: 2 fev. 2021.

SouzA, T. G. A Judicialização Residual da Saúde Proposta pela Defensoria Pública do Estado do Rio de Janeiro: um forte indicativo do grau de desempenho dos serviços públicos de saúde e da efetividade do direito à saúde, 2018. Dissertação de Mestrado, Rio de Janeiro: Escola Nacional de Saúde Pública Sergio Arouca, Fundação Oswaldo Cruz.

SUPREMO TRIBUNAL FEDERAL (STF). Brasil. Ações diretas de inconstitucionalidade (ADIs) n. 6.34I, 6.343, 6.422, 6.421, 6.428, 6.425, 6.427, 6.431 e 6.424, 2020.

SUPREMO TRIBUNAL FEDERAL (STF). Brasil. Reclamação constitucional n. 46.965, 202I. Disponível em<www3.tjrj.jus.br/consultaprocessual/\#/consultapublica\#porNumero > Acesso em: 2 fev. 202I .

TRIBUNAL DE JUSTIÇA DO ESTADO DO RIO DE JANEIRO (TJRJ). Ações civis públicas n. 02984941 5.20 I 7.8. I 9.000 I,03 I I 224-24.20 I 8.8.19.000 I e 0327400-44.20 I 9.8. 19.000 I. Rio de Janeiro, 20 I 72019. Disponíveis em: <www3.tjrj.jus.br/consultaprocessual/\#/consultapublica\#porNumero>. Acesso em: 21 fev. 2021.

TRIBUNAL DE JUSTIÇA DO ESTADO DO RIO DE JANEIRO (TJRJ). Ações civis públicas n. 0025 I 9215.2020.8.19.0038, 00I1982-96.2020.8.19.0004 e 0000562-55.2020.8.19.0017. Rio de Janeiro, 2020a. Disponíveis em: <www3.tjrj.jus.br/consultaprocessual/\#/consultapublica\#porNumero>. Acesso em: 21 fev. 2021 .

TRIBUNAL DE JUSTIÇA DO ESTADO DO RIO DE JANEIRO (TJRJ). Ações civis públicas n. 0025 I9215.2020.8.19.0038, $0011982-96.2020 .8 .19 .0004, \quad 0000562-55.2020 .8 .19 .0017, \quad 0011458-$ 69.2020.8.19.0014 e 0092893-07.2020.8.19.000I. Rio de Janeiro, 2020b. Disponíveis em: <www3. tjrj.jus.br/consultaprocessual/\#/consultapublica\#porNumero > Acesso em: 21 fev. 2021 .

TRIBUNAL DE JUSTIÇA DO ESTADO DO RIO DE JANEIRO (TJRJ). Pedidos de intervenção como assistente listisconsorcial nas ações civis públicas n. 5000827-4I.2020.4.02.5 I 05 e 00 I 6635-90.2020.8. I 9.002 I. Rio de Janeiro, 2020c. Disponíveis em: <https://eproc.jfrj.jus.br/eproc/externo_controlador. php?acao=processo_seleciona_publicaEacao_origem $=$ processo_consulta_publicaEacao_ retorno=processo_consulta_publicaEnum_processo $=50008274 \mathrm{I} 20204025 \mathrm{I} 05 \mathrm{Enum}$ chave $=\varepsilon$ num_chave_documento $=E$ hash $=$ a2799e55el $2488750 \mathrm{cf} 48 \mathrm{ce} 7$ eee08dc7 e <www3.tjrj. jus.br/consultaprocessual/\#/consultapublica\#porNumero>. Acesso em: 21 fev. 2021 . 
TRIBUNAL DE JUSTIÇA DO ESTADO DO RIO DE JANEIRO (TJRJ). Ação civil pública n. 008722992.2020.8.19.000 I. Rio de Janeiro, 2020d. Disponível em: <www3.tjrj.jus.br/consultaprocessual/\#/ consultapublica\#porNumero $>$. Acesso em: 21 fev. 2021.

TRIBUNAL DE JUSTIÇA DO ESTADO DO RIO DE JANEIRO (TJRJ). Ações civis públicas n. 006846 I21.2020.8.19.000 I e 01I7233-15.2020.8.19.000I. Rio de Janeiro, 2020e. Disponível em: <www3. tjrj.jus.br/consultaprocessual/\#/consultapublica\#porNumero>. Acesso em: 21 fev. 2021 .

TRIBUNAL DE JUSTIÇA DO ESTADO DO RIO DE JANEIRO (TJRJ). Ações civis públicas n. 028750020.2020.8.19.000I e 0072216-19.2021.8.19.0001. Rio de Janeiro, 2020-2021. Disponível em: <www3.tjrj.jus.br/consultaprocessual/\#/consultapublica\#porNumero>. Acesso em: 21 fev. 2021 .

TRIBUNAL DE JUSTIÇA DO ESTADO DO RIO DE JANEIRO (TJRJ). Ação civil pública n. 00722I619.2021.8.19.0001. Rio de Janeiro, 202I. Disponível em: <www3.tjrj.jus.br/consultaprocessual/\#/ consultapublica\#porNumero>. Acesso em: 21 fev. 2021. 



\title{
A Experiência do Proqualis na Produção e Divulgação de Informações para o Enfrentamento da Pandemia de Covid-19
}

\author{
Ana Luiza Braz Pavão, Victor Grabois, Carla Gouvêa, \\ Maria de Lourdes Moura, Marina Noronha e Sabrina Duarte
}

\footnotetext{
O
} s primeiros casos da doença transmitida pelo Sars-CoV-2, o novo coronavírus, denominada pela Organização Mundial da Saúde (OMS) Covid-19, ocorreram em dezembro de 2019, na China, e esse vírus espalhou-se rapidamente para várias regiões do mundo. Em I I de março de 2020, a OMS declarou pandemia por Covid- I 9 (Zhu et al., 2019 ; Da Silva, 2020; Anvisa, 2020). No Brasil, o primeiro caso confirmado da doença ocorreu em 26 de fevereiro de 2020 na cidade de São Paulo. Desde então, a doença se espalhou pelos diferentes estados e regiões do país. Atualmente, um ano após a OMS tê-la declarado, o Brasil tornou-se o epicentro global da pandemia e já acumula mais de 21,9 milhões de casos confirmados e mais de 610 mil óbitos pela doença (Brasil, 2021).

O Centro Colaborador para a Qualidade do Cuidado e Segurança do Paciente (Proqualis) é um portal de acesso aberto da Fundação Oswaldo Cruz (Fiocruz) voltado para a disseminação de informações e tecnologias relacionadas ao tema da qualidade do cuidado e da segurança do paciente. Foi criado em 2009 com o objetivo de contribuir para o aprimoramento das práticas de saúde por meio da produção e divulgação de conteúdos técnico-científicos e audiovisuais. Desde a sua criação, tem contado com o trabalho de uma equipe de profissionais e colaboradores, entre os quais pesquisadores, professores, profissionais da saúde e gestores especialistas nas temáticas do portal. Seu público-alvo é formado majoritariamente por profissionais da saúde.

No contexto da pandemia por Covid-19, os profissionais da saúde que atuam na linha de frente, nos serviços de saúde, em contato direto com pacientes suspeitos ou confirmados para Covid-19, tornaram-se um grupo altamente vulnerável e sujeito à infecção. Notícias da pandemia em vários países do mundo mostram que nenhum deles está preparado para oferecer a esses profissionais equipamentos de proteção individual (EPIs) 
e condições estruturais adequados e suficientes para o manejo seguro dos pacientes nos serviços de saúde. Ranney, Griffeth e Jha (2020) citam a situação da Itália, onde elevadas taxas de infecção e morte de profissionais da saúde pela Covid- 19 são devidas, em parte, ao acesso inadequado aos EPIs. Mencionam, também, as necessidades crescentes nos Estados Unidos da América (EUA) de máscaras de proteção respiratória e máscaras cirúrgicas, que superam a disponibilidade atual (Ranney, Griffeth E Jha, 2020).

A segurança dos trabalhadores da saúde assumiu protagonismo nas iniciativas em torno da qualidade do cuidado de saúde e da segurança do paciente no contexto da pandemia. Em virtude disso, a OMS definiu como tema da campanha do Dia Mundial da Segurança do Paciente de 2020 a segurança do trabalhador da saúde, que está diretamente relacionada com a segurança do paciente (WHO, 2020).

Atento a tal definição, o Proqualis identificou a necessidade premente de direcionar as suas ações para a Covid- 19 e contribuir para o enfrentamento da pandemia. Para isso, tem desenvolvido, desde fevereiro de 2020, quando do aparecimento do primeiro caso de Covid- 9 no Brasil, uma diversidade de iniciativas voltadas para a produção e divulgação de informações científicas de qualidade, relacionadas ao tema da Covid- 19 e à temática da qualidade e da segurança do cuidado em saúde, com o objetivo de auxiliar sobretudo os profissionais da saúde, mas também a população em geral, no enfrentamento da pandemia. Essas ações serão descritas com mais detalhes na próxima seção.

\section{INICIATIVAS DESENVOLVIDAS ENTRE 2020 E 2021}

As iniciativas voltadas para o enfrentamento da pandemia por Covid- 19 estiveram relacionadas principalmente às seguintes ações: criação de uma página específica sobre assuntos relacionados à pandemia; produção e divulgação de conteúdos audiovisuais, como entrevistas e vídeos educativos; realização de eventos de conteúdo científico, como os webinários; produção de materiais didáticos, como aulas e um curso autoinstrucional a distância; e o desenvolvimento de uma pesquisa realizada com profissionais da saúde e gestores de unidades de saúde. Para essas produções, o Proqualis contou com diversas parcerias externas e internas, estas últimas com a VideoSaúde Distribuidora e o Campus Virtual, ambos da Fiocruz. Tanto os webinários quanto as aulas estão disponíveis no portal e/ou no YouTube ou no Slideshare do Proqualis, respectivamente.

O Proqualis manteve, ao longo do período de janeiro de 2020 a março de 2021 , mais de 55 mil visualizações de suas páginas e o acesso de cerca de 30 mil usuários por mês, em média (Quadro I). Esses usuários são majoritariamente profissionais da saúde, oriundos de diferentes regiões do país. A página Covid- 19 foi criada em março de 2020 no portal, tendo como objetivo atualizar periodicamente as principais evidências científicas, 
recomendações, manuais, aulas e diretrizes sobre o tema. Desde a sua criação, essa nova página temática, que divulga constantemente conteúdos exclusivos ou provenientes de outras fontes, sempre com respaldo técnico e científico, tem alcançado elevados números de visualizações e de usuários, chegando a figurar entre as cinco mais visitadas do portal no período entre janeiro de 2020 e a primeira quinzena de março de 2021 (Quadro 2), equiparando-se a outras páginas temáticas já consagradas no portal, como a de Segurança do Paciente.

Levando em conta o período em que a página de Covid-19 está no ar, ela já é a segunda mais visitada no portal, atrás apenas da página inicial, o que evidencia a sua importância na disseminação de informações com embasamento técnico e científico para profissionais, gestores e usuários do sistema de saúde, de modo a auxiliar no enfrentamento da pandemia.

Quadro I - Estatísticas de acesso ao portal Proqualis: número de visualizações e de usuários - Jan. 2020 a mar. 2021

\begin{tabular}{|l|c|c|}
\hline \multicolumn{1}{|c|}{ Mês/Ano } & Visualizações & Usuários \\
\hline Janeiro 2020 & 41.664 & 20.391 \\
\hline Fevereiro 2020 & 47.144 & 23.339 \\
\hline Março 2020 & 65.236 & 33.364 \\
\hline Abril 2020 & 57.684 & 30.868 \\
\hline Maio 2020 & 58.803 & 34.674 \\
\hline Junho 2020 & 63.145 & 35.088 \\
\hline Julho 2020 & 59.599 & 32.544 \\
\hline Agosto 2020 & 64.753 & 35.203 \\
\hline Setembro 2020 & 71.910 & 39.975 \\
\hline Outubro 2020 & 68.938 & 39.018 \\
\hline Novembro 2020 & 64.756 & 38.273 \\
\hline Dezembro 2020 & 41.219 & 24.128 \\
\hline Janeiro 2021 & 38.934 & 21.965 \\
\hline Fevereiro 2021 & 45.168 & 23.987 \\
\hline Março 2021 (até 15/03) & 31.283 & 17.523 \\
\hline
\end{tabular}

Fonte: Proqualis, 2021. 
Quadro 2 - Páginas mais visitadas do portal Proqualis, segundo número de visualizações - Jan. 2020 a 15 mar. 2021

\begin{tabular}{|l|c|}
\hline \multicolumn{1}{|c|}{ Página } & Visualizações \\
\hline Página inicial (home page) & 25.081 \\
\hline Segurança do paciente & 14.917 \\
\hline Covid-19 & 13.300 \\
\hline
\end{tabular}

Fonte: Proqualis, 2021.

Ainda no primeiro trimestre de 2020, o Proqualis rapidamente buscou oferecer aos seus usuários informações que auxiliassem no enfrentamento da pandemia. Duas entrevistas foram realizadas com especialistas da Fiocruz: "Coronavírus: como enfrentar a epidemia?" e "Medidas de enfrentamento da pandemia de Covid- 19 para profissionais da saúde". Também nesse período foram traduzidos para o português e disponibilizados no portal dois vídeos educativos da OMS sobre o uso adequado das máscaras: "Quando usar uma máscara?" e "Como colocar, retirar e descartar uma máscara".

Ao longo do ano de 2020 e até o final do primeiro trimestre de 2021, foram realizados I I webinários sobre temas relacionados com segurança do paciente e Covid- 19, dos quais dois em parceria com o Observatório Covid- 19 da Fiocruz. Os temas dos webinários e 0 número de visualizações estão registrados no Quadro 3. Os webinários contaram com a participação de profissionais da saúde de diferentes instituições públicas e privadas brasileiras, com experiência no tema.

Além dos webinários, em setembro de 2020, em comemoração ao Dia Mundial da Segurança do Paciente, foi realizado um seminário em parceria com o Observatório Covid- 19 da Fiocruz: Desafios e Lições da Covid- 19 para a Segurança do Paciente e do Trabalhador da Saúde. 
Quadro 3 - Webinários realizados, segundo tema e número de visualizações - Jun. 2020 a mar. 2021

\begin{tabular}{|c|c|c|}
\hline Tema & Data & Visualizações \\
\hline Prevenção da transmissão intra-hospitalar da Covid- I 9 & 03/06/2020 & 2.876 \\
\hline $\begin{array}{l}\text { Prevenção e manejo clínico do tromboembolismo } \\
\text { venoso na Covid- I } 9\end{array}$ & I 7/06/2020 & 1.093 \\
\hline $\begin{array}{l}\text { Limpeza e desinfecção de superfícies e equipamentos } \\
\text { na pandemia de Covid- I } 9\end{array}$ & $01 / 07 / 2020$ & 8.119 \\
\hline Erros diagnósticos no contexto da Covid- 19 & I 5/07/2020 & 1.669 \\
\hline $\begin{array}{l}\text { Desafios do uso de equipamentos de proteção } \\
\text { individual na Covid- I } 9\end{array}$ & $29 / 07 / 2020$ & 1.932 \\
\hline $\begin{array}{l}\text { Assistência segura a gestação, parto e puerpério na } \\
\text { Covid-19}\end{array}$ & $26 / 08 / 2020$ & 1.056 \\
\hline $\begin{array}{l}\text { Prevenção de lesão por pressão na assistência à } \\
\text { Covid-19 }\end{array}$ & $01 / 10 / 2020$ & 1.087 \\
\hline $\begin{array}{l}\text { Manejo seguro do paciente com Covid- } 19 \text { após a alta } \\
\text { da UTI }\end{array}$ & $04 / 11 / 2020$ & 647 \\
\hline $\begin{array}{l}\text { Infecção por microrganismos multirresistentes no } \\
\text { contexto da Covid-19}\end{array}$ & | 8/| | /2020 & 1.019 \\
\hline Segurança e eficácia de vacinas contra a Covid- $19^{*}$ & $26 / 02 / 2021$ & 1.378 \\
\hline $\begin{array}{l}\text { Vigilância dos eventos adversos pós-vacinação contra } \\
\text { a Covid- } 19^{*}\end{array}$ & $10 / 03 / 202 \mid$ & 1.207 \\
\hline
\end{tabular}

Fonte: Proqualis, 2021.

* Em parceria com o Observatório Covid- 19 da Fiocruz.

Desses webinários, os mais acessados foram "Limpeza e desinfecção de superfícies e equipamentos na pandemia de Covid-19", com 8.119 visualizações, "Prevenção da transmissão intra-hospitalar da Covid-19", com 2.876 visualizações, e "Desafios do uso de equipamentos de proteção individual na Covid-1 9", em com 1.932 visualizações. Ressalta-se o interesse dos usuários pelo tema da limpeza e desinfecção de superfícies e equipamentos. O webinário menos visualizado até o momento foi aquele sobre o tema "Manejo seguro do paciente com Covid- I 9 após a alta da UTI", com 647 visualizações.

Além dessas iniciativas, o Proqualis também vem atuando em ações mais voltadas para o ensino e a pesquisa, tais como a elaboração do relatório "Recomendações para a organização de Centros de Isolamento Assistido Covid- 19" e de uma nota técnica sobre o 
diagnóstico laboratorial da Covid- 19 no Brasil, ambos publicados no site do Observatório Covid- 19 da Fiocruz; a elaboração e a disponibilização no portal de 16 aulas sobre temas relacionados à Covid-19, das quais 12 disponibilizadas no portal de Boas Práticas do Instituto Nacional de Saúde da Mulher, da Criança e do Adolescente Fernandes Figueira (IFF), como exposto no Quadro 2; a realização do curso Qualidade do Cuidado de Saúde e Segurança nas Instituições de Longa Permanência para Idosos (ILPIs) no Contexto da Covid- 19 e de pesquisa, em andamento, sobre a segurança dos profissionais da saúde que atuam na linha de frente do combate à Covid-9.

Quadro 2 - Aulas relacionadas à pandemia por Covid- 19 publicadas no portal Proqualis - Jun. 2020 a mar. 2021

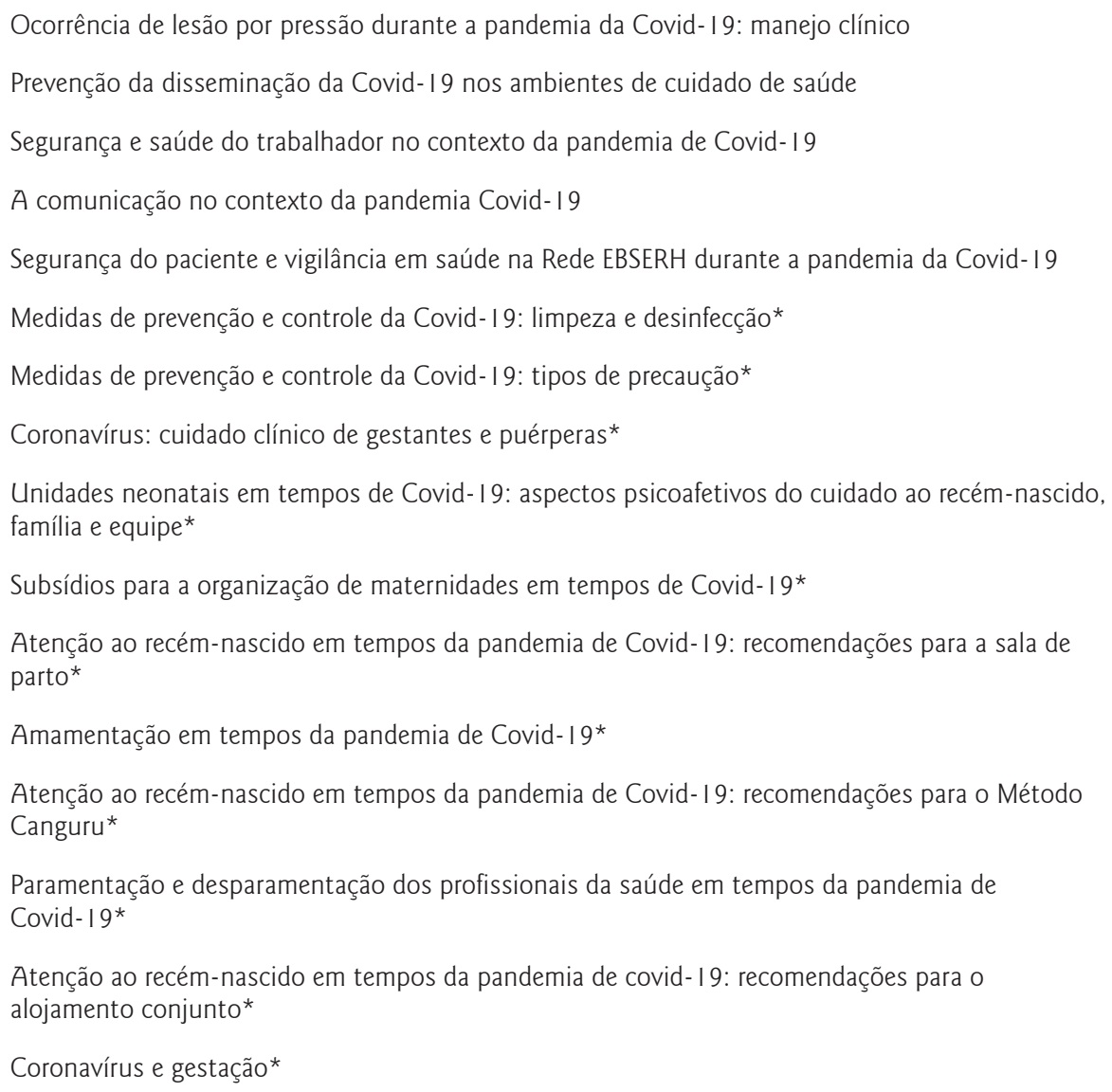

* Aulas originalmente publicadas no Portal de Boas Práticas do Instituto Fernandes Figueira. 
No segundo semestre de 2020, o Proqualis iniciou o desenvolvimento, junto com o Campus Virtual da Fiocruz, de um curso autoinstrucional (sem tutoria), na modalidade a distância, com carga horária total de 12 horas, denominado Cuidado de Saúde e Segurança nas Instituições de Longa Permanência para Idosos (ILPIs) no Contexto da Covid-19, que foi lançado em março de 2021. Este curso on-line e gratuito também contou com a colaboração do Comitê de Saúde da Pessoa Idosa da Fiocruz. Em suas aulas são abordadas diferentes temáticas, entre as quais se destacam: medidas de prevenção e controle da disseminação de doenças; cuidados em áreas comuns; fragilidade e violência; vacinação para proteção da Covid- 19 nas ILPIs; contatos sociais em tempos de isolamento; estratégias de comunicação para garantir o contato da pessoa idosa com a sua família ou comunidade; recomendações para a comunicação de notícias difíceis.

Consideradas as necessidades de formação em saúde no contexto da Covid-19, o curso contribui para discutir as especificidades do cuidado em saúde de uma população bastante vulnerável, pois, além de todos os tabus que envolvem a pessoa idosa, essa população é mais suscetível ao novo coronavírus. Se medidas de prevenção específicas não forem adotadas, as ILPIs podem se tornar um ambiente de propagação da Covid- I9, o que caracteriza risco para os idosos residentes, os profissionais ali atuantes e todos os familiares envolvidos (Figura I).

Figura I - Página do curso autoinstrucional na modalidade a distância Cuidado de Saúde e Segurança nas Instituições de Longa Permanência para Idosos (ILPIs) no Contexto da Covid- 19, no site do Campus Virtual, Fiocruz

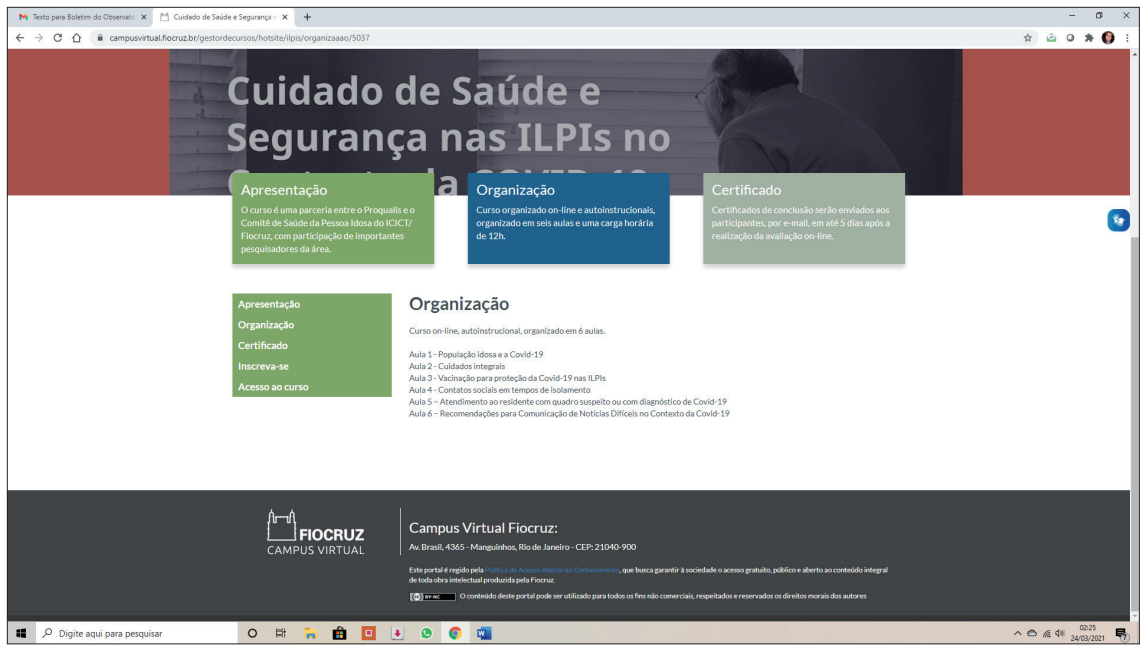

Fonte: Campus Virtual Fiocruz, 2021. Disponível em: < https://campusvirtual.fiocruz.br/gestordecursos/ hotsite/ilpis/organizaaao/5037>. Acesso em: II nov. 2021 . 
A pesquisa sobre a segurança dos profissionais da saúde, intitulada Segurança do Profissional da Área de Saúde Durante o Enfrentamento da Infecção pelo Novo Coronavírus (Covid-19), é um estudo transversal, do tipo inquérito, baseado na aplicação de dois questionários: um voltado para profissionais da saúde e outro para gestores dos estabelecimentos de saúde. Seu objetivo é avaliar a exposição desses profissionais à Covid-19, focalizando: 1) a adoção de medidas de segurança pelo profissional da área da saúde em seus processos de trabalho, relacionada principalmente ao uso adequado de EPIs e à organização do estabelecimento de saúde em relação à oferta de equipamentos e insumos, limpeza e desinfecção dos ambientes; e 2) indicadores de capacitação e acompanhamento dos seus funcionários.

A pesquisa foi aprovada pelo Comitê de Ética em Pesquisa da Escola Politécnica Joaquim Venâncio (CAAE 32538620.1 .0000.5241) e conta com apoio financeiro do Programa Fiocruz de Fomento à Inovação, o Inova Fiocruz. A coleta de dados do primeiro ciclo de avaliação da pesquisa ocorreu entre julho e setembro de 2020, e a do segundo ciclo de avaliação, entre junho e outubro de 2021 . Os questionários foram respondidos de forma on-line via Google Forms. A divulgação foi feita principalmente em grupos de WhatsApp ligados à qualidade do cuidado e segurança do paciente e à Sociedade Brasileira para Qualidade do Cuidado e Segurança do Paciente (Sobrasp), compostos por profissionais de diversas categorias, como médicos, dentistas, enfermeiros, farmacêuticos, auxiliares de enfermagem, entre outros; no portal do Proqualis; na mídia (rádio, assessoria de comunicação institucional); em contato com os conselhos profissionais e com alunos e tutores egressos do Curso de Especialização em Qualidade em Saúde e Segurança do Paciente promovido pela Escola Nacional de Saúde Pública Sergio Arouca/Fiocruz.

Análises preliminares do primeiro ciclo de avaliação da pesquisa mostram que aceitaram participar 2.933 profissionais da área de saúde. Após a exclusão das duplicidades, a amostra final constituiu-se por 2.832 respondentes, oriundos de todos os estados da federação, com maior proporção das regiões Sudeste $(54,7 \%)$ e Sul (17,3\%). A maioria era do sexo feminino $(81,4 \%)$, com idade mediana de 39 anos. Quase a metade dos respondentes eram enfermeiros ( $n=1.356,48,1 \%)$, seguidos pelos técnicos de enfermagem ( $n=735,26,1 \%)$. Essas foram as categorias profissionais de maior prevalência e representatividade na pesquisa. Em seguida, os médicos foram responsáveis por 7,6\% das respostas $(n=2 \mid 4)$, seguidos pelos fisioterapeutas $(n=101,3,6 \%)$, farmacêuticos $(n=94 ; 3,3 \%)$ e auxiliares de enfermagem ( $n=64 ; 2,3 \%)$. Mais da metade informou trabalhar em hospitais (59,2\%) e 20,2\% na Atenção Primária à Saúde. A maioria (79,3\%) relatou ter prestado assistência a pacientes com Covid-19. Em relação às respostas dos gestores, foram obtidos 225 registros que, após remoção das duplicidades, formaram 
uma amostra de 199 respondentes. Dos 199 gestores, a maior parte era oriunda da região Sudeste ( $93 ; 46,7 \%)$, seguida das regiões Sul e Nordeste (38; 1 9, I \% cada) e Norte e Centro-Oeste (17; 8,5\% e 13; 6,5\%, respectivamente). Quanto à natureza jurídico-administrativa do estabelecimento de saúde, a maior parte relatou ser do nível municipal (62; 31,6\%), estadual $(38 ; 19,4 \%)$, setor privado $(36 ; 18,4 \%)$ e público federal (29; $14,8 \%$ ). Sobre o tipo de estabelecimento de saúde, a maior parte relatou trabalhar em hospital geral $(71 ; 35,7 \%)$, seguido por hospital especializado $(38 ; 19,1 \%)$ e unidade básica de saúde (32; 16,1\%). Cento e dois gestores (51,5\%) responderam que o estabelecimento de saúde em que trabalha é referência para atendimento a casos suspeitos e confirmados de Covid- 19 e 136 (68,3\%) disseram que o estabelecimento de saúde é porta de entrada para casos suspeitos e confirmados da doença.

\section{AVALIAÇÃO E PERSPECTIVAS}

A experiência do Proqualis na produção e disseminação de informações para auxiliar o enfrentamento da pandemia por Covid- 19 e o retorno recebido de seus usuários indicam a importância e a necessidade de se ampliar a divulgação de informações científicas reconhecidas, confiáveis e de qualidade para os profissionais da saúde e para a população em geral. Paralelamente, observa-se a necessidade de mais investimentos na formação desses profissionais e em ações ligadas à educação em saúde, que subsidiem o exercício de suas atividades de forma mais segura. As condições de trabalho dos profissionais da saúde devem ser objeto de prioridades em saúde pública, pois afetam diretamente a qualidade e a segurança do cuidado prestado aos pacientes.

O Centro Colaborador para a Qualidade do Cuidado e Segurança do Paciente (Proqualis) tem contribuído para o enfrentamento da pandemia por Covid- 19 por meio de publicação de artigos, notas técnicas, entrevistas e outros materiais de interesse no portal, como forma de divulgar informações científicas de qualidade; tradução e divulgação de materiais da OMS, vídeos educativos, realização de webinários, produção de aulas e curso a distância, entre outros, como contribuição para a formação e atualização dos profissionais da saúde; e realização de pesquisa voltada para a avaliação da segurança dos profissionais da saúde que atuam na linha de frente do combate à pandemia por Covid-19, enfatizando a importância das condições de trabalho desses profissionais para a qualidade e a segurança do cuidado em saúde. 


\section{REFERÊNCIAS}

AGÊNCIA NACIONAL DE VIGILÂNCIA SANITÁRIA (ANVISA). Gerência Geral de Tecnologia em Serviços de Saúde. Gerência de Vigilância e Monitoramento em Serviços de Saúde. Nota técnica GVIMS/ GGTES/Anvisa n. 04/2020. Orientações para serviços de saúde: medidas de prevenção e controle que devem ser adotadas durante a assistência aos casos suspeitos ou confirmados de infecção pelo novo coronavírus (Sars-CoV-2).

BRASIL. Ministério da Saúde. Covid-19 no Brasil. Disponível em: <https://susanalitico.saude.gov.br/ extensions/covid-19_html/covid- I9_html.html >. Acesso em: 25 mar. 202I.

DA SILVA, L. L. S. et al. Medidas de distanciamento social para o enfrentamento da Covid- I 9 no Brasil: caracterização e análise epidemiológica por estado. Cadernos de Saúde Pública, 36(9): e00 I 85020, 2020. Disponível em: <http://cadernos.ensp.fiocruz.br/csp/artigo/II83/medidas-de-distanciamentosocial-para-o-enfrentamento-da-covid-19-no-brasil-caracterizacao-e-analise-epidemiologica-porestado\#CI >. Acesso em: 29 set. 2020.

RANNEY, M.L.; GRIFFETH, V. \&JHA, A. K. Critical supply shortages: the need for ventilators and personal protective equipment during the Covid- 19 pandemic. New England Journal of Medicine, 382(I8): e4I, Apr 30 2020. doi: 10.1056/NEJMp2006141.

WORLD HEALTH ORGANIZATION (WHO). WHO Campaigns. World Patient Safety Day Objectives 2020. Disponível em: <www.who.int/campaigns/world-patient-safety-day/2020/campaignessentials >. Acesso em: 29 set. 2020.

ZHU, N. et al. A novel coronavirus from patients with pneumonia in China, 2019. New England Journal of Medicine, 382(8): 727-733, 2020. 


\title{
Enfrentamento da Pandemia de Covid-19 no Estado do Rio de Janeiro
}

\author{
a experiência do Cosems RJ
}

Maria da Conceição de Souza Rocha, Marcela de Souza Caldas e

Marta Gama de Magalhães

O

s Conselhos de Secretarias Municipais de Saúde (Cosems) nascem da necessidade de criar mecanismos de pactuação entre os gestores do Sistema único de Saúde (SUS), nas três esferas de governo. Essas entidades integram a própria história da política pública de saúde do Brasil.

Ainda que com sua existência declarada em diversas normas do SUS, somente com a edição da lei 12.466 de 24 de agosto de 20 I I (Brasil, 20 I I) os Cosems foram legalmente institucionalizados e passaram a ser reconhecidos como entidades que representam os entes municipais, no âmbito estadual, para tratar de matérias referentes à saúde, desde que vinculados institucionalmente ao Conselho Nacional de Secretarias Municipais de Saúde (Conasems), na forma disposta em seus estatutos.

No estado do Rio de Janeiro, o Cosems foi oficialmente instituído em 1987, com a eleição do seu primeiro presidente. Portanto, muito antes das normas operacionais, o Conselho de Secretarias Municipais de Saúde do Estado do Rio de Janeiro (Cosems RJ) já existia formal e legalmente, como representante dos entes municipais para articulação e pactuação das políticas de saúde neste estado (Silva, 20l4).

No processo de construção do SUS, os conselhos de representação das secretarias estaduais e municipais de Saúde são importantes instâncias de consolidação das normativas desse sistema, especialmente as de intercâmbio e construção de responsabilidades sanitárias, solidárias e cooperativas. Para Lima (2013), o Conselho Nacional de Secretários de Saúde (Conass), o Conasems e os Cosems estaduais são espaços de extrema importância para a articulação política e formação de pactos horizontais envolvendo os gestores da mesma esfera de governo. É correto afirmar também que tais instituições se destacam por seu importante papel no apoio técnico, na informação e no aprendizado 
para as secretarias de Saúde, especialmente aquelas com condições administrativas mais precárias e as situadas em municípios de menor porte.

Após essa breve contextualização sobre o lugar e a importância de tais conselhos no nosso sistema de saúde, descreveremos algumas das características do Cosems RJ.

O Cosems RJ definiu como sua missão, que consta em sua página eletrônica,

Contribuir para a formulação e implementação de políticas de saúde e apoiar tecnicamente as Secretarias Municipais na condução das ações de saúde, promovendo, de maneira proativa, a articulação e a pactuação técnica e política em torno dos interesses municipais, com vistas à defesa dos princípios e diretrizes do SUS. (Cosems RJ, 2020)

Para alcançar sua missão institucional, o Cosems RJ organiza sua atuação de forma técnica e política. A representação política é feita por sua diretoria, composta pelos cargos de presidente, vice-presidentes, secretário-geral e diretor financeiro, que atuam em conjunto com quatro diretorias temáticas, as de Comunicação; Relações Institucionais e Parlamentares; Direito Sanitário; Regionalização e Descentralização. Sua atuação é suprapartidária, funcionando com uma composição que tem procurado, historicamente, contemplar a representação de todas as regiões de Saúde do Rio de Janeiro de modo a garantir ampla legitimidade nos encaminhamentos de pautas relevantes para o SUS de todo o estado.

No que se refere à atuação técnica, seu arranjo organizacional conta com um corpo técnico qualificado, o qual responde pelas assessorias técnica, jurídica, administrativa e de comunicação, além de uma equipe de apoiadores regionais que atuam distribuídos nas nove regiões de Saúde fluminenses. Esses atores estratégicos do Cosems RJ, ativadores dos processos de gestão e cuidado em saúde junto com os gestores de saúde e equipes técnicas municipais, proporcionam suporte para o aprimoramento e transformação das práticas de trabalho da gestão municipal, visando a fortalecer coletivos e a possibilitar caminhos e reflexões solidárias e colaborativas para o SUS.

Para a operacionalização das suas atividades, o Cosems RJ realiza mensalmente assembleias de secretários municipais de Saúde, espaço fundamental de integração dos gestores no qual são discutidas as pautas para pactuação na Comissão Intergestores Bipartite (CIB) e deliberadas questões de interesse dos municípios na área da saúde. Além desta, participa das reuniões da Comissão Intergestores Regionais (CIR) por intermédio dos secretários de Saúde e apoiadores regionais e desempenha a coordenação conjunta com a Secretaria Estadual de Saúde (SES) das reuniões da CIB, ambas instâncias de pactuação do SUS. Segundo Lima (2013), a realização de assembleias gerais e/ou de 
encontros regionais é uma forma de organização e articulação entre os secretários e um meio de divulgação de informações por esses conselhos.

Diante da pandemia decretada no país e da necessidade de adoção do isolamento social, medida crucial para diminuir a transmissão do coronavírus, o Cosems RJ, na defesa e na busca de melhorias para a saúde fluminense, passou a realizar, desde o mês de abril de 2020, suas assembleias mensais de forma remota, por meio de uma sala virtual, objetivando garantir discussões e o diálogo permanente entre os gestores e técnicos municipais de saúde.

Para sua atuação no quadriênio 20 I 9-2022, o Cosems RJ construiu uma agenda afirmativa de proposições para o fortalecimento do SUS no estado do Rio de Janeiro, expressa nas seguintes diretrizes:

- Fortalecer a atenção básica como política de Estado e ordenadora do sistema, conforme legislação vigente, por meio da Estratégia Saúde da Família;

- Estabelecer a regulação como uma política de Estado estruturante, com capacidade de garantir acesso da população a respostas a todas as suas necessidades de saúde;

- Implementar as ações de vigilância em saúde, considerando o agravamento das várias demandas do cenário epidemiológico;

- Garantir o financiamento tripartite do SUS, regular, mais justo e igualitário;

- Implementar e executar a Política Estadual de Assistência Farmacêutica;

- Implementar o processo de regionalização e construção das redes de atenção à saúde, com fortalecimento dos mecanismos de governança estadual e regional;

- Buscar estratégias para o fortalecimento da SES RJ no seu efetivo papel de coordenar e implementar as políticas de Estado para a efetivação das diretrizes do sus.

Posto isso, afirmamos que em consonância com a atual conjuntura da gestão do SUS no estado do Rio de Janeiro, o Cosems RJ tem atuado em prol da consolidação, aprimoramento e defesa da saúde pública, buscando mobilizar parceiros e sociedade para mudanças que contribuam na melhoria da qualidade de vida da população e no avanço da construção coletiva do direito à saúde.

A crise sanitária produzida pela pandemia de Covid- 19 desencadeou novas demandas, desafios e preocupações para o SUS, com forte impacto em todos os entes federados e especial sobrecarga para os municípios, ente executor das políticas de saúde e autoridade sanitária do território onde vive e convive a população brasileira. 
O SUS, o maior sistema público de saúde do mundo, busca proporcionar aos brasileiros acesso universal e integral à saúde, em todo o território nacional. Seu complexo sistema integrado entre os níveis federal, estadual e municipal permite a existência de uma rede de saúde com ampla capilaridade e alcance populacional, que atua para prover desde ações da atenção básica até aquelas de maior complexidade, como cirurgias de alto risco. O Brasil estabeleceu em sua Constituição que saúde é direito de todos e, portanto, é dever do Estado garantir a defesa da vida em todas as suas demandas e singularidades.

Ao longo da pandemia, ampliou-se a percepção sobre a importância e as potencialidades do SUS e sobre quão maiores seriam as dificuldades que enfrentaríamos no combate à Covid- 19 se não possuíssemos um sistema de saúde com os princípios da universalidade, integralidade e equidade. Em prévia da pesquisa sobre os desafios da pandemia de Covid- 19 realizada pela Organização das Nações Unidas (ONU) e apresentada em setembro de 2020, o acesso à saúde universal e medidas contra as desigualdades foram as prioridades elencadas por mais de 5 mil brasileiros (Andrade, 202 I). E pesquisa realizada pelo jornal O Estado de S. Paulo registrou que " $69 \%$ dos entrevistados concordaram que sem o SUS, as consequências da pandemia seriam muito piores e também $62 \%$ relataram que passaram a valorizar mais o SUS depois da disseminação da doença” (Chiara, 2021).

Nesse contexto, é importante destacar a força, o compromisso operacional e pragmático dos profissionais da saúde da linha de frente do combate à Covid-19, resilientes no seu papel de proporcionar cuidado à população, nos vários níveis de atenção do sistema de saúde. Todavia, em razão do subfinanciamento e dos baixos investimentos no SUS ao longo dos anos, a assistência dirigida à Covid- 9 tem levado ao colapso do sistema de saúde em várias regiões do país, dificultando a assistência clínica qualificada para toda a população devido à falta de leitos de terapia intensiva e de equipamentos de suporte ventilatório, à baixa testagem, à insuficiência e sobrecarga de profissionais da saúde e à fragilidade da atenção básica e da vigilância em saúde.

Além disso, no Brasil, diferentemente de outros países, o governo federal mostrou toda a sua fragilidade no processo de coordenação das ações de controle da pandemia e suas consequências, fazendo com que estados e municípios agissem sozinhos e criassem suas próprias diretrizes. Para Sodré (2020: 4), instalou-se a "centralidade dos governadores e ações fragmentadas aconteciam entre os municípios como se não houvesse um Sistema Único de Saúde que pudesse prever a ação entre os três âmbitos da federação".

Diante desse quadro, desde o início do ano de 2020, especialmente a partir do momento em que a Organização Mundial de Saúde (OMS) decretou a pandemia, o 
Cosems RJ pleiteou à SES RJ a instituição de um grupo interinstitucional para discutir e acompanhar os movimentos de enfrentamento da pandemia do novo coronavírus no território fluminense. Porém, apesar da publicação de uma resolução estabelecendo esse grupo, foram muitos os problemas para a realização de suas reuniões e para a sua manutenção, pois o período era de grande instabilidade do governo estadual e alternâncias na gestão de sua Secretaria de Saúde: ao longo de 2020, o estado do Rio de Janeiro teve um governador afastado e quatro secretários de estado da Saúde.

Segundo Peres, Sant'Ana e Rodrigues (2020), a SES RJ sofreu durante o ano de 2020 um longo processo de desmonte e graves problemas com seu quadro de servidores, reduzido e mal remunerado. Essa fragilidade institucional contribuiu para que o Cosems $\mathrm{RJ}$ se tornasse, por intermédio de suas equipes diretora e técnica, a referência na gestão da saúde pública para os municípios fluminenses, substituindo, muitas vezes, a SES em seu papel de enfrentar tecnicamente a pandemia.

Embora tenham ocorrido algumas reuniões sobre o tema entre SES e municípios nos meses de janeiro e fevereiro de 2020, isso não resultou em processo de planejamento ascendente, a partir de discussões e deliberações nas regiões de Saúde, para ações de combate à pandemia. Desse modo, decisões foram tomadas pelos municípios de forma isolada, sem que houvesse um diagnóstico e análise das reais necessidades de ampliação da capacidade instalada das regiões por parte da SES RJ. Assim, o processo de abertura de hospitais de campanha se deu com incipiência de parâmetros técnicos e sem que fossem consideradas as possibilidades de ampliação de estruturas já existentes.

A esse cenário somou-se outra preocupação relacionada à gestão das estruturas estaduais de atendimento a casos de Covid-19, inclusive os hospitais de campanha, que foi delegada a organizações sociais (OS). Para viabilizar sua construção e a compra de equipamentos, foram destinados significativos recursos financeiros, alvo de investigações por improbidade administrativa ou corrupção. Para Silva e Ruiz (2020), o modelo privatista baseado nas OS tem gerado barreiras para a população usuária, seja no tocante à gestão, seja no tocante ao atendimento de qualidade.

A ação estratégica do Cosems RJ de apoiar a gestão municipal do SUS foi intensamente potencializada pela emergência sanitária provocada pela Covid-19, por meio da atuação de seus assessores técnicos e apoiadores regionais diante das imensas demandas apresentadas pelos municípios, gestores e equipes técnicas municipais. A intensificação do uso de diversos mecanismos de comunicação, como as redes sociais e aplicativos de mensagens instantâneas para smartphones, foi fundamental diante da necessidade de capilarizar informações necessárias à tomada de decisões no cenário de pandemia. 
Em face das dificuldades apresentadas pelos gestores municipais relacionadas à pandemia, o corpo técnico do Cosems RJ buscou aprimoramento dos seus conhecimentos e intensificou o trabalho de articulação com as demais representações dos estados e municípios no país, outros Cosems, Conasems e o Conass, visando ao repasse de informações qualificadas, seguras e em tempo oportuno. No caso dos apoiadores regionais, a agenda de trabalho foi intensificada através da Rede Colaborativa para Fortalecimento da Gestão Municipal do SUS, coordenada pelos Conasems e pelo Hospital Alemão Oswaldo Cruz (HAOC). Sua rotina de trabalho tem sido exaustiva para atender às demandas de divulgação e orientação quanto às portarias, resoluções e notas técnicas. Além de serem a principal referência técnica para gestores e técnicos dos municípios, esses apoiadores também atuam na escuta de angústias, temores e apreensões. Solidariedade, afeto e troca têm feito a diferença na condução desse processo que envolve sofrimento, morte, coragem e responsabilidade sanitária.

Perante todos esses desafios e por considerar que o conhecimento científico contribui e orienta para respostas mais efetivas, o Cosems RJ buscou apoio na Fundação Oswaldo Cruz (Fiocruz), instituição acadêmica reconhecida por seu trabalho para a consolidação do SUS, como forma de promover a interação entre pesquisa e inovação, gestão pública e qualificação dos serviços para a melhoria da ação pública setorial no campo da saúde.

Para a efetivação da parceria entre Cosems RJ e Fiocruz, as instituições se pautaram na consolidação e fortalecimento da cooperação técnica vigente entre os partícipes, conforme acordo n. 87/20 I 7, que visa a fortalecer a gestão municipal do SUS no estado do Rio de Janeiro e apoiar o aprimoramento da sua capacidade técnica de resposta à pandemia de Covid-19. E se viabilizou uma agenda estratégica entre as instituições para a construção conjunta dos eixos centrais, integradores e prioritários das ações a serem implementadas, coordenada pela Chefia de Gabinete da Presidência e o Observatório Covid- 19 da Fiocruz e pela Presidência do Cosems RJ e seu corpo técnico. A parceria assim constituída contou com a participação da Associação Estadual de Municípios do Rio de Janeiro (Aemerj), que difundiu entre os prefeitos do estado do Rio de Janeiro e outras instituições por ela mobilizadas o apoio institucional do Cosems RJ e da Fiocruz, o que favoreceu maior adesão política dos governos municipais à referida agenda.

O objetivo e os principais eixos estruturantes da parceria entre o Cosems RJ e a Fiocruz estão detalhados a seguir. 


\section{OBJETIVO DA PARCERIA ENTRE O COSEMS RJ E A FIOCRUZ}

Desenvolver ações de apoio técnico institucional, para fortalecimento da gestão municipal do SUS no estado do Rio de Janeiro, mediante aporte de conhecimento e de informação técnica qualificada para gestores e técnicos municipais, visando ao aprimoramento das responsabilidades municipais e da tomada de decisão diante dos necessários movimentos estratégicos e operacionais da gestão municipal na condução de ações contra a pandemia da Covid- 19.

\section{EIXOS INTEGRADORES E PRIORITÁRIOS PARA AS AÇÕES DE FORMAÇÃO E DE APOIO TÉCNICO AOS GESTORES E TÉCNICOS MUNICIPAIS DA SAUUDE}

\section{Eixo Gestão da Clínica}

Atenção Primária à Saúde (APS)

- Manejo clínico na APS: Covid e não Covid.

- Operacionalização do teste rápido para Covid.

- Monitoramento da vulnerabilidade do território: habitação, comorbidade, idosos, crianças.

- Integração entre Vigilância em Saúde (VS) e APS: difusão de informações e monitoramento de casos.

- Teleatendimento na atenção aos pacientes de Covid: monitoramento e cuidado.

- Reorganização dos processos de trabalho.

- Fortalecimento da articulação comunitária: a função do agente comunitário de saúde.

Atenção Especializada, Atenção Pré-Hospitalar e Hospitalar

- Acesso à diagnose: exames laboratoriais e imagem (tomografia e raios X).

- Tomografias: necessidade de definição de protocolo para utilização, pois há casos de uso indiscriminado. Usar oxímetro para indicação.

- Fluxo de acesso para o atendimento médico especializado aos pacientes suspeitos/confirmados de Covid.

- Protocolo de manejo clínico na atenção.

- Organização de leitos: separação de fluxos de pacientes Covid e não Covid.

- Segurança do paciente. 


\section{Eixo Vigilância em Saúde (VS)}

- Integração da VS e APS: difusão de informações e monitoramento de casos.

- Maior divulgação dos critérios para a definição de casos.

- Necessidade de melhor notificação dos casos atendidos na rede privada de saúde.

- Necessidade de notificação nos sistemas e-SUS Vigilância Epidemiológica (VE) e e-SUS VE hospitalar.

- Testes rápido: utilização e relação com a notificação (vigilância laboratorial).

- Uso da VS para enxergar e analisar o deslocamento do coronavírus e sua relação com as medidas de isolamento.

- Capacidade de análise epidemiológica dos cenários: incidência, letalidade etc.

- Divulgação qualificada da informação: casos confirmados, suspeitos, óbitos...

- Vigilância do óbito.

- VS: qualificação da equipe (arcabouço jurídico); atuação em comércios, indústrias, serviços etc.

- Vigilância em Saúde do Trabalhador: Covid- 9 é doença ocupacional; emissão de Comunicação de Acidente de Trabalho; notificação no Sistema de Informação de Agravo de Notificação etc.

\section{Eixo Organização dos Serviços de Saúde}

- Reorganização de atendimento das unidades para atendimento Covid e não Covid no serviço pré-hospitalar (unidades de Pronto Atendimento, postos de Saúde).

- Regulação única de leitos para a pandemia: referências internas e regionais.

- Rede regionalizada de atenção à saúde: princípios e diretrizes.

- Organização da assistência farmacêutica: dispensação de medicamentos Covid e não Covid e insumos.

- Logística de insumos e equipamentos.

- Pacientes da saúde mental: especificidades do atendimento; necessidade de que a equipe do Centro de Atenção Psicossocial (Caps) cuide de pacientes Covid e não Covid.

- Recursos humanos: quantitativo necessário; qualificação/capacitação de profissionais para assistência; 
- Funcionamento dos centros de Triagem Covid, alguns ligados à APS e outros ao serviço hospitalar.

- Gestão do atendimento pré-hospitalar móvel (Samu, Corpo de Bombeiros e frotas dos próprios municípios); dificuldades na transferência de pacientes; olhar especial para a Baixada Fluminense.

- Transporte sanitário para funeral.

O cenário epidemiológico da pandemia impôs aos municípios uma nova organização da gestão municipal da saúde, com ênfase na reorganização da sua rede de atenção com vistas à a incorporação de processos de cuidado do paciente com Covid- 19, considerando as singularidades de cada território de saúde.

Em consideração a esse cenário, o Cosems RJ se reinventou e promoveu, em cooperação com a Fiocruz e outros parceiros como o Instituto de Medicina Social da Universidade do Estado do Rio de Janeiro (IMS/Uerj), a Universidade Federal do Rio de Janeiro (UFRJ), a Associação Brasileira de Saúde Coletiva (Abrasco) e a SES RJ, debates on-line em forma de live com convidados especiais para levar informação segura e precisa sobre a atual situação da saúde pública no estado em tempos de pandemia, potencializando seu papel estratégico de apoio à gestão municipal do SUS. Os encontros foram transmitidos pela plataforma Zoom, pelo Facebook e pelos canais no YouTube do Cosems RJ e da Fiocruz. Os webinários contaram sempre com palestrantes pesquisadores de excelência das áreas afins e das instituições parceiras no tema apresentado, técnicos do Cosems RJ e gestores municipais, que apresentaram as experiências produzidas pelos municípios para mitigação dos efeitos da pandemia. Esse diálogo entre o conhecimento científico e os saberes produzidos nas práticas municipais possibilitou um enriquecimento dos debates, aprendizado e democratização do conhecimento.

A iniciativa teve início no dia 5 de junho de 2020, quando foi realizado o primeiro webinário, "Atenção Primária à Saúde em tempos de Covid". Ainda no mês de junho, houve os debates "Organização da rede municipal de saúde com ênfase na APS para o enfrentamento da pandemia: a experiência de Florianópolis", na busca por agregar conhecimento e discussão com as equipes de atenção primária dos municípios, porta de entrada e ordenadora do cuidado nos territórios do SUS, e "As relações interfederativas no SUS e o enfrentamento da Covid", que contou com a participação da presidente do Cosems RJ, Maria da Conceição de Souza Rocha, do ex-ministro da Saúde Arthur Chioro e do secretário estadual de Saúde do Maranhão e presidente do Conass, Carlos Lula. Discutir as relações intergovernamentais possibilitou importante reflexão sobre a responsabilidade sanitária de cada ente da federação perante a emergência sanitária da Covid- 19. 
Em julho de 2020 foram debatidos os temas "Flexibilização do distanciamento social e interiorização da Covid no estado do Rio de Janeiro" e "Estratégias para ampliação de testes Covid no estado do Rio de Janeiro". No mesmo mês, o Cosems RJ desempenhou papel fundamental na realização, em parceria com a SES RJ, do fórum de assistência farmacêutica on-line denominado Componente Especializado da Assistência Farmacêutica (CEAF): Fórum Estadual de Assistência.

Os demais webinários realizados em 2020 também foram dedicados a temas de forte impacto na qualificação do cuidado nos serviços de saúde do SUS no estado do Rio de Janeiro:

- Desafios da atenção básica no enfrentamento da pandemia de Covid no SUS no estado do Rio de Janeiro;

- Painéis de monitoramento de dados na Atenção Primária à Saúde;

- Importância e desafios do rastreamento de contatos da Covid;

- Coordenação regional de políticas públicas e redes de atenção à saúde: limites, avanços e perspectivas;

- Desafios e perspectivas da atuação da Vigilância em Saúde do Trabalhador na pandemia;

- Que vigilância é essa? O que está sendo feito e o que podemos fazer?

- Desafios do cuidado no território em tempos de pandemia;

- Cenários da regionalização da saúde no estado do Rio de Janeiro;

- Dispensa de licitação para aquisição de bens e serviços, para enfrentamento da Covid;

- Conversando sobre o encerramento da gestão: aspectos jurídicos, financeiros e orçamentários do encerramento da gestão municipal, no âmbito do SUS.

Nestes dias em que vemos se agravar a crise humanitária provocada pela pandemia de Covid-19, certamente novos desafios surgirão, entre os quais já podemos apontar a troca de gestores municipais e a campanha de vacinação contra a Covid- 19.

O Cosems RJ seguirá no esforço de apoiar os gestores municipais de saúde, promovendo encontros regionais com todos eles para apresentar a entidade e suas principais atividades. É de extrema importância que os novos gestores tenham participação ativa na entidade e nos espaços de pactuação técnica e política, de forma integrada com a diretoria e com o escritório do Cosems RJ, para que possam atuar nos principais debates sobre a gestão da saúde pública no estado e no país, sempre em defesa do Sistema Único de Saúde. 


\section{REFERÊNCIAS}

ANDRADE, H. Pandemia faz brasileiro priorizar apoio à saúde universal, aponta ONU. CNN Brasil, São Paulo, 18 set. 2020. Disponível em: <www.cnnbrasil.com.br/saude/2020/09/18/pandemia-fazbrasileiro-priorizar-apoio-a-saude-universal-aponta-on>. Acesso em: 10 fev. 2021 .

BRASIL. Lei n. 12.466, de 24 ago. 20II. Acrescenta arts. I4-A e I4-B à Lei n. 8.080, de 19 set. I990, que "dispõe sobre as condições para a promoção, proteção e recuperação da saúde, a organização e o funcionamento dos serviços correspondentes e dá outras providências", para dispor sobre as comissões intergestores do Sistema Único de Saúde (SUS), o Conselho Nacional de Secretários de Saúde (Conass), o Conselho Nacional de Secretarias Municipais de Saúde (Conasems) e suas respectivas composições, e dar outras providências. Diário Oficial da União, Brasília, 20I I. Disponível em: <www.planalto.gov. br/ccivil_03/_ato201 I-2014/201 I/lei/l I2466.htm >. Acesso em: 18 dez. 2020.

CHIARA, M. Com a pandemia do coronavírus, papel do SUS ganha força entre paulistanos. Estadão, São Paulo, 5 maio 2020. Disponível em: < https://saude.estadao.com.br/noticias/geral,com-apandemia-do-coronavirus-papel-do-sus-ganha-forca-entre-paulistanos,70003292385>. Acesso em: 10 fev. 2021.

CONSELHO DE SECRETARIAS MUNICIPAIS DE SAÚDE DO ESTADO DO RIO DE JANEIRO (COSEMS RJ). Missão e Visão. Disponível em: <www.cosemsrj.org.br/missao-e-visao/>. Acesso em: 18 dez. 2020.

LIMA, L. D. A coordenação federativa do sistema público de saúde no Brasil. In: GADELHA, P.; CARVAlho, J. N. E PEREIRA, T. R. (Orgs.). A Saúde no Brasil em 2030 - Prospecção Estratégica do Sistema de Saúde Brasileiro: organização e gestão do sistema de saúde. v. 3. Rio de Janeiro: Fiocruz, Ipea, Ministério da Saúde, Secretaria de Assuntos Estratégicos da Presidência da República, 2013.

Peres, A. M. A. M.; SANT'ANA, D. R. E RODRIGUES, P. H. A. O processo de desmonte da Secretaria de Estado da Saúde do Rio de Janeiro e sua invisibilidade. Physis: Revista de Saúde Coletiva, 30(3): e300315, 2020.

SODRÉ, F. Epidemia de Covid-19: questões críticas para a gestão da saúde pública no Brasil. Trabalho, Educação e Saúde, 18(3): e00302134, 2020. Disponível em: <www.scielo.br/j/tes/a/ YtCRHxTywqWm4SChBHvqPBB/abstract/?lang=ptEformat=html>. Acesso em: 10 fev. $202 \mathrm{l}$.

SILVA, M. L. O Cosems RJ: origem, identidade e seu papel na defesa das Secretarias Municipais de Saúde. In: PINHEIRO, R. et al. (Orgs.). Apoiadores Regionais: uma experiência brasileira. Ed. rev. Rio de Janeiro: Cepesc, IMS/Uerj, Cosems/RJ, Opas, 2014.

SILVA, W. M. F. \& RUIZ, J. L. S. A centralidade do SUS na pandemia do coronavírus e as disputas com o projeto neoliberal. Physis: Revista de Saúde Coletiva, 30(3): e300302, 2020. Disponível em: <www. scielo.br/j/physis/a/5LqczYMjkxnqZXGfXfckxTK/?lang=pt>. Acesso em: 10 fev. 2021 . 



\title{
Pandemia de Covid-19
}

\author{
a experiência da organização da rede \\ de serviços de saúde em Florianópolis
}

\author{
João Paulo Mello da Silveira, Ronaldo Zonta, Fernanda Paese, \\ Fernanda K. Melchior Silva Pinto, Filipe de Barros Perini, \\ Ana Cristina Magalhães Fernandes Báfica, Elizimara Ferreira Siqueira, \\ Júlia Maria Souza e Fernanda Lazzari Freitas
}

A pandemia de Covid-19 em 2020 significou, para muitos profissionais clínicos e gestores da saúde, o maior evento pessoal e profissional de suas carreiras. Com a decretação da emergência em saúde pública no Brasil, as equipes técnicas que conduzem as redes de serviços que compõem o Sistema Único de Saúde foram desafiadas a compreender a intensidade e a gravidade da crise, bem como seus impactos sobre as populações atendidas e os profissionais que compõem os serviços de saúde (Pueyo, 2020b; WHO, 2020a). Em poucos dias e semanas foram feitas escolhas e tomadas decisões que definiram a qualidade dos serviços prestados e muitas das experiências vividas pelas pessoas em seu contato com o sistema de saúde nesse período.

Santa Catarina é o segundo estado mais ao sul do Brasil e sua população estimada é de 7.252.502 pessoas. Florianópolis, sua capital, que tem uma porção de seu território continental e outra insular, denominada Ilha de Santa Catarina, abriga cerca de 508.826 habitantes (IBGE, 2020).

A rede de Atenção Primária à Saúde (APS) de Florianópolis é composta por 49 clínicas. Em março de 2020 essa rede contava com 150 equipes implantadas e 1.462 profissionais. A faixa de usuários adscritos à equipe de APS em cada clínica está representada na Figura I. 
Figura I - 49 áreas de adstrição por número de usuários vinculados - Florianópolis, 20 I 9

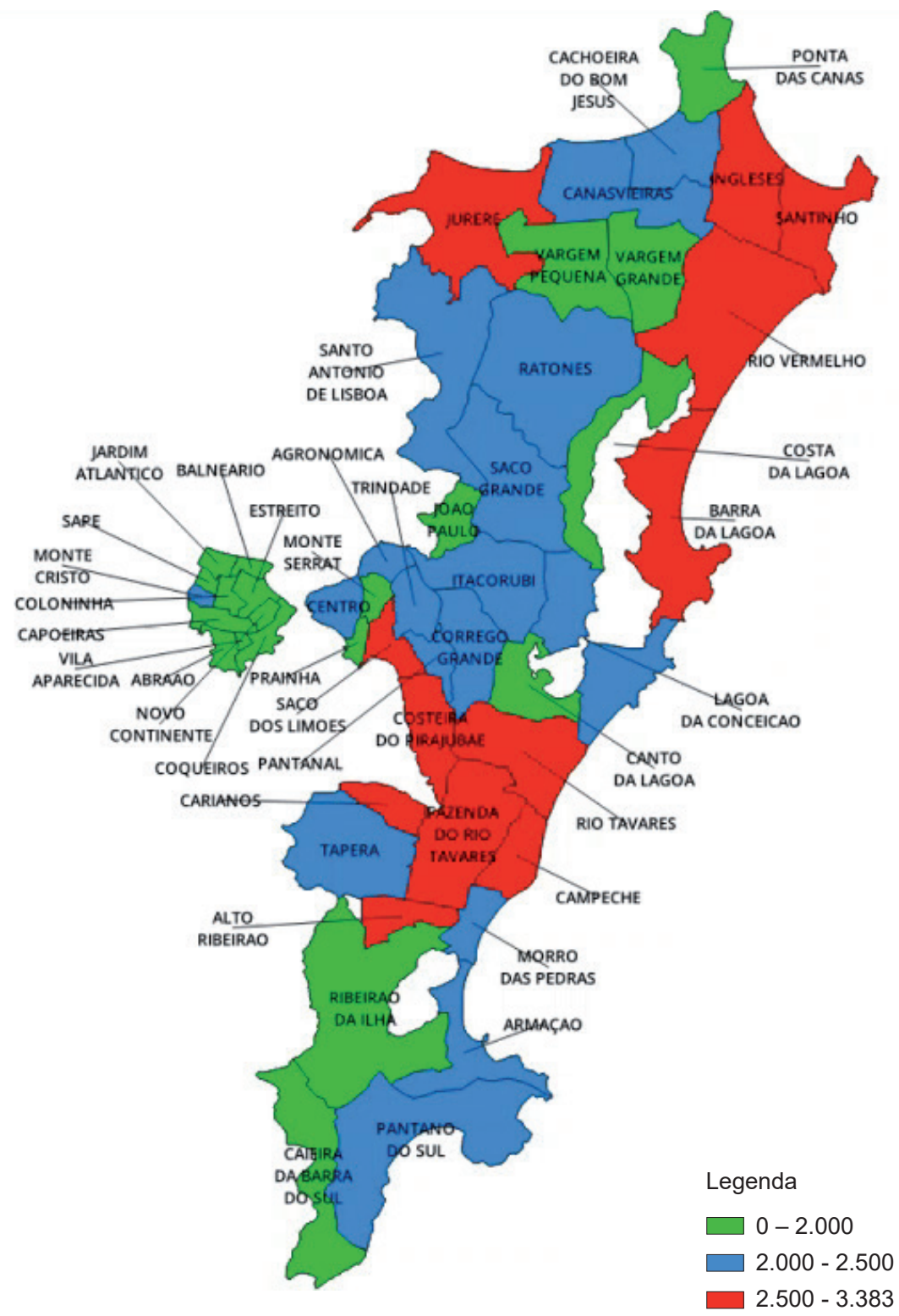

Fonte: acervo Gerência de Atenção Primária/SMS Florianópolis. 
Em II de março de 2020, a Covid- 9 foi caracterizada pela Organização Mundial da Saúde (OMS) como uma pandemia, e o primeiro caso foi confirmado em Florianópolis no dia 12 do mesmo mês. Essa sequência de eventos levou à instituição de um comitê de enfrentamento da crise, no qual a equipe técnica da Secretaria Municipal de Saúde (SMS) definiu as seguintes questões: I) Que materiais e insumos seriam necessários e quais os mais cruciais para a garantia de serviços adequados diante dessa calamidade? 2) Qual seria a melhor organização assistencial da rede de atenção para atender as pessoas suspeitas de Covid-19: centralizada em unidades de referência, ou de forma descentralizada na APS, com cada pessoa sendo atendida preferencialmente na sua clínica comunitária de referência? 3) Como manter um grande número de clínicas funcionando em rede sem promover aglomerações e evitando contágios na rotina dos serviços? 4) Que critérios de suspeição, notificação e diagnóstico, bem como de manejo clínico, estavam disponíveis e respaldados por evidências para adoção na rede? 5) Que estratégias e tecnologias se demonstravam efetivas nas abordagens populacionais em diferentes países que já enfrentavam a pandemia? 6) Qual a temporalidade dos eventos e seus efeitos diretos sobre a população de Florianópolis?

Com base nesses questionamentos e para dar resposta às necessidades de organização dos serviços e de atendimento direto à população, foram abertas as seguintes frentes de trabalho: I) Revisão de evidências e referências técnicas para adoção das medidas operacionais necessárias para redução e, se possível, controle da transmissibilidade em todas as clínicas, considerando desde a aquisição de equipamentos de proteção individual (EPIs), a logística de sua distribuição, até a elaboração de protocolos de atendimento clínico e o devido treinamento em biossegurança da rede (OurWorldinData. Org, 2020; CDC, 2020; WHO, 2020b); 2) Manutenção do atendimento em rede de APS: cada usuário preferencialmente atendido pela sua clínica de atenção primária, todas as clínicas de APS possíveis funcionando, mantendo longitudinalidade e coordenação do cuidado no enfrentamento da nova demanda relacionada à Covid- 19 (Bodenheimer et al., 20I4); 3) Conversão do acolhimento presencial em acesso mediado por smartphone e implementação de videoconsultas resolutivas (Greenhalgh, 2020); 4) Elaboração de um protocolo municipal conciso, claro e viável para adoção pelos profissionais da linha de frente, considerando um critério de suspeição abrangente e baseado em soma de critérios e as devidas ações comunicativas para potencializar a tradução do conhecimento/ adesão pelas equipes (Galhardi E Zonta, 2019); 5) Adoção de uma estratégia de testagem ampla e monitoramento de usuários considerando desde a definição de critérios sensíveis para testagem de casos leves e contatos próximos (contenção da transmissão comunitária) até a aquisição própria de testes disponíveis no mercado (WHO, 2020c); 6) Recomendação de lockdown precoce para conter a disseminação inicial e viabilizar a 
elaboração de um plano de contingência, com adoção de políticas públicas voltadas para a população em geral e para populações mais vulneráveis (Pueyo, 2020a).

Serão detalhadas aqui as ações definidas para as frentes de trabalho descritas e os resultados observados durante todo o processo.

Em meados de janeiro de 2021 , dez meses após a emergência do vírus da Covid- 19 no país, registravam-se 217.037 mortos no Brasil, com letalidade de 2,5\% entre os acometidos pela doença. Santa Catarina apresentava, nesse mesmo período, 6.124 óbitos, com letalidade de I, 1\%. Florianópolis, por sua vez, apresentou taxa de letalidade de $0,8 \%$ e o total de 48.867 casos e 39 I óbitos (Florianópolis, 2020a).

\section{CONTROLE DA TRANSMISSIBILIDADE E BIOSSEGURANÇA}

Em 13 de março de 2020 verificou-se que a quantidade de EPIs disponível era insuficiente para o enfrentamento da Covid- 19. Houve um esforço para adquirir esses equipamentos e com isso garantir que todas as unidades estivessem em condição de atender com qualidade preservando a segurança dos usuários e profissionais.

Realizamos a primeira adaptação da tabela do Center for Disease Control and Prevention (CDC) para o cálculo do número de EPIs necessários, o que subsidiou a estimativa de aquisição considerando inclusive o período estimado de pico da pandemia (CDC, 2020). Para consolidar as orientações quanto à aquisição e utilização desses equipamentos, seguimos a recomendação da OMS. O documento específico emitido pela instituição em março de 2020 (WHO, 2020b) foi traduzido e adaptado pelas áreas técnicas da Diretoria de Atenção à Saúde, originando o documento "Uso racional de equipamentos de proteção individual no contexto da Covid-19” (Florianópolis, 2020a).

Os principais EPIs utilizados foram: máscaras cirúrgicas e N95; aventais descartáveis com gramatura mínima de $40 \mathrm{~g}$ e para as recomendações em urgência/emergência, de 50g; toucas e gorros descartáveis; luvas de procedimentos; protetores faciais (face shields); óculos de proteção e propés.

As áreas técnicas embasaram a especificação de EPIs nos seguintes documentos reguladores: "Uso racional de EPIs" (WHO, 2020b) e "Norma regulamentadora n. 6 - NR 6" (Brasil, 200 I). Além disso, identificou-se a necessidade de incorporar termômetros infravermelhos e oxímetros para uso rotineiro nos serviços, os quais foram adquiridos para distribuição a todas as unidades de APS. Cada equipe recebeu um oxímetro digital e cada clínica recebeu um oxímetro de mesa e um termômetro infravermelho. 
Como política de saúde, foi estabelecido um protocolo de notificação segundo o qual profissionais da área devem ter prioridade na testagem e obtenção de resultados. O protocolo prevê ainda afastamento do caso suspeito e de todos os seus contatos até a definição diagnóstica (Florianópolis, 2020b). Foi elaborada também uma portaria visando ao deslocamento dos profissionais da saúde que estivessem em grupos de risco (maiores de 60 anos ou com alguma comorbidade de risco, conforme evidências disponíveis na época e atualizadas posteriormente) da linha de frente para a modalidade de teletrabalho (Florianópolis, 2020c). Nas situações de identificação de casos suspeitos entre profissionais, foi realizada desinfecção das respectivas unidades com retomada dos atendimentos 24 horas depois, mediante avaliação dos contatos próximos por critério epidemiológico. O impacto do afastamento dos profissionais pertencentes aos grupos de risco foi compensado, em parte, pela cobertura de profissionais da atenção especializada (policlínicas municipais), cujos serviços foram suspensos nos primeiros três meses da pandemia.

\section{ADAPTAÇÃO DA REDE DE APS PARA O ATENDIMENTO DE PACIENTES COM COVID-19}

Quarenta e sete (47) unidades de APS de Florianópolis continuaram abertas, adotando os protocolos de biossegurança para evitar aglomerações. Duas unidades tiveram seu corpo clínico deslocado para unidades próximas, uma devido a uma reforma estrutural e outra por inadequação do espaço físico para atender aos protocolos.

O protocolo preconiza o estabelecimento de dois fluxos de usuários, para separar os sintomáticos respiratórios dos assintomáticos, reduzindo assim a possibilidade de contágio durante o atendimento na APS (Florianópolis, 2020b). Para tanto, foram montadas barreiras físicas na entrada de cada clínica, com um profissional devidamente paramentado para acolhimento dos usuários e identificação dos sintomáticos respiratórios. Uma escala é estabelecida para que haja um profissional, com EPI adequado e um termômetro infravermelho, recepcionando os usuários e os direcionando corretamente para a respectiva porta de acesso. Dessa maneira, os pacientes sintomáticos respiratórios e os que consultam por outras necessidades e se apresentam assintomáticos têm seu contato reduzido ao mínimo.

Na rotina de manutenção das clínicas de APS foram incorporados procedimentos operacionais padrão (POPs) para correta desinfecção de cada sala/ambiente das unidades (Florianópolis, 2020d). Para sua efetiva aplicação foram organizados treinamentos em cada local, envolvendo a participação de todos os profissionais, para a apropriação do conteúdo dos documentos e dos fluxos definidos para organização dos serviços, 
principalmente na reiteração da importância do uso correto dos EPIs pelos profissionais e pelos usuários. Foram garantidas duas horas de treinamento, com divulgação prévia para a população e organização de clínica vizinha para que desse apoio e atuasse como a referência de atendimento naquele horário.

Ainda no mês de março, foi preciso organizar o serviço para a oferta de vacina contra influenza/HI N I, uma vez que os primeiros casos de Covid- 19 em Florianópolis ocorreram concomitantemente ao início da campanha da gripe. Na ocasião, todos os grupos prioritários foram deslocados para escolas ou outros pontos de vacinação no modelo drive thru, e além disso a vacina foi ofertada em bairros mais afastados dos pontos de vacinação, de maneira itinerante com a colaboração de cooperativas e do Conselho Municipal de Saúde. Para idosos acamados ou pessoas com deficiências, a vacinação foi realizada por uma equipe técnica em visitas domiciliares. A ação contou com a colaboração de voluntários da rede Somar Floripa, de universidades e da sociedade civil.

Na Figura 2 está sintetizada a ocorrência das principais ações nos primeiros trinta dias de resposta à pandemia.

Figura 2 - Linha do tempo das principais ações de organização da rede de saúde diante da pandemia - 16 mar. a 8 abr. 2021

\section{Medidas Para Organização dos Serviços de Saúde - $\mathbf{3 0}$ dias iniciais Linha do Tempo}

150 Equipes Clínicas Atuando Em 49 Centros de Saúde

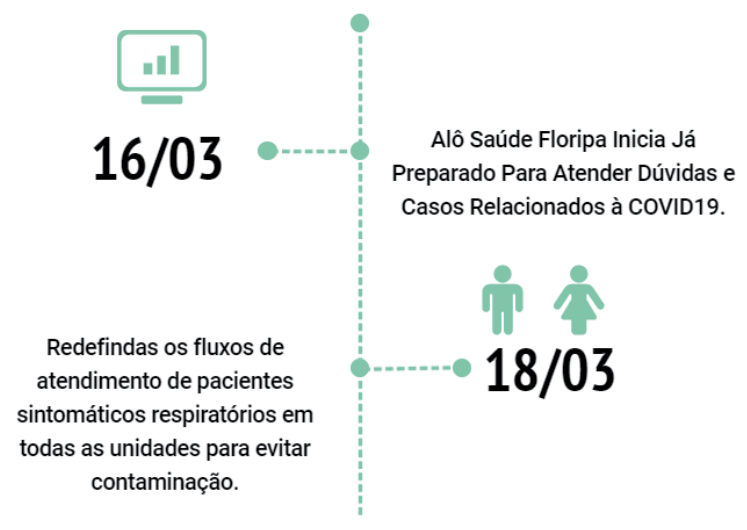


Figura 2 - Linha do tempo das principais ações de organização da rede de saúde diante da pandemia - 16 mar. a 8 abr. 2021 (continuação)

\section{$19 / 03$}

Compras Emergenciais de EPI para garantir atendimento com segurança em toda rede: estoque sobe de 3300 máscaras para 300.000 em 1 semana.

\section{VACINA DA GRIPE} Florianópolis

\subsection{0 doses}

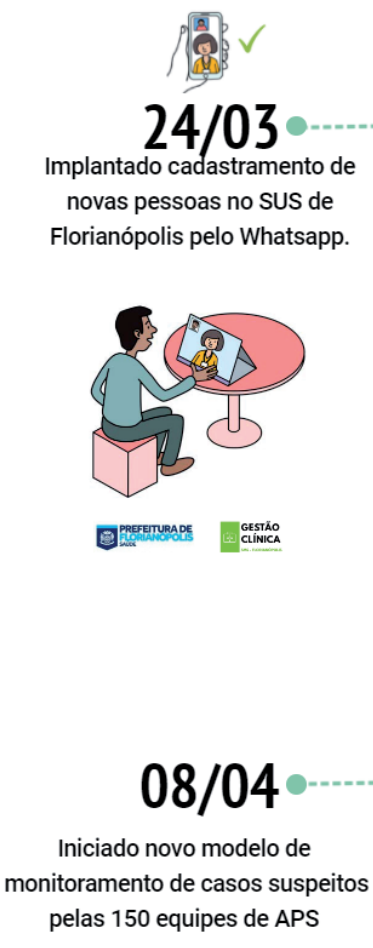

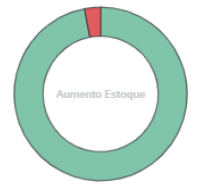
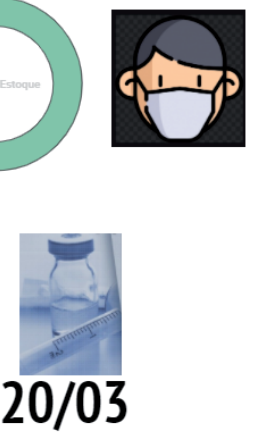

Montada Estratégias de Vacinação Sem Aglomeração: drivethru, domiciliar e em condomínios.

\section{4/04}

Implantadas TELECONSULTAS MÉDICAS E DE ENFERMAGEM com emissão de Receitas e Atestados de Forma Digital

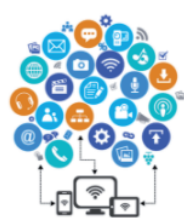

1736 pessoas em monitoramento por profissionais de saúde

Fonte: Gerência de APS/SMC Florianópolis. 
Em relação ao controle da contaminação interna nas clínicas de APS, até o mês de janeiro de 202 I foram confirmados para Covid- I 9208 profissionais, representando I4\% do total de trabalhadores. Os meses de maior contaminação desses profissionais da saúde foram de outubro a dezembro de 2020. As categorias profissionais em que houve maior proporção de confirmação diagnóstica para a Covid- 19 foram as de agentes comunitários de saúde - 52 (25\%), técnicos de enfermagem - 46 (22\%), enfermeiros - 31 (15\%) e médicos - 21 (10\%).

Em uma análise mais específica (investigação epidemiológica) para avaliar se os profissionais foram contaminados no seu meio social ou realizando suas atividades laborais, constatou-se que $83 \%$ foram contaminados externamente ao local de trabalho e 17\% provavelmente durante sua atividade profissional na APS (Florianópolis, 2020f).

$\mathrm{Na}$ distribuição por categoria registrou-se que $83 \%$ dos agentes comunitários de saúde, $89 \%$ dos técnicos de enfermagem, $65 \%$ dos enfermeiros e $76 \%$ dos médicos tiveram seu contato índice fora da unidade de saúde em que atuam, conforme Figura 3.

Figura 3 - Possível fonte de contaminação para Covid- 19 dos profissionais da APS Florianópolis, 13 mar. 2020 a 22 jan. 2021

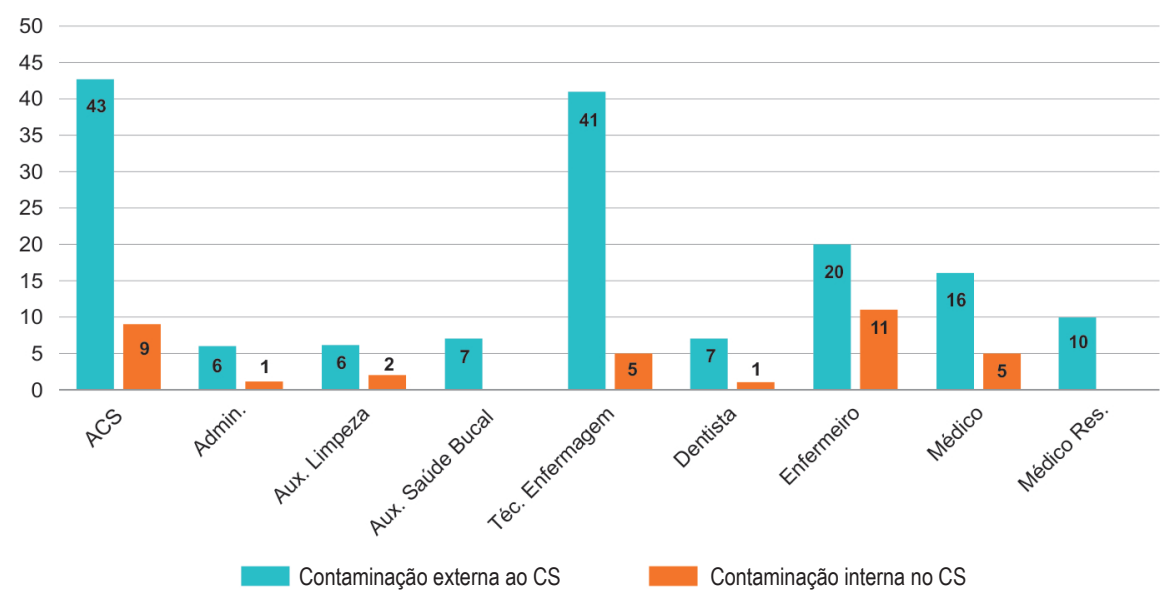

Fonte: Florianópolis, $2020 f$.

\section{A OPÇÃO PELO TELEATENDIMENTO}

Mesmo antes do início da pandemia no Brasil, Florianópolis estava organizando o lançamento de um serviço de atendimento pré-clínico denominado Alô Saúde Floripa, para oferecer avaliação telefônica por profissional da saúde 24 horas por dia, 7 dias 
por semana, com base em algoritmos e protocolos validados para a APS, capaz de realizar orientações e referenciamentos adequados para a rede pública de atenção à saúde existente na cidade. Tal serviço foi associado à ampliação do acesso remoto à APS com base em um modelo de incorporação de smartphones pelas equipes de Saúde da Família. Para tanto, cada equipe de APS recebeu um smartphone, um número (chip) pós-pago, manual e treinamento para utilização da plataforma gratuita WhatsApp ${ }^{\circledR}$, de modo a implementar um canal de acesso e comunicação efetivos com a população.

No período de 16 de março a 31 de dezembro de 2020 o serviço Alô Saúde Floripa registrou 112.762 ligações, 91 .44I das quais concluídas, com tempo médio de espera de 10 segundos. Das 91.441 ligações atendidas, 42.25I passaram pelo algoritmo de Covid-19. Dessas, 29.947 receberam orientação de autocuidado e autoisolamento e foram direcionados para que a APS realizasse teleconsulta. E nesse atendimento telefônico, apresentaram sintomas de maior gravidade, com necessidade de atendimento presencial, apenas 3.594 pacientes, que foram encaminhados para contato com o Serviço de Atendimento Móvel de Urgência (Samu), emergência hospitalar ou Unidade de Pronto Atendimento (UPA). Houve cerca de 5 mil ligações de moradores de outros municípios (Florianópolis, 202 lb).

Foram distribuídas 150 contas pós-pagas (chips de celular) para as equipes de APS (um para cada equipe), para contato direto com os usuários, e concomitantemente foi divulgado o canal 0800 do Alô Saúde Floripa. Neste serviço, o usuário, ao ligar, é atendido por profissional da saúde (técnicos de enfermagem e enfermeiros) segundo algoritmos validados pela equipe técnica da instituição e ao final do atendimento é direcionado para acompanhamento pela equipe de referência na qual está cadastrado, cujo contato via WhatsApp ${ }^{\circledR}$ Ihe é fornecido. Para as pessoas sem cadastro foi implementado o cadastro on-line. Desde maio de 2020 também estão em funcionamento 49 canais de WhatsApp ${ }^{\circledR}$ (um por unidade) para a realização de novos cadastros e para atendimento de demandas administrativas.

No contexto da ampliação das formas de contato com o serviço de saúde, em 2020 foram realizados pelas clínicas de família 41.581 novos cadastros de moradores de Florianópolis e mais 3.903 cadastros de usuários de outros municípios.

Com a chegada da pandemia, esse serviço pré-clínico foi fortalecido e integrado aos canais de acesso das equipes, e foram utilizadas estratégias de comunicação para a ampla divulgação destas modalidades entre a população. A decisão da equipe técnica foi por disponibilizar um único link, agrupando os contatos de todas as clínicas e de todas as equipes (https://sus.floripa.br/contatoscs/). 
Assim, com a experiência técnica já adquirida associada à cultura de inovação preexistente, foi possível reorganizar os serviços de APS para manter o acesso e a coordenação do cuidado, garantindo também a longitudinalidade a partir de qualquer entrada do usuário no sistema, seja ela virtual pelo serviço pré-clínico, virtual por contato direto pelo Whats $A p p \AA$ ou presencial. Nesse arranjo o usuário recebe avaliação, atendimento e monitoramento diante de uma suspeita de Covid- 19 pela mesma equipe à qual está vinculado pelo modelo territorial da APS.

A incorporação dessas tecnologias permitiu garantir o atendimento inicial e o cuidado integral dos usuários sintomáticos respiratórios de maneira remota, seja por meio do WhatsApp ${ }^{\circledR}$ da equipe, seja pelo Alô Saúde Floripa. O paciente era orientado sobre o isolamento e avaliado por teleconsulta, o teste para Covid- 19 era realizado em domicílio quando necessário e o paciente era monitorado pela sua equipe de APS para avaliação de sinais de gravidade, orientações de autocuidado e verificação do cumprimento do isolamento. De março a dezembro de 2020, foram avaliadas como suspeitas de Covid- 19 pelo serviço de atendimento pré-clínico 42.25 I pessoas, das quais 29.947 receberam orientação de autocuidado, autoisolamento e foram direcionadas para que sua equipe de APS realizasse teleconsulta (Florianópolis, 2020f). A orientação nesse período foi privilegiar o teleatendimento para todos os pacientes sintomáticos respiratórios e para as outras demandas.

Em maio de 2020, a Secretaria de Atenção Primária à Saúde (SAPS) do Ministério da Saúde lançou a iniciativa Consultório Virtual de Saúde da Família, para fornecimento de certificados digitais para médicos, e em dezembro estendeu o cadastramento para enfermeiros e odontólogos. Em 30 de dezembro, a SMS Florianópolis havia registrado 398 profissionais no referido programa, tendo efetivamente obtido o certificado digital para 164 profissionais entre médicos, médicos de família e médicos residentes, representando 100\% dos profissionais médicos atuantes na rede de APS.

Para tornar as teleconsultas mais resolutivas, foram estruturadas, além dos atos autorizativos (Florianópolis, 2020f), da certificação digital e das demais tecnologias incorporadas, outras ações, tais como a elaboração de manuais e oferta de treinamentos on-line para médicos e enfermeiros sobre o tema (Florianópolis, 2020g); a publicação de normativa para a rede de farmácias próprias efetivar a dispensação das prescrições de medicamentos comuns, antibióticos e terapia antirretroviral (Tarv) com assinatura digital (Florianópolis, 2020h, 2020i); o estabelecimento de acordo contratualizado com laboratórios para incorporação de solicitações e requisições em formato eletrônico; a implantação de código de barras bidimensional e respectivo link na web para verificação 
dos atestados médicos assinados digitalmente; e, não menos importante, a implementação de uma forma de registro das teleconsultas em prontuário eletrônico com devido manual e orientações para o registro pelos profissionais.

Ainda como parte dos esforços para evitar aglomerações e contágio no contato com serviço de saúde, as equipes de APS se organizaram para levar os medicamentos nos domicílios das pessoas em uso de prescrições contínuas e pertencentes aos grupos de risco. Seguindo a mesma lógica, foi implementada parceria em 26 de março de 2020 entre a SMS e organizações da sociedade civil para a entrega da Tarv de pessoas vivendo com HIV com dificuldade para buscá-la. Até dezembro de 2020, o projeto intitulado Apoio TARV Floripa já auxiliou mais de 550 pessoas vivendo com HIV para que não abandonem seu tratamento.

As equipes também foram orientadas a realizar busca ativa telefônica ou por meio do Whats $A p p \AA$ de usuários em situações clínicas de maior risco ou vulnerabilidade (gestantes com comorbidades, usuárias para primeira consulta de puericultura, pacientes crônicos já conhecidos das equipes, usuários hipertensos ou diabéticos descompensados), de modo a manter o atendimento presencial necessário de acordo com a possibilidade de cada paciente. Para os pacientes com risco moderado, a orientação às equipes foi a de contatá-los antecipadamente e realizar, sempre que possível, o atendimento a distância das demandas, de forma a evitar exposições desnecessárias e reduzir o risco de contágio.

Assim, ao final de dezembro de 2020 a rede de atenção à saúde de Florianópolis registrou 2.092.892 atendimentos entre consultas presenciais, teleconsultas, vacinas, dispensação de medicamentos e outros procedimentos. Desse total, registraram-se 845.018 consultas clínicas (com médicos, enfermeiros e odontólogos). Em comparação, as três UPAs realizaram 543.068 consultas clínicas para 134.54 I pessoas nesse mesmo período. As teleconsultas representaram 20\% desses procedimentos (174.006 registradas por médicos, enfermeiros, dentistas, profissionais do Núcleo de Apoio à equipe da Saúde da Família e residentes em medicina, enfermagem, odontologia e multiprofissionais, atendendo 97.554 pessoas (Florianópolis, 202 Ia).

\section{PROCESSO DE ELABORAÇÃO DO PACK (PRACTICAL APPROACH TO CARE KIT)-COVID}

Para o treinamento e orientação do atendimento, no novo contexto da pandemia de Sars-CoV-2, de usuários com sintomas respiratórios ou febre nos centros de Saúde, a SMS de Florianópolis optou por utilizar a estratégia de qualificação clínica que desenvolve desde 2016, o Programa PACK Brasil. 
A SMS de Florianópolis desenvolve o PACK Brasil em parceria com a Unidade de Tradução do Conhecimento do Instituto do Pulmão da Universidade da Cidade do Cabo, na África do Sul. O programa, que se desenvolve na África do Sul há mais de 15 anos com bons resultados na qualidade e no custo-efetividade da APS, consiste em: um guia baseado em evidências e adaptado à realidade clínico-epidemiológica local; uma estratégia de treinamento; propostas de mudanças no perfil técnico-assistencial da APS; e uma estratégia de monitoramento e avaliação do impacto do programa. Baseiase no conceito de tradução do conhecimento, visando a que a melhor evidência seja incorporada na prática clínica de médicos e enfermeiros da APS (Florianópolis, 2020c). O guia, chamado de PACK, apresenta as recomendações em formato de algoritmos e é elaborado para utilização no atendimento dos pacientes, apoiando os profissionais médicos e enfermeiros no diagnóstico e manejo das principais condições agudas e crônicas atendidas na APS. Nessa estratégia, os próprios profissionais (médicos e enfermeiros) da rede de APS são treinados para, por sua vez, utilizando o guia em pequenos grupos e no local de trabalho, realizarem o treinamento dos demais profissionais clínicos das equipes com base em simulações de casos.

Com a pandemia da Covid-19, mais do que nunca foi necessário orientar, atualizar e treinar de forma rápida e baseada em evidências os profissionais clínicos para manejar os pacientes com sintomas respiratórios/febre nesse novo contexto epidemiológico. Assim, lançamos já nas primeiras semanas de março de 2020 a primeira versão do guia PACK, voltada para o manejo da Covid-19, e iniciamos treinamento remoto dos profissionais (Florianópolis, 2020b). Ao longo do ano de 2020, o guia teve oito atualizações, feitas à medida que novas evidências sobre a Covid- 19 e orientações para o seu manejo surgiam. Todas as versões foram acompanhadas de treinamentos em plataformas virtuais e estratégias de divulgação direta entre os profissionais (Figura 4). 
Figura 4 - Divulgação da 8a atualização do protocolo municipal - Florianópolis, 2021

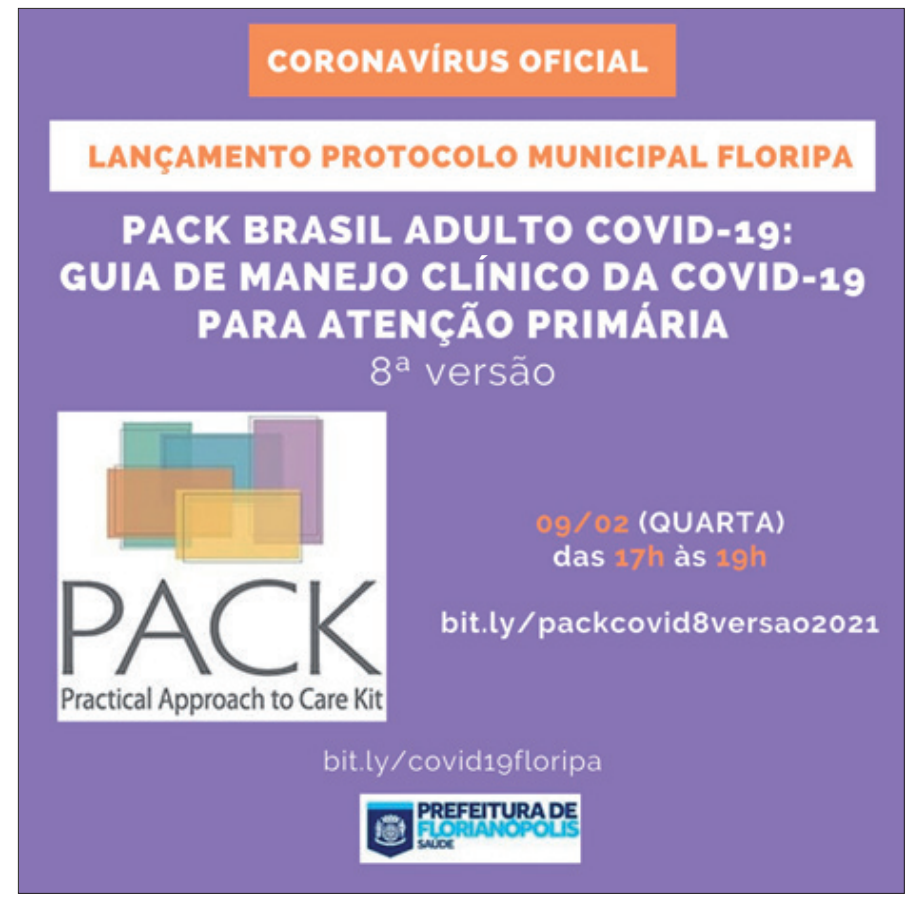

Fonte: acervo do Departamento de Gestão Clínica da Gerência de Integração Assistencial/SMC Florianópolis.

Para as dúvidas clínicas e fluxo de atendimento que surgissem ao longo do cuidado clínico de pacientes com sintomas respiratórios/febre, foi criado um grupo de WhatsApp ${ }^{\circledR}$ de apoio clínico matricial para Covid-19. Esse grupo reúne técnicos da Vigilância Epidemiológica e de diversos setores da SMS e os profissionais clínicos envolvidos no atendimento direto e indireto de pacientes com suspeita/confirmação de Covid-19. Os profissionais das equipes de APS recorrem ao grupo para, resguardadas as informações pessoais e o anonimato dos pacientes atendidos, apresentar aos seus diversos participantes suas dúvidas relacionadas ao manejo dos casos em atendimento, como forma de obter apoio na avaliação e sugestões de conduta.

\section{ESTRATÉGIA DE TESTAGEM E TELEMONITORAMENTO}

O município de Florianópolis adotou a estratégia de testagem ampla e monitoramento de usuários considerando uma definição de critérios sensíveis para testagem de casos leves e contatos próximos (contenção da transmissão comunitária). Inicialmente, o 
único teste disponível era o RT-PCR coletado pelo município e processado no Laboratório Central de Santa Catarina (Lacen-SC). Diante da sobrecarga, da intermitência da oferta desse teste e da eventual demora nos resultados, foram também adquiridos testes rápidos sorológicos e contratado o fornecimento de mais testes de RT-PCR para Sars-CoV-2. As coletas foram e continuam sendo ofertadas à população em ambiente domiciliar (RT-PCR), em drive-thru em terminal de ônibus (de abril a julho/2020) e em todas as 49 clínicas de família, pelos profissionais das equipes da APS (médicos, enfermeiros e odontólogos). Posteriormente foram implementados centros de Testagem Distritais (CTDs) com o objetivo de ampliar a capacidade de testagem, em especial a de RT-PCR. Nos dez meses de pandemia em 2020, foram notificadas 87.547 pessoas em todo o município, somadas as notificações feitas por todas as instituições públicas e privadas em todos os níveis de atenção. As clínicas de família realizaram 42.136 testes rápidos e o laboratório municipal (Lamuf) efetuou 41.945 coletas de RT-PCR (WHO, 2020c).

O telemonitoramento de casos, por sua vez, foi iniciado pela equipe de vigilância epidemiológica, e diante das projeções de aumento exponencial dos casos foi planejado um processo de task shifting (mudança de tarefa) para sua execução pelas equipes de APS. Nesse processo, as equipes recebem, em tela própria dentro do prontuário eletrônico, todos os usuários notificados cujo endereço corresponde à sua área de adscrição, considerando os casos suspeitos notificados pela rede municipal e estadual e pelos serviços privados. Com o aumento ainda maior dos casos e de suas redes de contatos próximos, o telemonitoramento foi reforçado com profissionais das equipes multiprofissionais territorializadas na APS, cinquenta médicos e trinta enfermeiros residentes, profissionais da equipe de saúde bucal e médicos da Gerência de Atenção Especializada (policlínicas). A equipe responsável pelo território faz contato telefônico com a pessoa para o telemonitoramento no $3^{\circ}, 7^{\circ}, 10^{\circ}$ e $14^{\circ}$ dias de sintomas, e se esta relatar algum agravamento ou alguma demanda, oferta-se uma teleconsulta agendada ou atendimento imediato por médico ou enfermeira. Até II de janeiro de 2021 as equipes de vigilância e da APS já haviam monitorado 34.467 casos, dos quais 28.257 já concluídos (Florianópolis, 202 la).

\section{ADOÇÃO DE POLÍTICAS PÚBLICAS VOLTADAS PARA A POPULAÇÃO EM GERAL E PARA POPULAÇÕES MAIS VULNERÁVEIS}

Sobre o distanciamento físico e isolamento social, a gestão central do município esteve aberta a ouvir o corpo técnico e estabelecer as medidas iniciais de restrição de mobilidade, fechamento de serviços, distanciamento social e uso de máscaras (inclusive caseira) para todos. A adoção de lockdown precoce contribuiu para a elaboração do 
plano de testagem abrangente e estruturação das ações de resposta à pandemia. A APS apoiou a divulgação de informações relativas à tomada de decisão pelo gestor municipal e à adoção de cuidados preventivos usando o aplicativo Whats $A p p \AA$ das equipes, no que se mostrou uma importante estratégia para responder às notícias falsas sobre a pandemia e minimizar os efeitos destas.

A articulação intersetorial e com a sociedade civil foi feita juntamente com a Secretaria de Assistência Social e o Projeto Somar Floripa, rede de organizações voluntárias. Com essa parceria foi possível organizar a distribuição de cestas básicas para a população carente; adaptar hotel para acolher os moradores de rua e mulheres em situação de violência que, hospedadas em casas de passagem, não tinham como fazer o isolamento social, iniciativa da qual também participou o setor privado; e mobilização da comunidade para ajudar idosos que estão em casa e precisam fazer compras e não podem sair devido à necessidade de distanciamento social.

Para acolher as pessoas em vulnerabilidade social, as secretarias de Saúde e Assistência Social alugaram, em parceria, um hotel no centro da cidade, que no período de 24 de março a 31 de dezembro de 2020 abrigou 91 pessoas com suspeita da Covid- 19, as quais contaram com apoio e assistência clínica da equipe do Consultório na Rua da APS.

Outra ação relevante foi a parceria com organizações não governamentais para garantir a entrega de medicamentos a pessoas que vivem com vírus da imunodeficiência humana (HIV) e, devido à suspensão do transporte público, apresentavam dificuldades no acesso à medicação.

Nas ações de fiscalização dos estabelecimentos públicos e privados, destaca-se a parceria entre a Gerência de Vigilância Sanitária/SMS e a Guarda Municipal. Nos supermercados, pontos identificados como de alto risco de contágio, há protocolos importantes para evitar a disseminação do vírus, como o uso obrigatório de máscara, aferição de temperatura antes da entrada no estabelecimento e restrição de entrada para pessoas apresentando febre. E foram exigidas instalação de equipamentos para desinfecção de mãos, restrição da capacidade máxima de pessoas que podem ingressar no mesmo momento e sinalização visual para a organização de filas de modo a evitar aglomerações. Além disso, foi estabelecida uma barreira sanitária no aeroporto para abordagem de todas as pessoas que chegam à cidade, com ciência e adesão ao termo de restrição: as que apresentam sintomas na abordagem são avaliadas por uma equipe clínica, com possibilidade de testagem oportuna (teste rápido) ou de coleta programada para RT-PCR no domicílio/hospedagem (segundo a evolução temporal dos sintomas) e prescrição de isolamento social enquanto se confirma ou se descarta a infecção por Covid- 19. 


\section{A APS NO ENFRENTAMENTO DA PANDEMIA}

A pandemia de Covid- 19 colocou à prova todo o sistema de saúde, exigindo dos gestores respostas rápidas. As principais lições aprendidas pela gestão da rede de saúde de Florianópolis foram:

- A APS cumpre papel crucial que deve ser potencializado durante emergências de saúde pública;

- Na tomada de decisões deve-se buscar o aporte das melhores evidências disponíveis, mesmo que se trate de situações novas, em que não se conta com um repertório de estudos prévios;

- Atuando em uma rede estruturada, com o devido apoio da gestão, as equipes de APS são capazes de responder rapidamente aos desafios incorporando novas ações, processos de trabalho e competências;

- A incorporação de ações remotas por meio de tecnologias digitais foi decisiva para a proteção dos usuários e profissionais, para a otimização do acesso aos serviços de saúde e para a coordenação do cuidado necessária ao desempenho da APS;

- As ações de tradução do conhecimento e comunicação institucional entre a gestão dos serviços e profissionais da saúde têm papel fundamental na reorganização assistencial.

\section{REFERÊNCIAS}

BODENHEIMER, T. et al. The 10 building blocks of high-performing primary care. The Annals of Family Medicine, 12(2): 166-171, 2014.

BRASIL. Secretaria do Trabalho. Portaria n. 25, de 15 out. 200।. Altera a Norma Regulamentadora que trata de Equipamento de Proteção Individual - NR 6 e dá outras providências. Diário Oficial da União, Brasília, 200 I. Disponível em: <www.gov.br/trabalho/pt-br/inspecao/seguranca-e-saude-notrabalho/sst-portarias/200I/portaria_25_nova_nr_06.pdf>. Acesso em: 7 abr. 2020.

CENTER FOR DISEASE CONTROL AND PREVENTION (CDC). Personal Protective Equipment (PPE) Burn Rate Calculator. Disponível em: <www.cdc.gov/coronavirus/20I9-ncov/hcp/ppe-strategy/burncalculator.html>. Acesso em: 7 abr. 2020.

FLORIANÓPOLIS. Secretaria Municipal de Saúde. Uso racional de equipamentos de proteção individual no contexto da Covid- 19, 2020a.

FLORIANÓPOLIS. Secretaria Municipal de Saúde. PACK Brasil Adulto Covid- I 9: guia de manejo clínico da Covid- 19 para atenção primária, 2020b. 
FLORIANÓPOLIS. Secretaria Municipal de Saúde. Portaria n. 90/SMS/GAB/2020. Normatiza o regime excepcional de teletrabalho durante a pandemia de Covid-19 no âmbito da Secretaria Municipal de Saúde. Diário Oficial Eletrônico do Município, Florianópolis, n. 2713, 2020c.

FLORIANÓPOLIS. Secretaria Municipal de Saúde. Limpeza concorrente e desinfecção terminal de todos os pontos de atenção à saúde do município de Florianópolis, 2020d.

FLORIANÓPOLIS. Secretaria Municipal de Saúde. Gerência de Atenção Primária. Controle interno de profissionais notificados por Covid 19. 2020e.

FLORIANÓPOLIS. Secretaria Municipal de Saúde. Gerência de Atenção Primária. Regulamentação de atividades clínicas remotas - teleconsulta - no âmbito da APS. Comunicação interna, circular 3, 2020 f.

FLORIANÓPOLIS. Secretaria Municipal de Saúde. Gerência de Integração Assistencial, Departamento de Gestão da Clínica. Guia de videoconsultas para médicos e enfermeiros, 2020g.

FLORIANÓPOLIS. Secretaria Municipal de Saúde. Gerência de Integração Assistencial, Departamento de Assistência Farmacêutica. Sobre o atendimento de prescrições digitalizadas na rede. Comunicação interna, circular 9, 2020h.

FLORIANÓPOLIS. Secretaria Municipal de Saúde. Gerência de Integração Assistencial, Departamento de Assistência Farmacêutica. Sobre a dispensação de TARV através de formulários em formato digital na rede municipal de saúde. Comunicação interna, circular 14, 2020i.

FLORIANÓPOLIS. Covidômetro. Sala de Situação online. Disponível em: < https://app.powerbi.com/w? $\mathrm{r}=$ eyjrljoiMzc5YmY0NmQtNTFkOS00ZDAxLWE2ZmQtOTZmZDkzM2M5NzAxliwidCl6IjYyMTIxZ mE I LWU3NTAtNDZIYS I hNjg0LTJhZmM2ZDIwYzYyyij9>. Acesso em: 20 jan. 202 Ia.

FLORIANÓPOLIS. Secretaria Municipal de Saúde. Sistema de Informação em Saúde. CELK Sistemas. $202 \mathrm{Ib}$.

GALHARDI, M. P. \& ZONTA, R. Como utilizar a informação na consulta. In: G.; LOPES, J. M. C. \& DIAS, L. C. (Orgs.). Tratado de Medicina de Família e Comunidade: princípios, formação e prática. 2. ed. Porto Alegre: Artmed, 2019.

GREENHALGH, T. Video consultations for covid-19. British Medical Journal, I (368): I-2, 2020. Disponível em: <www.bmj.com>. Acesso em: 18 mar. 2020.

INSTITUTO BRASILEIRO DE GEOGRAFIA E ESTATÍSTICA (IBGE). População estimada de Florianópolis. Disponível em: <https://cidades.ibge.gov.br/brasil/sc/florianopolis/panorama>. Acesso em: 24 jan. 2021 .

PUEYO, T. Coronavirus: the hammer and the dance. What the next I 8 months can look like, if leaders buy us time. Medium, 19 mar. 2020a. Disponível em: <https://tomaspueyo.medium.com/coronavirusthe-hammer-and-the-dance-be9337092b56>. Acesso em: 28 mar. 2020.

PUEYO, T. Coronavirus: why you must act now. Medium, I0 mar. 2020b. Disponível em: <https:// tomaspueyo.medium.com/coronavirus-act-today-or-people-will-die-f4d3d9cd99ca>. Acesso em: 10 mar. 2020.

OURWORLDINDATA.ORG. Coronavirus pandemic (Covid- 19). Disponível em: < https://ourworldindata. org/coronavirus >. Acesso em: I abr. 2020. 
WORLD HEALTH ORGANIZATION (WHO). Critical preparedness, readiness and response actions for Covid- 19: interim guidance. Geneva: WHO, 22 mar. 2020a. Disponível em: < https://apps.who.int/iris/ handle/I0665/33 I5 I I >. Acesso em: II mar. 2020.

WORLD HEALTH ORGANIZATION (WHO). Rational use of personal protective equipment for coronavirus disease (Covid-19): interim guidance. Geneva: WHO, 2020b. Disponível em: <https:// apps.who.int/iris/handle/I 0665/331215>. Acesso em: 27 fev. 2020.

WORLD HEALTH ORGANIZATION (WHO). Considerations in the investigation of cases and clusters of Covid- 19: interim guidance. Geneva: WHO, 2020c. Disponível em: <www.who.int/publicationsdetail/considerations-in-the-investigation-of-cases-and-clusters-of-covid-19>. Acesso em: 10 abr. 2020. 
Desafios e Repercussões na Organização da Atenção Primária à Saúde no Contexto da Covid-19

o caso do CSEGSF/Teias Manguinhos

\author{
Gisele O'Dwyer, Regina Paiva Daumas, \\ Denise Cotrim da Cunha e Mellina Marques Vieira Izecksohn
}

\footnotetext{
$\mathrm{O}$
} Centro de Saúde Escola Germano Sinval Faria (CSEGSF), da Escola Nacional de Saúde Pública Sergio Arouca da Fundação Oswaldo Cruz (Ensp/Fiocruz), atuando na tríade ensino, pesquisa e assistência, tem cumprido sua função de formador de trabalhadores para a saúde e assumido papel crucial no atendimento à população desde 1967.

O CSEGSF foi palco de diversas iniciativas inéditas no campo da assistência e promoção da saúde (Reis, 2002). Essa trajetória permitiu a implantação das primeiras equipes de Estratégia Saúde da Família (ESF) em 2000, quando a cobertura nesta área no município do Rio de Janeiro era ínfima. No mesmo ano, iniciou-se a experiência de Conselho Gestor, inaugurando a gestão participativa no território. Em 2009, durante um movimento de expansão da Atenção Primária à Saúde (APS) no município do Rio de Janeiro, a ESF alcançou I00\% de cobertura em Manguinhos e passou a ser gerida pela organização social Fundação para o Desenvolvimento Científico e Tecnológico em Saúde (Fiotec), mediante um contrato de gestão com o município que estabelecia o Projeto Teias: Território Integrado de Atenção à Saúde - Manguinhos.

A ESF de Manguinhos conta com duas clínicas: uma no interior do CSEGSF, com sete equipes de Saúde da Família (eSF), e outra localizada fora do campus da Fiocruz, conjugada com a Unidade de Pronto Atendimento (UPA) Manguinhos, a Clínica da Família Victor Valla (CFVV), inaugurada em 2010, com seis eSF e uma equipe de consultório na rua. A estrutura física e a disponibilidade de recursos são diferentes, em especial pela presença dos servidores da Fiocruz no CSEGSF, atuando em conjunto com as eSF.

Por ser uma unidade mista vinculada à Fiocruz e à Secretaria Municipal de Saúde do Rio de Janeiro (SMS-RJ), o CSEGSF conta com estruturas incomuns em unidades de 
APS, como um Núcleo de Vigilância em Saúde (NVS) e uma Comissão Interna de Biossegurança e Controle de Infecção $(\mathrm{ClBCl})$. A Comissão do Cuidado reúne coordenador do Cuidado, diretor médico, gerente da ESF, responsáveis técnicos de enfermagem e de odontologia, e coordenadores do NVS, de Farmácia, Laboratório e das comissões de Biossegurança, Prontuários e Segurança do Paciente. Juntamente com a Chefia do CSECSF e a Coordenação do Teias, essas instâncias tiveram grande importância na organização das ações assistenciais propostas para o CSEGSF e a CFVV durante a pandemia.

Para permitir o atendimento seguro a casos suspeitos da Covid-1 9 e a manutenção das atividades regulares das unidades de APS, evitando as consequências danosas da desassistência em períodos de pandemia, um conjunto de ações foi realizado ao longo do ano de 2020, algumas das quais geraram documentos instrutivos/protocolares. Embora esses documentos sejam muito atrelados a características locais, alguns deles podem servir de modelo e inspiração para outras unidades ou como um resgate histórico dessa fase crítica vivenciada pelas unidades básicas de saúde (UBS) com a chegada da Covid- 19.

O trabalho aqui apresentado foi fruto do esforço de muitos profissionais do CSECSF e da ESF que se empenharam em criar soluções para lidar com o cenário desafiador da pandemia. Com este relato, ainda que parcial, visamos a reconhecer e dar visibilidade a esse esforço.

\section{BIOSSEGURANÇA E REORGANIZAÇÃO DO ESPAÇO FÍ́SICO}

Com o surgimento da Covid-19, grande parte das ações necessárias para prover o atendimento a casos suspeitos envolvia questões relativas à biossegurança, dada a alta transmissibilidade do Sars-CoV-2. O risco de transmissão demandava, além do uso de equipamentos de proteção individual (EPIs), a separação das áreas de atendimento e a constante atenção para a desinfecção das superfícies (Anvisa, 2020).

Preparando os profissionais para a possível chegada de casos suspeitos de Covid-19, a Comissão Interna de Biossegurança e Controle de Infecção (CIBCl) publicou, em 6 de fevereiro de 2020, a primeira versão do documento Orientações para atendimento de pessoas com suspeita de infecção pelo Sars-CoV-2, que teve diversas atualizações posteriores. Com a mesma intenção, realizou, a partir de 5 de março de 2020, treinamentos de todos os profissionais das UBS, incluindo equipe de higiene e limpeza, quanto às precauções respiratórias (gotículas e aerossóis) e de contato, higienização das mãos e utilização de EPIs. A CIBCI produziu também os vídeos Sequência de Paramentação (https://youtu.be/ssTIB4k-aD8) e Desparamentação 
(https://youtu.be/SmNNPvlPzIw), que serviram de apoio aos treinamentos, além de materiais impressos com orientações aos profissionais e aos pacientes, como o cartaz Se você está GRIPADO ou com TOSSE (Figura I), que foram afixados nos locais de atendimento. Recomendações para o afastamento e retorno ao trabalho de profissionais de saúde também foram publicadas e atualizadas nos meses posteriores, de acordo com novas publicações do Centro de Controle de Doenças (CDC) norteamericano (CDC, 2020a, 2020b).

Figura I - Cartaz: Se você está gripado ou com tosse! - fev. 2020

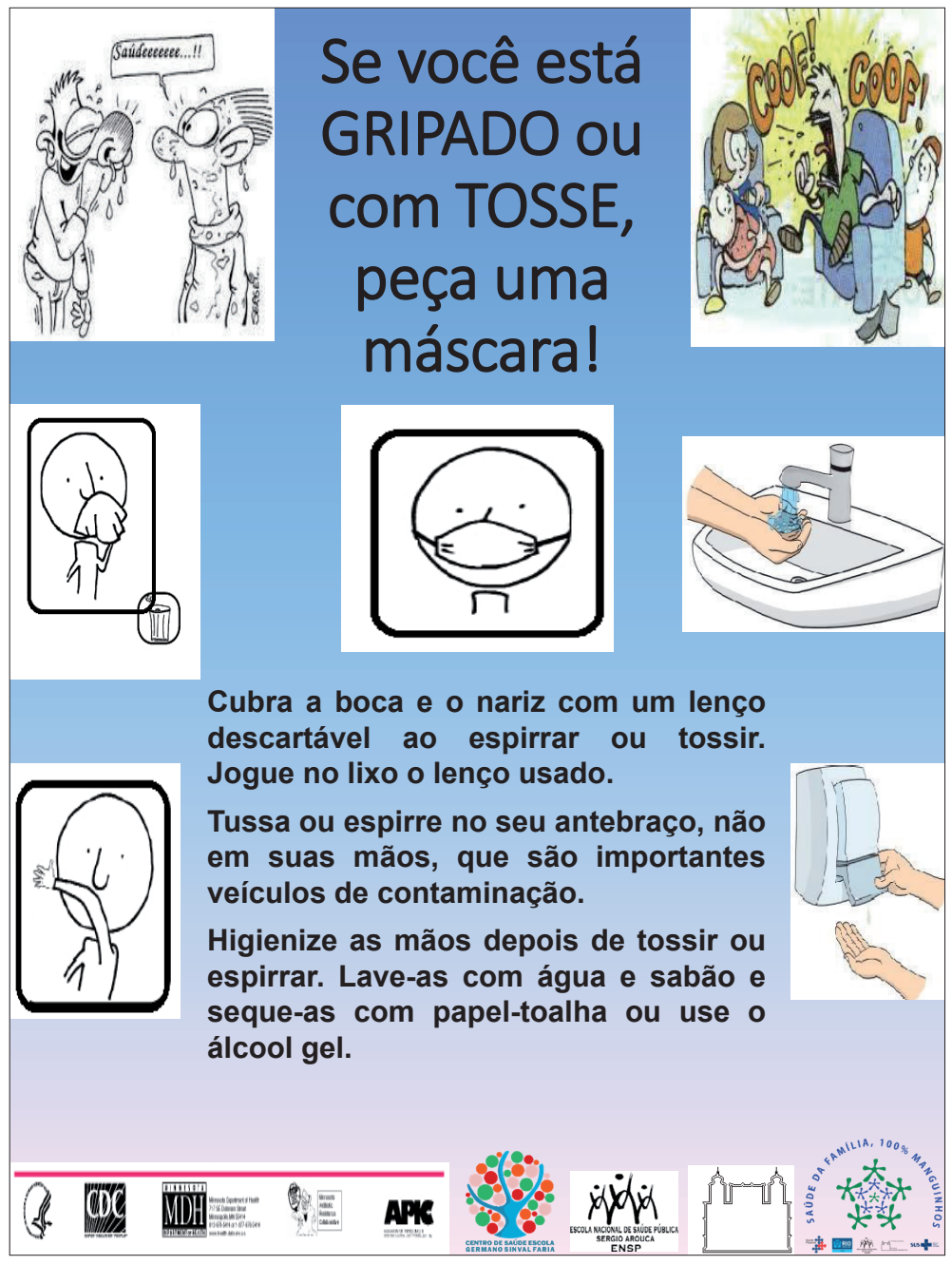


Com o reconhecimento da transmissão comunitária da Covid- 19 no Rio de Janeiro em 13 de março de 2020, era essencial modificar todos os processos de trabalho em razão da expectativa de aumento do número de pacientes com sintomas respiratórios agudos e da necessidade de realizar esses atendimentos em condições de biossegurança adequadas para minimizar a possibilidade de contágio. Era necessário, então, rastrear os pacientes no primeiro contato com o serviço e implementar todas as precauções para o controle de infecção de acordo com as recomendações vigentes (WHO, 2020a). Estas incluíam atendimento em áreas externas, limitação do contato físico, modificações de fluxo, designação de áreas de atendimento e espera separadas para os casos suspeitos, distanciamento entre pacientes, colocação de barreiras físicas e disponibilização e uso racional de EPIs (WHO, 2020b).

Considerando esse novo cenário epidemiológico, novos fluxos assistenciais, gerenciais e de vigilância foram implementados no CSEGSF e na CFVV a partir de 16 de março, primeiro dia útil após o reconhecimento da transmissão comunitária da Covid- 19 no Rio de Janeiro, mediante mobilização dos recursos locais e adaptações dos espaços de atendimento existentes. Esses fluxos eram revisados diariamente nas primeiras semanas e foram sendo documentados das mais variadas formas; a comunicação com os profissionais era realizada em breves reuniões com as equipes e por WhatsApp, dada a necessidade de adaptações e confecção de escalas para os diversos pontos de atendimento externo criados. Todos os pacientes passaram a ter a temperatura aferida e a higienizar as mãos com álcool 70\% ao primeiro contato com o serviço.

Para separar pacientes suspeitos de Covid- 19 dos pacientes com outras demandas, equipes de Resposta Rápida (ERRs) com médico, enfermeiro, técnico de enfermagem e agente comunitário de saúde foram compostas para atuar nos espaços físicos adaptados, sem prejuízo da observância das normas de biossegurança adequadas à transmissibilidade do vírus emergente. A logística de montagem dos espaços, de fornecimento de EPIs e de fluxo de registros e notificações foi operacionalizada e, com o transcorrer do tempo, redesenhada de acordo com os novos conhecimentos e normativas. Recomendações para o uso adequado de EPI no CSEGSF segundo local e tipo de atendimento (Figura 2) foram publicadas e atualizadas a cada mudança nas recomendações internacionais ou na organização local. 
Figura 2 - Recomendações para o uso adequado de EPI no CSEGSF segundo local e tipo de atendimento - set. 2020
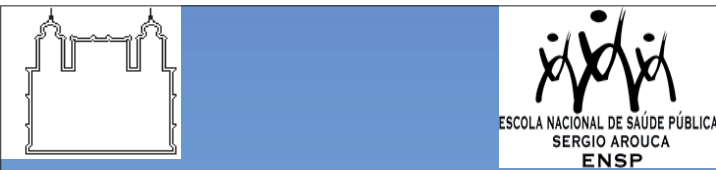

COVID-19

Recomendações para o uso adequado de EPI no CSEGSF

TRIAGEM - ÁREA EXTERNA

HIGIENE DAS MÃOS, MÁSCARA CIRÚRGICA, ÓCULOS OU PROTETOR FACIAL, AVENTAL (gramatura $30 \mathrm{~g} / \mathrm{m}^{2}$ ) E

DISTANCIAMENTO ESPACIAL DE, PELO MENOS, 1,5m.

AO IDENTIFICAR USUÁRIO COM SINTOMAS SUSPEITOS, ENCAMINHÁ-

LO PARA A ÁREA DE RESPOSTA RÁPIDA. OFERECER MÁSCARA CASO O USUÁRIO NÃO ESTEJA USANDO.

\section{ÁREA DA EQUIPE DE RESPOSTA RÁPIDA}

HIGIENE DAS MÃOS, MÁSCARA CIRÚRGICA, ÓCULOS OU PROTETOR FACIAL, GORRO, LUVAS, AVENTAL (gramatura $40 \mathrm{~g} / \mathrm{m}^{2}$ ) E

DISTANCIAMENTO ESPACIAL DE, PELO MENOS, 1,5m.

EM CASO DE PROCEDIMENTO GERADOR DE AEROSSÓIS (COLETA DE SWAB, POR EX.), UTILIZAR MÁSCARA PFF2/N95.

ÁREAS INTERNAS ASSISTENCIAIS DO CSEGSF

HIGIENE DAS MÃOS, MÁSCARA CIRÚRGICA + EPI DE ACORDO COM AS PRECAUÇÕES PADRÃO E, SE NECESSÁRIO, PRECAUÇÕES ESPECÍFICAS.

ÁREAS ADMINISTRATIVAS - TODOS OS TRABALHADORES, INCLUINDO OS PROFISSIONAIS DE SAÚDE

HIGIENE DAS MÃOS, MÁSCARA CIRÚRGICA E DISTANCIAMENTO ESPACIAL DE, PELO MENOS, $1,5 \mathrm{~m}$.

FONTE: NOTA TÉCNICA 07/2020 ANVISA ATUALIZADO EM 15/09/2020 - CIBCI 
As duas unidades têm espaços físicos muito distintos. No CSEGSF, foi possível atender em área externa e ventilada, nos consultórios com filtro Hepa (high efficiency particulate air) e acesso por entrada externa à unidade. Na CFVV, iniciou-se o primeiro atendimento na Academia Carioca, ao lado da clínica, para todos os casos suspeitos, e foram reservados dois consultórios com janelas para exame clínico mais detalhado de adultos e crianças que apresentassem algum sinal de gravidade ou dúvida diagnóstica.

$\mathrm{Na}$ segunda semana de abril, em razão do aumento do número de atendimentos, o estacionamento em frente ao CSECSF foi adaptado para a recepção e separação dos casos suspeitos de Covid- 19 e outras demandas, com tendas instaladas nos dois espaços (Figura 3). Mas essa solução logo pareceu insuficiente diante da explosão do número de casos de síndrome respiratória aguda de todo espectro de gravidade, aliada à necessidade de preservar o acesso para pacientes com outras demandas de saúde agudas e crônicas, mantendo as medidas de controle de infecção (Paho, 2020). Assim, já em 27 de abril o CSEGSF encaminhou à Direção da Ensp o Projeto de Reorganização e Reforço da Capacidade Resolutiva do Centro de Saúde Escola Germano Sinval Faria para o Enfrentamento da Pandemia de Covid- 9 no Âmbito da Atenção Primária, que tinha como objetivo principal

ampliar a capacidade assistencial do Centro de Saúde Escola Germano Sinval Faria para atender ao crescente número de pacientes com síndrome respiratória aguda e dar condições para a continuidade das ações de promoção, prevenção e atenção à saúde inerentes à APS no contexto da pandemia da Covid- 19.

Figura 3 - Atendimento aos sintomáticos respiratórios em área externa ao Centro de Saúde Germano Sinval Faria - dez. 2020

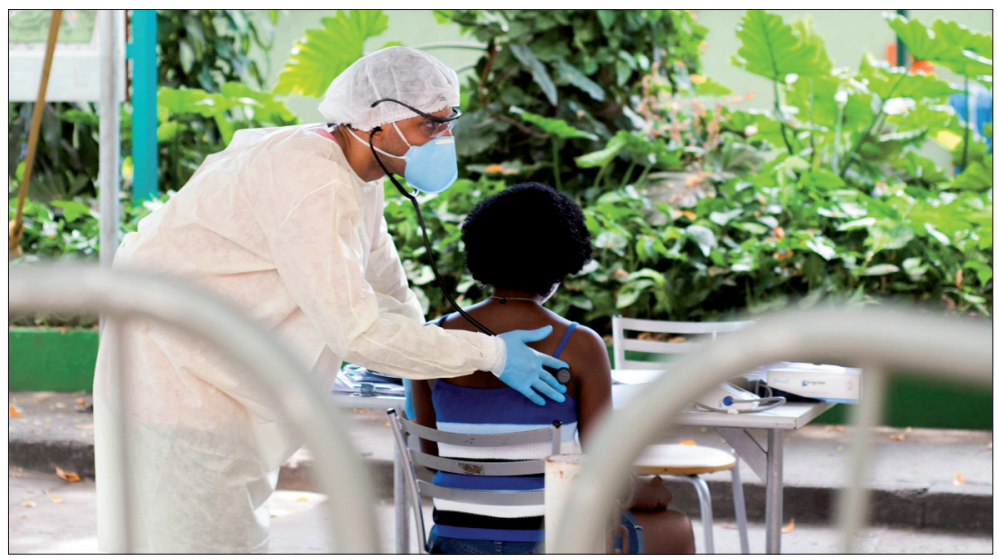

Foto Amanda Cruz da Silva. 
Nessa mesma ocasião, diante do aumento de casos graves chegando às unidades de APS, foi realizado treinamento para médicos e enfermeiros para o manejo de emergências, incluindo manuseio emergencial de vias aéreas e ressuscitação cardiopulmonar, com uso de manequins adquiridos por doação. Instrutivos relativos aos procedimentos e medicações para intubação em sequência rápida foram elaborados e afixados nas salas de atendimento.

Para o atendimento aos casos suspeitos de Covid-19, foi também viabilizado pela Farmácia o abastecimento de medicamentos importantes para cujo fornecimento a Prefeitura do Rio de Janeiro estava encontrando problemas e/ou que não constavam na grade de medicamentos padronizados para as UBS, bem como de medicamentos para sedação em caso de intubação orotraqueal. A equipe de enfermagem elaborou Rotina de enfermagem na Sala de Pesquisa Clínica Covid- 19 e os checklists Covid- 19 para sistematizar a assistência em enfermagem da ERR, incluindo a preparação da sala de atendimento e o provimento de todos os materiais necessários à assistência no âmbito da APS; esses materiais estão disponíveis na intranet da instituição.

As ações planejadas e os materiais produzidos no CSEGSF foram sendo compartilhados e adaptados à CFVV sempre que considerados adequados à sua realidade. Em muitos casos, estratégias próprias mais condizentes com o contexto local foram produzidas pelos gestores e trabalhadores da própria unidade. Em agosto, após conflito armado na área da Academia Carioca, o primeiro atendimento passou a ser feito na entrada da clínica, sem espaço confortável para espera de pacientes. A instalação de tendas externas não foi viabilizada, apesar de indicada, por questão de segurança local. Porém, em 7 de dezembro, já com aumento expressivo de casos de Covid- 19 e a temperatura elevada causando grande desconforto para a equipe assistencial e para os usuários, a Academia Carioca voltou a ser utilizada como espaço para o primeiro atendimento e sala de espera (Figura 4). 
Figura 4 - Atendimento aos sintomáticos respiratórios na área da Academia Carioca anexa à Clínica da Família Victor Valla - dez. 2020

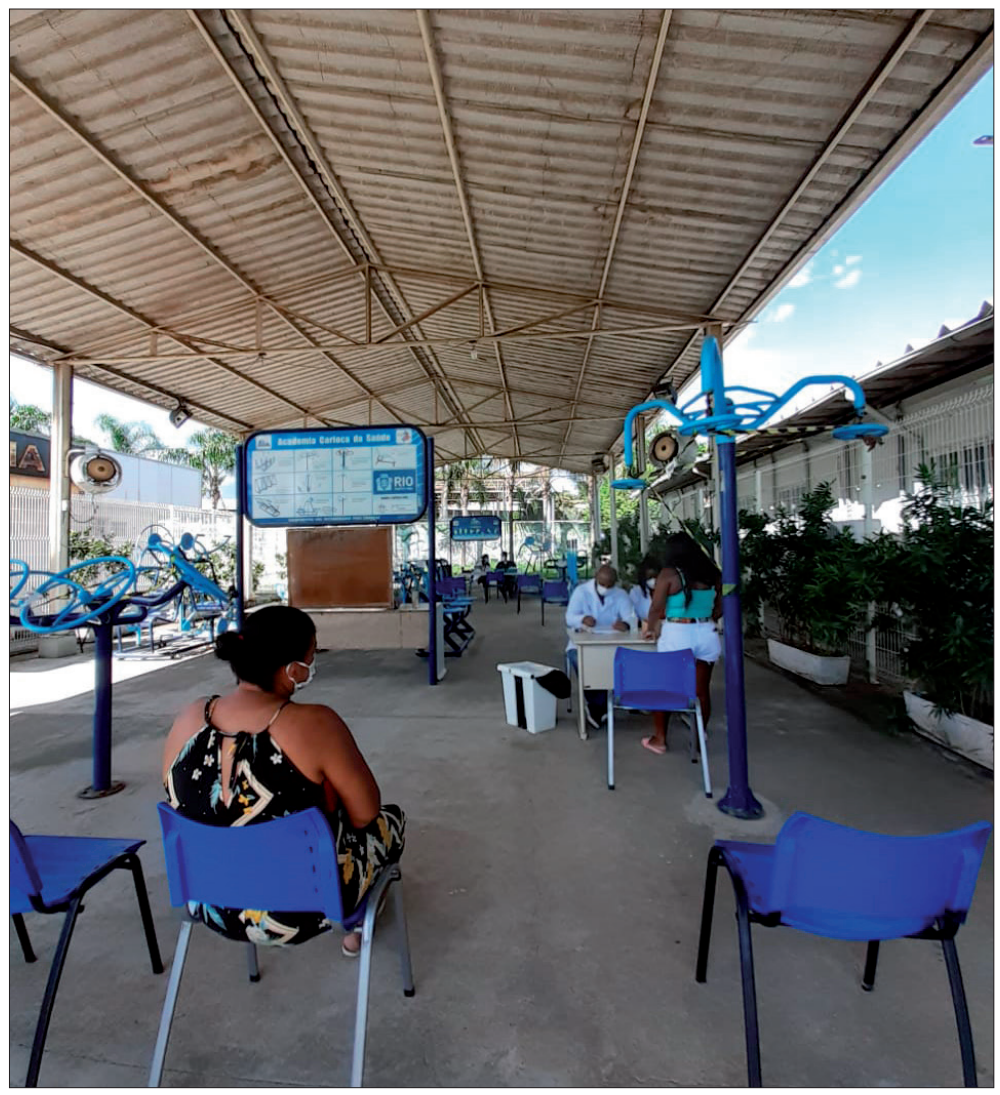

Foto Amanda Cruz da Silva.

\section{VIGILÂNCIA E MONITORAMENTO DE CASOS}

A partir de 16 de março de 2020 ( $12^{\text {a }}$ semana epidemiológica), todos os casos de síndrome gripal (SG) passaram a ser notificados como suspeitos de Covid- 19. Para otimizar o tempo de atendimento e padronizar os registros feitos pela Equipe de Resposta Rápida (ERR), foi elaborado o Formulário de avaliação de indivíduo com sintomas respiratórios (Figura 5), que ao longo do tempo sofreu várias adaptações, até a versão única de atendimento e notificação. O formulário contempla todas as informações necessárias à notificação, além de campos para o registro de sinais vitais e conduta médica e de enfermagem, dispensando o preenchimento da notificação pela equipe de assistên- 
cia, exceto para os casos de síndrome respiratória aguda grave (Srag), para os quais há um formulário próprio. A equipe de vigilância recolhe os formulários da ERR, seleciona aqueles classificados como suspeitos de Covid- I9, notifica no sistema e-SUS VE e insere seus dados na Planilha de Notificação Covid- 19.

Figura 5 - Avaliação de indivíduo com sintomas respiratórios ERR. Versão 6 - set. 2020
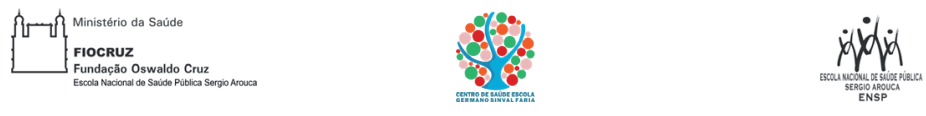

AVALIAÇÃO DE INDIVÍDUO COM SINTOMAS RESPIRATÓRIOS

ENFERMAGEM

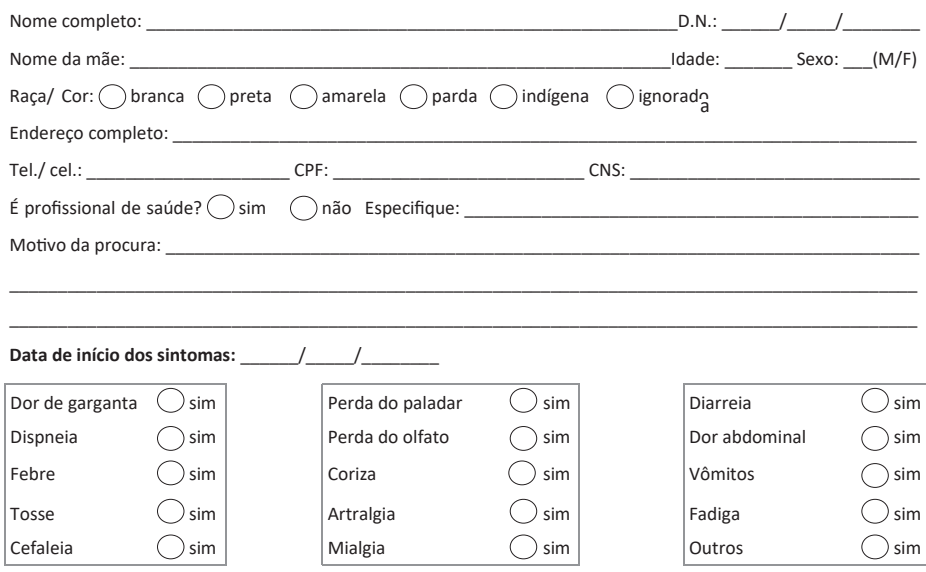

Se apresenta outros sinais e/ ou sintomas relevantes, quais?

\begin{tabular}{|c|c|}
\hline Doenças respiratórias crônicas & Gestante \\
\hline Doenças cardíacas crônicas & Puérpera \\
\hline Diabetes & Obesidade \\
\hline Doenças renais crônicas em estágio avançado & Doenças cromossômicas \\
\hline Imunossupressão & Outra \\
\hline Hipertensão arterial & Qual? \\
\hline
\end{tabular}

Faz uso de medicamentos de uso contínuo? $\bigcirc \operatorname{sim} \bigcirc$ não se sim, descreva:

Apresenta alergia a medicamentos? $\bigcirc \operatorname{sim} \bigcirc$ não se sim, descreva:

História de cirurgias prévias ou internações recentes? $\bigcirc \operatorname{sim} \bigcirc$ não Se sim, descreva:

Profissional (nome/ carimbo): Data: 
Figura 5 - Avaliação de indivíduo com sintomas respiratórios ERR. Versão 6 - set. 2020 (continuação)
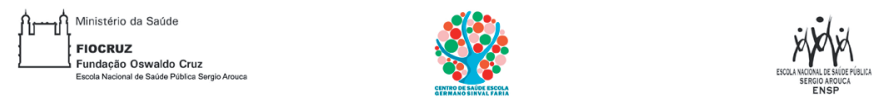

\section{AVALIAÇÃO DE INDIVÍDUO COM SINTOMAS RESPIRATÓRIOS}

EQUIPE DE RESPOSTA RÁPIDA

Sinais vitais e exame físico

(registrar nos casos com sintomas atípicos, dispneia ou comprometimento importante do estado geral):

\begin{tabular}{|c|c|c|}
\hline Temperatura axilar (TAX): & Frequência cardíaca $(\mathrm{FC})$ : & Frequência respiratória (FR): \\
\hline${ }^{\circ} \mathrm{C}$ & BPM & IRPM \\
\hline Saturação de oximetria (SatO2): & Pressão arterial (PA): & \\
\hline$\%$ & & \\
\hline
\end{tabular}

Síndrome Gripal suspeito de CoviD19? (B34.2) $\bigcirc \operatorname{sim} \bigcirc$ não

Definição de SG: Indivíduo com quadro respiratório agudo, caracterizado por pelo menos dois (2) dos seguintes sinais e sintomas: febre (mesmo que referida), calafrios, dor de garganta, dor de cabeça, tosse, coriza, distúrbios olfativos ou distúrbios gustativos. (Na suspeita de COVID-19, a febre pode estar ausente e sintomas gastrointestinais (diarreia) podem estar presentes).

*Em crianças: considera-se também obstrução nasal, na ausência de outro diagnóstico específico.

*Em idosos: deve-se considerar também critérios especificos de agravamento como sincope, confusão mental, sonolência excessiva, irritabilidade e inapetência.

Presença de comorbidade grave ou descompensada com alto risco de agravamento? $\bigcirc$ sim $\bigcirc$ não Qual?

Caso de Síndrome Respiratória Aguda Grave (SRAG)? (U04.9) $\bigcirc \operatorname{sim} \bigcirc$ não

Definição de SRAG: Síndrome Gripal que apresente: dispneia/desconforto respiratório OU pressão persistente no tórax OU saturação de $\mathrm{O} 2$ menor que $95 \%$ em ar ambiente OU taquipneia (>30 irpm) OU hipotensão (<90 x 60 ou sinais de má perfusão periférica) OU piora de doença de base OU alteração do estado mental.

Conduta médica:

Conduta de enfermagem:

Profissional (nome/ carimbo):

Data:

1

Esta ficha servirá de base para a notificação em formulário eletrônico pela Vigilância em Saúde

Versão 6 - 19/09/2020

A consolidação dessas informações tornou possível acompanhar os casos notificados como suspeitos de Covid- 19 e programar o monitoramento remoto, estratégia por meio da qual cada paciente notificado continua em acompanhamento por um período de 14 dias a contar do início dos sintomas. 
O monitoramento de pacientes suspeitos de Covid- 19 tem sido feito desde 23 de março de 2020 por meio de telefonemas estruturados, com perguntas sobre os sintomas, realizados em dias alternados. Isso permite acompanhar a evolução da doença entre os casos notificados, identificar sinais de agravamento e orientar os pacientes quando há necessidade de atendimento presencial imediato (Greenhalgh, Koh E Car, 2020). Durante o monitoramento também são reforçadas as orientações e é avaliada a manutenção do isolamento domiciliar. Um roteiro de telemonitoramento foi elaborado para o registro padronizado desses contatos, posteriormente adaptado para o Google Forms.

Para dar visibilidade aos dados epidemiológicos, a Equipe de Informação em Saúde do Teias Escola Manguinhos elaborou o Painel de Situação Manguinhos Covid-19 (https://bit.ly/manguinhoscovid I9), que permite visualizar em tempo real os dados de notificação e do telemonitoramento dos casos suspeitos de Covid- 19 atendidos pelas clínicas. Nesse painel é possível identificar áreas de maior disseminação da doença no território. Trata-se de importante instrumento para a gestão e para o controle social, inclusive para orientar as comunidades quanto às medidas de distanciamento social.

\section{TESTAGEM PARA COVID-19}

Após treinamento dos profissionais e confecção de um instrutivo orientador, em março de 2020 o CSEGSF iniciou a testagem dos trabalhadores do Teias e do CSEGSF com suspeita de Covid-19. Com o aumento dos casos entre usuários e trabalhadores, ao final de abril a equipe do Centro de Estudos da Saúde do Trabalhador e Ecologia Humana (Cesteh) assumiu, após treinamento no CSEGSF, a coleta de testes moleculares (RT-PCR) para Covid- 19 dos trabalhadores da Ensp e do Teias.

Quanto aos usuários, após o reconhecimento da transmissão comunitária da Covid- 9 no Rio de Janeiro, a coleta de RT-PCR ficou restrita aos pacientes internados, não sendo disponibilizada para as UBS. No entanto, no CSEGSF e na CFVV, em diferentes períodos, projetos de pesquisa da Fiocruz oportunizaram às crianças ou adultos suspeitos o acesso ao teste (Brasil, 2020; Noronha, 2020). Em de julho de 2020, os profissionais do CSEGSF passaram a coletar também o exame de RT-PCR para os casos suspeitos que não fossem incluídos nas pesquisas, sendo os exames processados no Laboratório de Vírus Respiratórios do Instituto Oswaldo Cruz/Fiocruz. A CFVV realiza a coleta de RT-PCR desde dezembro de 2020. Um terceiro projeto de pesquisa (Struchiner, 2020) iniciou um inquérito sorológico domiciliar em Manguinhos, em setembro de 2020. 


\section{PESQUISAS NA APS}

Dez pesquisas sobre a Covid- 19 foram iniciadas em 2020 no CSECSF e na CFVV, cinco das quais coordenadas por pesquisadores do CSECSF. Ambas as unidades adaptaram seu espaço físico e fluxos a fim de conciliar as demandas das pesquisas com a assistência e oportunizar à população os potenciais benefícios pela participação. Entre os estudos clínicos envolvendo assistência a casos suspeitos de Covid-19, além dos citados estudos observacionais e de testes diagnósticos, foi iniciada, em setembro de 2020, uma pesquisa para avaliação de custo-efetividade da oximetria domiciliar e de videoconsultas no acompanhamento desses pacientes (Daumas, 2020).

\section{ATENÇÃO INTEGRAL À SAÚDE: TODA A APS QUE NÃO É COVID-19}

Para além das necessidades inerentes ao atendimento de pacientes com suspeita de Covid-19, é preciso lembrar que pacientes com outras demandas de saúde continuaram dependendo das unidades de APS para a continuidade de seus tratamentos e realização de ações preventivas, como a vacinação de rotina.

Foram mantidos os atendimentos prioritários, seguindo orientação da SMS-RJ, de gestantes, lactentes, portadores de tuberculose e pessoas vivendo com HIV, entre outras. As urgências continuaram sendo avaliadas e atendidas. A vacinação de rotina se manteve ativa, sendo adaptado o local de realização das campanhas, como a da gripe, executada inicialmente na sala de grupos e depois transferida para o espaço da biblioteca da Ensp, que se encontrava desativada e foi adaptada para esse fim.

Para melhorar a comunicação das eSF com os usuários, em maio cada equipe recebeu um telefone celular para enviar e receber mensagens dos usuários de suas respectivas áreas via WhatsApp. Com esse novo canal de atendimento visava-se a garantir o acesso e a continuidade do cuidado a usuários com demandas de saúde diversas, principalmente portadores de condições crônicas, cujo atendimento presencial na unidade foi inicialmente muito restrito devido aos riscos de infecção. Apesar de não ser uma ferramenta de uso universal, especialmente em uma comunidade com baixo índice de desenvolvimento humano (IDH), foi uma alternativa de acesso importante naquele momento.

Outros exemplos de adequação ao contexto da pandemia foram os atendimentos remotos realizados por uma nutricionista, pela educadora física e pela Equipe de Saúde Mental, que permitiram o seguimento de usuários já em acompanhamento, bem como um primeiro atendimento de casos encaminhados pelas equipes. 


\section{SAÚDE DOS TRABALHADORES DA SAÚDE}

Já no mês de março muitos profissionais foram afastados do trabalho presencial por serem considerados, de acordo com critérios oficiais, do grupo de risco para Covid- 19. Entre esses estavam agentes comunitários de saúde, técnicos de enfermagem, enfermeiros, profissionais do Núcleo Ampliado de Saúde da Família (Nasf), da gestão e equipe multiprofissional do CSEGSF, além de trabalhadores terceirizados.

Graças ao apoio da Ensp e da Presidência da Fiocruz, em maio de 2020 foi possível a contratação de médicos, enfermeiros e técnicos de enfermagem para atuar com os profissionais das duas clínicas no atendimento dos casos suspeitos de Covid-19. Esses contratos permitiram a retomada dos atendimentos aos portadores de condições crônicas de forma mais intensiva a partir de junho, quando esses pacientes voltaram a procurar a unidade em maior número, com demandas que não puderam ser atendidas nos meses anteriores. A maior parte desses contratos, contudo, finalizou em novembro de 2020 , recriando as dificuldades para o acolhimento de toda essa demanda assistencial.

Assim como a redução do contingente de pessoas em trabalho presencial, os afastamentos temporários para isolamento ou quarentena, devido a sintomas da Covid- 19 ou ao contato com o vírus, foram também um fator de estresse para os trabalhadores, que sofreram com a sobrecarga e a necessidade de constantes reorganizações das escalas de trabalho.

Nesse contexto, gostaríamos de destacar algumas importantes iniciativas de cuidado com os trabalhadores. Desde o início da pandemia, em março, a carga de trabalho exaustiva, associada aos temores decorrentes do surgimento de uma nova doença, motivou um grupo multidisciplinar de profissionais composto por psicólogos, educadores físicos, residentes médicos e multiprofissionais a reformular e ampliar o trabalho do grupo Cuidando de Quem Cuida, com o objetivo de proporcionar momentos de descontração e ajudar a lidar com o estresse do trabalho. Esse grupo já atuava antes da pandemia com atividades lúdicas e de relaxamento para os agentes comunitários de saúde. A partir de sua reformulação, foi elaborada uma grade de atividades oferecidas para todos os profissionais, em diferentes turnos, conduzidas por pessoas do grupo e com a participação voluntária dos trabalhadores disponíveis, incluindo meditação, alongamento, massagem orientada, automassagem e danças diversas.

Além dessas atividades, foram conduzidas por um psicólogo do CSEGSF, de forma regular, às quintas-feiras à tarde, rodas de meditação, reflexão, dinâmicas de grupo e música, que contaram com a participação simultânea de um número maior de trabalha- 
dores e permitiram importantes trocas entre eles. Foram também ofertadas pelo grupo de Práticas Integrativas e Complementares em Saúde (Pics) da Ensp terapia com florais de Bach e sessões remotas de Reiki, individuais e coletivas.

\section{ENSINO}

Para atender aos alunos que estão sob responsabilidade do CSEGSF, ou em campo de estágio nas duas unidades de APS, algumas adequações foram necessárias.

O Programa de Residência Médica em Medicina de Família e Comunidade do CSEGSF se readequou ao contexto da pandemia com revisão dos estágios, atualizados frequentemente, e adaptação dos canais teóricos pelas plataformas Zoom e Google Meet. Os residentes participaram de lives da comunidade e da renovação do Cuidando de Quem Cuida, entraram na composição da ERR e participaram da organização e utilização dos celulares das equipes no atendimento remoto.

As residências multiprofissionais em Saúde da Família da Ensp e a de Enfermagem em Saúde Coletiva da Universidade Federal Fluminense permaneceram atuando nas equipes e auxiliando nas demandas relacionadas à Covid-19, como por exemplo o telemonitoramento e a organização da porta de entrada.

Quanto aos alunos de graduação das duas clínicas, houve a manutenção do internato e estágio dos acadêmicos de medicina bolsistas do município, por via remota em parceria com professores da Universidade Federal do Rio de Janeiro. As atividades realizadas foram, por meio do telemonitoramento, a orientação específica sobre os cuidados domiciliares dos casos suspeitos e a busca ativa das crianças para vacinação de papilomavírus humano (HPV) e vacina meningocócica conjugada quadrivalente (ACWY).

\section{CONQUISTAS, LIMITAÇÕES E LIÇÕES APRENDIDAS}

As ações implementadas visando ao enfrentamento da pandemia nas UBS permitiram compartilhar com todos os trabalhadores os conhecimentos sobre como se proteger da infecção no local de trabalho; manter os atendimentos regulares de pré-natal e vacinação sem interrupção durante o período; aumentar os atendimentos a doenças cardiovasculares e diabetes após o pico da pandemia; mobilizar diferentes trabalhadores para compor escalas de atendimento e recepção; monitorar usuários em casa; promover a integração das equipes e ofertar aos trabalhadores espaços de reflexão e cuidado para mitigar os efeitos de todo o estresse desse período.

Ter uma Comissão de Biossegurança e Controle de Infecção, com profissionais experientes e coordenada por uma infectologista, foi vital para a preparação das unidades de 
saúde. A capacidade técnica local e o trabalho em equipe da Comissão do Cuidado permitiram desenvolver protocolos e elaborar soluções adequadas à nossa realidade antes mesmo de termos diretrizes claras emanadas das instâncias superiores.

Apesar de termos produzido muitos materiais e rotinas para organizar o nosso trabalho, a necessidade de dar conta de tarefas urgentes limitou nossa capacidade de organizar e compartilhar em tempo real as soluções que foram sendo criadas ao longo da pandemia.

A APS se mostrou um espaço muito rico para a produção e experimentação de soluções para problemas de saúde pública emergentes. Acreditamos que a participação de mais sanitaristas das áreas de epidemiologia e planejamento no acompanhamento das atividades assistenciais poderia potencializar a produção de conhecimento aplicado à prática.

Chegamos ao final de 2020 com equipes exaustas e tendo pela frente mais uma avalanche de casos de Covid- 19 que se superpõe a um conjunto de outras demandas reprimidas, algumas das quais inadiáveis, que precisavam ser manejadas em um momento em que ocorria o término do contrato de boa parte dos profissionais que atuaram na ERR nas unidades de saúde.

Percebemos a necessidade de planejar soluções a médio e longo prazos para o novo cenário epidemiológico, incluindo modificações estruturais e instalação de filtros Hepa. Muitas das adequações feitas funcionaram por um tempo, mas foram planejadas como provisórias. O calor do verão já castiga pacientes e profissionais, que trabalham cobertos por EPIs em área externa sem nenhum conforto térmico.

Ao escrever este relato nos primeiros dias do ano de 2021 , temos pela frente como desafios: manter a saúde física e mental dos trabalhadores, garantindo descanso, autocuidado e condições adequadas de trabalho; promover mudanças no espaço físico das unidades de APS para se adequarem às exigências de biossegurança; garantir condições materiais e de pessoal que permitam incorporar à rotina o atendimento aos casos suspeitos de Covid-19, o telemonitoramento e as consultas remotas, sem prejuízo das atividades habituais; e, ainda, organizar e executar no nível local a maior campanha de vacinação já realizada em nosso país. 


\section{REFERÊNCIAS}

AGÊNCIA NACIONAL DE VIGILÂNCIA SANITÁRIA (ANVISA). Nota técnica GVIMS/GGTES/Anvisa n. 4/2020 atualizada (Versão I.7). Orientações para serviços de saúde: medidas de prevenção e controle que devem ser adotadas durante a assistência aos casos suspeitos ou confirmados de infecção pelo novo coronavírus (Sars-CoV-2), 3 I mar. 2020. Disponível em: <http://portal.anvisa.gov.br>. Acesso em: 10 dez. 2020.

BRASIL, P. História natural da infecção por Sars-CoV-2 em uma população de adultos, gestantes, recémnatos, lactentes e crianças. Projeto de pesquisa. Rio de Janeiro, 2020.

CENTERS FOR DISEASE CONTROL AND PREVENTION (CDC). Criteria for return to work for healthcare personnel with Sars-CoV-2 infection: interim guidance, 2020a. <www.cdc.gov/coronavirus/20I9ncov/hcp/return-to-work.html>. Acesso em: 5 fev. 2021.

CENTERS FOR DISEASE CONTROL AND PREVENTION (CDC). Duration of isolation and precautions for adults with Covid- 19, 2020b. <www.cdc.gov/coronavirus/20 I 9-ncov/hcp/duration-isolation.html > . Acesso em: 5 fev. 2021.

DAUMAS, R. P. Inova Manguinhos - Soluções digitais. Projeto de pesquisa. Rio de Janeiro, 2020.

GREENHALGH, T; KOH, G. C. H. E CAR, J. Covid- I 9: avaliação remota em Atenção Primária à Saúde. Revista Brasileira de Medicina de Família e Comunidade, 15(42), 2020. Disponível em: <https://rbmfc. org.br/rbmfc/article/view/246 I >. Acesso em: 28 dez. 2020.

NORONHA, T. G. Estudo de validação clínica de teste sorológico para diagnóstico laboratorial da doença causada pelo vírus SARS-CoV-2 (Covid-19): testes rápidos para triagem qualitativa com detecção de anticorpos IgM e IgG para Sars-CoV2 de Bio-Manguinhos/Fiocruz. Projeto de pesquisa. Rio de Janeiro, 2020.

PAN-AMERICAN HEALTH ORGANIZATION (PAHO). Recomendaciones para la reorganización y ampliación progresiva de los servicios de salud para la respuesta a la pandemia de Covid- 19. Disponível em: <www.paho.org/en/documents/recomendaciones-para-reorganizacion-ampliacion-progresivaservicios-salud-para-respuesta >. Acesso em: 19 abr. 2020.

REIS, I. N. C. Promoção da saúde e reorientação de serviço: a experiência do Centro de Saúde Escola Germano Sinval Faria. In: ZANCAN, L.; BODSTEIN, R. \& MARCONDES, W. B. (Orgs.). Promoção da Saúde como Caminho para o Desenvolvimento Local: a experiência em Manguinhos-RJ. Rio de Janeiro: Abrasco, Fiocruz, 2002.

STRUCHINER, C. S. Estudo de coorte de Covid-19: risco de transmissão intradomiciliar, pesquisa longitudinal de soroprevalência, resposta imune e dinâmica genômica de SARS-CoV-2. Projeto de pesquisa. Rio de Janeiro, 2020

WORLD HEALTH ORGANIZATION (WHO). Operational considerations for case management of Covid- 19 in health facility and community: interim guidance. Geneva: WHO, 19 mar. 2020a. Disponível em: <https://apps.who.int/iris/handle/10665/331492>. Acesso em: 10 dez. 2020.

WORLD HEALTH ORGANIZATION (WHO). Rational use of personal protective equipment (PPE) for coronavirus disease (Covid-19): interim guidance. Geneva: WHO, 19 mar. 2020b. Disponível em: <https://apps.who.int/iris/handle/I0665/33I498>. Acesso em: 10 dez. 2020. 


\title{
Papel do SUS no Retorno às Atividades Escolares Presenciais na Pandemia de Covid-19
}

a experiência do município de Niterói, RJ

\author{
Mírian Ribeiro Conceição, Josy Maria de Pinho da Silva, \\ Ciane dos Santos Rodrigues, Camilla Maia Franco e \\ Rodrigo Alves Torres Oliveira
}

E m 3 de dezembro de 2021, o cenário da pandemia de Covid- 19 no mundo comple-

L tava pouco mais de um ano e somava, segundo o Painel Coronavírus da Organização Mundial da Saúde (OMS), 262.866.050 casos confirmados (WHO, 202 I). Muito se tem discutido sobre seus efeitos na vida das pessoas infectadas, mas também sobre seu impacto na vida cotidiana de cada indivíduo e das comunidades. As medidas de mitigação, implementadas pelos governos como principal estratégia de diminuição dos riscos de transmissão, como o isolamento interpessoal e o lockdown, não apenas regularam a circulação das pessoas, mas determinaram novos modos de fazer o cotidiano da vida.

Algumas atividades que ofereciam mais risco de transmissão da Covid- 19 exigiram maior atenção de governos, autoridades sanitárias e órgãos reguladores. Nesse quadro, o contexto escolar exigiu especial atenção aos impactos do isolamento social e à função da escola na vida das crianças e adolescentes. A equação entre a essencialidade da educação e as avaliações e classificação dos riscos da retomada das atividades presenciais no ambiente escolar determinou uma complexidade que exigiu da gestão municipal, dos profissionais das instituições de ensino público e privado e dos familiares dos alunos esforços coletivos e coordenados para a elaboração de protocolos de segurança para todos da comunidade escolar (Niterói, 2020a).

O ambiente escolar é cenário de desenvolvimento biopsicossocial, não apenas em sua função pedagógica formal, mas na garantia da saúde física e mental de crianças e adolescentes. Dessa forma, o fechamento das instituições de ensino tem impactos e efeitos indiretos na vida e saúde das crianças, tais como elencados em documento produzido pela Fundação Oswaldo Cruz (Fiocruz): repercussões no ensino, na socialização e no desenvolvimento; o estresse afetando a saúde mental, gerando aumento de sinto- 
mas de depressão e ansiedade; aumento da violência contra a criança, o adolescente e a mulher e a consequente diminuição da procura por atendimento nos serviços de proteção; diminuição das coberturas vacinais; redução da cobertura de programas de triagens universais; aumento da epidemia de sedentarismo e obesidade; aumento da fome e do risco alimentar e exagero no uso de mídias/telas, entre outros (Fiocruz, 2020). Esses efeitos, adicionados à suspensão das atividades de ensino, e seus impactos no futuro, inclusive atrasos socioeconômicos, são alguns dos elementos que impulsionam a discussão sobre a necessidade de reabertura das escolas.

A situação epidemiológica e as informações científicas sobre o grupo populacional escolar produzidas até o momento são centrais na compreensão desse quadro. Pesquisas recentes de monitoramento da pandemia pelo mundo demonstraram que há menor incidência de casos entre crianças.

Um estudo de grande escala realizado na Alemanha com 4.964 participantes entre crianças de I a 10 anos e adultos responsáveis identificou soroprevalência 3 vezes menor entre crianças e uma relação entre criança positivada e familiar negativado em testagem para Covid- 19 4,3 vezes menor do que a relação contrária, indicando maior potencial de transmissão do adulto para a criança. Entre as crianças que continuaram frequentando a escola, a positividade foi estatisticamente semelhante às demais (Tönshoff et al., 202 I).

Além desse, há estudos de campo com experiências que demonstraram a retomada das atividades escolares sem impacto no aumento de casos ou no número de infecções em crianças e adolescentes, enfatizando que em um ambiente escolar organizado para as medidas de prevenção é possível reduzir drasticamente os riscos de transmissão, e que a transmissão no domicílio é mais comum entre os escolares (Lee E Raszka, 2020; Posfay-Barbe et al., 2020).

Desse modo, diferentes países centrais e também periféricos têm construído e adequado protocolos de segurança e de vigilância municipal que garantam o retorno seguro às aulas, levando em consideração as informações científicas atualizadas, orientações quanto a precauções respiratórias e de contato, além das informações epidemiológicas locais.

O Fundo Internacional de Emergência das Nações Unidas para a Infância (Unicef) disponibilizou, a partir de fevereiro de 2020, mapa mundial de monitoramento da situação escolar (Figura I). 
Figura I - Mapa mundial da situação escolar dos países - fev. 2020 a abr. 202 I

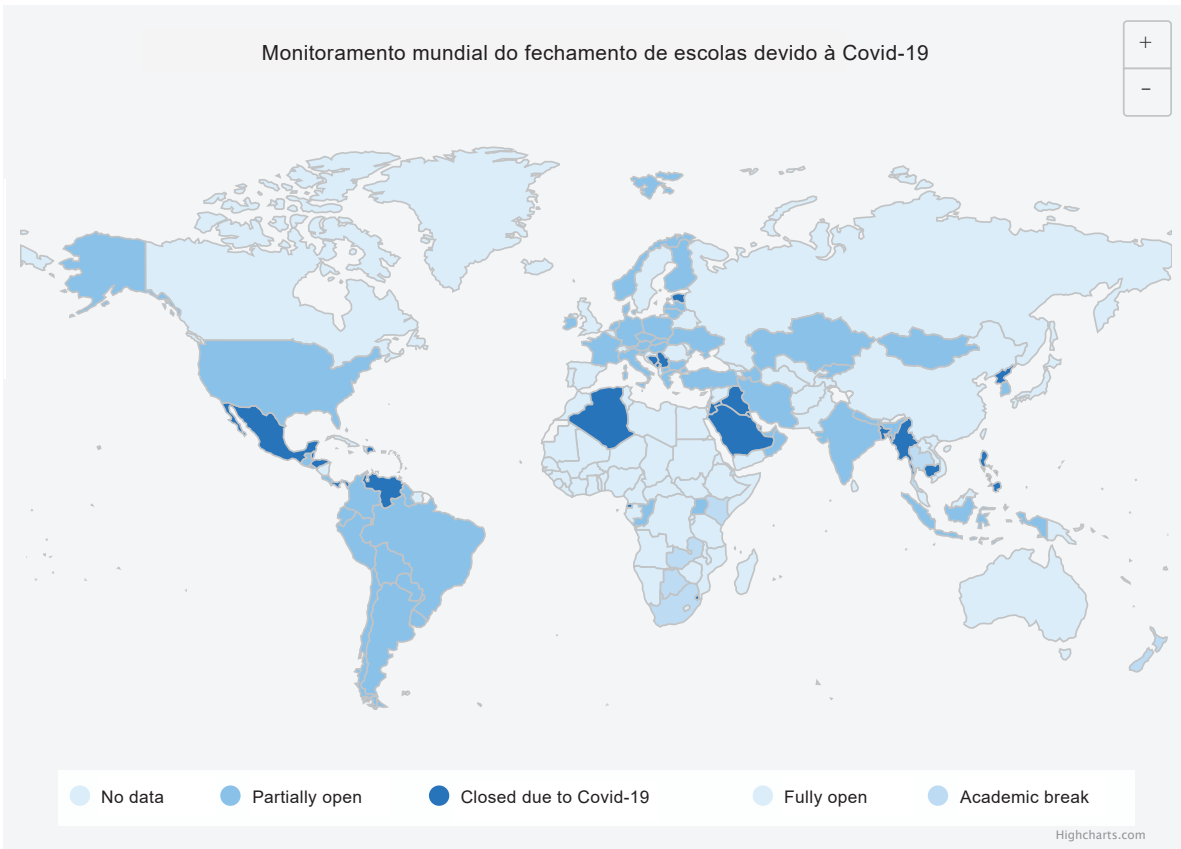

$30 / 04 / 2021$

$2 \mathrm{G}$

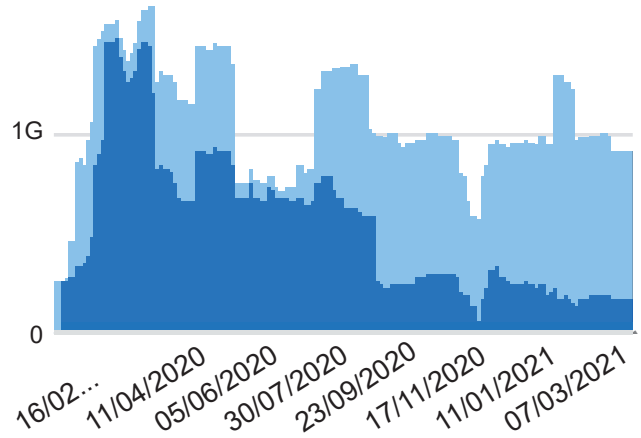

Fonte: <https://pt.unesco.org/covid I 9/educationresponse>. Acesso em: abr. 2021. 
De maneira geral, os países têm optado pela modalidade presencial e on-line, ficando a critério do/da aluno/a-família definir o método. Nos protocolos de segurança têm sido considerados aspectos infraestruturais, a organização dos horários de intervalo entre as salas de aula com atividades presenciais em um mesmo turno, o número de alunos/as por turma e fluxos para notificação de casos suspeitos.

Somadas às possibilidades de criar um ambiente seguro quanto aos riscos de transmissão da Covid- 19, outro fator importante na defesa do retorno das aulas, tidas como essenciais ao desenvolvimento de crianças e adolescentes, é o cenário epidemiológico da doença na faixa etária escolar.

No Brasil, o Boletim Epidemiológico 52, do Ministério da Saúde, informa que até $1^{\circ}$ de março de 202 I tivemos 200.2 12 casos de síndrome respiratória aguda grave (Srag). Desse total, os casos classificados por Covid-19 foram I14.817. A análise da distribuição desses casos por faixa etária permitiu identificar que o percentual de crianças e adolescentes que tiveram Srag foi de 7,3\% (14.709) e que o percentual desta faixa etária entre os casos de Srag classificados por Covid- 19 foi de 1,8\%. Estratificando as faixas etárias de crianças e adolescentes que tiveram Srag causados por Covid- 19, foi possível observar que 30\% desses casos foram em menores de I ano, 28,7\% na faixa entre I e 5 anos e 41,3\% entre 6 e 19 anos (Brasil, 2021).

\section{A REABERTURA DAS ESCOLAS: IMPLICAÇÃO E COMPARTILHAMENTO ENTRE SAÚDE E EDUCAÇÃO NO MUNICÍPIO}

Niterói, localizada na Região Metropolitana II do Estado do Rio, tem 515.317 habitantes (IBGE, 2020). No enfrentamento da pandemia, o município teve importante atuação com a antecipação das tomadas de decisão de modo a evitar mortes e garantir os cuidados em saúde, com a ampliação do número de leitos, aquisição de equipamentos, distribuição de kits de higiene e máscaras e testagem massiva da população. Além das ações diretamente ligadas à a assistência em saúde, Niterói investiu em medidas de mitigação, como por exemplo garantia de renda básica e apoio aos comerciantes para a manutenção dos postos de trabalho.

O município foi uma das primeiras cidades a realizar o fechamento das escolas, em 16 de março de 2020 e, em especial, a distribuição de cestas básica para mitigar os efeitos de tal fechamento e garantir a segurança alimentar e minimizar alguns dos seus impactos sobre o desenvolvimento das crianças e adolescentes, sobretudo para a população mais vulnerável. Em estimativa de 2020, Niterói teria 105.930 crianças adolescentes de 0 a 19 anos, dos quais 80.585 em idade escolar. O sistema escolar do 
município conta com instituições privadas, municipais, estaduais e federais. Contudo, as articulações de apoio a essa experiência foram realizadas apenas nas parcerias com instituições privadas e municipais, que somaram, respectivamente, cerca de 289 e 1 I 4 unidades escolares.

Após a primeira onda da Covid-19, o controle dos casos, a testagem massiva, o controle maior das transmissões no município e a elaboração de um sistema de monitoramento consolidou a implantação do Plano de Transição Gradual para o Novo Normal (Niterói, 2020a). Na reafirmação do setor da educação como pauta fundamental na retomada das atividades presenciais após período de lockdown, a Secretaria Municipal de Saúde e a Secretaria Municipal de Educação iniciaram processo de trabalho intenso e minucioso para a construção de diretrizes em biossegurança aplicáveis a diferentes contextos e para a consolidação de um sistema de vigilância específico para o monitoramento da transmissão da Covid- 19 no ambiente escolar. Como resultado, duas publicações com as diretrizes e orientações a toda a comunidade escolar, pública e privada, foram ponto de partida para a organização das instituições para a retomada das atividades (Niterói, 2020b, 2020c).

A elaboração das Diretrizes para a Construção dos Planos Locais de Retorno às Atividades Presenciais da Educação Municipal de Niterói foi esforço conjunto entre Secretaria Municipal de Educação, Ciência e Tecnologia, Fundação Municipal de Educação (FME) e Fundação Municipal de Saúde (FMS). O processo teve início em junho de 2020, quando Saúde e Educação se reuniram em intenso processo de revisão da literatura científica, análise e debate sobre as adaptações do ambiente e das atividades escolares presenciais, e estabelecimento de fluxos de testagem e monitoramento para a comunidade escolar. Como produto desse planejamento foram elaborados os dois manuais de orientação para as escolas públicas e privadas já mencionados (Niterói, 2020a, 2020c).

A multiplicidade dos cenários, os fluxos e contatos entre crianças e adolescentes, professores e funcionários apresentam desafios quanto ao risco de transmissão da Covid-19, exigindo, portanto, estratégia metodológica específica para o ambiente que crie capacidade de abranger as diferentes atividades realizadas, não apenas a sala de aula. Desse modo, a construção de protocolos de biossegurança se baseou na interseção entre fluxos, itinerários e nos microcenários que compõem o ambiente escolar - o preparo e a oferta da merenda, a secretaria, a chegada e saída, a hora do intervalo e o pátio da escola, a sala de aula, as atividades pedagógicas, entre outros (Niterói, 2020a).

Desagregar os diferentes ambientes que compõem as instituições de ensino era importante para definir orientações que pudessem abarcar a singularidade de cada ativida- 
de e com isso permitir maior segurança. O processo de discussões sobre tais orientações, portanto, teve como propulsores não apenas o conteúdo pedagógico formal a ser transmitido nas atividades presenciais, mas principalmente a possibilidade de retomada das relações sociais de modo protegido, controlado e propício à qualificação da interação interpessoal, por meio do fortalecimento dos vínculos professor-aluno e aluno-aluno, com o principal objetivo de promover o bem-estar físico e psíquico das crianças e adolescentes do município de Niterói (Niterói, 2020a, 2020c).

Além disso, a singularidade do contexto e a diversidade de ambiente e do público exigiam também análise específica das condições epidemiológicas do setor e mecanismos e estratégias que pudessem nortear decisões rápidas e assertivas para evitar contaminações e surtos locais.

Então, o Sistema Único de Saúde (SUS), cumprindo seu papel e responsabilidade de orientar medidas sanitárias e coordenar as ações de vigilância e saúde do município, tendo modelo universal, ou seja, de acesso a todos, assumiu a coordenação dos esforços adicionais de enfrentamento da Covid-19, para garantir a segurança de toda a comunidade escolar do município, fosse da rede pública ou privada. Desse modo, o trabalho coletivo e compartilhado de revisão, construção de estratégias e análise do contexto local das unidades escolares deu origem aos dois documentos já mencionados, que permitem orientar escolas privadas e públicas municipais sobre suas atividades durante a pandemia. O primeiro, Diretrizes para a Construção dos Planos Locais de Retorno às Atividades Presenciais da Educação Municipal de Niterói: cuidar de si, do outro e do ambiente em tempos de Covid-19, foi produzido para orientar as medidas de proteção e diminuição dos riscos de contaminação pela Covid-19, mediante a garantia de cenários seguros para a comunidade escolar (Niterói, 2020a).

Para a implementação dos protocolos no ambiente escolar, além desse documento de referência para escolas públicas e privadas do município, contou-se também com percurso formativo com discussão sobre a implementação das medidas de prevenção, com realização de debates on-line com as instituições privadas e com a visita da Vigilância Sanitária no diálogo sobre adequações necessárias dos protocolos propostos.

No segundo documento, "Diretrizes para sistema de vigilância escolar: monitoramento do retorno às atividades da educação de Niterói”, confere-se ao SUS maior protagonismo na responsabilidade e nas vigilâncias em saúde. Criou-se, então, sistema intersetorial de vigilância escolar, com o objetivo de antever cenários para o planejamento de ações e de respostas rápidas a fim de evitar o aumento dos casos, considerando as especificidades do contexto escolar da infância e adolescência. O Sistema de Monitoramento e Vigilância Epidemiológica Escolar estabelece fluxo específico para testagem e detecção de casos e 
monitoramento, a partir de cenários adscritos e de parcerias territoriais entre serviços de saúde e escolas, com indicadores de monitoramento para o ambiente escolar postos em diálogo com os indicadores gerais do município (Niterói, 2020c).

A observação de contextos específicos e a avaliação dos riscos justificaram o instrumento adicional de monitoramento da Covid- 9 no ambiente escolar para garantir análise singular e celeridade no encadeamento de ações, possibilitando responder prontamente às necessidades do percurso de reabertura em um cenário delicado e sensível ao desenvolvimento de crianças e adolescentes. Além disso, o acompanhamento dos profissionais do setor educacional, dos alunos e familiares garante orientações mais singulares, permitindo balizar as avaliações periódicas de segurança sanitária de todos para a tomada de decisões necessárias ao desenvolvimento das atividades presenciais.

A criação de um fluxo em rede implementado para as escolas privadas e públicas municipais amplia parcerias e ações compartilhadas já desenvolvidas pelos sistemas públicos de educação e saúde. A iniciativa serve de inspiração para a construção de novas políticas que reafirmam os princípios do SUS: universalidade, equidade e integralidade.

\section{VIGILÂNCIA SANITÁRIA E EPIDEMIOLÓGICA NO AMBIENTE ESCOLAR}

Campo de destaque entre as ações do SUS, as vigilâncias em saúde são responsáveis por ações de vigilância, prevenção e controle de doenças transmissíveis, pela vigilância de fatores de risco para o desenvolvimento de doenças crônicas não transmissíveis, para a saúde ambiental e do trabalhador e também pela análise da situação de saúde da população brasileira (Fiocruz, 202I).

Em seu objetivo principal de propiciar orientação técnica, a Vigilância Epidemiológica (VE) tem a responsabilidade de decidir sobre a execução das ações sanitárias. Seu escopo está no âmbito da prevenção, detecção e controle das doenças ou agravos nas esferas individual e coletiva (Brasil, 1990). No cenário de enfrentamento da pandemia de Covid-19, a VE exerce papel fundamental no monitoramento e controle da transmissão do Sars-CoV-2. As parcerias relatadas neste capítulo estão relacionadas a esse escopo.

Para efetivação de um sistema de vigilância específico para as unidades, foram criados instrumentos simples que pudessem orientar fluxos: fluxograma de orientação; ficha de referência e contrarreferência de Covid- 19 para orientação da conduta escolar; formulário de notificação dos casos. Concomitantemente, procedeu-se ao referenciamento das policlínicas com as unidades escolares do território como ponto de apoio para orientações e ordenamento dos fluxos, em interface direta com os setores de vigilância do município. 
Entre os referidos instrumentos de vigilância da Covid- I 9 nas escolas, a Secretaria Municipal de Saúde de Niterói disponibilizou um fluxograma para orientar os estabelecimentos escolares (Figura 2).

Figura 2 - Fluxograma para os estudantes suspeitos de Covid- 19

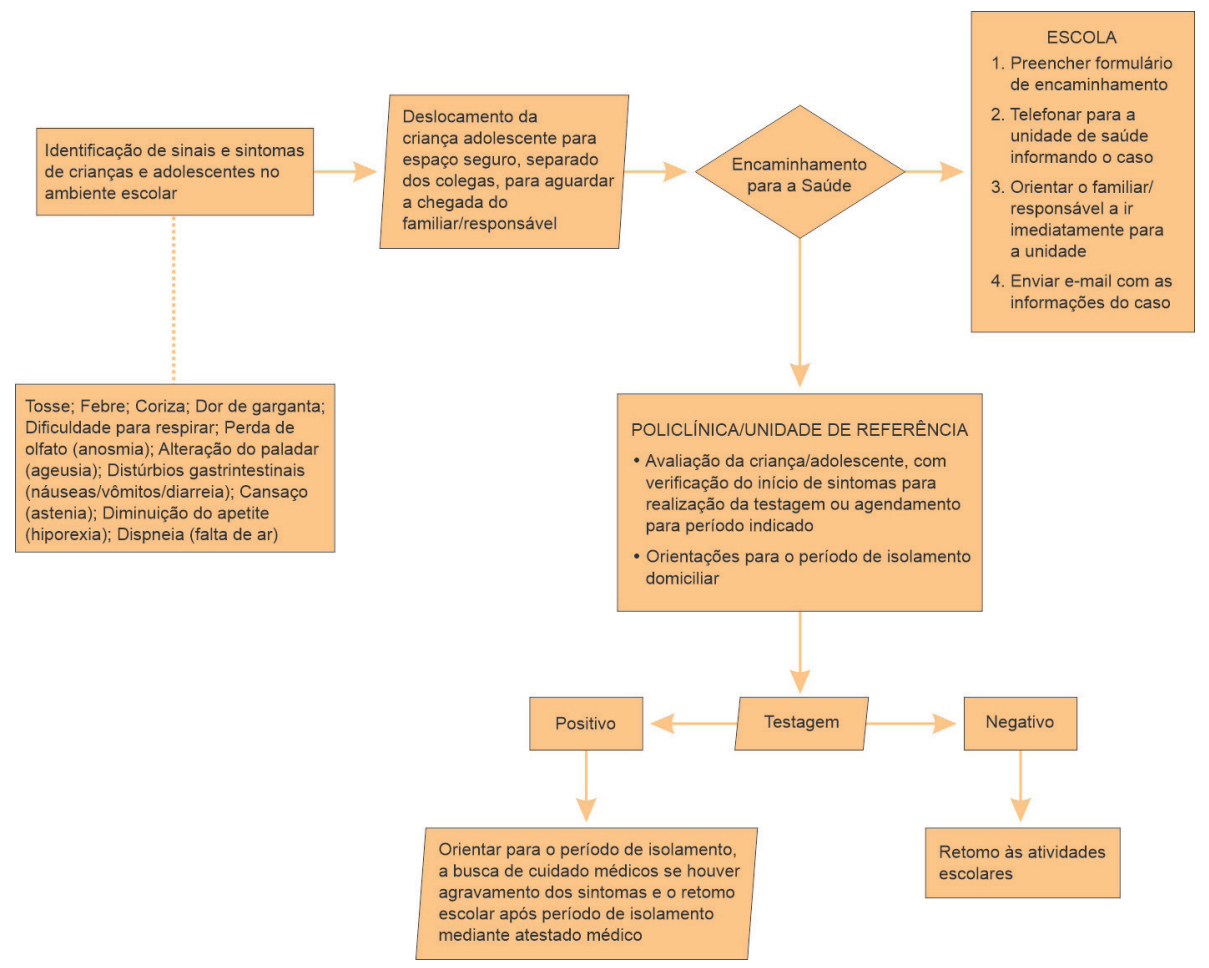

Fonte: Niterói, 2020c.

Por fim, acompanhando a estratégia proposta no Plano de Transição Gradual para o Novo Normal, uma estratégia similar de indicadores de monitoramento foi definida para as vigilâncias escolares para facilitar a comunicação com a população. Então, a composição dos indicadores de monitoramento municipal da Covid- 19 do plano para o novo normal e dos indicadores específicos de acompanhamento dos profissionais do setor educacional e alunos estabelece referência que baliza as avaliações periódicas de segurança sanitária de todos para a tomada de decisões necessárias ao desenvolvimento das aulas presenciais. Com a finalidade de monitorar de forma mais segura os efeitos da retomada dessas atividades, são monitorados continuamente os casos de alunos e trabalhadores da educação. 
Quadro I - Critérios para tomada de decisão sobre os estabelecimentos escolares

\begin{tabular}{|c|c|c|c|}
\hline Situação* & Intervenção & Decisão a tomar & Observação \\
\hline $\begin{array}{l}\text { I - Um caso suspeito } \\
\text { em sala de aula }\end{array}$ & $\begin{array}{l}\text { Afastamento } \\
\text { imediato do caso e } \\
\text { encaminhamento para } \\
\text { testagem - Resposta } \\
\text { em até } 48 \text { horas }\end{array}$ & $\begin{array}{l}\text { Mantém em } \\
\text { observação toda a } \\
\text { turma }\end{array}$ & \\
\hline $\begin{array}{l}2 \text { - Mais um caso } \\
\text { suspeito em sala de } \\
\text { aula durante período } \\
\text { de testagem ( } 48 \mathrm{~h} \text { ) do } \\
\text { primeiro suspeito }\end{array}$ & $\begin{array}{l}\text { Segundo caso } \\
\text { também é } \\
\text { encaminhado para a } \\
\text { testagem }\end{array}$ & $\begin{array}{l}\text { Toda a turma } \\
\text { permanece em } \\
\text { quarentena de } 14 \text { dias }\end{array}$ & $\begin{array}{l}\text { Havendo qualquer } \\
\text { outro caso com } \\
\text { sintoma, realiza-se } \\
\text { a testagem a contar } \\
\text { da data do início } \\
\text { de sintoma e este } \\
\text { permanecerá em } \\
\text { afastamento }\end{array}$ \\
\hline $\begin{array}{l}3 \text { - Duas turmas de } \\
\text { um mesmo turno } \\
\text { com afastamentos } \\
\text { como indicado na } \\
\text { situação } 2\end{array}$ & $\begin{array}{l}\text { Testagem dos casos } \\
\text { sintomáticos e } \\
\text { contatantes }\end{array}$ & $\begin{array}{l}\text { Todo o turno } \\
\text { permanece em } \\
\text { afastamento de } 14 \\
\text { dias }\end{array}$ & $\begin{array}{l}\text { Todos os alunos } \\
\text { em afastamento } \\
\text { permanecem em } \\
\text { observação de } \\
\text { sintomas, e na } \\
\text { presença de sintoma } \\
\text { serão testados }\end{array}$ \\
\hline $\begin{array}{l}4 \text { - Duas turmas } \\
\text { com afastamento na } \\
\text { escola que já tiver um } \\
\text { turno suspenso }\end{array}$ & $\begin{array}{l}\text { Testagem dos casos } \\
\text { sintomáticos e } \\
\text { contatantes }\end{array}$ & $\begin{array}{l}\text { A escola permanece } \\
\text { sem atividades } \\
\text { presenciais por } 14 \\
\text { dias }\end{array}$ & $\begin{array}{l}\text { Todos os alunos } \\
\text { em afastamento } \\
\text { permanecem em } \\
\text { observação de } \\
\text { sintomas, e na } \\
\text { presença de sintoma } \\
\text { serão testados }\end{array}$ \\
\hline
\end{tabular}

Fonte: elaboração própria.

*A avaliação da situação, produção de orientação e tomada de decisão é feita por profissionais da saúde e das vigilâncias para a instituição de ensino com base nos fluxos anteriormente apresentados.

\section{ALGUNS RESULTADOS}

A vigilância epidemiológica no ambiente escolar identificou que, até o dia 17 de setembro de 2021, o percentual de casos positivos para Covid-19, entre os casos notificados de trabalhadores da educação e alunos, foi de $29,6 \%$.

Neste ano de 2021, a proporção dos casos confirmados de Covid-1 9 entre crianças e adolescentes corresponde a 8,6\%, como se pode observar no Gráfico 1. 69,8\% dos casos ocorreram entre pessoas de 20 a 59 anos, faixa etária seguida das faixas de 60 anos ou mais $(21,6 \%)$. 
Gráfico I - Distribuição dos casos confirmados de Covid- 19 por faixa etária - Niterói, jan. a nov. 2021

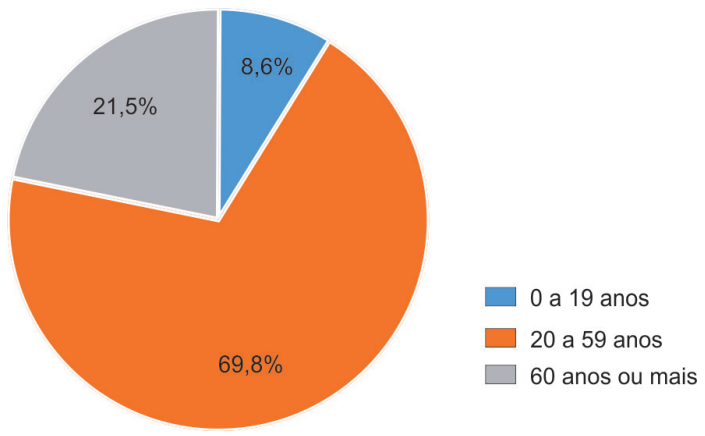

Fonte: e-SUS Notifica, Sivep Gripe, atualizado em 03 nov. 2021.

A análise dos casos de Srag no município de Niterói, também em 2021 , revela menor risco entre pessoas abaixo de 20 anos. Do total de 7.205 casos de Srag notificados de residentes de Niterói, apenas $9,4 \%$ dos casos têm idade inferior a 20 anos; 52,8\% são idosos e 37,8\% são pessoas entre 20 e 59 anos de idade. A Covid- 19 foi responsável por $44,8 \%$ dos casos de Srag, totalizando 3.229 casos de todas as faixas etárias. Dos casos de Srag por Covid-19, é possível observar menor ocorrência também nas faixas etárias menores, como na Tabela I. Destaca-se que a faixa etária de crianças e adolescentes (0 a 19 anos) representa apenas 2,1\% dos casos de Srag por Covid- 19.

Tabela I - Distribuição de casos de Srag por faixa etária de residentes - Niterói, 2021

\begin{tabular}{l|r|r|r|r}
\hline \multirow{2}{*}{ Faixa etária } & \multicolumn{1}{|c|}{ Srag por Covid-19 } & \multicolumn{2}{c}{ Srag total } \\
\cline { 2 - 5 } & $\mathrm{N}$ & $\%$ & $\mathrm{~N}$ & $\%$ \\
\hline Neonatal precoce (0 a 6 dias) & 3 & 0,1 & 13 & 0,2 \\
\hline Neonatal tardio (7 a 27 dias) & 3 & 0,1 & 5 & 0,1 \\
\hline Pós-neonatal (28 dias a II meses) & 15 & 0,5 & 220 & 3,1 \\
\hline I a 4 anos & 16 & 0,5 & 263 & 3,7 \\
\hline 5 a 9 anos & 7 & 0,2 & 88 & 1,2 \\
\hline I0 a I9 anos & 25 & 0,8 & 91 & 1,3 \\
\hline 20 a 29 anos & 84 & 2,6 & 252 & 3,5 \\
\hline 30 a 39 anos & 253 & 7,8 & 506 & 7,0 \\
\hline 40 a 49 anos & 369 & 11,4 & 775 & 10,8
\end{tabular}


Tabela I - Distribuição de casos de SRAG por faixa etária de residentes - Niterói, 202 I (continuação)

\begin{tabular}{l|r|r|r|r}
\hline \multirow{2}{*}{ Faixa etária } & \multicolumn{1}{|c|}{ Srag por Covid-19 } & \multicolumn{2}{c}{ Srag total } \\
\cline { 2 - 5 } & $\mathrm{N}$ & $\%$ & $\mathrm{~N}$ & $\%$ \\
\hline 50 a 59 anos & 580 & 18,0 & 1.188 & 16,5 \\
\hline 60 a 69 anos & 689 & 21,3 & 1.391 & 19,3 \\
\hline 70 a 79 anos & 641 & 19,9 & 1.242 & 17,2 \\
\hline 80 a 89 anos & 398 & 12,3 & 865 & 12,0 \\
\hline 90 anos e mais & 146 & 4,5 & 306 & 4,2 \\
\hline Total & 3.229 & 100 & 7.205 & 100,0 \\
\hline
\end{tabular}

Fontes: Notificações: Sistema de Informação de Vigilância Epidemiológica da Gripe (Sivep Gripe). Secretaria Estadual de Saúde, Subsecretaria de Vigilância em Saúde. Notificações de 2013 a 2021 atualizadas até 02/I2/202I, sujeitas a alterações.

Quanto à mortalidade, no ano de 2020 ocorreram 3 óbitos de crianças e adolescentes residentes de Niterói: I óbito de $<$ I ano, I óbito na faixa de I a 4 anos e I óbito na faixa de 15 a 19 anos. Quanto aos idosos, 84,3\% dos óbitos foram de pessoas com 60 anos ou mais. No ano de 202I, ocorreu I óbito de criança < I ano e I óbito de criança entre 10 e 14 anos, o equivalente a $0,16 \%$ dos óbitos ocorridos. A maior proporção de óbitos ocorreu na faixa etária dos idosos, como se pode observar no Gráfico 2. 
Gráfico 2 - Distribuição dos óbitos por Covid-19 de residentes segundo faixa etária Niterói, 2021

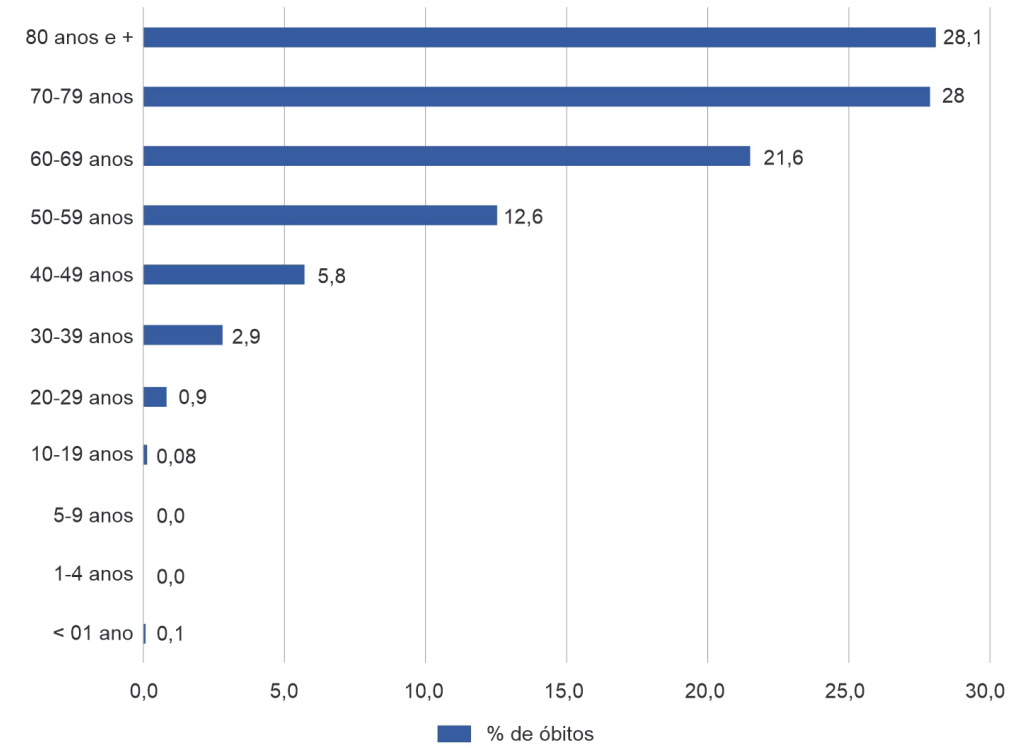

Fonte: Sistema de Informações sobre Mortalidade (SIM), atualizado em 3 nov. 202I.

Com base nas informações apresentadas, consideramos que o município de Niterói tem realizado o monitoramento efetivo das escolas, por meio de um protocolo seguro que garante rápida identificação de surto e oportuna atuação.

As atividades escolares são prioritárias por sua importância no ensino, mas também porque a escola é um espaço de proteção e acolhimento. O município tem realidades sociais díspares, em um cenário em que a comunidade escolar, seu corpo docente e orientadores pedagógicos são, entre outros, suporte fundamental no cotidiano de crianças e adolescentes que vivenciam diferentes vulnerabilidades sociais.

\section{CONCLUSÃO}

O Brasil, na comiseração de mais de 600 mil óbitos por Covid-19, vive, há quase dois anos de pandemia, um cenário de luta em defesa da vida. Assistiu às inúmeras e diversificadas atuações do SUS para a proteção de milhares de brasileiros, reconhecendo a importância e expertise de seus 32 anos de atuação sobre as bases de sua diretriz de descentralização. Diretriz que, até mesmo em razão da fragilidade da ordenação federal, demonstrou potencial e capilarização suficientes para se reinventar e reproduzir. 
A pandemia levou a um cenário de escassez, disputas éticas e políticas de amplitude global, adversidades e asperezas na corrida contra o tempo de quem estava a favor da vida. Nela, o SUS demonstrou todo o seu potencial nos diferentes níveis e campos de sua atenção.

O reconhecimento do papel da escola como fundamental para o desenvolvimento biopsicossocial da criança e do adolescente impõe o debate sobre as atividades escolares para além de processos de aprendizados pedagógicos formais. O apoio e dedicação do SUS de Niterói, fundamentado no entendimento do impacto cotidiano escolar na vida das crianças, acentua a relevância nas medidas de mitigação implementadas: 1) controle e obrigatoriedade da apresentação da carteira de vacinação no ato da matrícula escolar; 2) orientação sobre os protocolos de biossegurança para reduzir os riscos de transmissão da doença; 3) notificação em 24 horas, pela escola, dos casos suspeitos em um sistema paralelo ao do Ministério da Saúde; 4) indicadores específicos para acompanhamento da evolução do número de casos na comunidade escolar; 5) orientações às instituições públicas e privadas, aprofundando a universalização de sua atuação.

As estratégias lançadas em campo para a retomada das atividades presenciais no município de Niterói evidenciam a importância de um sistema único de saúde. O esforço de um sistema de vigilância em ambiente escolar é medida ulterior para garantir agilidade do cuidado e segurança a toda a comunidade escolar, além de reafirmar o SUS como modelo de defesa da vida e fundamental à democratização da saúde.

\section{REFERÊNCIAS}

BRASIL. Lei n. 8.080, de 19 set. 1990. Dispõe sobre as condições para a promoção, proteção e recuperação da saúde, a organização e o funcionamento dos serviços correspondentes e dá outras providências. Diário Oficial da União, Brasília, 1990. Disponível em: <www.planalto.gov.br/ccivil_03/ leis/L8080.htm>. Acesso em: maio 2021 .

BRASIL. Ministério da Saúde. Secretaria de Vigilância em Saúde. Boletim Epidemiológico n. 52, 2021. Disponível em: <www.gov.br/saude/pt-br/media/pdf/202l/marco/05/boletim_epidemiologico_ covid_52_final2.pdf>. Acesso em: mar. 2021.

FUNDAÇÃO OSWALDO CRUZ (FIOCRUZ). Contribuições para o retorno das atividades escolares presenciais no contexto da pandemia Covid-19. Rio de Janeiro: Fiocruz, 2020. Disponível em: $<$ https://portal.fiocruz.br/sites/portal.fiocruz.br/files/documentos/contribuicoes_para_o_retorno_ escolar_-_08.09_4_I.pdf $>$.

FUNDAÇÃO OSWALDO CRUZ (FIOCRUZ). Vigilância em Saúde. Disponível em: < https://pensesus. fiocruz.br/vigilancia-em-saude $>$. Acesso em: abril 2021.

INSTITUTO BRASILEIRO DE GEOGRAFIA E ESTATÍSTICA (IBCE). Cidade e estados: população estimada 202 I. Disponível em: <www.ibge.gov.br/cidades-e-estados/rj/niteroi.html>. Acesso em: abril 202 I. 
LEE, B. \& RASZKA, W. V. Covid- 19 transmission and children: the child is not to blame. Pediatrics, I 46(2): 8, 2020. Disponível em: <https://pediatrics.aappublications.org/content/I 46/2/e2020004879/tabarticle-info >. Acesso em: dez. 2020.

NITERÓI. Prefeitura Municipal de Niterói. Decreto n. 13.604/2020. Institui o Plano de Transição Gradual para o Novo Normal - Distanciamento Responsável para fins de prevenção e de enfrentamento à epidemia causada pelo novo coronavírus (Covid-19) no âmbito do Município de Niterói. Rio de Janeiro: Niterói, 2020a. Disponível em: < https://leismunicipais.com.br/a/rj/n/niteroi/ decreto/2020/136I/13604/decreto-n-13604-2020-institui-o-plano-de-transicao-gradual-parao-novo-normal-distanciamento-responsavel-para-fins-de-prevencao-e-de-enfrentamento-aepidemia-causada-pelo-novo-coronavirus-covid-I 9-no-ambito-do-municipio-de-niteroi>. Acesso em: fev. 2021.

NITERÓI. Prefeitura de Niterói. Semect/FME/SMS. Diretrizes para a Construção dos Planos Locais de Retorno às Atividades Presenciais da Educação Municipal de Niterói: cuidar de si, do outro e do ambiente em tempos de Covid-19. Rio de Janeiro: Secretaria Municipal de Educação, Ciência e Tecnologia de Niterói, 2020b. Disponível em: <https://drive.google.com/file/d/I6ACvGvznJdDACYT22VyOyhNlw3UOp5G/view>. Acesso em: abr. 2021.

NITERÓI. Prefeitura de Niterói. Semect/FME/SMS. Diretrizes para sistema de vigilância escolar: monitoramento do retorno às atividades da educação de Niterói. Rio de Janeiro: Secretaria Municipal de Educação, Ciência e Tecnologia de Niterói, 2020c. Disponível em: <www.saude. niteroi.rj.gov.br/extras/DIRETRIZES\%20Vigil\%C3\%A2ncia_Atualizado_Final202 I \%20-\%20 agosto.pdf> Acesso em: abr. 202I.

POSFAY-BARBE, K. M. et al. Covid- 19 in children and the dynamics of infection in families. Pediatrics, 146(2): e2020 I576, 2020. Disponível em: < https://pediatrics.aappublications.org/content/pediatrics/ early/2020/05/22/peds.2020-1576.full.pdf>. Acesso em: jan. 2021.

TÖNSHOFF, M. D. B. et al. Prevalence of Sars-CoV-2 infection in children and their parents in Southwest Germany. Jama Pediatrics, I75(6): 586-593, 202I. Disponível em: < https://jamanetwork.com/journals/ jamapediatrics/fullarticle/2775656>. Acesso em: abr. 202I.

WORLD HEALTH ORGANIZATION (WHO). Coronavirus (Covid- 19) Dashboard. Disponível em: < https:// covid I 9.who.int>. Acesso em: abr. 2021. 


\section{Integrando Vigilância e Atenção em Saúde Durante a Pandemia de Covid-19}

a experiência do Conexão Saúde na favela da Maré

Luna Escorel Arouca e Fernando A. Bozza

O

Projeto Conexão Saúde: de olho na Covid reúne seis organizações - Fundação Oswaldo Cruz (Fiocruz), Saúde, Alegria e Sustentabilidade Brasil (SAS Brasil), Redes da Maré, Dados do Bem, Conselho Comunitário de Manguinhos e União Rio para oferecer à população de dois territórios de favelas cariocas, Maré e Manguinhos, serviços de saúde com o objetivo de reduzir o impacto da pandemia de Covid- 19. Aqui focalizamos a Maré, porque o maior tempo de execução do projeto neste território gerou maior volume de dados e experiências a serem analisadas e compartilhadas. No projeto propõe-se um novo modelo de vigilância em saúde para o período da pandemia, que traz inovações ao incorporar tecnologias móveis que ampliam o acesso à saúde, gerando o desenvolvimento de respostas rápidas e eficazes às demandas das populações dos territórios.

Para responder à questão central aqui apresentada, "Como uma experiência desenvolvida, ao longo da pandemia, em uma favela, pode trazer aprendizados para o sistema de saúde e servir de referência para outras organizações?”, estruturamos o texto em três partes. Na primeira, contextualizamos a Maré e os principais problemas enfrentados por sua população durante o período da pandemia. Na segunda, apresentamos o modelo e os conceitos que são a base do projeto. E na terceira trazemos os dados produzidos em seu âmbito e seu impacto nos seis meses de atuação, de junho a dezembro de 2020, elencando os desafios e apontando os aprendizados e oportunidades dele decorrentes. 


\section{ELABORAÇÃO DO PROJETO}

\section{Contexto}

No início de março de 2020, o governo brasileiro anunciou a identificação dos primeiros casos do novo coronavírus (Sars-CoV-2) no país. Logo, especialistas apresentaram suas preocupações com a contenção do vírus em regiões de favelas e periferias, em razão do adensamento populacional e das estruturas precárias de moradia e saneamento básico, bem como a limitação de acesso aos serviços de saúde. À medida que protocolos de cuidado e prevenção para a Covid- 19 eram desenvolvidos, ficava evidente que essas populações teriam inúmeras dificuldades para se manter saudáveis e evitar a contaminação. Em alguns locais, o simples ato de lavar as mãos não é possível. Milhares de brasileiros não puderam se prevenir do risco de contágio porque não tinham, e ainda não têm, acesso a água e sabão. Em muitas favelas, além da falta de água, o atendimento médico é insuficiente e a crise econômica chegou junto com a crise de saúde. Os trabalhadores mais pobres, muitos deles mulheres e homens negros, são aqueles com maiores limitações para praticar o isolamento social, pois muitos são obrigados a continuar trabalhando em setores da economia que não pararam, como supermercados, farmácias, postos de gasolina e serviços de entregas em residências, entre outros. Outra parcela significativa da população perdeu parte de ou toda sua renda e teve somente o auxílio emergencial como fonte principal de sustento.

A Maré é o maior conjunto de favelas do estado do Rio de Janeiro. Nessa região habitam atualmente em torno de 140 mil pessoas, distribuídas em 16 localidades distintas, com características sociodemográficas e históricas particulares. Atualmente, sua população é majoritariamente negra e feminina. No quesito gênero, mais de $50 \%$ dos moradores são mulheres e 62, 1\%, se declararam como pretos e pardos (Redes da Maré, $2019)$. Geograficamente, a Maré está localizada entre as principais vias de acesso à cidade - avenida Brasil e Linhas Amarela e Vermelha -, pelas quais circulam diariamente mais de I milhão de cariocas, o que the confere uma visibilidade ímpar mas ao mesmo tempo é responsável pelos graves problemas de saúde relacionados à péssima qualidade do ar que se respira na região.

No que tange ao acesso à saúde, somente na década de 1970 a população da Maré passou a ter seu primeiro Centro Municipal de Saúde, o CMS Américo Veloso, estrutura claramente insuficiente para a demanda local; frequentemente, a população dependia de serviços privados presentes na comunidade ou de vagas em hospitais de diferentes regiões da cidade. Ao longo da década de 1990 foram incorporados oito novos centros municipais de Saúde (CMS). Os novos centros foram distribuídos 
geograficamente de forma a atender a população por comunidades, mas ainda assim havia frequentes reclamações dos moradores sobre a qualidade dos serviços e a oferta de atendimento. A partir de 2010 , ocorreu uma expansão da Estratégia Saúde da Família, com a reestruturação do sistema de saúde municipal, em cujo âmbito alguns dos CMS se tornaram clínicas de Saúde da Família. Atualmente a Maré possui três CMS e quatro clínicas de Saúde da Família. No campo do atendimento de urgência e emergência, desde 2007 a Maré tem uma Unidade de Pronto Atendimento (UPA) na Vila do João, o que facilitou o acesso dos moradores a este serviço.

Apesar das conquistas, a população da Maré ainda encontra restrições no acesso aos serviços de saúde. Em 2017, a cidade do Rio de Janeiro contava com mais de 62\% de cobertura de unidades básicas de saúde (UBS), mas desde então tais serviços têm sofrido sucessivos cortes orçamentários. Ao longo de 2019, as equipes da Saúde da Família sofreram com múltiplos atrasos salariais, além de demissões, faltas de insumos básicos, o que culminou no quadro atual, com o município dispondo de pouco mais de $55 \%$ de cobertura da Atenção Básica à Saúde (ABS) (Fernandes E Ortega, 2020). Dessa forma, a pandemia se desenvolveu em um cenário de precarização e desinvestimento por parte do Estado, sobretudo no que tange aos serviços de ABS. No caso da Maré, essa precariedade se soma a uma história de desigualdades e falta de investimento público em áreas de favela. Alguns exemplos recentes refletem essa precariedade, como a queda do teto de uma das UBS por falta de manutenção (Euclides, 2020b) e o funcionamento de outra com um gerador por não ter instalação da rede elétrica, o que impede, por exemplo, o funcionamento das geladeiras para conservação das vacinas (Euclides, 2020a).

A Redes de Desenvolvimento da Maré, organização da sociedade civil que atua há anos no território com ações voltadas para a garantia dos direitos dos moradores da Maré, se viu, por um lado, impossibilitada de seguir com suas atividades em razão dos riscos impostos pela pandemia. Por outro lado, precisou reformular o seu trabalho de forma a reduzir o impacto da pandemia no território. Desse esforço surgiu a campanha Maré Diz Não ao Coronavírus (Redes da Maré, 2020e), que desenvolveu uma série de ações, como entrega de cestas básicas, apoio a artistas locais, produção de informações seguras, entre outras. Entre essas iniciativas, foi criado o De Olho no Corona!, ação de monitoramento dos casos de Covid- 19 realizada por meio de uma rede de parceiros que identificava e reportava os casos. Do início da pandemia até fim de abril de 2020, o Painel Rio Covid-19, da Prefeitura do Rio, havia registrado 28 casos no conjunto de favelas da Maré, ao passo que a equipe da Redes da Maré já havia sido informada por parceiros do território sobre 89 casos suspeitos ou confirmados da doença. Essa disparidade dos dados indicava a subnotificação e o fato de que o vírus já havia se espalhado pelas diversas favelas que compõem a Maré (Redes da Maré, 2020b). 
Se existiu um denominador comum às várias ações desenvolvidas pela Redes da Maré durante a pandemia, este foi o envolvimento de moradores, parceiros e trabalhadores em uma resposta conjunta às necessidades impostas pelo momento. Foi com base nessa sinergia que a organização resolveu buscar apoio para um projeto voltado para a área da saúde. A Fiocruz, parceira histórica da organização e importante ator na construção da Atenção Primária em Saúde (APS) na Maré, reuniu um conjunto de organizações que, de forma coordenada, pudesse desenvolver ações de controle, testagem e atenção à saúde e responder às necessidades impostas pela pandemia no território. Somaram-se a esse esforço quatro organizações: Dados do Bem, SAS Brasil, União Rio e Conselho Comunitário de Manguinhos. Desse encontro surgiu o Conexão Saúde: de olho na Covid. Com o apoio do Todos pela Saúde, fundo criado pelo Itaú Unibanco e parceiros para ações de combate ao coronavírus em todo o país, o projeto recebeu financiamento inicialmente por três meses a partir de julho de 2020, mas conseguiu seguir operando até dezembro, quando recebeu novo apoio para operar durante os primeiros três meses de 2021 .

\section{O MODELO}

O trabalho do Conexão Saúde está estruturado em torno de quatro eixos principais (Figura I).

Figura I - Principais eixos de atuação do Conexão Saúde

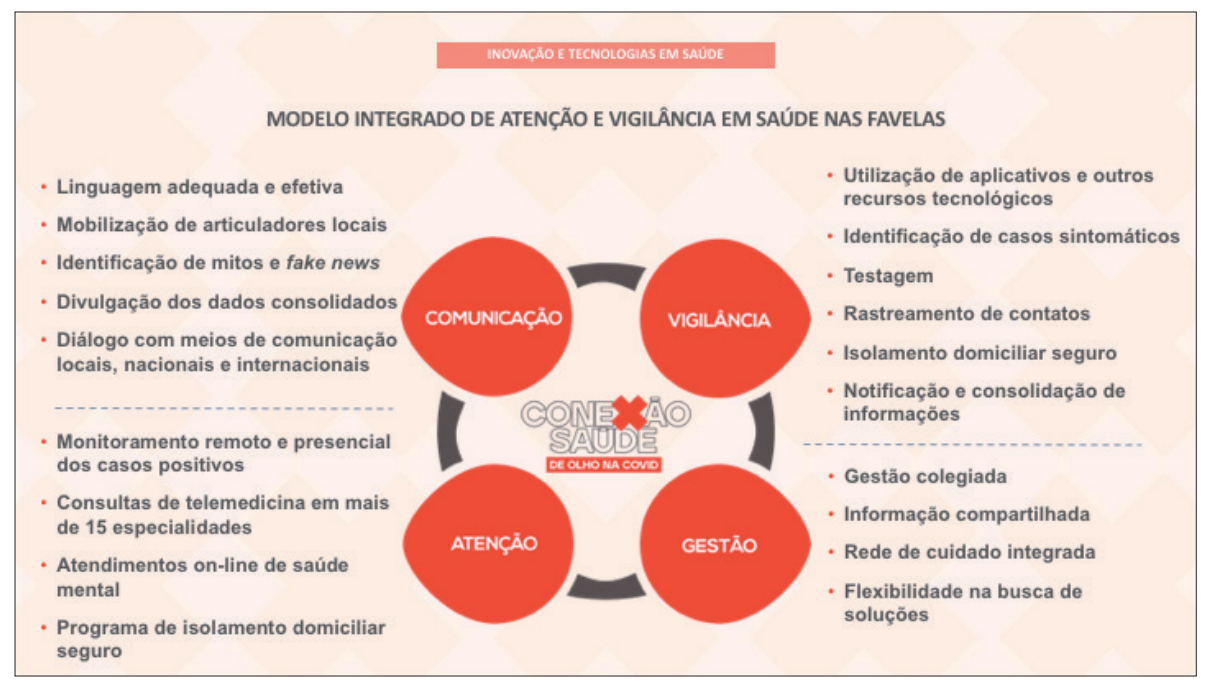

Fonte: Comitê Gestor do Conexão Saúde. 
No eixo Comunicação, o foco foi a apresentação para os moradores dos serviços do projeto, a resposta a dúvidas e a informação ao maior número de pessoas sobre a pandemia, ampliando o acesso da comunidade a informações relevantes. Para tanto foi essencial a equipe de articuladores locais, formada por moradores que todos os dias circulavam pelas favelas da Maré dialogando com a população. Para apoiar a ação dos articuladores foram produzidos diversos materiais de comunicação, como flyers, cartazes, banners (colocados nas UBS) e faixas (alocadas nas principais vias da favela). Os articuladores trabalharam com diferentes estratégias de divulgação: comunicação de porta em porta com distribuição de álcool em gel e máscaras, uso do megafone para chegar aos moradores dos andares mais altos dos prédios, visitas às UBS e às associações de moradores (Figura 2).

Figura 2 - Articuladores da Redes da Maré e SAS Brasil em ação no território
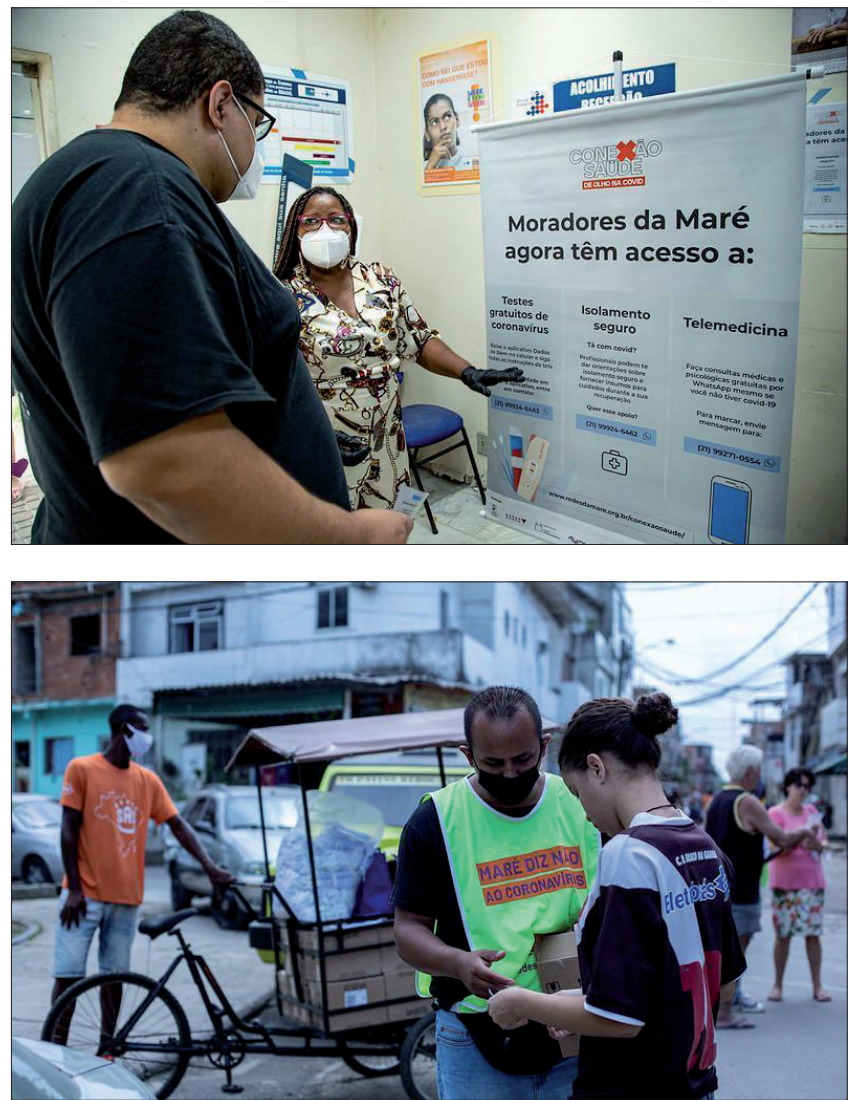

Fotos Douglas Lopes. 
Um diálogo próximo, em linguagem direta, foi essencial para as ações de comunicação. Nesse processo, os articuladores também levantavam as dúvidas e mitos que estavam circulando na favela, apoiando a equipe de comunicação na produção de peças e em novas estratégias para redes sociais e grupos de WhatsApp de moradores. As matérias e reportagens em grandes veículos de imprensa - tanto nacionais quanto internacionais - também foram uma estratégia importante, pois garantiram que a informação sobre o projeto chegasse a um maior número de moradores e aproximou pessoas e organizações interessadas em contribuir.

No eixo Vigilância, o foco do projeto foi identificar os casos sintomáticos, oferecer testagem gratuita, rastrear e testar seus contactantes, garantindo um resultado rápido e confiável, direto para o paciente. Para tanto, tem sido utilizado um aplicativo, Dados do Bem, que usa algoritmos de inteligência artificial para identificar os casos sintomáticos e fazer a gestão da testagem e entrega dos resultados. A Dados do Bem - iniciativa sem fins lucrativos, fruto da parceria do Instituto D'Or de Pesquisa e Ensino (Idor) com a Zoox Smart Data e apoiada por vários parceiros como Instituto Brasileiro de Petróleo e Biocombustíveis (IBP), HDI Seguros e Rede d'Or - foi criada no início da pandemia, em março de 2020, e combina metodologia de testagem (PCR ou sorológica) com inteligência epidemiológica, de forma a reunir dados geolocalizados para acompanhamento, em tempo real, da evolução da epidemia. Todos os casos positivos são notificados e, portanto, passam a compor os dados oficiais do Painel Rio Covid- 19. Dessa forma foi possível reduzir a taxa de subnotificação e ter um conhecimento mais claro da pandemia na Maré.

No eixo Atenção, o projeto atuou com atendimento médico remoto para os casos de Covid e oferta de atendimento em outras especialidades, respondendo às demandas reprimidas em decorrência da diminuição do atendimento nas UBS. No caso de pacientes com Covid-19, o atendimento on-line permitiu acompanhar a evolução dos casos, evitando seu agravamento e, quando necessário, direcionando o paciente para serviços de maior complexidade. Essa frente foi liderada pela SAS Brasil, organização social sem fins lucrativos que proporciona acesso à saúde especializada a comunidades economicamente menos desenvolvidas. Toda a comunicação entre a equipe de agendamento e a população é feita diretamente por WhatsApp. Apenas a consulta é feita a partir de um link gerado dentro do prontuário médico. A SAS Brasil também ofertou atendimento em saúde mental, uma demanda crescente durante a pandemia em decorrência dos seus diversos impactos na vida dos moradores.

Por fim, ainda no eixo Atenção, os pacientes com teste positivo para Covid- 19 são encaminhados para o Programa de Isolamento Domiciliar Seguro, que propõe ações com as quais se procura auxiliar pessoas contaminadas com a Covid- 19 para que possam 
ficar em casa sem contaminar outras pessoas e com as condições de acompanhamento e apoio social necessárias. Uma equipe de assistentes sociais entra em contato com a família, levanta informações sobre as condições de moradia, o número de membros, pessoas do grupo de risco etc. De posse dessas informações, os profissionais propõem à família uma ou mais opções da caixa de ferramentas do programa, entre as quais produtos de higiene, kits de proteção e alimentação (Figura 3).

Figura 3 - Kit de limpeza e entrega do kit de alimentação
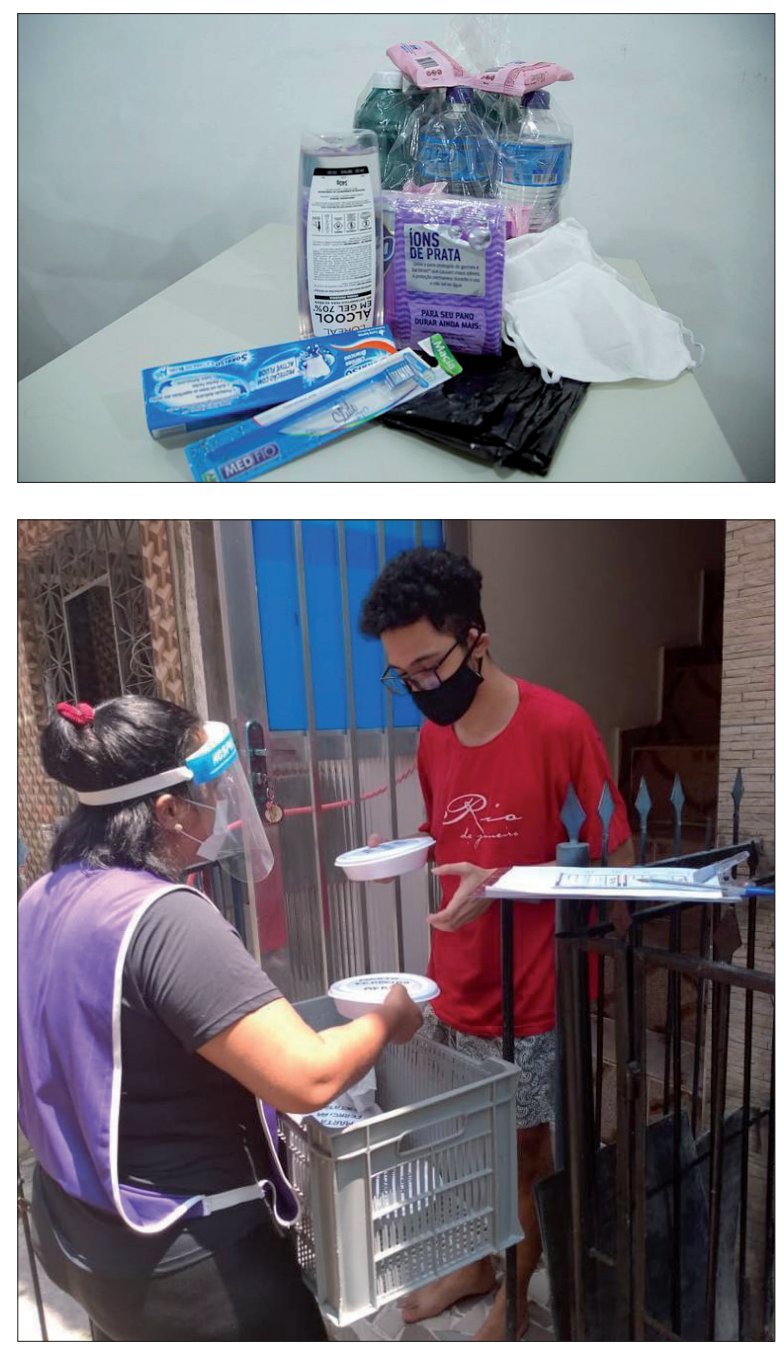

Fotos Douglas Lopes. 
No eixo Gestão, o trabalho se concentrou na integração entre as organizações participantes entre si e o Sistema Único de Saúde (SUS). Para o trabalho entre as organizações, foi estruturado um comitê gestor, com um representante de cada instituição, que em reuniões semanais delibera sobre uma agenda comum e estratégica, com os pontos de direcionamento do projeto. Essa organização possibilitou agilidade na tomada de decisões com compartilhamento de visões, de forma a adequar o planejamento e responder rapidamente às mudanças no curso da pandemia. A análise conjunta sobre o trabalho em suas diferentes perspectivas também permitiu ampliar a visão sobre os desafios e as soluções. No quesito integração com o SUS foi possível criar um fluxo de encaminhamento das UBS para o polo de testagem, assim como implementar um programa de interconsulta, com o apoio dos médicos especialistas do SAS Brasil. O objetivo da integração e diálogo com as UBS e seus profissionais é o fortalecimento do SUS, apoiando e complementando suas ações, além da formação de uma rede de cuidados integrada.

\section{RESULTADOS}

\section{Produção de dados e divulgação de informações}

Um dos principais produtos da sistematização de informações e ações do projeto e de relatos da dinâmica da pandemia na Maré foi o boletim De Olho no Corona! (Figura 4). Nas 25 edições publicadas até dezembro foi apresentada a situação epidemiológica quinzena a quinzena e também foram detalhadas questões relacionadas à pandemia e seu impacto social.

Figura 4 - Capa do número 25 do boletim De Olho no Corona!

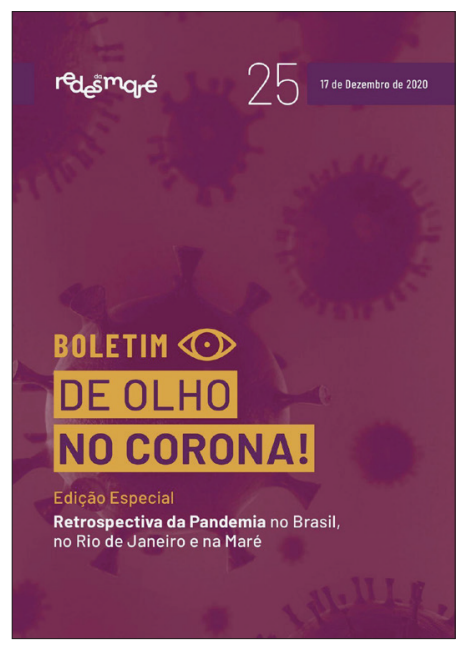


A análise da totalidade das publicações permite observar como os temas escolhidos dialogavam com as principais questões em relação ao estágio da pandemia. No boletim número 2, publicado em maio, abordou-se o problema das internações, quando a ocupação dos leitos no Rio de Janeiro havia chegado a 98\% (Redes da Maré, 2020a). Na quinta edição do boletim abordou-se a dificuldade dos moradores de receber atendimento nas UBS, trazendo relatos (Redes da Maré, 2020c). No número seguinte tratou-se dos erros de notificação, evidenciando-se que a Maré, apesar de ser um bairro desde 1994, ainda sofre com a identificação de território pertencente a bairros vizinhos. Esse elemento se expressou no registro dos casos e óbitos de Covid (Redes da Maré, 2020d).

Em dezembro de 2020, na 25a edição (Redes da Maré, 2020e), foi possível fazer uma análise dos dados produzidos ao longo do ano. Nesse período, o Conexão Saúde realizou 6.714 testes, dos quais 4.732 de RT-PCR (535 com resultado positivo) e 1.982 sorológicos (685 com resultado positivo). No atendimento on-line foram realizados 1.828 atendimentos médicos e 1.046 atendimentos psicológicos. No Programa de Isolamento Domiciliar Seguro 246 pessoas foram incluídas por estarem contaminadas com Covid e precisando de apoio para garantir o isolamento (Figura 5). No que diz respeito ao momento do contágio na Maré, até dezembro o Painel Rio Covid- 19 havia registrado I.205 casos confirmados e 137 óbitos (Redes da Maré, 2020f).

Figura 5 - Principais resultados apresentados no número 25 do boletim De Olho no Corona!

\begin{tabular}{|c|c|c|}
\hline \multicolumn{3}{|l|}{$\begin{array}{l}\text { BOLEEII @ } \\
\text { DE OLHO NO CORONA! }\end{array}$} \\
\hline \multicolumn{3}{|c|}{ 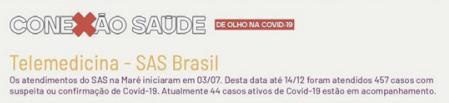 } \\
\hline \multicolumn{3}{|c|}{ 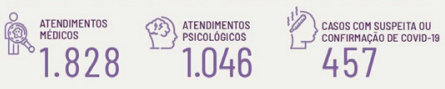 } \\
\hline \multicolumn{3}{|c|}{ 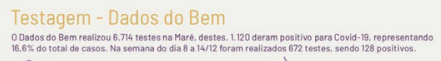 } \\
\hline \multicolumn{3}{|c|}{ 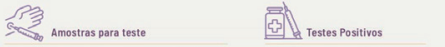 } \\
\hline 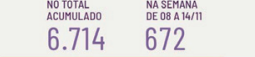 & 1.220 & 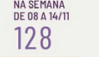 \\
\hline $\begin{array}{lll}5.732 & 440\end{array}$ & 535 & 69 \\
\hline $\begin{array}{ll}1.982 & 232 \\
\end{array}$ & 685 & 59 \\
\hline \multicolumn{3}{|l|}{ 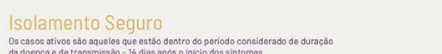 } \\
\hline 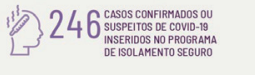 & în5 & 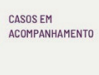 \\
\hline
\end{tabular}


Quanto ao impacto, pudemos observar importante queda na taxa de mortalidade após o início do projeto. No período anterior à sua implementação, até a Semana Epidemiológica 30 de 2020 a taxa de mortalidade da Maré era praticamente o dobro da taxa da cidade do Rio de Janeiro, uma das mais altas do país. Após 15 semanas de funcionamento do projeto, essa taxa se reduziu significativamente, chegando a valores semelhantes à taxa média do país e inferiores à da cidade do Rio de Janeiro (Figura 6). Esses dados podem indicar que a implementação de um programa de testagem gratuito permitiu ampliar o universo de casos positivos, tornando os valores a este relacionados mais próximos da realidade e reduzindo a subnotificação. Mas, além desse fator, é possível também que o tripé testagem, acompanhamento médico e apoio ao isolamento domiciliar tenha permitido melhor monitoramento e cuidado dos casos, com impacto direto sobre a mortalidade no território.

Figura 6 - Evolução da proporção de óbitos por Covid- 19 após a intervenção - Brasil, cidade do Rio de Janeiro e favela da Maré, Semana Epidemiológica 30 de 2020

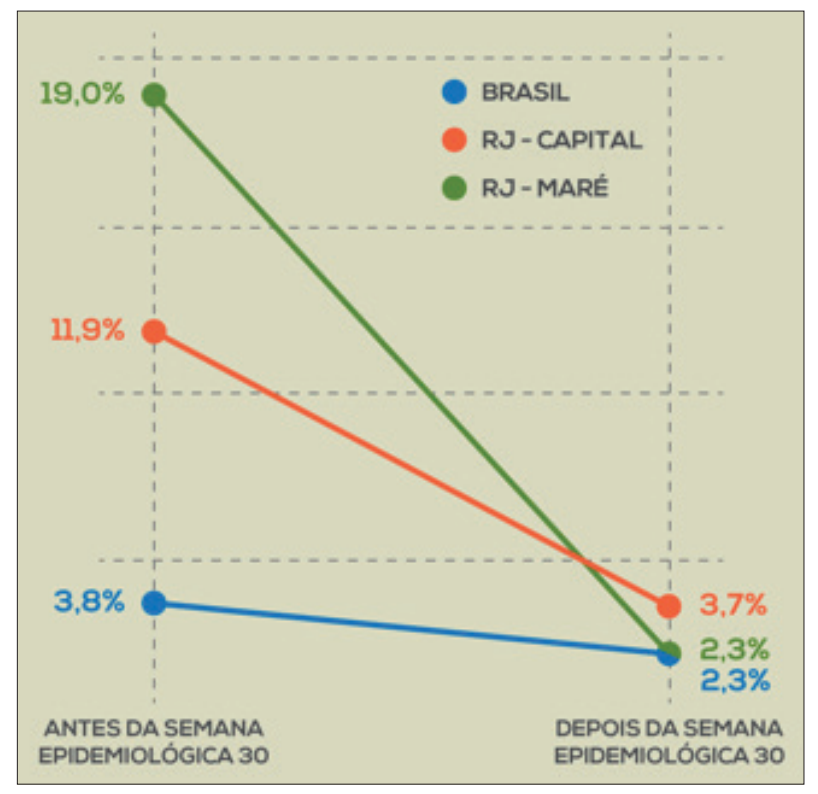

Fonte: elaborada por Suzane Santos.

\section{Produtos de comunicação}

Na Comunicação, um dos eixos fundamentais do projeto, vários produtos foram criados para atingir diferentes públicos (Figura 7). 
Figura 7 - Produtos usados na estratégia de comunicação do Conexão Saúde e seus quantitativos
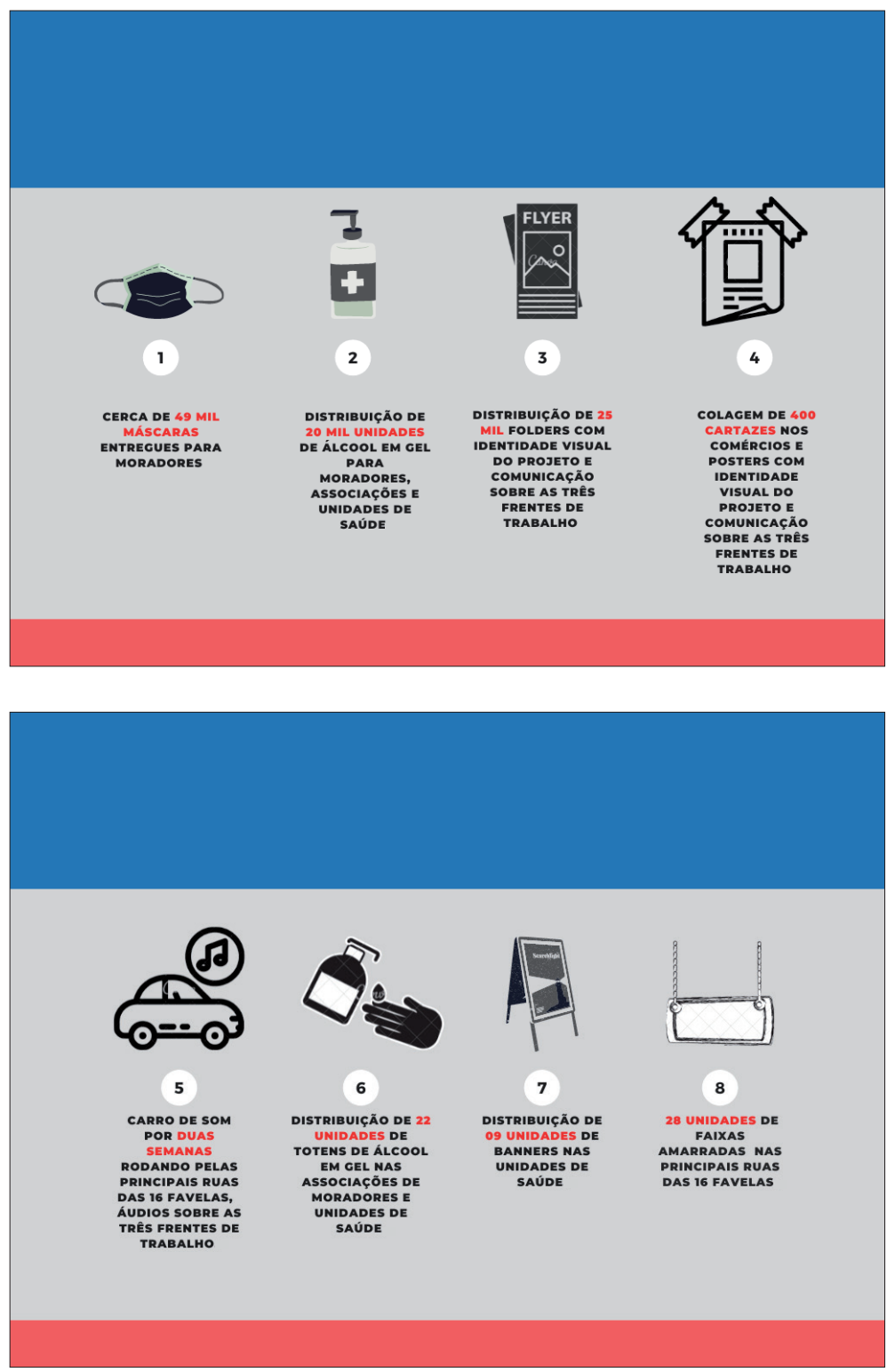

Fonte: elaboração própria. 
No projeto também se produziu um guia de isolamento domiciliar (Figura 8) para orientar pessoas em isolamento na organização da sua rotina e da higiene domiciliar, evitando a transmissão para outros membros da família. O guia foi construído em parceria com a Fiocruz, para garantir bases científicas sobre como se proteger, e adaptado pela Redes da Maré à realidade dos moradores, esclarecendo as principais dúvidas sobre como manter o isolamento de forma segura.

Figura 8 - Guia de isolamento domiciliar e algumas de suas recomendações
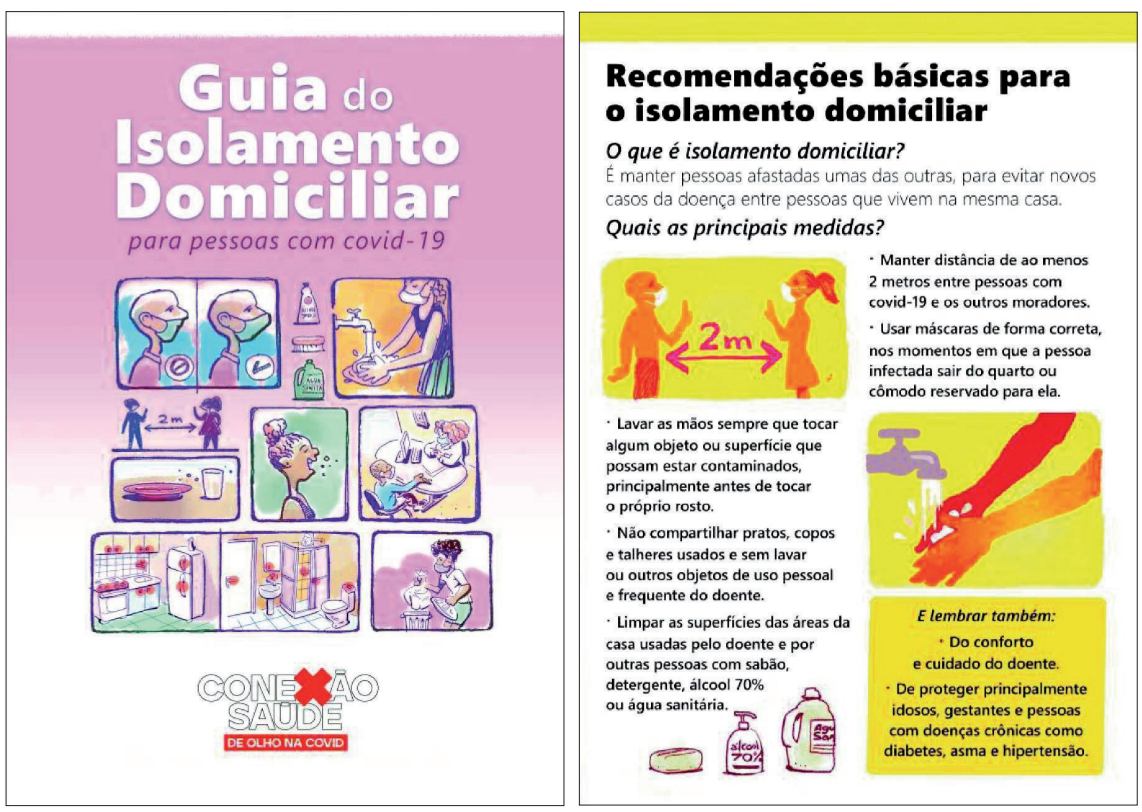

Avaliação dos serviços pelos usuários

Ao final do acompanhamento dos casos de isolamento domiciliar seguro, a equipe aplica um questionário de avaliação sobre as ações desenvolvidas pelo Conexão Saúde. Até dezembro, 238 pessoas já haviam respondido o questionário. Os entrevistados eram em sua maioria mulheres (64\%) de 30 a 39 anos (25,7\%), autodeclaradas pardas ou pretas $(64,7 \%)$.

Na avaliação das ações do projeto, 206 pessoas o consideraram como ótimo e 32 como bom e nenhum usuário o avaliou como regular, ruim ou péssimo. Quando perguntados que nota de I a 5 dariam para o programa de isolamento domiciliar, 225 usuários deram a nota máxima (5) e 7 deram nota 4 e I pessoa deu nota I (Figura 9). 
Figura 9 - Dados da avaliação do projeto na percepção dos usuários

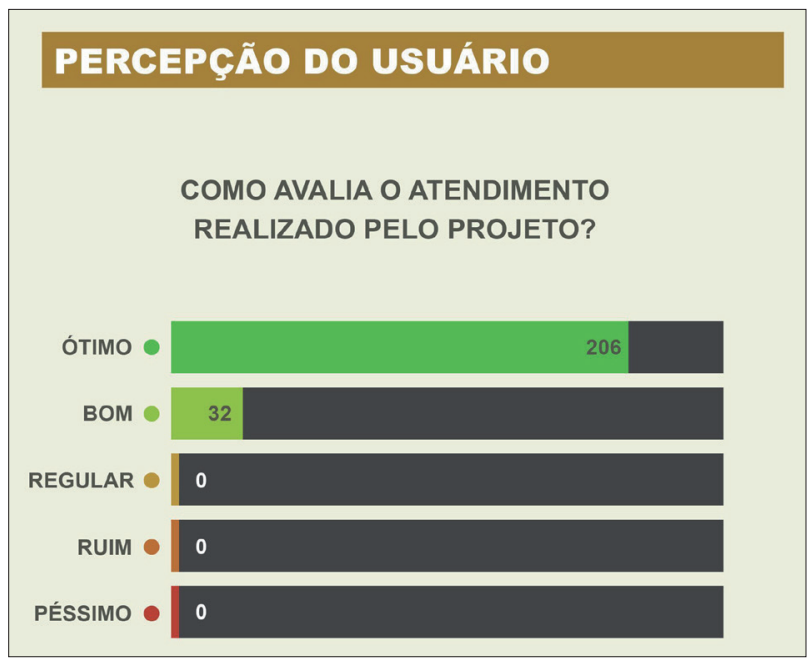

Fonte: elaboração própria.

\section{APRENDIZADOS E PERSPECTIVAS}

Após três meses de projeto foi possível, com o recurso obtido pela parceria com o Todos pela Saúde, estender o projeto por mais dois meses, garantindo o tripé testagem, telemedicina e programa de isolamento domiciliar até dezembro do ano de 2020. Ao longo desse percurso procurou-se, no âmbito do projeto, responder a várias demandas e questões relacionadas às incertezas impostas pela pandemia, o que o levou a respostas rápidas e eficientes.

O primeiro objetivo foi garantir acesso e informação ao maior número de moradores. Para isso, foi imprescindível a atuação da Redes da Maré no território e o envolvimento dos moradores e suas redes de contato. Depois dos primeiros meses de trabalho, a comunicação repercutiu positivamente, garantindo procura por todos os serviços, mesmo no período de diminuição das taxas de contágio.

Outro conjunto de soluções centrais do projeto envolveu o acesso a novas tecnologias. O Conexão Saúde se destaca, entre outros aspectos, pelo uso da tecnologia móvel como forma de facilitar o acesso dos moradores aos serviços de saúde. No entanto, como ocorre em muitas regiões de favelas e periferias, os serviços de internet são precários, com regiões sem sinal. Soma-se a essa realidade o fato de que muitos moradores contam com poucos recursos econômicos e têm dificuldade em possuir um celular e/ou 
plano de dados para utilizá-lo rotineiramente. Como forma de reduzir tais dificuldades, negociou-se com as principais companhias telefônicas a liberação do pacote de dados para o aplicativo de testagem. Além disso, foi necessário desenhar "portas de entrada" em todos os serviços para pessoas sem celular ou acesso à internet. No caso da testagem, foram disponibilizadas vagas avulsas, para as pessoas que não tivessem celular. Para aquelas com celular, mas sem pacote de dados, a equipe disponibilizou uma rede sem fio e o cadastro realizado na própria tenda. Para maior acesso à telemedicina, foram instaladas duas cabines de autoatendimento em dois prédios da Redes da Maré. Com isso, a equipe de campo poderia identificar o morador que precisava da consulta e combinar um horário para que este se dirigisse ao local que contava com internet, computador, além de impressora para entrega das receitas.

Por fim, um dos grandes objetivos do projeto é a integração com o SUS. Uma das suas primeiras ações foi a visita a todas as UBS para apresentar o Conexão Saúde e propor fluxos de encaminhamento. Apesar da falta de investimento dos governos na APS e das dificuldades vivenciadas pelos profissionais na resposta à pandemia, foi possível construir importantes parcerias tanto para dar suporte aos profissionais e moradores que precisavam de acesso ao teste quanto para responder às demandas por consultas médicas e psicológicas que as UBS não conseguiam atender. Além disso, foi ofertada às clínicas da família a possibilidade de solicitar interconsultas nas 17 especialidades médicas oferecidas pelo SAS Brasil, o que facilitou o acesso ao atendimento com especialistas. Reconhecemos nosso compromisso com o fortalecimento do SUS, tendo como uma das principais preocupações do projeto a integração da APS.

Com a continuação da pandemia, no âmbito do projeto se tem buscado ampliar ações como forma de aprofundar os seus eixos de atuação e atingir públicos e perfis com que ainda não se teve contato. Ao mesmo tempo, neste novo período do projeto pretendese dialogar com a preparação para a vacinação, trabalhando a difusão de informação, mas também colhendo informações sobre os mitos e medos dos moradores e lhes oferecendo respostas. O projeto se destaca pelo trabalho conjunto e coordenado entre várias iniciativas, no qual se criou capacidade de apresentar respostas para o período da pandemia em um território com uma grande população e muitas complexidades. Por essa razão, entendemos que essa experiência tem potencial de ser replicada em outras localidades e servir como inspiração para a criação de modelos de vigilância em regiões de favela e periferia. 


\section{Agradecimentos}

O trabalho aqui sistematizado pelos autores só foi possível com o empenho de muitas pessoas e organizações. Agradecemos a todos os membros do Comitê Gestor do Conexão Saúde - Ana Carneiro (Fiocruz), André Luiz da Silva Lima (Conselho Comunitário de Manguinhos), Eduardo Pádua (União Rio), Mariana Antunes (Dados do Bem), Sabine Zink (SAS) e Valcler Rangel (Fiocruz) -, por toda a dedicação e persistência para garantir a existência do projeto. E a todas as organizações e iniciativas envolvidas, por seus importantes trabalhos na transformação deste mundo.

Agradecemos também a todos os trabalhadores do Conexão Saúde: à equipe do isolamento domiciliar (Henrique Gomes, Laís Araujo, Maurilia Rodrigues e Danielle dos Santos Cardoso); à equipe de articuladores territoriais (Eduardo da Silva, Priscila Ribeiro, Suelem Carvalho de Castro, Vânia Silva e Leonardo Silva); à equipe do SAS Brasil (Aline de Aquino da Silva Miranda, Joice da Silva Cruz, Letícia Santos, Roy Bento, Gustavo Nunes, Larissa Fernandes, Maiara Carvalho, Ricardo Gusmão e Vinicius da Silva); à equipe da testagem (Fernanda Vianna, Everton Gomes, Kátia do Nascimento Lopes, Minervina Alves de Lima, Maiara Felix da Silva, Rosangela Mello da Silva Correia, Patrícia Amorim dos Santos e Thaís Andrade do Nascimento) e à equipe do galpão (Fabiana Lima de Freitas, Romário Roma, Trícia Maria Araújo de Lima e Rosenira Costa Cláudio). Agradecemos a todos por se colocarem na linha de frente da contenção da pandemia.

À equipe de comunicação, pelo trabalho de construção dos materiais informativos e desenho de estratégias que nos permitiram chegar ao maior número de moradores, também agradecemos. E especialmente a Camila Barros, Andreia Blum, Dálcio Marinho, Luciana Bento, Jéssica Pires, Amapola Rios e Fábio Machado, pela elaboração, pesquisa e produção dos boletins do De Olho no Corona!

Agradecemos a todas as organizações que permitiram, com apoio financeiro e estrutural, que o projeto fosse operacionalizado - Todos Pela Saúde, Fiocruz, Instituto D’Or, Zoox, União Rio, Fundação de Amparo à Pesquisa do Estado do Rio de Janeiro, Conselho Nacional de Desenvolvimento Científico e Tecnológico - e a todos que contribuíram com a campanha Maré Diz Não ao Coronavírus, da Redes da Maré. 


\section{REFERÊNCIAS}

EUCLIDES, H. A saúde municipal no vermelho. Maré de Notícias On-Line, Rio de Janeiro, 3 jan. 2020a. Disponível em: <https://mareonline.com.br/a-saude-municipal-no-vermelho/>. Acesso em: 3 maio 2021 .

EUCLIDES, H. Teto da Clínica da Saúde na Vila do João, na Maré, desaba. Maré de Notícias On-Line, Rio de Janeiro, 16 set. 2020b. Disponível em: < https://mareonline.com.br/cms-vila-do-joao-pedesocorro/>. Acesso em: 3 maio 2021 .

FERNANDES, L. E ORTEGA, F. A Atenção Primária no Rio de Janeiro em tempos de Covid- 19. Physis: Revista de Saúde Coletiva, 30(3): I - I I, 2020. Disponível em: <www.scielo.br/pdf/physis/v30n3/0 I 03 733 I-physis-30-03-e300309.pdf>. Acesso em: 3 maio 202I.

REDES DA MARÉ. Censo Populacional da Maré, 20I9. Disponível em: <www.redesdamare.org.br/ media/downloads/arquivos/CensoMare_WEB_04MAI.pdf>. Acesso em: 26 maio 2021.

REDES DA MARÉ. De Olho no Corona!, Boletim n. 2, 2020a. Disponível em: <www.redesdamare.org. br/media/downloads/arquivos/05E02-BoletimDeOlho.pdf>. Acesso em: 26 maio 2021.

REDES DA MARÉ. De Olho no Corona!, Boletim n. 3, 2020b. Disponível em: <www.redesdamare.org. br/media/downloads/arquivos/05E03-BoletimDeOlho.pdf>. Acesso em: 26 maio 2021.

REDES DA MARÉ. De Olho no Corona!, Boletim n. 5, 2020c. Disponível em: <www.redesdamare.org. br/media/downloads/arquivos/06E05-BoletimDeOlho.pdf>. Acesso em: 26 maio 2021.

REDES DA MARÉ. De Olho no Corona!, Boletim n. 6, 2020d. Disponível em: <www.redesdamare.org. br/media/downloads/arquivos/06E06-BoletimDeOlho.pdf>. Acesso em: 26 maio 2021.

REDES DA MARÉ. De Olho no Corona!, Boletim n. 25, 2020e. Disponível em: <www.redesdamare.org. $\mathrm{br} / \mathrm{media} /$ downloads/arquivos/I 2E25-BoletimDeOlho.pdf>. Acesso em: 26 maio 2021.

REDES DA MARÉ. Campanha Maré diz não ao coronavírus. Relatório de atividades da campanha. 2020f. Disponível em: <www.redesdamare.org.br/media/downloads/arquivos/RdM_Relatorio_campanha. pdf>. Acesso em: 26 maio 2021 . 


\section{OUTROS TÍTULOS DA SÉRIE \\ Informação para Ação na Covid- 19}

Diplomacia da Saúde e Covid- 19: reflexões a meio caminho

Paulo Marchiori Buss e Luiz Eduardo Fonseca (orgs.)

http://books.scielo.org/id/hdyfg

Os Impactos Sociais da Covid- I 9 no Brasil:

populações vulnerabilizadas e respostas à pandemia

Gustavo Corrêa Matta, Sergio Rego, Ester Paiva Souto e Jean Segata (orgs.)

http://books.scielo.org/id/r3hc2

Covid- 19 no Brasil: cenários epidemiológicos e vigilância em saúde

Carlos Machado de Freitas, Christovam Barcellos e Daniel Antunes Maciel Villela (orgs.) https://books.scielo.org/id/zx6p9 
Formato: $16 \times 23 \mathrm{~cm}$

Tipologia: GoudySnas Lt BT, GoudySans Md BT e Interstate-LightCondensed Rio de Janeiro, janeiro de 2022

Os livros da Editora Fiocruz podem ser encontrados nas boas livrarias e em www.livrariaeditorafiocruz.com.br ou books.scielo.org/fiocruz

Av. Brasil, 4036, térreo, sala II 12 - Manguinhos

2 1 040-36 I - Rio de Janeiro, RJ

Tel.: (2 I) 3882-9039 e 3882-9007

Telefax: (2I) 3882-9006

editora@fiocruz.br

www.fiocruz.br/editora 
Passados os primeiros meses da pandemia do novo coronavírus no Brasil, o Observatório Covid- I 9 Fiocruz, em parceria com a Editora Fiocruz e com o apoio da Rede SciELO Livros, traz para o público leitor um conjunto de livros instantâneos sobre as análises nele realizadas desde que foi criado para subsidiar o seu combate.

Nesta série Informação para Ação na Covid- I 9 será apresentado um balanço do conjunto de documentos (notas e relatórios técnicos, boletins, informes, recomendações, ensaios, artigos, entre outros) produzidos em resposta à pandemia. Cada volume da série se estrutura em torno de um tema: aspectos globais da pandemia e da diplomacia em saúde; cenários epidemiológicos e vigilância em saúde; as políticas e a gestão dos serviços e sistemas de saúde; orientações para os cuidados e a saúde dos trabalhadores da saúde; impactos sociais e desigualdades sociais na pandemia.

Com a publicação destes estudos em livros de acesso aberto colocamos à disposição do público o conjunto de informações e conhecimentos gerados no âmbito do Observatório Covid- 19 Fiocruz, realizamos um balanço e uma reflexão sobre como chegamos ao cenário atual e apontamos caminhos para um futuro próximo. E, ao mesmo tempo, mantemos o registro histórico desse conhecimento produzido a quente, no calor da hora.

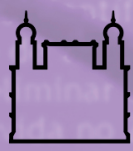

